DOE/ID/13867

\title{
USE OF RESIDUAL SOLIDS FROM PULP AND PAPER MILLS FOR ENHANCING STRENGTH AND DURABILITY OF READY-MIXED CONCRETE
}

Final Report for the Period January 1, 2000 to June 30, 2003

September 18, 2003

Tarun R. Naik, Yoon-moon Chun, and Rudolph N. Kraus

UNIVERSITY OF WISCONSIN - MILWAUKEE (UWM)

UWM Center for By-Products Utilization (CBU)

College of Engineering and Applied Science

Milwaukee, Wisconsin 53201

U.S. DOE patent clearance is not required prior to the publication of this document. 


\section{DISCLAIMER}

Any opinions, findings, and conclusions or recommendations expressed in this material are those of the author(s) and do not necessarily reflect the views of the Department of Energy.

\section{FULL LEGAL DISCLAIMER}

This report was prepared as an account of work sponsored by an agency of the United States Government. Neither the United States Government nor any agency thereof, nor any of their employees, nor any of their contractors, subcontractors or their employees, makes any warranty, express or implied, or assumes any legal liability or responsibility for the accuracy, completeness, or any third party's use or the results of such use of any information, apparatus, product, or process disclosed, or represents that its use would not infringe privately owned rights. Reference herein to any specific commercial product, process, or service by trade name, trademark, manufacturer, or otherwise, does not necessarily constitute or imply its endorsement, recommendation, or favoring by the United States Government or any agency thereof or its contractors or subcontractors. The views and opinions of authors expressed herein do not necessarily state or reflect those of the United States Government or any agency thereof.

\section{TRADEMARK DISCLAIMER}

Reference herein to any specific commercial product, process, or service by trade name, trademark, manufacturer, or otherwise, does not necessarily constitute or imply its endorsement, recommendation, or favoring by the United States Government or any agency thereof or its contractors or subcontractors. 


\section{USE OF RESIDUAL SOLIDS FROM PULP AND PAPER MILLS FOR ENHANCING STRENGTH AND DURABILITY OF READY-MIXED CONCRETE}

Final Report for the Period January 1, 2000 to June 30, 2003

Date Issued/Published September 18, 2003

Tarun R. Naik, Yoon-moon Chun, and Rudolph N. Kraus

PREPARED FOR THE UNITED STATES

DEPARTMENT OF ENERGY

IDAHO OPERATIONS OFFICE

Work Performed Under Contract No. DE-FC07-00ID13867 


\section{FINAL REPORT}

Project Title: $\quad$ Use of Residual Solids from Pulp and Paper Mills for Enhancing Strength and Durability of Ready-Mixed Concrete

Covering Period: January 1, 2000 to June 30, 2003

Date of Report: $\quad$ September 18, 2003

Awardee Name: $\quad$ University of Wisconsin - Milwaukee

UWM Center for By-Products Utilization

College of Engineering and Applied Science

DOE Award Number: DE-FC07-00ID13867

Subcontractors: None

Other Partners: Weyerhaeuser Company, NCASI, and Stora-Enso

Principal Investigator: Tarun R. Naik

Director, UWM Center for By-Products Utilization 3200 N. Cramer Street

P.O. Box 784, Milwaukee, WI 53201

Ph: (414) 229-6696

Fax: (414) 229-6958

E-mail: tarun@uwm.edu, (also copy e-mail to: rudik@uwm.edu)

Project Team: $\quad$ David W. Robertson, Project Manager

U.S. DOE Idaho Operations Office

850 Energy Drive, MS 1220

Idaho Falls, ID 83401-1563 


\begin{abstract}
This research was conducted to establish mixture proportioning and production technologies for ready-mixed concrete containing pulp and paper mill residual solids and to study technical, economical, and performance benefits of using the residual solids in the concrete.
\end{abstract}

Fibrous residuals generated from pulp and paper mills were used, and concrete mixture proportions and productions technologies were first optimized under controlled laboratory conditions.

Based on the mixture proportions established in the laboratory, prototype field concrete mixtures were manufactured at a ready-mixed concrete plant. Afterward, a field construction demonstration was held to demonstrate the production and placement of structural-grade cold-weather-resistant concrete containing residual solids. 


\section{TABLE OF CONTENTS}

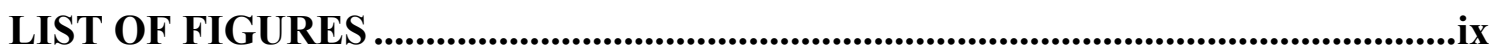

LIST OF TABLES ..................................................................................................

LIST OF ACRONYMS AND ABBREVIATIONS .................................................. xviii

ACKNOWLEDGMENT .....................................................................................................

CHAPTER 1 EXECUTIVE SUMMARY ............................................................1

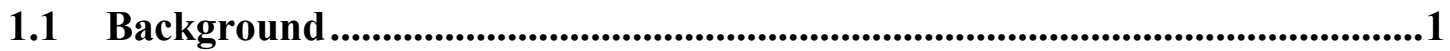

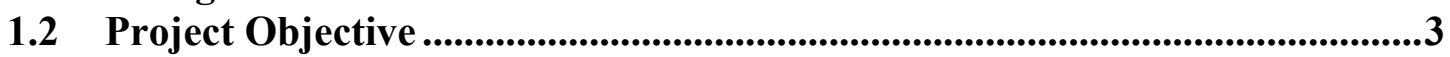

1.3 Summary of the Findings of This Project .............................................................4

1.4 Milestone .............................................................................................................................6

1.5 Patents 7

1.6 Publications/Presentations...........................................................................

CHAPTER 2 INTRODUCTION .................................................................................

\section{CHAPTER 3 LITERATURE REVIEW .................................................................10}

3.1 Generation and Management of Pulp and Paper Mill Residual Solids.......10

3.1.1 Pulp and Paper Industry Solid Residue ..................................................10

3.1.2 Wastewater Treatment Plant Residuals .....................................................10

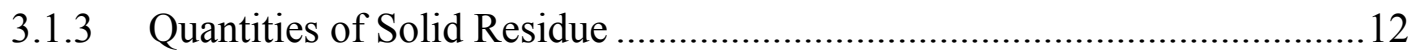

3.1.4 Generation and Management of Wastewater Treatment Residuals............13

3.2 Overview of Fiber-Reinforced Concrete (FRC) ………….................................15

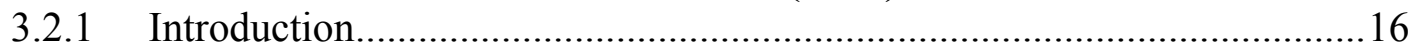

3.2.2 Principles of Fiber-Reinforced Concrete ................................................... 16

3.2.3 Types of Fibers and Their Properties.......................................................

3.2.4 Steel-Fiber-Reinforced Concrete (SFRC)............................................... 18

3.2.5 Glass-Fiber-Reinforced Concrete (GFRC) ……….................................19

3.2.6 Polymeric-Fiber-Reinforced Concrete.......................................................20

3.2.7 Carbon-Fiber-Reinforced Concrete (CFRC) ………..................................20

3.2.8 Natural-Fiber-Reinforced Concrete ..........................................................20

3.3 Steel- or Carbon-Microfiber-Reinforced Cement Pastes and Mortars........22

3.4 Overview of Pulp and Paper Technology ...........................................................26

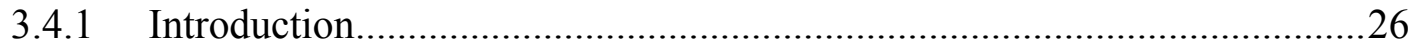

3.4.2 Characteristics of Wood and Wood Pulp Fibers.............................................31

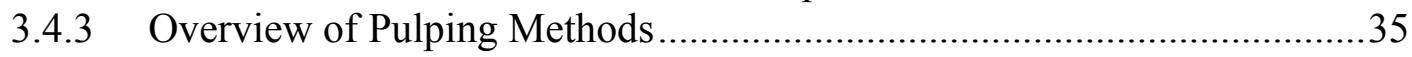

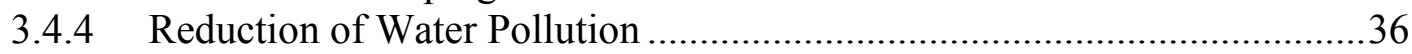

3.5 Cellulose-Fiber-Reinforced Cement-Based Composites ...................................38

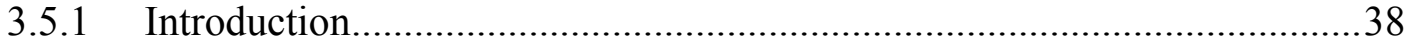

3.5.2 Production of Cellulose-Fiber-Reinforced Cement-Based Composites ......38

3.5.3 Strength of Different Types of Wood Fibers ..................................................39

3.5.4 Time of Setting and Curing of Cement in the Presence of Cellulose Fibers39 
3.5.5 Beating (or refining) of Fibers ..................................................................40

3.5.6 Properties of Cellulose Fiber-Cement Composites......................................4

3.5.7 Applications for Cellulose Fiber-Cement Composites ...................................4 47

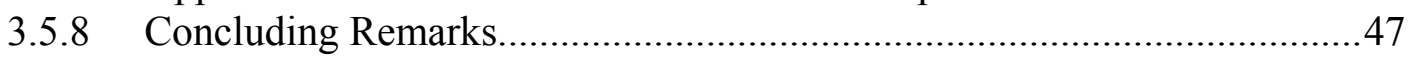

3.6 Use of Virgin Processed Cellulose Fibers in Mortar and Concrete ...............47

3.6.1 Mortar with Processed Cellulose Fibers ......................................................4

3.6.2 Concrete with Processed Cellulose Fibers.................................................48

3.7 Use of Pulp and Paper Mill Residual Solids in Cement-Based Materials...49

3.7.1 Use of Paper Mill Residual Solids In Cementitious Composites ................49

3.7.2 Use of Paper Mill Residual Solids In Concrete ..........................................51

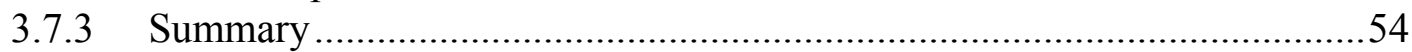

3.8 Measurement of Workability of Fiber-Reinforced Concrete.........................55

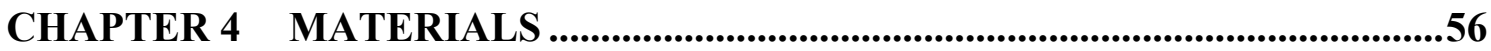

4.1 Introduction .............................................................................................................56

4.2 Portland Cements ..............................................................................................56

4.3 Fine Aggregates .......................................................................................................58

4.4 Coarse Aggregates ....................................................................................................58

4.5 High Range Water Reducing Admixture (HRWRA) ......................................60

4.6 Air Entraining Admixture (AEA) ...................................................................61

4.7 Residual Solids ...................................................................................................62

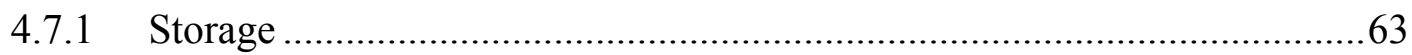

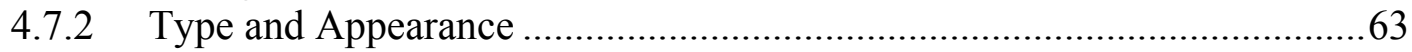

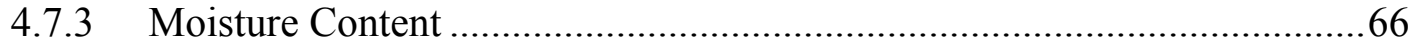

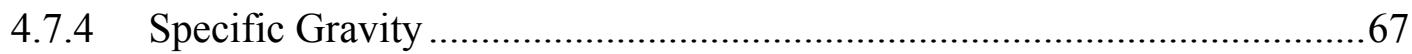

4.7.5 As-Received Bulk Density …………………........................................68

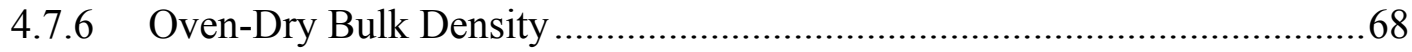

4.7.7 Fiber Length......................................................................................

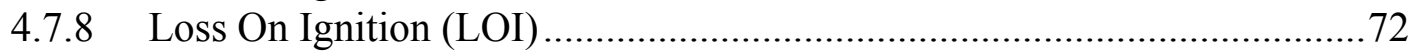

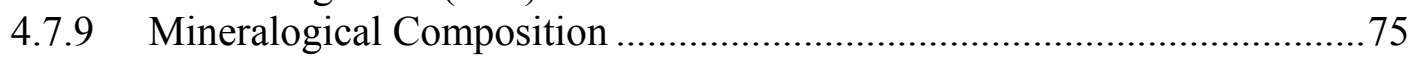

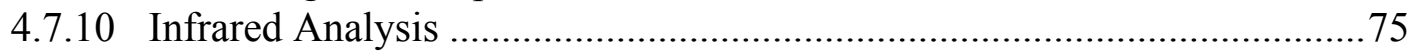

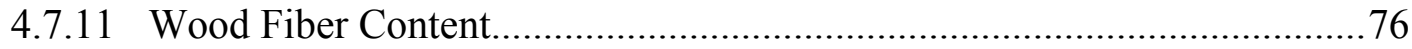

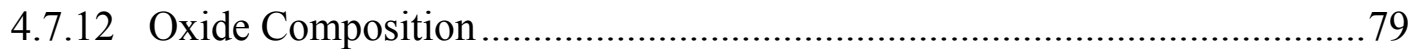

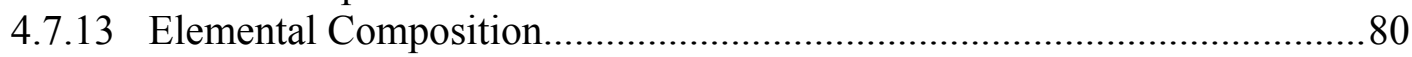

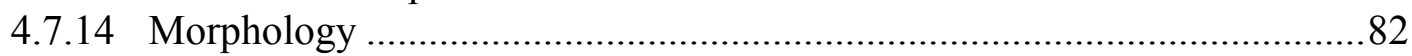

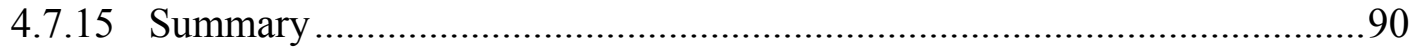

CHAPTER 5 DEFLOCCULATING EXPERIMENTS ......................................92

5.1 Deflocculating Experiments....................................................................................92

5.2 Deflocculation (or "Repulping") of Residuals ...................................................98

CHAPTER 6 SPECIMEN PREPARATION AND TEST METHODS..................99

6.1 Specimen Preparation ................................................................................................99

6.2 Test Methods.............................................................................................................100

6.3 Pictures of Testing .......................................................................................................106 


\section{CHAPTER 7 MIXTURE PROPORTIONS, TEST RESULTS, AND}

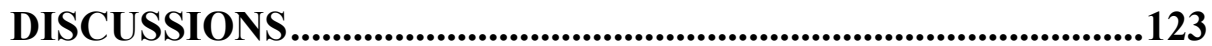

7.1 Overview..............................................................................................................123

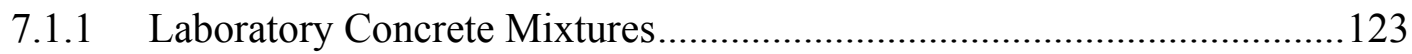

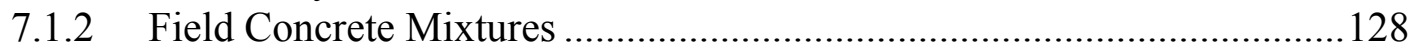

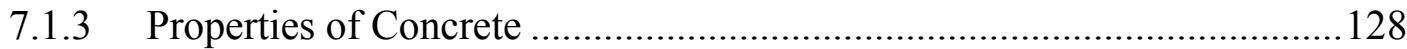

7.2 Preliminary Laboratory Mixtures ................................................................129

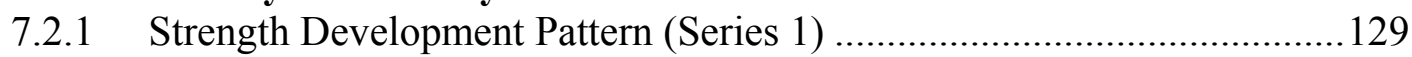

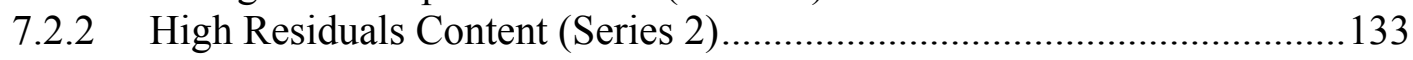

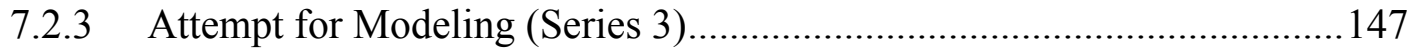

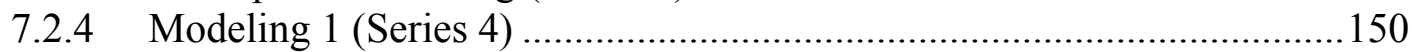

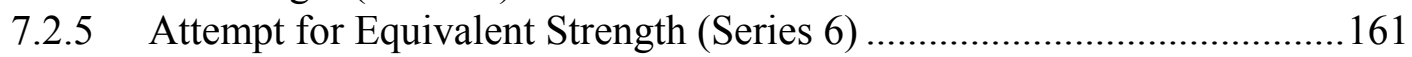

7.2.6 Equivalent Strength for C1, C2, WG, and WV (Series 7) ........................166

7.2.7 Equivalent Strength for BR, I, and S (Series 11)....................................173

7.3 Laboratory Mixtures for Durability and Long-Term Properties................176

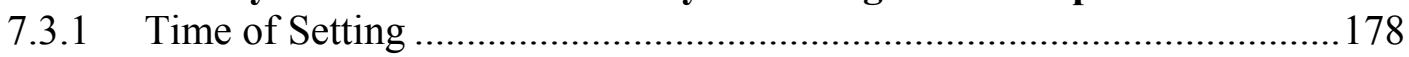

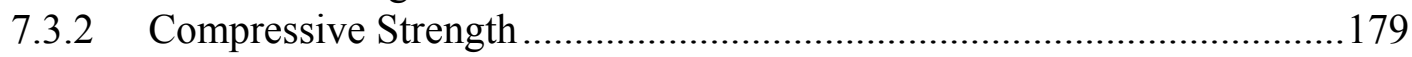

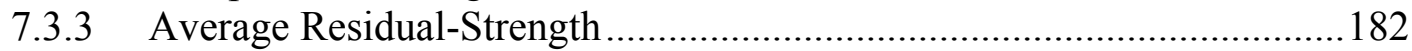

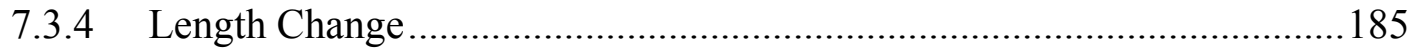

7.3.5 Resistance to Chloride-Ion Penetration ..................................................... 187

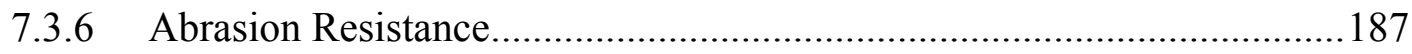

7.3.7 Resistance to Rapid Freezing and Thawing..............................................190

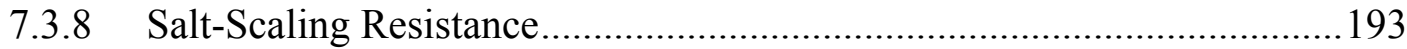

7.4 Field Mixtures.....................................................................................................195

7.4.1 Field Prototype Concrete Mixtures Manufactured at a Commercial Plant195

7.4.2 Technology Transfer Workshop and Field Concrete Mixture for Construction Demonstration ..................................................................200

7.5 Additional Laboratory Mixtures ........................................................................203

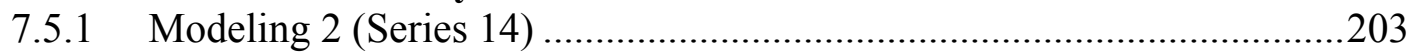

7.5.2 Splitting Tensile and Flexural Strengths (Series 15) ................................212

7.5.3 Response to AEA (Series 16) .................................................................2.

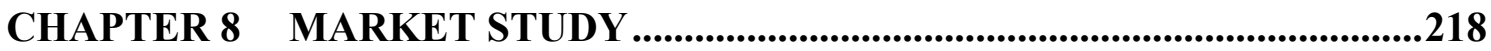

8.1 Overview......................................................................................................218

8.2 Market Survey ...........................................................................................................218

8.3 Survey Results.........................................................................................223

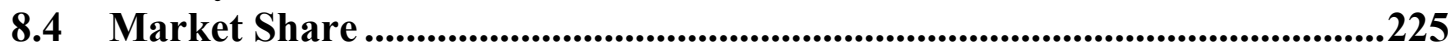

8.5 Technical Issues Identified by the Market Survey …......................................226

CHAPTER 9 ECONOMIC IMPACT ….................................................................227

CHAPTER 10 GUIDELINES FOR PRODUCING CONCRETE CONTAINING RESIDUAL SOLIDS ............................................................................231

CHAPTER 11 SUMMARY, CONCLUSIONS, AND RECOMMENDATIONS .234

11.1 Summary .........................................................................................................234 
11.2 Conclusions

11.3 Recommendations for Further Study ....................................................235

CHAPTER 12 REFERENCES......................................................................238

CHAPTER 13 APPENDIXES .......................................................................244

13.1 Appendix A. Model Building Using Two-Level Factorial Designs ............244

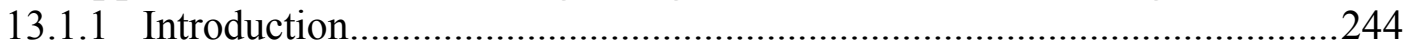

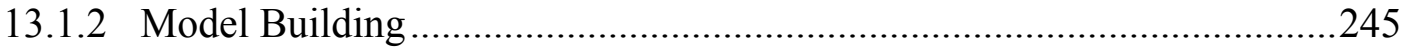

13.1.3 Example ..............................................................................248

13.2 Appendix B. Setup for Average Residual-Strength Test (ASTM C 1399) 250

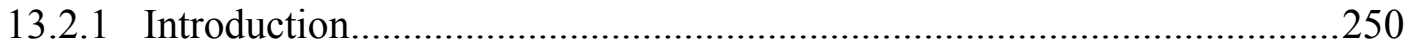

13.2.2 Apparatus and Test Setup for ASTM C 1399 _....................................251

13.3 Appendix C. Miscellaneous Laboratory Mixtures .....................................259

13.3.1 Paste, Mortar, and Concrete (Series 5) .............................................259

13.3.2 Attempt for Maximum Residuals Content (Series 8) .............................261

13.3.3 Attempt for Maximum HRWRA Content (Series 10) ............................267

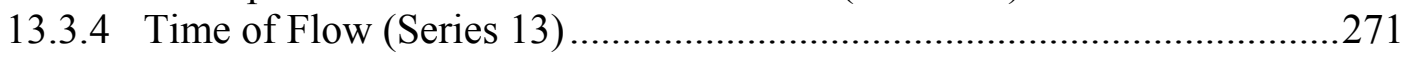




\section{LIST OF FIGURES}

Fig. 1. Paper mill wastewater treatment process [6] ...................................................10

Fig. 2. Typical Composition of paper mill primary residual (\% by mass) ......................11

Fig. 3. Quantities of solid residue generated by the U.S. pulp and paper industry since

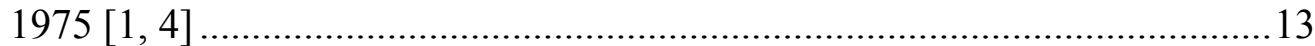

Fig. 4. Wastewater treatment residuals management in the U.S. pulp and paper industry

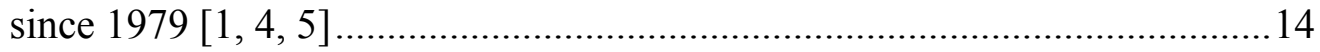

Fig. 5. Microscopic and submicroscopic structure of cellulose fiber [21] ….................28

Fig. 6. Chemical composition of wood [21] ……….................................................2

Fig. 7. Different levels of hydrogen bonding of cellulose fibers: (A) loosely through water molecules; (B) more tightly through a mono-layer of water molecules;

(C) directly [21]

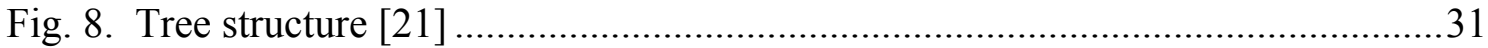

Fig. 9. Latewood and early wood on the cross-section of Douglas Fir [21] ...................32

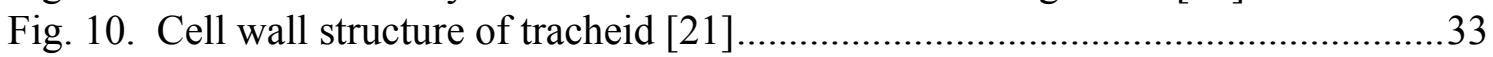

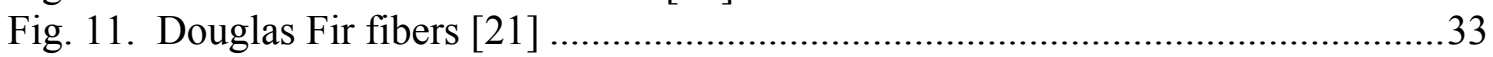

Fig. 12. Hardwood and softwood cells: (a) hardwood vessel segments, (b) hardwood libriform fiber, and (c) softwood tracheid [21] ..............................................34

Fig. 13. Change of flexural load-deflection curves of cellulose fiber-cement composites due to accelerated weathering [32] ..............................................................44

Fig. 14. Typical flexural stress-deflection curves of cellulose fiber-cement sheet composites [27] .................................................................................. 46

Fig. 15. Relation between the bulk density values of as-received residuals and oven-dry

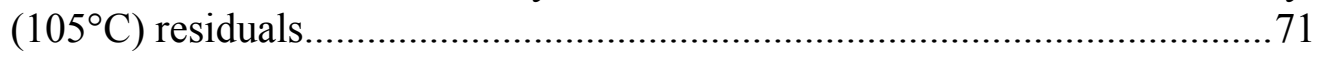

Fig. 16. Relation between (1) Percentage of minerals or oxides containing silicon and/or titanium and (2) LOI from $590^{\circ} \mathrm{C}$ to $1000^{\circ} \mathrm{C}$ of residuals ............................74

Fig. 17. Relation between wood fiber content and LOI at $575^{\circ} \mathrm{C}$ of residual solids .......77

Fig. 18. Relation between wood fiber content and LOI at $590^{\circ} \mathrm{C}$ of residual solids .......78

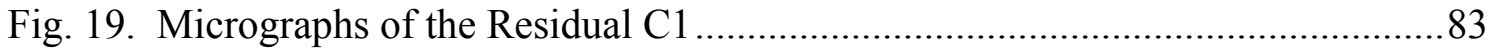

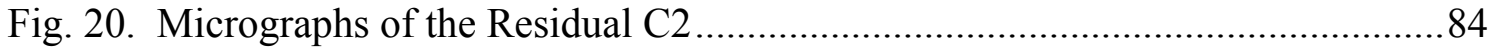

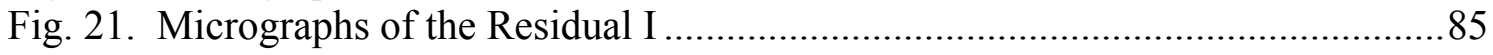

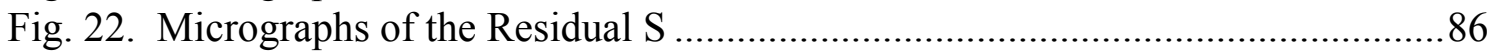

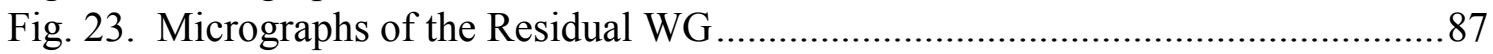

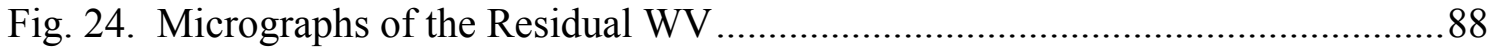

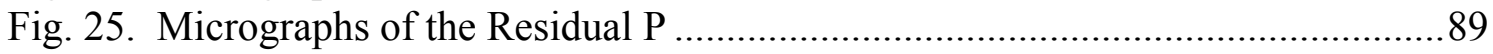

Fig. 26. High-speed motor with a rotor for "repulping" residuals...................................93

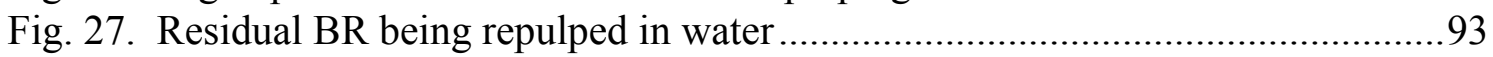

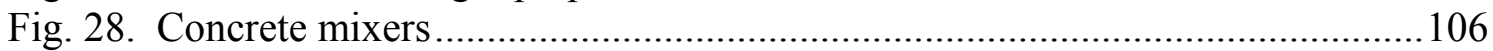

Fig. 29. Curing of specimens in lime saturated water .................................................. 106

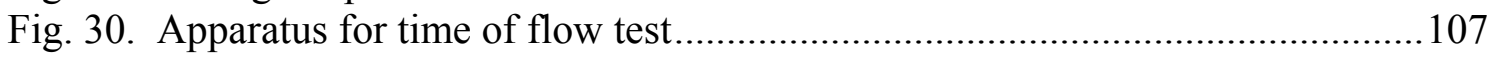

Fig. 31. Inverted slump cone for time of flow test (viewed from above) ...................... 107

Fig. 32. Inverted slump cone for time of flow test (viewed from side) ..........................108

Fig. 33. Inverted slump cone set on top of ASTM C 29 one- $\mathrm{ft}^{3}$ bucket ........................ 108

Fig. 34. Determination of time of flow of concrete (not actual testing) ........................109

Fig. 35. Wet-sieving of concrete to obtain mortar for time of setting test......................110 
Fig. 36. Mortar samples in cans for time of setting test.......................................... 110

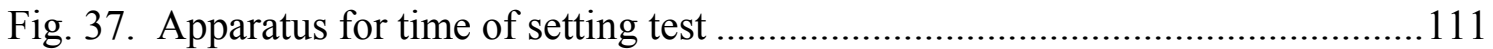

Fig. 38. Determination of penetration resistance (time of setting test) ....................... 111

Fig. 39. Concrete cylinder ready for compression test .......................................... 112

Fig. 40. Concrete cylinder under compressive load............................................... 112

Fig. 41. Concrete cylinder broken in compression ................................................. 113

Fig. 42. Setup for initial loading of beam and steel plate (for determining avg. residualstrength after cracking)

Fig. 43. Close-up of setup for initial loading of beam and steel plate (for determining avg. residual-strength after cracking) ......................................................114

Fig. 44. Setup for reloading pre-cracked beam for determining avg. residual-strength1 14

Fig. 45. Close-up of setup for reloading pre-cracked beam for determining avg. residual-

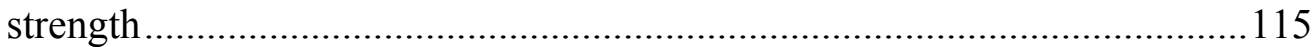

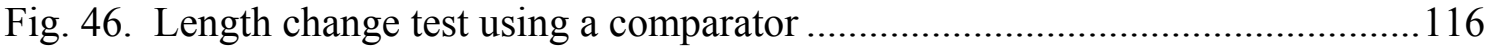

Fig. 47. Setup for chloride-ion penetration resistance test .................................... 116

Fig. 48. Specimens in contact with $3 \% \mathrm{NaCl}(-)$ and $0.3 \mathrm{~N} \mathrm{NaOH}(+)$ solutions and

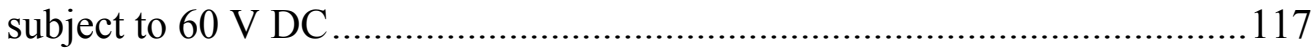

Fig. 49. Rotating-cutter drill press for abrasion resistance test ................................ 117

Fig. 50. Rotating cutters and setup for clamping abrasion specimen ......................... 118

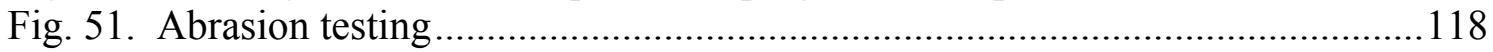

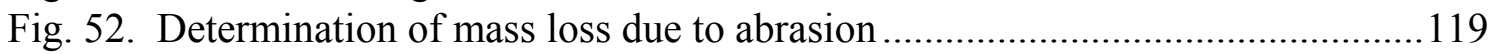

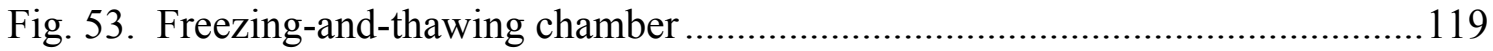

Fig. 54. Temperature control specimen (middle) with thermocouples ........................120

Fig. 55. Freezing-and-thawing specimens frozen at the end of freezing phase ............ 120

Fig. 56. Setup for fundamental transverse frequency test (for determining resistance to freezing and thawing)....................................................................... 121

Fig. 57. Beam ready for fundamental transverse frequency test (for determining resistance to freezing and thawing).................................................... 121

Fig. 58. Curing of salt-scaling specimens in air following 14 days of moist-curing....122

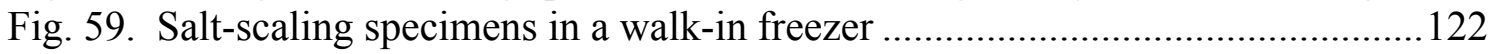

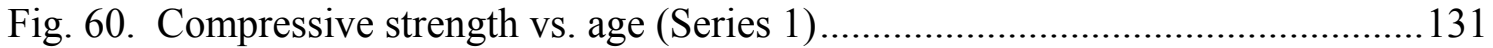

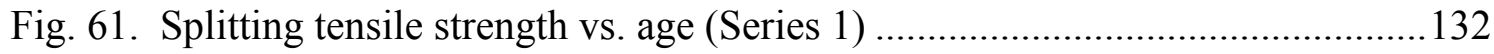

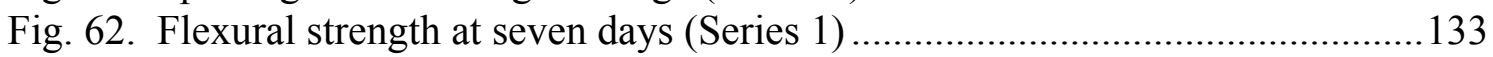

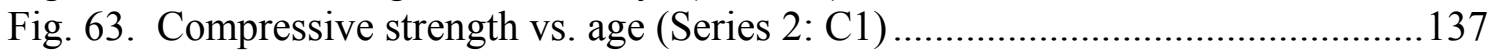

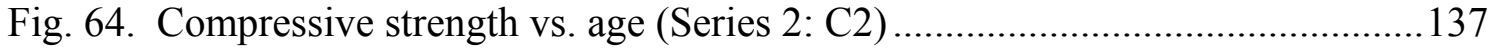

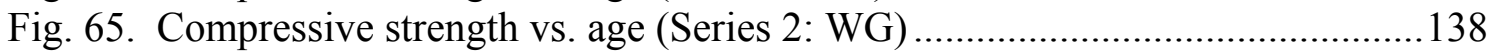

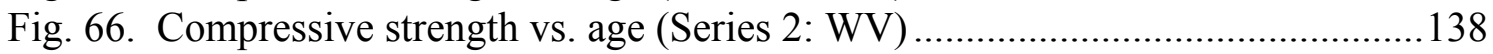

Fig. 67. Compressive strength vs. age (Series 2: P) ............................................. 139

Fig. 68. 28-day compressive strength vs. as-received residual content (Series 2) ......139

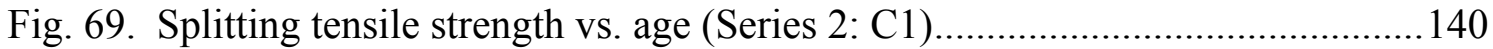

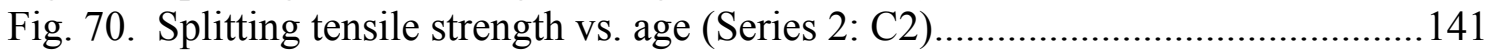

Fig. 71. Splitting tensile strength vs. age (Series 2: WG) ...................................... 141

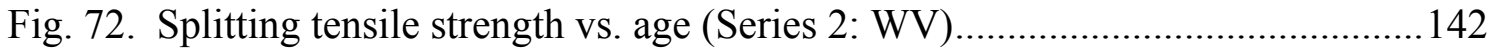

Fig. 73. Splitting tensile strength vs. age (Series 2: P) ........................................... 142

Fig. 74. 28-day splitting tensile strength vs. as-received residual content (Series 2)...143

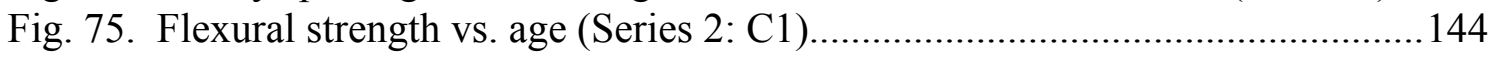




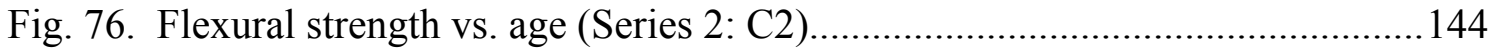

Fig. 77. Flexural strength vs. age (Series 2: WG)...................................................... 145

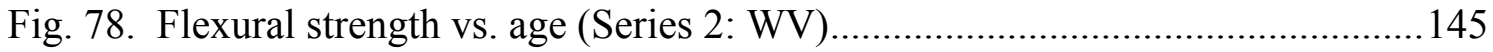

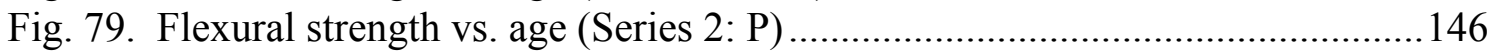

Fig. 80. 28-day flexural strength vs. as-received residual content (Series 2) ................146

Fig. 81. Compressive strength vs. age of concrete (Series 3) ....................................149

Fig. 82. Compressive strength vs. age (Series 4: C1) ……..........................................153

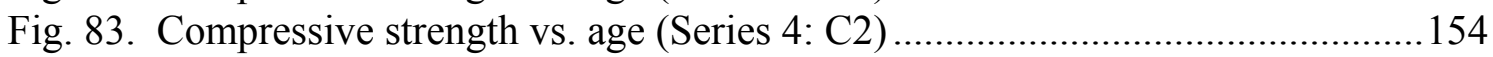

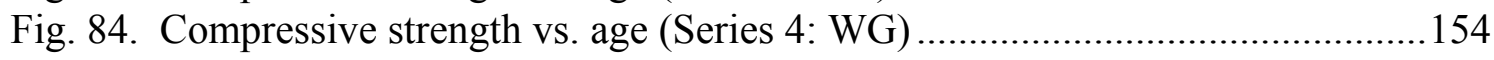

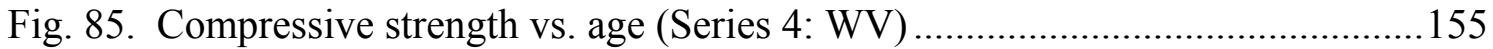

Fig. 86. 28-day compressive strength of concrete as influenced by residual and HRWRA

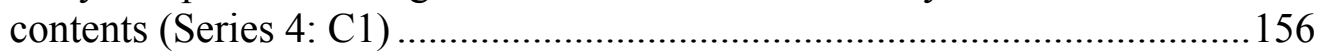

Fig. 87. 28-day compressive strength of concrete as influenced by residual and HRWRA

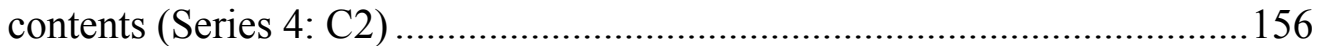

Fig. 88. 28-day compressive strength of concrete as influenced by residual and HRWRA

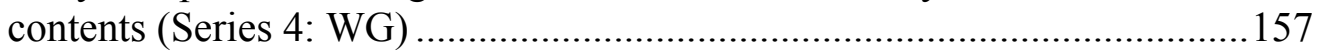

Fig. 89. 28-day compressive strength of concrete as influenced by residual and HRWRA contents (Series 4: WV) ........................................................................ 157

Fig. 90. Overall-average 28-day compressive strength of concrete as influenced by residual and HRWRA contents (Series 4)...................................................158

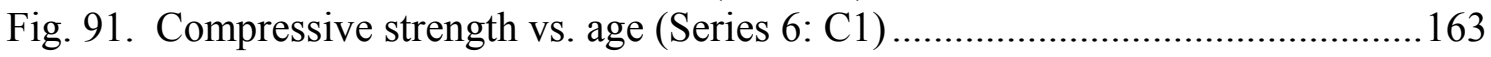

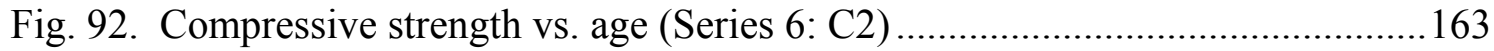

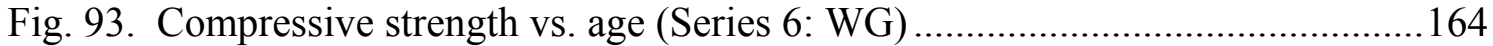

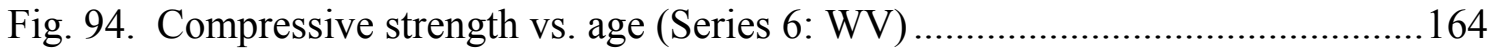

Fig. 95. 28-day compressive strength vs. as-received residual content (Series 6) .......165

Fig. 96. 28-day compressive strength vs. as-received residual content (Series 2) (partial reproduction of Fig. 68.) ……………..................................................... 165

Fig. 97. Compressive strength vs. age (Series 7: C1) ................................................169

Fig. 98. Compressive strength vs. age (Series 7: C2) …….........................................170

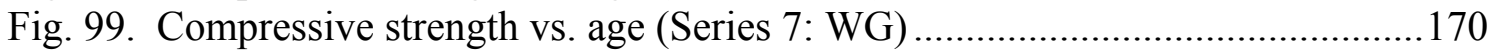

Fig. 100. Compressive strength vs. age (Series 7: WV) ……………………............. 171

Fig. 101. 3-day compressive strength vs. as-received residuals content (Series 7)......171

Fig. 102. 7-day compressive strength vs. as-received residuals content (Series 7) ......172

Fig. 103. 28-day compressive strength vs. as-received residuals content (Series 7)....172

Fig. 104. Compressive strength of concrete vs. residuals content (Series 11) .............175

Fig. 105. Compressive strength of concrete vs. residuals content (Series 11) .............175

Fig. 106. Compressive strength of concrete vs. residuals content (Series 11) .............176

Fig. 107. Relation between time of setting and HRWRA content of concrete (Series 9

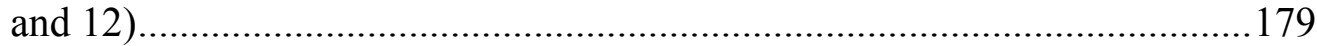

Fig. 108. Compressive strength of concrete vs. age (Series 9) ………..........................180

Fig. 109. Compressive strength of concrete vs. age (Series 12) ...................................180

Fig. 110. Relation between 28-day compressive strength and HRWRA content of

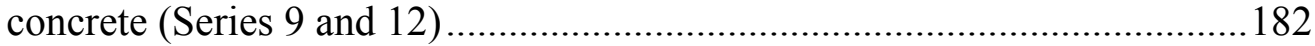

Fig. 111. Residual strength index of concrete (Series 9 and 12) ................................. 185

Fig. 112. Length change of concrete due to curing in water until the age of 28 days and subsequent drying in air (Series 9). 186 
Fig. 113. Length change of concrete due to curing in water until the age of 28 days and subsequent drying in air (Series 12).

Fig. 114. Mass loss of concrete specimens due to abrasion (Series 9) .........................189

Fig. 115. Mass loss of concrete specimens due to abrasion (Series 12) .......................189

Fig. 116. Mass loss of concrete specimens due to abrasion for six minutes (Series 9 and 12) 190

Fig. 117. Specimens after 300 cycles of freezing and thawing (Series 9) 191

Fig. 118. Specimens after 300 cycles of freezing and thawing (Series 12) 191

Fig. 119. Salt scaling of concrete after 15 cycles of freezing and thawing while covered with deicing salt solution (Series 12).

Fig. 120. Relation between time of setting and HRWRA content of concrete (Prototype Field Mixtures). 197

Fig. 121. Compressive strength of concrete vs. age (Prototype Field Mixtures) .........197

Fig. 122. Flexural strength of concrete vs. age (Prototype Field Mixtures) ..................198

Fig. 123. Mass loss of concrete specimens due to abrasion (Prototype Field Mixtures)

Fig. 124. Length change of concrete (Prototype Field Mixtures).................................200

Fig. 125. Compressive strength of concrete vs. age (Construction Demonstration) ....202

Fig. 126. Flexural strength of concrete vs. age (Construction Demonstration)............202

Fig. 127. Mass loss of concrete specimens due to abrasion (Construction Demonstration) 203

Fig. 128. Overall-average 3-day compressive strength of concrete as influenced by residual and HRWRA contents (Series 14)..............................................210

Fig. 129. Overall-average 7-day compressive strength of concrete as influenced by residual and HRWRA contents (Series 14)................................................210

Fig. 130. Overall-average 28-day compressive strength of concrete as influenced by residual and HRWRA contents (Series 14)..................................................211

Fig. 131. Flexural and splitting tensile strengths of concrete in relation to compressive

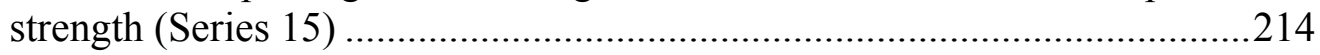

Fig. 132. Compressive strength of concrete (Series 16) ..............................................217

Fig. 133. Sample of market survey - letter of transmittal and questionnaire ................221

Fig. 134. Schematic of test setup for average residual-strength (ASTM C 1399)........253

Fig. 135. LVDTs and supports for average residual-strength test................................254

Fig. 136. LVDTs with their tips held back for setting the beam on supports...............255

Fig. 137. LVDTs with their tips in contact with the beam ..........................................25

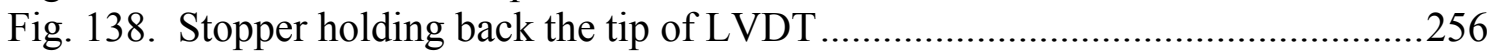

Fig. 139. Tip of LVDT released from the stopper .....................................................256

Fig. 140. Clamping device for securing the LVDT in place........................................257

Fig. 141. LVDTs, beam, and supports viewed from the back ....................................257

Fig. 142. LVDTs, beam, and supports viewed from the front .....................................258

Fig. 143. Load cell, top loading apparatus, LVDTs, beam, and supports ....................258

Fig. 144. Relation between HRWRA content and compressive strength of concrete containing no residuals (Series 10) ...........................................................22

Fig. 145. Relation between residuals content and compressive strength of concrete containing no HRWRA (Series 10) .........................................................2.270

Fig. 146. Relation between time-of-flow and slump of concrete (Series 13: Set 1).....276 
Fig. 147. Relation between modified-time-of-flow and slump of concrete (Series 13: Set

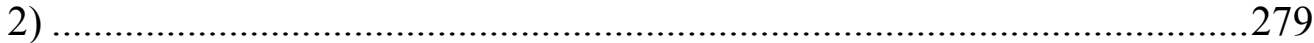

Fig. 148. Relation between time of flow and slump of concrete (Series 13: Sets 1 \& 2) 


\section{LIST OF TABLES}

Table 1. Milestone

Table 2. Quantities of Solid Residue Generated by the U.S. Pulp and Paper Industry Since $1975[1,4]$

Table 3. Wastewater Treatment Residuals Management in the U.S. Pulp and Paper

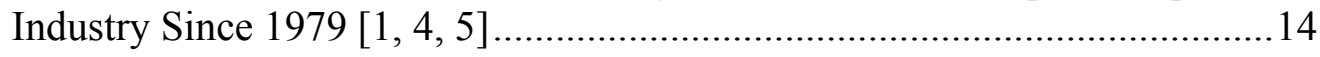

Table 4. Selected Fiber Types and Their Properties [12] ............................................... 18

Table 5. Properties of Microfibers [12, 18, 19, 20, 21] ..............................................22

Table 6. Freezing-and-Thawing Damage of Mortars [18] ...........................................24

Table 7. Deicer-Salt Scaling of Mortars [18] ……………............................................24

Table 8. Freezing-and-Thawing Damage of Pastes and Mortars [19] ............................25

Table 9. Deicer-Salt Scaling of Pastes and Mortars [19].................................................25

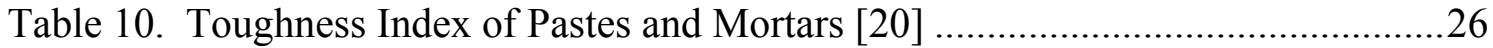

Table 11. Average Length, Average Diameter, and Length-Diameter Ratio of Wood Pulp

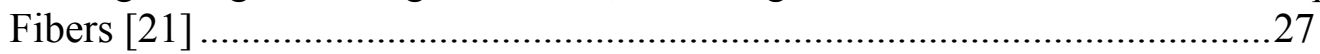

Table 12. Degree of Polymerization Values [21] …….............................................27

Table 13. Structure of Softwood Tracheid (diameter: $20-40 \mu \mathrm{m}$ ) [21] ..........................33

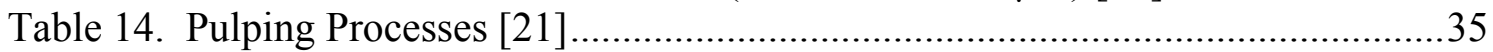

Table 15. Chemical Composition of Portland Cements....................................................57

Table 16. Physical Properties of Portland Cements.......................................................57

Table 17. Properties of Fine Aggregates ...............................................................58

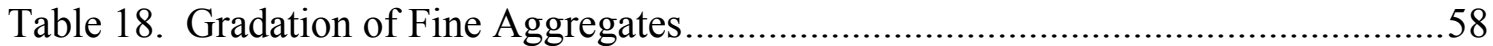

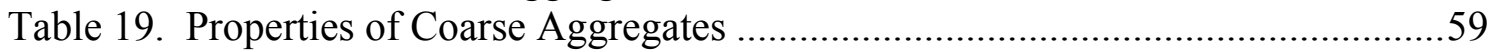

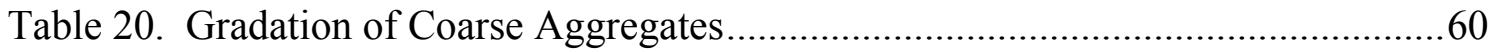

Table 21. Manufacturers' Recommended Dosage Rates of HRWRAs ..........................60

Table 22. Ingredient of HRWRAs .........................................................................61

Table 23. Physical and Chemical Properties of HRWRAs............................................61

Table 24. Manufacturer's Recommended Dosage Rate of AEA .......................................62

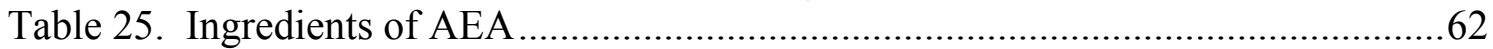

Table 26. Physical and Chemical Properties of AEA ....................................................62

Table 27. Classification and Description of Residual Solids............................................64

Table 28. As-Received Moisture Content of Residual Solids ........................................66

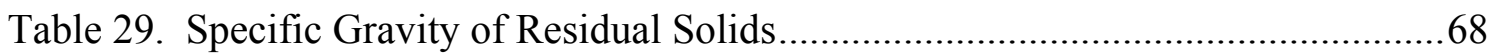

Table 30. Bulk Density of As-Received Residual Solids .............................................69

Table 31. Bulk Density of Oven-Dry Residual Solids....................................................69

Table 32. Relation Between the Bulk Density Values of As-Received Residuals and

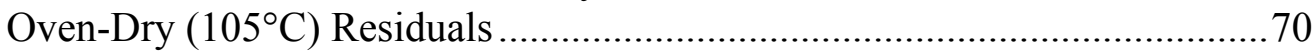

Table 33. Average Fiber Length of Residual Solids (in mm) ………...........................72

Table 34. Loss On Ignition (LOI)* of Residual Solids at 575, 590, and $1000^{\circ} \mathrm{C}$............73

Table 35. Relation Between (1) Percentage of Minerals or Oxides Containing Silicon and/or Titanium and (2) LOI from $590^{\circ} \mathrm{C}$ to $1000^{\circ} \mathrm{C}$ of Residuals (Based on Tables 34, 37, 42) ............................................................................

Table 36. Comparison of LOI* at $590^{\circ} \mathrm{C}$ of Residuals of the $1^{\text {st }}$ and $2^{\text {nd }}$ Deliveries ......74

Table 37. Mineralogical Compositions of Residual Solids by Powder Diffraction

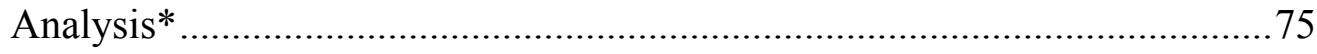


Table 38. Infrared Analysis on Selective Residuals*

Table 39. Loss On Ignition (LOI) at $575^{\circ} \mathrm{C}$ and Wood Fiber Content of Residual Solids

Table 40. Loss On Ignition (LOI) at $590^{\circ} \mathrm{C}$ and Wood Fiber Content of Residual Solids

Table 41. Wood Fiber Content of Residual Solids* ...................................................... 78

Table 42. XRF* Oxides, $\mathrm{SO}_{3}$, and LOI at $1000^{\circ} \mathrm{C}$ of Residual Solids, $\%$ by mass........ 79

Table 43. Elemental Composition of Residual Solid (in ppm) .....................................8

Table 44. Relative Ease of Repulping Residuals of the $1^{\text {st }}$ Delivery .............................94

Table 45. Repulping Experiment on Residual 'I' Using Water, Detergent, HRWRA, and

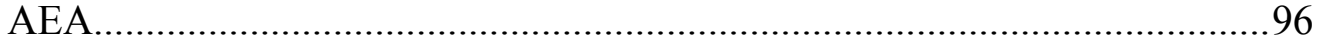

Table 46. Repulping Experiment on Residuals 'WV' and 'I' Using Water, Antiprecipitant, Antiscalant, and Flocculant .............................................. 97

Table 47. Overview of Test Methods for Fresh Concrete Properties ......................... 101

Table 48. Overview of Test Methods for Mechanical Properties............................... 103

Table 49. Overview of Test Methods for Long-Term Properties and Durability ......... 104

Table 50. Overview of Preliminary Series of Laboratory Concrete Mixtures (Sect. 7.2, p. 129) 124

Table 51. Overview of Series of Laboratory Concrete Mixtures for Durability (Series 9 and 12, Sect. 7.3, p. 176) and Additional Series of Laboratory Mixtures (Sect. 7.5 , p. 203)

Table 52. Overview of Miscellaneous Series of Laboratory Concrete Mixtures (Sect.

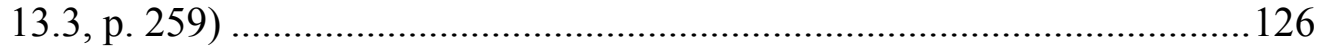

Table 53. Mixture Proportions and Fresh Properties of Concrete (Series 1)...............130

Table 54. Compressive Strength of Concrete (in psi) (Series 1) ............................... 131

Table 55. Splitting Tensile Strength of Concrete (in psi) (Series 1) ...........................132

Table 56. Flexural Strength of Concrete (in psi) (Series 1) ...................................... 133

Table 57. Mixture Proportions and Fresh Properties of Concrete (Series 2: C1) .........134

Table 58. Mixture Proportions and Fresh Properties of Concrete (Series 2: C2, WG) 134

Table 59. Mixture Proportions and Fresh Properties of Concrete (Series 2: WV, P)...135

Table 60. Compressive Strength of Concrete (in psi) (Series 2: C1) .........................136

Table 61. Compressive Strength of Concrete (in psi) (Series 2: C2, WG) ..................136

Table 62. Compressive Strength of Concrete (in psi) (Series 2: WV, P) .....................136

Table 63. Splitting Tensile Strength of Concrete (in psi) (Series 2: C1)....................140

Table 64. Splitting Tensile Strength of Concrete (in psi) (Series 2: C2, WG) .............140

Table 65. Splitting Tensile Strength of Concrete (in psi) (Series 2: WV, P) ...............140

Table 66. Flexural Strength of Concrete (in psi) (Series 2: C1) ................................ 143

Table 67. Flexural Strength of Concrete (in psi) (Series 2: C2, WG) .........................143

Table 68. Flexural Strength of Concrete (in psi) (Series 2: WV, P) ...........................143

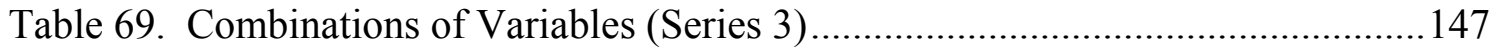

Table 70. Mixture Proportions and Fresh Properties of Concrete (Series 3)...............148

Table 71. Compressive Strength of Concrete (in psi) (Series 3) ............................... 148

Table 72. Test Setup for Two-Level Factorial Design (Series 4) ............................... 151

Table 73. Test Setup in a Cartesian Coordinate System (Series 4) ............................ 151

Table 74. Mixture Proportions and Fresh Properties of Concrete (Series 4: C1, C2) .. 152

Table 75. Mixture Proportions and Fresh Properties of Concrete (Series 4: WG, WV)152 
Table 76. Compressive Strength of Concrete (in psi) (Series 4: C1, C2) ....................153

Table 77. Compressive Strength of Concrete (in psi) (Series 4: WV) ........................153

Table 78. Overall Averages of $w / \mathrm{cm}$, Air Content, Fresh Concrete Density, and 28-day Compressive Strength of Concrete (Series 4)

Table 79. Coefficients for Prediction Models of Responses (Series 4) .......................160

Table 80. Mixture Proportions and Fresh Properties of Concrete (Series 6)...............161

Table 81. Compressive Strength of Concrete (in psi) (Series 6) ................................ 162

Table 82. Mixture Proportions and Fresh Properties of Concrete (Series 7)................168

Table 83. Compressive Strength of Concrete (in psi) (Series 7) ................................. 169

Table 84. Mixture Proportions and Fresh Properties of Concrete (Series 11).............174

Table 85. Compressive Strength of Concrete (in psi) (Series 11) ................................174

Table 86. Mixture Proportions and Fresh Properties of Concrete (Series 9 and 12)....177

Table 87. Test Methods, Specimens, and Test Ages (Series 9 and 12) .......................178

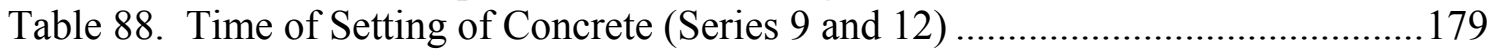

Table 89. Compressive Strength of Concrete (in psi) (Series 9 and 12) ....................180

Table 90. HRWRA Content and 28-day Compressive Strength of Concrete (Series 9 and 12)

Table 91. Average Residual-Strength of Concrete (Series 9 and 12).........................185

Table 92. Length Change of Concrete Due to Curing in Water Until the Age of 28 Days and Subsequent Drying in Air (in \%) (Series 9 and 12) ............................ 186

Table 93. Mass Loss of Concrete Due to Abrasion (in grams) (Series 9 and 12) ........188

Table 94. Relation between Ease of Repulping of Residuals and Freezing-and-Thawing Durability Factor of Concrete ................................................................. 192

Table 95. Ease of Repulping Residuals and Salt-Scaling Resistance of Concrete ....... 195

Table 96. Mixture Proportions and Fresh Properties for Prototype Field Mixtures ..... 196

Table 97. Time of Setting (Prototype Field Mixtures) ............................................. 196

Table 98. Compressive Strength of Concrete (Prototype Field Mixtures) ...................197

Table 99. Flexural Strength of Concrete (Prototype Field Mixtures)..........................198

Table 100. Mass Loss of Concrete Due to Abrasion (in grams) (Prototype Field

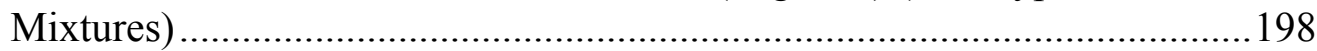

Table 101. Mixture Proportions and Fresh Properties of Concrete (Construction Demonstration) 201

Table 102. Compressive and Flexural Strengths of Concrete (Construction

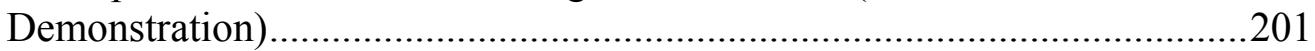

Table 103. Mass Loss of Concrete Due to Abrasion (Construction Demonstration)...202

Table 104. Test Setup for Two-Level Factorial Design (Series 14) ...........................204

Table 105. Mixture Names and Levels of Residuals and HRWRA (Series 14) ..........204

Table 106. Mixture Proportions and Fresh Properties (Series 14: $(-1,-1),(-1,+1)) . .205$

Table 107. Mixture Proportions and Fresh Properties (Series 14: $(+1,+1)) \ldots \ldots \ldots \ldots \ldots . . .205$

Table 108. Mixture Proportions and Fresh Properties (Series 14: $(+1,-1))$................206

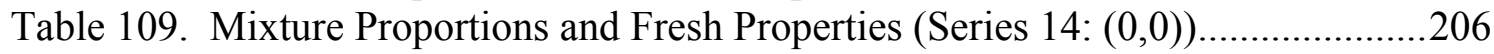

Table 110. Summary of Air Content of Concrete (in \%) (Series 14) ..........................207

Table 111. Summary of Density of Fresh Concrete (in $\left.\mathrm{lb} / \mathrm{ft}^{3}\right)$ (Series 14) ....................207

Table 112. Compressive Strength of Reference and H Concrete Mixtures (in psi) (Series

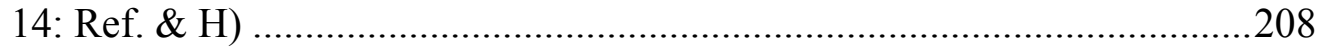


Table 113. Compressive Strength of Concrete with High Levels of Residuals and

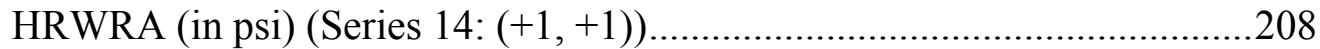

Table 114. Compressive Strength of Concrete with High Level of Residuals and Low Level of HRWRA (in psi) (Series 14: $(+1,-1))$..........................................208

Table 115. Compressive Strength of Concrete with Medium Levels of Residuals and HRWRA (in psi) (Series 14: $(0,0))$...........................................................208

Table 116. Summary of 3-day Compressive Strength of Concrete (in psi) (Series 14)209

Table 117. Summary of 7-day Compressive Strength of Concrete (in psi) (Series 14)209

Table 118. Summary of 28-day Compressive Strength of Concrete (in psi) (Series 14)

119. Mixture Proportions and Fresh Properties of Concrete (Series 15)

Table 120. Compressive, Splitting Tensile, and Flexural Strength of Concrete at 28-days

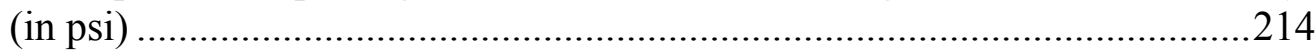

Table 121. Mixture Proportions and Fresh Properties of Concrete (Series 16)...........216

Table 122. Compressive Strength of Concrete (Series 16) (in psi) ...........................217

Table 123. Potential Annual Impact of the Use of Residuals in Concrete on U.S. State

Economies 229

Table 124. Potential Annual Impact of the Use of Residuals in Concrete on U.S.

National Economy. 230

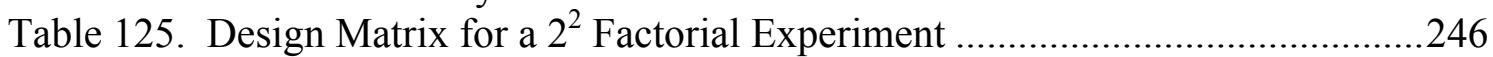

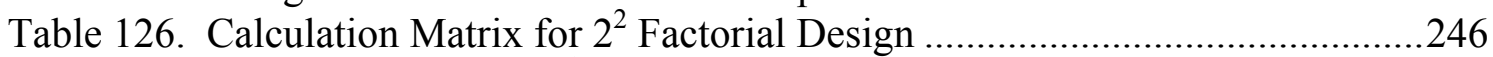

Table 127. Design Matrix for a $2^{3}$ Factorial Experiment ............................................247

Table 128. Calculation Matrix for $2^{3}$ Factorial Design ..............................................248

Table 129. Apparatus for Average Residual-Strength Test (ASTM C 1399) ..............252

Table 130. Proportions and Fresh Properties of Cement-Based Mixtures (Series 5) ...260

Table 131. Compressive and Flexural Strengths of Cement-Based Mixtures at 3 days

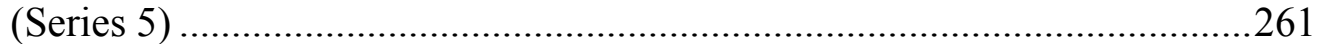

Table 132. Mixture Proportions and Fresh Properties of Concrete (Series 8: C2) .......262

Table 133. Mixture Proportions and Fresh Properties of Concrete (Series 8: WV).....262

Table 134. Mixture Proportions and Fresh Properties of Concrete (Series 8: S) ........263

Table 135. Mixture Proportions and Fresh Properties of Concrete (Series 8: BR) ......263

Table 136. Compressive Strength of C2 Concrete (in psi) (Series 8).........................265

Table 137. Compressive Strength of WV Concrete (in psi) (Series 8)........................265

Table 138. Compressive Strength of S Concrete (in psi) (Series 8) ............................266

Table 139. Compressive Strength of BR Concrete (in psi) (Series 8) ........................266

Table 140. Mixture Proportions and Fresh Properties of Concrete (Series 10)...........268

Table 141. Compressive Strength of Concrete (in psi) (Series 10) ...........................269

Table 142. Mixture Proportions and Fresh Properties of Concrete (Series 13: Set 1) .275

Table 143. Mixture Proportions and Fresh Properties of Concrete (Series 13: Set 2) .278

Table 144. Slump and Time of Flow of Fresh Concrete (Series 13: Sets $1 \&$ 2) ........280 


\section{LIST OF ACRONYMS AND ABBREVIATIONS}

ACI American Concrete Institute

ASTM American Society for Testing and Materials

NCASI National Council of the Paper Industry for Air and Stream Improvement, Inc.

TAPPI Technical Association of the Pulp and Paper Industry

$\begin{array}{ll}\text { AEA } & \text { Air-Entraining Admixture } \\ \text { F\&T } & \text { Freezing and Thawing } \\ \text { fl oz } & \text { fluid ounce } \\ \text { FRC } & \text { Fiber-Reinforced Concrete } \\ \text { HRWRA } & \text { High-Range Water-Reducing Admixture (also called superplasticizer) } \\ \text { LOI } & \text { Loss On Ignition } \\ \text { MC } & \text { Moisture Content } \\ \text { RH } & \text { Relative Humidity } \\ \text { SSD } & \text { Saturated Surface-Dry } \\ \text { TMP } & \text { Thermo-mechanical Pulp }\end{array}$




\section{ACKNOWLEDGMENT}

This material is based upon work supported by the U. S. Department of Energy under Award No. DE-FC07-00ID13867.

Major funding for the work was also provided by: National Council for Air and

Stream Improvement (NCASI), Research Triangle Park, NC; Weyerhaeuser Co., Federal Way, WA; and Stora Enso North America Co., Wisconsin Rapids, WI.

Additional support was provided by: Advance Cast Stone Co., Random Lake, WI; Best Block Co., Butler, WI; Fiber Clay Council, Darien, CT; Fox River Fiber Co., DePere, WI; New Berlin Redi-Mix Inc., New Berlin, WI; We Energies Co., Milwaukee, WI; Wisconsin Paper Council, Neenah, WI; and Wisconsin Public Service Corp., Green Bay, WI. In-kind funding and construction demonstration facilities were provided by County Concrete Inc., Biron, WI.

All these contributions are gratefully acknowledged.

The help provided by staff of the UWM Center for By-Products Utilization in data collection is gratefully acknowledged.

The UWM Center for By-Products Utilization was established in 1988 with a generous grant from the Dairyland Power Cooperative, La Crosse, WI; Madison Gas and Electric Company, Madison, WI; National Minerals Corporation, St. Paul, MN; Northern States Power Company, Eau Claire, WI; We Energies, Milwaukee, WI; Wisconsin Power and Light Company, Madison, WI; and, Wisconsin Public Service Corporation, Green Bay, WI. Their financial support and additional grants and support from Manitowoc Public Utilities, Manitowoc, WI, are gratefully acknowledged. 


\section{CHAPTER 1 EXECUTIVE SUMMARY}

\subsection{Background}

Each year (1995) over 15 million wet tonnes (or about 5.3 million dry tonnes) of pulp and paper mill effluent treatment solids (a.k.a. "sludge") containing useful fibers and natural chemicals are generated in the USA. About half of these solids is disposed in landfills. Assuming an average disposal cost of $\$ 30 /$ wet tonne, this translates into over a $\$ 225$ million/year cost to the industry. Some mills report disposal costs up to $\$ 100 /$ wet tonne. One quarter of the total generated residual solids is burned to reduce its volume for landfill disposal and extract energy, and one eighth is beneficially applied to land as a soil conditioner. The remaining one eighth is reused or recycled in miscellaneous applications. However, these options are not always feasible at many mills for various reasons, including air emissions concerns, or limited or rotating availability of farm lands. Disposal in landfills for such residuals remains the primary option for many pulp and paper mills, even though it may involve potential long-term environmental risks. Industrialists as well as environmentalists now agree that this is a lost opportunity for resource recovery. Therefore, it has become essential to find value-added constructive use options for these residuals. The residuals included in this study are primary treatment solids, and de-ink \& recycling solids from paper recycling. No current funding (1997) for this or other closely related project existed.

The proposed research program was to develop a new type of ready-mixed concrete using fibrous residuals from pulp and paper mill. Varying lengths of fibers available from such residuals should help lead to a reduction in the plastic and drying 
shrinkage cracks in the concrete. Based upon research data available, decreased cracking of concrete exposed to weather improves its durability and its life span. Earlier work by T. R. Naik in the states of Wisconsin and Washington had also concluded that judicious use of fibers leads to decreased cracking in concrete which increases the compressive strength, tensile strength, flexural strength, flexural-fatigue strength, and ductility (i.e., total energy required to failure or modulus of toughness) of the concrete. Many studies

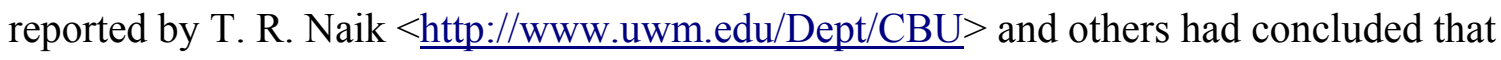
high-strength/high-performance/high-quality/high-durability concrete can be made only with selective use of concrete mixture proportions, including use of chemical admixtures, mineral additives, and fibers. Such concrete can be expected to last 100 years or more, rather than the normally accepted life span of 25 to 35 years. This proposed project is expected to at least double the life span of concrete structures through the addition of residual solids from pulp and paper mills. Initial work completed by T. R. Naik, using four different sources of residual solids, had shown that compressive strength can be increased up to 25 to 50 percent at the age of 7 to 28 days, with a corresponding increase in tensile strength. This is due to the fibers and chemicals available from pulp and paper mill residuals, which improve the microstructure of the ready-mixed concrete at the interface of the cement hydration products and the sand grain and/or coarse aggregate (stone) surface. Such new ready-mixed concrete with cellulose fibers can be used for increasing the life span of our nation's infrastructure, especially highways, roadways, and airport pavements because these structures are subjected to extreme forces of nature, constant assault by vehicles, and degradation by application of de-icing salts. 


\subsection{Project Objective}

This project was proposed to provide a practical solution to disposal problems for pulp and paper mill fibrous by-products and provide an economical source of fiber reinforcement for ready-mixed concrete production. The first year's project activities were directed toward optimizing mixture proportions and production technologies under controlled laboratory conditions. Fibrous residuals generated from pulp and paper mills were used. The second year's activities (Year 2) involved study of market acceptance as well as market barriers for the use of residual solids in the ready-mixed concrete. Economic impact was studied and additional specialized tests were conducted. The activities for the third year (Year 3) involved pilot-scale production and construction demonstration at a ready-mixed concrete manufacturing plant with concrete mixtures containing pulp and paper mill fibrous by-products.

Specifically, the goals of this project were:

(1) Monitor new literature and research for specifications and other requirements for concrete with residual solids.

(2) Collect laboratory performance data for high-strength/high-performance/highquality/high-durability concrete containing residual solids.

(3) Conduct tests for physical, chemical, and morphological properties of residual solids to ensure that the residual solids will have the desirable characteristics for the intended field application in various types of ready-mixed concrete production.

(4) Conduct a market study to understand market acceptance as well as market barriers for the use of residual solids in ready-mixed concrete. Evaluate economic impact. 
(5) Conduct specialized long-term and durability laboratory tests on concrete containing residual solids.

(6) Conduct field performance evaluation for production of ready-mixed concrete with residual solids and construction demonstration.

(7) Provide practical production and construction information to potential users, producers, engineers, owners, paper industry officials, government officials, and others regarding ready-mixed concrete with residual solids. Prepare information on various options for use, mixture proportioning, and results of a field demonstration. Conduct technology transfer workshop for products containing residual solids in conjunction with a field demonstration.

(8) Provide guidelines for mixture proportioning for production of ready-mixed concrete with residual solids for manufacturers.

(9) Produce draft specifications for residual solids use to guide pulp and paper mills, ready-mixed concrete producers, and other users in potential applications and to satisfy other requirements such as strength and durability.

(10) Work with selected pulp and paper mills to implement this new technology in their geographical area.

\subsection{Summary of the Findings of This Project}

Mixture proportions and productions technologies were developed in the laboratory for concrete containing fibrous residuals generated from pulp and paper mills.

Following laboratory investigation, prototype field concrete mixtures were manufactured at a ready-mixed concrete plant. A field construction demonstration was 
also held to demonstrate the production and placement of structural-grade frost-resistant concrete containing residual solids.

This project has shown that fibrous residuals from pulp and paper mills can be used as an economical and effective source of microfibers for reinforcement of readymixed concrete against attacks of freezing-and-thawing and salt-scaling. 


\subsection{Milestone}

Table 1. Milestone

\begin{tabular}{|c|c|c|c|c|c|}
\hline Task & Task / Milestone Description & Section & Page & $\begin{array}{c}\text { Planned } \\
\text { Completion } \\
\end{array}$ & $\begin{array}{c}\text { Actual } \\
\text { Completion } \\
\end{array}$ \\
\hline & Year $1(2000)$ & ב... & $\ldots$ & & \\
\hline 1 & $\begin{array}{l}\text { Background Feasibility and Literature } \\
\text { Search }\end{array}$ & 3 & 10 & $03 / 31 / 2000$ & $03 / 31 / 2000$ \\
\hline 2 & Characterization of Residual Solids & 4.7 & 62 & $07 / 31 / 2000$ & $07 / 31 / 2000$ \\
\hline 3 & $\begin{array}{l}\text { Development of Mixture Proportions } \\
\text { for Ready-Mixed Concrete and } \\
\text { Testing }\end{array}$ & 7.2 & 129 & $11 / 30 / 2000$ & $12 / 31 / 2000$ \\
\hline \multirow[t]{2}{*}{4} & Reporting for Year 1 & $\ldots$ & $\ldots$ & $12 / 31 / 2000$ & $12 / 31 / 2000$ \\
\hline & Year $2(2001)$ & $\ldots$ & & & \\
\hline 5 & Development of Market Study & 8 & 218 & $08 / 31 / 2001$ & $08 / 31 / 2001$ \\
\hline 6 & Economic Impact Study & 9 & 227 & $09 / 30 / 2001$ & $09 / 30 / 2001$ \\
\hline $7 *$ & $\begin{array}{l}\text { Durability and Long-Term Testing of } \\
\text { Manufactured Concrete }\end{array}$ & 7.3 & 176 & $12 / 31 / 2001$ & $12 / 31 / 2001$ \\
\hline 8 & $\begin{array}{l}\text { Evaluation of Effects of Variability of } \\
\text { Residual Solids }\end{array}$ & 4.7 & 62 & $11 / 30 / 2001$ & $12 / 31 / 2001$ \\
\hline 9 & $\begin{array}{l}\text { Residual Solids Utilization Criteria } \\
\text { and Specifications }\end{array}$ & 10 & 231 & $12 / 31 / 2001$ & $12 / 31 / 2001$ \\
\hline \multirow[t]{2}{*}{10} & $\begin{array}{l}\text { Initial Technology Transfer Activities } \\
\text { and Reporting }\end{array}$ & $\ldots$ & $\ldots$ & $12 / 31 / 2001$ & $12 / 31 / 2001$ \\
\hline & Year 3 (2002) & $\ldots$ &. & & \\
\hline 11 & $\begin{array}{l}\text { Manufacturing Concrete at a } \\
\text { Commercial Plant }\end{array}$ & 7.4 .1 & 195 & $07 / 31 / 2002$ & $08 / 31 / 2002$ \\
\hline 12 & $\begin{array}{l}\text { Construction Demonstration and Field } \\
\text { Performance Evaluation }\end{array}$ & 7.4 .2 & 200 & $08 / 31 / 2002$ & $11 / 30 / 2002$ \\
\hline 13 & $\begin{array}{l}\text { Long-Term Evaluation of Laboratory } \\
\text { Testing }\end{array}$ & 7.3 & 176 & $09 / 30 / 2002$ & $06 / 30 / 2002$ \\
\hline 14 & Evaluation of Field Construction & 0 & 195 & $11 / 30 / 2002$ & $07 / 31 / 2003$ \\
\hline 15 & Technology Transfer Activities & 7.4 .2 & 200 & $11 / 30 / 2002$ & $11 / 30 / 2002$ \\
\hline 16 & Final Project Report & $\ldots$ & $\ldots$ & $12 / 31 / 2002 \dagger$ & $09 / 18 / 2003$ \\
\hline
\end{tabular}

* Continued in Task 13.

$\dagger$ New date 09/28/2003. 


\subsection{Patents}

No Patents have been issued to-date for this project.

\subsection{Publications/Presentations}

The following are products developed under the award and technology transfer activities:

1. Naik, T. R., "Greener Concrete Using Recycled Materials," Concrete International (published by the American Concrete Institute [ACI]), Vol. 24, No. 7, July 2002, pp. 45-49.

2. Naik, T. R., Chun, Y., and Kraus, R. N., "Concrete Containing Pulp and Paper Mill Residuals," Presented at the ACI International Spring Convention, Vancouver, British Columbia, Canada, April 2003.

3. Naik, T. R., "Enhancing Strength and Durability of Concrete with Pulp and Paper Mill Residuals," Report No. CBU-2002-25, presented and published at the UWMCBU Workshop and Construction Demonstration for Use of Fibers from Paper Industry Residuals in Concrete, Wisconsin Rapids, WI, November 2002. 


\section{CHAPTER 2 INTRODUCTION}

Pulp and paper mill residual solids (also called sludge) are composed mainly of cellulose fibers, moisture, and papermaking fillers (mostly kaolinitic clay and/or calcium carbonate).

In 1995, U.S. pulp and paper industry generated about 5.3 million metric dry tons of mill wastewater treatment residuals, which is approximately equivalent to 15 million metric tons of wet residuals. About half of this was landfilled, a quarter was burned, and the rest was utilized in land application, recycle/reuse, and other beneficial use options [1]. Due to increasing cost of landfilling, increasingly stringent environmental regulations, and potential long-term environmental liabilities, the percentage of the residuals disposed of in landfills has decreased considerably over the years. However, still significant amount of residuals need to be diverted from landfilling.

Concrete is weak in tension (3-9 MPa). Wood cellulose fibers are strong in tension (300-900 MPa). Therefore, use of cellulose fibers in concrete should improve the usefulness of concrete.

The residual solids have a potential to become an economical source of cellulose fibers in concrete industry for micro-fiber reinforcement of concrete. To paper industry, this application could become an economical and beneficial alternative to landfilling or other use options.

The objectives of this research were to study technical, economical, and performance benefits of using pulp and paper mill residual solids in ready-mixed concrete and to establish optimum mixture proportions and production technology for concrete containing residual solids. 
Experimental approach included characterization of residual solids, development of mixture proportions, and evaluation of strength and durability of concrete containing residual solids based upon statistical experimental design and performance modeling.

Chapter 3 provides literature review on generation and management of residual solids, fiber-reinforced concrete, cellulose fibers, cellulose-fiber-reinforced cement-based sheet composites, concrete with cellulose fibers, and earlier limited work by Naik [2,3] and others on the use of pulp and paper mill residual solids in concrete and cement-based composites.

Chapter 4 deals with properties of materials used in this research. Physical, chemical, and morphological properties of residual solids are included.

Chapter 5 presents the results of deflocculating experiment on residual solids. Chapter 6 gives an overview of concrete specimen preparation and test methods. Chapter 7 presents concrete mixture proportions, test results, and discussions. Chapter 8 presents results of market study. Chapter 9 presents results of economic impact study. Chapter 10 presents guidelines for producing concrete containing residual solids. Chapter 11 gives summary, conclusions, and recommendations. 


\section{CHAPTER 3 LITERATURE REVIEW}

\subsection{Generation and Management of Pulp and Paper Mill Residual Solids}

\subsubsection{Pulp and Paper Industry Solid Residue}

The highest volume solid residues generated by the pulp and paper industry are wastewater treatment residuals and ash (from burning coal, wood/bark, and wastewater treatment residuals). Other solid residues include wood yard waste, pulping or papermaking rejects, causticizing wastes, broke, and general mill refuse [4].

\subsubsection{Wastewater Treatment Plant Residuals}

Pulp and paper mill wastewater treatment plant residuals, also called sludge, is the solid residue removed from mill wastewater before the water is discharge into the environment or reused in the mill. Residual is removed by two steps in the process of treating the wastewater $[4,5,6,7]$. Paper mill wastewater treatment process is schematically shown in Fig. 1.

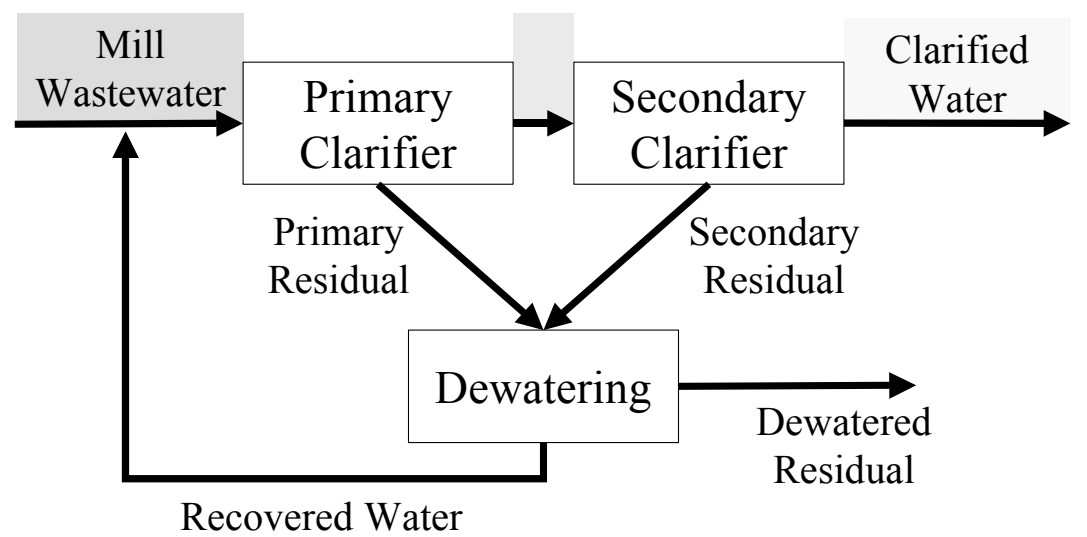

Fig. 1. Paper mill wastewater treatment process [6] 
Primary residual is the solids removed by the first stage of the wastewater treatment processing at the primary clarifier. Primary clarification is usually carried out by sedimentation and sometimes by dissolved air flotation. In sedimentation process, chemical additives are used to make non-settleable solids settleable through flocculation. Primary residual consists mainly of cellulose fibers and papermaking fillers (calcium carbonate, kaolinitic clay, and/or titanium dioxide). In some cases, ash generated at pulp and paper mill and inert solids rejected during chemical recovery processes become part of the primary residual. Typical composition of primary residual is shown Fig. 2.

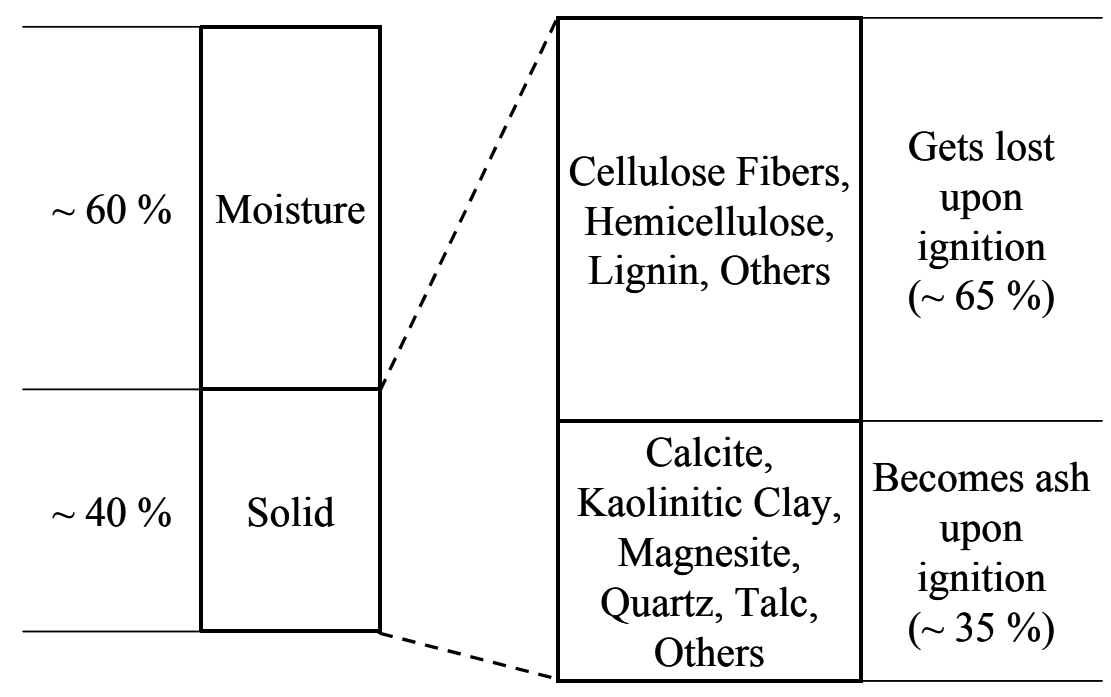

Fig. 2. Typical Composition of paper mill primary residual (\% by mass)

The water clarified by the primary treatment is passed on to the secondary treatment. Secondary treatment is usually a biological process in which micro-organisms convert soluble organic matter to carbon dioxide and water while consuming oxygen.

Secondary residual is mainly microbial biomass (also called biosolids) grown during this process and removed through clarification. 
In most cases, the residual solids are dewatered prior to disposal or beneficial use. In general, primary residuals are easy to dewater, while secondary residuals are difficult to dewater. Many times primary and secondary residuals are combined to facilitate dewatering of secondary residuals and also for easier handling of residuals.

Primary and secondary residuals are combined less often recently (2002) for adopting various recycling options.

\subsubsection{Quantities of Solid Residue}

Quantitative data on solid residue generation and management in the U.S. pulp and paper industry are available starting in 1975 for wastewater treatment residuals, and 1988 for all solid residue. The most current data are from 1995 [4]. The quantities of solid residue generated by the U.S. pulp and paper industry since 1975 are presented in Table 2 and Fig. 3.

Table 2. Quantities of Solid Residue Generated by the U.S. Pulp and Paper Industry Since 1975 [1, 4]

\begin{tabular}{|c|c|c|c|}
\hline \multirow{2}{*}{ Solid Residue Type } & \multicolumn{3}{|c|}{$\begin{array}{c}\text { Solid Residue Quantity } \\
\text { (million metric dry tons) }\end{array}$} \\
\cline { 2 - 4 } & 1975 & 1988 & 1995 \\
\hline \hline Wastewater Treatment Residuals & $\sim 3.5$ & 4.2 & 5.3 \\
\hline Ash* & $\ldots$ & 2.6 & 2.5 \\
\hline Other & $\ldots$ & 4.0 & 5.4 \\
\hline Total & $\ldots$ & 10.8 & 13.2 \\
\hline
\end{tabular}

* From burning coal, wood/bark, and wastewater treatment residuals. 


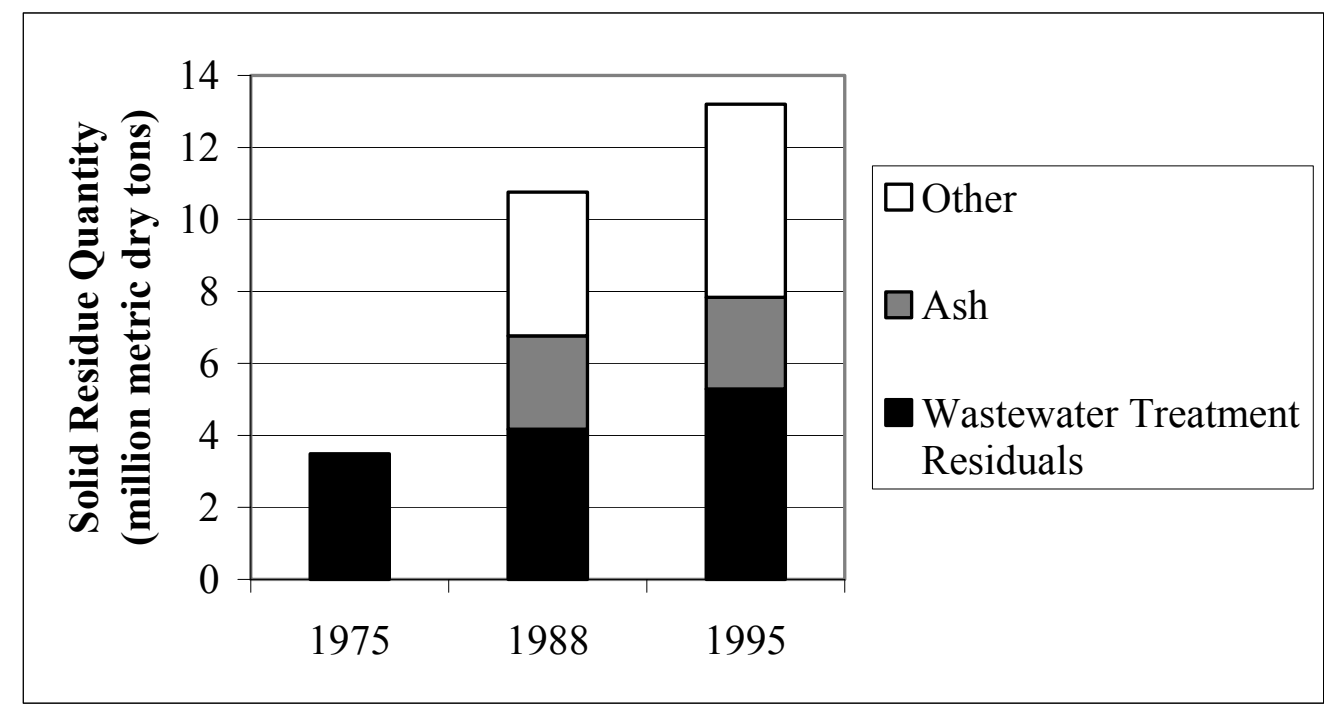

Fig. 3. Quantities of solid residue generated by the U.S. pulp and paper industry since $1975[1,4]$

\subsubsection{Generation and Management of Wastewater Treatment Residuals}

In 1995 , in terms of dry tonnage as generated, about $86 \%$ of the pulp and paper mill wastewater treatment residuals was primary residual, 9\% was secondary residual, and 5\% was intermittently dredged material [1].

In 1995 , in terms of dry tonnage as managed, $54 \%$ of the residuals was combined (primary plus secondary) residual, 40\% was primary residual, 5\% was intermittently dredged material, and 1\% was secondary residual. Average percentage of secondary residual (biosolids) in the combined residual was about 14\% [1].

In 1995 , about $90 \%$ of the wastewater treatment residual was subjected to dewatering before their disposal or beneficial use. Average solid content in dewatered residuals was about $34 \%$ by mass [1].

Management practices of residuals since 1979 are shown in Table 3 and Fig. 4. 
Table 3. Wastewater Treatment Residuals Management in the U.S. Pulp and Paper Industry Since $1979[1,4,5]$

\begin{tabular}{||l||c|c|c||}
\hline \multicolumn{1}{||c||}{$\begin{array}{c}\text { Management } \\
\text { Options }\end{array}$} & \multicolumn{3}{c||}{$\begin{array}{c}\text { Residuals As Managed } \\
\text { (\% based on dry mass) }\end{array}$} \\
\cline { 2 - 4 } & 1979 & 1988 & 1995 \\
\hline Landfill/Lagoon & 86 & 70 & 51 \\
\hline Burn & 11 & 21 & 26 \\
\hline Land Apply & 2 & 8 & 12 \\
\hline Recycle/Reuse & $<1$ & 1 & 5.6 \\
\hline $\begin{array}{l}\text { Other Beneficial } \\
\text { Use }\end{array}$ & $<1$ & $<1$ & 5.5 \\
\hline \hline
\end{tabular}

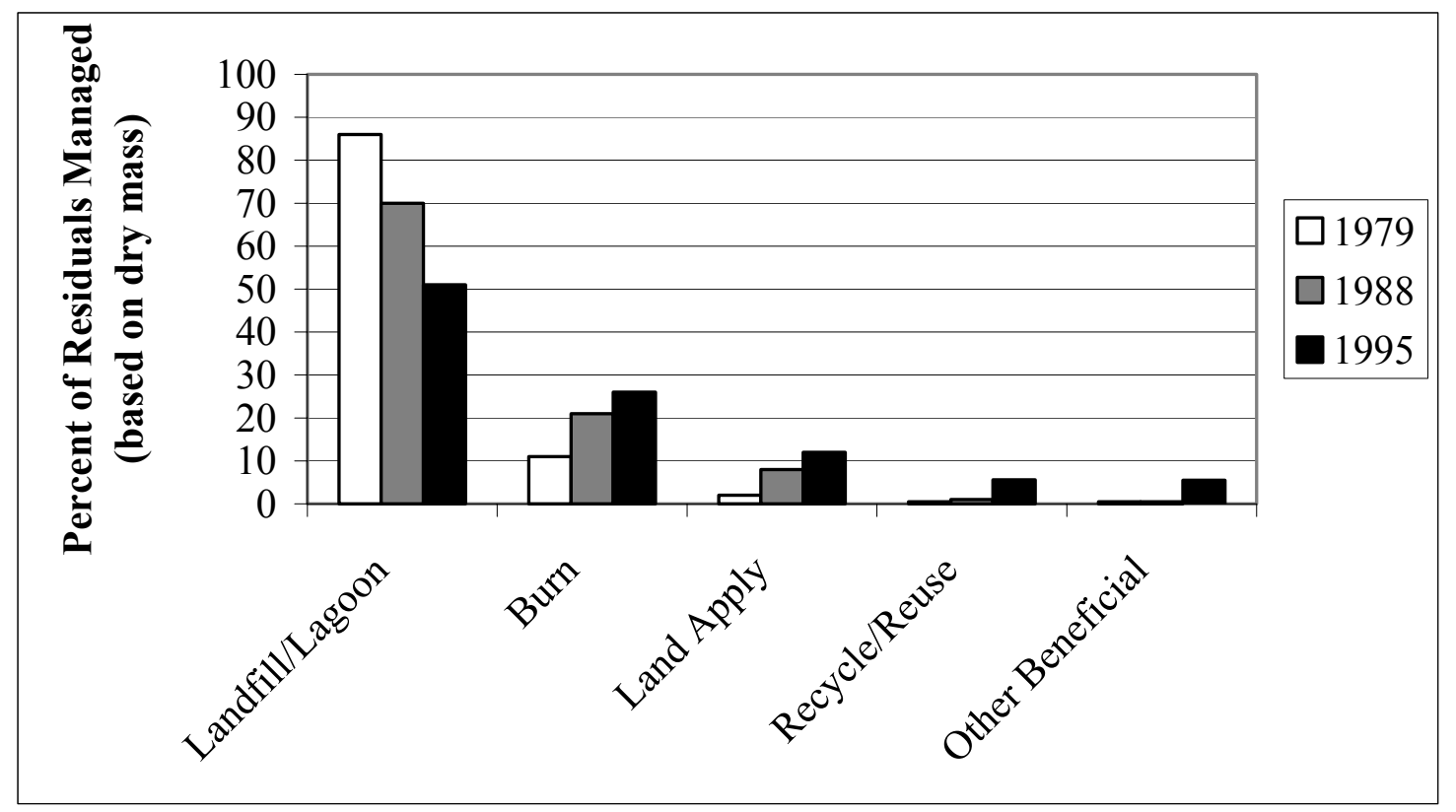

Fig. 4. Wastewater treatment residuals management in the U.S. pulp and paper industry since $1979[1,4,5]$

In 1995, about half of the wastewater treatment residuals was disposed in landfills/lagoons, a quarter was burned, one-eighth was applied on farmland/forest, onesixteenth was reused in mills, and the rest one-sixteenth was used in some other ways [1].

In 1995, about 0.43 million metric dry tons of ash was generated from burning paper mill wastewater treatment residuals [1]. Due to moisture present in dewatered 
residuals, there is typically little or low energy benefit. Burning is done primarily to reduce the mass and volume of residuals, and the resulting ash is usually (about $70 \%$ in '95) disposed in landfills.

Alternatives to land disposal, burning, land application, and recycle/reuse include landfill daily/final cover, composting, oil/grease absorbent granules, herbicide/pesticide carrier granules, mine-land/aggregate-pit reclamation, animal bedding/litter, molded products, pyrolysis, gasification, and lightweight aggregate $[7,8,9,10]$.

\subsection{Overview of Fiber-Reinforced Concrete (FRC)}

Steel fibers are sometimes used for applications such as airport runways, highways, bridge decks, hydraulic structures, industrial floors, etc. Steel fibers greatly improve toughness and impact resistance of concrete.

Toughness represents the energy absorption capacity of concrete. Flexural toughness can be determined by measuring the area under the load-deflection curve of a concrete beam subjected to flexural load. Impact resistance represents the energy absorption capability of concrete subjected to impact load. A method of measuring impact resistance of concrete involves subjecting a concrete disk to repeated blows of impact loading and counting the numbers of blows that cause first visible crack and then failure of the concrete disk [11].

Glass fibers are used for thin-section applications. However, glass fibers can be damaged during mixing process. Also, there may be a long-term durability problem associated with the use of glass fibers. Polymeric fibers are used either as asbestos fibercement replacement or for special applications. They have the disadvantage of poor 
bonding characteristics and/or high price. Carbon fibers are more expensive than other types of fibers.

Natural fibers are cheaper than man-made fibers $[12,13,14]$. Cellulose fibercement composites offer high strength to cost ratio [13, 14, 15, 16, 17].

\subsubsection{Introduction}

Without reinforcement, a cement-based matrix is brittle and possesses very low tensile strength. By incorporating fibers into a cement matrix, its toughness and tensile strength, as well as deformation characteristics can be improved.

\subsubsection{Principles of Fiber-Reinforced Concrete}

Fiber-reinforced cement composites possess improved tensile strength, flexural strength, ductility, and crack control capacity. These properties are influenced by: (1) physical properties of the fiber and cement matrix; and (2) strength of bond between the fiber and cement matrix.

Major differences between conventionally reinforced system and fiber-reinforced system are:

(1) Fibers are distributed throughout a given cross section whereas reinforcing bars are placed only where needed.

(2) Fibers are short and closely spaced compared with reinforcing bars, which are long and continuous.

(3) Generally a fiber-reinforcing system has a lower reinforcement ratio (area of reinforcement to area of concrete) than conventionally steel reinforced concrete. 
Practical design methods for fiber-reinforced concrete have been based on actual experimental test data acquired from parametric investigations.

\section{Advantages and Disadvantages of Fiber-Reinforced Concrete (FRC)}

Because of two-dimensional (2-D) or three-dimensional (3-D) random fiber orientation, only a small percentage of fiber content may be efficient in resisting tensile or flexural stresses. Efficiency factor can be as low as 0.4 for 2-D random orientation and 0.25 for 3-D random orientation. The efficiency factor depends on fiber diameter and critical embedment length. From a conceptual point of view, reinforcing with fibers is not highly efficient in improving tensile strength [12].

Fiber-reinforced concrete is best suited for thin-section shapes where correct placement of conventional reinforcement would be extremely difficult. In addition, spraying of FRC accommodates the fabrication of irregularly shaped products.

\subsubsection{Types of Fibers and Their Properties}

There are synthetic organic (e.g. polypropylene, carbon), synthetic inorganic (e.g. steel, glass), natural organic (e.g. cellulose, sisal), and natural inorganic (e.g. asbestos) fibers. Due to health hazards, asbestos-cement products are rapidly being replaced by other cement-based composites throughout the world. Their use in the USA is now nonexistent. Selected fiber types and their properties are listed in Table 4. 
Table 4. Selected Fiber Types and Their Properties [12]

\begin{tabular}{|c|c|c|c|c|c|}
\hline Fiber type & $\begin{array}{l}\text { Diameter } \\
(\mathrm{mm})\end{array}$ & $\begin{array}{l}\text { Specific } \\
\text { Gravity }\end{array}$ & $\begin{array}{l}\text { Young's } \\
\text { modulus } \\
(\mathrm{GPa})\end{array}$ & $\begin{array}{c}\text { Tensile } \\
\text { strength } \\
(\mathrm{MPa})\end{array}$ & $\begin{array}{l}\text { Strain at } \\
\text { failure } \\
(\%)\end{array}$ \\
\hline $\begin{array}{l}\text { Steel } \\
\text { High tensile } \\
\text { Stainless }\end{array}$ & $\begin{array}{l}0.100-1.000 \\
0.010-0.330\end{array}$ & $\begin{array}{l}7.80 \\
7.80\end{array}$ & $\begin{array}{l}200 \\
160\end{array}$ & $\begin{array}{c}350-1700 \\
2100\end{array}$ & $\begin{array}{l}3.5 \\
3.0\end{array}$ \\
\hline $\begin{array}{l}\text { Glass } \\
\text { E } \\
\text { Alkali resistant (AR) }\end{array}$ & $\begin{array}{l}0.010 \\
0.013\end{array}$ & $\begin{array}{l}2.50 \\
2.70\end{array}$ & $\begin{array}{l}72 \\
80\end{array}$ & $\begin{array}{l}3500 \\
2500\end{array}$ & $\begin{array}{l}4.8 \\
3.6\end{array}$ \\
\hline $\begin{array}{l}\text { Polymeric } \\
\text { Polypropylene } \\
\text { Monofilament } \\
\text { Fibrillated } \\
\text { Polyethylene } \\
\text { Polyester } \\
\text { Acrylic } \\
\text { Aramid } \\
\text { Kevlar } 29 \\
\text { Kevlar } 49\end{array}$ & $\begin{array}{l}0.100-0.200 \\
0.500-4.000 \\
0.025-1.000 \\
0.010-0.075 \\
0.005-0.020\end{array}$ & $\begin{array}{l}0.90 \\
0.90 \\
0.96 \\
1.38 \\
1.18\end{array}$ & $\begin{array}{c}5 \\
3 \\
5-170 \\
10-17 \\
18 \\
\\
60 \\
120\end{array}$ & $\begin{array}{c}450 \\
550-760 \\
200-3000 \\
550-1200 \\
200-1000 \\
\\
3600 \\
3600\end{array}$ & $\begin{array}{c}18 \\
8 \\
3-80 \\
10-50 \\
28-50 \\
\\
3.6 \\
2.5\end{array}$ \\
\hline $\begin{array}{l}\text { Asbestos } \\
\text { Crocidolite } \\
\text { Chrysotile } \\
\end{array}$ & $\begin{array}{c}0.0001-0.020 \\
0.00002-0.030\end{array}$ & $\begin{array}{l}3.40 \\
2.60\end{array}$ & $\begin{array}{l}200 \\
160\end{array}$ & $\begin{array}{c}200-1800 \\
3500\end{array}$ & $\begin{array}{l}2-3 \\
2-3\end{array}$ \\
\hline $\begin{array}{l}\text { Carbon } \\
\text { I (high modulus) } \\
\text { II (high strength) }\end{array}$ & $\begin{array}{l}0.008 \\
0.009 \\
\end{array}$ & $\begin{array}{l}1.90 \\
1.90 \\
\end{array}$ & $\begin{array}{l}380 \\
230 \\
\end{array}$ & $\begin{array}{r}1800 \\
2600 \\
\end{array}$ & $\begin{array}{l}0.5-0.7 \\
1.0-1.5 \\
\end{array}$ \\
\hline $\begin{array}{l}\text { Natural } \\
\text { Wood cellulose }\end{array}$ & $0.020-0.120$ & 1.50 & $10-40$ & $300-900$ & \\
\hline
\end{tabular}

\subsubsection{Steel-Fiber-Reinforced Concrete (SFRC)}

\section{Steel Fibers}

Carbon steel fibers are the primary type of steel fibers used in steel-fiber-reinforced concrete (SFRC). Stainless steel fibers are used for high-temperature applications. 


\section{Types of SFRC and Fabrication Methods}

\section{Conventionally Mixed SFRC}

Generally, steel-fiber-reinforced concrete (SFRC) is mixed and placed by conventional means. Conventionally mixed SFRC has been mainly used in airport pavements as overlay for repair and in new construction. SFRC has also shown potential for use in highways, bridge decks, industrial floors, and hydraulic structures. SFRC has higher tensile and flexural strengths and greater impact resistance and toughness compared with plain concrete. By using SFRC, joint spacing can be increased and crack widths can be reduced.

\section{Sprayed SFRC (Shotcrete)}

Sprayed SFRC is well suited to thin-layer applications. It has been often used for rock slope stabilization, tunnel linings, etc.

\section{Slurry Infiltrated Fiber Concrete (SIFCON)}

SIFCON is produced by placing fibers in a form or mold and pumping fine-grained cementitious materials slurry into the bed of fibers. Steel fiber contents as high as $18 \%$ by volume has been used. Applications are cost effective in structures subject to severe service conditions, where high strength and ductility are required.

\section{Mixture Proportioning}

Uniform dispersion of fibers and sufficient workability of mixture must be ensured.

\subsubsection{Glass-Fiber-Reinforced Concrete (GFRC)}

GFRC is principally used in thin-sections, where high strength and impact resistance are required. GFRC are fabricated either by spray-up process or premix process. Glass fibers could become damaged during fabrication. 
Initially GFRC typically possess considerable load and strain capacity beyond the cracking strength (or proportional elastic limit, PEL). However, for many exposure conditions, modulus of rupture (MOR) of GFRC eventually decreases to the level of PEL.

\subsubsection{Polymeric-Fiber-Reinforced Concrete}

Polypropylene fibers are very cost competitive with other types of fibers. However, they have poor bond with the cement matrix, a low melting point, and combustibility.

Polyester fibers can be used to inhibit shrinkage cracking as an alternative to steel wire-mesh.

Aramid fibers are more expensive than other types of polymeric fibers and have been used primarily as an asbestos replacement in certain high-stress applications.

\subsubsection{Carbon-Fiber-Reinforced Concrete (CFRC)}

Compared with plain concrete, CFRC can show as high as $400 \%$ increase in tensile strength, $100 \%$ increase in impact strength, and reduction in creep strain. However, carbon fibers are substantially more expensive than other types of fibers.

\subsubsection{Natural-Fiber-Reinforced Concrete}

\section{Wood-Cellulose-Fiber-Reinforced Concrete}

Wood consists of cellulose, hemi-cellulose, and lignin. The process by which wood is reduced to a fibrous mass is called pulping. Mechanical, chemical, semi-chemical, and thermo-mechanical pulping processes have been used to extract cellulose fibers from wood. 
Lignin has an adverse effect on the strength of cellulose fibers. De-lignified cellulose fibers can be produced using a chemical pulping process.

\section{Fabrication}

Most common and effective methods for producing thin-sheet products involve mixing cellulose fibers with cement slurry at high water content and then vacuum dewatering the mixture.

Sugar or other organic impurities from the fibers can retard or even completely inhibit concrete set. Using delignified fibers produced by chemical pulping processes can eliminate this chemical interaction.

\section{Properties of Wood-Cellulose-Fiber-Reinforced Concrete}

Reinforcing with wood cellulose fibers can increase flexural strength and flexural toughness.

Cellulose fiber-cement composites subjected to repeated cycles of wetting and drying have shown decrease in flexural toughness.

Moisture content of cellulose fiber-cement composites significantly influences mechanical properties of such composites. Lower moisture content causes increase in fiber-matrix bond, which in turn causes increase in flexural strength and decrease in flexural toughness. On the other hand, fiber pullout failure mode at higher moisture content results in greater composite ductility and toughness.

Improvements in the bond between cellulose fibers and the cement matrix can be realized by coating the fibers with coupling agents such as alkoxides of titanium, titanates, and silanes. 


\subsection{Steel- or Carbon-Microfiber-Reinforced Cement Pastes and Mortars}

Properties of cement pastes and mortars reinforced with microfibers, other than cellulose fibers, are reviewed in this section. Only the results that are most relevant to the current project are reviewed.

A group of researchers conducted a series of investigations on mechanical properties and durability of steel- or carbon-microfiber-reinforced cement pastes and mortars $[18,19,20]$.

Properties of the steel and the carbon micro-fibers used in the investigations are presented in Table 5. Properties of virgin wood cellulose fibers [12,21] are also presented for comparison.

Table 5. Properties of Microfibers [12, 18, 19, 20, 21]

\begin{tabular}{|l|c|c|c|}
\hline \multirow{2}{*}{ Properties } & \multicolumn{3}{c|}{ Type of Microfibers } \\
\cline { 2 - 4 } & Steel & Carbon & $\begin{array}{c}\text { Virgin Wood } \\
\text { Cellulose }\end{array}$ \\
\hline Length, $L(\mathrm{~mm})$ & 3 & 10 & $2-4$ \\
\hline Diameter, $D(\mu \mathrm{m})$ & $12.6^{*}$ & 18 & $\begin{array}{c}22-40 \\
(14-26) \dagger\end{array}$ \\
\hline Aspect Ratio, $L / D$ & 238 & 556 & $\begin{array}{c}90-100 \\
(140-155) \dagger\end{array}$ \\
\hline Specific Gravity & 7.85 & 1.65 & $1.50 \dagger$ \\
\hline Tensile Strength $(\mathrm{MPa})$ & 600 & 600 & $300-900$ \\
\hline Modulus of Elasticity $(\mathrm{GPa})$ & 200 & 30 & $10-40$ \\
\hline
\end{tabular}

$*$ Equivalent diameter. Actual cross-section $=5 \mu \mathrm{m} \times 25 \mu \mathrm{m}$.

$\uparrow$ Using equivalent diameter when cellulose fibers are collapsed (flat crosssection $)\left(D_{\text {equiv. }}=\operatorname{sqrt}(4 t(D-t))=\sim 0.65 D\right.$, using fiber wall thickness $(t)$ of about $0.12 D$ ).

† On oven-dry basis. 
It is noteworthy that the steel and carbon micro-fibers are comparable to cellulose fibers in many aspects. The steel micro-fibers are comparable to cellulose fibers in length, diameter, aspect ratio, and tensile strength, but had higher specific gravity ( 7.85 vs. 1.50 ) and modulus of elasticity (200 GPa vs. $10-40 \mathrm{GPa}$ ) than cellulose fibers.

The carbon micro-fibers were similar to cellulose fibers in diameter, specific gravity, tensile strength, and modulus of elasticity, but were longer (10 mm vs. $2-4 \mathrm{~mm}$ ) and slender $(L / D$ : 556 vs. $90-160)$ than cellulose fibers.

Steel micro-fibers and carbon micro-fibers had no significant influence on compressive strength, drying shrinkage, and chloride-ion penetration resistance of mortars [18]. As far as air void system characteristics were concerned, microfiberreinforced mortars showed much higher air content, generally somewhat higher specific surface, and considerably lower spacing factor than non-reinforced mortars.

Use of the micro-fibers significantly improved freezing-and-thawing (F\&T) resistance (Table 6) and deicer-salt scaling resistance (Table 7) of mortars [18]. Higher resistance to cycles of F\&T was manifested as lower expansion of mortar bars, and higher resistance to cycles of F\&T under deicer-salt solution was manifested as less surface scaling of mortar slabs. The positive influence of the micro-fibers on F\&T resistance was attributed to suppression of crack propagation by the micro-fibers. The improvement of the $\mathrm{F} \& \mathrm{~T}$ resistance and the salt-scaling resistance was also attributed in part to the "air entrainment" properties of the microfibers. 
Table 6. Freezing-and-Thawing Damage of Mortars [18]

\begin{tabular}{|l|c|c|}
\hline $\begin{array}{c}\text { Microfiber } \\
\text { Type }\end{array}$ & $\begin{array}{c}\text { Microfiber } \\
\text { Content } \\
(\text { vol. \%) }\end{array}$ & $\begin{array}{c}\text { Avg. Length Change } \\
\text { after 300 Cycles } \\
(\mu \mathrm{m} / \mathrm{m})\end{array}$ \\
\hline None & 0 & $>5080$ \\
\hline Steel & 1 & 930 \\
\hline Carbon & 2 & 34 \\
\hline
\end{tabular}

Table 7. Deicer-Salt Scaling of Mortars [18]

\begin{tabular}{|l|c|c|}
\hline $\begin{array}{c}\text { Microfiber } \\
\text { Type }\end{array}$ & $\begin{array}{c}\text { Microfiber } \\
\text { Content } \\
(\text { vol. } \%)\end{array}$ & $\begin{array}{c}\text { Avg. Scaled-Off Mass } \\
\text { after 50 Cycles } \\
\left(\mathrm{kg} / \mathrm{m}^{2}\right)\end{array}$ \\
\hline None & 0 & 1.45 \\
\hline Steel & 1 & 0.33 \\
& 2 & 0.14 \\
\hline Carbon & 1 & 0.20 \\
& 2 & 0.15 \\
\hline
\end{tabular}

In a subsequent research [19], batching of paste and mortar mixtures was done under vacuum in order to minimize the volume of air entrapped by microfibers. The pastes showed very low air content $(0.1-0.5 \%)$.

As for the mortars batched under vacuum, they showed lower air content, lower specific surface, and higher spacing factor compared with the mortars made in the previous investigation. Air content increased with microfiber content. The microfibers had no clear and systematic influence on specific surface and spacing factor.

Steel-microfiber-reinforced pastes and mortars showed generally somewhat higher compressive strength than unreinforced pastes and mortars.

The use of micro-fibers (especially carbon fibers) significantly reduced the deterioration of pastes and mortars due to cycles of freezing and thawing (Table 8). The micro-fibers also significantly reduced deicer-salt scaling of pastes and mortars (Table 9). 
Table 8. Freezing-and-Thawing Damage of Pastes and Mortars [19]

\begin{tabular}{|l|l|c|c|}
\hline $\begin{array}{c}\text { Specimen } \\
\text { Type }\end{array}$ & $\begin{array}{c}\text { Microfiber } \\
\text { Type }\end{array}$ & $\begin{array}{c}\text { Microfiber } \\
\text { Content } \\
(\text { vol. \%) }\end{array}$ & $\begin{array}{c}\text { Avg. Length Change } \\
\text { after 300 Cycles } \\
(\mu \mathrm{m} / \mathrm{m})\end{array}$ \\
\hline \multirow{4}{*}{ Paste } & None & 0 & $*$ \\
\cline { 2 - 4 } & Steel & 2 & 6520 \\
& Carbon & 5 & 5550 \\
\hline \multirow{3}{*}{ Mortar } & None & 0 & 1860 \\
\cline { 2 - 4 } & Steel & 1 & $*$ \\
\cline { 2 - 4 } & Carbon & 1 & 4650 \\
& & 2 & 3860 \\
\hline
\end{tabular}

* Specimens destroyed before the end of the test.

Table 9. Deicer-Salt Scaling of Pastes and Mortars [19]

\begin{tabular}{|l|l|c|c|}
\hline $\begin{array}{c}\text { Specimen } \\
\text { Type }\end{array}$ & $\begin{array}{c}\text { Microfiber } \\
\text { Type }\end{array}$ & $\begin{array}{c}\text { Microfiber } \\
\text { Content } \\
(\text { vol. \%) }\end{array}$ & $\begin{array}{c}\text { Avg. Scaled-Off Mass } \\
\text { after 50 Cycles } \\
\left(\mathrm{kg} / \mathrm{m}^{2}\right)\end{array}$ \\
\hline \multirow{4}{*}{ Paste } & None & 0 & 5.6 \\
\cline { 2 - 4 } & Steel & 2 & 1.0 \\
& Carbon & 5 & 0.3 \\
\hline \multirow{4}{*}{ Mortar } & None & 0 & 0.2 \\
\cline { 2 - 4 } & Steel & 1 & 5.3 \\
\cline { 2 - 4 } & Carbon & 1 & 1.3 \\
& & 2 & 1.6 \\
\hline
\end{tabular}

Again the improvement of F\&T and salt-scaling resistance was attributed to the ability of micro-fibers to reduce the rate of crack propagation [19].

Addition of steel micro-fibers resulted in significant improvement of flexural toughness of cement pastes and moderate improvement of flexural toughness of cement mortars (Table 10) [20]. The toughness index of steel-microfiber-reinforced pastes was twice as high as that of unreinforced pastes. The toughness index of mortars increased with microfiber content. 
Table 10. Toughness Index of Pastes and Mortars [20]

\begin{tabular}{|c|c|c|}
\hline \multirow{2}{*}{$\begin{array}{c}\text { Steel Microfiber Content } \\
\text { (vol. \%) }\end{array}$} & \multicolumn{2}{|c|}{ Toughness Index } \\
\cline { 2 - 3 } & Paste & Mortar \\
\hline 0 & 1.0 & 1.3 \\
\hline 2.5 & 2.0 & 1.4 \\
\hline 5 & 2.0 & 1.7 \\
\hline
\end{tabular}

\subsection{Overview of Pulp and Paper Technology}

\subsubsection{Introduction}

\section{Pulp and Paper}

Paper is a felted sheet formed on a fine screen from wood fibers suspended in water.

Paper also contains non-fibrous additives.

Pulp is the fibrous raw material for papermaking and usually of vegetable origin.

\section{Pulp and Paper Operations}

As shown below, pulp and paper mill utilizes wood residuals as the basic raw material:

Logs $\rightarrow$ Wood Mill $\rightarrow$ Highest value lumber, plywood, and particleboard

$$
\text { Wood residuals } \rightarrow \text { Pulp } \rightarrow \text { Paper }
$$

\section{Papermaking Fibers}

Papermaking fibers must be conformable (i.e. capable of being matted and pressed into a uniform sheet) and must develop strong bond at the points of contact.

Wood is the most abundant source of papermaking fibers. Some characteristics of wood cellulose fibers are presented in Table 11. 
Table 11. Average Length, Average Diameter, and Length-Diameter Ratio of Wood Pulp Fibers [21]

\begin{tabular}{|c|c|c|c|}
\hline Fiber & $\begin{array}{c}\text { Avg. Length, L } \\
(\mathrm{mm})\end{array}$ & $\begin{array}{c}\text { Avg. Diameter, D } \\
(\mu \mathrm{m})\end{array}$ & Aspect Ratio, L/D \\
\hline Softwood (coniferous) & 4.0 & 40 & 100 \\
\hline Hardwood (deciduous) & 2.0 & 22 & 90 \\
\hline
\end{tabular}

Vegetable fibers are embedded in a matrix of lignin, hemicellulose, resins and gums. Pulping processes free the fibers from the lignin matrix.

\section{Fiber Chemistry}

\section{Cellulose}

Cellulose determines the character of the fiber. Cellulose is a polymer of glucose. The chemical formula for cellulose is $\left(\mathrm{C}_{6} \mathrm{H}_{10} \mathrm{O}_{5}\right)_{\mathrm{n}}$, where $n$ is the number of repeating glucose units or the degree of polymerization (DP). Degree of polymerization values of native cellulose fibers and papermaking fibers are about 3500 and 600-1500, respectively (Table 12).

Table 12. Degree of Polymerization Values [21]

\begin{tabular}{|c|c|}
\hline Native cellulose (in-situ) & 3500 \\
\hline Commercial wood pulps & $600-1500$ \\
\hline
\end{tabular}

Under acidic conditions, pure cellulose can be hydrolyzed to glucose $\left(\mathrm{C}_{6} \mathrm{H}_{10} \mathrm{O}_{6}\right)$. Decreasing the DP of cellulose molecules below a certain level decreases the strength of the cellulosic materials.

Fig. 5 illustrates the microscopic and submicroscopic structure of the cellulose fiber. 


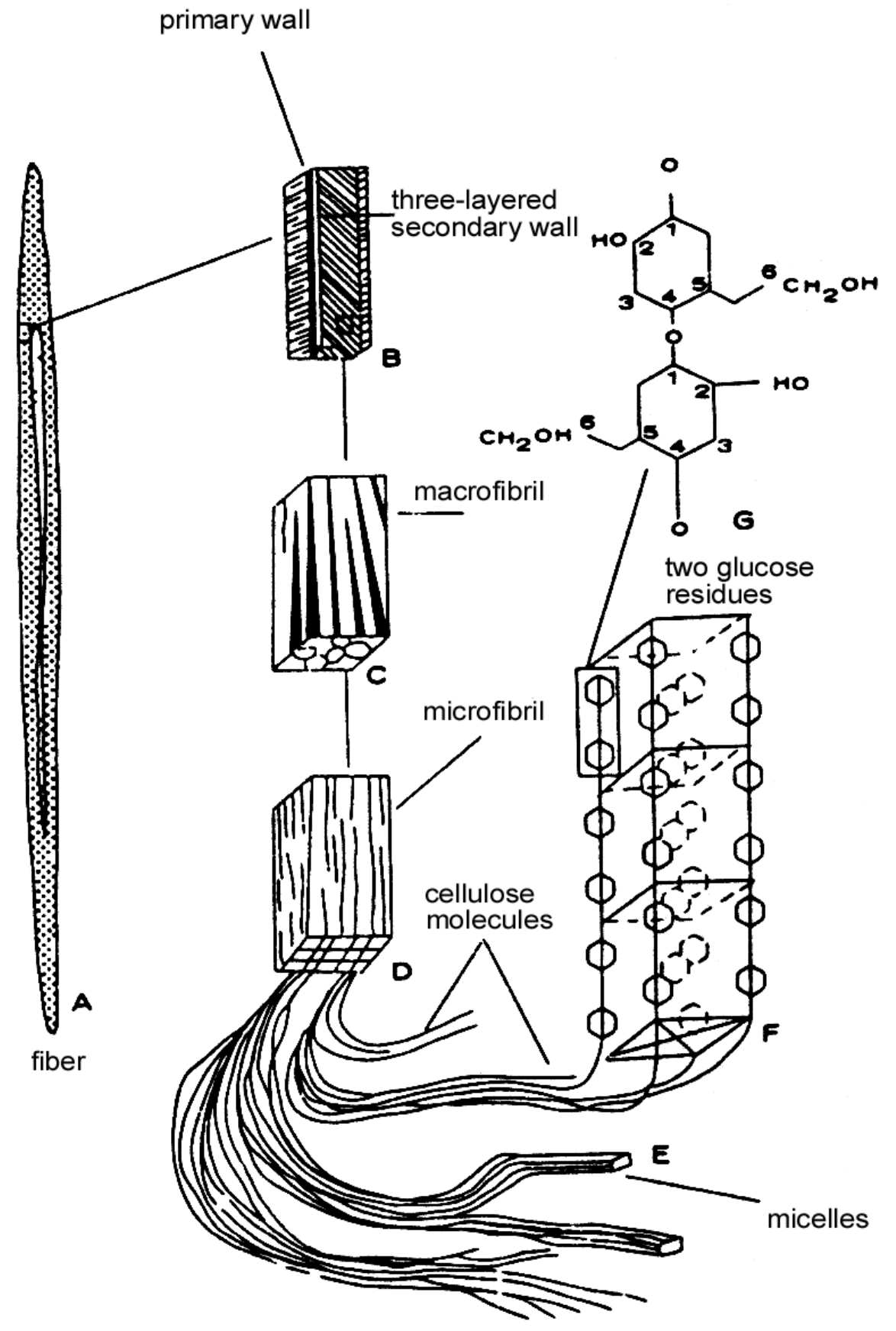

Fig. 5. Microscopic and submicroscopic structure of cellulose fiber [21]

\section{Hemicelluloses}

Fig. 6 illustrates the chemical composition of wood. Hemicelluloses are

polysaccharides of five different sugars (glucose, mannose, galactose, xylose, arabinose).

Compared with cellulose, hemicelluloses are more easily degraded and dissolved. 


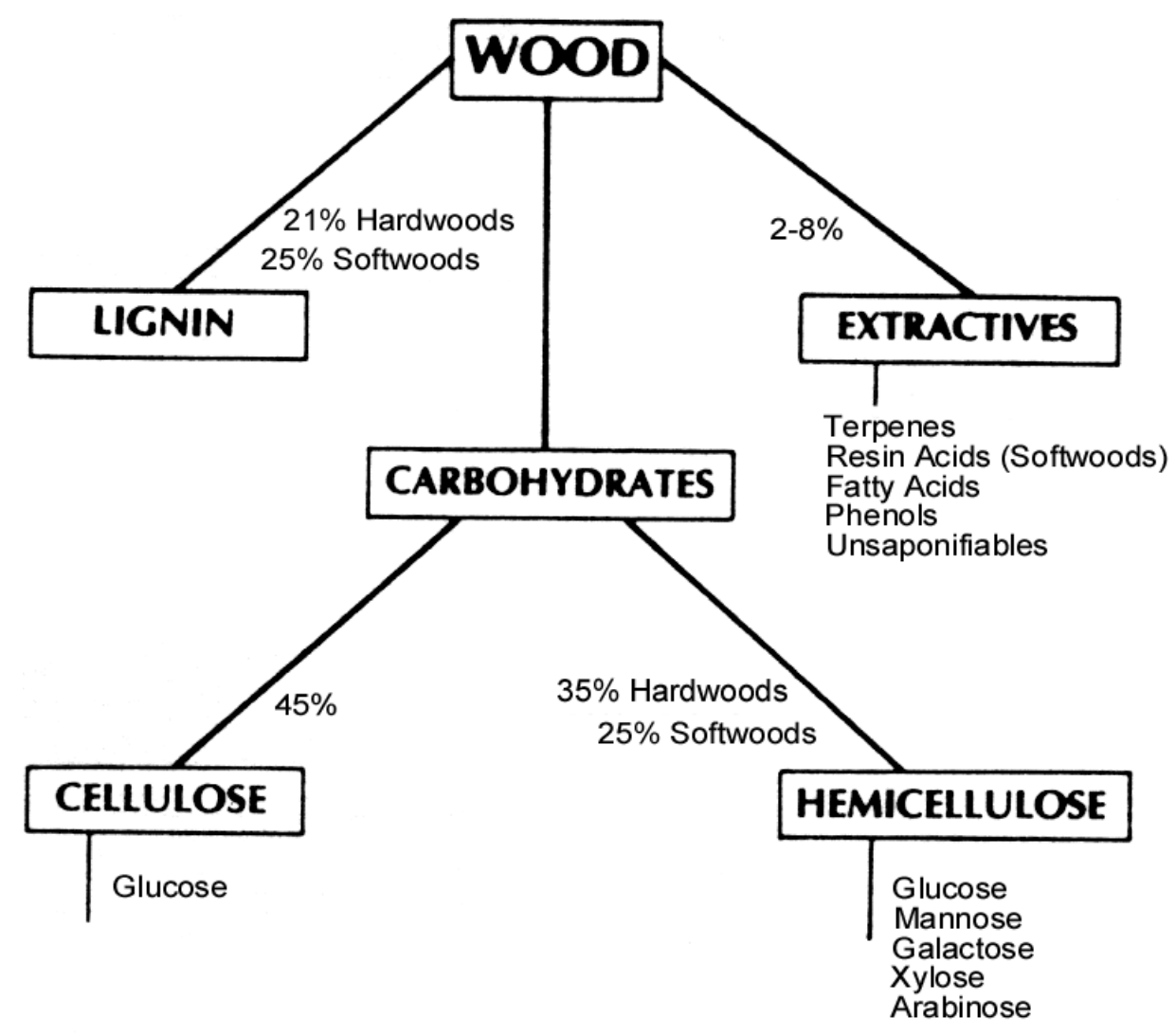

Fig. 6. Chemical composition of wood [21]

\section{Lignin}

In addition to cellulose and hemicellulose, woody plants contain an amorphous, highlypolymerized non-carbohydrate substance called lignin. It forms the middle lamella of the cellulose fiber and the intercellular material that cements (i.e. glues) the fibers together.

\section{Extractives}

Extractives include resin acids (in softwoods), fatty acids, terpenes, phenols, and alcohols.

\section{Papermaking Properties of Cellulosic Fibers}

Papermaking properties of cellulosic fibers become optimum when most of the lignin is removed while substantial amounts of hemicellulose are retained. Also, properties of 
fibers improve by a mechanical treatment (i.e. beating or refining). A mechanical treatment removes the thin, relatively impermeable primary fiber walls and causes the fibers to take water into the structure and swell. This increases flexibility and bonding power of fibers. Beating or refining optimizes bonding but reduces individual fiber strength.

Wood fibers are hydrophilic. Such fibers absorb water readily and are dispersed easily in water. Bonding between wet fibers is promoted by the polar attractions of the water molecules $\left(\mathrm{H}^{+}-\mathrm{O}^{2-}-\mathrm{H}^{+}\right)$for each other and for the hydroxyl $\left(\mathrm{O}^{2-}-\mathrm{H}^{+}\right)$groups covering the cellulose surface. Upon evaporation of water from a formed sheet, the hydroxyl groups on opposing fiber surfaces link together by hydrogen bonds. Hydrogen bonds are indicated as dotted lines in Fig. 7.

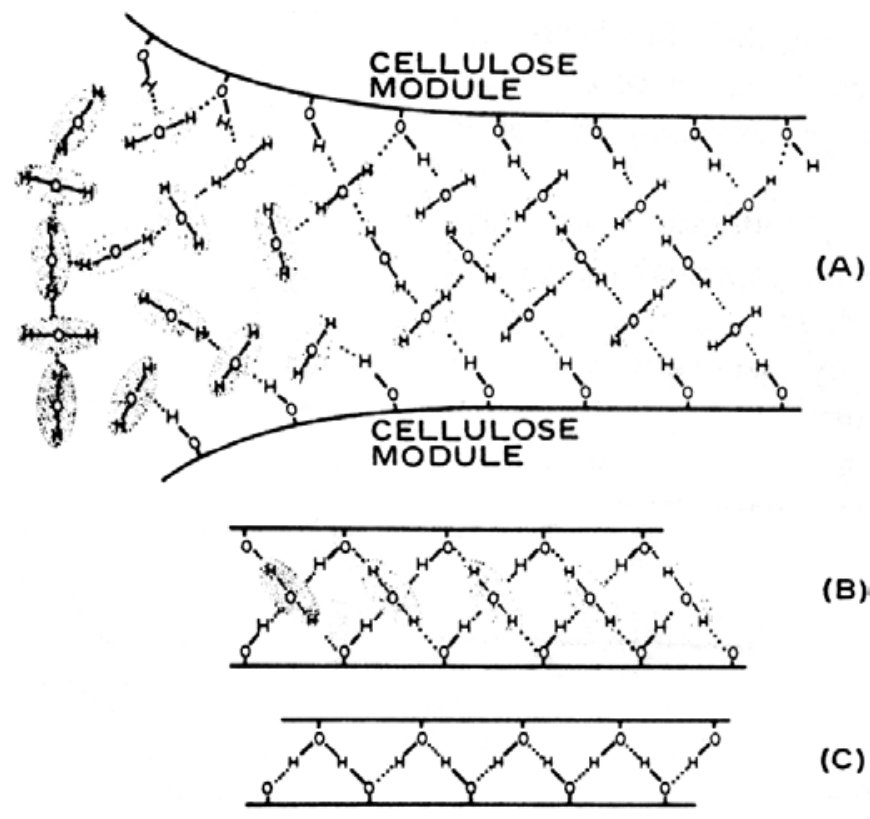

Fig. 7. Different levels of hydrogen bonding of cellulose fibers: (A) loosely through water molecules; (B) more tightly through a mono-layer of water molecules; (C) directly [21] 


\subsubsection{Characteristics of Wood and Wood Pulp Fibers}

Wood provides over $90 \%$ of the world's virgin fiber requirement for papermaking. Onethird of paper products are recycled into secondary fiber [21]. The recycling rate has gone up to $70 \%$ most recently (1999).

\section{Tree Structure}

Fig. 8 shows the structure of a tree trunk.

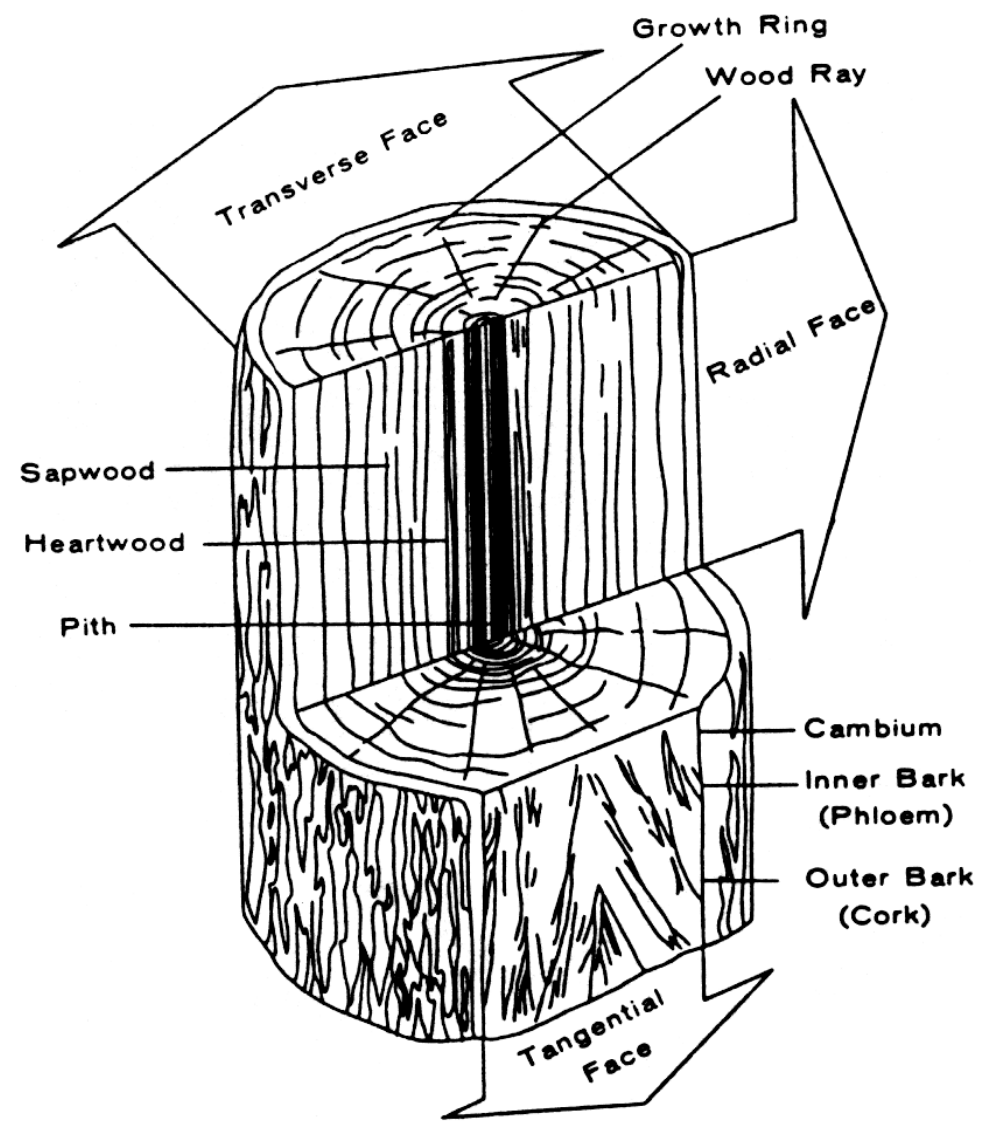

Fig. 8. Tree structure [21]

Wood is generated through cell divisions of vascular cambium. Enlargement, wall thickening, and lignification of cells follow cambium division. 
The cambium is a thin layer of tissue between the inner bark and the sapwood. In temperate climates, the rate of cambial growth varies with the seasons. Thin-wall fiber cells (earlywood) are produced in the spring and more dense thick-wall fiber cells (latewood) are produced in the fall.

\section{Characteristics of Wood}

Woods are classified into two major groups: softwoods (or conifers) and hardwoods (or broad-leafed trees).

\section{Softwoods}

The vertical structure of softwoods is composed of long, tapering cells called tracheids.

The density of the latewood (or summerwood) tissue is two to three times that of the earlywood (or springwood) tissue. Latewood and early wood are shown in Fig. 9. The specific gravity of cell wall itself is about 1.5 on oven-dry basis.

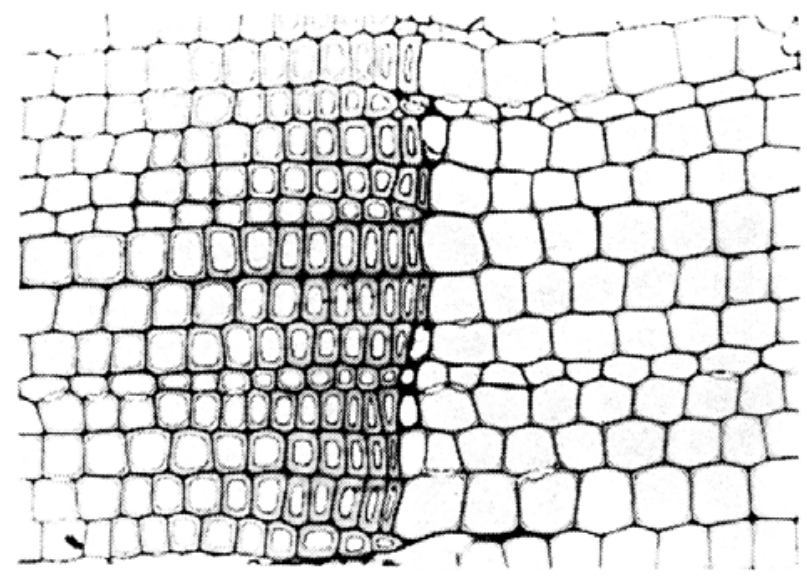

Fig. 9. Latewood and early wood on the cross-section of Douglas Fir [21]

The wall of a tracheid or fiber is composed of several layers (Table 13 and Fig. 10). Each layer has specific alignments of microfibrils. Douglas fir fibers are shown in Fig. 11 . 
Table 13. Structure of Softwood

Tracheid (diameter: 20-40 $\mu \mathrm{m})$ [21]

Middle Lamella (ML)

- bond between fibers, lignin

Primary Wall (P)

- 0.05- $\mu \mathrm{m}$ thick, relatively impermeable covering

Secondary Wall (S)

- $\mathrm{S}_{1}: 0.1-0.2 \mu \mathrm{m}$ thick

- $\mathrm{S}_{2}: 2$ to $10 \mu \mathrm{m}$ thick, main body of the fiber

- $\mathrm{S}_{3}: 0.1 \mu \mathrm{m}$ thick

Lumen (L)

- the central canal of fiber

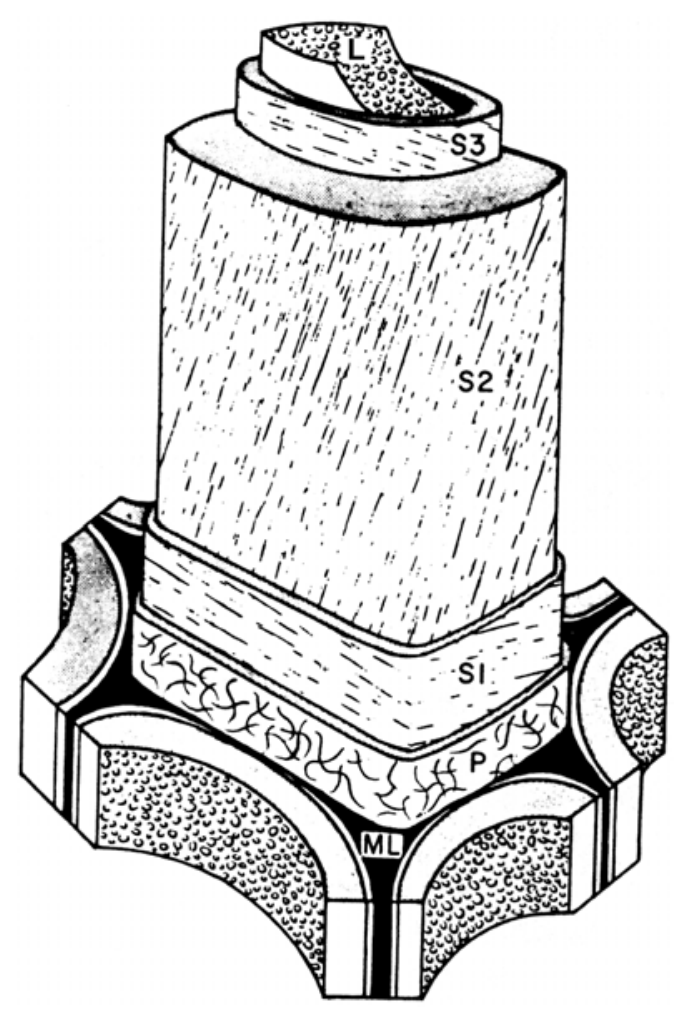

Fig. 10. Cell wall structure of tracheid [21]

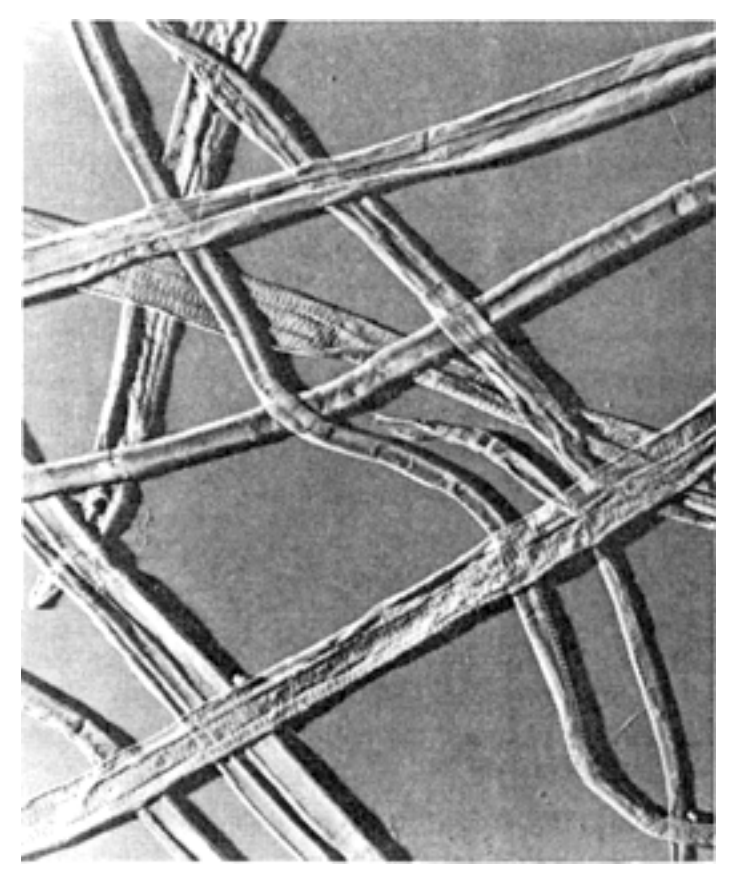

Fig. 11. Douglas Fir fibers [21] 


\section{Hardwoods}

The vertical structure of hardwoods is composed of long, narrow cells, called libriform fibers, and short, wider cells, called vessels.

\section{Softwoods vs. Hardwoods}

The softwood fibers are typically two to three times as long as hardwood fibers (Fig. 12).
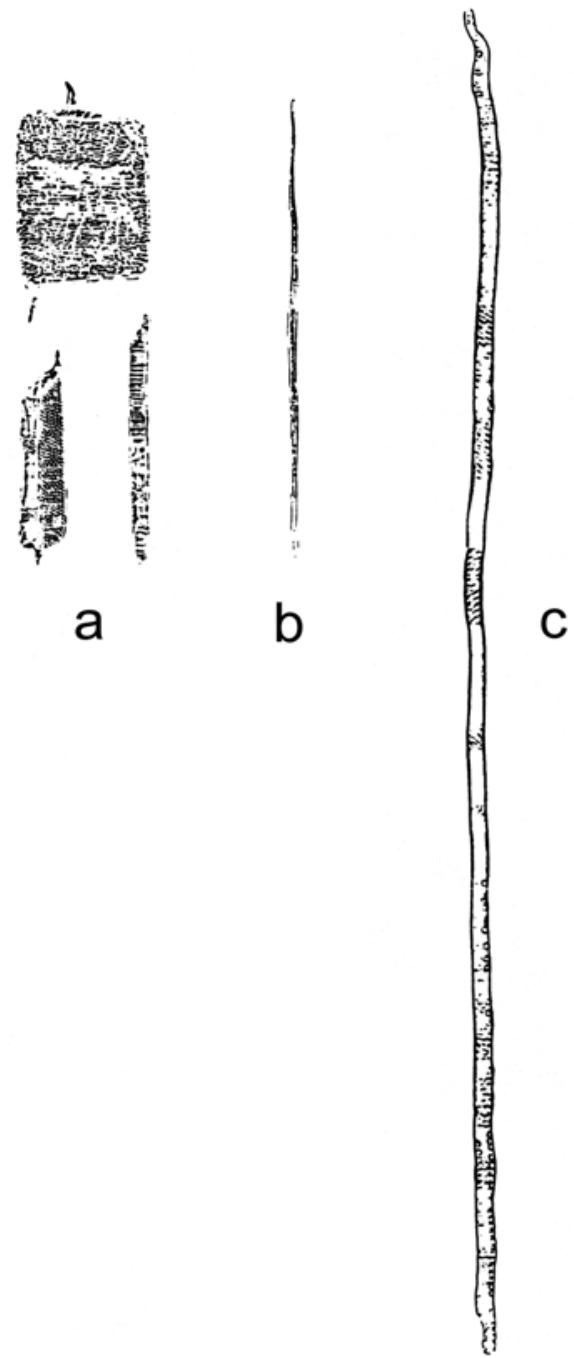

Fig. 12. Hardwood and softwood cells:

(a) hardwood vessel segments, (b) hardwood libriform fiber, and (c) softwood tracheid [21] 


\subsubsection{Overview of Pulping Methods}

Pulping is a process by which wood is reduced to a fibrous mass. It is a process that ruptures the bonds within the wood structure. Commercial pulping processes are classified as mechanical, chemical, and semichemical (Table 14).

Table 14. Pulping Processes [21]

\begin{tabular}{|c|c|c|}
\hline Mechanical & Semichemical & Chemical \\
\hline $\begin{array}{l}\text { By mechanical energy } \\
\text { (small amount of chemicals } \\
\text { and heat) }\end{array}$ & $\begin{array}{l}\text { Combination of chemical } \\
\text { and mechanical pulping }\end{array}$ & $\begin{array}{l}\text { By chemicals and heat } \\
\text { (little or no mechanical } \\
\text { energy) }\end{array}$ \\
\hline Yield*: $85-95 \%$ & Yield: $55-85 \%$ & Yield: $40-55 \%$ \\
\hline $\begin{array}{l}\text { Short, weak, unstable, } \\
\text { impure fibers }\end{array}$ & $\begin{array}{l}\text { Intermediate properties, } \\
\text { some unique properties }\end{array}$ & $\begin{array}{l}\text { Long, strong, stable } \\
\text { fibers }\end{array}$ \\
\hline Good print quality & Intermediate quality & Poor print quality \\
\hline $\begin{array}{ll}\text { - } & \text { stone groundwood } \\
\text { - } & \text { refiner mechanical pulp } \\
\text { - } & \text { thermomechanical pulp }\end{array}$ & $\begin{array}{ll}\text { - } & \text { neutral sulfite } \\
\text { - } & \text { high-yield kraft } \\
\text { - } & \text { high-yield sulfite }\end{array}$ & $\begin{array}{ll}\text { - } & \text { kraft (alkaline) } \\
\text { - } & \text { sulfite (acidic) } \\
\text { - } & \text { soda }\end{array}$ \\
\hline
\end{tabular}

* Yield: weight of pulp / weight of wood (oven-dry basis)

Newsprint is traditionally composed of $75 \%$ mechanical pulp groundwood and $25 \%$ chemical pulp. Mechanical pulps are usually produced from softwood species.

In North America, chemical pulping accounts for $70 \%$ of pulp production. The kraft (alkaline) process is the dominant form of chemical pulping. Kraft process produces highest strength pulp.

In chemical pulping, lignin degrades and dissolves away and most cellulose and hemicellulose are left behind in the form of intact fibers.

In addition to virgin fibers, there are secondary fibers, which are produced by recovering usable pulp fibers from various waste paper sources. 


\section{Comparison of Pulp Properties and Application}

If pulp is dried prior to papermaking, irreversible internal bonds are formed. The fiber becomes stiffer and stronger internally, but becomes less capable of swelling and bonding to other fibers.

Mechanical pulp has been used mainly for newsprint and coated printing paper grades.

Chemical bleaching or brightening has little effect on mechanical properties of wood cellulose fibers. All chemical pulps need to be mechanically worked to develop optimum papermaking properties.

Softwood kraft pulps produce the strongest papers. They are used for wrapping, sack, and box-liner papers. Bleached kraft fibers are added to newsprint to strengthen the sheet.

Sulfite pulps are used in bond, writing, and reproducing papers where good formation and moderate strength are required.

\subsubsection{Reduction of Water Pollution}

Typical mill wastes are initially weakly toxic before discharge and become essentially non-toxic following biological treatment. However, certain pulp effluent constituents are toxic (e.g., resin acids, unsaturated fatty acids, chlorinated phenolics).

Entrapment of fibers in the gill tissue of fish can cause infection and suffocation. Accumulation of organic material in water causes the growth of anaerobic bacteria and other undesirable life forms. 


\section{Primary Treatment}

Primary treatment is the methodology for removing suspended solids from mill effluents.

\section{Sedimentation}

Sedimentation can be done in any holding pond. Higher efficiencies of suspended solids removal are possible through use of additives because they make non-settleable solids settleable through flocculation.

\section{Flotation Clarifiers}

Dissolved air flotation is a process where fine air bubbles become attached to the suspended particles, thus causing them to float to the surface ready to be skimmed off.

\section{Secondary Treatment}

Secondary treatment is a biological treatment that is carried out under controlled conditions and usually at accelerated rates. Aeration lagoon, activated sludge, and biological filter methods are used.

\section{Solids Handling}

The sludge from primary treatment and/or biological treatment must be concentrated (i.e. water content minimized) before final disposition. The sludge can be thickened to 40$45 \%$ solids (i.e. $60-55 \%$ water) in one operation.

In general, primary sludges are easy to dewater, while biological sludges are difficult to dewater.

\section{Landfilling}

Usually landfilling is the ultimate disposal method for residuals (i.e. sludges).

The environmental problem associated with landfilling is the potential for leachate contamination of ground water. Usually, disposal in wetlands, flood plains, 
perma-frost zones, watersheds, and critical habitats is prohibited. Stricter controls are being applied in all areas by state environmental agencies and US-EPA.

\subsection{Cellulose-Fiber-Reinforced Cement-Based Composites}

\subsubsection{Introduction}

Since the end of the 19th century, asbestos-cement has had a wide range of applications, such as corrugated roofing elements, pipes, and tiles. However, because of the wellknown health risks involved with the use of asbestos fibers, there has been considerable research for the development of new high-performance reinforcing fibers.

Although cellulose fibers have relatively poor mechanical properties compared with man-made fibers, they have the advantage of low-cost and low-energy demand [13, 22].

\subsubsection{Production of Cellulose-Fiber-Reinforced Cement-Based Composites}

The basic constituents of cellulose fiber-cement sheet composites are virgin cellulose fibers and a cementitious binder. Fine aggregate (e.g. ground silica) may also be added [14]. Coarse aggregates are not used.

The manufacturing procedure can be categorized as either molding or slurrydewatering.

\section{Molding procedure}

The molding procedure is similar to that used for the production of conventional mortars. The products are manufactured manually by molding followed by rolling or other surface treatment $[13,14]$. 


\section{Slurry-dewatering procedure}

In slurry-dewatering procedure, cement composite sheets reinforced with cellulose fibers are produced through industrial production by the Magnani or Hatschek processes. Initially, slurry with high-water content is produced to achieve higher fiber content and uniform fiber dispersion, and then the extra water is removed through the application of vacuum and pressure $[13,14,22]$.

\section{Curing}

Either normal moist curing or autoclaving can be used [23].

\subsubsection{Strength of Different Types of Wood Fibers}

Springwood fibers have a thin-walled structure compared with thick-walled summerwood fibers. Summerwood fibers have higher strength than springwood fibers [24].

Mechanical pulp fibers are weaker than chemical pulp fibers.

Among chemical pulp fibers, kraft (alkaline) process fibers are always stronger than sulfite (acid) process fibers. Kraft fibers are the dominant type of cellulose fibers used in cement-based materials [13].

\subsubsection{Time of Setting and Curing of Cement in the Presence of Cellulose Fibers}

Hardwood hemicellulose has an inhibitory effect on the time of setting of cement.

Starches, sugars, tannins, and certain phenols are also inhibitory [13]. These compounds tend to prolong the setting times. 


\section{Mechanical Pulp Fibers}

Mechanical pulps, which contain higher lignin and hemicellulose contents than kraft pulps, may require attention for preventing the dissolving of lignin in the alkaline environment of cement. Time of setting tends to increase in the presence of mechanical fibers [14].

\section{Kraft and Other Chemical Pulp Fibers}

The chemical pulping process produces a low yield of partially collapsed, delignified fibers. These fibers have little effect on the time of setting and curing of the cement [13]. Kraft fibers have not developed durability problems in past applications [14]. Time of final setting tends to increase slightly in the presence of kraft fibers [14].

\section{Bleaching of Fibers}

Unbleached fibers contain various amounts of lignin, and can, therefore, inhibit the time of setting and curing of cement. Bleaching the fibers increases both the elastic modulus and flexural strength but reduces the specific work of fracture [13].

\subsubsection{Beating (or refining) of Fibers}

Mechanically beaten fibers have exposed fibrils on their surfaces, which improve mechanical bonding and tend to prevent the loss of cement particles during the suction stage of slurry-dewatering. Refining improves the proportional elastic limit (PEL) and the modulus of rupture (MOR) at some expense to the fracture toughness.

Freeness (TAPPI 207) test can give a measure of fiber refinement. The test measures the rate at which a suspension of three gram of pulp in one-liter water may be drained. The rate depends upon the quantity of debris present, the degree of fibrillation 
of fibers, their flexibility, and fineness. The higher the value of the freeness, the lesser would be the refinement $[25,26,27]$.

\subsubsection{Properties of Cellulose Fiber-Cement Composites}

\section{General}

Cellulose fiber reinforcement leads to increased water content (necessary for the desired workability), void content, water absorption, and reduced specific gravity of cementitious materials $[14,15,28]$

The compressive strength drops with increasing cellulose fiber content [14].

The mode of failure of cellulose fiber-cement composites in flexure consists of a complex combination of multiple cracking, fiber debonding, stress redistribution to secondary cracks, fiber pullout, fiber fracture, and a shift of the tensile zone towards the compressive zone through the specimen thickness [29].

The limit of linearity or proportionality (LOP) or point of elastic limit (PEL) in flexural test is consistent with the development of the first matrix microcrack (typically, 1 $\mu \mathrm{m}$ width) [30].

Defined as the area under the flexural load-deflection curve, fracture toughness is a material property, which may be as desirable as flexural strength [14]. The origin of fracture toughness is mainly fiber pullout, which is associated with the frictional energy dissipation $[25,26,28,31]$. The area under the post-crack load-deflection curve is more important than the total area, which includes the triangular area before cracking. This triangular area is proportional to first-cracking strength $(\mathrm{A}=\sim 1 / 2 \mathrm{x}$ load at first-crack $\mathrm{x}$ 
deflection at first-crack) and has little to do with toughness. Using the total area alone can be misleading.

By reducing the sand content, flexural strength can be increased, though at a reduced toughness [26].

Improvement of flexural strength and toughness over plain mortar has been reported for cellulose fiber-cement composites with $2 \%$ fibers by mass. This improvement was more pronounced with the use of kraft fibers than mechanical fibers [32].

Up to $500 \%$ increase in the flexural strength and even greater increase in fracture toughness of fiber-cement composites has been reported with the use of kraft pulp at a fiber mass fraction of $2 \%$ [14].

Composites containing softwood kraft pulp and hardwood kraft pulp can produce comparable flexural strength and toughness [26].

Increased fiber content leads to slight increase in flexural strength and substantial increase in toughness; but reduction in PEL has been noticed [24, 25, 26]

\section{Cracking Characteristics}

When ring-type specimens were used for restrained shrinkage-cracking tests, concrete reinforced with 0.5 percent cellulose fiber by volume showed excellent performance in controlling shrinkage cracking (maximum crack width was about one-third of that of plain mortar) [33].

\section{Moisture Sensitivity}

Recently developed cellulose fiber-cement composites have dry strength levels similar to asbestos-cement sheets. However, flexural strength, tensile strength, and modulus of 
elasticity of cellulose fiber-cement composites decrease when the composites are wet. Normally, increases in impact strength and flexural toughness can be observed upon wetting [13].

Microstructural studies indicated that wetting leads to increased tendency toward fiber pullout rather than rupture of fibers. There appears to be more microcracking of the composites under load in wet conditions $[25,26,28,30]$.

\section{Long-Term Durability}

\section{Natural Aging}

No evidence is available to indicate that natural fibers can become decomposed biologically when used in cement-based materials [14, 34].

The strain capacity of the composites decreases with time [13]. Exposure of naturally cured or autoclaved cellulose fiber-cement composites to natural weathering led to an overall increase in flexural strength, tensile strength, modulus of elasticity, and moisture movement with age, while flexural toughness decreased [35, 36].

Upon natural weathering, bond between the fibers and cement matrix improved $[29,30]$.

Higher relative humidity and higher moisture content caused rapid carbonation of cellulose fiber cement-based composites. Painting the fiber cement sheet virtually eliminated carbonation [36].

Some of the cellulose fiber-reinforced cement sheets that were produced and used during World War II in Denmark are still in service. They show good strength retention after 50 years of natural weathering [13]. 
Recently, rapid deterioration (within two or three years) for one brand of wood fiber-cement shingles in service was reported. Petrified fibers and extensive cracking and delamination of shingles were observed [37].

\section{Accelerated Aging}

After accelerated aging in the laboratory, flexural toughness of cellulose-fiber-reinforced cement composites was almost lost; the shape of flexural load-deflection curve of the composites became like that of plain mortar (Fig. 13) [15, 32].

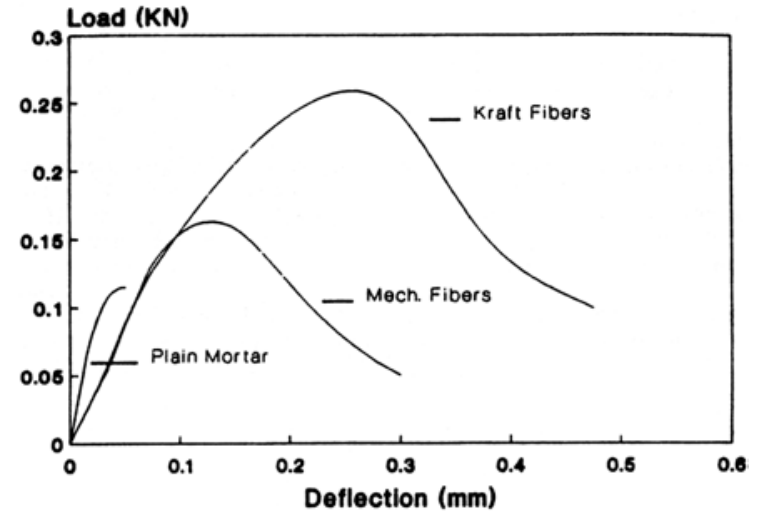

Unaged (0 cycle of wetting-drying)

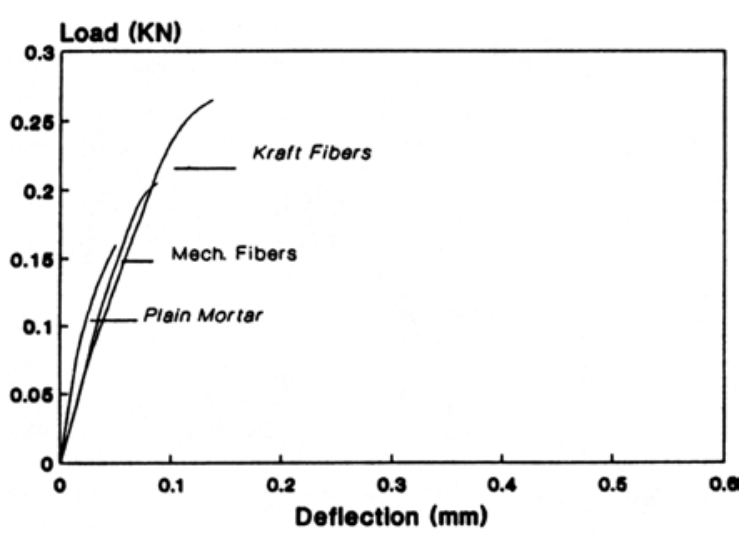

Aged (120 cycles of wetting-drying)

\section{Fig. 13. Change of flexural load-deflection curves of cellulose fiber-cement} composites due to accelerated weathering [32]

Repeated wetting and drying in $\mathrm{CO}_{2}$-rich environment seems to be the most

effective accelerated aging method for reproducing the natural aging process $[34,35,38]$.

Accelerated aging in a $\mathrm{CO}_{2}$-rich environment for three months simulated closely the chemical and mechanical property development of a 5-year-old naturally weathered product [35].

The dominant mode of fracture in composites aged in $\mathrm{CO}_{2}$-rich environment was fiber fracture because of the petrifaction of fibers and densification of interface zone, while un-aged specimens showed fiber pullout or a combination of fiber pullout and fiber 
fracture. In un-aged specimens, the matrix around the fibers was not extremely dense $[32,38]$.

The formation of calcium carbonate through the carbonation of calcium hydroxide and its deposition in fiber cores and on fiber-matrix interfaces seem to be responsible for the embrittlement of the composites [38].

Accelerated wetting-drying and hot-water soaking of cellulose fiber-cement composites resulted in slight improvement in flexural strength and considerable reduction in flexural toughness of the composites. The addition of $30 \%$ fly ash and $15 \%$ silica fume were not effective in preventing the reduction of flexural toughness $[15,16]$.

$30 \%$ replacement of cement with silica fume in recycled-fiber cement composites was found to be highly effective in reducing the amount of calcium hydroxide and controlling the aging mechanisms and moisture effects [39].

The aging of the autoclaved composites resulted in little petrifaction of the cellulose fibers, in spite of the fact that the composites had undergone carbonation. The flexural strength and elastic modulus of these products did not change much during weathering [38].

Exposure of fully carbonated wood-fiber cement sheets in a fungal cellar showed that cellulose fiber cement composites have some degree of fungal resistance; however, a moderate decline in mechanical properties was observed [34].

\section{Resistance to Cycles of Freezing-Thawing}

When subjected to cycles of freezing and thawing $(\mathrm{F} \& \mathrm{~T})$, the relative dynamic modulus of elasticity of cellulose fiber-cement composites slightly increased initially, indicating 
slight improvement in F\&T resistance, but "a gradual decrease in the relative dynamic modulus of elasticity" was observed at later cycles [32].

Freezing and thawing decreased initial stiffness of the composites [39].

\section{Properties of Recycled Paper Fiber-Cement Composites}

Compared with virgin fiber-cement composites, the optimized recycled fiber-cement sheet composites showed lower flexural strength and fracture toughness, while initial stiffness was higher (Fig. 14) [27].

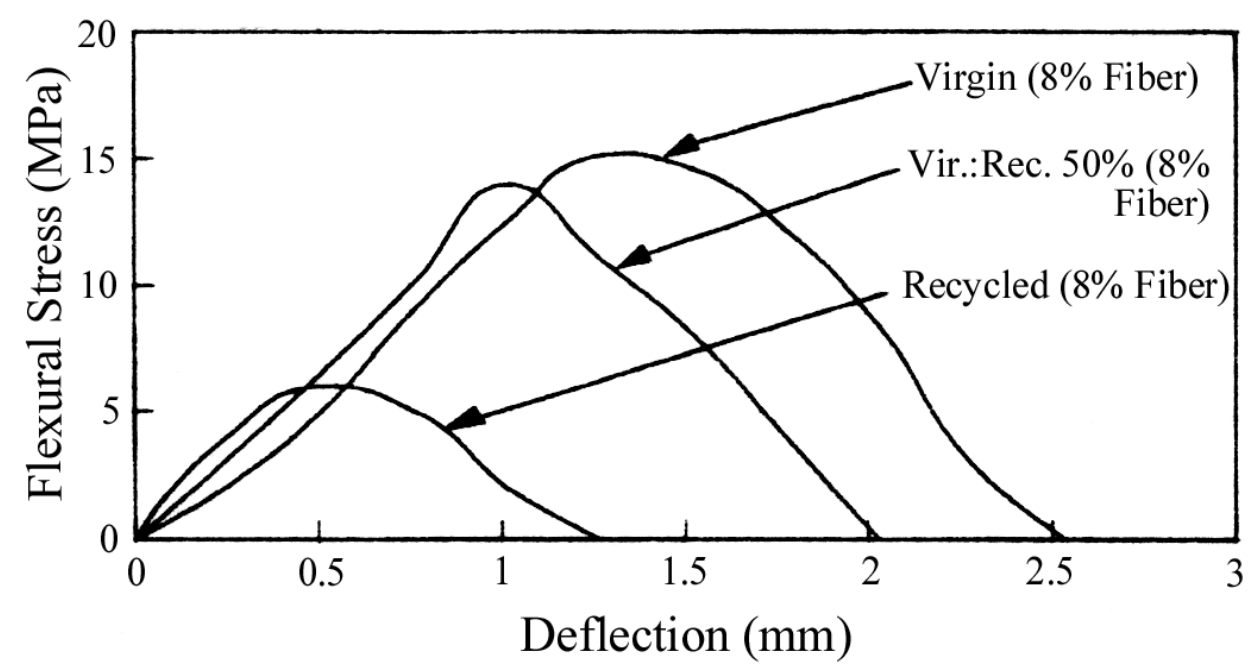

Fig. 14. Typical flexural stress-deflection curves of cellulose fiber-cement sheet composites [27]

The shapes of flexural stress-deflection curves were quite similar regardless of fiber origin. From a mechanics point of view, due to relatively low modulus of elasticity, cellulose fibers do not contribute to flexural strength of cement composites greatly. The lower flexural strength of the composite containing recycled fibers might be due to lower strength of cement paste. 
When subjected to saturation and to repeated cycles of wetting-and-drying, recycled fiber-cement composites and virgin fiber-cement composite sheets suffered comparable damage in initial stiffness, flexural strength, and flexural toughness [39].

\subsubsection{Applications for Cellulose Fiber-Cement Composites}

Cellulose-fiber-reinforced cement composites have found successful commercial applications in the manufacture of flat and corrugated sheets for cladding and roofing. Non-pressure pipes can also be produced. Successful use of cellulose fiber-cement composites for the manufacture of cable pits has also been reported $[14,40]$.

\subsubsection{Concluding Remarks}

Cellulose-fiber-reinforced cement-based composites have higher flexural toughness than plain cement-based materials. Currently several commercial cladding and roofing products are available.

Loss of flexural toughness of the composites upon aging needs to be addressed.

\subsection{Use of Virgin Processed Cellulose Fibers in Mortar and Concrete}

Several investigations have been conducted on the use of virgin cellulose fibers in mortar and concrete $[11,41,42]$. The fibers used in these investigations were indicated to be cellulose fibers processed specifically for use in concrete.

\subsubsection{Mortar with Processed Cellulose Fibers}

When 1-in. thick, 2-in. wide mortar specimens were subjected to third-point loading on a span of 6 in., the shape of flexural load-deflection curve of mortar beams containing 
cellulose fibers was quite similar to that of mortar beams without fibers [11]. Thus, little improvement in post-crack flexural toughness of mortar was obtained with the use of cellulose fibers.

\subsubsection{Concrete with Processed Cellulose Fibers}

Fibers can enhance the durability of concrete through suppression and stabilization of microcracks. Being finer than most normal synthetic fibers, cellulose fibers can be placed more closely to each other and more uniformly in concrete. This means that cellulose fibers can bridge more microcracks, thereby suppressing and stabilizing microcracks more efficiently [11]. Cellulose fibers are microfibers.

Being very short and fine, cellulose fibers are not readily noticeable on the surface of concrete.

As is the case with any type of fibers, addition of cellulose fibers to concrete caused reduction in slump [11].

When concrete ring specimens (each specimen cast around a steel ring) were subjected to air-drying at 35\% relative humidity since five hours after casting, concrete without cellulose fibers developed a $0.05-\mathrm{mm}$ wide drying-shrinkage crack at the age of about 40 days, whereas concrete containing cellulose fibers developed a $0.01-\mathrm{mm}$ wide crack at about 75 days [41]. Similar results were reported elsewhere [11].

When the restrained drying-shrinkage cracking tests were conducted on highearly strength concrete containing higher amount of cement, concrete without cellulose fibers developed a $0.08-\mathrm{mm}$ wide crack at about 20 days, which widened gradually and reached about $0.14 \mathrm{~mm}$ in width at about 160 days. On the other hand, high-early strength concrete containing cellulose fibers developed two smaller cracks: the first $0.05-$ 
mm wide crack at about 80 days, and the second $0.04-\mathrm{mm}$ wide crack at about 100 days. These two cracks did not widen further [41].

When subjected to restrained plastic shrinkage, total area and maximum width of plastic-shrinkage cracks visible on the top surface of concrete containing cellulose fibers were smaller than those of concrete without cellulose fibers [42].

\subsection{Use of Pulp and Paper Mill Residual Solids in Cement- Based Materials}

A few investigations have been reported on the use of pulp and paper mill wastewater treatment residuals in cement-based materials $[2,3,17,43,44,45,46]$. However, only several $[2,3,17]$ of these investigations were on the use of the residuals as a source of cellulose fibers for fiber reinforcement of cement-based materials. In this section, only such investigations are reviewed.

Pulp and paper mill residual solids might biodegrade if it is left unused for extended period of time in warm, acidic condition $[8,17]$.

Long-term performance of cement-based materials containing residual solids is not yet known and needs to be evaluated.

\subsubsection{Use of Paper Mill Residual Solids In Cementitious Composites}

In 1987, Thomas et al. [17] reported the manufacture of composite of portland cement and fibrous sludge from a wastepaper recycling plant. These composites were studied for potential use as economical building blocks, wallboards, shingles, fire retardants, and insulations. 
The sludge used in this research contained about $55 \%$ cellulose fibers, $44 \%$ kaolinitic clay, and $1 \%$ miscellaneous materials such as ink and dyes.

Two methods of mixing were investigated. One method involved mixing the cement with dewatered sludge with 35\% solid content. The other method involved mixing the cement with non-dewatered wet sludge with $5 \%$ solid content, which was collected prior to chemical conditioning or mechanical dewatering.

In both methods, mixture of cement and sludge was vacuum dewatered. The resulting sludge cake was compacted under vibration into a 2"-diameter perforated pipe. Afterward, specimens were cut to a length of 4 in. for compression test.

Compressive strength of the composites of cement and non-dewatered sludge was about four times the strength of the composites of cement and dewatered sludge. This was attributed to the improved dispersion of fibers in the composites of cement and nondewatered wet sludge. Also, non-dewatered sludge did not contain a polyelectrolyte, which is a flocculating agent.

From the mixture of cement and non-dewatered wet sludge, 2" deep and 1.5" wide beams were cast and tested under center-point flexural loading on a 10-in. span. The composite showed lower flexural strength than conventional unreinforced mortar consisting of cement and sand. However, unlike the brittle failure of unreinforced mortar, the composite of cement and wet sludge showed a considerable load-carrying capacity beyond cracking and peak-load. 


\subsubsection{Use of Paper Mill Residual Solids In Concrete}

\section{Investigation 1}

In 1997, Naik [2] conducted an investigation on the use of pulp and paper mill residuals in portland cement concrete. Three sources of dewatered primary residuals were received. One source was from a recycled de-ink mill. The other two sources contained virgin cellulose fibers. The residuals were composed of moisture, wood fibers, papermaking fillers (kaolin-type clay or calcium carbonate), and carbon. Silica and silicate were also present in two sources of the residuals.

Concrete mixing was done using a revolving drum, tilting mixer. Regular sand and pea gravel with $3 / 8$ " maximum size were used as aggregates.

For concrete mixing, the residuals were deflocculated before they were added to the concrete mixer. The amount of residuals required for each concrete mixture was immersed in a solution of water and high-range water-reducing admixture (HRWRA) in a plastic bucket, and the mixture was subjected to high-speed agitation and rotation by rotor blades. The solution was prepared with the assumption that the use of HRWRA would help deflocculate wood cellulose fibers contained in residuals. The results of deflocculating experiments (p. 92) conducted in the current research, however, suggest that this assumption may not be valid.

For each source of residual, concrete mixtures containing various amount of asreceived residual were produced. In most cases, residuals content was in the range of 0 to $0.8 \%$ of concrete by mass. One mixture contained $1.2 \%$ of residual. Amount of wood fibers (on dry basis) ranged from 0 to up to $10.6 \mathrm{lb}$ per cubic yard of concrete. HRWRA content in majority of the mixtures was in the range of 60 to $188 \mathrm{fl} . \mathrm{oz} . / \mathrm{yd}^{3}$ of concrete. 
One mixture contained 316 fl. oz. of HRWRA / yd $\mathrm{d}^{3}$ of concrete. In general, HRWRA content increased with the increase of residuals content.

Water-cement ratio $(w / c)$ ranged from 0.39 to 0.52 . Slump of most of mixtures was in the range of 2.5 to $6.5 \mathrm{in}$. Several mixtures showed very high slump (9 to $10 \mathrm{in}$.). Density of fresh concrete ranged from 151 to $126 \mathrm{lb} / \mathrm{ft}^{3}$. The density values of several mixtures containing residuals were equivalent to that of the control concrete without residuals. In general, density decreased with the increase of residuals content.

For two sources of residuals, concrete containing up to about $0.6 \%$ of residuals showed compressive and splitting tensile strengths that were comparable to those of Control mixture. Compressive and splitting tensile strengths of the control mixture were 6510 and 592 psi, respectively, at 28 days. The concrete with the highest amount of HRWRA showed excessive delay in strength development, leading to compressive and splitting tensile strengths of zero at three days. The strengths of the concrete increased to 1420 and 212 psi, respectively, at seven days.

For each source of residual, a certain degree of correlation was observed between $w / c$ and the strengths of concrete. Overall, however, a very low correlation was observed between $w / c$ and the strengths. On the other hand, overall, a relatively high degree of correlation was observed between density and the strength of concrete. The strength increased as the density increased. The results suggested that, by achieving equivalent density of concrete, strength of concrete containing residuals may be made equivalent to that of concrete without residuals. 


\section{Investigation 2}

In 1998, Naik et al. [3] studied the use in concrete of wastewater treatment residuals received from an office paper recycling plant. The residual solid had moisture content of about $50 \%$ based on oven-dry mass and specific gravity of about two. Loss on ignition at $590^{\circ} \mathrm{C}$ (approximate wood fiber content) and mineral content were both about 50\%, based on oven-dry mass. Before concrete mixing, the residual solids were deflocculated by mechanically mixing them in a solution of water and HRWRA. As discussed earlier and later (p. 92), however, it is probably not proper to assume HRWRA as a deflocculating agent for residual solids. Regular sand and crushed stone with 3/4 " maximum size were used as aggregates.

One control concrete mixture without the residuals was produced. And five concrete mixtures containing 0.2 to $1.2 \%$ of as-received residuals by mass of concrete were produced. This corresponded to 7.7 to $43.4 \mathrm{lb}$ of residuals per cubic yard of concrete in actual mixtures. Corresponding amount of wood fibers from the residuals was about 2 to $11 \mathrm{lb}$ (on dry basis) / $\mathrm{yd}^{3}$ of concrete.

More HRWRA was used as the amount of residuals increased. Hardening and strength development of the concrete mixture with the highest amount of HRWRA (11.5 $\mathrm{gal} / \mathrm{yd}^{3}$ ) were noticeably impaired; its compressive strength was only $20 \mathrm{psi}$ at 28 days. Water-cement ratio $(w / c)$, slump, and air content of the control concrete mixture were $0.41,5$ in., and $1.8 \%$, respectively. As the residuals content of concrete mixtures increased from 0.2 to $1.2 \%, w / c$ increased from 0.39 to 0.45 , slump decreased from 5.5 to 1.5 in., and air content increased from 5.4 to $7.8 \%$. Fresh and hardened concrete density values of the control concrete were 152 and $154 \mathrm{lb} / \mathrm{ft}^{3}$, respectively. Corresponding 
average values of the mixtures containing the residuals were about 139 and $144 \mathrm{lb} / \mathrm{ft}^{3}$, respectively.

At 28 days, compressive, splitting tensile, and flexural strengths of the control concrete were 7480, 725, and 1105 psi, respectively. Corresponding strengths of concrete containing residual solids (excluding the mixture whose strength development was impaired) were in the ranges of about 51 to $67 \%, 66$ to $73 \%$, and 44 to $63 \%$ of the strengths of the control concrete. Overall, a certain degree of correlation between strength and $w / c$ of concrete was observed; however, a higher correlation between strength and density of hardened concrete was observed.

\subsubsection{Summary}

Very few investigations $[2,3,17]$ have been reported on the use of pulp and paper mill wastewater treatment solid residuals as a source of cellulose fibers for microfiber reinforcement of cement-based materials.

Compared with the use of flocculated and dewatered residuals, use of nonflocculated and non-dewatered residuals greatly improved compressive strength of composites of cement and residuals. This was attributed to superior dispersion of wood fibers with the use of non-dewatered residuals.

For concrete mixing, as-received dewatered residuals were subjected to highspeed agitation and mixing in water to deflocculate and disperse wood fibers. In general, density of concrete decreased with the increase in residuals content. Compressive and splitting strengths of some concrete mixtures (containing up to about $0.6 \%$ of as-received residuals by mass of concrete) were higher than those of the control concrete without residuals. A high correlation was observed between strength and density of concrete 
containing residuals. Several concrete mixtures with excessive amount of HRWRA showed either delayed strength development or virtually permanent retardation.

Use of pulp and paper mill residual solids in concrete could become a viable alternative to landfilling. In order to improve the properties of concrete reinforced with residual solids, influence of its constituents needs to be evaluated. Methods need to be developed to improve and quantitatively measure the deflocculation of wood fibers.

\subsection{Measurement of Workability of Fiber-Reinforced Concrete}

For the determination of workability of fiber-reinforced concrete, ASTM Standard Specification for Fiber-Reinforced Concrete and Shotcrete (C 1116) [47] specifies the use of slump when the slump is expected to be 2 in. $(50 \mathrm{~mm})$ or more and the use of time of flow when the slump is expected to be less than 2 in. $(50 \mathrm{~mm})$. For fiber-reinforced concrete placed by vibration, the time of flow covered in ASTM Standard Test Method for Time of Flow of Fiber-Reinforced Concrete Through Inverted Slump Cone (C 995) [47] is claimed to be a better indicator of the workability than slump. In ASTM C 995, a time of flow of 8 to $15 \mathrm{sec}$ is recommended for fiber-reinforced concrete. 


\section{CHAPTER 4 MATERIALS}

\subsection{Introduction}

Cement used was tested for chemical composition and physical properties. Fine

aggregate (sand) and coarse aggregate (crushed stone) were tested for physical properties. Properties of chemical admixtures (HRWRA and AEA) were provided by their manufacturer.

Eight sources of pulp and paper mill residual solids were received and tested for moisture content, specific gravity, bulk density, fiber length, loss on ignition (LOI), mineralogy, oxide composition, elemental composition, and morphology.

\subsection{Portland Cements}

Two deliveries of one source of Type I portland cement were used in this research: the first delivery for making laboratory concrete mixtures, and the second delivery for making prototype field concrete mixtures and construction-demonstration concrete mixture. Chemical composition and physical properties of the two deliveries of portland cement are presented in Table 15 and Table 16, respectively, along with the requirements of ASTM Standard Specification for Portland Cement (C 150) [48]. Both the laboratory cement and the field cement met the standard chemical and physical requirements of ASTM C 150. 
Table 15. Chemical Composition of Portland Cements

\begin{tabular}{|l|c|c|c|}
\hline \multicolumn{1}{|c|}{ Analysis } & $\begin{array}{l}\text { Lab Cement } \\
\text { (\% by mass) }\end{array}$ & $\begin{array}{c}\text { Field Cement } \\
\text { (\% by mass) }\end{array}$ & $\begin{array}{c}\text { ASTM C 150 } \\
\text { (maximum) }\end{array}$ \\
\hline Silicon dioxide $\left(\mathrm{SiO}_{2}\right)$ & 21.9 & 20.8 & $\ldots$ \\
\hline Aluminum oxide $\left(\mathrm{Al}_{2} \mathrm{O}_{3}\right)$ & 4.9 & 4.7 & $\ldots$ \\
\hline Ferric oxide $\left(\mathrm{Fe}_{2} \mathrm{O}_{3}\right)$ & 3.0 & 2.6 & $\ldots$ \\
\hline Calcium oxide $(\mathrm{CaO})$ & 64.1 & 65.6 & $\ldots$ \\
\hline Magnesium oxide $(\mathrm{MgO})$ & 2.4 & 2.3 & 6.0 \\
\hline $\mathrm{TiO}_{2}$ & 0 & NA & $\ldots$ \\
\hline $\mathrm{K}_{2} \mathrm{O}$ & 0.5 & NA & $\ldots$ \\
\hline $\mathrm{Na}_{2} \mathrm{O}$ & 0.1 & NA & $\ldots$ \\
\hline $\mathrm{Sulfur}$ trioxide $\left(\mathrm{SO}_{3}\right)$ & 1.4 & 2.5 & $\begin{array}{l}\left.3.0 \text { (when } \mathrm{C}_{3} \mathrm{~A} \leq 8 \%\right) \\
3.5\left(\text { when } \mathrm{C}_{3} \mathrm{~A}>8 \%\right)\end{array}$ \\
\hline Loss on ignition $(\mathrm{LOI})$ & 1.7 & 1.5 & 3.0 \\
\hline Tricalcium aluminate $\left(\mathrm{C}_{3} \mathrm{~A}\right)$ & 7.9 & 8.0 & $\ldots$ \\
\hline
\end{tabular}

NA: Not available.

Table 16. Physical Properties of Portland Cements

\begin{tabular}{|c|c|c|c|c|}
\hline$\overline{\mathrm{ASTM}}$ & Test & $\begin{array}{c}\text { Lab } \\
\text { Cement }\end{array}$ & $\begin{array}{l}\text { Field } \\
\text { Cement }\end{array}$ & $\begin{array}{l}\text { ASTM } \\
\text { C } 150\end{array}$ \\
\hline C 185 & Air content of mortar (volume \%) & 8 & 5 & $\leq 12$ \\
\hline C 204 & $\begin{array}{l}\text { Fineness, specific surface, } \\
\text { by air permeability apparatus }\left(\mathrm{m}^{2} / \mathrm{kg}\right)\end{array}$ & 340 & 361 & $\geq 280$ \\
\hline C 151 & Autoclave expansion (\%) & 0.06 & 0.04 & $\leq 0.80$ \\
\hline C 109 & 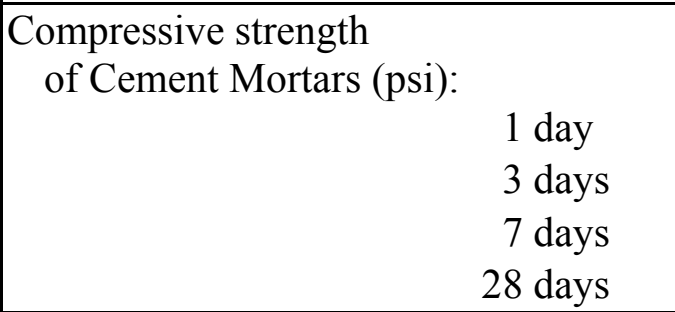 & $\begin{array}{l}2270 \\
3860 \\
4640 \\
5800\end{array}$ & $\begin{array}{l}2140 \\
3600 \\
4420 \\
5690\end{array}$ & $\begin{array}{c}\geq 1740 \\
\geq 2760 \\
\ldots\end{array}$ \\
\hline C 191 & $\begin{array}{l}\text { Time of setting by Vicat needle: } \\
\text { Initial setting time (minute) }\end{array}$ & 115 & 110 & $45 \sim 375$ \\
\hline C 188 & Density $\left(\mathrm{g} / \mathrm{cm}^{3}\right)$ & 3.13 & 3.15 & \\
\hline
\end{tabular}




\subsection{Fine Aggregates}

Two sources of fine aggregate (sand) were used in this research: one for making laboratory concrete mixtures, and another for making prototype field concrete mixtures and construction-demonstration concrete mixture. Properties of the fine aggregates are presented in Table 17. Sieve analysis results are presented in Table 18 along with the grading requirements of ASTM Standard Specification for Concrete Aggregates (C 33) [47]. The sands met the requirements of ASTM C 33.

Table 17. Properties of Fine Aggregates

\begin{tabular}{|l|c|c|c|c|c|c|c|}
\hline ASTM & C 136 & C 29 & C 29 & C 128 & C 128 & C 128 & C 128 \\
\hline Test & $\begin{array}{l}\text { Fineness } \\
\text { modulus }\end{array}$ & $\begin{array}{c}\text { Bulk } \\
\text { density }\end{array}$ & $\begin{array}{c}\text { Void } \\
\text { content } \\
\left(\mathrm{lb} / \mathrm{ft}^{3}\right)\end{array}$ & $\begin{array}{c}\text { Bulk specific } \\
\text { gravity on }\end{array}$ & $\begin{array}{c}\text { Bulk specific } \\
\text { OD* basis } \\
\text { gravity on } \\
\text { SSD } \dagger \text { basis }\end{array}$ & $\begin{array}{c}\text { Apparent } \\
\text { specific } \\
\text { gravity }\end{array}$ & $\begin{array}{c}\text { Absorption, } \\
\text { or SSD } \\
\text { MC } \\
(\%)\end{array}$ \\
\hline Lab Sand & 2.88 & 112 & 33 & 2.69 & 2.73 & 2.79 & 1.34 \\
\hline Field Sand & 2.78 & 115 & 30 & 2.64 & 2.66 & 2.68 & 0.62 \\
\hline
\end{tabular}
* oven-dry
† saturated surface-dry
† moisture content (on oven-dry basis)

Table 18. Gradation of Fine Aggregates

\begin{tabular}{|l|c|c|c|c|c|c|c|}
\hline & \multicolumn{7}{|c|}{ Amounts finer than each sieve (\% by mass) } \\
\hline Sieve & 3/8-in. & No. 4 & No. 8 & No. 16 & No. 30 & No. 50 & No. 100 \\
\hline Sieve openings & $9.5 \mathrm{~mm}$ & $4.75 \mathrm{~mm}$ & $2.36 \mathrm{~mm}$ & $1.18 \mathrm{~mm}$ & $600 \mu \mathrm{m}$ & $300 \mu \mathrm{m}$ & $150 \mu \mathrm{m}$ \\
\hline Lab Sand & 100 & 99 & 83 & 63 & 42 & 17 & 7 \\
\hline Field Sand & 100 & 95 & 81 & 71 & 54 & 19 & 3 \\
\hline ASTM C 33 & 100 & $95 \sim 100$ & $80 \sim 100$ & $50 \sim 85$ & $25 \sim 60$ & $5 \sim 30$ & $0 \sim 10$ \\
\hline
\end{tabular}

\subsection{Coarse Aggregates}

A source of crushed angular stone with 3/4-in. maximum size was used as a coarse aggregate in making laboratory concrete mixtures. In Series 5 mixtures, a source of pea 
gravel with a 3/8-in. maximum size was also used. Detailed testing for the $3 / 8$ " pea gravel was not conducted because Series 5 mixtures were made only for the purpose of gaining experience in concrete mixing with smaller size aggregates. The $3 / 8$ " pea gravel was obtained from a local ready-mixed concrete supplier, which stated that the material met the requirements of ASTM C 33.

In making prototype field concrete mixtures and construction-demonstration concrete mixture, a source of gravel with a 3/4-in. maximum size was used.

Properties of the coarse aggregates are presented in Table 19 along with the requirements of ASTM C 33. Sieve analysis results for the coarse aggregates are presented in Table 20 along with the grading requirements of ASTM C 33. The coarse aggregates met the requirements of ASTM C 33.

Table 19. Properties of Coarse Aggregates

\begin{tabular}{|l|c|c|c|c|c|c|}
\hline ASTM & C 29 & C 29 & C 127 & C 127 & C 127 & C 127 \\
\hline Test & $\begin{array}{c}\text { Bulk } \\
\text { density } \\
\left(\mathrm{lb} / \mathrm{ft}^{3}\right)\end{array}$ & $\begin{array}{c}\text { Void } \\
\text { content } \\
(\%)\end{array}$ & $\begin{array}{c}\text { Bulk specific } \\
\text { gravity on } \\
\text { OD* basis }\end{array}$ & $\begin{array}{c}\text { Bulk specific } \\
\text { gravity on } \\
\text { SSD } \dagger \text { basis }\end{array}$ & $\begin{array}{c}\text { Apparent } \\
\text { specific } \\
\text { gravity }\end{array}$ & $\begin{array}{c}\text { Absorption, } \\
\text { or SSD } \dagger \\
\text { MC } \ddagger \\
(\%)\end{array}$ \\
\hline Lab Stone & 98 & 41 & 2.66 & 2.67 & 2.69 & 0.41 \\
\hline Field Stone & 100 & 40 & 2.69 & 2.72 & 2.76 & 1.02 \\
\hline
\end{tabular}

* oven-dry

$\dagger$ saturated surface-dry

$\$$ moisture content (on oven-dry basis) 
Table 20. Gradation of Coarse Aggregates

\begin{tabular}{|l|c|c|c|c|c|c|}
\hline & \multicolumn{6}{|c|}{ Amounts finer than each sieve (\% by mass) } \\
\hline Sieve & 1 in. & $3 / 4$ in. & $1 / 2$ in. & $3 / 8$ in. & No. 4 & No. 8 \\
\hline Sieve openings (mm) & 25.0 & 19.0 & 12.5 & 9.5 & 4.75 & 2.36 \\
\hline Lab Stone & 100 & 92 & 37 & 14 & 0 & 0 \\
\hline ASTM C 33, Size No. 6* & 100 & $90 \sim 100$ & $20 \sim 55$ & $0 \sim 15$ & $0 \sim 5$ & $\ldots$ \\
\hline Field Stone & 100 & 78 & 38 & 17 & 2 & 1 \\
\hline ASTM C 33, Size No. 57† & $95 \sim 100$ & $\ldots$ & $25 \sim 60$ & $\ldots$ & $0 \sim 10$ & $0 \sim 5$ \\
\hline
\end{tabular}

* Nominal size of $3 / 4$ to $3 / 8$ " (19.0 to $9.5 \mathrm{~mm})$.

$\dagger$ Nominal size of 1" to No. 4 (25.0 to $4.75 \mathrm{~mm}$ ).

\subsection{High Range Water Reducing Admixture (HRWRA)}

A carboxylated polyether liquid admixture that complies with the requirements of ASTM Standard Specification for Chemical Admixtures for Concrete (C 494) [47] for Type F, High Range Water Reducing Admixture (HRWRA), was used as a HRWRA in making laboratory concrete mixtures and construction-demonstration concrete mixture. A proprietary copolymer HRWRA meeting the requirements of ASTM C 494 was used in making prototype field concrete mixtures.

Manufacturers' recommended dosage rates (or addition rates) of these HRWRAs are shown in Table 21.

Table 21. Manufacturers' Recommended Dosage Rates of HRWRAs

\begin{tabular}{|l||c|c|}
\hline \multicolumn{1}{|c||}{ Admixture } & $\begin{array}{c}\text { Dosage Rate } \\
\text { (fl oz/100 lb of } \\
\text { cementitious materials) }\end{array}$ & $\begin{array}{c}\text { Dosage Rate } \\
\text { (mL/100 kg of } \\
\text { cementitious materials) }\end{array}$ \\
\hline $\begin{array}{l}\text { HRWRA for Laboratory and } \\
\begin{array}{l}\text { Construction-Demonstration Concrete } \\
\text { Mixtures }\end{array}\end{array}$ & $3-10$ & $195-650$ \\
\hline $\begin{array}{l}\text { HRWRA for Prototype Concrete } \\
\text { Mixtures }\end{array}$ & $4-12$ & $260-780$ \\
\hline
\end{tabular}


Ingredients of the HRWRAs, according to the Material Safety Data Sheets

(MSDS) provided by the manufacturers, are shown in Table 22.

Key physical and chemical properties of the HRWRAs based on the MSDSs are presented in Table 23.

Table 22. Ingredient of HRWRAs

\begin{tabular}{|c|c|c|c|}
\hline Admixture & Ingredient & CAS\#* & $\begin{array}{l}\% \text { by } \\
\text { mass } \\
\end{array}$ \\
\hline $\begin{array}{l}\text { HRWRA for Laboratory and } \\
\text { Construction-Demonstration } \\
\text { Concrete Mixtures }\end{array}$ & $\begin{array}{l}\text { 2-Propenoic Acid Homopolymer } \\
\text { Reaction Product with } \\
\text { Polyalkoxyalkylamine }\end{array}$ & $179733-16-5$ & $\leq 35$ \\
\hline $\begin{array}{l}\text { HRWRA for Prototype } \\
\text { Concrete Mixtures }\end{array}$ & Proprietary Copolymer & Proprietary & $\leq 50$ \\
\hline
\end{tabular}

* CAS (Chemical Abstracts Service) Registry Number, a unique identifier for a chemical substance.

Table 23. Physical and Chemical Properties of HRWRAs

\begin{tabular}{|l||c|c||}
\hline Admixture & $\begin{array}{c}\text { HRWRA for Laboratory and } \\
\text { Construction-Demonstration } \\
\text { Concrete Mixtures }\end{array}$ & $\begin{array}{c}\text { HRWRA for } \\
\text { Prototype Concrete } \\
\text { Mixtures }\end{array}$ \\
\hline \hline Appearance & Amber, yellow liquid & Brown liquid \\
\hline Odor & A slight odor of acrylic acid & $\ldots$ \\
\hline Solubility in Water & Complete & $100 \%$ \\
\hline Specific Gravity & $1.0 \sim 1.1$ & 1.08 \\
\hline$\%$ Volatiles & $\sim 65 \%$ (as water) & $\ldots$ \\
\hline pH & $4-7$ & $\sim 6.5$ \\
\hline
\end{tabular}

\subsection{Air Entraining Admixture (AEA)}

An aqueous solution of neutralized resin acids and rosin acids that complies with ASTM Standard Specification for Air-Entraining Admixtures for Concrete (C 260) [47] was used as an air-entraining admixture (AEA) in this project. Manufacturer's recommended 
dosage rate (or addition rate) of this AEA and expected entrained air content are shown in Table 24.

Table 24. Manufacturer's Recommended Dosage Rate of AEA

\begin{tabular}{|c|c|c|c|}
\hline Admixture & $\begin{array}{c}\text { Dosage Rate } \\
\text { (fl oz/100 lb of } \\
\text { cementitious materials) }\end{array}$ & $\begin{array}{c}\text { Dosage Rate } \\
\text { (mL/100 kg of } \\
\text { cementitious materials) }\end{array}$ & $\begin{array}{c}\text { Expected Entrained } \\
\text { Air Content } \\
(\%)\end{array}$ \\
\hline AEA & $0.5-3$ & $30-200$ & $4-8$ \\
\hline
\end{tabular}

Ingredients of the AEA, according to the MSDS provided by the manufacturer, are presented in Table 25.

Table 25. Ingredients of AEA

\begin{tabular}{|l|c|c|}
\hline \multicolumn{1}{|c|}{ Ingredient } & CAS\# & Max. \% by mass \\
\hline Resin acids and Rosin acids, maleated, potassium salts & $085409-27-4$ & $1-5$ \\
\hline Resin acids and Rosin acids, potassium salts & $061790-50-9$ & $5-10$ \\
\hline
\end{tabular}

Key physical and chemical properties of the AEA based on the MSDS are presented in Table 26.

Table 26. Physical and Chemical Properties of AEA

\begin{tabular}{|l|l|}
\hline Appearance/Odor & Dark brown liquid with sweet, pine-like odor. \\
\hline Solubility In Water & Complete \\
\hline Specific Gravity (water $=1)$ & $1.0-1.1$ \\
\hline$\%$ Volatiles (g/L) at $21^{\circ} \mathrm{C}$ & $\sim 90 \%$ (as water) \\
\hline $\mathrm{pH}$ & $10-12$ \\
\hline
\end{tabular}

\subsection{Residual Solids}

A total of eight sources of pulp and paper mill residual solids were received representing a wide variation in the type of wood fibers and processes. Sources of the residuals were primary clarifier residual solids and screening rejects. 
The residual solids were tested for the following properties:

1. Physical: appearance, moisture content, specific gravity, bulk density, and fiber length.

2. Chemical: loss on ignition; and mineral, oxide, and elemental compositions.

3. Morphological: optical microscopy and scanning electron microscopy.

The residual solids showed noticeable differences in properties.

Six (C1, C2, S, WG, WV, and BR) of the eight sources of the residual solids samples were also obtained a second time for the evaluation of variability of residual

solids. The samples of the $2^{\text {nd }}$ delivery were tested for moisture content, specific gravity, bulk density, and loss on ignition. In the results presented below, sample delivery number is identified (for example, $1^{\text {st }}$ delivery, $2^{\text {nd }}$ delivery, C1-1, C1-2, BR-1, BR-2, etc.). If the delivery number is not shown, the test result pertains to the residuals of the $1^{\text {st }}$ delivery.

\subsubsection{Storage}

Since cellulose fibers mildew and may decompose rapidly at high humidity and high temperatures [49], the received residual solids were stored in a walk-in refrigerator at $40^{\circ} \mathrm{F}$ in the concrete laboratory until the time of their tests or use in a concrete mixture.

\subsubsection{Type and Appearance}

Classification and description of the residual solids are presented in Table 27. 
Table 27. Classification and Description of Residual Solids

\begin{tabular}{|c|c|c|c|c|c|c|}
\hline $\begin{array}{l}\text { Des- } \\
\text { igna- } \\
\text { tion }\end{array}$ & $\begin{array}{c}\text { Received } \\
\text { Date(s) }\end{array}$ & $\begin{array}{c}\text { Residual } \\
\text { Type }\end{array}$ & $\begin{array}{c}\text { Fiber } \\
\text { Origin(s) }\end{array}$ & $\begin{array}{l}\text { Source } \\
\text { Mill(s) }\end{array}$ & $\begin{array}{l}\text { Appearance/ } \\
\text { Material(s) other than Wood Fibers/ } \\
\text { Characteristics }\end{array}$ & $\begin{array}{l}\text { Pulping Process(es)/ } \\
\text { Species/ } \\
\text { Product(s) Manufactured }\end{array}$ \\
\hline $\mathrm{C} 1$ & $\begin{array}{c}1^{\text {st }}: 05 / 17 / 00 \\
2^{\text {nd }}: 11 / 01 / 01\end{array}$ & Primary & Virgin & Pulp, Paper & $\begin{array}{l}\text { White/ } \\
\text { Clay, pieces of wood/ } \\
\text { Hard when oven-dried. }\end{array}$ & $\begin{array}{l}\text { Groundwood, TMP } \\
\text { "Coated specialty papers" } \\
\text { "Lightweight coated } \\
\text { groundwood printing papers" }\end{array}$ \\
\hline $\mathrm{C} 2$ & $\begin{array}{c}1^{\text {st }}: 05 / 19 / 00 \\
2^{\text {nd }}: 11 / 01 / 01\end{array}$ & Primary & Virgin & $\begin{array}{l}\text { Pulp, } \\
\text { Paper, } \\
\text { Paperboard }\end{array}$ & $\begin{array}{l}\text { Brown/ } \\
\text { Calcium carbonate, clay, pieces of } \\
\text { wood, and bark. }\end{array}$ & $\begin{array}{l}\text { Kraft, groundwood, TMP } \\
\text { "Lightweight groundwood } \\
\text { coated printing papers" } \\
\text { "Heavier-weight groundwood- } \\
\text { free coated printing papers and } \\
\text { paperboard" }\end{array}$ \\
\hline I & $05 / 23 / 00$ & Primary & Recycled & Recycle & $\begin{array}{l}\text { Light gray agglomerations/ } \\
\text { "Calcium carbonate, clay, starch, } \\
\text { and a styrene-butadiene polymer"; } \\
\text { "Pigment and coating particles"/ } \\
\text { "Significant effervescence"; hard } \\
\text { when oven-dried. }\end{array}$ & $\begin{array}{l}\text { Mostly hardwood bleached } \\
\text { kraft fibers with lots of } \\
\text { parenchyma cells (fines). } \\
\text { Some softwood bleached kraft } \\
\text { fibers. }\end{array}$ \\
\hline $\mathrm{S}$ & $\begin{array}{c}1^{\text {st }}: 05 / 16 / 00 \\
2^{\text {nd }}: 10 / 23 / 01\end{array}$ & Primary & $\begin{array}{l}\text { Recycled } \\
(80 \%)+ \\
\text { Virgin } \\
(20 \%)\end{array}$ & $\begin{array}{l}\text { Pulp, } \\
\text { Recycle }\end{array}$ & $\begin{array}{l}\text { Light gray agglomerations/ } \\
\text { Calcium carbonate, clay, and } \\
\text { pigment; occasionally pieces of } \\
\text { wood. }\end{array}$ & $\begin{array}{l}\text { "Deinked market pulp" } \\
\text { "Pressurized groundwood } \\
\text { (spruce-50\%, balsam-50\%)" }\end{array}$ \\
\hline
\end{tabular}


Table 27. Classification and Description of Residual Solids (Cont'd.)

\begin{tabular}{|c|c|c|c|c|c|c|}
\hline $\begin{array}{l}\text { Des- } \\
\text { igna- } \\
\text { tion }\end{array}$ & $\begin{array}{l}\text { Received } \\
\text { Date(s) }\end{array}$ & $\begin{array}{l}\text { Residual } \\
\text { Type }\end{array}$ & $\begin{array}{c}\text { Fiber } \\
\text { Origin(s) }\end{array}$ & $\begin{array}{l}\text { Source } \\
\text { Mill(s) }\end{array}$ & $\begin{array}{l}\text { Appearance/ } \\
\text { Material(s) other than Wood Fibers/ } \\
\text { Characteristics }\end{array}$ & $\begin{array}{l}\text { Pulping Process(es)/ } \\
\text { Species/ } \\
\text { Product(s) Manufactured }\end{array}$ \\
\hline WG & $\begin{array}{l}1^{\text {st }}: 05 / 16 / 00 \\
2^{\text {nd }}: 11 / 06 / 01\end{array}$ & Primary & Virgin & Pulp & $\begin{array}{l}\text { Dark gray/ } \\
\text { "Fine particles from the ash handling } \\
\text { system and some lime waste from } \\
\text { the dregs drum"; shreds of wood/ } \\
\text { Dusty when oven-dried. }\end{array}$ & "Market pulp" \\
\hline WV & $\begin{array}{l}1^{\text {st }}: 05 / 17 / 00 \\
2^{\text {nd }}: 12 / 14 / 01\end{array}$ & Primary & Virgin & Paperboard & $\begin{array}{l}\text { Brown agglomerations/ } \\
\text { Pieces of wood, shreds of plastic, } \\
\text { and grits. }\end{array}$ & $\begin{array}{l}\text { "Kraft linerboard" } \\
\text { "Corrugating medium" }\end{array}$ \\
\hline$P$ & $06 / 14 / 00$ & $\begin{array}{l}\text { Screening } \\
\text { rejects* }\end{array}$ & $\begin{array}{l}\text { Virgin } \\
(75 \%)+ \\
\text { Recycled } \\
(25 \%) \\
\end{array}$ & $\cdots$ & $\begin{array}{l}\text { Dark brown/ } \\
\text { Tiny wood pieces or particles } \\
\text { ("shives") and "bark". }\end{array}$ & $\begin{array}{l}\text { "Soda, semichemical, } \\
\text { semimechanical" } \\
\text { Unbleached hardwood ("oak, } \\
\text { maple, aspen") }\end{array}$ \\
\hline$\overline{B R}$ & $\begin{array}{c}1^{\text {st. }}: 03 / 01 / 01 \\
2^{\text {nd }}: 11 / 14 / 01\end{array}$ & $\begin{array}{l}\text { Fiber } \\
\text { reclaim } \dagger\end{array}$ & Virgin & Pulp, Paper & Light brown & $\begin{array}{l}\text { Groundwood, TMP } \\
\text { "Lightweight groundwood } \\
\text { coated printing papers" }\end{array}$ \\
\hline
\end{tabular}

* Specifically, "paper machine rejects"

$\dagger$ Fibers reclaimed from primary residuals. 


\subsubsection{Moisture Content}

Samples of as-received residual solids were dried in oven at $105^{\circ} \mathrm{C}$ until constant mass was reached. Moisture content test results for the residual solids are presented in Table 28.

Table 28. As-Received Moisture Content of Residual Solids

\begin{tabular}{||c||c|c||}
\hline \multicolumn{1}{|c|}{} & \multicolumn{2}{c|}{ Moisture Content $(\% *)$} \\
\cline { 2 - 3 } Residual & $1^{\text {st }}$ delivery & $2^{\text {nd }}$ delivery \\
\hline \hline C1 & 185 & 154 \\
\hline C2 & 220 & 266 \\
\hline I & 95 & $\ldots$ \\
\hline S & 84 & 71 \\
\hline WG & 116 & 121 \\
\hline WV & 142 & 1290 \\
\hline P & 130 & $\ldots$ \\
\hline BR & 230 & 217 \\
\hline \hline Avg. & 150 & 354 \\
\hline Min. & 84 & 71 \\
\hline Max. & 230 & 1290 \\
\hline \hline Alt. Avg. $\dagger$ & 167 & 166 \\
\hline Alt. Min. $\dagger$ & 84 & 71 \\
\hline Alt. Max. $\dagger$ & 230 & 266 \\
\hline \hline
\end{tabular}

* Percent of oven-dry $\left(105^{\circ} \mathrm{C}\right)$ mass.

$\dagger$ Excluding I, WV, and P

The residual solid WV of the $2^{\text {nd }}$ delivery was immersed in water, and apparently the residue delivered had not been dewatered. One thing noteworthy was that the fibers of the WV-2 were already uniformly dispersed in water, as received. As discussed later, WV of the $1^{\text {st }}$ delivery (dewatered residual) was one of the most difficult sources of residuals to separate ("repulp") in water in the UWM-CBU concrete laboratory. 
As for the residue samples of the $1^{\text {st }}$ delivery, moisture content was in the range of 84 to $230 \%$ and the average was $150 \%$. When the results for I, WV, and P were

excluded, average moisture content values for the $1^{\text {st }}$ and the $2^{\text {nd }}$ deliveries were about the same (167 vs. $166 \%)$.

During the moisture content testing, it was realized that oven drying of pulp and paper mill residual solids is rather a time-consuming and energy-intensive process. For an efficient drying, samples of as-received residual solids should be spread thin on wide trays so that large surface area will be exposed to the heat in the oven.

\subsubsection{Specific Gravity}

Samples of as-received of residual solids were soaked in water for one day and then tested for apparent specific gravity according to the principles outlined in ASTM Standard Test Method for Specific Gravity and Absorption of Fine Aggregate (C 128) [47].

The apparent specific gravity was calculated as follows:

$$
\text { Apparent specific gravity }=A /(B+A-C)
$$

where:

$A=$ mass of specimen on oven-dry basis, $B=$ mass of pycnometer filled with water, $C=$ mass of pycnometer with specimen and water to calibration mark.

The specific gravity results on oven-dry basis are presented in Table 29 . 
As for the residual solid samples of the $1^{\text {st }}$ delivery, the values of specific gravity ranged from 1.41 to 2.17 and the average was 1.78 . The specific gravity of the $1^{\text {st }}$ delivery and that of the $2^{\text {nd }}$ delivery were about the same.

Table 29. Specific Gravity of Residual Solids

\begin{tabular}{|c|c|c|}
\hline \multirow{2}{*}{ Residual } & \multicolumn{2}{c|}{ Specific Gravity } \\
\cline { 2 - 3 } & $1^{\text {st }}$ delivery & $2^{\text {nd }}$ delivery \\
\hline $\mathrm{C} 1$ & 1.77 & 1.74 \\
\hline $\mathrm{C} 2$ & 1.69 & 1.75 \\
\hline $\mathrm{I}$ & 2.04 & $\ldots$ \\
\hline $\mathrm{S}$ & 2.00 & 1.98 \\
\hline $\mathrm{WG}$ & 2.17 & 2.26 \\
\hline $\mathrm{WV}$ & 1.62 & 1.65 \\
\hline $\mathrm{P}$ & 1.41 & $\ldots$ \\
\hline BR & 1.56 & 1.50 \\
\hline Avg. & 1.78 & 1.81 \\
\hline Min. & 1.41 & 1.50 \\
\hline Max. & 2.17 & 2.26 \\
\hline \hline Alt. Avg. $\dagger$ & 1.80 & 1.81 \\
\hline Alt. Min. $\dagger$ & 1.56 & 1.50 \\
\hline Alt. Max. $\dagger$ & 2.17 & 2.26 \\
\hline
\end{tabular}

$\dagger$ Excluding I and P

\subsubsection{As-Received Bulk Density}

For each source of residual solids, weight and volume of the sample in a 5-gallon (19liter) pail in as-received (moist) condition were determined, and the bulk density of the as-received residual was calculated. The results are shown in Table 30.

Averages for the two deliveries were about the same (49.2 vs. $\left.47.4 \mathrm{lb} / \mathrm{ft}^{3}\right)$.

\subsubsection{Oven-Dry Bulk Density}

Bulk density of oven-dry $\left(105^{\circ} \mathrm{C}\right)$ residual solids of the $1^{\text {st }}$ delivery was determined by filling a $0.1 \mathrm{ft}^{3}\left(0.00283 \mathrm{~m}^{3}\right)$ metal container with the oven-dry residuals in three layers, 
tamping each layer 25 times with a 1/8-in. $(3 \mathrm{~mm})$ diameter plastic rod for relatively soft dry residuals (WG, WV, I, S, P, BR) and with a 0.3-in. (8-mm) diameter round-tip steel rod for relatively hard dry residuals $(\mathrm{C} 1, \mathrm{C} 2)$. The results are presented in Table 31 .

Table 30. Bulk Density of As-Received Residual Solids

\begin{tabular}{|c|c|c|}
\hline \multirow{2}{*}{\multicolumn{1}{|c|}{ Residual }} & \multicolumn{2}{c|}{$\begin{array}{c}\text { As-Received Bulk Density } \\
\left(\mathrm{lb} / \mathrm{ft}^{3}\right)\end{array}$} \\
\cline { 2 - 3 } & $1^{\text {st }}$ delivery & $2^{\text {nd }}$ delivery \\
\hline $\mathrm{C} 1$ & 67.6 & 50.6 \\
\hline $\mathrm{C} 2$ & 62.6 & 58.7 \\
\hline I & 51.8 & $\ldots$ \\
\hline S & 40.9 & 48.3 \\
\hline WG & 46.6 & 55.1 \\
\hline WV & 35.8 & $\ldots$ \\
\hline BR & 28.3 & 24.5 \\
\hline \hline Avg. & 47.7 & 47.4 \\
\hline Min. & 28.3 & 24.5 \\
\hline Max. & 67.6 & 58.7 \\
\hline \hline Alt. Avg. $\dagger$ & 49.2 & 47.4 \\
\hline Alt. Min. $\dagger$ & 28.3 & 24.5 \\
\hline Alt. Max. $\dagger$ & 67.6 & 58.7 \\
\hline \multicolumn{2}{|c}{} \\
\hline
\end{tabular}

$\dagger$ Excluding I and WV

Table 31. Bulk Density of Oven-Dry Residual Solids

\begin{tabular}{|c|c|}
\hline $\begin{array}{c}\text { Residual } \\
\left(1^{\text {st }} \text { delivery }\right)\end{array}$ & $\begin{array}{c}\text { Oven-Dry }\left(105^{\circ} \mathrm{C}\right) \\
\text { Bulk Density }\left(\mathrm{lb} / \mathrm{ft}^{3}\right)\end{array}$ \\
\hline $\mathrm{C} 1$ & 18.3 \\
\hline $\mathrm{C} 2$ & 14.1 \\
\hline $\mathrm{I}$ & 21.4 \\
\hline $\mathrm{S}$ & 12.9 \\
\hline $\mathrm{WG}$ & 12.0 \\
\hline $\mathrm{WV}$ & 10.1 \\
\hline $\mathrm{P}$ & 7.5 \\
\hline BR & 5.1 \\
\hline Avg. & 12.7 \\
\hline Min. & 5.1 \\
\hline Max. & 21.4 \\
\hline
\end{tabular}


Due to the bulky nature of some sources of the residual solids (such as P and BR) and gaps between dry hard chunks and agglomerations for other sources of residual solids (such as C1 and C2), it was not easy to achieve the same degree of compaction for all sources of residuals. Thus, the bulk density values of oven-dry residual solids presented herein may be considered as approximate. Average for all eight sources was $12.7 \mathrm{lb} / \mathrm{ft}^{3}$.

There seems to be a correlation between the bulk density of as-received (moist) residuals and that of oven-dry residuals, as shown in Table 32 and Fig. 15. The values on the $y$-axis are calculated by assuming that the volume of residual solid does not change (no shrinkage) while the as-received residual solid is being dried in the oven.

Table 32. Relation Between the Bulk Density Values of As-Received Residuals and Oven-Dry $\left(105^{\circ} \mathrm{C}\right)$ Residuals

\begin{tabular}{|l|c|c|c|c|c|c|c|}
\hline \multirow{2}{*}{ Category } & \multicolumn{7}{|c|}{ Oven-Dry Bulk Density $\left(\mathrm{lb} / \mathrm{ft}^{3}\right)$} \\
\cline { 2 - 8 } & $\mathrm{C} 1$ & $\mathrm{C} 2$ & $\mathrm{I}$ & $\mathrm{S}$ & $\mathrm{WG}$ & $\mathrm{WV}$ & $\mathrm{BR}$ \\
\hline Actual & 18.3 & 14.1 & 21.4 & 12.9 & 12.0 & 10.1 & 5.1 \\
\hline Theoretical* $^{*}$ & 23.7 & 19.5 & 26.6 & 22.3 & 21.6 & 14.8 & 8.6 \\
\hline
\end{tabular}

* Calculated as as-received bulk density x $100 /(100+$ moisture content $)$ assuming no volume change during drying process (= oven-dry weight / as-received volume). 


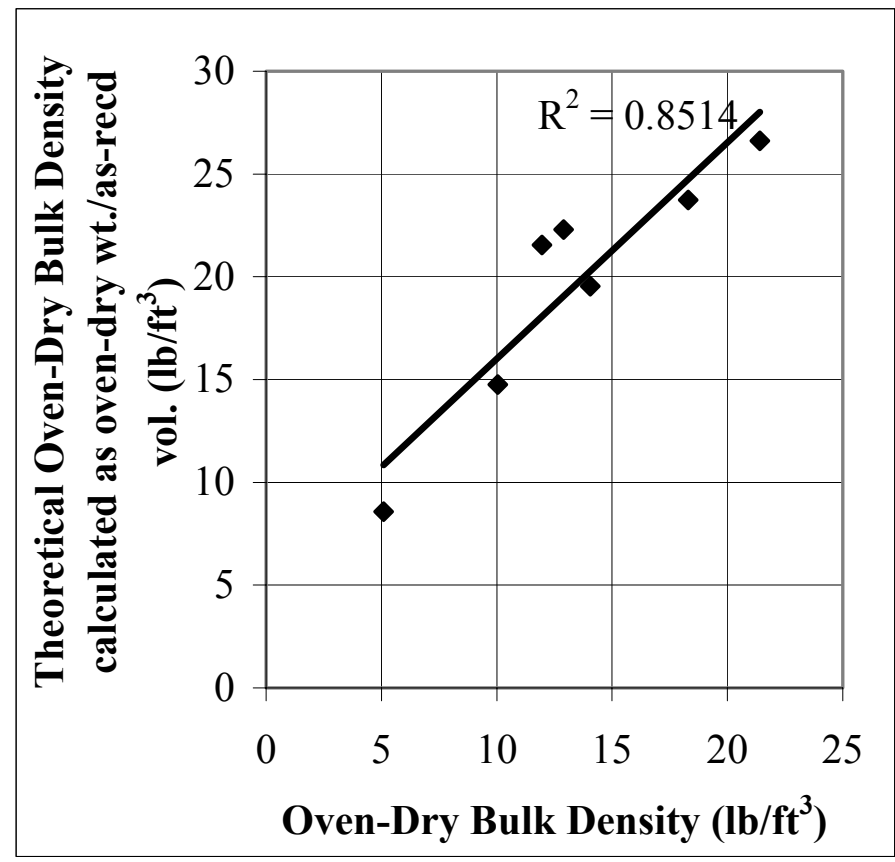

Fig. 15. Relation between the bulk density values of as-received residuals and ovendry $\left(105^{\circ} \mathrm{C}\right)$ residuals

\subsubsection{Fiber Length}

Average length of the wood fibers contained in the residual solid was determined by using Fiber Quality Analyzer (FQA) for most of the residuals of the $1^{\text {st }}$ delivery and by using Kajaani FS-100 measuring system for all the residuals of the $2^{\text {nd }}$ delivery. The FQA and the Kajaani are different systems, and their results are not directly comparable. The test results for average fiber length are presented in Table 33.

According to TAPPI method T 271 om-98, Fiber length of pulp and paper by automated optical analyzer using polarized light, "the arithmetic average fiber length is not always the most commonly used indicator of the fiber length because the effect of short fibers is emphasized. The commonly used expression is the length weighted average fiber length." For each source of the Residuals C1, C2, S, WG, and WV, the length-weighted average fiber length determined by using FQA for the $1^{\text {st }}$ delivery and 
the value determined by using Kajaani FS-100 for the $2^{\text {nd }}$ delivery were reasonably close to each other ( 1.22 vs. $1.22 ; 1.20$ vs. $0.92 ; 1.11$ vs. $1.14 ; 1.51$ vs. $2.13 ; 1.68$ vs. 1.91$)$.

Table 33. Average Fiber Length of Residual Solids (in mm)

\begin{tabular}{|c|c|c|c|c|c|c|c|}
\hline \multirow[b]{2}{*}{$\begin{array}{c}\text { Residual } \\
\text { Solid }\end{array}$} & \multicolumn{3}{|c|}{ Using Fiber Quality Analyzer } & \multirow[b]{2}{*}{$\begin{array}{c}\text { Residual } \\
\text { Solid }\end{array}$} & \multicolumn{3}{|c|}{ Using Kajaani FS-100 } \\
\hline & $\begin{array}{c}\text { Arithmetic } \\
\text { avg. fiber } \\
\text { length, } \\
L_{A}\end{array}$ & $\begin{array}{c}\text { Length } \\
\text { weighted } \\
\text { avg. fiber } \\
\text { length, } \\
L_{L}\end{array}$ & $\begin{array}{c}\text { Weight } \\
\text { weighted } \\
\text { avg. fiber } \\
\text { length, } \\
L_{W}\end{array}$ & & $\begin{array}{c}\text { Arithmetic } \\
\text { avg. fiber } \\
\text { length, } \\
L_{A}\end{array}$ & $\begin{array}{c}\text { Length } \\
\text { weighted } \\
\text { avg. fiber } \\
\text { length, } \\
L_{L}\end{array}$ & $\begin{array}{c}\text { Weight } \\
\text { weighted } \\
\text { avg. fiber } \\
\text { length, } \\
L_{W}\end{array}$ \\
\hline C1-1 & 0.34 & 1.22 & 2.23 & C1-2 & 0.53 & 1.22 & 1.98 \\
\hline $\mathrm{C} 2-1$ & 0.41 & 1.20 & 2.58 & $\mathrm{C} 2-2$ & 0.45 & 0.92 & 1.79 \\
\hline S-1 & 0.30 & 1.11 & 2.34 & S-2 & 0.50 & 1.14 & 2.15 \\
\hline WG-1 & 0.24 & 1.51 & 2.94 & WG-2 & 1.30 & 2.13 & 2.62 \\
\hline WV-1 & 0.41 & 1.68 & 2.74 & WV-2 & 0.90 & 1.91 & 2.81 \\
\hline $\mathrm{I}-1$ & 0.2 & 0.85 & 2.14 & BR-1 & 0.72 & 1.34 & 1.94 \\
\hline P-1 & 0.54 & 1.28 & 2.29 & BR-2 & 0.78 & 1.44 & 2.07 \\
\hline Avg. & 0.35 & 1.26 & 2.47 & Avg. & 0.74 & 1.44 & 2.19 \\
\hline Avg. 2* & 0.34 & 1.34 & 2.57 & Avg. 2* & 0.74 & 1.46 & 2.27 \\
\hline & \multicolumn{3}{|c|}{ Fines: $<0.2 \mathrm{~mm}$} & & \multicolumn{3}{|c|}{ Fines: $<0.1 \mathrm{~mm}$} \\
\hline
\end{tabular}

$$
L_{A}=\frac{\sum_{i=1}^{N} n_{i} l_{i}}{\sum_{i=1}^{N} n_{i}}, \quad L_{L}=\frac{\sum_{i=1}^{N} n_{i} l_{i}^{2}}{\sum_{i=1}^{N} n_{i} l_{i}}, \quad L_{W}=\frac{\sum_{i=1}^{N} n_{i} l_{i}^{3}}{\sum_{i=1}^{N} n_{i} l_{i}^{2}}
$$

* Average of results for $\mathrm{C} 1, \mathrm{C} 2, \mathrm{~S}, \mathrm{WG}$, and WV.

\subsubsection{Loss On Ignition (LOI)}

Results of the mass loss of the residual solids upon ignition at 575,590 , and $1000^{\circ} \mathrm{C}$ are presented in Table 34 . LOI at $590^{\circ} \mathrm{C}$ was determined according to ASTM Standard Test Method for Ash in Wood (D 1102) [50].

Minimum, average, and maximum of LOI at $590^{\circ} \mathrm{C}$ were $43.6,65.3$, and $96.0 \%$, respectively. Upon increase in ignition temperature, Residuals I, S, and WG showed 
large increases in mass loss, while Residuals $\mathrm{C} 1, \mathrm{C} 2$, and WV showed very small increases.

Table 34. Loss On Ignition (LOI)* of Residual Solids at 575, 590, and $1^{\circ 000} \mathrm{C}$

\begin{tabular}{|l||c|c|c|c|c|c|c|c|}
\hline \multicolumn{1}{|c||}{ Properties } & C1 & C2 & I & S & WG & WV & P & BR \\
\hline LOI at $575^{\circ} \mathrm{C}$ & 52.0 & 68.0 & $\ldots$ & $\ldots$ & 37.0 & 79.0 & $\ldots$ & $\ldots$ \\
\hline LOI at $590^{\circ} \mathrm{C}$ & 54.9 & 73.1 & 49.7 & 57.9 & 43.6 & 82.3 & 96.0 & 99.6 \\
\hline LOI at $1000^{\circ} \mathrm{C}$ & 55.4 & 74.0 & 58.0 & 64.7 & 62.6 & 83.8 & $\ldots$ & $\ldots$ \\
\hline LOI at $1000^{\circ} \mathrm{C}-$ LOI at $590^{\circ} \mathrm{C}$ & 0.5 & 0.9 & 8.3 & 6.8 & 19.0 & 1.6 & $\ldots$ & $\ldots$ \\
\hline
\end{tabular}

* Unit: \% of oven-dry $\left(105^{\circ} \mathrm{C}\right)$ mass

According to ASTM Standard Test Method for Ash in Pulp, Paper, and Paper Products (D 586) [51], "residue from cellulose products that contain oxides of silicon [Si] or titanium [Ti] in fillers, coatings, or pigments may undergo negligible changes in weight when ignited at either 525 or $900^{\circ} \mathrm{C}$." As shown later in Table 37 on p. 75 and Table 42 on p. 79, Residuals I, S, and WG contained less amount of minerals of silicon (kaolinite, quartz, talc) and oxides of titanium $\left(\mathrm{TiO}_{2}\right)$ than Residuals $\mathrm{C} 1, \mathrm{C} 2$, and WV. In Table 35 and Fig. 16, relation of the following two properties of residuals are presented: (1) the percentage of minerals or oxides containing silicon and/or titanium; and (2) LOI from $590^{\circ} \mathrm{C}$ to $1000^{\circ} \mathrm{C}$ (or LOI at $1000^{\circ} \mathrm{C}-\mathrm{LOI}$ at $590^{\circ} \mathrm{C}$ ).

Table 35. Relation Between (1) Percentage of Minerals or Oxides Containing Silicon and/or Titanium and (2) LOI from $590^{\circ} \mathrm{C}$ to $1000^{\circ} \mathrm{C}$ of Residuals (Based on Tables 34, 37, 42)

\begin{tabular}{|l|c|c|c|c|c|c|}
\hline \multicolumn{1}{|c|}{ Properties } & $\mathrm{C} 1$ & $\mathrm{C} 2$ & $\mathrm{I}$ & $\mathrm{S}$ & $\mathrm{WG}$ & $\mathrm{WV}$ \\
\hline $\mathrm{LOI}$ at $1000^{\circ} \mathrm{C}-\mathrm{LOI}$ at $590^{\circ} \mathrm{C}(\%)$ & 0.5 & 0.9 & 8.3 & 6.8 & 19 & 1.6 \\
\hline $\begin{array}{l}\mathrm{Kaolinite}+\text { Quartz }+ \text { Talc among } \\
\text { the minerals (\%) }\end{array}$ & 100.0 & 57.1 & 23.9 & 20.4 & 3.1 & 19.2 \\
\hline $\mathrm{SiO}_{2}+\mathrm{TiO}_{2}$ among the oxides (\%) & 53.8 & 68.5 & 33.1 & 29.2 & 8.6 & 48.1 \\
\hline
\end{tabular}




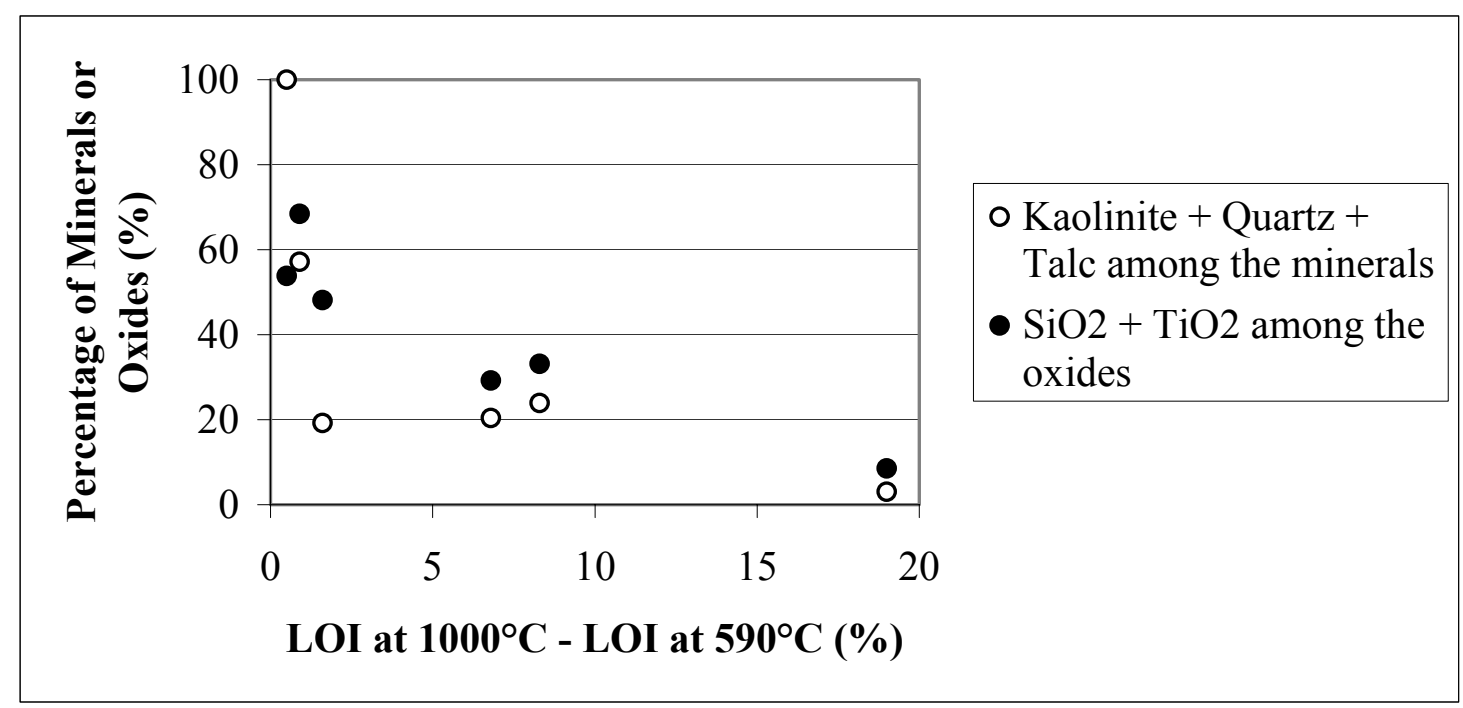

Fig. 16. Relation between (1) Percentage of minerals or oxides containing silicon and/or titanium and (2) $\mathrm{LOI}$ from $590^{\circ} \mathrm{C}$ to $1000^{\circ} \mathrm{C}$ of residuals

As the amount of minerals or oxides of $\mathrm{Si}$ and of $\mathrm{Ti}$ decreased, LOI from $590^{\circ} \mathrm{C}$ to $1000^{\circ} \mathrm{C}$ increased. That is, some of the minerals or oxides that did not contain $\mathrm{Si}$ or $\mathrm{Ti}$ were lost upon increase of ignition temperature from $590^{\circ} \mathrm{C}$ to $1000^{\circ} \mathrm{C}$.

For assessing the variability of residual solids in terms of LOI, LOI at $590^{\circ} \mathrm{C}$ values of the residuals of the $1^{\text {st }}$ and $2^{\text {nd }}$ deliveries are compared in Table 36.

Table 36. Comparison of LOI* at $590^{\circ} \mathrm{C}$ of Residuals of the $1^{\text {st }}$ and $2^{\text {nd }}$ Deliveries

\begin{tabular}{|c|c|c|c|c|c|c|c|}
\hline Delivery & $\mathrm{C} 1$ & $\mathrm{C} 2$ & $\bar{S}$ & WG & WV & BR & Avg. \\
\hline LOI of $1^{\text {st }}$ delivery & 54.9 & 73.1 & 57.9 & 43.6 & 82.3 & 99.6 & 68.5 \\
\hline LOI of $2^{\text {nd }}$ delivery & 62.5 & 69.9 & 51.2 & 30.1 & 89.6 & 99.8 & 67.2 \\
\hline LOI of $2^{\text {nd }}-$ LOI of $1^{\text {st }}$ & 7.6 & -3.2 & -6.7 & -13.5 & 7.4 & 0.3 & -1.4 \\
\hline
\end{tabular}

Unit: \% of oven-dry $\left(105^{\circ} \mathrm{C}\right)$ mass

As discussed later, $\mathrm{LOI}$ at $590^{\circ} \mathrm{C}$ is proportional to wood fiber content of paper mill residuals (p. 76). Wood fibers are lost upon ignition at $590^{\circ} \mathrm{C}$ while most of the papermaking fillers and coatings (if any) withstand the heat at this temperature. Thus 
variations in the proportions of wood fibers and papermaking fillers in residuals can be approximately estimated using LOI at $590^{\circ} \mathrm{C}$.

LOI at $590^{\circ} \mathrm{C}$ of Residual WG of the $2^{\text {nd }}$ delivery was about 13.5 percentage point lower than that of the $1^{\text {st }}$ delivery (Table 36). Overall, average values of LOI at $590^{\circ} \mathrm{C}$ of the $1^{\text {st }}$ and $2^{\text {nd }}$ deliveries were about the same (68.5 vs. $\left.67.2 \%\right)$.

\subsubsection{Mineralogical Composition}

Mineralogical compositions of the residual solids are presented in Table 37.

Table 37. Mineralogical Compositions of Residual Solids by Powder Diffraction Analysis*

\begin{tabular}{|l||c|c|c|c|c|c|}
\hline \multicolumn{1}{|c|}{ Mineral } & \multicolumn{7}{c|}{ Residual Solids } \\
\cline { 2 - 8 } & C1 & C2 & I & S & WG & WV \\
\hline Calcite $\left(\mathrm{CaCO}_{3}\right)$ & & 15 & 51 & 36 & 63 & 21 \\
\hline Kaolinite $\left(\mathrm{Al}_{2} \mathrm{Si}_{2} \mathrm{O}_{5}(\mathrm{OH})_{4}\right)$ & 52 & 14 & 16 & 7 & & 2 \\
\hline Magnesite $\left(\mathrm{MgCO}_{3}\right)$ & & & & 7 & & \\
\hline Quartz $\left(\mathrm{SiO}_{2}\right)$ & & 5 & & 1 & 2 & 3 \\
\hline Talc $\left(\mathrm{Mg}_{3} \mathrm{Si}_{4} \mathrm{O}_{10}(\mathrm{OH})_{2}\right)$ & & $<1$ & & 3 & & \\
\hline \hline Sum of Minerals & 52 & $<35$ & 67 & 54 & 65 & 26 \\
\hline
\end{tabular}

* Unit: \% of oven-dry $\left(105^{\circ} \mathrm{C}\right)$ mass

\subsubsection{Infrared Analysis}

Four out of the eight sources of residuals were selected for more detailed analysis. Table 38 shows results of infrared analysis on the four sources $(\mathrm{C} 1, \mathrm{C} 2, \mathrm{WG}$, and WV) of residuals. Calcium carbonate and kaolin-type clay contents in Table 38 were consistent with the corresponding values in Table 37. Wood (pulp) fiber contents presented in Table 38 were, on average, about $9 \%$ lower than the corresponding LOI at $590^{\circ} \mathrm{C}$ values in Table 37. As presented later (Eq. 1 on p. 77), LOI at $590^{\circ} \mathrm{C}$ can be used in approximately estimating wood fiber content in residual solids. 
Table 38. Infrared Analysis on Selective Residuals*

\begin{tabular}{|l|c|c|c|c|}
\hline \multirow{2}{*}{\multicolumn{1}{|c|}{ Components }} & \multicolumn{4}{c|}{ Residual } \\
\cline { 2 - 5 } & $\mathrm{C} 1$ & $\mathrm{C} 2$ & WG & WV \\
\hline Calcium carbonate $\left(\mathrm{CaCO}_{3}\right)$ & & 15 & 63 & $21 \uparrow$ \\
\hline Kaolin-type clay & 54 & 19 & & \\
\hline Solvent soluble organics & 3 & 2 & 1 & 2.5 \\
\hline $\begin{array}{l}\text { Carbonized material } \\
\text { (particles) }\end{array}$ & & & 1 & \\
\hline Wood fibers & 43 & 64 & 35 & 76.5 \\
\hline
\end{tabular}

* Unit: \% of oven-dry $\left(105^{\circ} \mathrm{C}\right)$ mass

$\dagger$ Inorganics - a mixture of calcium carbonate and silicates

\subsubsection{Wood Fiber Content}

Analyses of the $\mathrm{LOI}$ at $575^{\circ} \mathrm{C}$ and at $590^{\circ} \mathrm{C}$ (Table 34) and wood fiber content (Table 38) of the four sources of residual solids, $\mathrm{C} 1, \mathrm{C} 2, \mathrm{WG}$, and $\mathrm{WV}$, show that the LOI and wood fiber content have a close relationship, as shown in Tables 39 and 40, and Fig. 17 and 18.

Table 39. Loss On Ignition (LOI) at $575^{\circ} \mathrm{C}$ and Wood Fiber Content of Residual Solids

\begin{tabular}{|l|c|c|c|c|}
\hline \multicolumn{1}{|c|}{ Properties } & C1 & C2 & WG & WV \\
\hline \hline LOI at $575^{\circ} \mathrm{C} \mathrm{( \% )*}$ & 52 & 68 & 37 & 79 \\
\hline Wood Fiber Content (\%)* & 43 & 64 & 35 & 76.5 \\
\hline
\end{tabular}

* based on oven-dry $\left(105^{\circ} \mathrm{C}\right)$ mass 


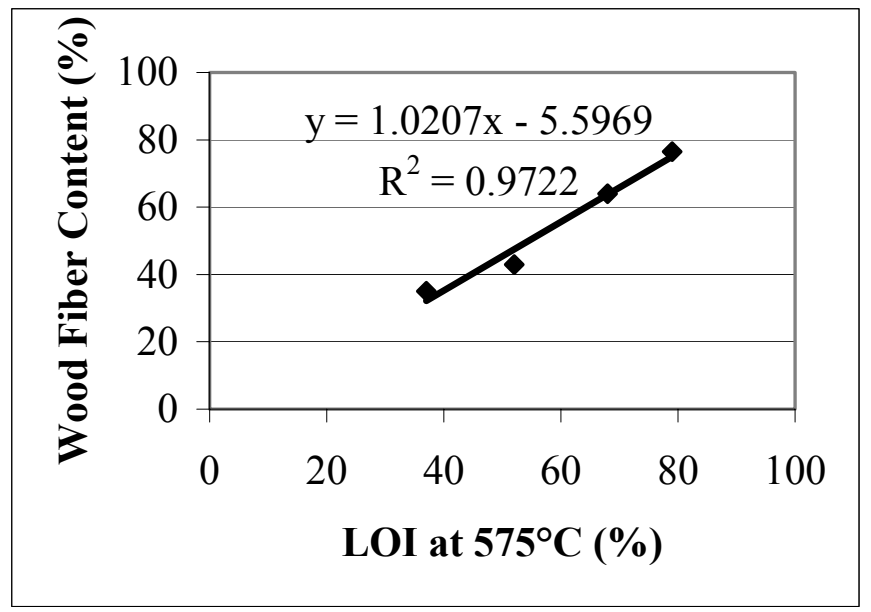

Fig. 17. Relation between wood fiber content and $\mathrm{LOI}$ at $575^{\circ} \mathrm{C}$ of residual solids

Assuming that the relationship between the wood fiber content and LOI at $590^{\circ} \mathrm{C}$ for the four sources of residual solids $(\mathrm{C} 1, \mathrm{C} 2, \mathrm{WG}, \mathrm{WV})$ applies to the rest of the residual solids (I, S, P, and BR), the following equation (from Fig. 18) could be used in estimating the wood fiber content of residual solids:

Wood Fiber Content $(\%)=1.083 *$ LOI at $590^{\circ} \mathrm{C}-14.1$

Table 40. Loss On Ignition (LOI) at $590^{\circ} \mathrm{C}$ and Wood Fiber Content of Residual Solids

\begin{tabular}{|l||c|c|c|c|}
\hline \multicolumn{1}{|c|}{ Properties } & C1 & C2 & WG & WV \\
\hline \hline LOI at $590^{\circ} \mathrm{C}(\%)^{*}$ & 54.9 & 73.1 & 43.6 & 82.3 \\
\hline Wood Fiber Content $(\%)^{*}$ & 43 & 64 & 35 & 76.5 \\
\hline
\end{tabular}

* Based on oven-dry $\left(105^{\circ} \mathrm{C}\right)$ mass 


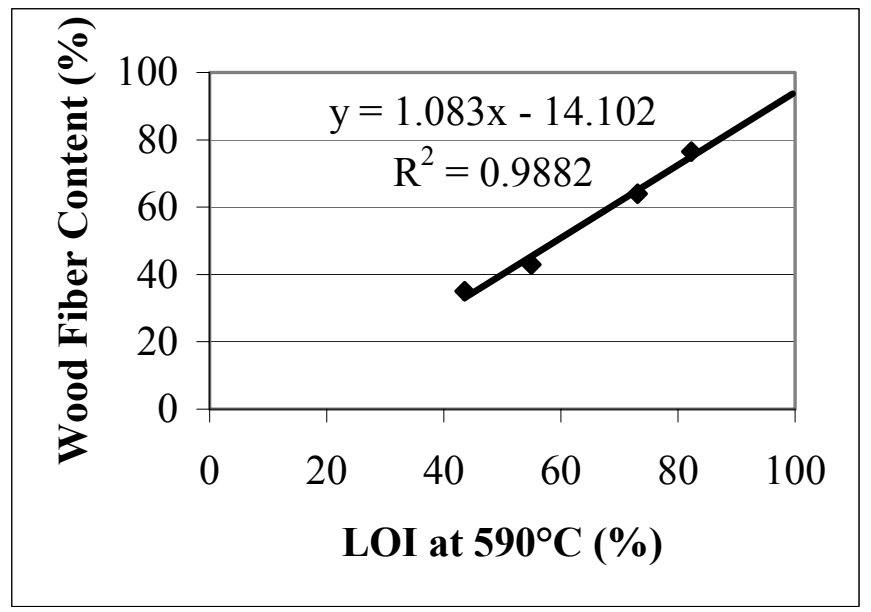

Fig. 18. Relation between wood fiber content and $\mathrm{LOI}$ at $590^{\circ} \mathrm{C}$ of residual solids

Combining the actual values of fiber content and the values estimated by using Eq. 1, wood fiber content of the residual solids are as shown in Table 41.

Table 41. Wood Fiber Content of Residual Solids*

\begin{tabular}{|l|c|c|c|c|c|c|c|c|c|c|c|}
\hline \multirow{2}{*}{ Properties } & \multicolumn{7}{|c|}{ Residual Solids } & \multirow{2}{*}{ Min } & \multirow{2}{*}{ Avg } & \multirow{2}{*}{ Max } \\
\cline { 2 - 13 } & $\mathrm{C} 1$ & $\mathrm{C} 2$ & $\mathrm{I}$ & $\mathrm{S}$ & $\mathrm{WG}$ & $\mathrm{WV}$ & $\mathrm{P}$ & $\mathrm{BR}$ & & & \\
\hline LOI at $590^{\circ} \mathrm{C}$ & 54.9 & 73.1 & 49.7 & 57.9 & 43.6 & 82.3 & 96 & 99.6 & 43.6 & 69.6 & 99.6 \\
\hline Wood Fiber & 43 & 64 & $40 \dagger$ & $49 \dagger$ & 35 & 77 & $90 \dagger$ & $94 \dagger$ & 35 & 61 & 94 \\
\hline
\end{tabular}

* Unit: \% of oven-dry $\left(105^{\circ} \mathrm{C}\right)$ mass

$\dagger$ Values estimated by using Eq. 1.

Wood fiber content was determined by infrared analysis (Table 38 on p. 76). But, the infrared analysis is a rather expensive test. Moreover, not all paper products testing laboratories are capable of conducting the infrared analysis. On the other hand, LOI test is cheaper and can be readily conducted. Comparison of the equations in Fig. 17 and 18 shows that LOI at $575^{\circ} \mathrm{C}$ is more closely related to wood fiber content than LOI at $590^{\circ} \mathrm{C}$ is (slope: $\sim 1.02$ vs. 1.08 ; intersection: $\sim-5.6$ vs. $-14.1 \%$ ). This is probably due to the loss of some of non-fibrous matters (that is, papermaking fillers and coatings) upon increase of ignition temperature from $575^{\circ} \mathrm{C}$ to $590^{\circ} \mathrm{C}$. 
However, a still better, economical, and quicker indicator of wood fiber content of residuals may be found in a future study by establishing a relationship between wood fiber content and LOI at $525^{\circ} \mathrm{C}$ of paper mill residuals. LOI at $525^{\circ} \mathrm{C}$ test is covered in ASTM D 586. This test is expected to lead to a better estimation equation for wood fiber content than Eq. 1, which is based on LOI at $590^{\circ} \mathrm{C}$.

\subsubsection{Oxide Composition}

Oxide composition and LOI at $1000^{\circ} \mathrm{C}$ for six sources of residual solids are presented in Table 42. On average, the presence of the oxides $\mathrm{CaO}, \mathrm{SiO}_{2}$, and $\mathrm{Al}_{2} \mathrm{O}_{3}$ were dominant. There exist proportional relationships between the amounts of $\mathrm{CaO}$ and Calcite $\left(\mathrm{CaCO}_{3}\right)$ and between the amounts of $\mathrm{Al}_{2} \mathrm{O}_{3}$ and Kaolinite $\left(\mathrm{Al}_{2} \mathrm{Si}_{2} \mathrm{O}_{5}(\mathrm{OH})_{4}\right)$.

Table 42. XRF* Oxides, $\mathrm{SO}_{3}$, and LOI at $1000^{\circ} \mathrm{C}$ of Residual Solids, \% by mass

\begin{tabular}{|c|c|c|c|c|c|c|c|}
\hline \multirow{2}{*}{$\begin{array}{c}\text { Oxides and } \\
\text { LOI }\end{array}$} & \multicolumn{7}{|c|}{ Residual Solids } \\
\hline & $\mathrm{C} 1$ & $\mathrm{C} 2$ & $\mathrm{I}$ & $\mathrm{S}$ & WG & WV & Avg. \\
\hline $\mathrm{SiO}_{2}$ & 21.8 & 17.5 & 9.3 & 9.4 & 3.2 & 7.8 & 11.5 \\
\hline $\mathrm{Al}_{2} \mathrm{O}_{3}$ & 19.1 & 3.4 & 7.8 & 5.3 & 0.4 & 1.4 & 6.2 \\
\hline $\mathrm{CaO}$ & 0.6 & 3.3 & 19.3 & 17.1 & 31.5 & 4.6 & 12.7 \\
\hline $\mathrm{MgO}$ & 0.2 & 0.6 & 0.5 & 1.7 & 1.0 & 0.2 & 0.7 \\
\hline $\mathrm{Fe}_{2} \mathrm{O}_{3}$ & 0.4 & 0.5 & 0.2 & 0.5 & 0.5 & 1.1 & 0.5 \\
\hline $\mathrm{TiO}_{2}$ & 2.2 & 0.3 & 4.6 & 0.9 & 0.0 & 0.0 & 1.3 \\
\hline $\mathrm{K}_{2} \mathrm{O}$ & 0.1 & 0.1 & 0.0 & 0.0 & 0.1 & 0.1 & 0.1 \\
\hline $\mathrm{Na}_{2} \mathrm{O}$ & 0.2 & 0.2 & 0.3 & 0.1 & 0.3 & 0.3 & 0.2 \\
\hline $\mathrm{SO}_{3}$ & 0.0 & 0.3 & 0.1 & 0.3 & 0.3 & 0.6 & 0.3 \\
\hline Sum of Oxides & 44.6 & 26.0 & 42.0 & 35.3 & 37.4 & 16.2 & 33.6 \\
\hline LOI at $1000^{\circ} \mathrm{C}$ & 55.4 & 74.0 & 58.0 & 64.7 & 62.6 & 83.8 & 66.4 \\
\hline Oxides + LOI & 100.0 & 100.0 & 100.0 & 100.0 & 100.0 & 100.0 & 100.0 \\
\hline
\end{tabular}

* X-Ray Fluorescence 


\subsubsection{Elemental Composition}

Elemental analysis for the residual solids was conducted using Instrumental Neutron

Activation Analysis. The results are presented in Table 43.

Table 43. Elemental Composition of Residual Solid (in ppm)

\begin{tabular}{|l|r|r|r|r|r|r|r|r|}
\hline \multicolumn{1}{|c|}{ Element } & $\mathrm{C} 1$ & \multicolumn{1}{c|}{$\mathrm{C} 2$} & $\mathrm{I}$ & $\mathrm{S}$ & $\mathrm{WG}$ & $\mathrm{WV}$ & Overall & (Rank) \\
\hline Aluminum (A1) & 56,300 & 22,900 & 31,600 & 21,900 & $<1,760$ & 9,320 & $<24,000$ & 1 \\
\hline Antimony (Sb) & 1 & $<1$ & 3 & 1 & $<1$ & 2 & & \\
\hline Arsenic (As) & 10 & 7 & 11 & 11 & 4 & 34 & & \\
\hline Barium (Ba) & $<66$ & $<84$ & $<71$ & $<49$ & 167 & $<97$ & & \\
\hline Bromine (Br) & 11 & 7 & 5 & 3 & 2 & 3 & & \\
\hline Cadmium (Cd) & 1,770 & 1,860 & 1,870 & 1,130 & 1,700 & 2,830 & 1,860 & 7 \\
\hline Calcium (Ca) & $<515$ & $<3,660$ & 21,000 & 17,200 & 33,000 & 7,860 & $<13,900$ & 2 \\
\hline Cerium (Ce) & 18 & 5 & 10 & 7 & 1 & 3 & & \\
\hline Cesium (Cs) & 0 & 0 & 0 & 0 & 0 & 1 & & \\
\hline Chlorine (Cl) & 243 & 810 & 733 & 341 & $<173$ & 179 & $<413$ & 9 \\
\hline Chromium (Cr) & 30 & 13 & 12 & 36 & 8 & 18 & & \\
\hline Cobalt (Co) & 2 & 1 & 1 & 3 & 0 & 1 & & \\
\hline Copper (Cu) & $<223$ & $<278$ & $<277$ & $<157$ & $<299$ & $<298$ & & \\
\hline Dysprosium (Dy) & $<3$ & $<4$ & $<2$ & $<2$ & $<5$ & $<4$ & & \\
\hline Europium (Eu) & 0 & 0 & 0 & 0 & 0 & 0 & & \\
\hline Gallium (Ga) & $<193$ & $<310$ & $<182$ & $<144$ & $<427$ & $<363$ & & \\
\hline Gold (Au) & 0 & 0 & 0 & 0 & 0 & 0 & & \\
\hline Hafnium (Hf) & 1 & 1 & 1 & 2 & 1 & 1 & & \\
\hline Holmium (Ho) & $<3$ & $<2$ & $<3$ & $<2$ & $<1$ & $<2$ & & \\
\hline Indium (In) & 0 & 0 & 0 & 0 & 0 & 0 & & \\
\hline Iodine (I) & $<6$ & $<10$ & $<7$ & $<5$ & $<12$ & $<11$ & & \\
\hline Iridium (Ir) & 0 & 0 & 0 & 0 & 0 & 0 & & \\
\hline Iron (Fe) & 2,070 & 4,010 & 969 & 2,740 & 2,650 & 9,080 & 3,580 & 4 \\
\hline Lanthanum (La) & 14 & 4 & 7 & 5 & 1 & 3 & & \\
\hline Lutetium (Lu) & 0 & 0 & 0 & 0 & 0 & 0 & & \\
\hline Magnesium (Mg) & 3,440 & 3,390 & 2,820 & 4,520 & 2,080 & 1,120 & 2,900 & 5 \\
\hline Manganese (Mn) & 274 & 2,090 & 242 & 394 & 7,640 & 3,010 & 2,270 & 6 \\
\hline Mercury (Hg) & 9 & 2 & 3 & 2 & 0 & 1 & & \\
\hline Molybdenum (Mo) & $<59$ & $<39$ & $<49$ & $<34$ & $<28$ & $<43$ & & \\
\hline Neodymium (Nd) & 7 & $<6$ & $<8$ & $<4$ & $<4$ & $<6$ & & \\
\hline Nickel (Ni) & $<1,630$ & $<1,200$ & $<1,580$ & 2,690 & $<827$ & $<1,300$ & & \\
\hline Palladium (Pd) & $<318$ & $<545$ & $<314$ & $<245$ & $<708$ & $<609$ & & \\
\hline
\end{tabular}


Table 43. Elemental Composition of Residual Solid (in ppm) (Cont'd.)

\begin{tabular}{|l|r|r|r|r|r|r|r|r|}
\hline \multicolumn{1}{|c|}{ Element } & \multicolumn{1}{c|}{$\mathrm{C} 1$} & \multicolumn{1}{c|}{$\mathrm{C} 2$} & $\mathrm{I}$ & \multicolumn{1}{c|}{$\mathrm{S}$} & $\mathrm{WG}$ & $\mathrm{WV}$ & Overall & (Rank) \\
\hline Potassium (K) & 1,070 & 1,430 & $<839$ & $<707$ & 1,360 & $<1,230$ & & \\
\hline Praseodymium (Pr) & $<8$ & $<7$ & $<9$ & $<6$ & $<7$ & $<9$ & & \\
\hline Rhenium (Re) & $<26$ & $<17$ & $<20$ & $<17$ & $<14$ & $<21$ & & \\
\hline Rubidium (Rb) & $<9$ & $<9$ & $<12$ & $<6$ & $<7$ & 8 & & \\
\hline Ruthenium (Ru) & 2 & 2 & $<3$ & 4 & 11 & 2 & & \\
\hline Samarium (Sm) & 2 & 1 & 1 & 1 & 0 & 1 & & \\
\hline Scandium (Sc) & 4 & 1 & 2 & 1 & 0 & 1 & & \\
\hline Selenium (Se) & $<113$ & $<77$ & $<101$ & $<61$ & $<49$ & $<81$ & & \\
\hline Silver (Ag) & $<10$ & $<8$ & $<10$ & $<6$ & $<5$ & $<8$ & & \\
\hline Sodium (Na) & 434 & 982 & 1,800 & 723 & 2,050 & 2,010 & 1,330 & 8 \\
\hline Strontium (Sr) & $<26$ & $<39$ & $<28$ & $<22$ & $<55$ & $<47$ & & \\
\hline Tantalum (Ta) & 1 & 0 & 0 & 1 & 0 & 0 & & \\
\hline Tellurium (Te) & 0 & 0 & 0 & 0 & 0 & 0 & & \\
\hline Terbidium (Tb) & 0 & 0 & $<1$ & 0 & 0 & 0 & & \\
\hline Thorium (Th) & 3 & 1 & 2 & 1 & 0 & 1 & & \\
\hline Thulium (Tm) & $<1$ & 0 & $<1$ & 0 & 0 & 0 & & \\
\hline Tin (Sn) & $<296$ & $<209$ & $<269$ & $<158$ & $<132$ & $<220$ & & \\
\hline Titanium (Ti) & 6,300 & 1,970 & 15,500 & 3,230 & $<1,060$ & $<984$ & $<4,840$ & 3 \\
\hline Tungsten (W) & 1 & 2 & $<1$ & 2 & $<1$ & 2 & & \\
\hline Uranium (U) & 7 & 1 & 2 & 2 & 0 & 1 & & \\
\hline Vanadium (V) & 31 & 22 & 19 & 16 & $<10$ & 10 & & \\
\hline Ytterbium (Yb) & 1 & 0 & 0 & 0 & 0 & 0 & & \\
\hline Zinc (Zn) & $<17$ & 17 & $<12$ & 67 & 72 & 71 & & \\
\hline Zirconium (Zr) & $<111$ & $<80$ & $<101$ & $<53$ & $<52$ & $<86$ & & \\
\hline
\end{tabular}

The residual solids showed similar elemental composition. Overall, the major constituent elements of the residual solids were aluminum $(\mathrm{Al})$, calcium $(\mathrm{Ca})$, titanium (Ti), iron $(\mathrm{Fe})$, magnesium $(\mathrm{Mg})$, manganese $(\mathrm{Mn})$, cadmium $(\mathrm{Cd})$, sodium $(\mathrm{Na})$, and chlorine $(\mathrm{Cl})$, in decreasing amounts. There exist proportional relationships between the amounts of $\mathrm{Ca}$ and $\mathrm{Calcite}\left(\mathrm{CaCO}_{3}\right)$ and between the amounts of $\mathrm{Al}$ and Kaolinite $\left(\mathrm{Al}_{2} \mathrm{Si}_{2} \mathrm{O}_{5}(\mathrm{OH})_{4}\right)$

Cadmium $(\mathrm{Cd})$ is a heavy metal. Overall, the amount of cadmium $(\mathrm{Cd})$ in the residual solids was about 1900 ppm (0.19\%). 
The concentration of cadmium in paper mill wastewater treatment residuals is well below the most restrictive concentrations specified for land applied municipal sewage treatment biosolids [52]. EP (Extraction Procedure) toxicity and TCLP (Toxicity Characteristic Leaching Procedure) characterizations of residuals show that paper mill residuals are non-hazardous [52].

\subsubsection{Morphology}

Optical micrographs and scanning electron micrographs (SEM) of oven-dry samples of seven sources residual solids, excluding BR, are presented in Fig. 19 through 25. An optical micrograph provides a different look at the material. The colors in an optical micrograph can be useful in identifying the components of the residual solids.

Note that because micrographs of oven-dry samples were taken, the clay (when present) in the micrographs of the residual solids might look stiff, especially in optical micrographs. Clay (when present) contained in as-received (moist) residual solids is softer than they appear on micrographs.

The relative magnifications for the lower left SEM, the top optical micrograph, and the lower right SEM are about 30, 80, and 100 times, respectively.

For C1 residual solids (Fig. 19), cellulose fibers and clay (white agglomerations in optical color micrograph) are visible. In Fig. 20 for C2 residual solids, fibers and some particulate materials are observed. In Fig. 21 for I residual solids, many fibers are tightly held together. Being a primary clarifier residual solid from a recycled paper mill, some blue and red impurities are observed. Along with WV residual solids, Fig. 24, I residual solids was one of the most "difficult" residual solids to de-flocculate ("repulp") in water. 


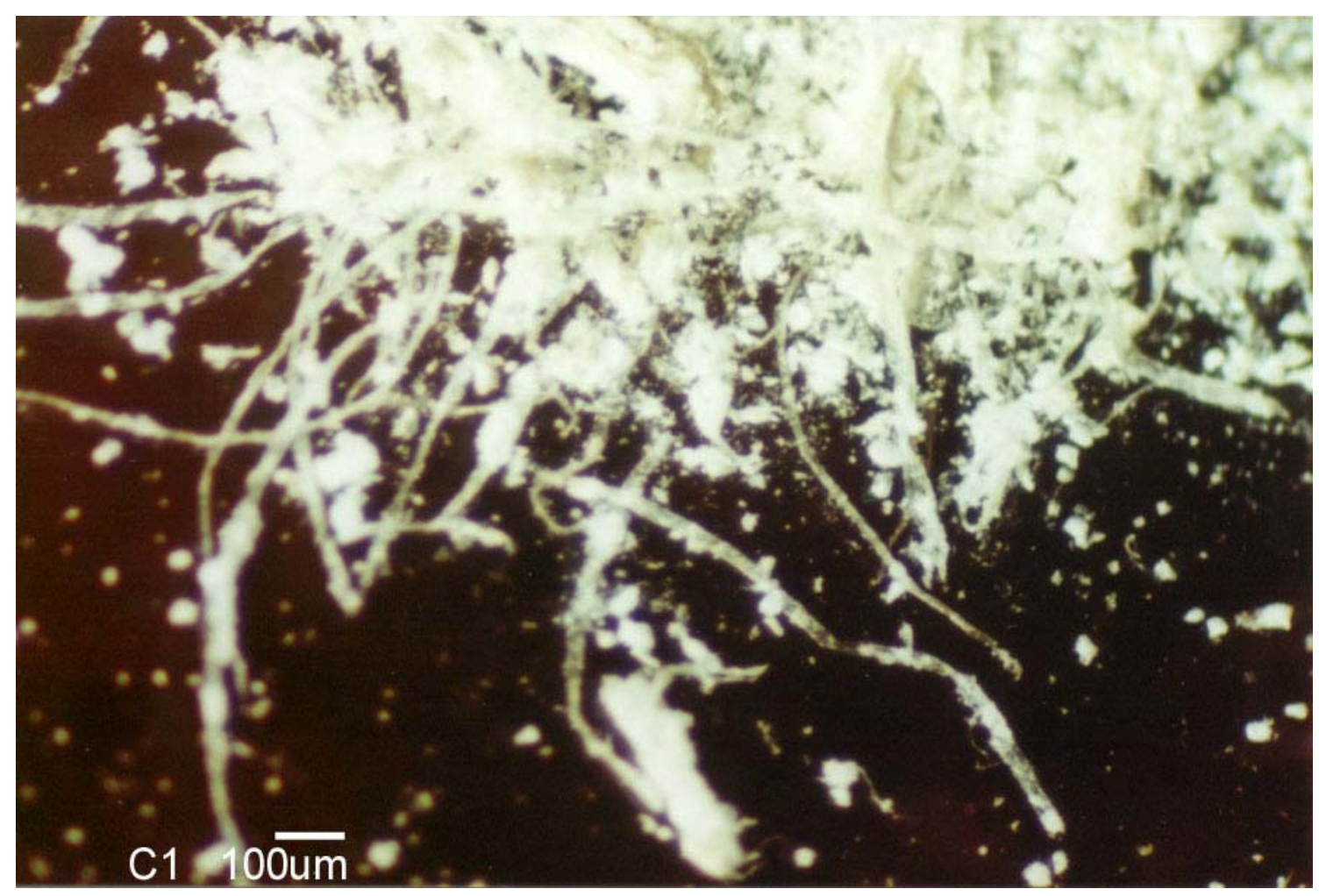

Optical (80 x)

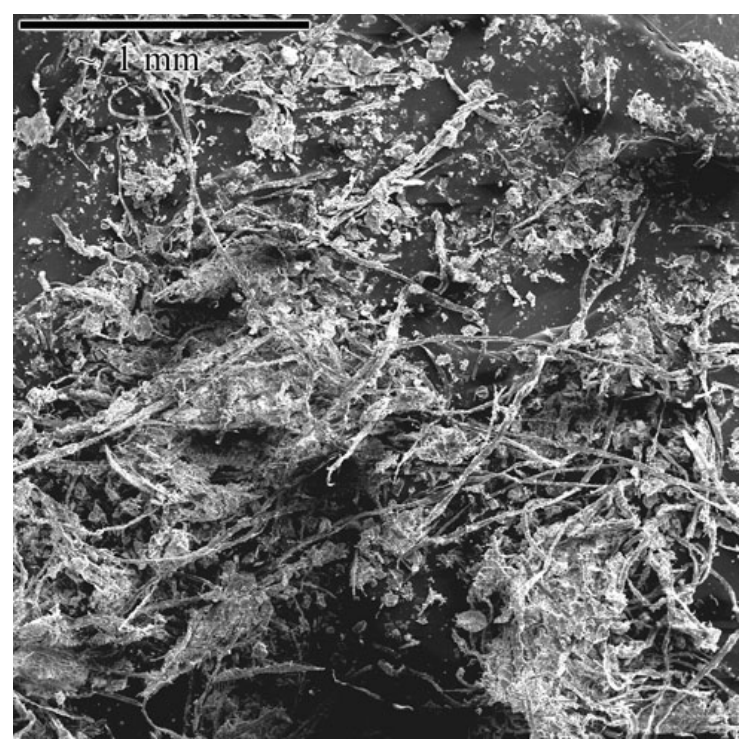

SEM (30 x)

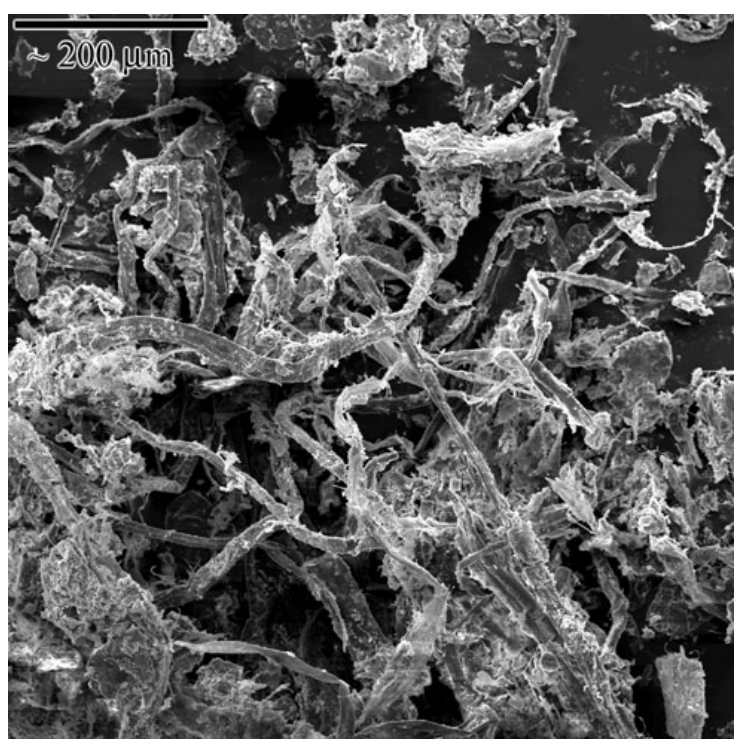

SEM (100 x)

Fig. 19. Micrographs of the Residual C1 


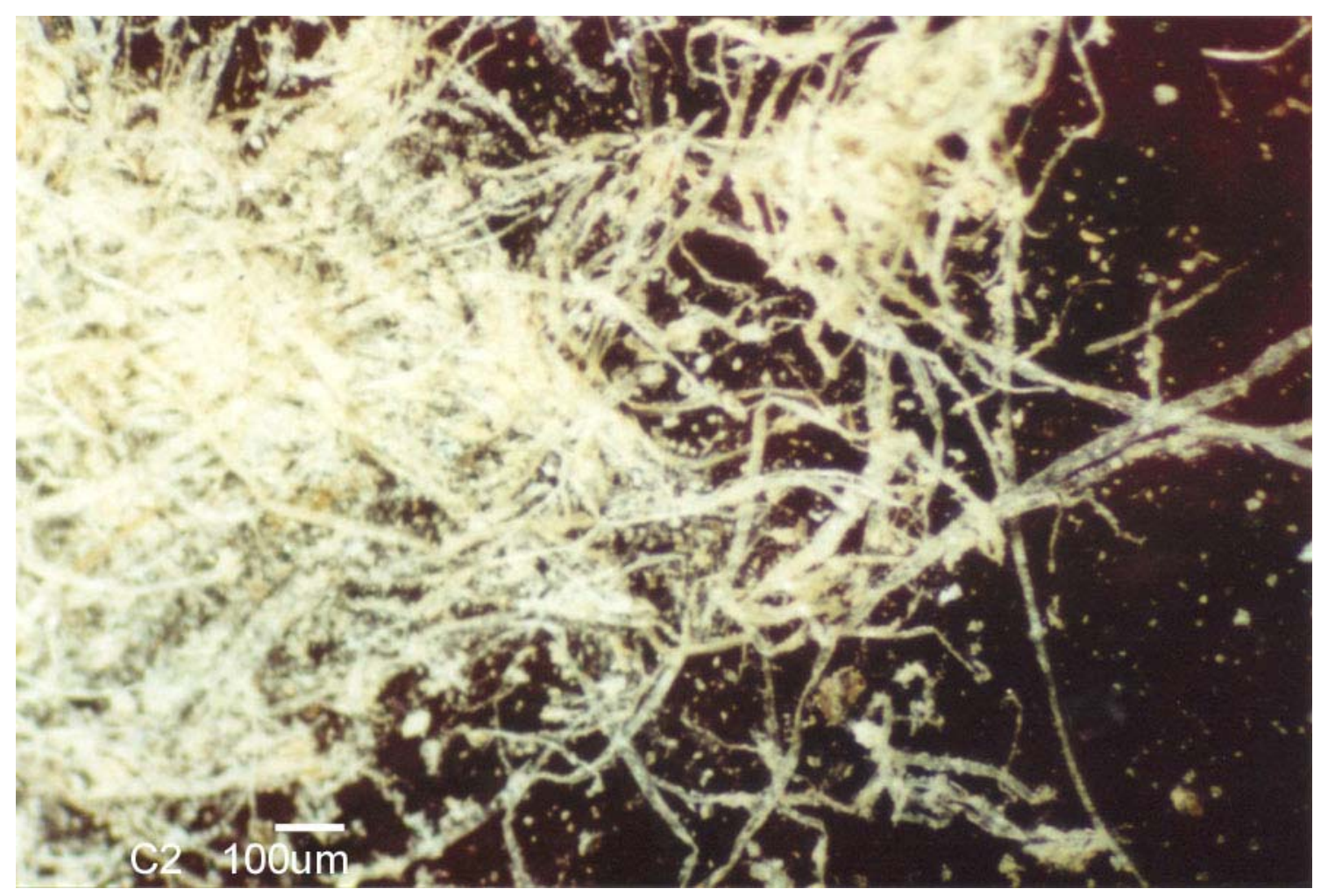

Optical (80 x)

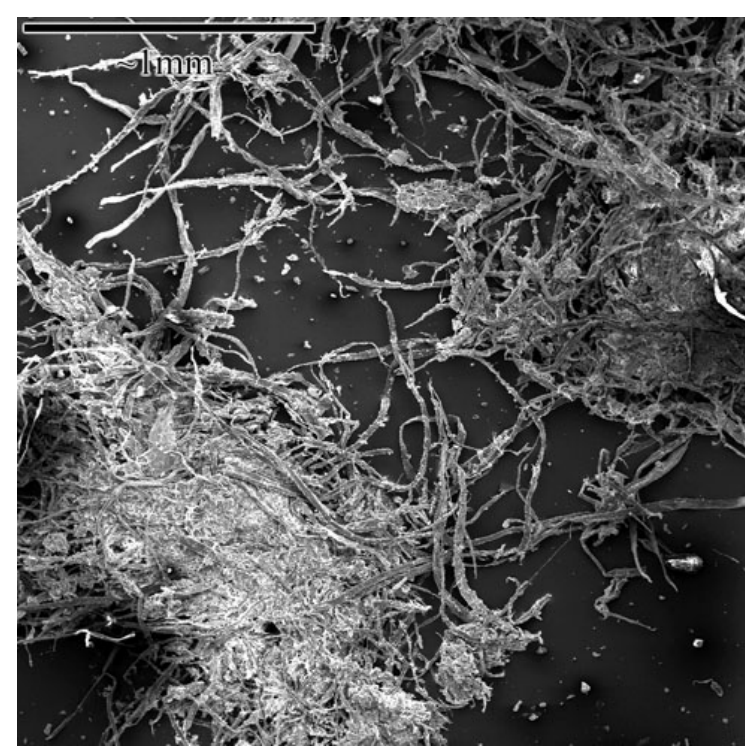

SEM (30 $x)$

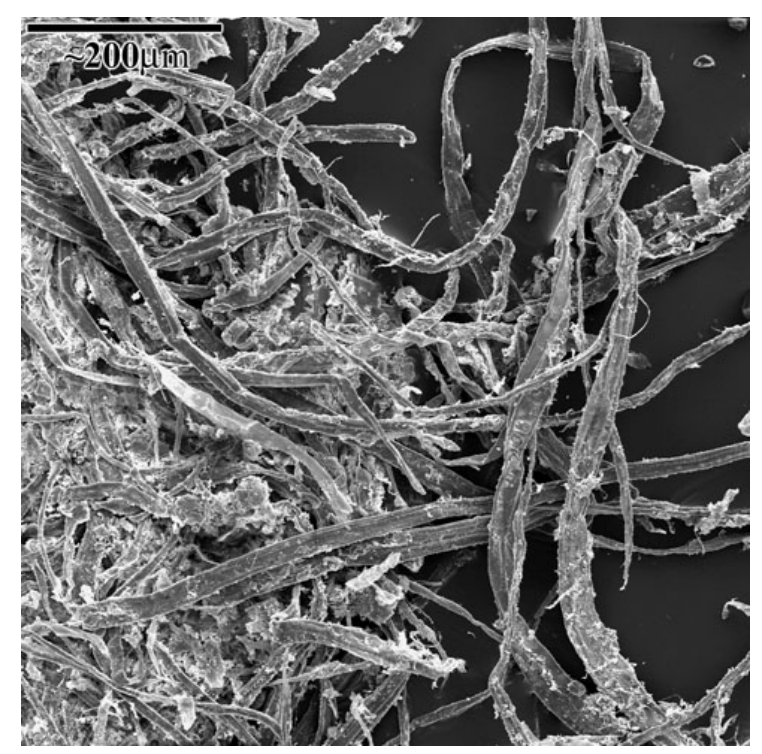

SEM (100 x)

Fig. 20. Micrographs of the Residual C2 


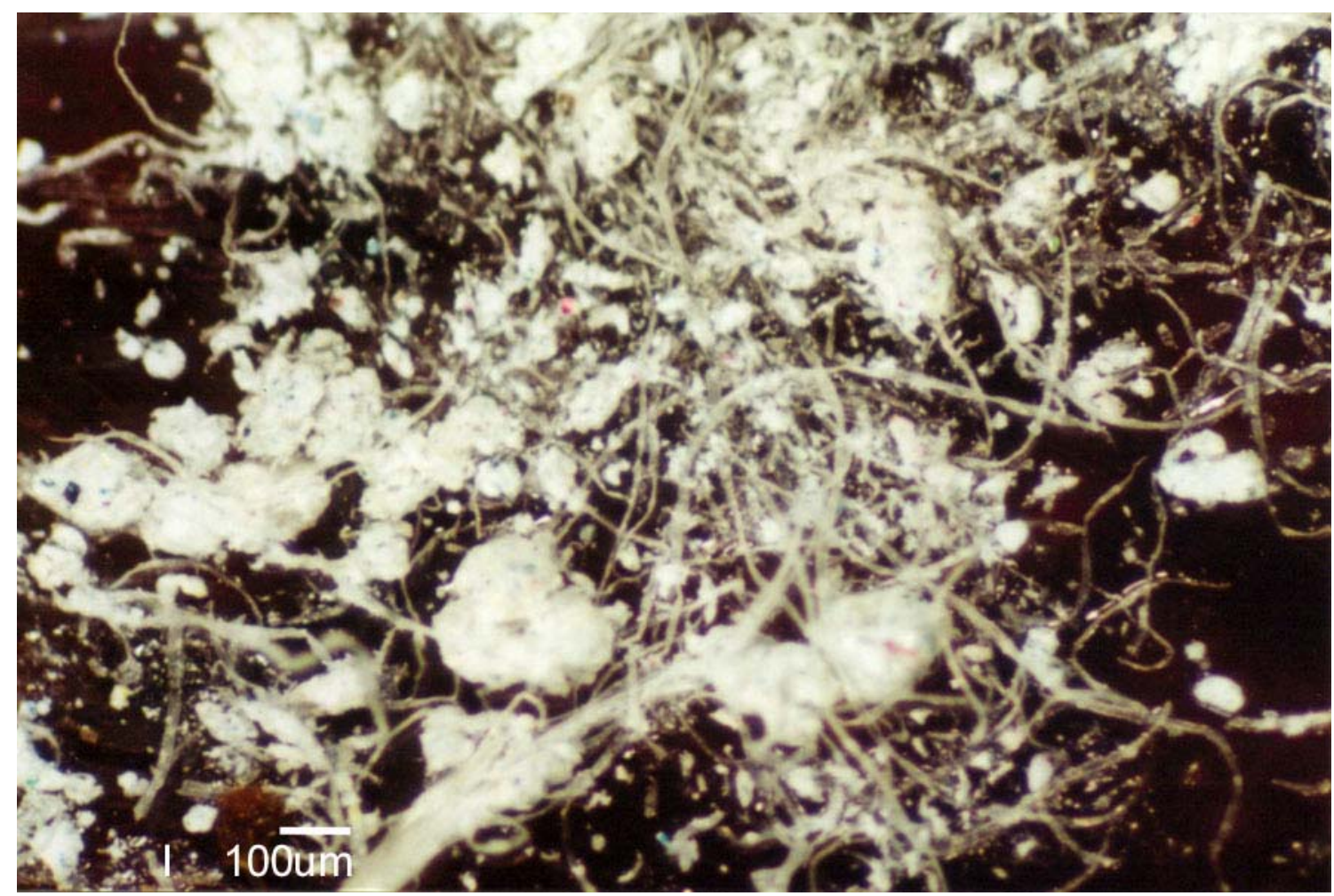

Optical (80 x)

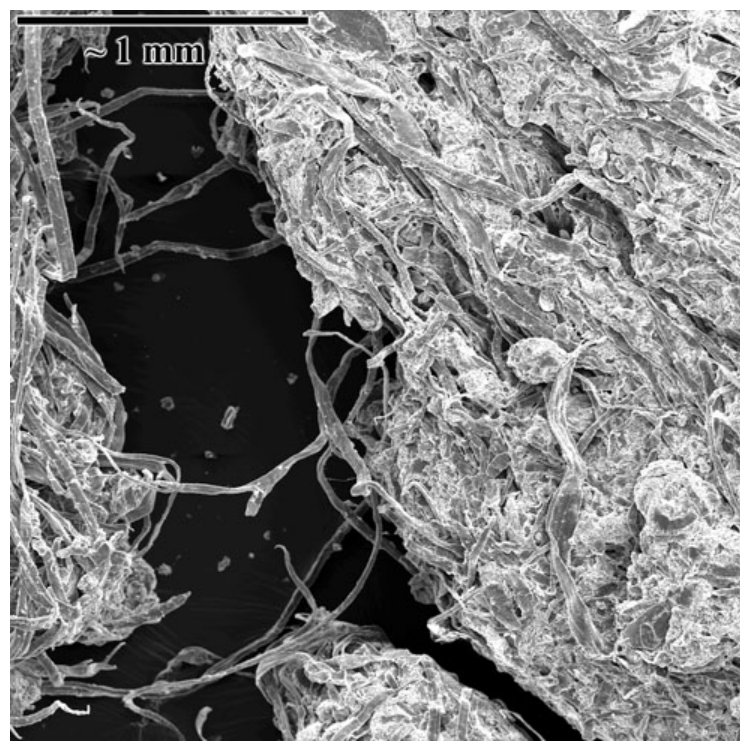

SEM (30 x)

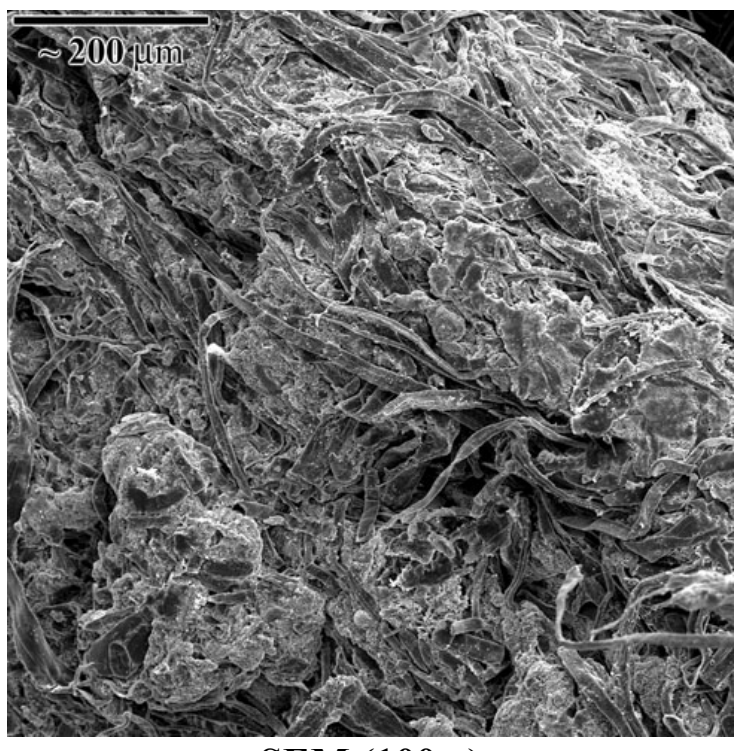

SEM (100 x)

Fig. 21. Micrographs of the Residual I 


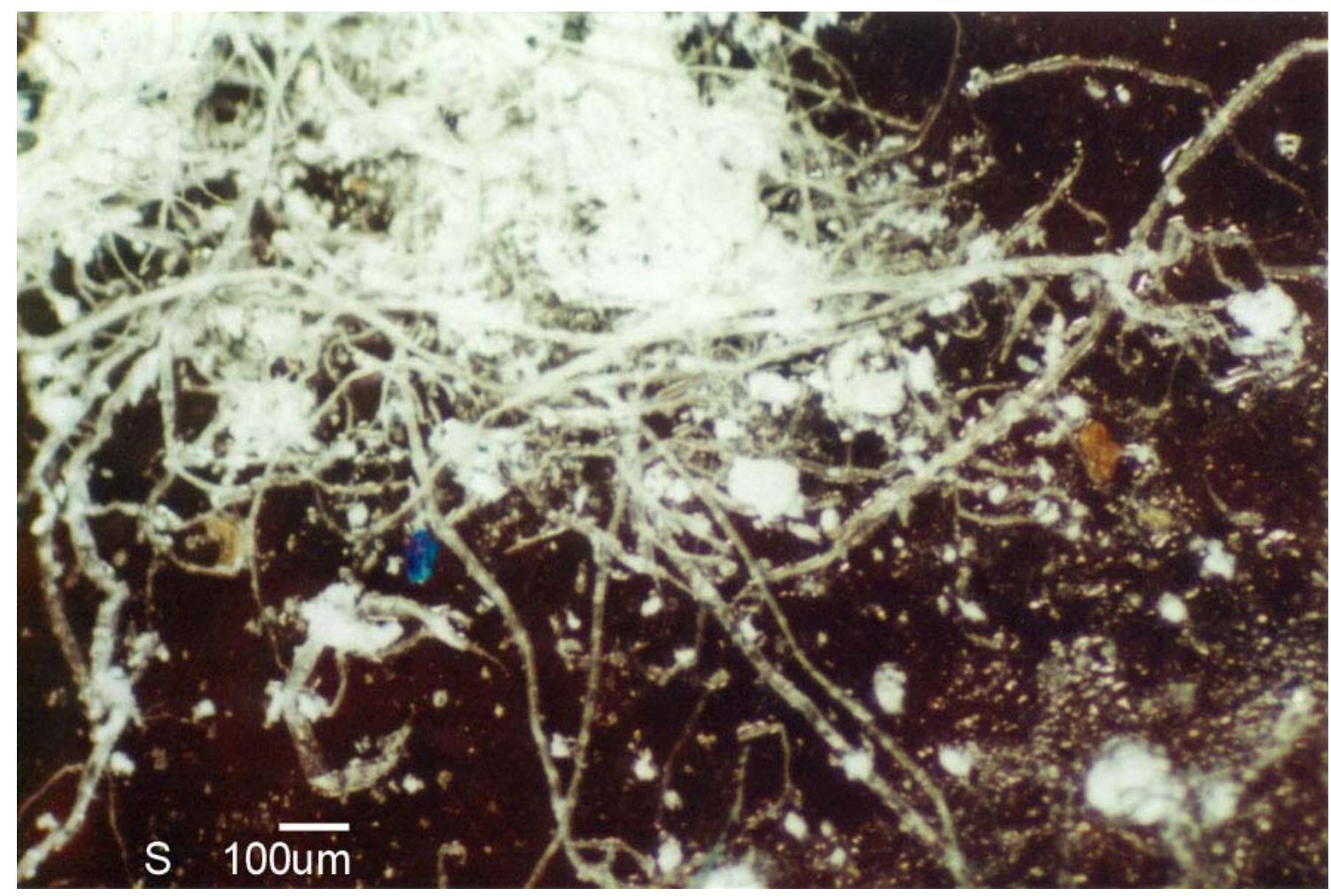

Optical (80 x)

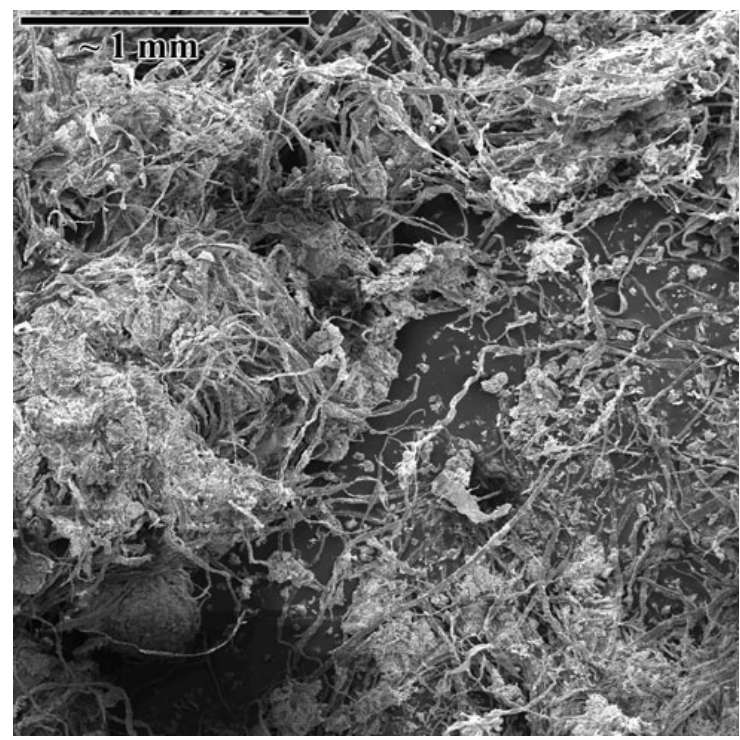

SEM (30 x)

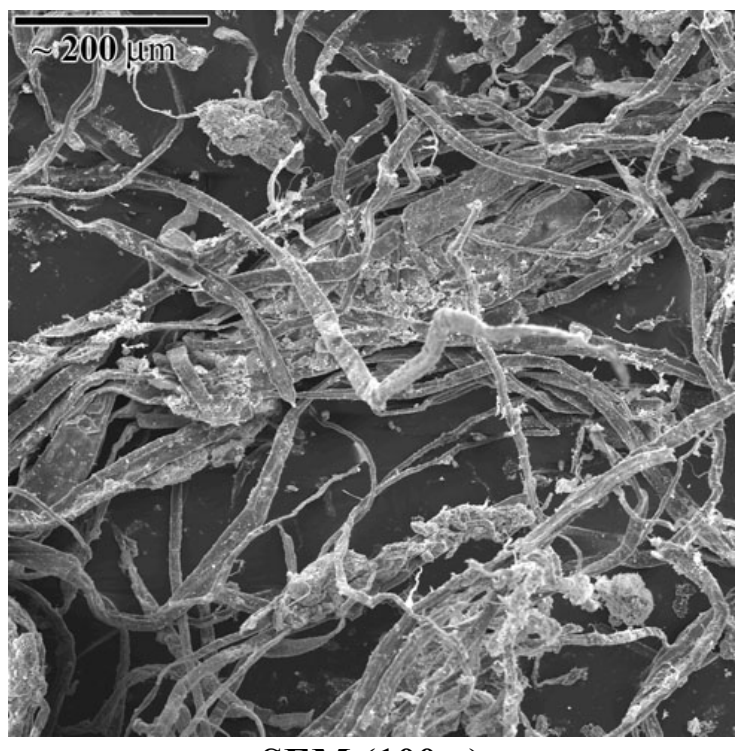

SEM (100 x)

Fig. 22. Micrographs of the Residual $S$ 


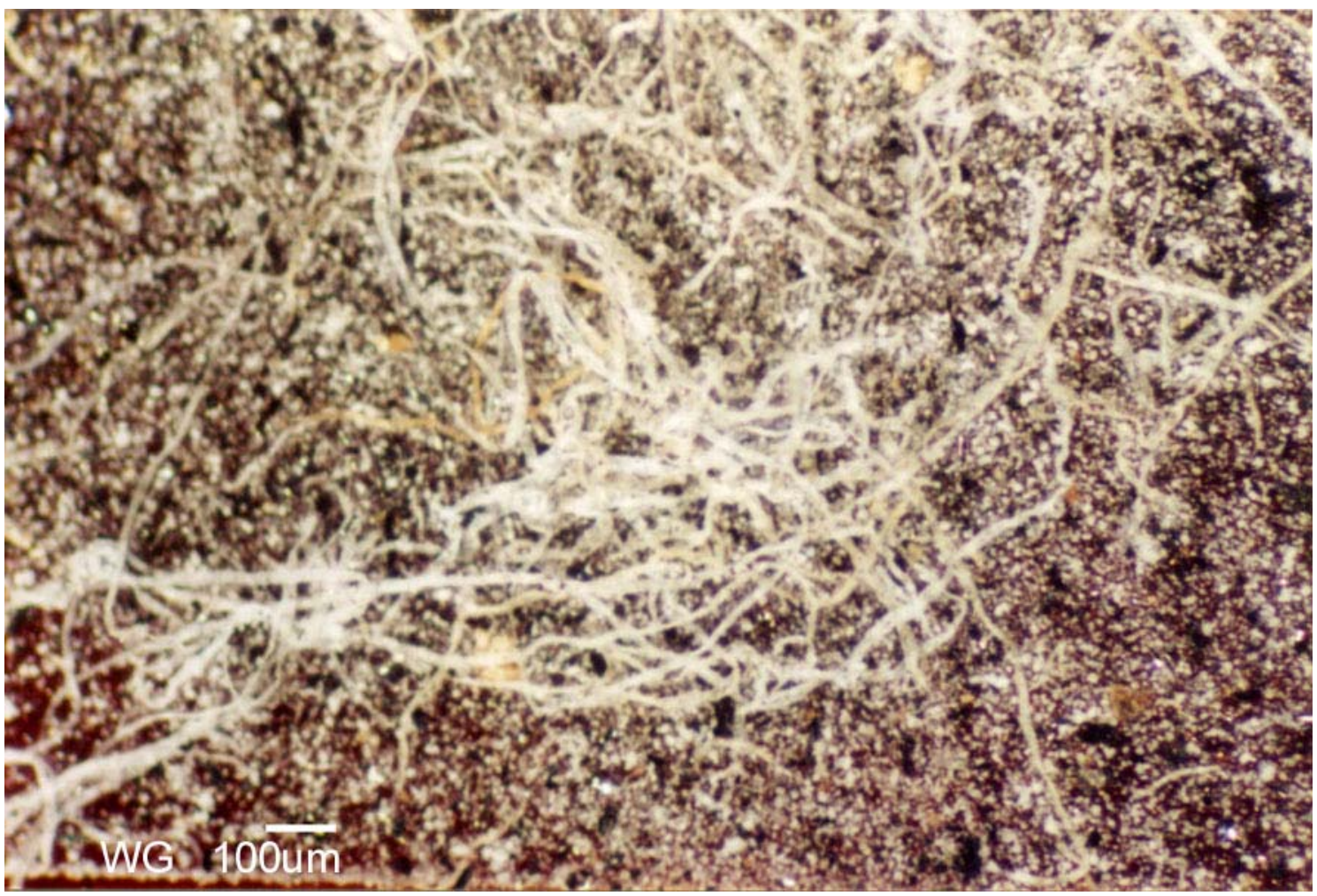

Optical (80 x)

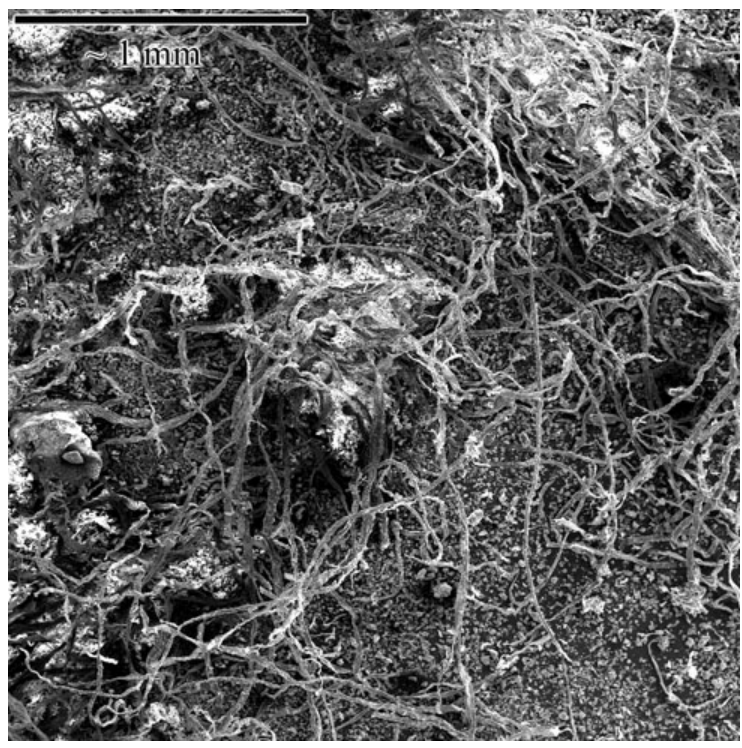

SEM (30 x)

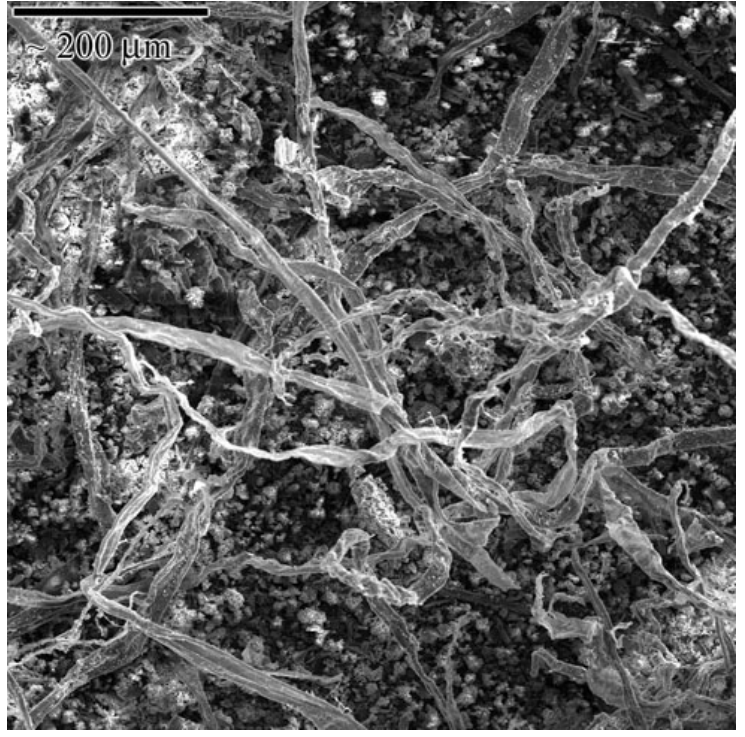

SEM (100 x)

Fig. 23. Micrographs of the Residual WG 

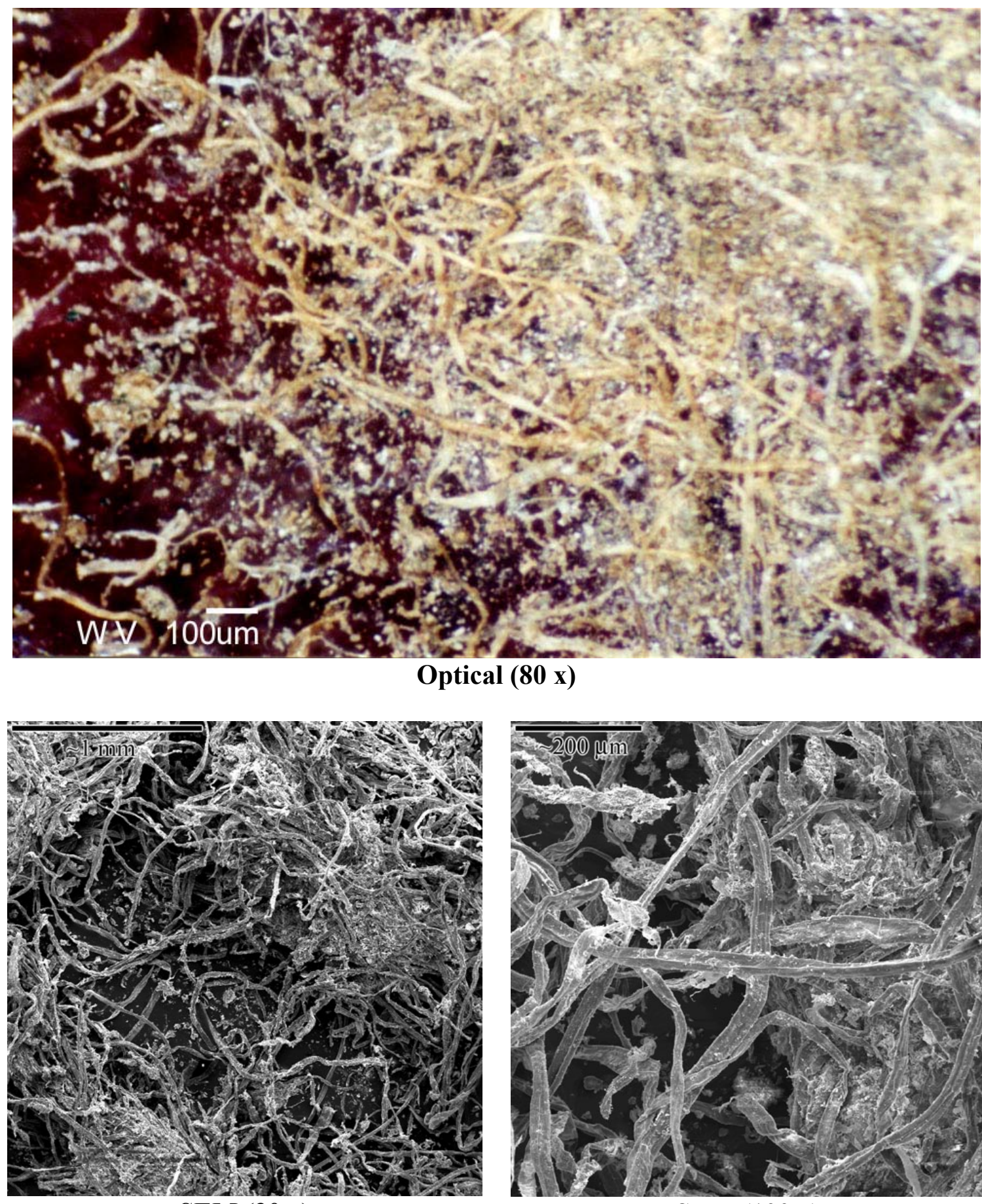

SEM (30 x)

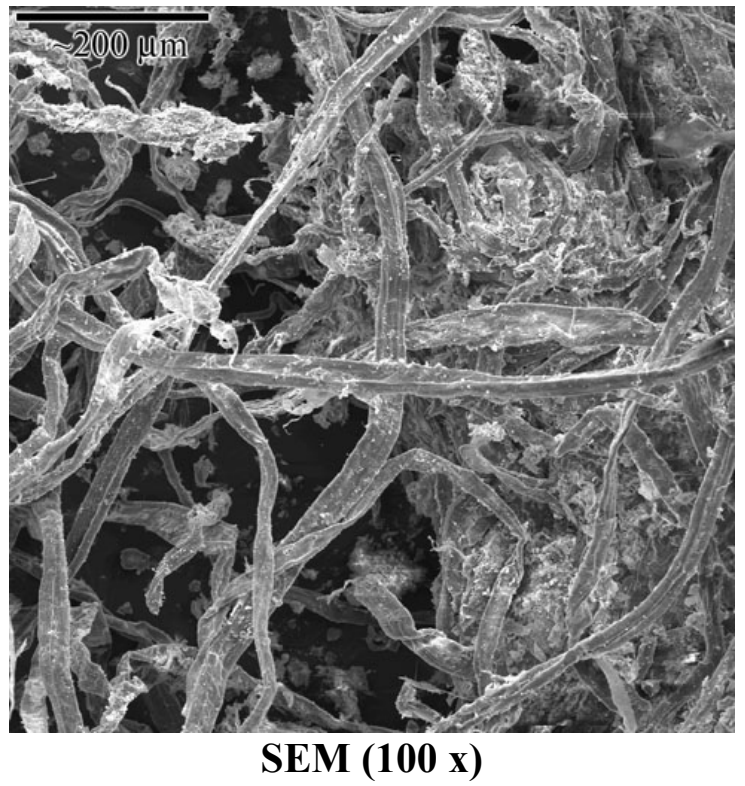

Fig. 24. Micrographs of the Residual WV 

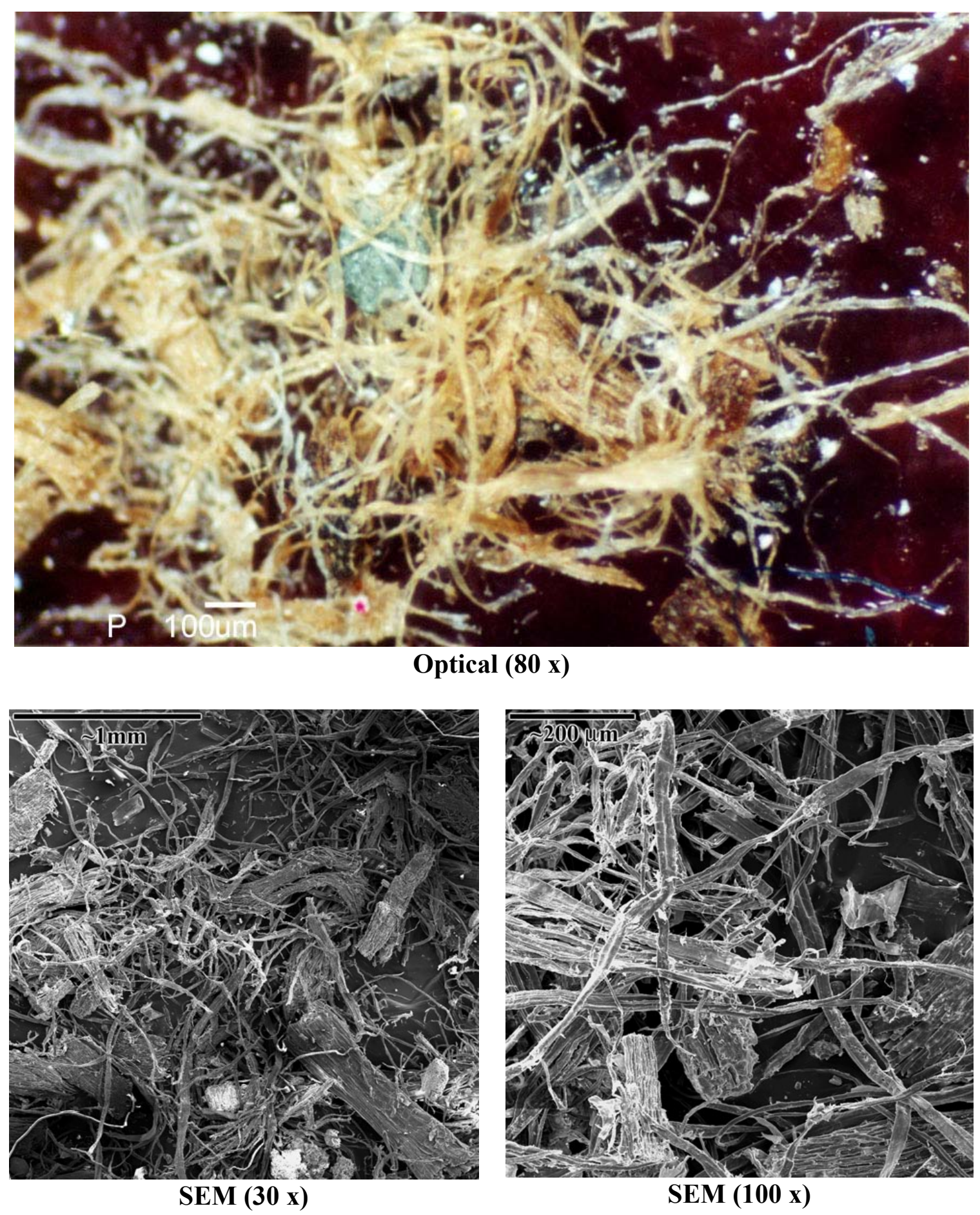

Fig. 25. Micrographs of the Residual $P$ 
In S residual solids (Fig. 22), particulate materials are visible. A spot of blue impurity is also visible. Many fine materials and fibers are observed in WG residual solids (Fig. 23). Note that the particles in the micrographs are actually fine dust, which could also be observed with the naked eye. The fibers were not bound by these particles.

Micrographs of the Residual WV (Fig. 24) show fibers and some particulate materials. Some of the fibers appear to be tightly held together by each other.

In case of the Residual P (Fig. 25), fibers, tiny pieces of wood, and tiny particles of grits can be observed. The minute pieces of wood are called shives and they are bundles of fibers not completely separated during the pulping process.

Overall, significant amounts of fibers were observed in every micrograph. For several sources of residual solids (C1, I, S), fibers are bound by clay. For others (C2, I, $\mathrm{S}, \mathrm{WV})$, fibers were clumped together.

Clumps of fibers and of clay may be considered as weaker spots in concrete compared with well-dispersed individual fibers and clay particles. Also, in order for the fibers to function as fibers, they must be separated into individual fibers. Therefore, it is highly desirable to properly de-flocculate clumps of fibers and clay in water and then add the mixture of "repulped" residual solids and water to a concrete mixer.

\subsubsection{Summary}

On average, the residual solids had about $167 \%$ as-received moisture content, 1.80 specific gravity, $47.7 \mathrm{lb} / \mathrm{ft}^{3}$ as-received bulk density, $12.7 \mathrm{lb} / \mathrm{ft}^{3}$ oven-dry bulk density, $1.46 \mathrm{~mm}$ length-weighted average fiber length by Kajaani test, and $65 \% \mathrm{LOI}$ at $590^{\circ} \mathrm{C}$. Overall, there was minor variation in the characteristics of residual solids in terms of 
moisture content, specific gravity, bulk density, and loss on ignition. Varying amounts of calcium carbonate and kaolin-type clay were contained in the residual solids. Average fiber content of the residual solids estimated from LOI at $590^{\circ} \mathrm{C}$ was about $61 \%$. According to elemental analysis, the residual solids did not contain hazardous elements, except $1900 \mathrm{ppm}$ of cadmium (Cd) on average. It has been reported that paper mill residuals are non-hazardous [52]. In micrographs of residual solids, clumps of cellulose fibers, clay, and other particulates were observed. 


\section{CHAPTER 5 DEFLOCCULATING EXPERIMENTS}

\subsection{Deflocculating Experiments}

Due to dewatering, as-received residuals contained fibrous clumps that consisted of wood fibers, clay (if any), and other particulates (if any). These clumps may be considered as weaker spots in concrete compared with well-dispersed individual fibers and particles (if any). Also, in order for the fibers to function in improving the quality of concrete, they must be separated into individual fibers.

Experiments were conducted to establish a practical way of deflocculating, or "repulping", pulp and paper mill residual solids into separated wood fibers and particulates (if any) for their use in concrete. The "pulper" used in this experiment in the UWM-CBU laboratory consisted of a 5-gallon plastic bucket and a high-shear mixer with a spinning rotor blades positioned above the bottom of the bucket. Mechanical repulping was performed by immersing the residuals in water in the bucket and subjecting the mixture to a high-speed rotation by the rotor blades. Pictures of the pulper and repulping operation are presented in Fig. 26 and 27.

Initially, for a comparison purpose, each of the eight sources of the residuals of the first delivery was subjected to mechanical mixing in room-temperature water for 20 minutes. The residuals are listed in the order of their relative ease of repulping in Table 44. 

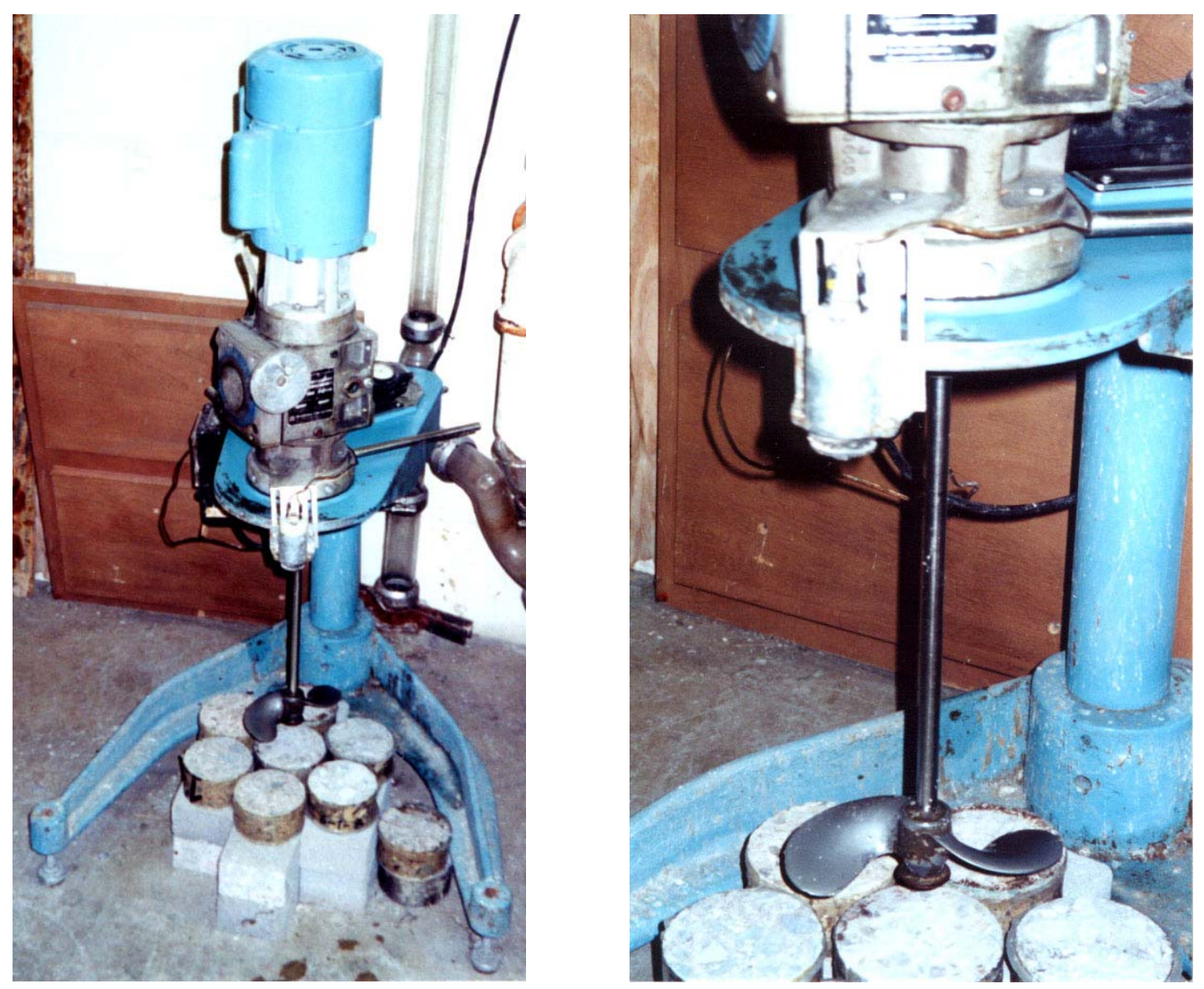

Fig. 26. High-speed motor with a rotor for "repulping" residuals

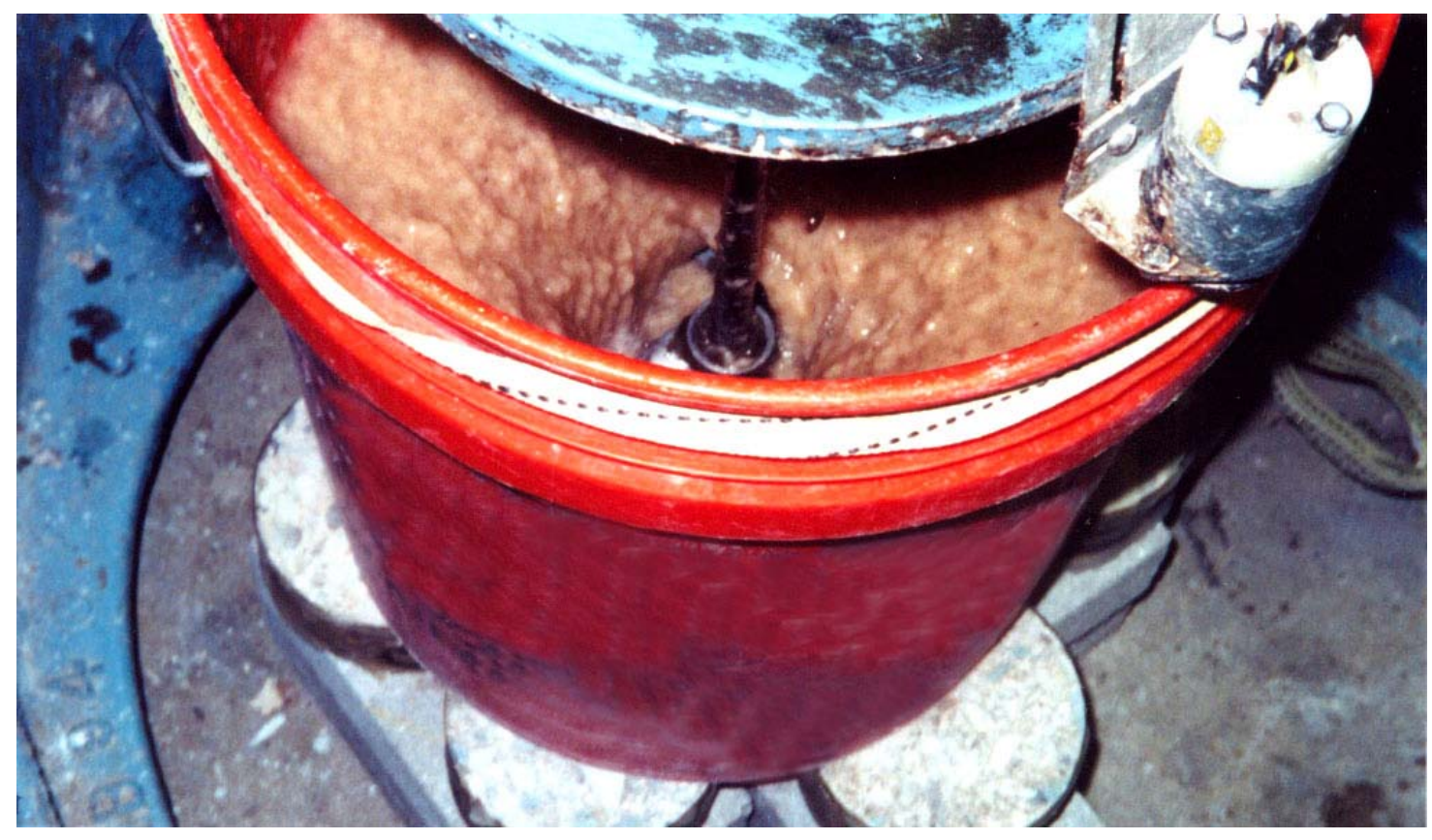

Fig. 27. Residual BR being repulped in water 
Table 44. Relative Ease of Repulping Residuals of the $1^{\text {st }}$ Delivery

\begin{tabular}{|l|c|c|c|c|c|c|c|c|}
\hline Order & $1^{*}$ & 2 & 3 & 4 & 5 & 6 & 7 & $8 \dagger$ \\
\hline Ease of Repulping & $\begin{array}{c}\mathrm{BR} \\
\mathrm{P}\end{array}$ & $\ldots$ & $\mathrm{C} 1$ & $\mathrm{C} 2$ & $\mathrm{WG}$ & $\mathrm{S}$ & $\ldots$ & $\mathrm{I}$, \\
$\mathrm{WV}$
\end{tabular}

* Easiest to repulp. $\quad \uparrow 8$ : Most difficult to repulp.

+ As discussed earlier (p. 66), unlike the $1^{\text {st }}$ delivery, as-received WV of the $2^{\text {nd }}$ delivery was in a well-deflocculated condition because it had not been dewatered at the paper mill wastewater treatment plant.

Residuals BR, $\mathrm{P}$, and $\mathrm{C} 1$ were the best sources of residuals as far as the ease of repulping was concerned; after repulping, no clump of fibers could be felt with bare fingers dipped into the mixture of residuals and water. Residuals C2 and WG deflocculated relatively easily upon mechanical repulping. However, after a mechanical mixing, clumps of fibers could hardly be felt with bare fingers.

However, it was not so easy to deflocculate Residuals S, I, and WV. After mechanical repulping in room temperature water for 20 minutes, some clumps of fibers could still be seen and felt in the mixture of each of these residuals and water. The reason for this was attributed to higher-degree of dewatering of S, I, and WV residuals before they were received for use in the UWM-CBU laboratory. It was especially hard to deflocculate Residuals I and WV.

Therefore, to find out whether the use of certain types of chemicals would be helpful in deflocculating Residuals I and WV, repulping experiments were conducted on Residuals I and WV using plain water and chemically treated water. Chemical solutions were prepared by adding to water the following types of chemicals at their usual dosage rates: detergent, HRWRA, AEA, antiprecipitant, antiscalant, and flocculant. Also, to find out whether the use of hot water solutions would help, repulping experiments were 
conducted on Residual WV using room temperature water solutions and hot water solutions.

The results of the repulping experiments on I and WV residuals are presented in Tables 45 and 46. Based on the amount of clumps of residuals retained on a No. 4 (4.75 mm openings) sieve after repulping, none of the chemicals investigated seemed to be helpful in freeing up wood fibers contained in the residual solids. Using water alone was as good as using any of the chemical solutions investigated. Regardless of the type of chemicals used, use of hot water solution showed superior separation and dispersion results for WV residuals over using room temperature water.

During concrete mixing, it became clear that, however easy it might be to mechanically repulp a given source of residual, the residual must be thoroughly re-mixed in water before it is added to a concrete mixer. Mechanical mixing in the concrete mixer had little beneficial effect on residual separation.

In conclusion, a high-speed mixing of residuals in room temperature water was the most practical and satisfactory means of repulping most of the residuals used in this research. In certain cases, repulping in hot water may be done for better repulping results. 
Table 45. Repulping Experiment on Residual 'I' Using Water, Detergent, HRWRA, and AEA

Mixer Speed Dial: $\quad 15$

Mixing Time: $\quad 20$ minutes

Amount of Water: $\quad 5.44 \mathrm{~kg}$

Temperature of Water: $\quad 18^{\circ} \mathrm{C}$

Residual Content Assumed ${ }^{\#}: \quad 0.94$ ( $\%$ of concrete by wt., on as-recd basis)

Amount of Cement Assumed ${ }^{\#}$ : $13.6 \mathrm{~kg}$

0.48 ( $\%$ of concrete by wt., on oven-dry basis)

( ${ }^{\#}$ for $w / \mathrm{cm}$ of 0.4$)$

\begin{tabular}{|c|c|c|c|c|c|c|}
\hline Solution Designation & Water & $\mathrm{DT}^{*}$ & HRWRA1 & HRWRA2 & AEA1 & AEA2 \\
\hline Type of Chemical & $\ldots$ & $\begin{array}{l}\text { Deter- } \\
\text { gent }\end{array}$ & $\begin{array}{c}\text { Naphthalene } \\
\text { HRWRA }\end{array}$ & \begin{tabular}{|c|} 
Poly- \\
carboxylate \\
HRWRA \\
\end{tabular} & $\begin{array}{l}\text { Vinsol } \\
\text { Resin } \\
\text { AEA }\end{array}$ & $\begin{array}{c}\text { Synthetic } \\
\text { AEA }\end{array}$ \\
\hline $\begin{array}{l}\text { Recommended Dosage } \\
\text { Rate }(\mathrm{mL} / 100 \mathrm{~kg} \\
\text { cement) }\end{array}$ & $\ldots$ & $1 \dagger$ & $650-1,600$ & $260-780$ & $16-260$ & $8-98$ \\
\hline $\begin{array}{l}\text { Recommended Dosage } \\
(\mathrm{mL})\end{array}$ & $\ldots$ & 5 & $88-218$ & $35-106$ & $2-35$ & $1-13$ \\
\hline Dosage Used (mL) & $\ldots$ & 5 & 158 & 72 & 19 & 9 \\
\hline 'I' Before Mixing $(\mathrm{g})^{\mathrm{pan}}$ & 436 & 436 & 436 & 436 & 436 & 436 \\
\hline 'I' After Mixing (g) & 8.1 & 8.6 & 10.0 & 10.1 & 12.6 & 8.0 \\
\hline
\end{tabular}

* Contained "anionic and nonionic surfactants" as cleaning agents.

$\dagger \mathrm{mL} / \mathrm{kg}$ of water

pan Amount on a pan, on oven-dry basis

\#4 Amount retained on a No. 4 sieve (4.75 mm openings), on oven-dry basis.

Average $9.6 \mathrm{~g}$. 
Table 46. Repulping Experiment on Residuals 'WV' and ' $I$ ' Using Water, Antiprecipitant, Antiscalant, and Flocculant

Mixer Speed Dial: $\quad 16$

Mixing Time: $\quad 20$ minutes

Amount of Water: $\quad 10 \mathrm{~kg}$

Temperature of Water: $\quad 18^{\circ} \mathrm{C}$, unless otherwise noted

\begin{tabular}{|l||c|c|c|c||c||}
\hline Solution Designation & Water & AP* & AS* $^{*}$ & FL* $^{*}$ & Avg. \\
\hline Type of Chemical & $\ldots$ & $\begin{array}{c}\text { Anti- } \\
\text { precipitant }\end{array}$ & $\begin{array}{c}\text { Anti- } \\
\text { scalant }\end{array}$ & Flocculant & $\ldots$ \\
\hline $\begin{array}{l}\text { Recommended Treatment } \\
\text { Level (ppm) }\end{array}$ & $\ldots$ & $1-10$ & $1-10$ & $250-5000$ & $\ldots$ \\
\hline Treatment Level Used (ppm) & $\ldots$ & 130 & 130 & 37 & $\ldots$ \\
\hline \hline 'I' Before Mixing (g) & 51 & 51 & 51 & 51 & 51 \\
\hline 'I' After Mixing (g) & 3.2 & 3.1 & 2.4 & 3.2 & 3.0 \\
\hline \hline 'WV' Before Mixing (g) & 8.3 & 8.3 & 8.3 & 8.3 & 8.3 \\
\hline 'WV' After Mixing (g) & 2.8 & 3.3 & 3.8 & 4.2 & 3.5 \\
\hline $\begin{array}{l}\text { 'WV' After Mixing in Hot' } \\
\text { Solution (g) }\end{array}$ & 0.6 & 0.7 & 0.6 & 0.4 & 0.6 \\
\hline \hline
\end{tabular}

* Chemical family: Anionic polyacrylamide

\#4 Amount retained on a No. 4 sieve (4.75 mm openings), on oven-dry basis.

$12.5 \mathrm{~mm}$ Amount retained on a sieve with $12.5 \mathrm{~mm}$ openings, on oven-dry basis.

$\dagger \quad$ Solution temperature: Initial $=93^{\circ} \mathrm{C}$, Final $=49^{\circ} \mathrm{C}$. 


\subsection{Deflocculation (or "Repulping") of Residuals}

All eight sources of residuals were deflocculated, or "repulped", into separated wood fibers and particulates (if any) before their addition to the concrete mixture. Mechanical repulping was performed by immersing the residuals in room-temperature water in a bucket and subjecting the mixture to a high-speed rotation by the rotor blades for not less than 20 minutes.

As discussed in the previous section, Residuals $\mathrm{C} 1, \mathrm{C} 2, \mathrm{WG}, \mathrm{BR}$, and $\mathrm{P}$ deflocculated readily upon mechanical repulping. However, it took higher mixing speed and longer mixing time to deflocculate Residuals I, S, and WV. 


\section{CHAPTER 6 SPECIMEN PREPARATION AND TEST METHODS}

\subsection{Specimen Preparation}

Test specimens of concrete were made and cured according to ASTM Standard Practice for Making and Curing Concrete Test Specimens in the Laboratory (C 192) [47].

The concrete mixers used in this research were electrical power-driven, revolving drum, tilting mixers.

Concrete mixing and specimen preparation were done as follows:

Before starting rotation of the mixer, coarse aggregate and some of the mixing water (or the mixture of water and "repulped" residual solids) were added. Then the mixer was started and was stopped after it turned a few revolutions. Then, fine aggregate (sand) was added, and the mixer was started again and was stopped again after it turned a few more revolutions. Then cement, the rest of the water (or the mixture of water and residual solids), and chemical admixture (if used) were added.

After all ingredients were in the mixer, the concrete was mixed for three minutes followed by a 3-minute rest, followed by an additional two minutes of final mixing. When necessary, either water or HRWRA was incrementally added during the mixing process to modify the concrete mixture to the desired slump.

Properties of freshly mixed concrete were determined, and test specimens were cast for the evaluation of mechanical properties, long-term properties, and durability of concrete. 
To prevent evaporation of water from the unhardened concrete, the cast specimens were covered with plastic sheets. The specimens were removed from the molds $24 \pm 8$ hours after casting. The demolded specimens were moist cured at $73 \pm 3^{\circ} \mathrm{F}$, either in a moist room at a relative humidity of not less than $95 \%$ or in lime-saturated water.

\subsection{Test Methods}

Overview of test methods is presented in Tables 47 through 49. 
Table 47. Overview of Test Methods for Fresh Concrete Properties

\begin{tabular}{|c|c|c|c|c|}
\hline $\begin{array}{c}\text { ASTM } \\
\text { Designation/ } \\
\text { Test Method } \\
\text { for }\end{array}$ & Specimens & Specifics & Summary of Test Method & $\begin{array}{c}\text { Calculation/ } \\
\text { Interpretation of Results }\end{array}$ \\
\hline $\begin{array}{l}\text { C } 143 \\
\text { Slump }\end{array}$ & $\begin{array}{l}\text { Freshly mixed } \\
\text { concrete }\end{array}$ & $\ldots$ & $\begin{array}{l}\text { - Fill the specified mold shaped as the frustum of a } \\
\text { cone with the concrete in three equal volume } \\
\text { layers, compacting each layer by rodding. } \\
\text { - Raise the mold. } \\
\text { - Measure the vertical distance between the original } \\
\text { and displaced position of the center of the top } \\
\text { surface of the specimen. }\end{array}$ & slump $=$ the vertical distance \\
\hline $\begin{array}{l}\text { C } 138 \\
\text { Unit Weight } \\
\text { (Density) }\end{array}$ & $\begin{array}{l}\text { Freshly mixed } \\
\text { concrete }\end{array}$ & $\begin{array}{l}\text { A } 0.25-\mathrm{ft}^{3} \\
\text { measure }\end{array}$ & $\begin{array}{l}\text { - Place the concrete in the measure in three layers, } \\
\text { compacting each layer by rodding it and tapping } \\
\text { the sides of the measure. } \\
\text { - Strike-off and finish the top surface. } \\
\text { - Determine the net weight of the concrete in the } \\
\text { measure. }\end{array}$ & $\begin{array}{l}\text { unit weight (or density) = wt. } \\
\text { of concrete / vol. of the } \\
\text { measure }\end{array}$ \\
\hline $\begin{array}{l}\text { C } 231 \\
\text { Air Content } \\
\text { by the } \\
\text { Pressure } \\
\text { Method }\end{array}$ & $\begin{array}{l}\text { Sample used } \\
\text { for unit weight } \\
\text { (or density) } \\
\text { test }\end{array}$ & $\begin{array}{l}\text { Type-B } \\
\text { meter }\end{array}$ & $\begin{array}{l}\text { - Clamp the cover to the bowl. } \\
\text { - Replace with water the air gap between the } \\
\text { sample and the cover. } \\
\text { - Raise the pressure in the air chamber to the } \\
\text { specified pressure. } \\
\text { - Open the air valve between the air chamber and } \\
\text { the bowl. } \\
\text { - Read the percentage of air. }\end{array}$ & $\begin{array}{l}\text { air content = apparent air } \\
\text { content - aggregate correction } \\
\text { factor }\end{array}$ \\
\hline
\end{tabular}


Table 47. Overview of Test Methods for Fresh Concrete Properties (Cont'd)

\begin{tabular}{|c|c|c|c|c|c|}
\hline $\begin{array}{l}\text { ASTM } \\
\text { Designation/ } \\
\text { Test Method } \\
\text { for }\end{array}$ & Specimens & Specifics & Summary of Test Method & \multicolumn{2}{|c|}{$\begin{array}{c}\text { Calculation/ } \\
\text { Interpretation of Results }\end{array}$} \\
\hline $\begin{array}{l}\text { C } 995 \\
\text { Time of } \\
\text { Flow of } \\
\text { Fiber- }\end{array}$ & $\begin{array}{l}\text { Freshly mixed } \\
\text { concrete }\end{array}$ & $\begin{array}{l}\text { Vibrator } \\
\text { head: } \\
1-1 / 8 " \\
\text { diameter; }\end{array}$ & $\begin{array}{l}\text { - Set an inverted slump cone } 4 \text { " above the bottom } \\
\text { of the ASTM C } 29 \text { one- } \mathrm{ft}^{3} \text { bucket. } \\
\text { - Fill the cone with the concrete in three equal } \\
\text { volume layers. }\end{array}$ & \multirow{2}{*}{\multicolumn{2}{|c|}{$\begin{array}{l}\text { time of flow }=\text { the time from } \\
\text { initial immersion of the } \\
\text { vibrating element to when the } \\
\text { cone first becomes empty }\end{array}$}} \\
\hline Concrete & & $\begin{array}{l}(177 \mathrm{~Hz}) \\
\text { while not } \\
\text { loaded }\end{array}$ & $\begin{array}{l}\text { - Let the vibrating element descend and touch the } \\
\text { bottom of the bucket in } 3 \pm 1 \mathrm{~s} \text {. } \\
\text { - Maintain the vibrating element in contact with the } \\
\text { bottom of the bucket. }\end{array}$ & & \\
\hline \multirow{2}{*}{$\begin{array}{l}\text { C } 403 \\
\text { Time of } \\
\text { Setting }\end{array}$} & \multirow{2}{*}{$\begin{array}{l}\text { Mortar } \\
\text { obtained by } \\
\text { sieving fresh } \\
\text { concrete } \\
\text { through a } 4.75- \\
\text { mm sieve }\end{array}$} & \multirow{2}{*}{$\begin{array}{l}\text { Stored in } \\
6 " \times 6 " \\
\text { cans. }\end{array}$} & \multirow{2}{*}{$\begin{array}{l}\text { - Keep the specimens covered to prevent } \\
\text { evaporation of moisture, except when the } \\
\text { penetration tests are being made. } \\
\text { At regular time intervals, measure the resistance } \\
\text { of the mortar to penetration by standard needles. }\end{array}$} & $\begin{array}{l}\text { Setting } \\
\text { Time }\end{array}$ & $\begin{array}{c}\text { Penetration } \\
\text { Resistance }\end{array}$ \\
\hline & & & & $\begin{array}{l}\text { Initial } \\
\text { Final }\end{array}$ & $\begin{array}{r}500 \mathrm{psi} \\
4,000 \mathrm{psi}\end{array}$ \\
\hline
\end{tabular}


Table 48. Overview of Test Methods for Mechanical Properties

\begin{tabular}{|c|c|c|c|c|}
\hline $\begin{array}{c}\text { ASTM } \\
\text { Designation/ } \\
\text { Test Method for }\end{array}$ & Specimens & Specifics & Summary of Test Method & $\begin{array}{c}\text { Calculation/ } \\
\text { Interpretation of Results }\end{array}$ \\
\hline $\begin{array}{l}\text { C } 39 \\
\text { Compressive } \\
\text { Strength }\end{array}$ & $\begin{array}{l}4 " \times 8 " \\
\text { cylinders }\end{array}$ & $\ldots$ & $\begin{array}{l}\text { Apply a compressive axial load to a moist cured } \\
\text { cylinder at a rate that is within a prescribed range } \\
\text { until failure occurs. }\end{array}$ & $\begin{array}{l}\text { compressive strength }=\text { max. } \\
\text { applied load / cross-sectional } \\
\text { area }\end{array}$ \\
\hline $\begin{array}{l}\text { C } 496 \\
\text { Splitting } \\
\text { Tensile } \\
\text { Strength }\end{array}$ & $\begin{array}{l}4 " \times 8 " \\
\text { cylinders }\end{array}$ & $\ldots$ & $\begin{array}{l}\text { Apply a diametral compressive force along the } \\
\text { length of a moist cured cylinder at a rate that is } \\
\text { within a prescribed range until failure occurs. }\end{array}$ & $\begin{array}{l}\text { splitting tensile strength }=2 * \\
\text { max. applied load } /(\pi * \\
\text { length } * \text { diameter })\end{array}$ \\
\hline $\begin{array}{l}\text { C } 78 \\
\text { Flexural } \\
\text { Strength }\end{array}$ & $\begin{array}{l}-3 " \text { x } 4 " \text { x } 12 " \\
\text { beams } \\
\text { - } 4 \text { " x } 4 " \text { x } 14 " \\
\text { beams }\end{array}$ & $\ldots$ & $\begin{array}{l}\text { Load a moist cured simply-supported beam with } \\
\text { third-point loading at a rate that is within a } \\
\text { prescribed range until rupture occurs. }\end{array}$ & $\begin{array}{l}\text { flexural strength }=\text { max. } \\
\text { applied load } * \text { span length / } \\
\left(\text { width } * \text { depth }^{2}\right)\end{array}$ \\
\hline $\begin{array}{l}\text { C } 1399 \\
\text { Avg. Residual } \\
\text { Strength of } \\
\text { Fiber- } \\
\text { Reinforced } \\
\text { Concrete }\end{array}$ & $\begin{array}{l}4 " \mathrm{x} 4 " \text { " } 14 " \\
\text { beams }\end{array}$ & $\begin{array}{l}\text { Tested at } \\
112 \text { days }\end{array}$ & $\begin{array}{l}\text { - Crack a moist-cured beam using the ASTM C } 78 \\
\text { third-point loading apparatus modified by a steel } \\
\text { plate used to assist in support of the beam. } \\
\text { - Remove the plate and reload the cracked beam to } \\
\text { plot a reloading load-deflection curve. }\end{array}$ & $\begin{array}{l}\text { avg. residual strength }=\text { avg. } \\
\text { of flexural strength values at } \\
\text { four specified deflections } \\
(0.02,0.03,0.04 \text {, and } 0.05 \text { in.) } \\
\text { on the reloading curve }\end{array}$ \\
\hline
\end{tabular}


Table 49. Overview of Test Methods for Long-Term Properties and Durability

\begin{tabular}{|c|c|c|c|c|c|}
\hline $\begin{array}{c}\text { ASTM } \\
\text { Designation/ } \\
\text { Test Method } \\
\text { for }\end{array}$ & Specimens & Specifics & Summary of Test Method & \multicolumn{2}{|c|}{$\begin{array}{c}\text { Calculation/ } \\
\text { Interpretation of Results }\end{array}$} \\
\hline $\begin{array}{l}\text { C } 157 \\
\text { Length } \\
\text { Change }\end{array}$ & $\begin{array}{l}3 " \text { × } 3 " \text { × } 11 \\
1 / 4 " \text { beams }\end{array}$ & $\begin{array}{l}\text { - Stored in lime- } \\
\text { saturated water until an } \\
\text { age of } 28 \text { days. } \\
\text { - Then, stored in drying } \\
\text { room at } 50 \pm 4 \% \mathrm{RH} \\
\text { and } 73.4 \pm 3^{\circ} \mathrm{F} \text {. }\end{array}$ & $\begin{array}{l}\text { After specified periods of moist } \\
\text { curing and air storage, take } \\
\text { comparator readings }(C R) \text { of each } \\
\text { specimen and the reference bar and } \\
\text { determine the difference }(C R D) \text {. }\end{array}$ & \multicolumn{2}{|c|}{$\begin{array}{l}\text { length change }(\%)=(C R D- \\
\text { initial } C R D) / 10 " \text { (gage length) } * \\
100\end{array}$} \\
\hline $\begin{array}{l}\text { C } 944 \\
\text { Abrasion } \\
\text { Resistance }\end{array}$ & $\begin{array}{l}\text { Top surface of } \\
1.75 \text {-in. thick } \\
\text { slices saw-cut } \\
\text { from the top of } \\
6 " \times 12 " \\
\text { cylinders }\end{array}$ & $\begin{array}{l}\text { - Double load (44 lbf). } \\
\text { - Moist cured until an } \\
\text { age of } 27 \text { days. } \\
\text { - Then, cured in air at } \\
50 \pm 4 \% \text { RH for one } \\
\text { day. }\end{array}$ & $\begin{array}{l}\text { - Abrade the top surface of the } \\
\text { specimen with rotating cutters } \\
\text { under the load. } \\
\text { - Determine the specimen mass at } \\
\text { the end of each 2-min abrasion } \\
\text { period. } \\
\text { - Determine the rate of mass loss } \\
\text { due to evaporation. }\end{array}$ & \multicolumn{2}{|c|}{$\begin{array}{l}\text { mass loss due to abrasion }= \\
\text { apparent mass loss due to } \\
\text { abrasion- mass loss due to } \\
\text { evaporation }\end{array}$} \\
\hline \multirow{2}{*}{$\begin{array}{l}\text { C } 1202 \\
\text { Resistance to } \\
\text { Chloride Ion } \\
\text { Penetration }\end{array}$} & \multirow{2}{*}{$\begin{array}{l}2 \text {-in. thick } \\
\text { slices saw-cut } \\
\text { from the top of } \\
4 " x 8^{\prime \prime} \\
\text { cylinders }\end{array}$} & \multirow{2}{*}{$\begin{array}{l}\text { - Moist cured until an } \\
\text { age of } 25 \text { days. } \\
\text { - Side surface was } \\
\text { coated. } \\
\text { - Specimen was } \\
\text { vacuumed and } \\
\text { immersed in water. } \\
\text { - Tested at } 28 \text { days }\end{array}$} & \multirow{2}{*}{$\begin{array}{l}\text { Maintain, for six hours, a potential } \\
\text { difference of } 60 \mathrm{~V} \mathrm{dc} \text { across the } \\
\text { ends of the specimen, one of which } \\
\text { is immersed in a } 3 \% \mathrm{NaCl} \text { solution, } \\
\text { and the other in a } 0.3 \mathrm{~N} \mathrm{NaOH} \\
\text { solution. }\end{array}$} & $\begin{array}{l}\text { Charge Passed } \\
\text { (Coulomb) }\end{array}$ & $\begin{array}{l}\text { Chloride Ion } \\
\text { Penetrability }\end{array}$ \\
\hline & & & & $\begin{array}{l}>4,000 \\
2,000-4,000 \\
1,000-2,000 \\
100-1,000 \\
<100\end{array}$ & $\begin{array}{r}\text { High } \\
\text { Moderate } \\
\text { Low } \\
\text { Very Low } \\
\text { Negligible }\end{array}$ \\
\hline
\end{tabular}


Table 49. Overview of Test Methods for Long-Term Properties and Durability (Cont'd)

\begin{tabular}{|c|c|c|c|c|}
\hline $\begin{array}{c}\text { ASTM } \\
\text { Designation/ } \\
\text { Test Method } \\
\text { for }\end{array}$ & Specimens & Specifics & Summary of Test Method & $\begin{array}{c}\text { Calculation/ } \\
\text { Interpretation of Results }\end{array}$ \\
\hline $\begin{array}{l}\text { C } 666 \\
\text { Resistance to } \\
\text { Rapid } \\
\text { Freezing and } \\
\text { Thawing }\end{array}$ & $\begin{array}{l}3 " \times 4 " \times 16^{\prime \prime} \\
\text { beams }\end{array}$ & $\begin{array}{l}\text { - Procedure A. } \\
\text { - Test started at } 42 \\
\text { days. }\end{array}$ & $\begin{array}{l}\text { - Subject the specimen, which is } \\
\text { surrounded by a heat-exchange } \\
\text { medium }\left(\mathrm{H}_{2} \mathrm{O}\right) \text {, to cycles of } \\
\text { freezing (to } 0^{\circ} \mathrm{F} \text { in } 2.5 \mathrm{hr} \text { ) and } \\
\text { thawing (to } 40^{\circ} \mathrm{F} \text { in } 1.25 \mathrm{hr} \text { ). } \\
\text { - At specified intervals, determine } \\
\text { fundamental transverse frequency } \\
(N) \text {, pulse velocity }(V) \text {, and weight } \\
\text { of the specimen. }\end{array}$ & $\begin{array}{l}\text { - relative dynamic modulus of } \\
\text { elasticity }(P)(\%)=\left(N / N_{\text {initial }}\right)^{2} * \\
100 \\
\text { - durability factor }=60 *(N \text { at } \\
\text { which } P \text { reaches } 60 \%) / 300 \text { OR } \\
P(>60 \%) \text { at } 300 \text { cycles } \\
\text { - relative } V(\%)=\left(V / V_{\text {initial }}\right) * \\
100\end{array}$ \\
\hline \multirow{2}{*}{$\begin{array}{l}\text { C } 672 \\
\text { Salt Scaling } \\
\text { Resistance }\end{array}$} & \multirow{2}{*}{$\begin{array}{l}\text { Top surface of } \\
9 " \text { x 9" x 3" } \\
\text { blocks }\end{array}$} & \multirow[b]{2}{*}{$\begin{array}{l}\text { - The top surface was } \\
\text { toweled and brushed. } \\
\text { - A dike was placed } \\
\text { along its perimeter. } \\
\text { - Moist cured until the } \\
\text { age of } 14 \text { days. } \\
\text { - Then, cured in air for } \\
14 \text { days at } 73.5 \pm 3.5^{\circ} \mathrm{F} \\
\text { and } 50 \pm 5 \% \mathrm{RH} \text {. }\end{array}$} & \multirow[b]{2}{*}{$\begin{array}{l}\text { - Cover the top surface with } 1 / 4 " \text { of a } \\
0.36 \mathrm{M} \mathrm{CaCl}_{2} \text { solution ( } 4 \mathrm{~g} \text { of } \\
\mathrm{CaCl}_{2} / 100 \mathrm{~mL} \text { of solution). } \\
\text { - Subject the specimen to cycles of } \\
\text { freezing (at } 0 \pm 5^{\circ} \mathrm{F} \text { for } 16-18 \mathrm{~h} \text { ) } \\
\text { and thawing (at } 73.5 \pm 3.5^{\circ} \mathrm{F} \text { and } 50 \\
\pm 5 \% \mathrm{RH} \text { for } 6-8 \mathrm{~h} \text { ). } \\
\text { - Flush off the surface at the end of } \\
\text { each } 5 \text { cycles, and make a visual } \\
\text { examination. }\end{array}$} & \begin{tabular}{l|l|} 
Rating & Scaling \\
\end{tabular} \\
\hline & & & & \begin{tabular}{l|l}
0 & none \\
1 & very slight \\
& $(1 / 8$ in. depth, max \\
no coarse aggregate \\
visible) \\
slight to moderate \\
moderate \\
2 & $\begin{array}{l}\text { (some coarse aggregate } \\
\text { visible) } \\
\text { moderate to severe } \\
\text { severe } \\
4\end{array}$ \\
5 & (coarse aggregate visible \\
over the entire surface)
\end{tabular} \\
\hline
\end{tabular}




\subsection{Pictures of Testing}

Pictures of test apparatus, specimens, and testing are presented in Fig. 28 through 59.

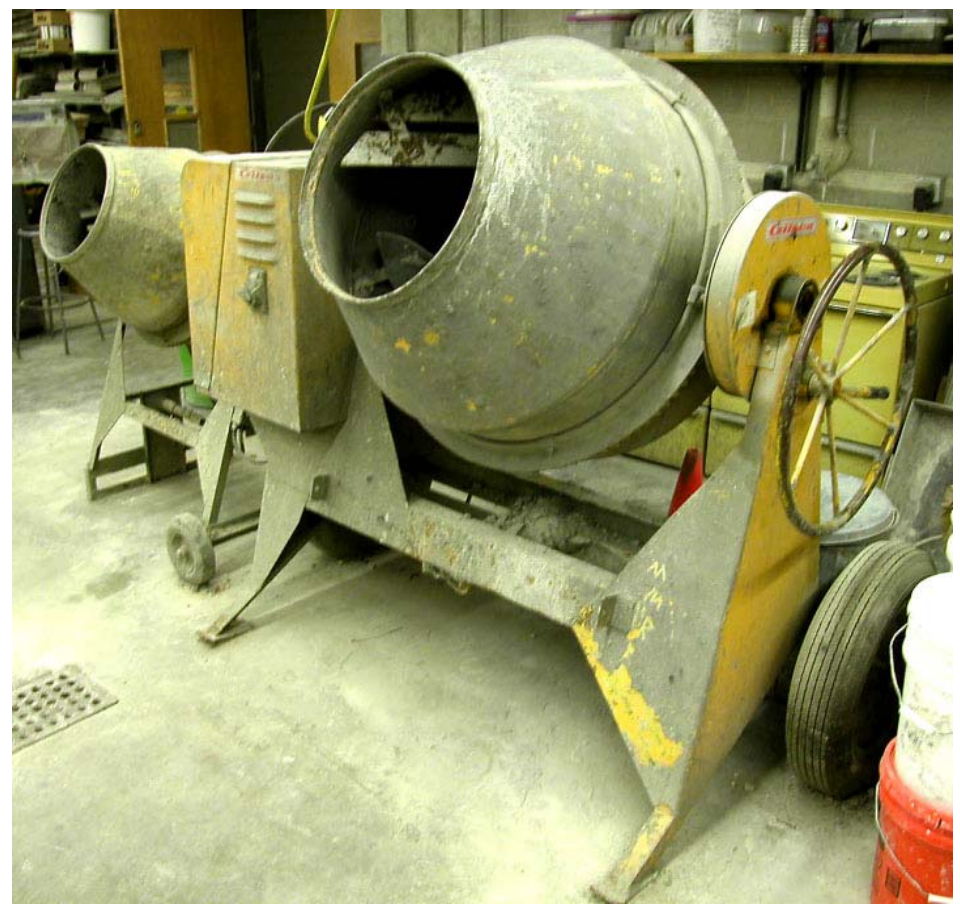

Fig. 28. Concrete mixers

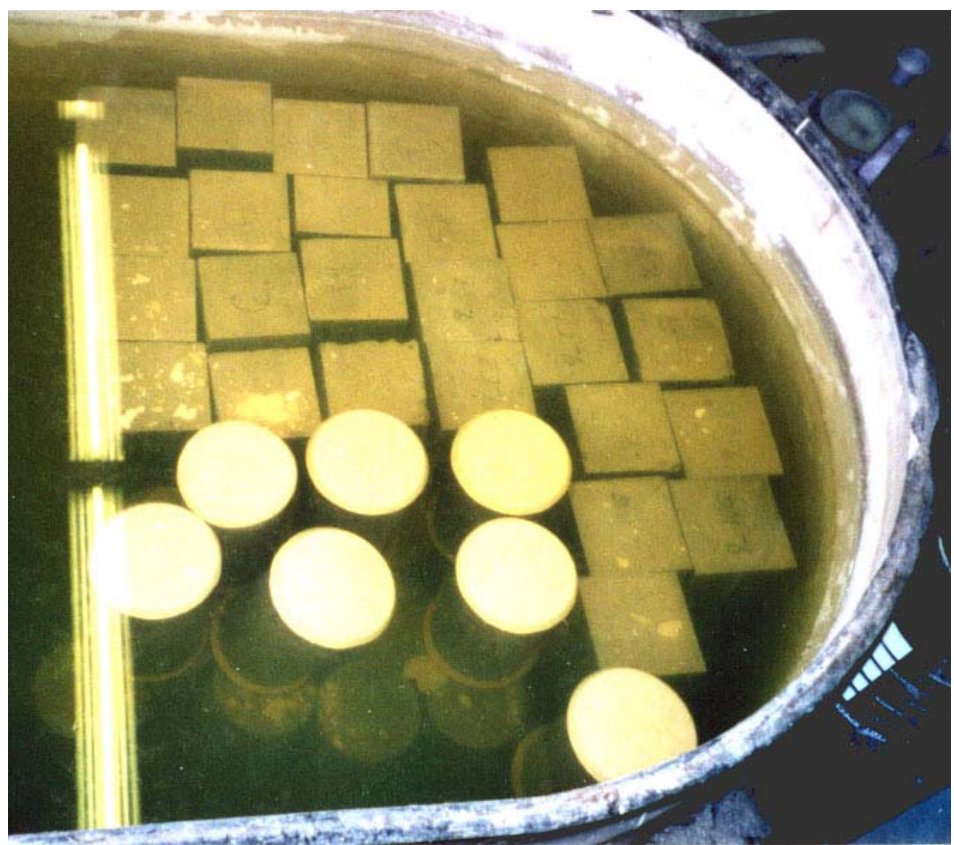

Fig. 29. Curing of specimens in lime saturated water 


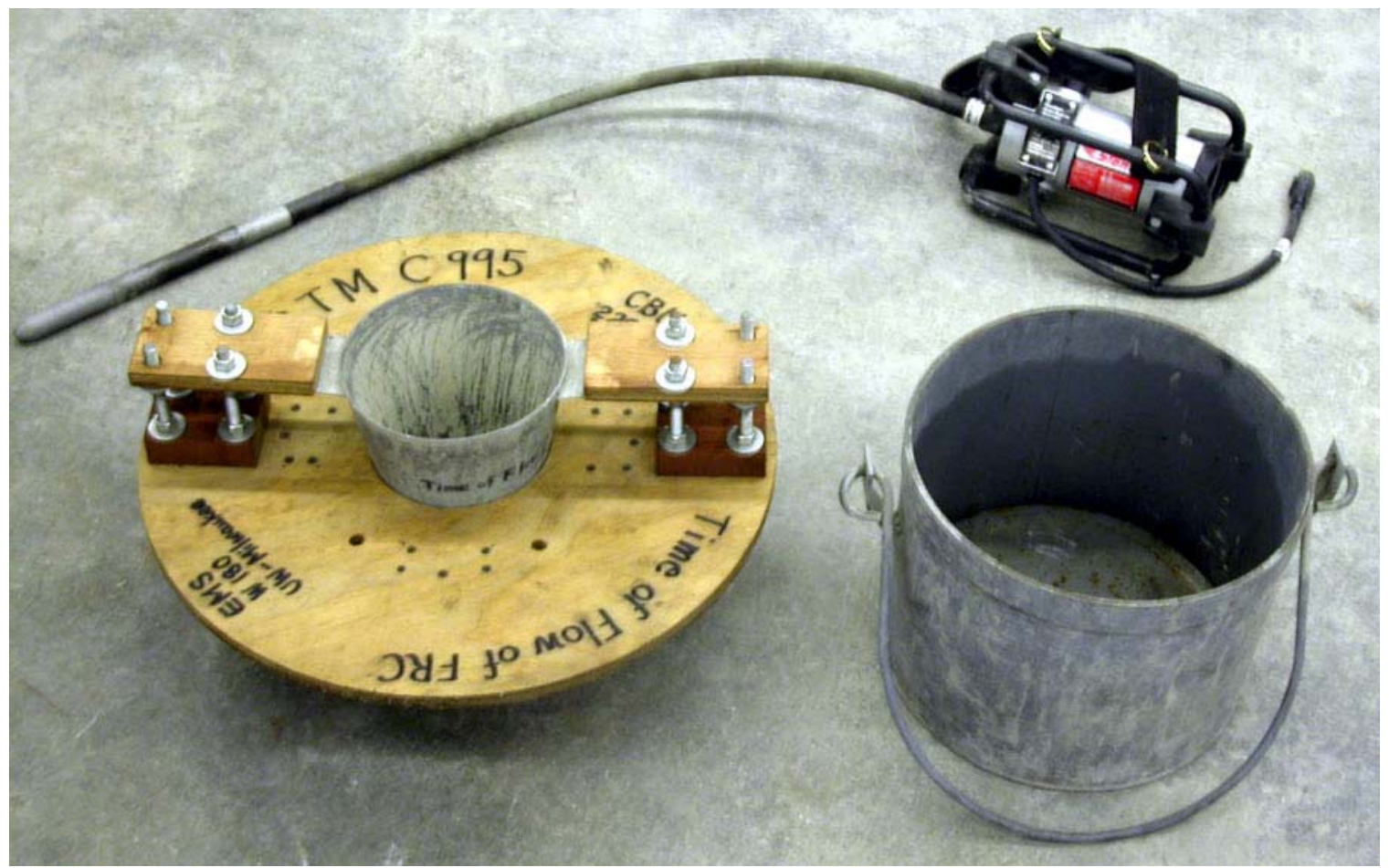

Fig. 30. Apparatus for time of flow test

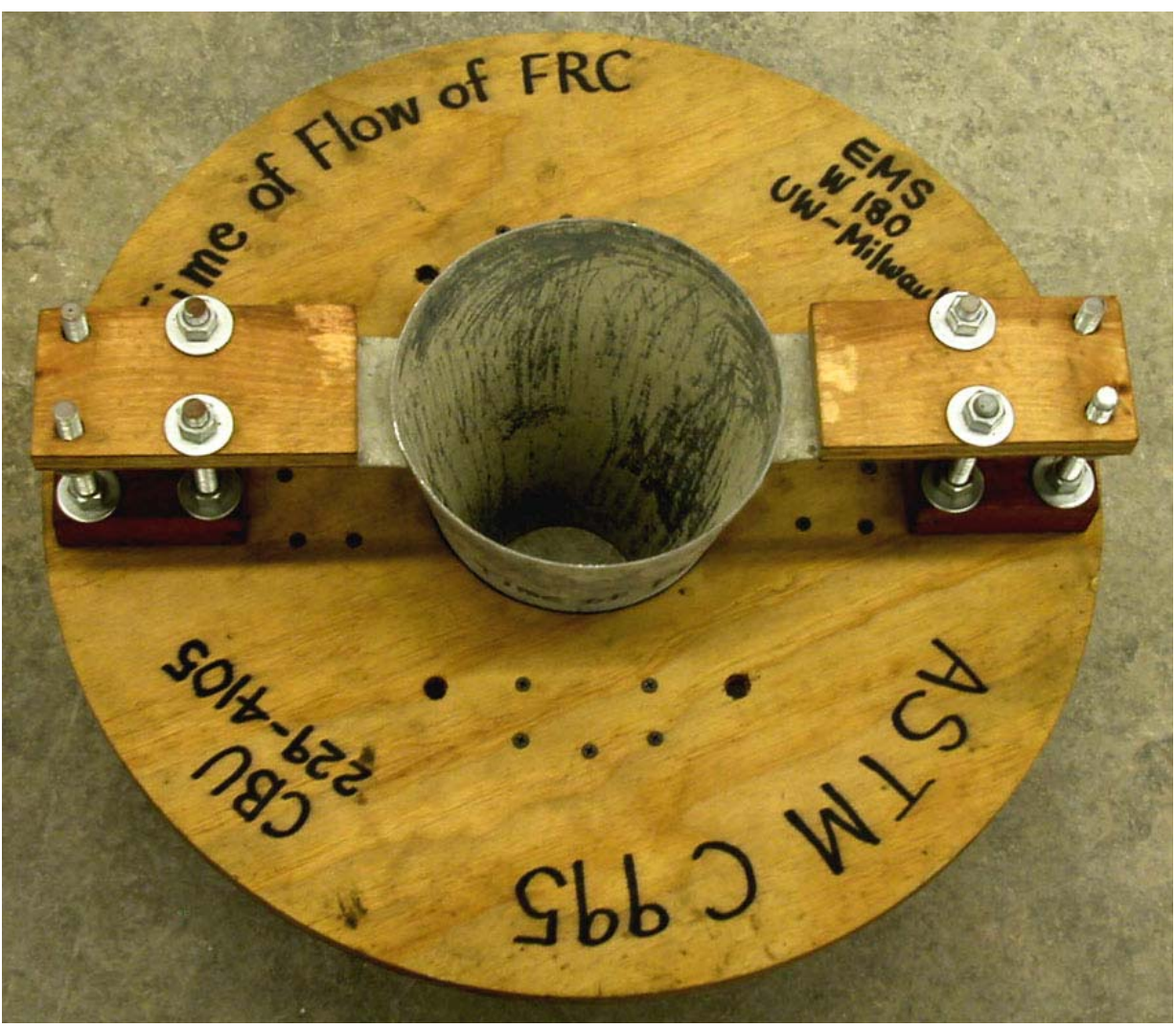

Fig. 31. Inverted slump cone for time of flow test (viewed from above) 


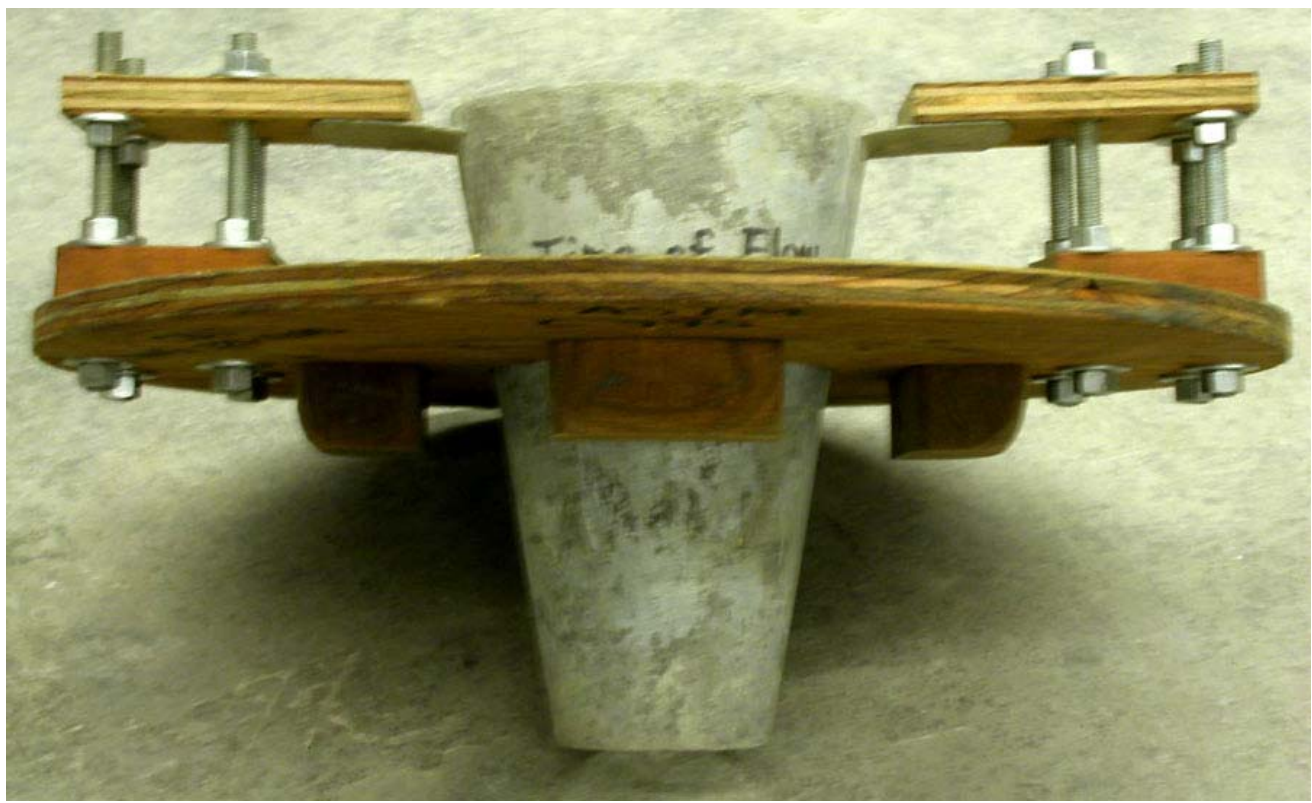

Fig. 32. Inverted slump cone for time of flow test (viewed from side)

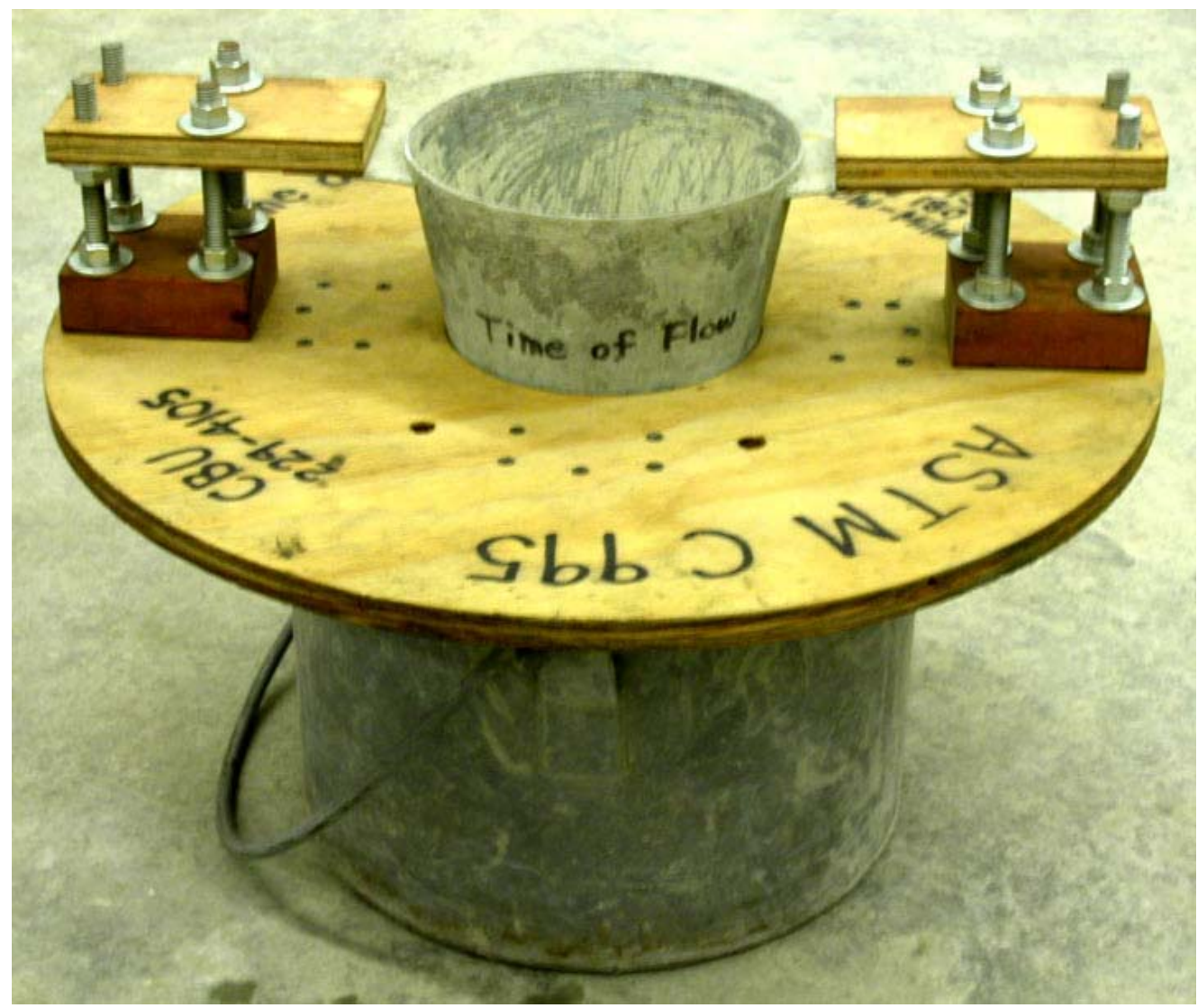

Fig. 33. Inverted slump cone set on top of ASTM C 29 one-ft ${ }^{3}$ bucket (There is a 4" clearance between the small end of the cone and the bottom of the bucket. Two vent holes are visible on plywood disk.) 


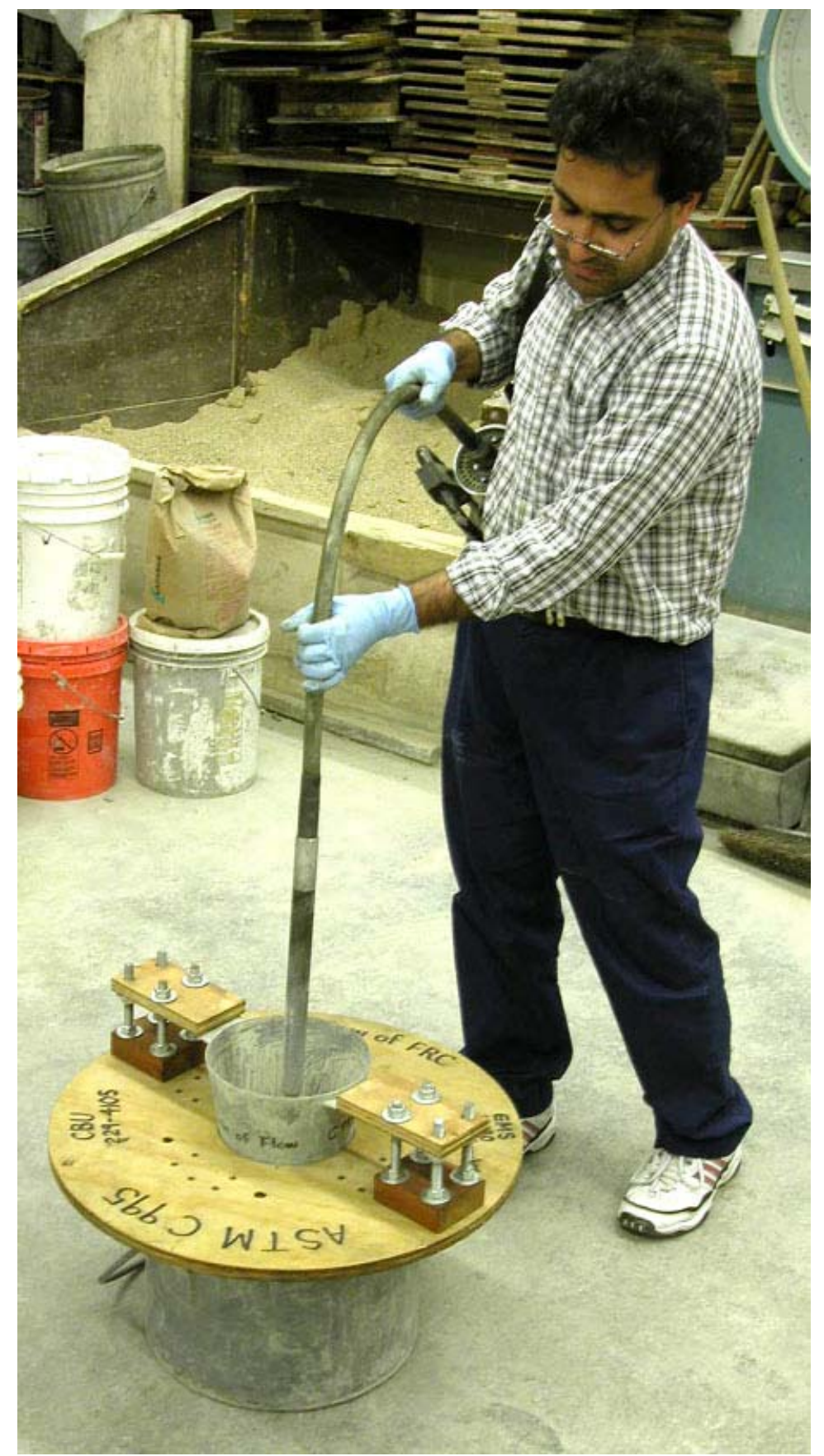

Fig. 34. Determination of time of flow of concrete (not actual testing) 


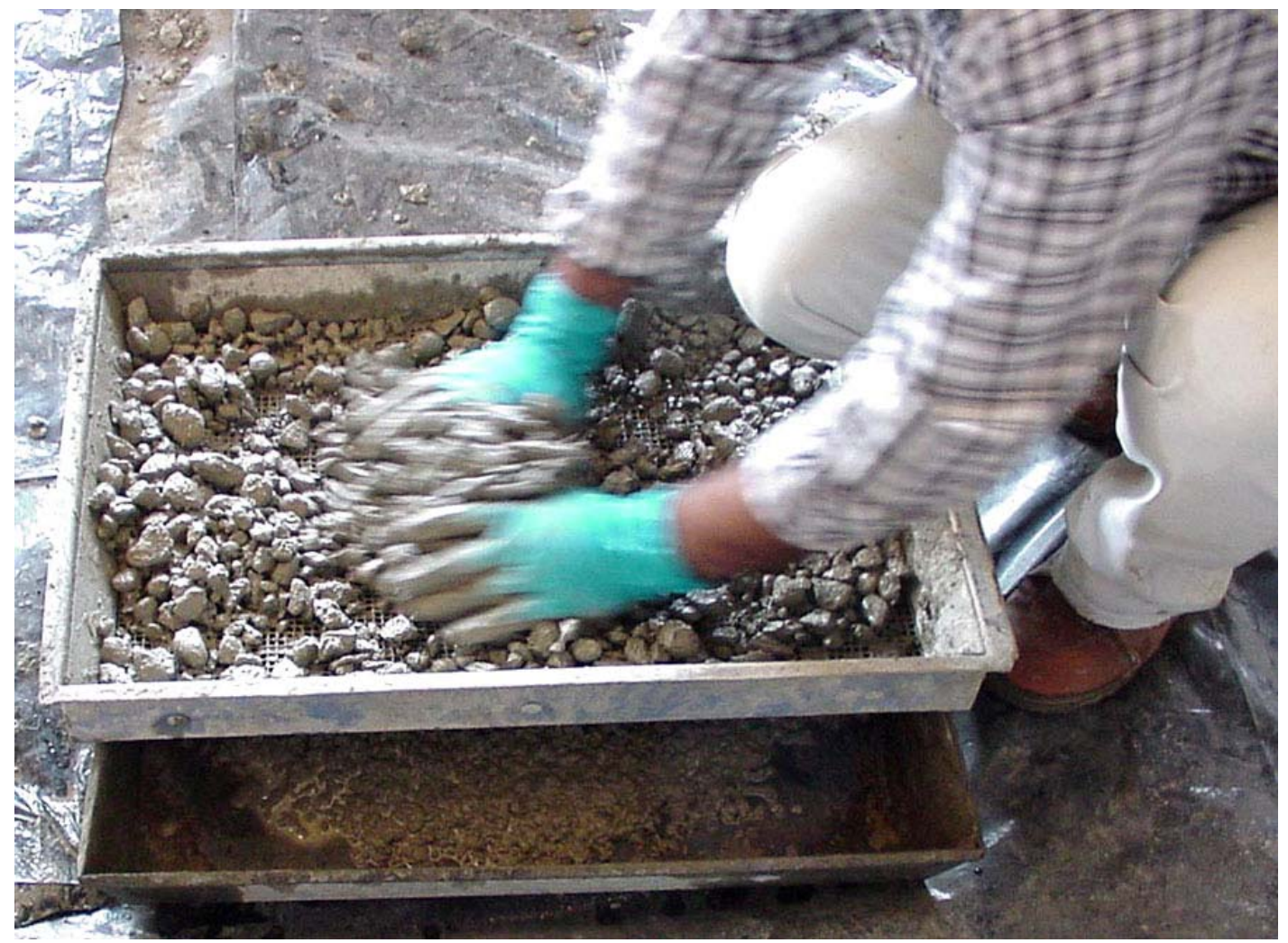

Fig. 35. Wet-sieving of concrete to obtain mortar for time of setting test

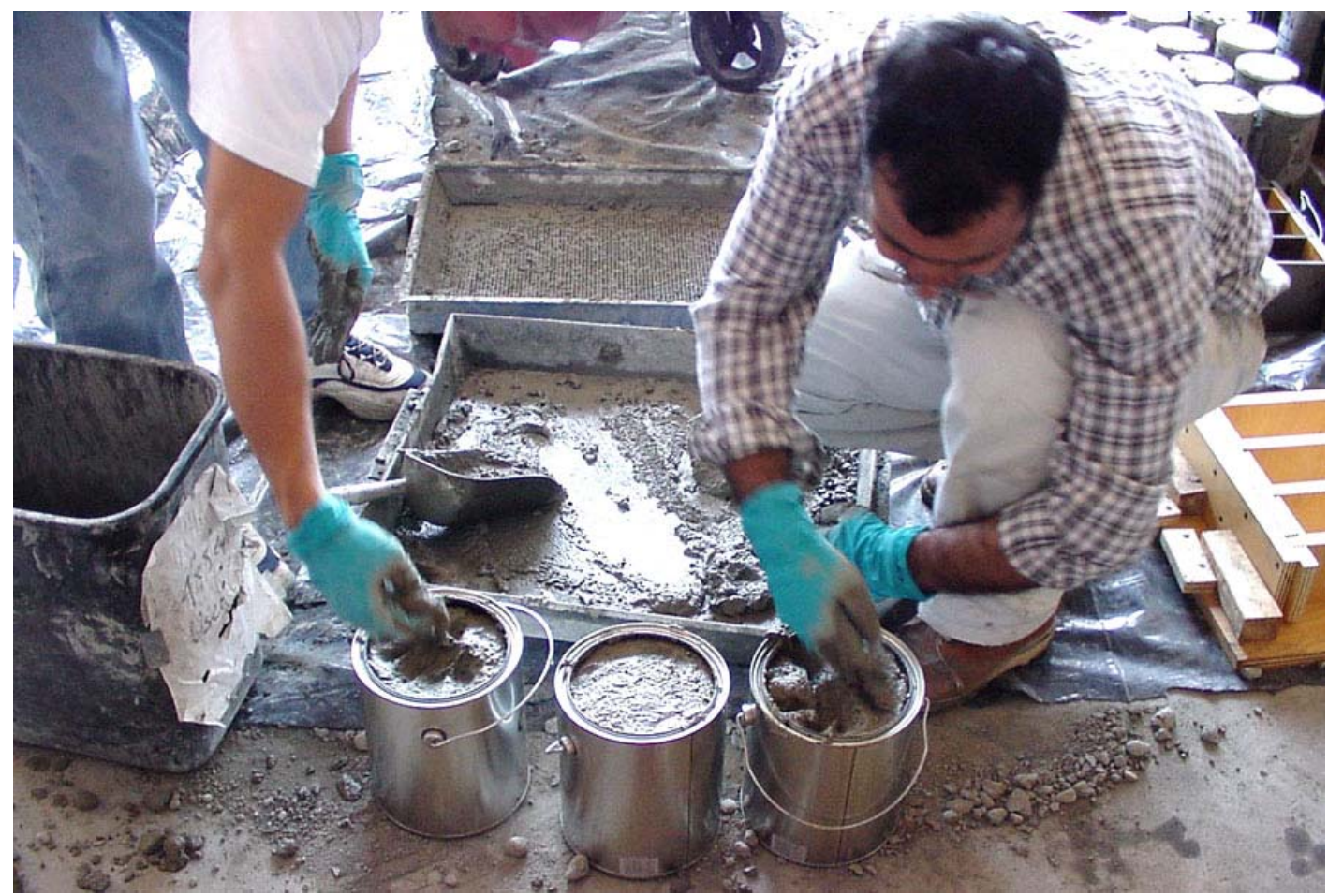

Fig. 36. Mortar samples in cans for time of setting test 


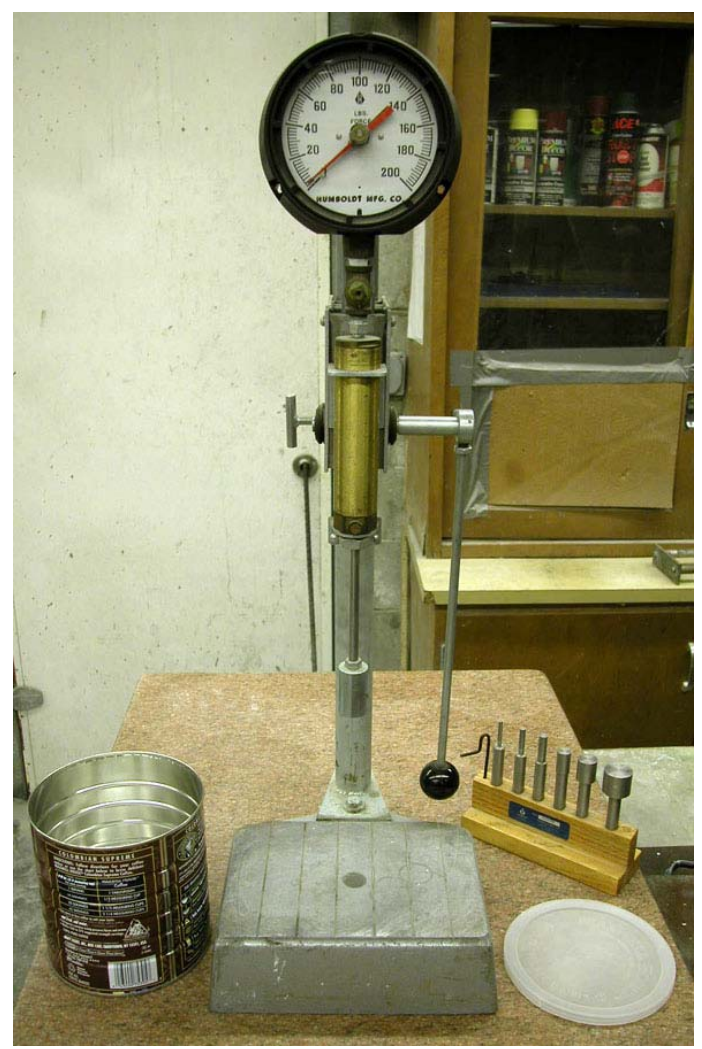

Fig. 37. Apparatus for time of setting test

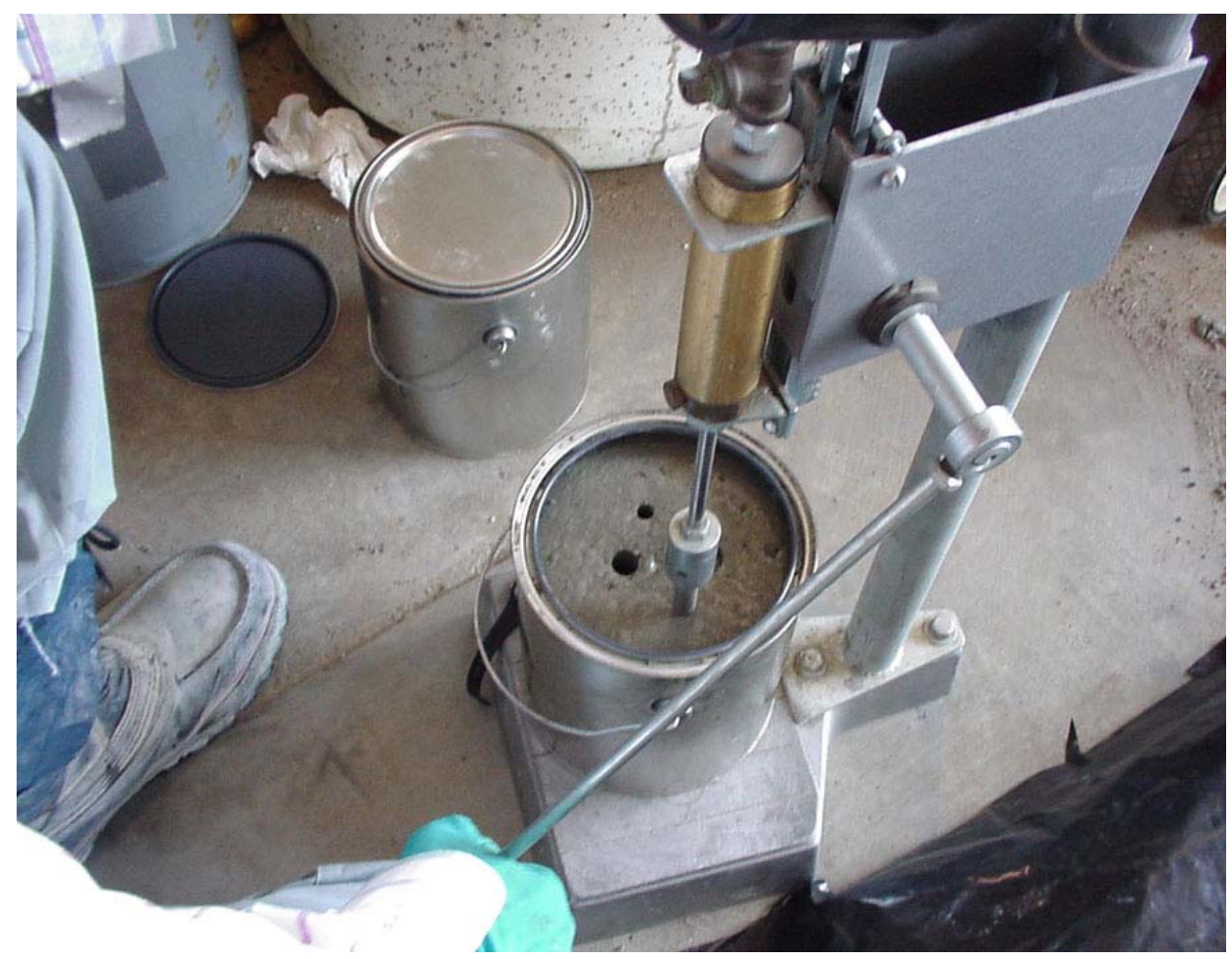

Fig. 38. Determination of penetration resistance (time of setting test) 


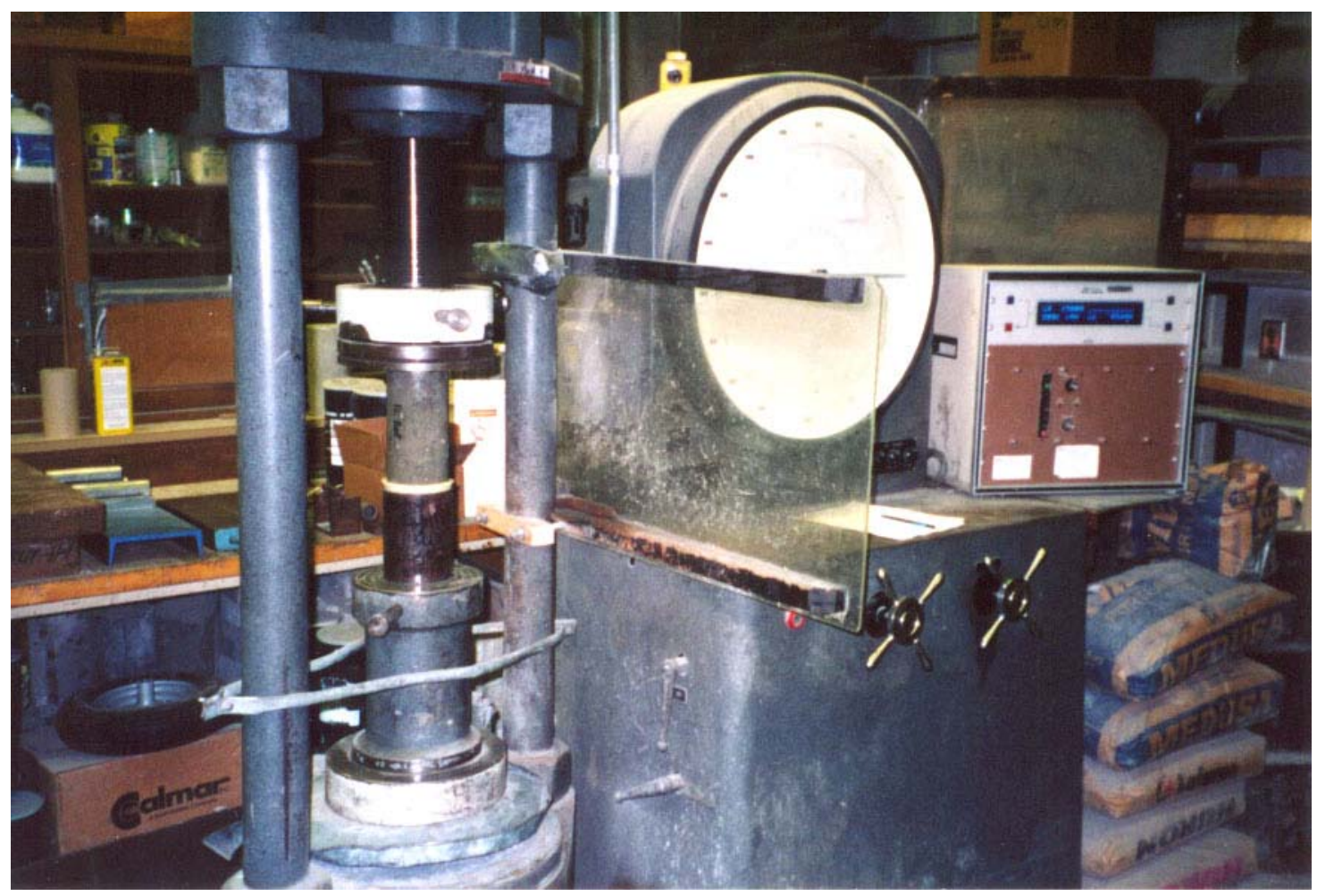

Fig. 39. Concrete cylinder ready for compression test

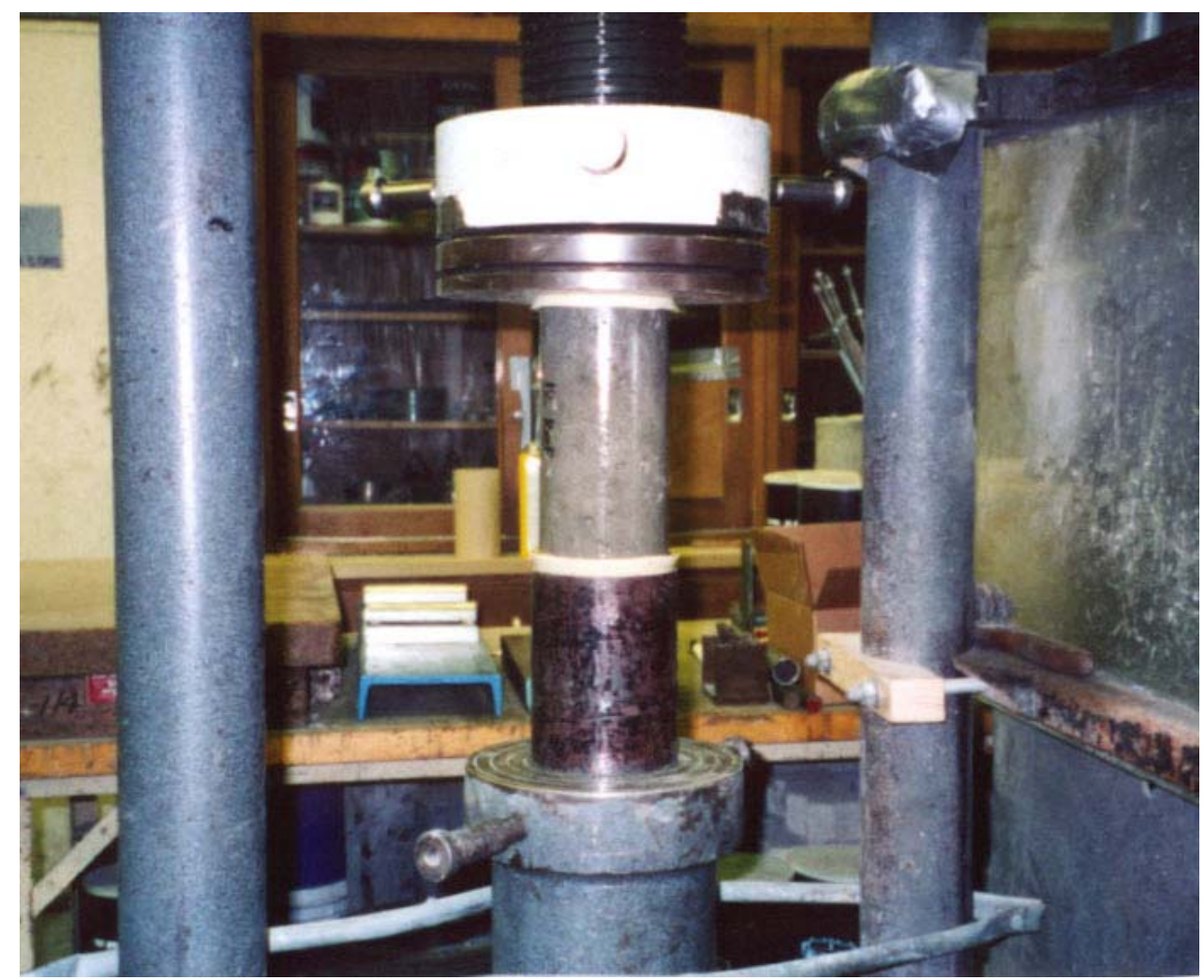

Fig. 40. Concrete cylinder under compressive load 


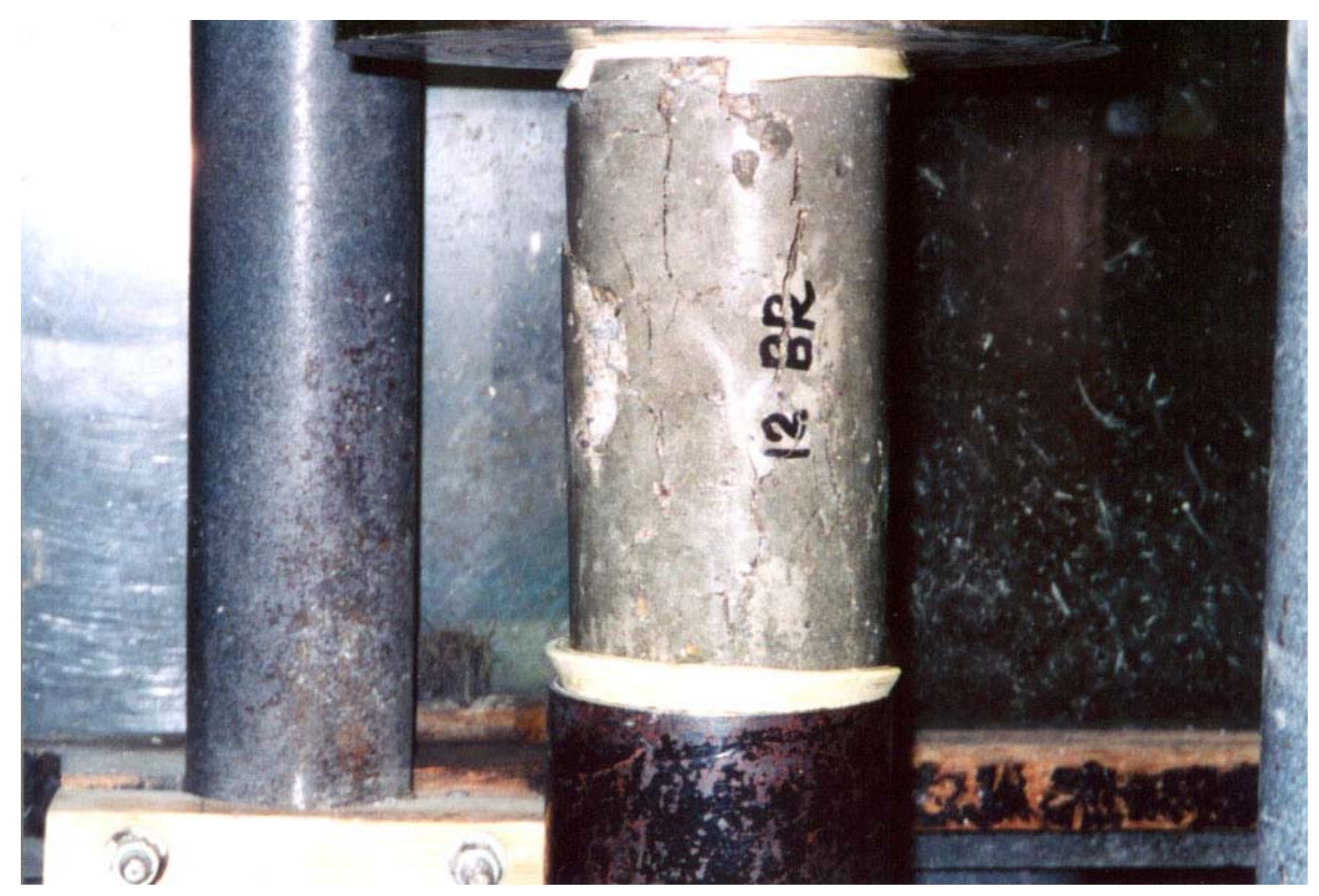

Fig. 41. Concrete cylinder broken in compression

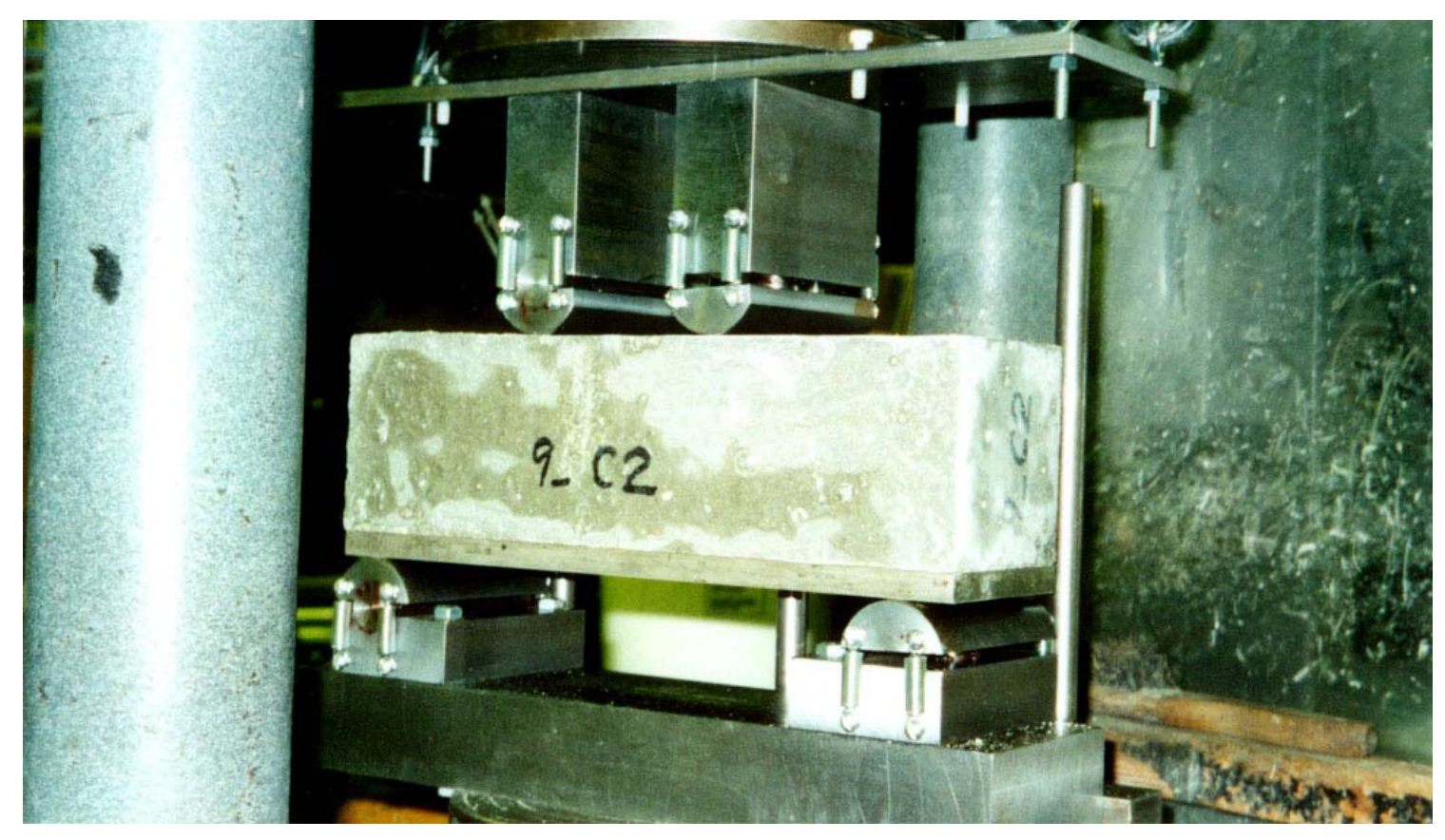

Fig. 42. Setup for initial loading of beam and steel plate (for determining avg. residual-strength after cracking) 


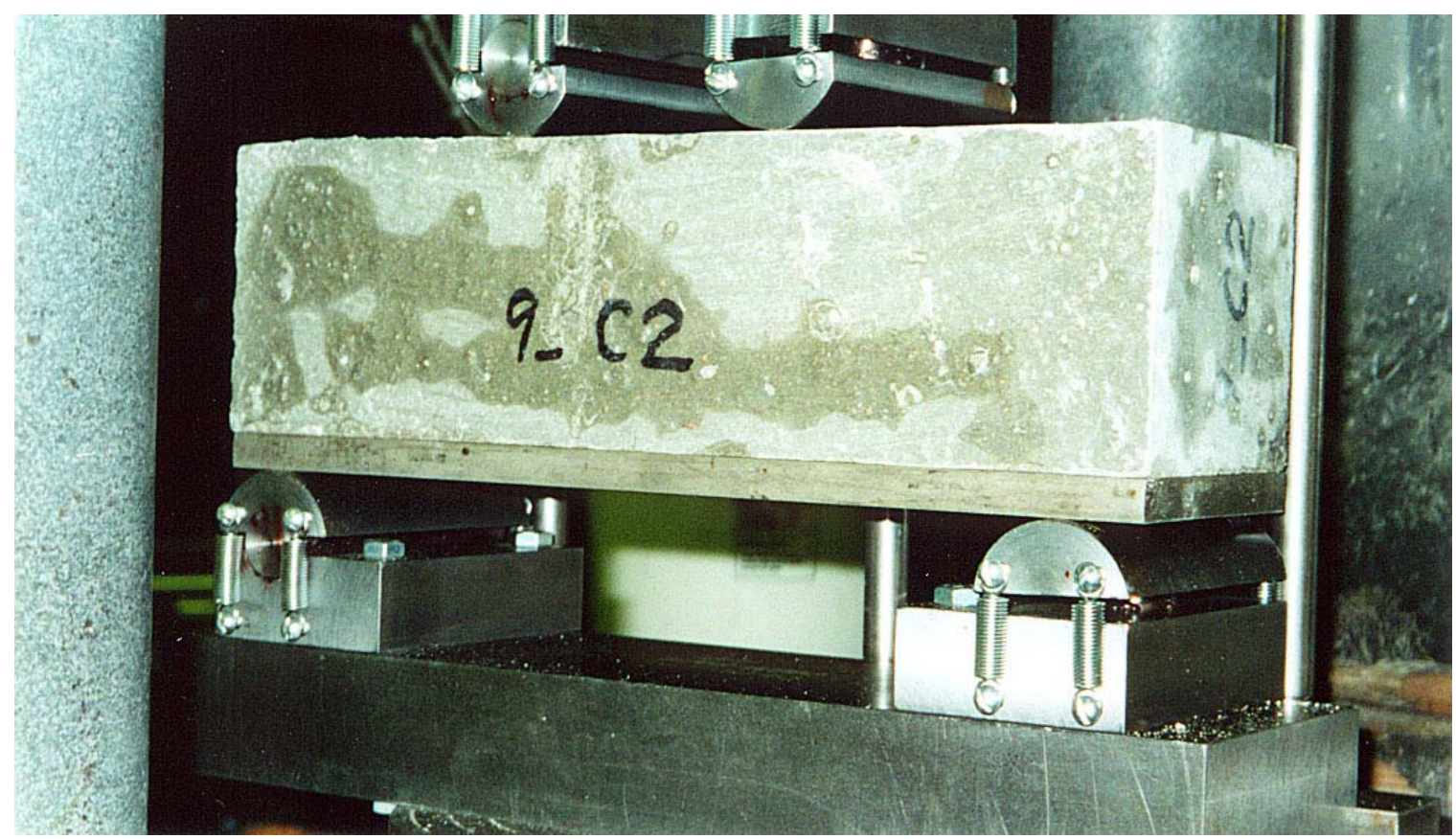

Fig. 43. Close-up of setup for initial loading of beam and steel plate (for determining avg. residual-strength after cracking)

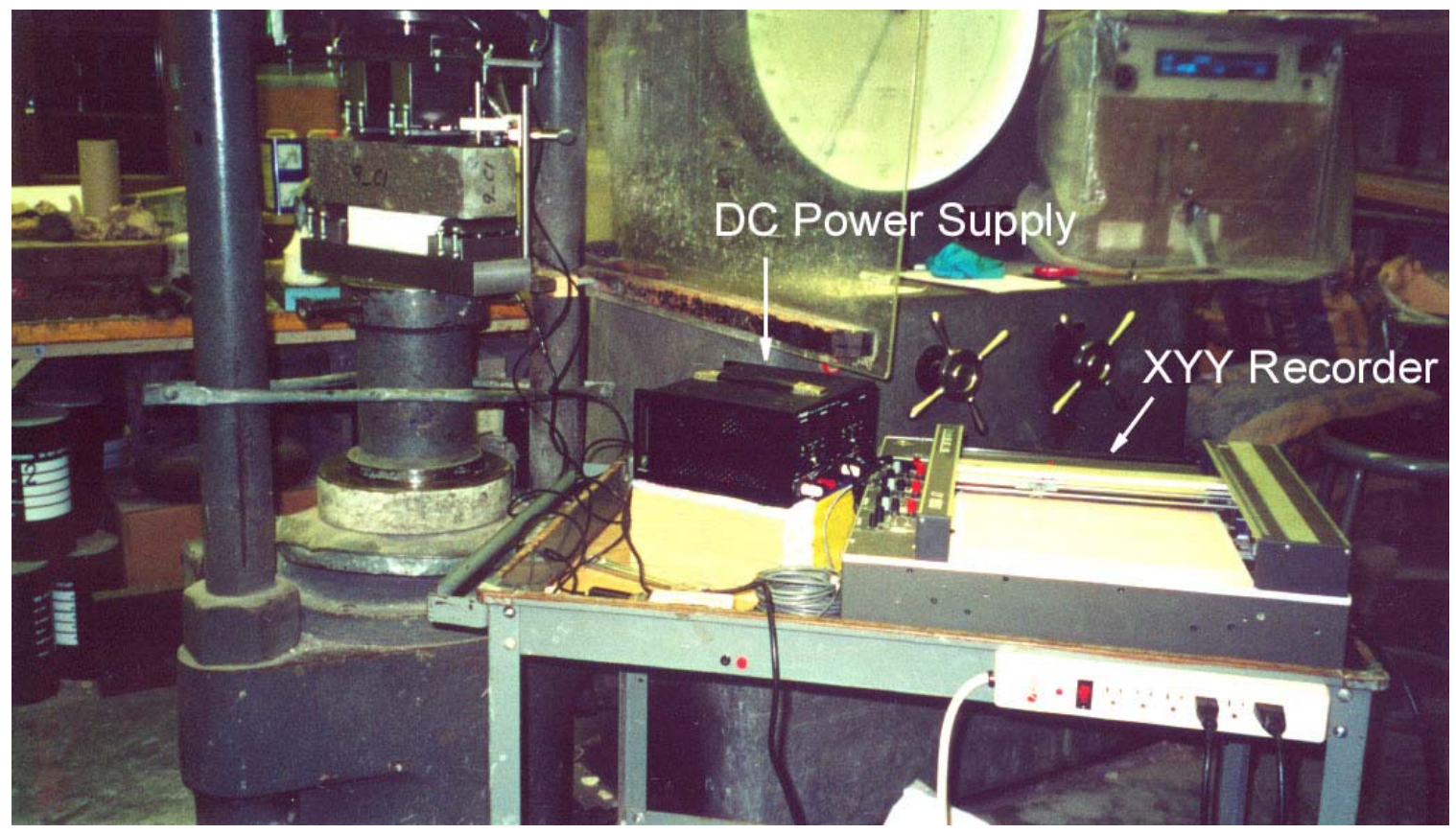

Fig. 44. Setup for reloading pre-cracked beam for determining avg. residualstrength 


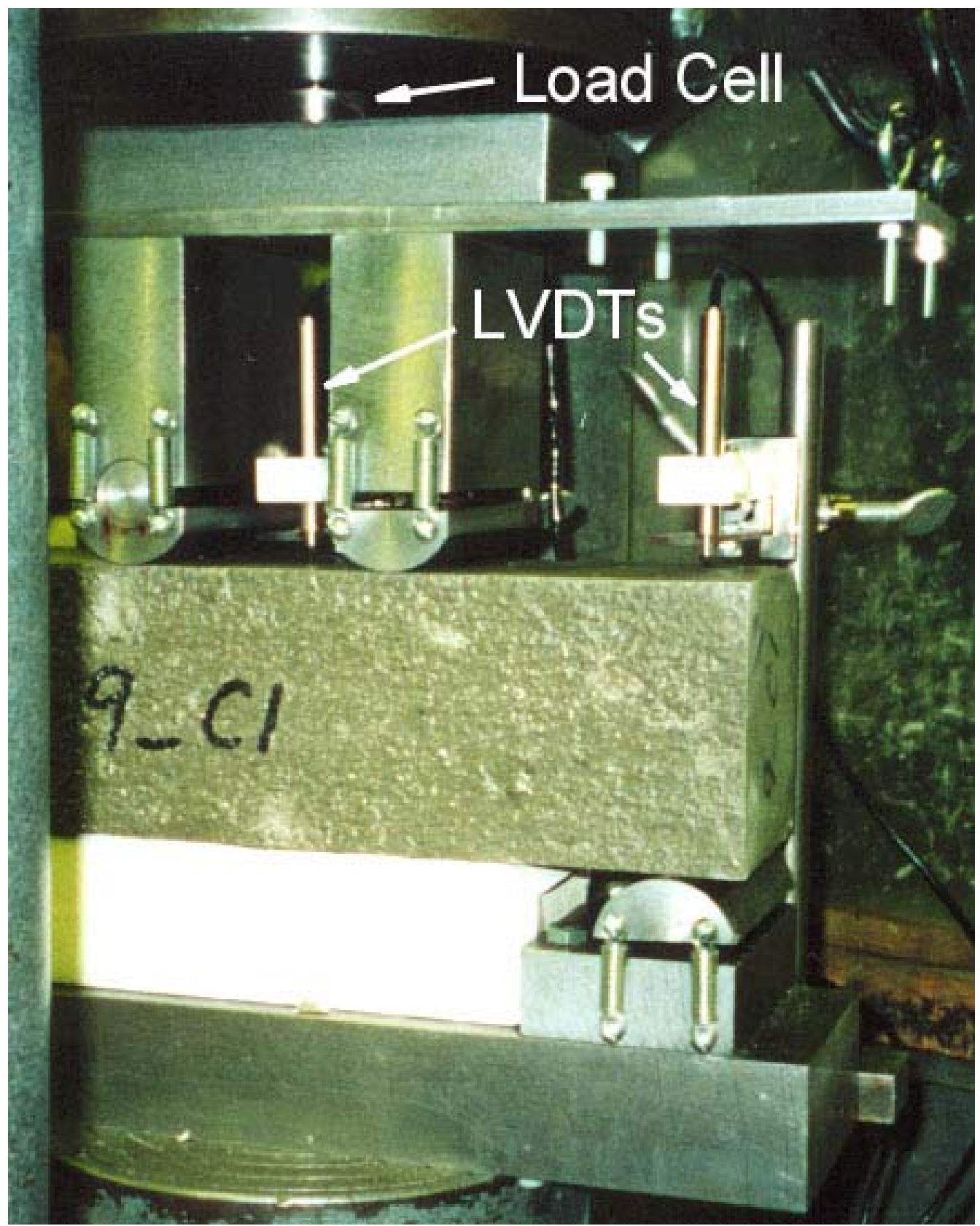

Fig. 45. Close-up of setup for reloading pre-cracked beam for determining avg. residual-strength

A masonry brick is placed under the beam with a clearance of $1 / 8$ " between the brick and the beam. (White portion on the brick is paper.) At the moment when the beam ruptures, the brick receives the broken beam so that the extent of rotations and movements of the broken halves of the beam may be small and the tips of the LVDTs at ends of the beam may be protected.

* LVDT: Linear Variable Differential Transformer (or Transducer) 


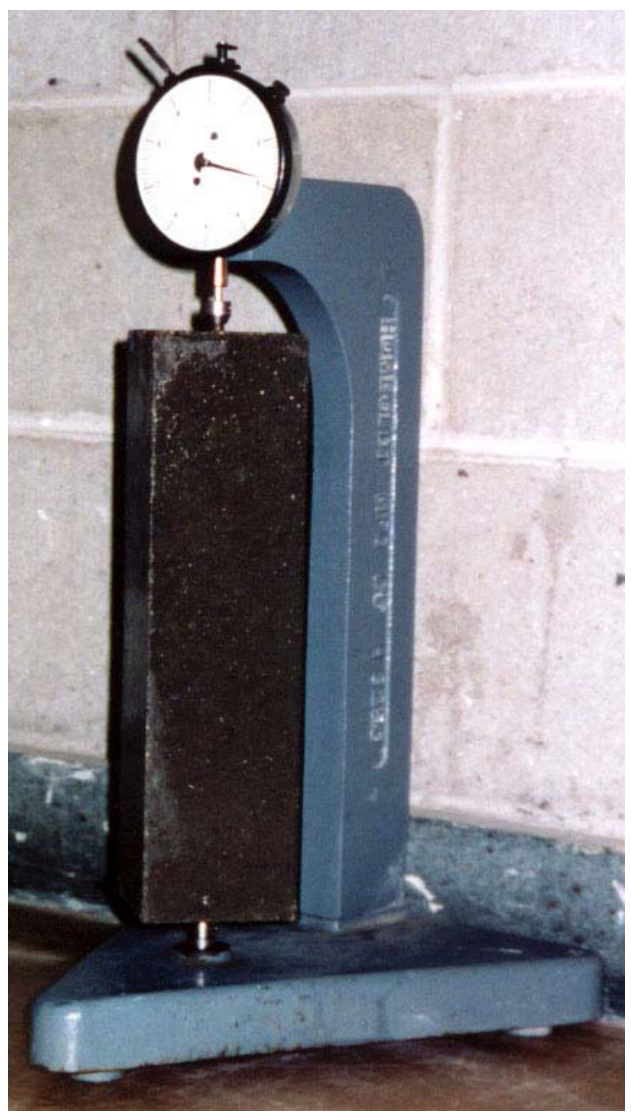

(a) Specimen

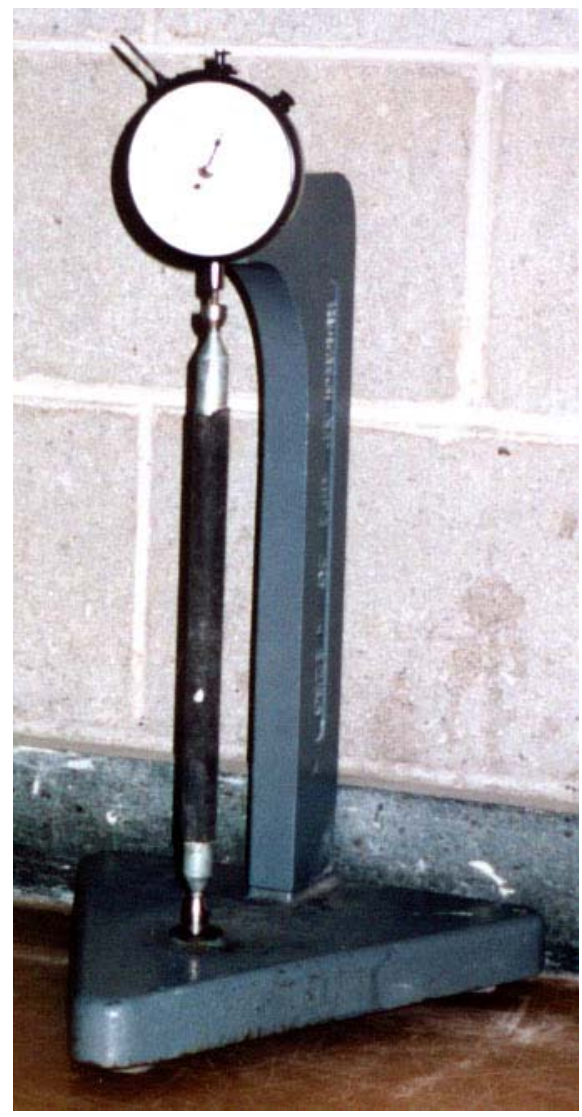

(b) Reference bar

Fig. 46. Length change test using a comparator

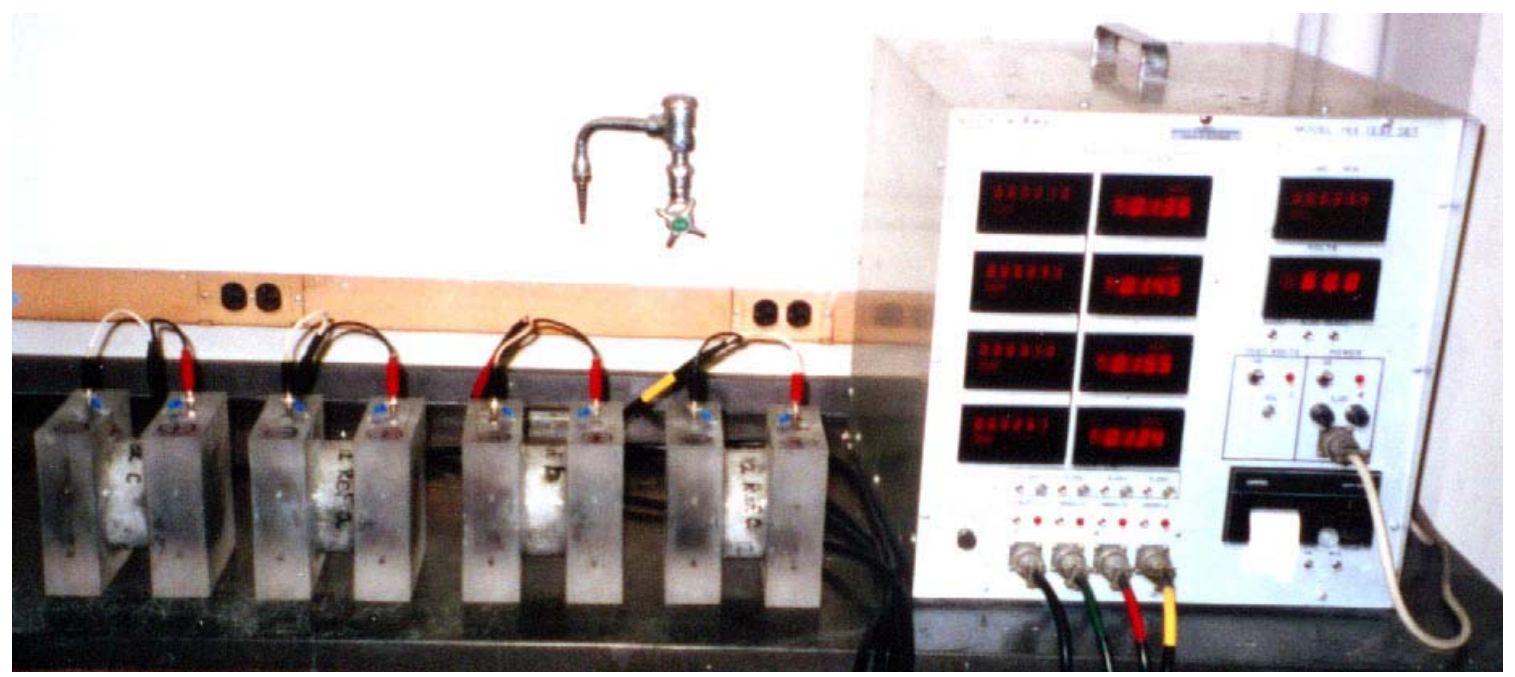

Fig. 47. Setup for chloride-ion penetration resistance test 


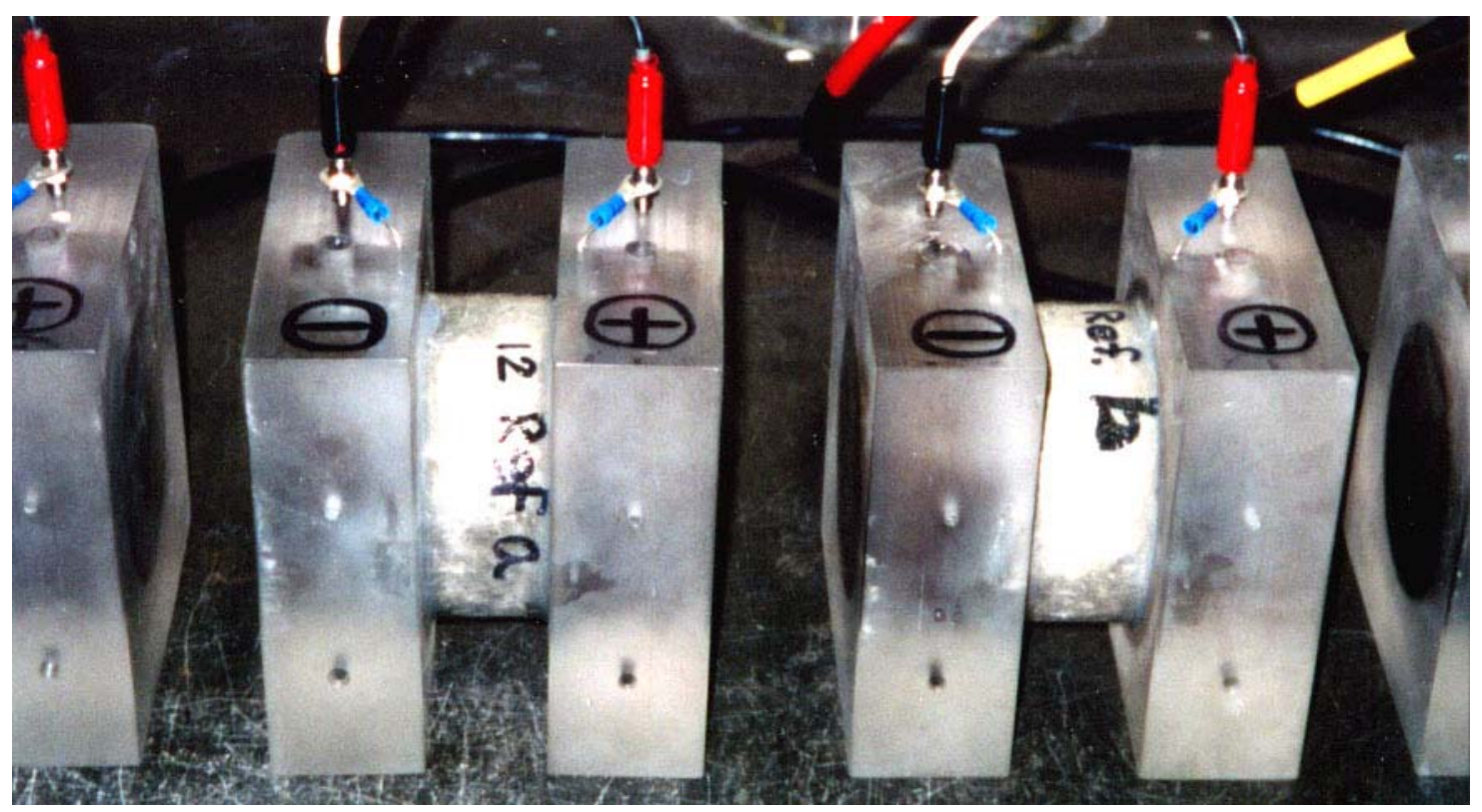

Fig. 48. Specimens in contact with $3 \% \mathrm{NaCl}(-)$ and $0.3 \mathrm{~N} \mathrm{NaOH} \mathrm{(+)} \mathrm{solutions} \mathrm{and}$ subject to $60 \mathrm{~V}$ DC

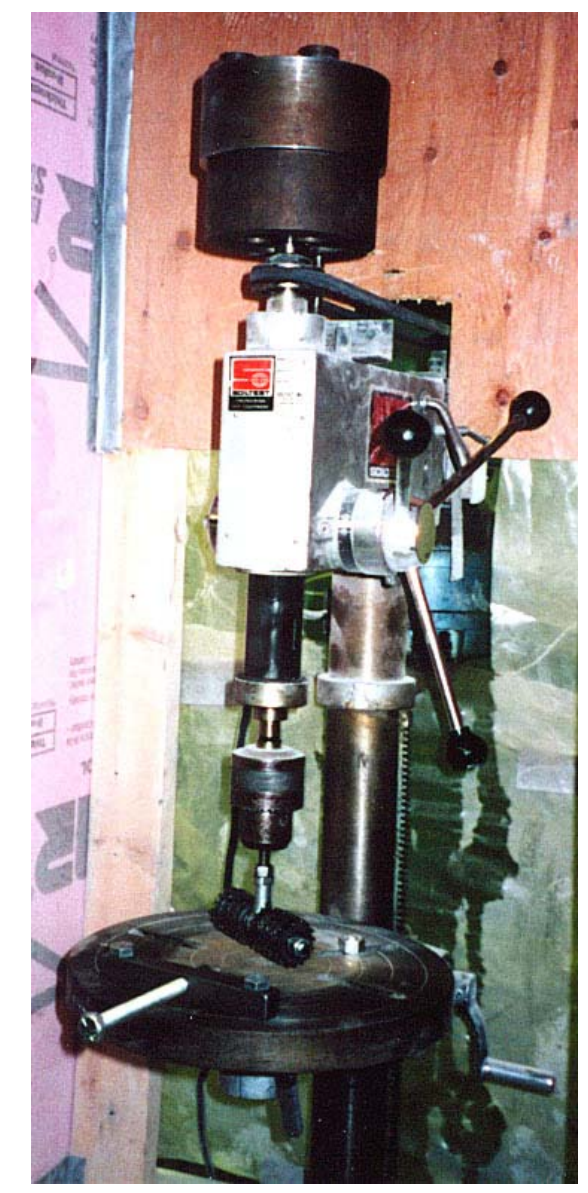

Fig. 49. Rotating-cutter drill press for abrasion resistance test 


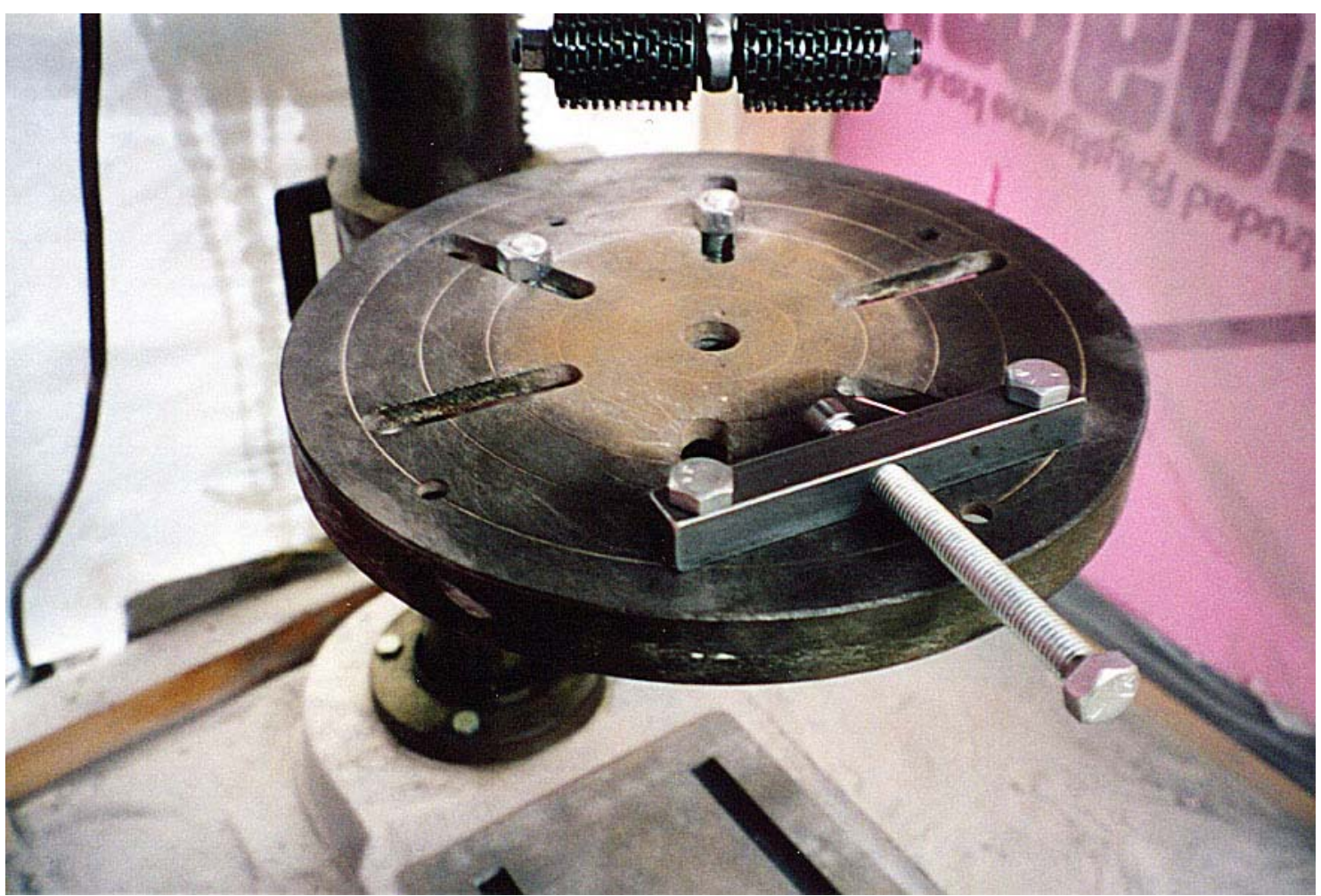

Fig. 50. Rotating cutters and setup for clamping abrasion specimen

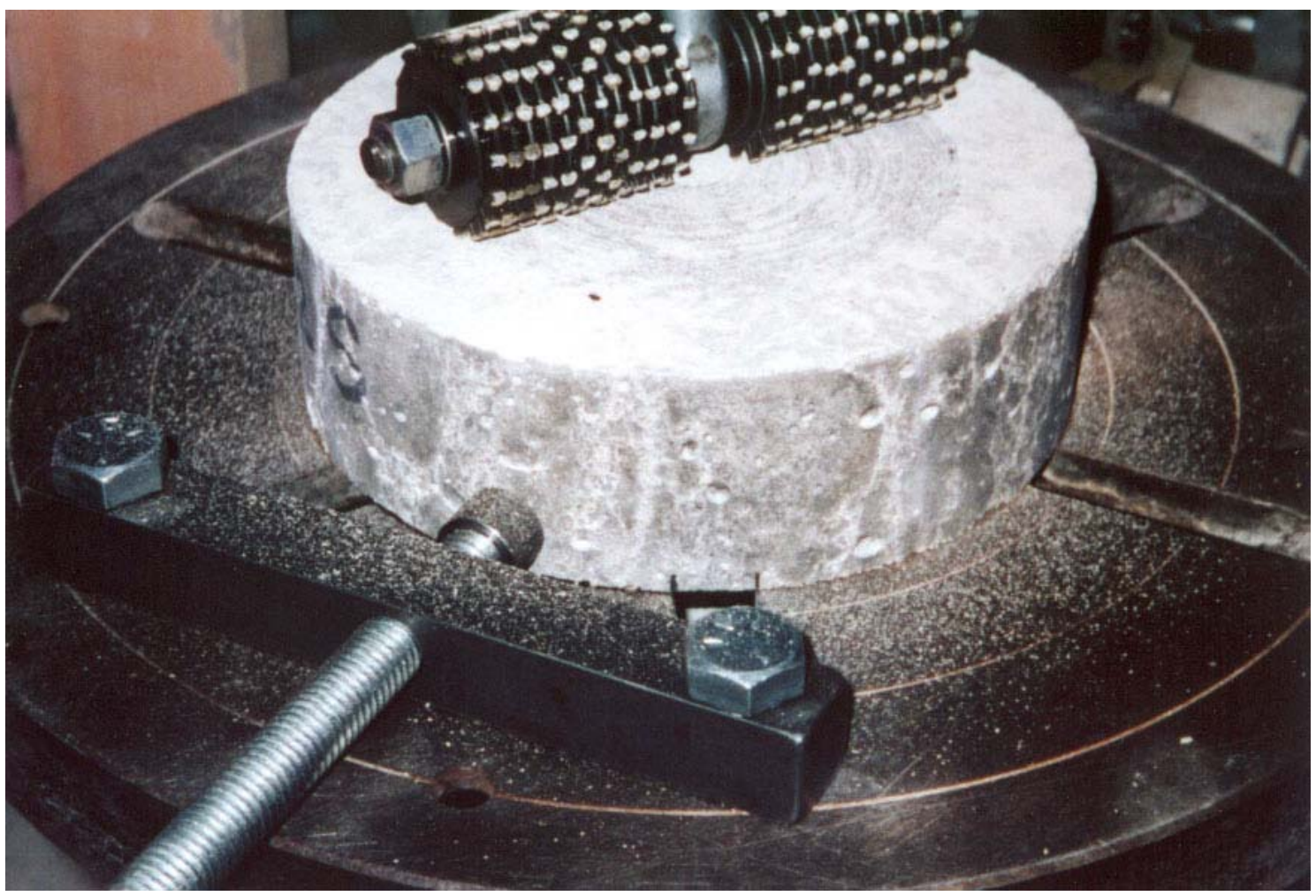

Fig. 51. Abrasion testing 


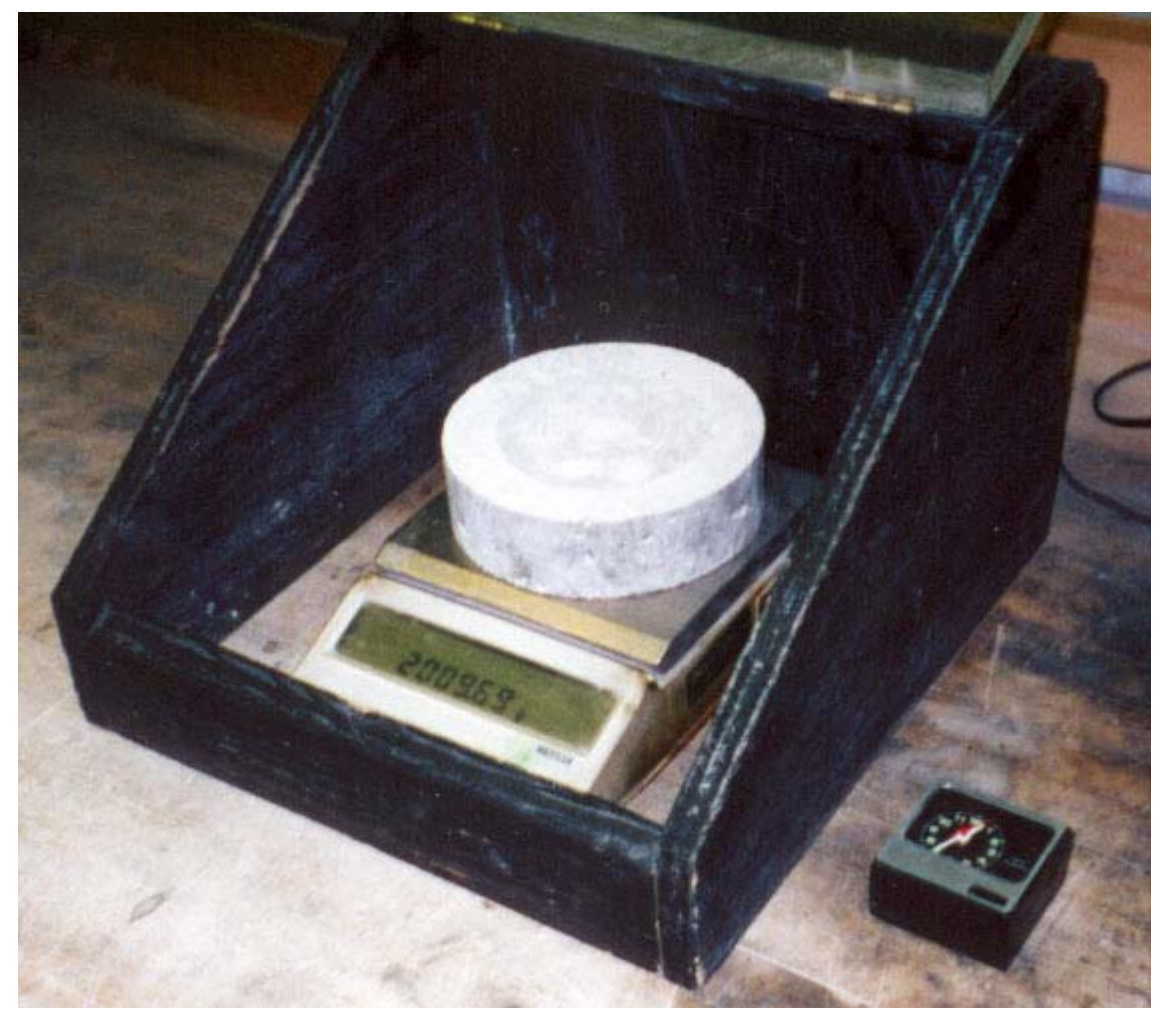

Fig. 52. Determination of mass loss due to abrasion

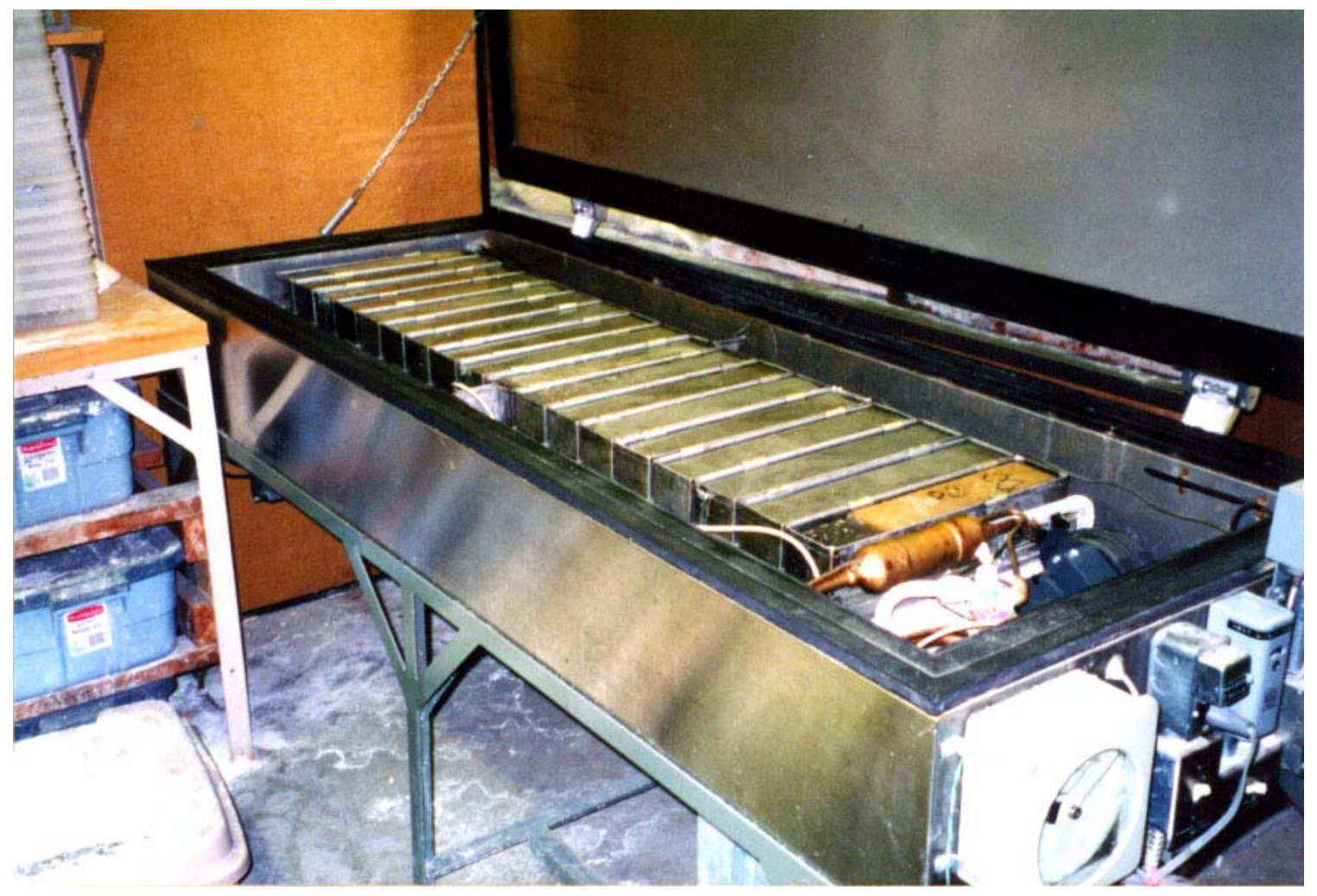

Fig. 53. Freezing-and-thawing chamber 


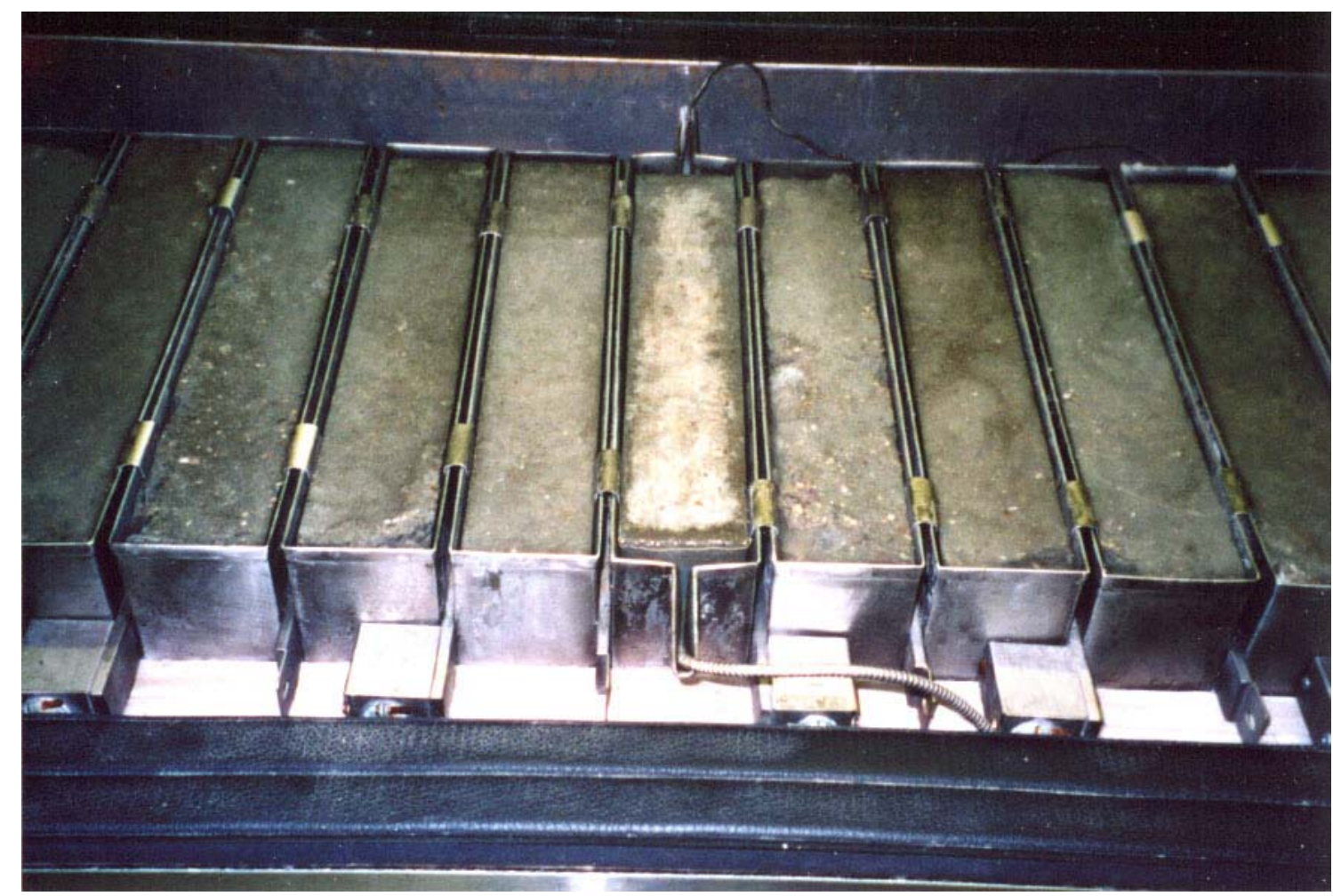

Fig. 54. Temperature control specimen (middle) with thermocouples

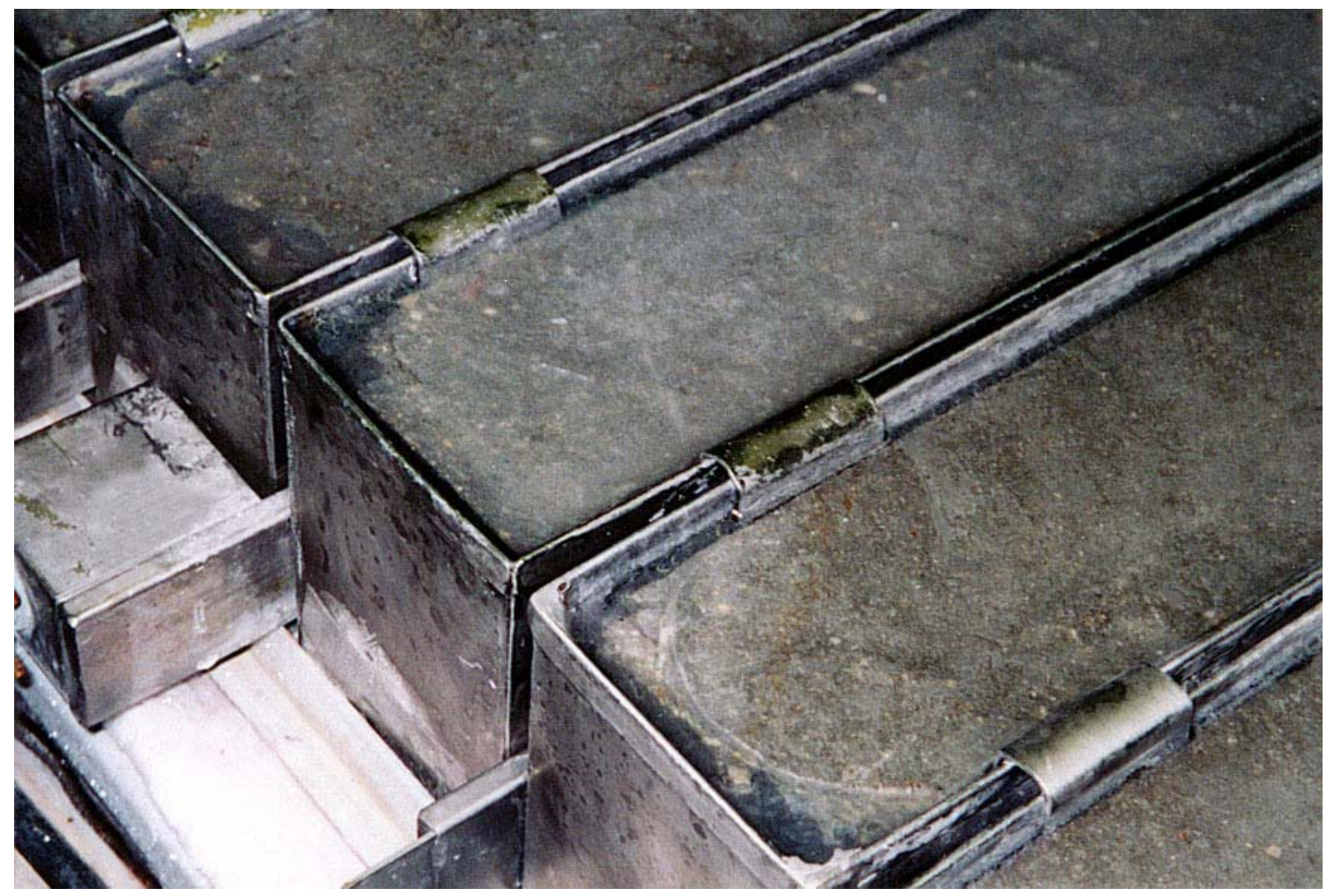

Fig. 55. Freezing-and-thawing specimens frozen at the end of freezing phase 


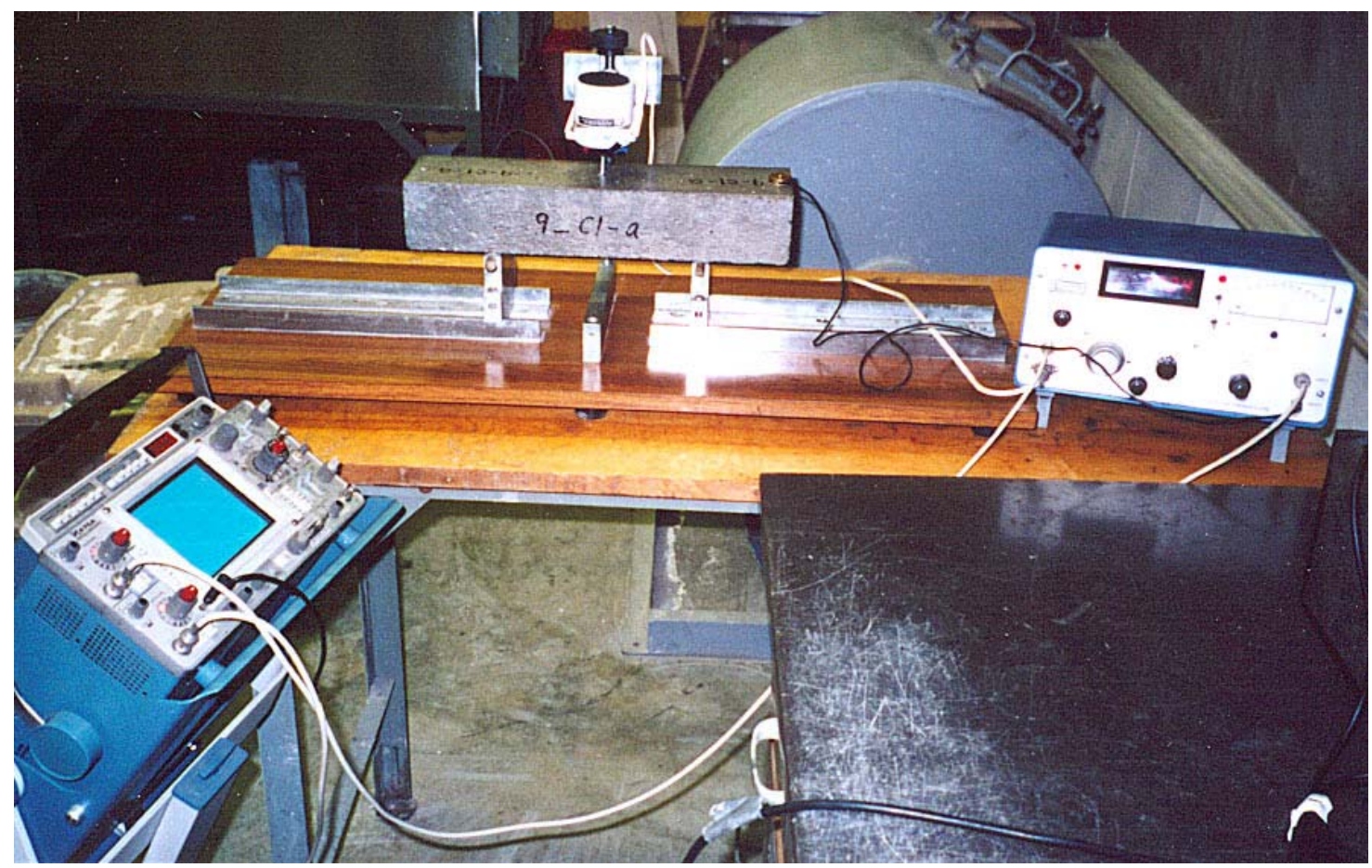

Fig. 56. Setup for fundamental transverse frequency test (for determining resistance to freezing and thawing)

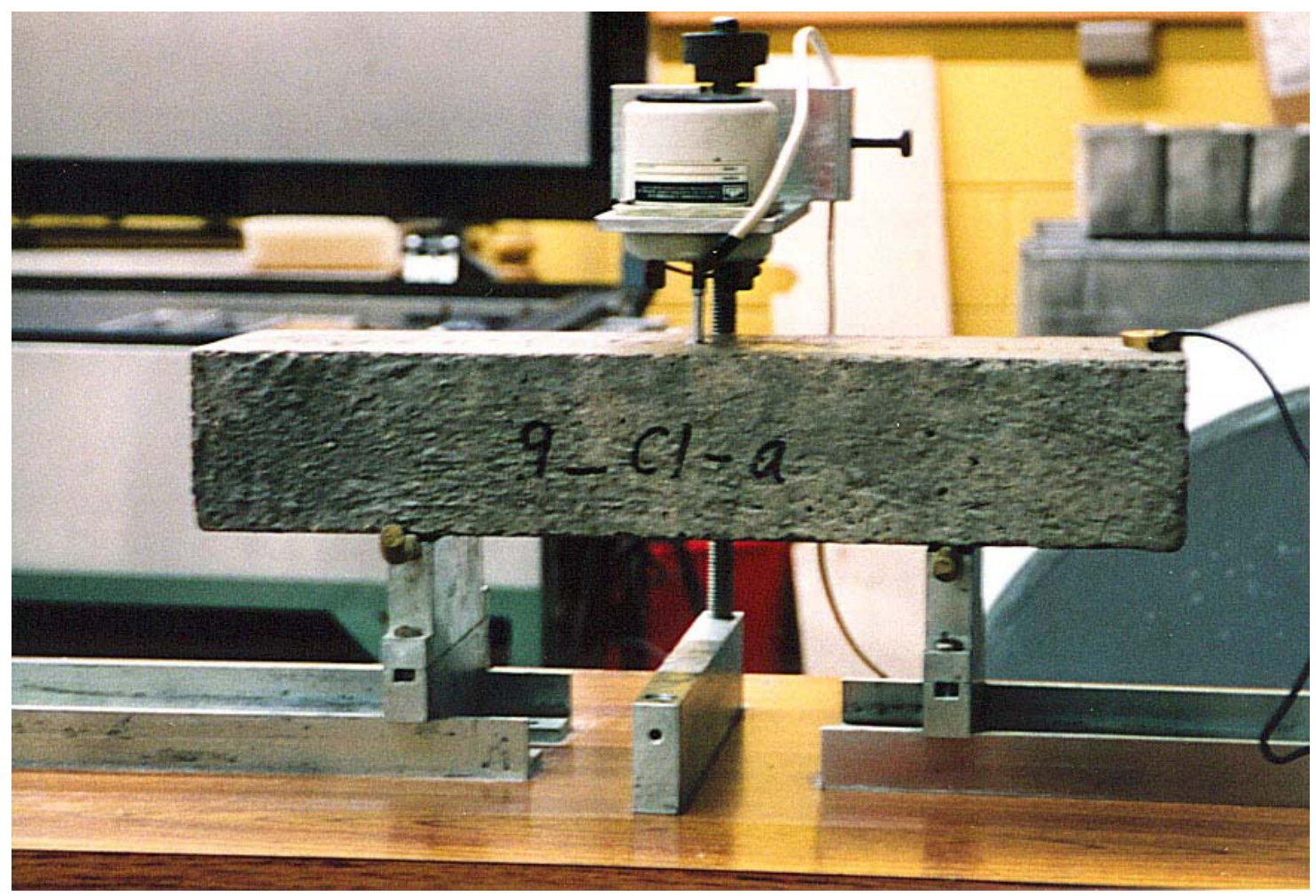

Fig. 57. Beam ready for fundamental transverse frequency test (for determining resistance to freezing and thawing) 


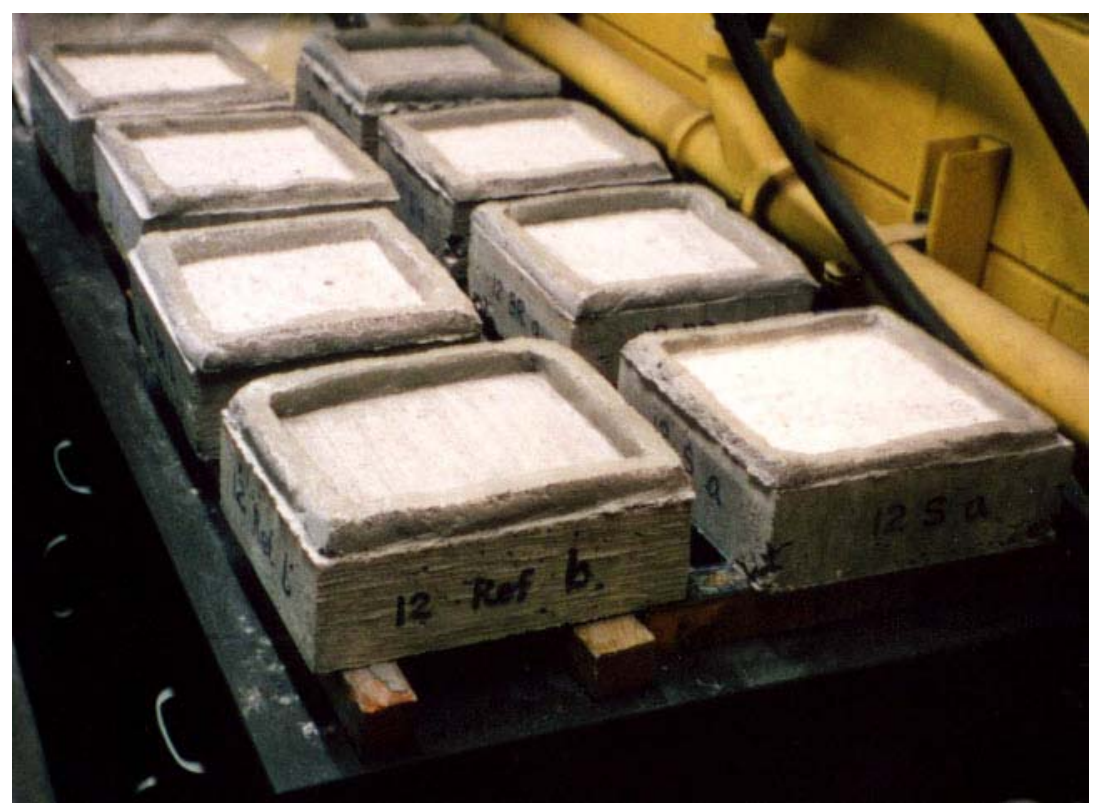

Fig. 58. Curing of salt-scaling specimens in air following 14 days of moist-curing

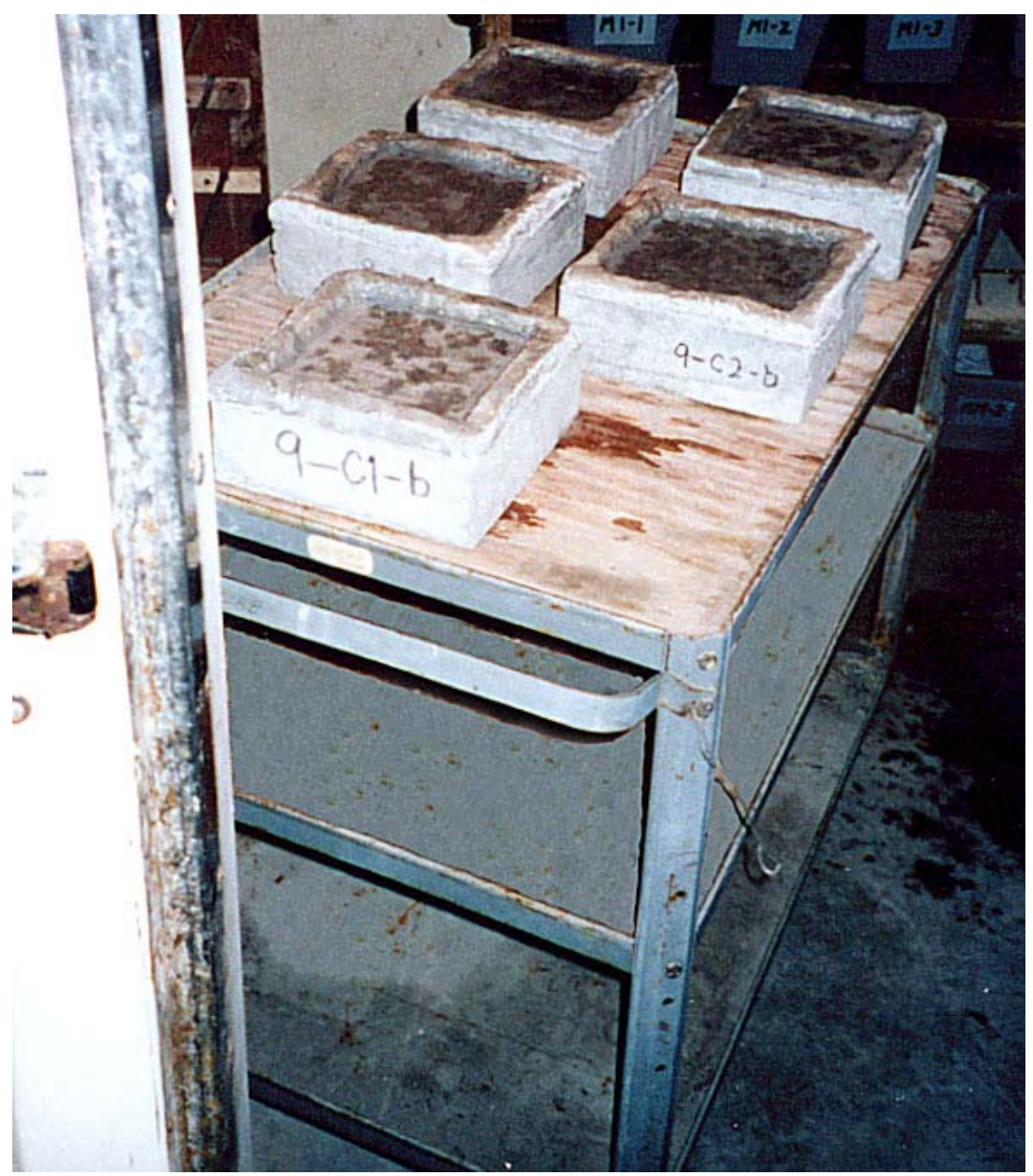

Fig. 59. Salt-scaling specimens in a walk-in freezer 


\section{CHAPTER 7 MIXTURE PROPORTIONS, TEST RESULTS, AND DISCUSSIONS}

\subsection{Overview}

\subsubsection{Laboratory Concrete Mixtures}

Overview of the series of concrete mixtures produced in laboratory is presented in Tables 50 to 52 .

A total of 16 series of concrete mixtures containing various amounts of paper mill residual solids of the first delivery were produced in four broad categories: (1)

preliminary; (2) durability; (3) additional; and (4) miscellaneous. Mineral additives (for example, fly ash) were not used in any series of the mixtures.

\section{Preliminary Laboratory Mixtures}

The preliminary series of mixtures (Sect. 7.2, p. 129) were produced in order to establish optimum mixture proportions for the evaluation of durability and long-term properties of concrete containing pulp and paper mill fibrous residuals. For each source of residuals (except Residual P), concrete mixture proportions were established for producing residuals concrete that was equivalent to reference (no-residuals) concrete in slump and compressive strength. 
Table 50. Overview of Preliminary Series of Laboratory Concrete Mixtures (Sect. 7.2, p. 129)

\begin{tabular}{|c|c|c|c|c|c|}
\hline Series & Characteristics & Residual(s) & $\begin{array}{l}\text { Admix- } \\
\text { ture }\end{array}$ & Test(s) & Observation(s) \\
\hline $\begin{array}{l}\text { 1. Strength } \\
\text { Development } \\
\text { Pattern }\end{array}$ & No HRWRA & $\begin{array}{l}\text { C1, C2, } \\
\text { WG, WV, } \\
\text { I, S, P }\end{array}$ & $\ldots$ & $\begin{array}{l}\text { Comp., } \\
\text { Tens., } \\
\text { Flex. }\end{array}$ & $\begin{array}{l}- \text { Residuals reduced slump but did not adversely } \\
\text { affect the strengths of concrete. }\end{array}$ \\
\hline $\begin{array}{ll}\text { 2. } & \text { High } \\
\text { Residuals } \\
\text { Content }\end{array}$ & $\begin{array}{l}- \text { No HRWRA. } \\
\text { - Higher residuals } \\
\text { content. }\end{array}$ & $\begin{array}{l}\mathrm{C} 1, \mathrm{C} 2, \\
\mathrm{WG}, \mathrm{WV}, \\
\mathrm{P}\end{array}$ & $\ldots$ & $\begin{array}{l}\text { Comp., } \\
\text { Tens., } \\
\text { Flex. }\end{array}$ & $\begin{array}{l}\text { - Residuals concrete showed low slump. } \\
\text { - As residuals content increased, density and } \\
\text { strengths decreased. }\end{array}$ \\
\hline $\begin{array}{l}\text { 3. Attempt for } \\
\text { Modeling of } \\
\text { Compressive } \\
\text { Strength }\end{array}$ & $\begin{array}{l}- \text { Three variables: } \\
\text { residual, HRWRA, } \\
\text { and water contents. }\end{array}$ & $\mathrm{WV}$ & HRWRA & Comp. & $\begin{array}{l}\text { - Widespread slump. } \\
\text { - No significant and systematic differences in } \\
\text { strength. }\end{array}$ \\
\hline 4. Modeling 1 & $\begin{array}{l}- \text { Two variables: } \\
\text { residual and HRWRA } \\
\text { contents. } \\
\text { - Slump kept within a } \\
\text { prescribed range. }\end{array}$ & $\begin{array}{l}\mathrm{C} 1, \mathrm{C} 2 \\
\mathrm{WG}, \mathrm{WV}\end{array}$ & HRWRA & Comp. & $\begin{array}{l}\text { - Residuals decreased strength, and HRWRA } \\
\text { increased strength. } \\
\text { - With proper combinations of residuals and } \\
\text { HRWRA contents, it would be possible to produce } \\
\text { residuals concretes that are equivalent to reference } \\
\text { concrete in slump and compressive strength. }\end{array}$ \\
\hline $\begin{array}{l}\text { 6. Attempt for } \\
\text { Equivalent } \\
\text { Strength }\end{array}$ & $\begin{array}{l}\text { Residuals and } \\
\text { HRWRA contents } \\
\text { derived from Model } 1 \\
\text { were used. }\end{array}$ & $\begin{array}{l}\text { C1, C2, } \\
\text { WG, WV }\end{array}$ & HRWRA & Comp. & $\begin{array}{l}- \text { Almost equivalent strength regardless of } \mathrm{C} 1 \text { and } \\
\mathrm{C} 2 \text { contents. } \\
\text { - Reduction in strength with the increase in } \mathrm{WG} \\
\text { and WV contents. }\end{array}$ \\
\hline $\begin{array}{l}\text { 7. Equivalent } \\
\text { strength } 1\end{array}$ & Uniform density & $\begin{array}{l}\text { C1, C2, } \\
\text { WG, WV }\end{array}$ & HRWRA & Comp. & $\begin{array}{l}\text { - Equivalent density, slump, and compressive } \\
\text { strength regardless of residuals contents. }\end{array}$ \\
\hline $\begin{array}{l}\text { 11. Equivalent } \\
\text { strength } 2\end{array}$ & Uniform density & $\mathrm{BR}, \mathrm{I}, \mathrm{S}$ & HRWRA & Comp. & $\begin{array}{l}\text { - Equivalent strength for I and S residuals concrete } \\
\text { - Segregation and drop in strength for higher BR } \\
\text { content. }\end{array}$ \\
\hline
\end{tabular}


Table 51. Overview of Series of Laboratory Concrete Mixtures for Durability (Series 9 and 12, Sect. 7.3, p. 176) and Additional Series of Laboratory Mixtures (Sect. 7.5, p. 203)

\begin{tabular}{|c|c|c|c|c|c|}
\hline Series & Characteristics & Residual(s) & $\begin{array}{l}\text { Admix- } \\
\text { ture(s) }\end{array}$ & $\operatorname{Test}(\mathrm{s})$ & Observation(s) \\
\hline $\begin{array}{l}\text { 9. } \mathrm{C} 1, \mathrm{C} 2 \\
\mathrm{WG}, \mathrm{WV} \\
\text { 12. BR, I, S }\end{array}$ & $\begin{array}{l}\text { Mixtures for time of } \\
\text { setting, average } \\
\text { residual-strength, } \\
\text { durability, and long- } \\
\text { term properties. }\end{array}$ & $\begin{array}{l}\mathrm{C} 1, \mathrm{C} 2, \mathrm{WG} \\
\mathrm{WV}, \mathrm{BR}, \mathrm{I}, \mathrm{S}\end{array}$ & HRWRA & $\begin{array}{l}\text { Setting, Comp., } \\
\text { Avg. Residual- } \\
\text { Strength, Length } \\
\text { Change, } \\
\text { Chloride-Ion } \\
\text { Penetration, } \\
\text { Abrasion, F\&T, } \\
\text { Salt-Scaling. }\end{array}$ & $\begin{array}{l}\text { - Delay in time of setting due to the use of } \\
\text { HRWRA. } \\
\text { - Comparable compressive strength, avg. } \\
\text { residual-strength, length change, and } \\
\text { resistance to chloride-ion penetration and } \\
\text { abrasion. }\end{array}$ \\
\hline 14. Modeling 2 & $\begin{array}{l}\text { Modeling of } \\
\text { compressive } \\
\text { strength } 2 \text {. } \\
\end{array}$ & $\begin{array}{l}\mathrm{C} 1, \mathrm{C} 2, \mathrm{WG}, \\
\mathrm{WV}, \mathrm{BR}, \mathrm{I}, \mathrm{S}\end{array}$ & HRWRA & Comp. & $\begin{array}{l}\text { Equivalent compressive strength with } \\
\text { proper combinations of residual and } \\
\text { HRWRA contents. }\end{array}$ \\
\hline $\begin{array}{l}\text { 15. Tensile and } \\
\text { Flexural } \\
\text { Strengths }\end{array}$ & $\begin{array}{l}\text { Splitting tensile and } \\
\text { flexural strengths. }\end{array}$ & $\begin{array}{l}\mathrm{C} 1, \mathrm{C} 2, \mathrm{WG}, \\
\mathrm{WV}, \mathrm{BR}, \mathrm{I}, \mathrm{S}\end{array}$ & HRWRA & $\begin{array}{l}\text { Comp., Tens., } \\
\text { Flex. }\end{array}$ & $\begin{array}{l}\text { Higher splitting tensile and flexural } \\
\text { strengths at same level of compressive } \\
\text { strength. }\end{array}$ \\
\hline $\begin{array}{l}\text { 16. Response } \\
\text { to AEA }\end{array}$ & $\begin{array}{l}\text { Response of } \\
\text { residuals concrete to } \\
\text { AEA. }\end{array}$ & $\begin{array}{l}\mathrm{C} 1, \mathrm{C} 2, \mathrm{WG} \\
\mathrm{WV}, \mathrm{BR}, \mathrm{I}, \mathrm{S}\end{array}$ & $\begin{array}{l}\text { HRWRA, } \\
\text { AEA }\end{array}$ & Comp. & $\begin{array}{l}\text { Lower air content and higher compressive } \\
\text { strength at same AEA dosage rate. }\end{array}$ \\
\hline
\end{tabular}


Table 52. Overview of Miscellaneous Series of Laboratory Concrete Mixtures (Sect. 13.3, p. 259)

\begin{tabular}{|c|c|c|c|c|c|}
\hline Series & Characteristics & Residual(s) & $\begin{array}{l}\text { Admix- } \\
\text { ture(s) }\end{array}$ & Test(s) & Observation(s) \\
\hline $\begin{array}{l}\text { 5. Paste, } \\
\text { Mortar, } \\
\text { Concrete }\end{array}$ & $\begin{array}{l}\text { Cement paste, mortar, } \\
\text { concrete with maximum } \\
\text { aggregate sizes of } 3 / 8 \text { " } \\
\text { and } 3 / 4 " .\end{array}$ & $\mathrm{P}$ & HRWRA & $\begin{array}{l}\text { Comp., } \\
\text { Flex. }\end{array}$ & $\begin{array}{l}\text { More residual solids could be incorporated in } \\
\text { paste and mortar than in concrete. }\end{array}$ \\
\hline $\begin{array}{l}\text { 8. } \text { Maximum } \\
\text { Residuals } \\
\text { Content }\end{array}$ & $\begin{array}{l}\text { Maximum residual } \\
\text { content with the use of } \\
\text { HRWRA. }\end{array}$ & $\begin{array}{l}\text { C2, WV, } \\
\mathrm{BR}, \mathrm{S}\end{array}$ & HRWRA & Comp. & $\begin{array}{l}\text { - Maximum C2 content of about } 1 \% \text { by } \\
\text { weight of concrete. } \\
\text { - Segregation of concrete containing higher } \\
\text { amount of BR. } \\
\text { - Decrease in strength with excessive amounts } \\
\text { of WV, BR, and S. }\end{array}$ \\
\hline $\begin{array}{l}\text { 10. Attempt for } \\
\text { Maximum } \\
\text { HRWRA } \\
\text { Content }\end{array}$ & $\begin{array}{l}\text { Attempt for maximum } \\
\text { HRWRA content in } \\
\text { concrete. }\end{array}$ & $\mathrm{I}$ & HRWRA & Comp. & $\begin{array}{l}\text { Segregation of fresh concrete and decrease in } \\
\text { compressive strength when HRWRA was } \\
\text { used in non-residuals concrete in excess of } \\
\text { manufacturer's recommended maximum } \\
\text { dosage. }\end{array}$ \\
\hline $\begin{array}{l}\text { 13. Time of } \\
\text { Flow }\end{array}$ & $\begin{array}{l}\text { Relation between time of } \\
\text { flow and slump. }\end{array}$ & $\mathrm{C} 2, \mathrm{BR}$ & $\begin{array}{l}\text { HRWRA, } \\
\text { AEA }\end{array}$ & $\begin{array}{l}\text { Time of } \\
\text { Flow, } \\
\text { Slump }\end{array}$ & $\begin{array}{l}\text { Correlation exists between time of flow and } \\
\text { slump. }\end{array}$ \\
\hline
\end{tabular}


Major findings from the preliminary investigation were as follows:

1. Residuals did not affect compressive strength development of concrete.

2. With proper combination of residuals and HRWRA, slump and compressive strength of concrete can be adjusted.

3. By achieving equivalent density of concrete, residuals concrete can be produced that is equivalent to reference (no-residuals) concrete in slump and compressive strength.

\section{Laboratory Mixtures for Durability and Long-Term Properties}

Using the optimum mixture proportions established during the preliminary stage, two series of main mixtures (Sect. 7.3, p. 176) were produced for the evaluation of time of setting, average residual-strength, durability, and long-term properties.

\section{Additional Laboratory Mixtures}

Several more series of mixtures (Sect. 7.5, p. 203) were also produced in the laboratory in order to obtain information on compressive, splitting tensile, and flexural strengths of concrete and to observe the response of residuals concrete to air-entraining admixture (AEA).

\section{Miscellaneous Laboratory Mixtures}

At various steps of the research, several miscellaneous series of mixtures (Sect. 13.3, p. 259) were produced that provided additional information on residuals concrete. 


\subsubsection{Field Concrete Mixtures}

\section{Field Prototype Concrete Mixtures Manufactured at a Commercial Plant}

Based on the mixture proportions developed in the laboratory, pilot scale (three cubic yards) concrete mixtures (Sect. 7.4.1, p. 195) were produced at a ready-mixed concrete plant for two sources of residuals ( $\mathrm{C} 1$ and $\mathrm{BR})$. Incompatibility between the specific HRWRA supplied by the ready-mixed concrete plant and the residuals was noted in the form of high air content (5.3 to 15\%) of concrete. Chemical composition of this proprietary HRWRA is not known. By reverting to the HRWRA that had been used in the laboratory, this problem was eliminated.

\section{Field Concrete Mixture for Construction Demonstration}

Construction demonstration with concrete containing one source of residual (C1) (Sect. 7.4.2, p. 200) was conducted at the ready-mixed concrete plant. The concrete showed a low air content (3\%), good workability (8.25 in. slump), and structural-grade strength (28-day compressive strength of $7510 \mathrm{psi}$ ).

\subsubsection{Properties of Concrete}

Overall, the following properties of concrete were determined:

1. Fresh concrete properties

Slump, air content, density, time of setting, and time of flow

2. Mechanical properties

Compressive, splitting tensile, flexural, and average residual-strengths 
3. Durability

a. Length change (drying shrinkage)

b. Resistance to chloride-ion penetration, abrasion, freezing-and-thawing, and saltscaling

\subsection{Preliminary Laboratory Mixtures}

\subsubsection{Strength Development Pattern (Series 1)}

In order to compare the pattern of strength development for concrete containing residual solids with that of reference (no-residuals) concrete and to gain experience with recycling residual solids, concrete mixtures were produced without using any mineral additives or liquid chemical admixtures. The amount of residual solids in concrete was set at $0.1 \%$ (based on LOI at $590^{\circ} \mathrm{C}$ ) by weight of concrete, except for Residual $\mathrm{P}$ whose amount in concrete was $0.2 \%$. Corresponding residuals content based on as-received weight ranged from 0.29 to $0.52 \%$ of the weight of concrete. A Reference (or Control) concrete mixture was made for comparison. Mixture proportions and fresh properties of concrete are presented in Table 53.

Water-cementitious materials ratio $(w / \mathrm{cm})$ of residuals concrete were about same as that of Reference Concrete (i.e., 0.50). Density of residuals concrete (avg. $146 \mathrm{lb} / \mathrm{ft}^{3}$ ) was somewhat lower than that of Reference Concrete $\left(149 \mathrm{lb} / \mathrm{ft}^{3}\right)$. Slump of residuals concrete was mostly in the range of 1 to $1.5 \mathrm{in}$. This is considered acceptable for such applications as slab-on-grade, parking and materials handling area, and pavement. Slump of Reference Concrete mixture was 4.25 in. 
Table 53. Mixture Proportions and Fresh Properties of Concrete (Series 1)

\begin{tabular}{|c|c|c|c|c|c|c|c|c|}
\hline Mixture Name & Ref. & $\mathrm{C} 1$ & $\mathrm{C} 2$ & $\bar{I}$ & $\bar{S}$ & WG & WV & $\overline{\mathrm{P}}$ \\
\hline $\begin{array}{l}\text { Residuals, as-recd (\% of } \\
\text { concrete by wt.) }\end{array}$ & 0 & 0.52 & 0.44 & 0.39 & 0.32 & 0.49 & 0.29 & 0.48 \\
\hline Wood Fibers $\left(\mathrm{lb} / \mathrm{yd}^{3}\right) \dagger$ & 0 & 3.0 & 3.4 & 3.1 & 3.3 & 3.1 & 3.6 & 7.3 \\
\hline $\begin{array}{l}\text { Residuals, LOI at } 590^{\circ} \mathrm{C} \\
(\mathrm{lb} / 100 \mathrm{lb} \text { cement })\end{array}$ & 0 & 0.68 & 0.68 & 0.68 & 0.68 & 0.67 & 0.68 & 1.36 \\
\hline Residuals, as-recd (lb/yd $\left.{ }^{3}\right)$ & 0 & 20.0 & 17.2 & 15.3 & 12.5 & 19.4 & 11.4 & 18.7 \\
\hline Cement $\left(\mathrm{lb} / \mathrm{yd}^{3}\right)$ & 588 & 566 & 575 & 575 & 577 & 579 & 566 & 572 \\
\hline Sand, SSD $\left(1 \mathrm{lb} / \mathrm{yd}^{3}\right)$ & 1370 & 1320 & 1340 & 1340 & 1340 & 1350 & 1320 & 1330 \\
\hline $\begin{array}{l}\text { Coarse Aggregate, } 3 / 4 " \text { max., } \\
\text { SSD }\left(1 \mathrm{lb} / \mathrm{yd}^{3}\right)\end{array}$ & 1770 & 1710 & 1730 & 1730 & 1740 & 1750 & 1700 & 1720 \\
\hline Water $\left(\mathrm{lb} / \mathrm{yd}^{3}\right)$ & 292 & 272 & 280 & 295 & 291 & 287 & 290 & 289 \\
\hline$w / \mathrm{cm}$ & 0.50 & 0.48 & 0.49 & 0.51 & 0.50 & 0.50 & 0.51 & 0.50 \\
\hline Slump (in.) & 4.25 & 2.5 & 1.25 & 1 & 1.25 & 1.5 & 1 & 1.25 \\
\hline Air Content (\%) & 1.5 & 4.7 & 3.3 & 3.0 & 2.5 & 2.2 & 4.3 & 3.0 \\
\hline Density $\left(\mathrm{lb} / \mathrm{ft}^{3}\right)$ & 149 & 144 & 146 & 147 & 147 & 147 & 144 & 146 \\
\hline
\end{tabular}

$\dagger$ From residuals, dry basis

For each concrete mixture, compressive strength of concrete was determined at 1 ,

3 , and 7 days by testing two cylinders at each test age. Splitting tensile strength was determined by testing two cylinders at each test age of 3 and 7 days. Flexural strength was determined at 7 days by testing three 3 " x 4 " x 12 " beams.

Test results for compressive, splitting tensile, and flexural strengths are presented in Tables 54 to 56 and Fig. 60 to 62 . Due to lower density, residuals concrete showed lower strengths than Reference Concrete. Changes in compressive and splitting tensile strengths over time for residuals concrete were very much similar to those for Reference Concrete.

The test results suggest that residual solids decreased slump (which implies decreased workability), but did not cause appreciable difference in strength development of concrete. 
Table 54. Compressive Strength of Concrete (in psi) (Series 1)

\begin{tabular}{|c|c|c|c|c|c|c|c|c|}
\hline Age (day) & Ref. & C1 & C2 & I & S & WG & WV & P \\
\hline 1 & 2280 & 1710 & 1870 & 1980 & 1930 & 2030 & 1660 & 1810 \\
\hline 3 & 4140 & 3270 & 3490 & 3470 & 3510 & 3590 & 3150 & 3460 \\
\hline 7 & 5550 & 4330 & 4640 & 4730 & 4710 & 4650 & 4290 & 4650 \\
\hline
\end{tabular}

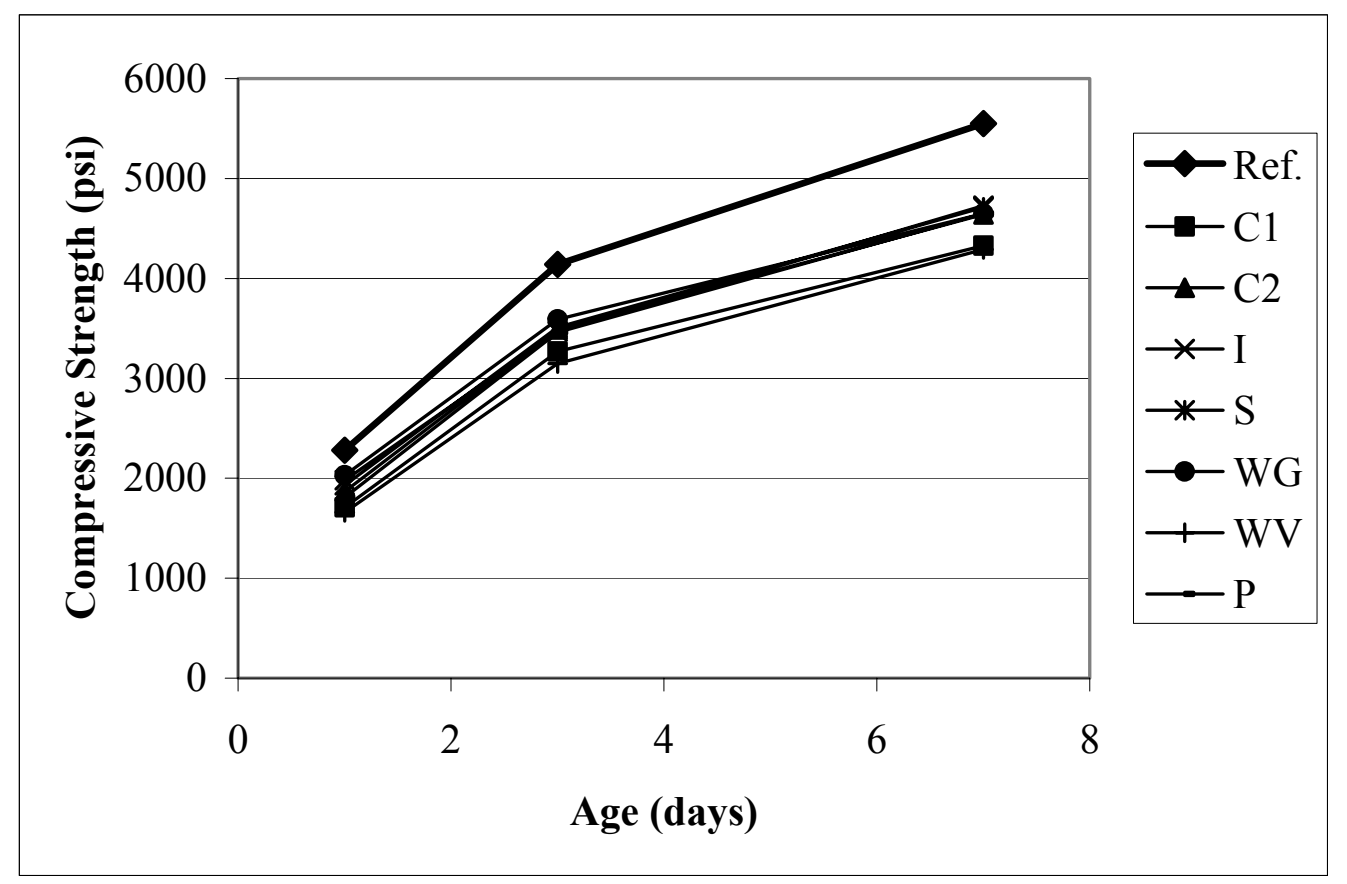

Fig. 60. Compressive strength vs. age (Series 1) 
Table 55. Splitting Tensile Strength of Concrete (in psi) (Series 1)

\begin{tabular}{|c|c|c|c|c|c|c|c|c|}
\hline Age (days) & Ref. & C1 & C2 & I & S & WG & WV & P \\
\hline 3 & 500 & 395 & 474 & 456 & 431 & 486 & 417 & 433 \\
\hline 7 & 578 & 539 & 558 & 549 & 539 & 562 & 532 & 561 \\
\hline
\end{tabular}

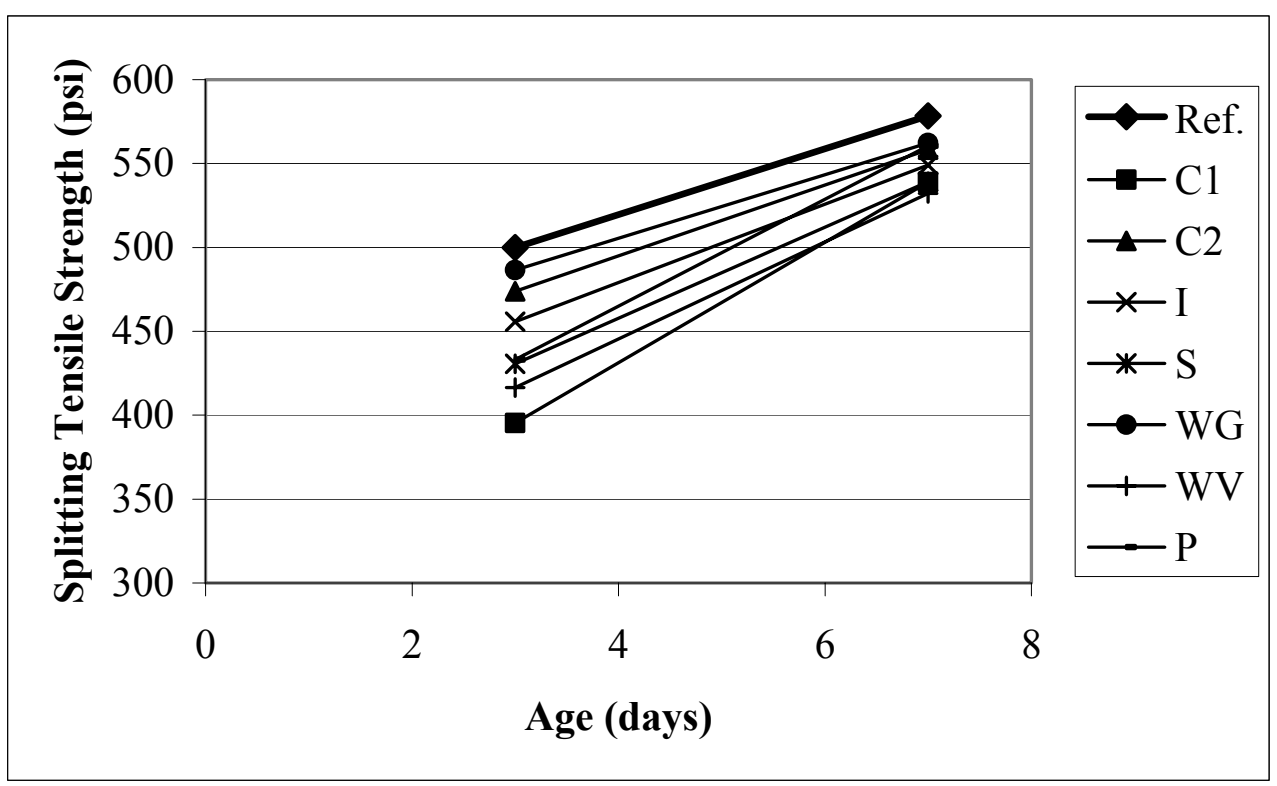

Fig. 61. Splitting tensile strength vs. age (Series 1) 
Table 56. Flexural Strength of Concrete (in psi) (Series 1)

\begin{tabular}{|c|c|c|c|c|c|c|c|c|}
\hline Age (days) & Ref. & C1 & C2 & I & S & WG & WV & P \\
\hline 7 & 777 & 660 & 693 & 705 & 703 & 802 & 690 & 710 \\
\hline
\end{tabular}

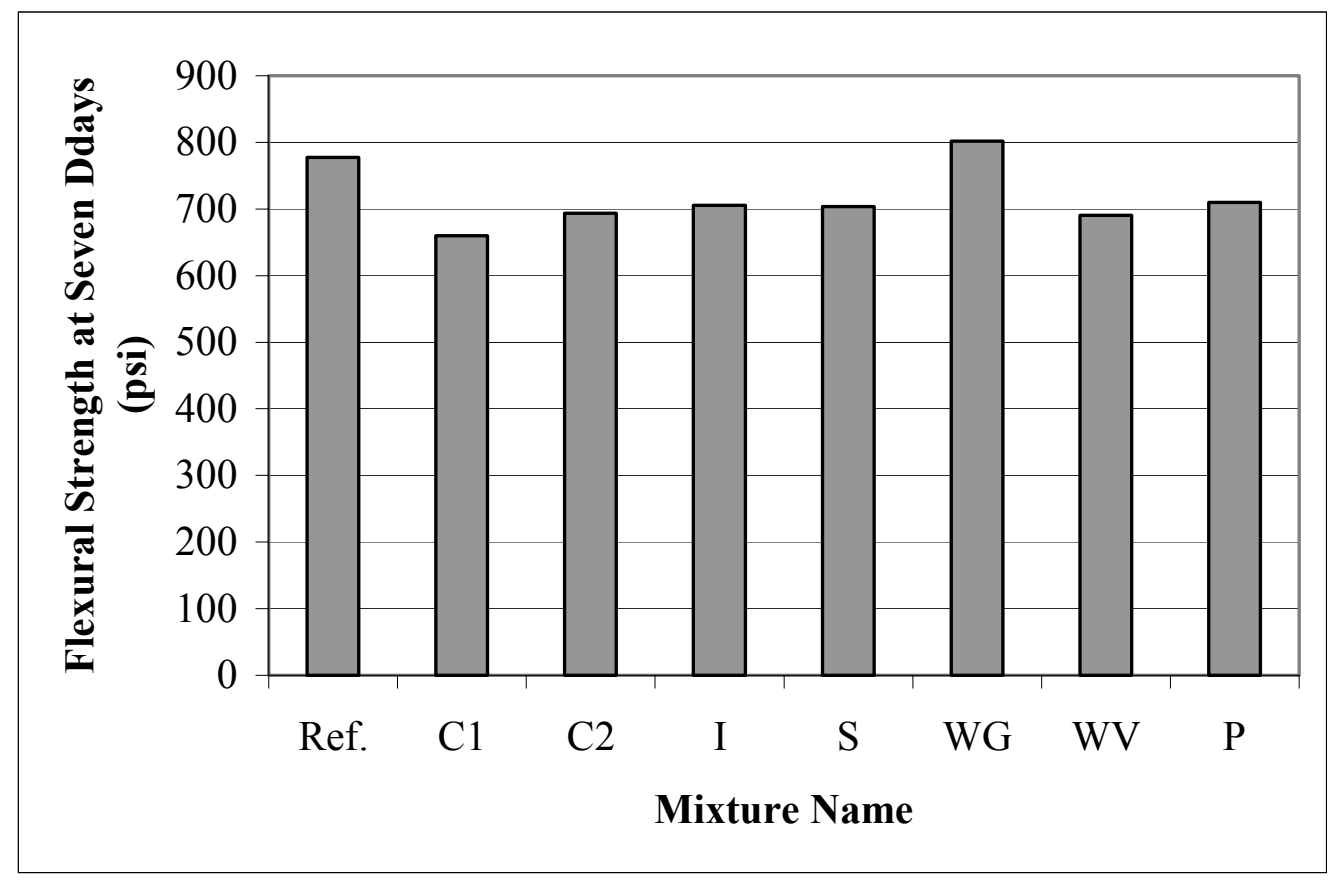

Fig. 62. Flexural strength at seven days (Series 1)

\subsubsection{High Residuals Content (Series 2)}

For Series 2 mixtures, residuals content of up to $1 \%$ (based on LOI at $590^{\circ} \mathrm{C}$ ) by weight of concrete was used. Depending on the source of residuals, up to 2.4 to $4.9 \%$ of asreceived residuals by weight of concrete were used (Tables 57 to 59). Mineral additives and chemical admixtures were not used. This series of experiments allowed recycling of significantly higher amounts of residuals. 
Table 57. Mixture Proportions and Fresh Properties of Concrete (Series 2: C1)

\begin{tabular}{|c|c|c|c|c|c|c|}
\hline Mixture Name & $\begin{array}{c}\text { Ref. } \\
1\end{array}$ & $\mathrm{C} 1-1$ & C1-2 & $\mathrm{C} 1-3$ & C1-4 & $\mathrm{C} 1-5$ \\
\hline $\begin{array}{l}\text { Residuals, as-recd (\% } \\
\text { of concrete by wt.) }\end{array}$ & 0 & 1.0 & 2.0 & 3.0 & 3.9 & 4.9 \\
\hline Wood Fibers $\left(\mathrm{lb} / \mathrm{yd}^{3}\right) \dagger$ & 0 & 6.1 & 11.8 & 17.3 & 22.4 & 27.8 \\
\hline $\begin{array}{l}\text { Residuals, LOI at } \\
590^{\circ} \mathrm{C}(\mathrm{lb} / 100 \mathrm{lb} \\
\text { cement) }\end{array}$ & 0 & 1.4 & 2.7 & 4.1 & 5.5 & 6.9 \\
\hline 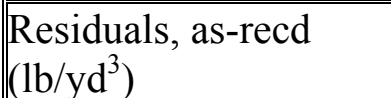 & 0 & 40 & 78 & 114 & 148 & 184 \\
\hline Cement $\left(\mathrm{lb} / \mathrm{yd}^{3}\right)$ & 591 & 564 & 547 & 535 & 521 & 516 \\
\hline Sand, SSD (lb/yd $\left.{ }^{3}\right)$ & 1390 & 1320 & 1280 & 1250 & 1220 & 1210 \\
\hline $\begin{array}{l}\text { Coarse Aggregate, } 3 / 4 " \\
\max ., \text { SSD }\left(\mathrm{lb} / \mathrm{yd}^{3}\right)\end{array}$ & 1790 & 1710 & 1660 & 1620 & 1580 & 1560 \\
\hline Water $\left(\mathrm{lb} / \mathrm{yd}^{3}\right)$ & 272 & 279 & 289 & 293 & 297 & 285 \\
\hline$w / \mathrm{cm}$ & 0.46 & 0.49 & 0.53 & 0.55 & 0.57 & 0.55 \\
\hline Slump (in.) & 4.25 & 0.625 & 0.625 & 1.25 & 1.25 & 0.75 \\
\hline Air Content (\%) & 1.7 & 4.7 & 4.2 & 3.7 & 3.7 & 3.3 \\
\hline Density $\left(\mathrm{lb} / \mathrm{ft}^{3}\right)$ & 150 & 145 & 143 & 141 & 139 & 139 \\
\hline
\end{tabular}

$\dagger$ From residuals, dry basis

Table 58. Mixture Proportions and Fresh Properties of Concrete (Series 2: C2, WG)

\begin{tabular}{|c|c|c|c|c|c|c|c|c|c|c|c|}
\hline Mixture Name & \begin{tabular}{|c|} 
Ref. \\
2 \\
\end{tabular} & $\mathrm{C} 2-1$ & $\mathrm{C} 2-2$ & $\mathrm{C} 2-3$ & $\mathrm{C} 2-4$ & $\mathrm{C} 2-5$ & \begin{tabular}{|c|} 
WG- \\
1 \\
\end{tabular} & $\begin{array}{c}\text { WG- } \\
2\end{array}$ & \begin{tabular}{|c} 
WG- \\
3 \\
\end{tabular} & $\begin{array}{c}\text { WG- } \\
4\end{array}$ & $\begin{array}{c}\text { WG- } \\
5\end{array}$ \\
\hline $\begin{array}{l}\text { Residuals, as-recd (\% } \\
\text { of concrete by wt.) }\end{array}$ & 0 & 0.9 & 1.7 & 2.6 & 3.4 & 4.2 & 1.0 & 2.0 & 2.9 & 3.8 & 4.7 \\
\hline Wood Fibers $\left(\mathrm{lb} / \mathrm{yd}^{3}\right) \dagger$ & 0 & 7.0 & 13.3 & 19.2 & 24.5 & 29.7 & 6.4 & 12.6 & 18.1 & 23.5 & 28.4 \\
\hline $\begin{array}{l}\text { Residuals, LOI at } \\
590^{\circ} \mathrm{C}(\mathrm{lb} / 100 \mathrm{lb} \text { cem. }\end{array}$ & 0 & 1.4 & 2.7 & 4.1 & 5.5 & 6.8 & 1.3 & 2.7 & 4.1 & 5.4 & 6.8 \\
\hline $\begin{array}{l}\text { Residuals, as-recd } \\
\left(\mathrm{lb} / \mathrm{yd}^{3}\right)\end{array}$ & 0 & 35 & 67 & 96 & 123 & 149 & 40 & 78 & 112 & 145 & 175 \\
\hline Cement (lb/yd $\left.{ }^{3}\right)$ & 611 & 584 & 556 & 534 & 512 & 495 & 591 & 579 & 555 & 539 & 523 \\
\hline Sand, SSD (lb/yd $\left.{ }^{3}\right)$ & 1420 & 1360 & 1290 & 1240 & 1190 & 1150 & 1360 & 1340 & 1290 & 1250 & 1210 \\
\hline $\begin{array}{l}\text { Coarse Aggregate, } 3 / 4 " \\
\max ., \text { SSD }\left(1 \mathrm{lb} / \mathrm{yd}^{3}\right)\end{array}$ & 1740 & 1660 & 1580 & 1520 & 1460 & 1410 & 1680 & 1650 & 1580 & 1530 & 1490 \\
\hline Water $\left(\mathrm{lb} / \mathrm{yd}^{3}\right)$ & 295 & 298 & 324 & 338 & 352 & 370 & 303 & 304 & 322 & 342 & 347 \\
\hline$w / \mathrm{cm}$ & 0.48 & 0.51 & 0.58 & 0.63 & 0.69 & 0.75 & 0.51 & 0.52 & 0.58 & 0.63 & 0.66 \\
\hline Slump (in.) & 3 & 1 & 1.25 & 1 & 0.75 & 0.75 & 1.125 & 0.5 & 0.25 & 0.25 & 0.06 \\
\hline Air Content $(\%)$ & 1.5 & 3.4 & 4.1 & 4.1 & 4.7 & 4.1 & 2.1 & 2.4 & 2.3 & 2.3 & 2.8 \\
\hline Density $\left(\mathrm{lb} / \mathrm{ft}^{3}\right)$ & 151 & 146 & 142 & 138 & 134 & 132 & 147 & 146 & 143 & 141 & 139 \\
\hline
\end{tabular}

$\dagger$ From residuals, dry basis 
Table 59. Mixture Proportions and Fresh Properties of Concrete (Series 2: WV, P)

\begin{tabular}{|c|c|c|c|c|c|c|c|c|c|c|c|}
\hline Mixture Name & \begin{tabular}{|c|} 
Ref. \\
2 \\
\end{tabular} & \begin{tabular}{|c|} 
WV- \\
1
\end{tabular} & $\begin{array}{c}\text { WV- } \\
2 \\
\end{array}$ & $\begin{array}{c}\text { WV- } \\
3 \\
\end{array}$ & $\begin{array}{c}\text { WV- } \\
4 \\
\end{array}$ & $\begin{array}{c}\text { WV- } \\
5\end{array}$ & P-1 & P-2 & $\mathrm{P}-3$ & P-4 & $\mathrm{P}-5$ \\
\hline $\begin{array}{l}\text { Residuals, as-recd (\% } \\
\text { of concrete by wt.) }\end{array}$ & 0 & 0.6 & 1.2 & 1.7 & 2.3 & 2.8 & 0.5 & 1.0 & 1.4 & 1.9 & 2.4 \\
\hline Wood Fibers $\left(\mathrm{lb} / \mathrm{yd}^{3}\right) \dagger$ & 0 & 7.4 & 14.2 & 20.4 & 26.5 & 31.1 & 7.7 & 15.0 & 22.0 & 28.6 & 34.7 \\
\hline $\begin{array}{l}\text { Residuals, LOI at } \\
590^{\circ} \mathrm{C}(\mathrm{lb} / 100 \mathrm{lb} \\
\text { cement) }\end{array}$ & 0 & 1.4 & 2.7 & 4.1 & 5.5 & 6.9 & 1.4 & 2.7 & 4.1 & 5.5 & 6.8 \\
\hline $\begin{array}{l}\text { Residuals, as-recd } \\
\left(\mathrm{lb} / \mathrm{yd}^{3}\right)\end{array}$ & 0 & 23 & 45 & 65 & 84 & 98 & 20 & 38 & 56 & 73 & 89 \\
\hline Cement $\left(\mathrm{lb} / \mathrm{yd}^{3}\right)$ & 611 & 581 & 557 & 535 & 519 & 488 & 598 & 587 & 572 & 558 & 543 \\
\hline Sand, SSD (lb/yd $\left.{ }^{3}\right)$ & 1420 & 1360 & 1300 & 1250 & 1210 & 1140 & 1400 & 1360 & 1330 & 1290 & 1260 \\
\hline $\begin{array}{l}\text { Coarse Aggregate, } 3 / 4 " \\
\max , \text { SSD }\left(\mathrm{lb} / \mathrm{yd}^{3}\right)\end{array}$ & 1740 & 1650 & 1580 & 1520 & 1480 & 1390 & 1700 & 1670 & 1630 & 1590 & 1540 \\
\hline Water $\left(\mathrm{lb} / \mathrm{yd}^{3}\right)$ & 295 & 287 & 325 & 352 & 385 & 440 & 291 & 302 & 301 & 316 & 334 \\
\hline$w / \mathrm{cm}$ & 0.48 & 0.49 & 0.58 & 0.66 & 0.74 & 0.90 & 0.49 & 0.51 & 0.53 & 0.57 & 0.62 \\
\hline Slump (in.) & 3 & 0.625 & 0.25 & 0.375 & 0.25 & 0.625 & 0.75 & 1 & 1.25 & 0.75 & 1 \\
\hline Air Content (\%) & 1.5 & 4.3 & 4.7 & 4.9 & 4.7 & 5.3 & 2.5 & 2.9 & 3.7 & 4.2 & 4.3 \\
\hline Density $\left(\mathrm{lb} / \mathrm{ft}^{3}\right)$ & 151 & 145 & 141 & 138 & 136 & 132 & 148 & 147 & 144 & 142 & 140 \\
\hline
\end{tabular}

$\dagger$ From residuals, dry basis

During the mixing process, it became apparent that due to the large volume of bulky residual solids in concrete, residual solids were displacing parts of cement, sand, and coarse aggregate in a unit volume of concrete, thereby reducing the density of concrete.

Also, as the residuals content increased, amount of mixing water was increased considerably in an attempt to keep the slump of residuals concrete comparable to that of Reference Concrete. However, the slump of residuals concrete would not increase beyond 1.25 inches. Adding more mixing water did not improve the slump but only diluted the residuals concrete mixtures. But, in spite of low slump, the residuals concrete mixtures were workable. 
Use of larger amounts of residuals and mixing water resulted in decrease in density, increase in $w / \mathrm{cm}$, and ultimately decrease in strengths of concrete.

For each concrete mixture, compressive strength of concrete was determined at 3 , 7, and 28 days by testing two cylinders at each test age (except for $\mathrm{C} 1$ for which three cylinders were tested at each test age), and the results are presented in Tables 60 to 62 and Fig. 63 to 68 . Splitting tensile strength was determined at 3, 7, 28 days by testing two cylinders at each test age (except for $\mathrm{C} 1$ for which three cylinders were tested at each test age), and the results are presented in Tables 63 to 65 and Fig. 69 to 74 . Flexural strength was determined at 7 and 28 days by testing three 3 " x 4" x 12 " beams at each test age, and the results are presented in Tables 66 to 68 and Fig. 75 to 80 . As the residuals content increased, compressive, splitting tensile, and flexural strengths decreased.

Table 60. Compressive Strength of Concrete (in psi) (Series 2: C1)

\begin{tabular}{|c||c|c|c|c|c|c|}
\hline Age (days) & Ref. 1 & C1-1 & C1-2 & C1-3 & C1-4 & C1-5 \\
\hline \hline 3 & 4760 & 2900 & 2280 & 1770 & 1110 & 1210 \\
\hline 7 & 6140 & 4030 & 3170 & 2510 & 1680 & 1950 \\
\hline 28 & 7570 & 5080 & 4130 & 3470 & 2450 & 2520 \\
\hline
\end{tabular}

Table 61. Compressive Strength of Concrete (in psi) (Series 2: C2, WG)

\begin{tabular}{|c|c|c|c|c|c|c|c|c|c|c|c|}
\hline Age (days) & Ref. 2 & C2-1 & C2-2 & C2-3 & C2-4 & C2-5 & WG-1 & WG-2 & WG-3 & WG-4 & WG-5 \\
\hline \hline 3 & 4390 & 3040 & 2030 & 1260 & 850 & 570 & 2890 & 2290 & 1530 & 880 & 690 \\
\hline 7 & 5590 & 4010 & 2860 & 1840 & 1220 & 900 & 4200 & 3130 & 2180 & 1220 & 960 \\
\hline 28 & 7010 & 5280 & 3860 & 2680 & 1900 & 1300 & 5350 & 3970 & 2750 & 1710 & 1280 \\
\hline
\end{tabular}

Table 62. Compressive Strength of Concrete (in psi) (Series 2: WV, P)

\begin{tabular}{|c||c|c|c|c|c|c|c|c|c|c|c|}
\hline \hline Age (days) & Ref. 2 & WV-1 & WV-2 & WV-3 & WV-4 & WV-5 & P-1 & P-2 & P-3 & P-4 & P-5 \\
\hline \hline 3 & 4390 & 3290 & 1930 & 1160 & 820 & 560 & 4020 & 2780 & 2300 & 1850 & 1200 \\
\hline 7 & 5590 & 4390 & 2640 & 1770 & 1180 & 870 & 5160 & 3940 & 3080 & 2630 & 1740 \\
\hline 28 & 7010 & 5480 & 3620 & 2340 & 1610 & 1160 & 6680 & 5260 & 4340 & 3840 & 2750 \\
\hline
\end{tabular}




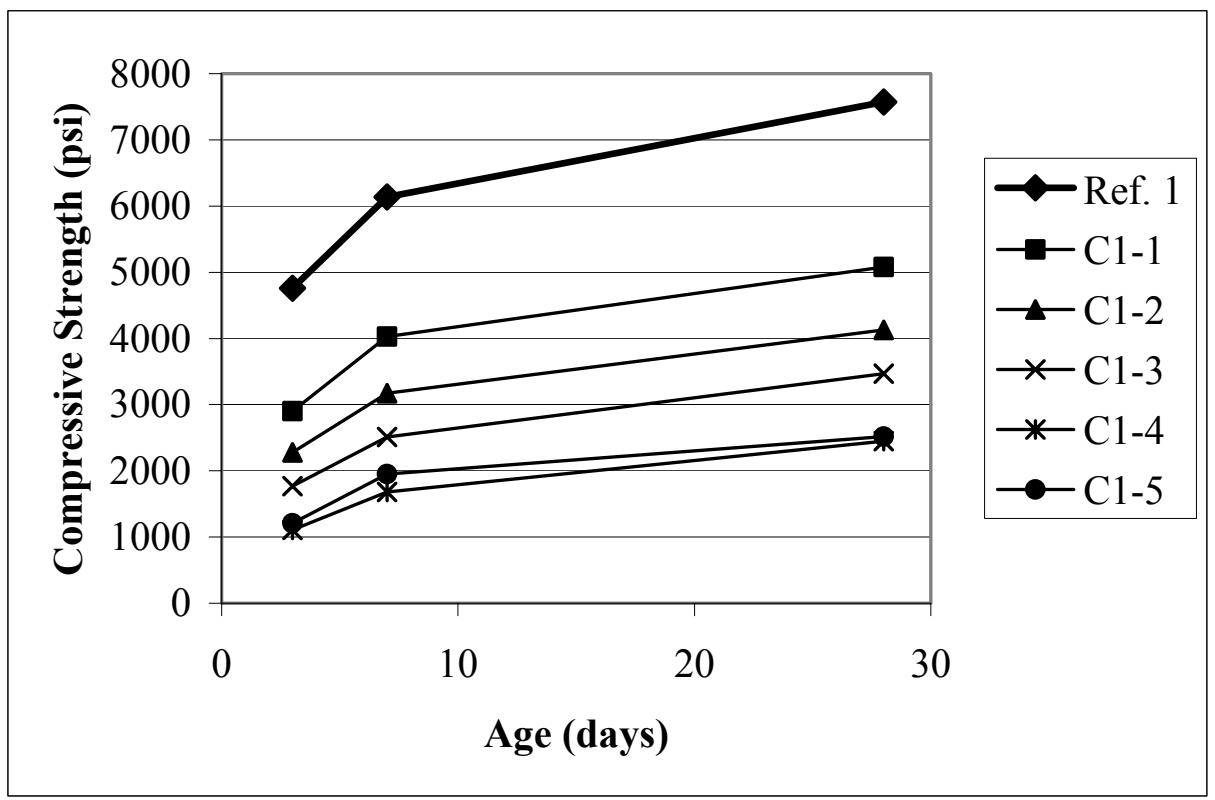

Fig. 63. Compressive strength vs. age (Series 2: C1)

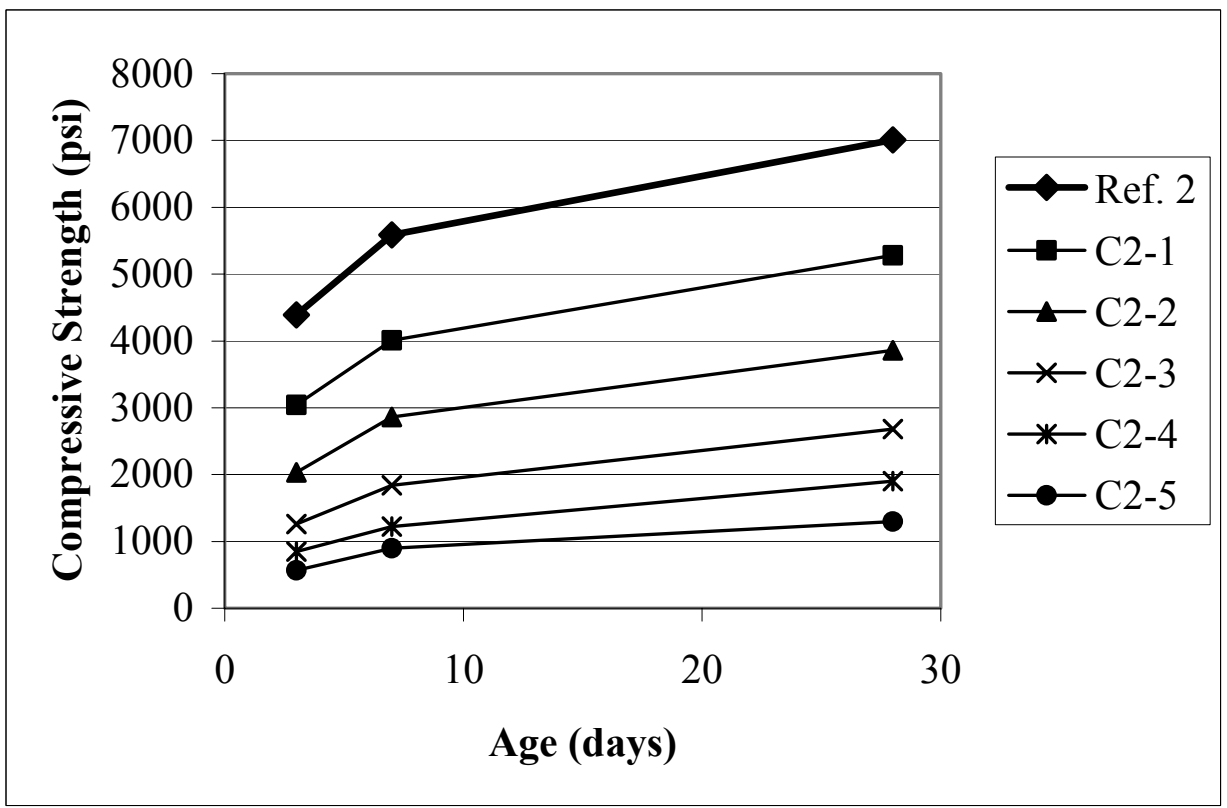

Fig. 64. Compressive strength vs. age (Series 2: C2) 


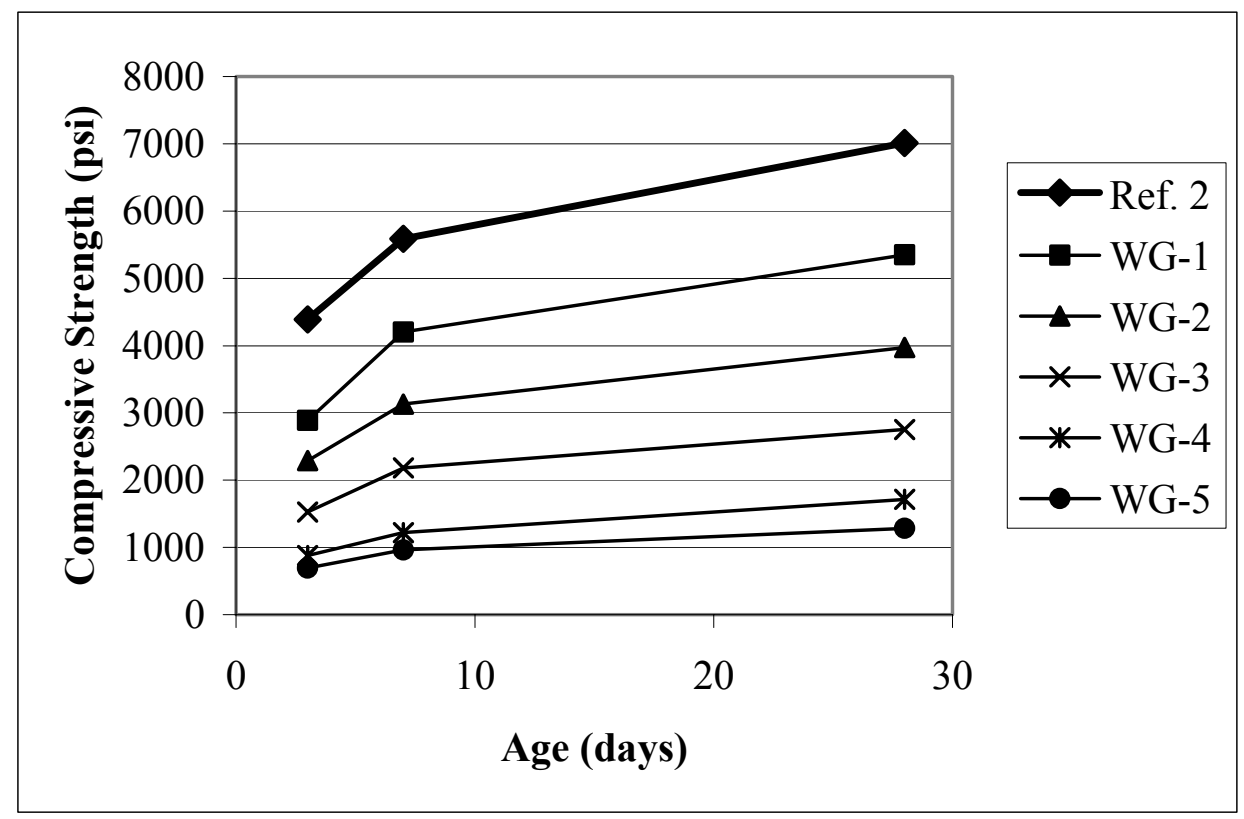

Fig. 65. Compressive strength vs. age (Series 2: WG)

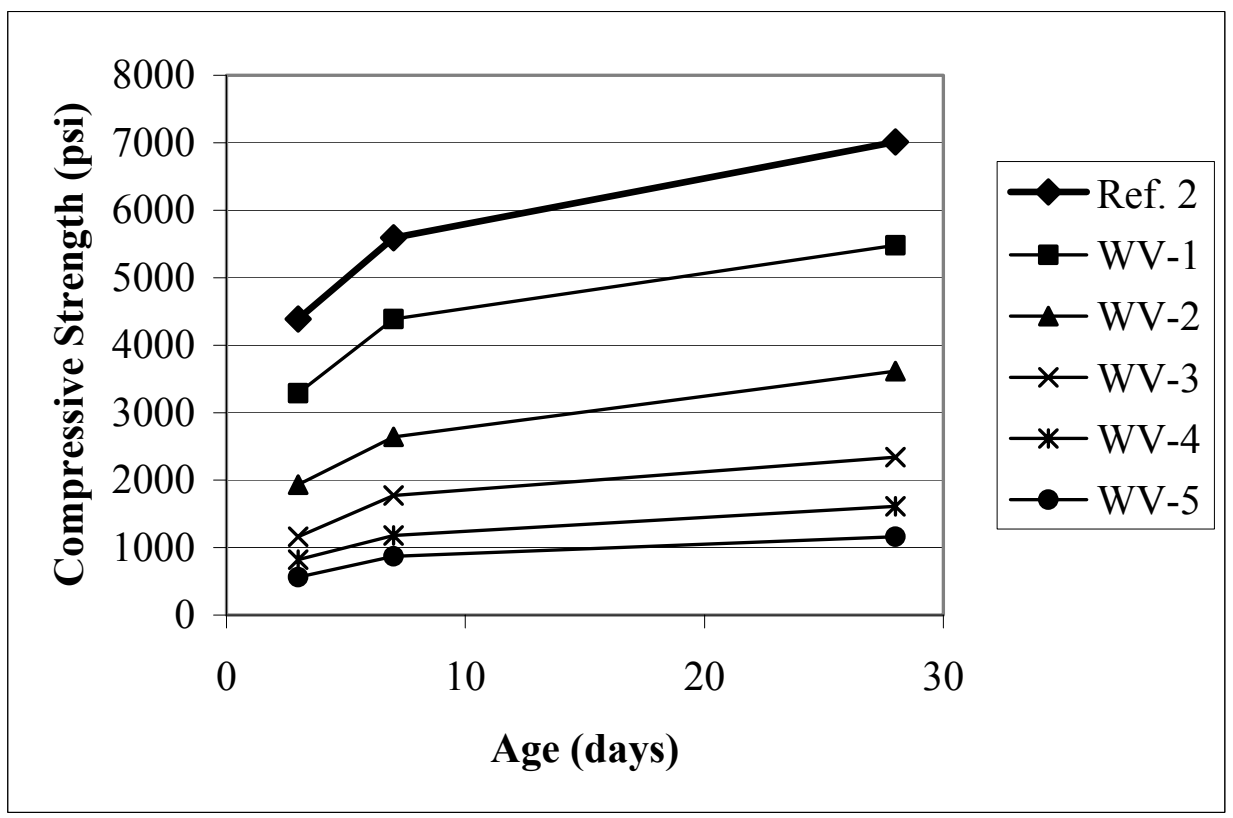

Fig. 66. Compressive strength vs. age (Series 2: WV) 


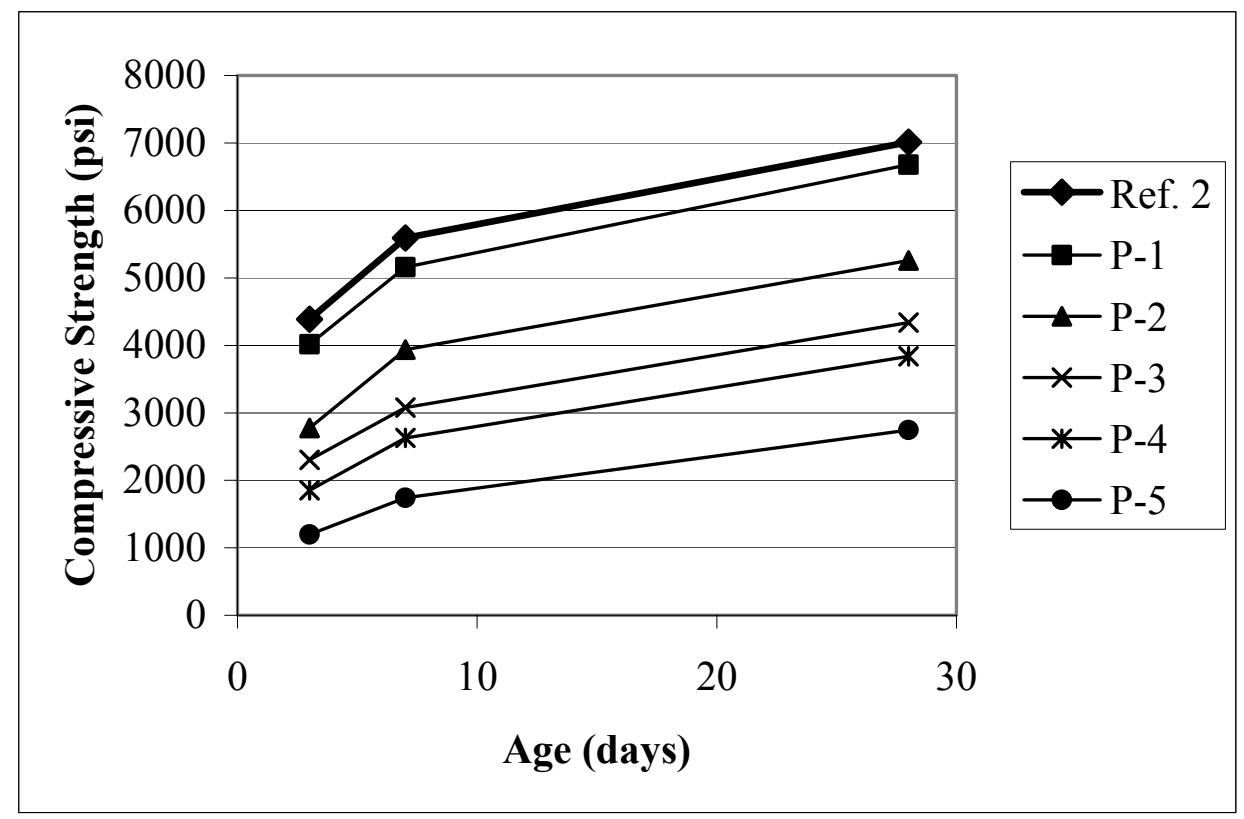

Fig. 67. Compressive strength vs. age (Series 2: P)

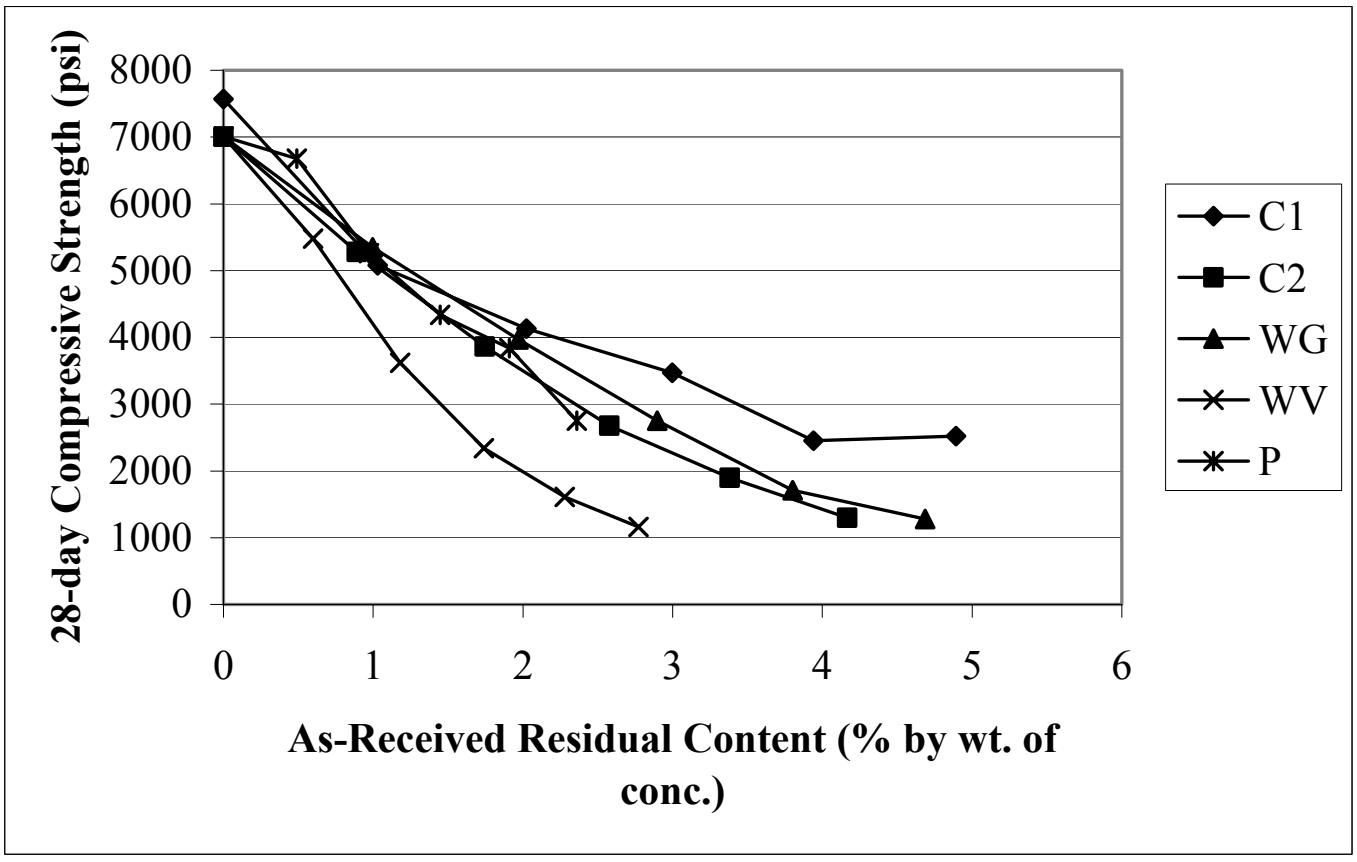

Fig. 68. 28-day compressive strength vs. as-received residual content (Series 2) 
Table 63. Splitting Tensile Strength of Concrete (in psi) (Series 2: C1)

\begin{tabular}{|c||c||c|c|c|c|c|}
\hline Age (days) & Ref. 1 & C1-1 & C1-2 & C1-3 & C1-4 & C1-5 \\
\hline \hline 3 & 548 & 383 & 337 & 281 & 178 & 189 \\
\hline 7 & 622 & 500 & 416 & 369 & 258 & 293 \\
\hline 28 & 665 & 583 & 517 & 456 & 358 & 362 \\
\hline
\end{tabular}

Table 64. Splitting Tensile Strength of Concrete (in psi) (Series 2: C2, WG)

\begin{tabular}{|c||c|c|c|c|c|c||c|c|c|c|c|}
\hline Age (days) & Ref. 2 & C2-1 & C2-2 & C2-3 & C2-4 & C2-5 & WG-1 & WG-2 & WG-3 & WG-4 & WG-5 \\
\hline \hline 3 & 513 & 416 & 292 & 210 & 136 & 99 & 405 & 366 & 285 & 193 & 142 \\
\hline 7 & 585 & 506 & 412 & 292 & 217 & 165 & 499 & 486 & 360 & 265 & 215 \\
\hline 28 & 653 & 580 & 487 & 380 & 289 & 234 & 577 & 568 & 416 & 328 & 286 \\
\hline
\end{tabular}

Table 65. Splitting Tensile Strength of Concrete (in psi) (Series 2: WV, P)

\begin{tabular}{|c||c|c|c|c|c|c|c|c|c|c|c|c|}
\hline \hline Age (days) & Ref. 2 & WV-1 & WV-2 & WV-3 & WV-4 & WV-5 & P-1 & P-2 & P-3 & P-4 & P-5 \\
\hline \hline 3 & 513 & 432 & 300 & 212 & 161 & 120 & 499 & 411 & 357 & 290 & 208 \\
\hline 7 & 585 & 497 & 383 & 313 & 249 & 168 & 596 & 500 & 455 & 386 & 304 \\
\hline 28 & 653 & 594 & 478 & 388 & 320 & 238 & 656 & 609 & 556 & 517 & 419 \\
\hline
\end{tabular}

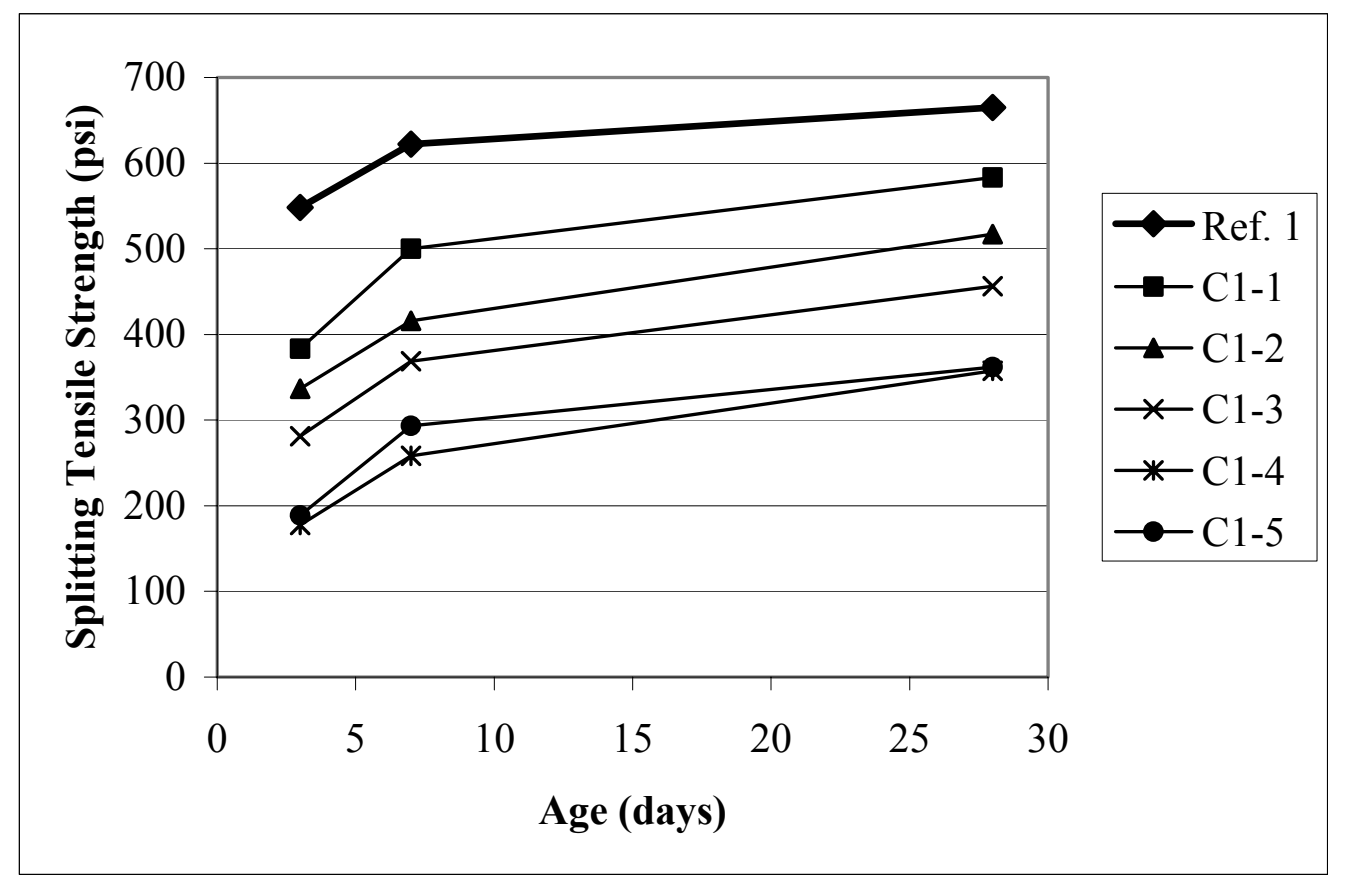

Fig. 69. Splitting tensile strength vs. age (Series 2: C1) 


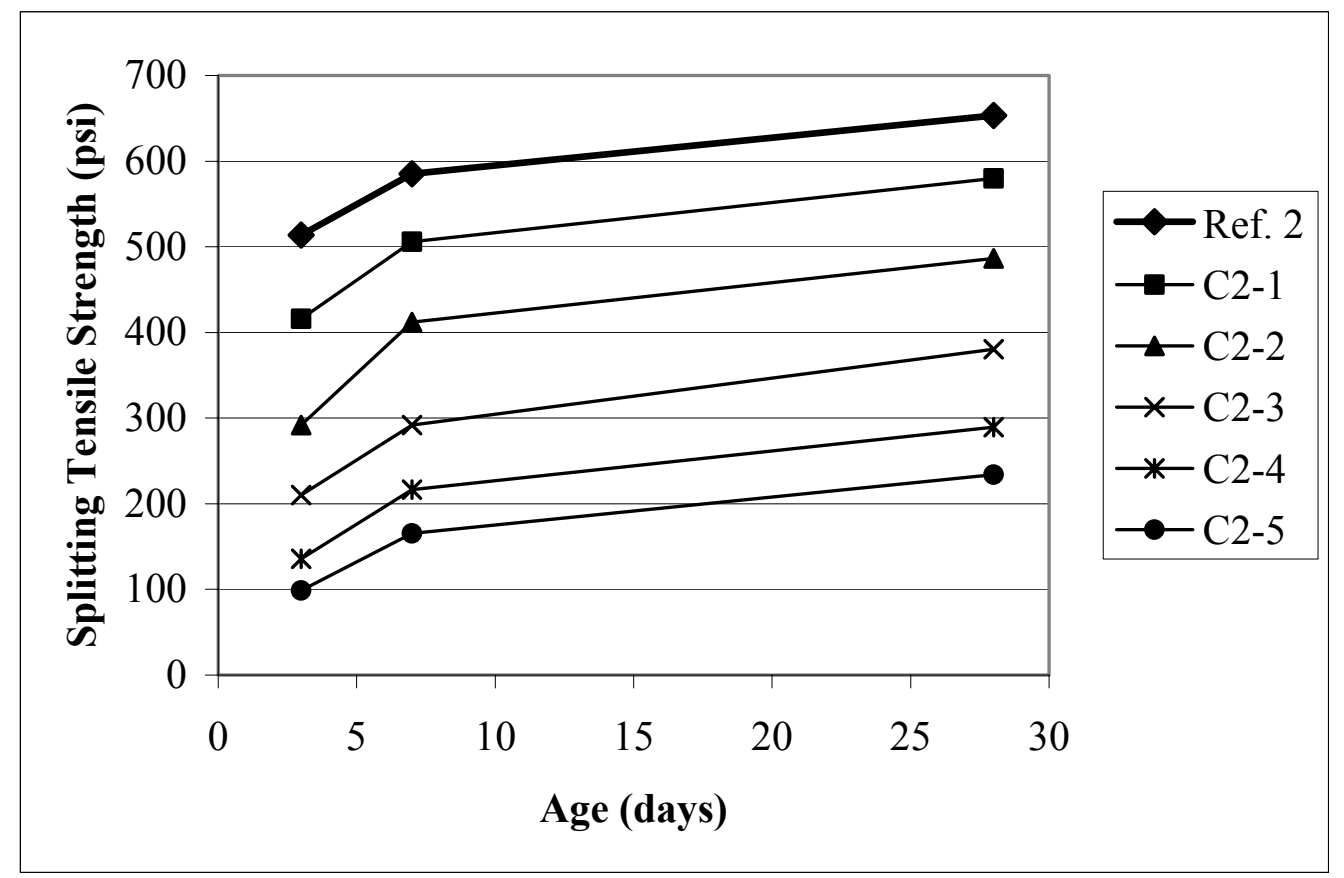

Fig. 70. Splitting tensile strength vs. age (Series 2: C2)

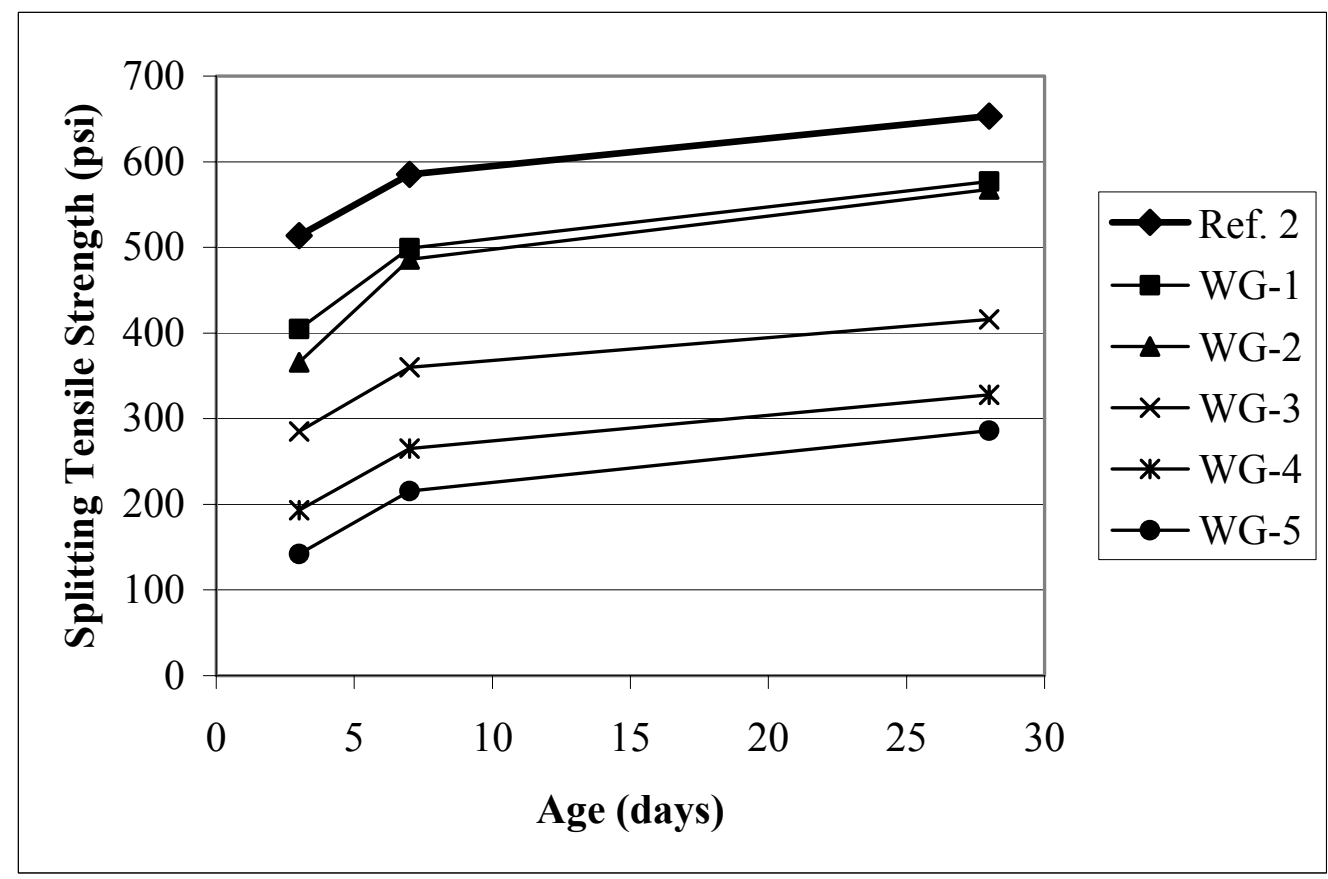

Fig. 71. Splitting tensile strength vs. age (Series 2: WG) 


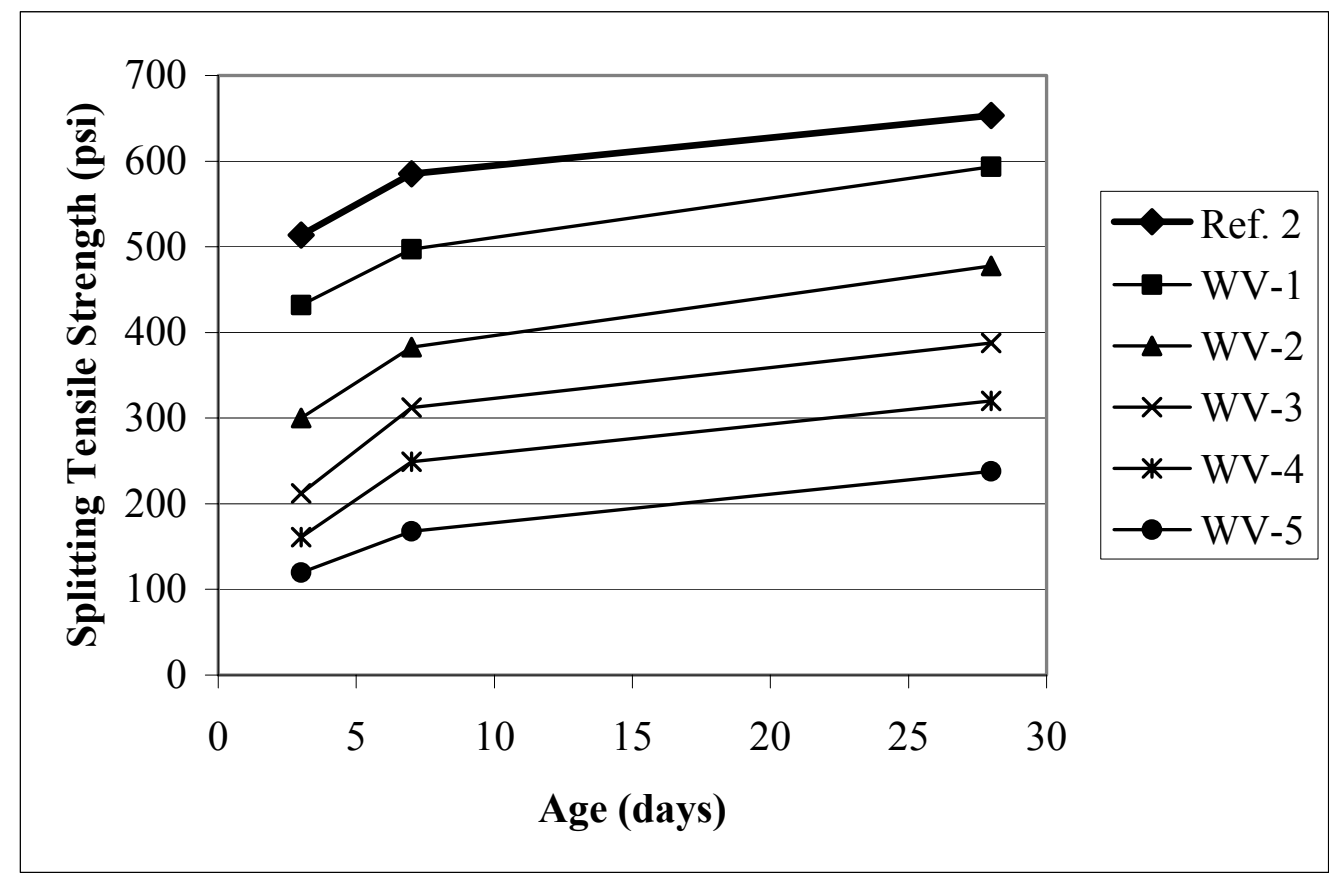

Fig. 72. Splitting tensile strength vs. age (Series 2: WV)

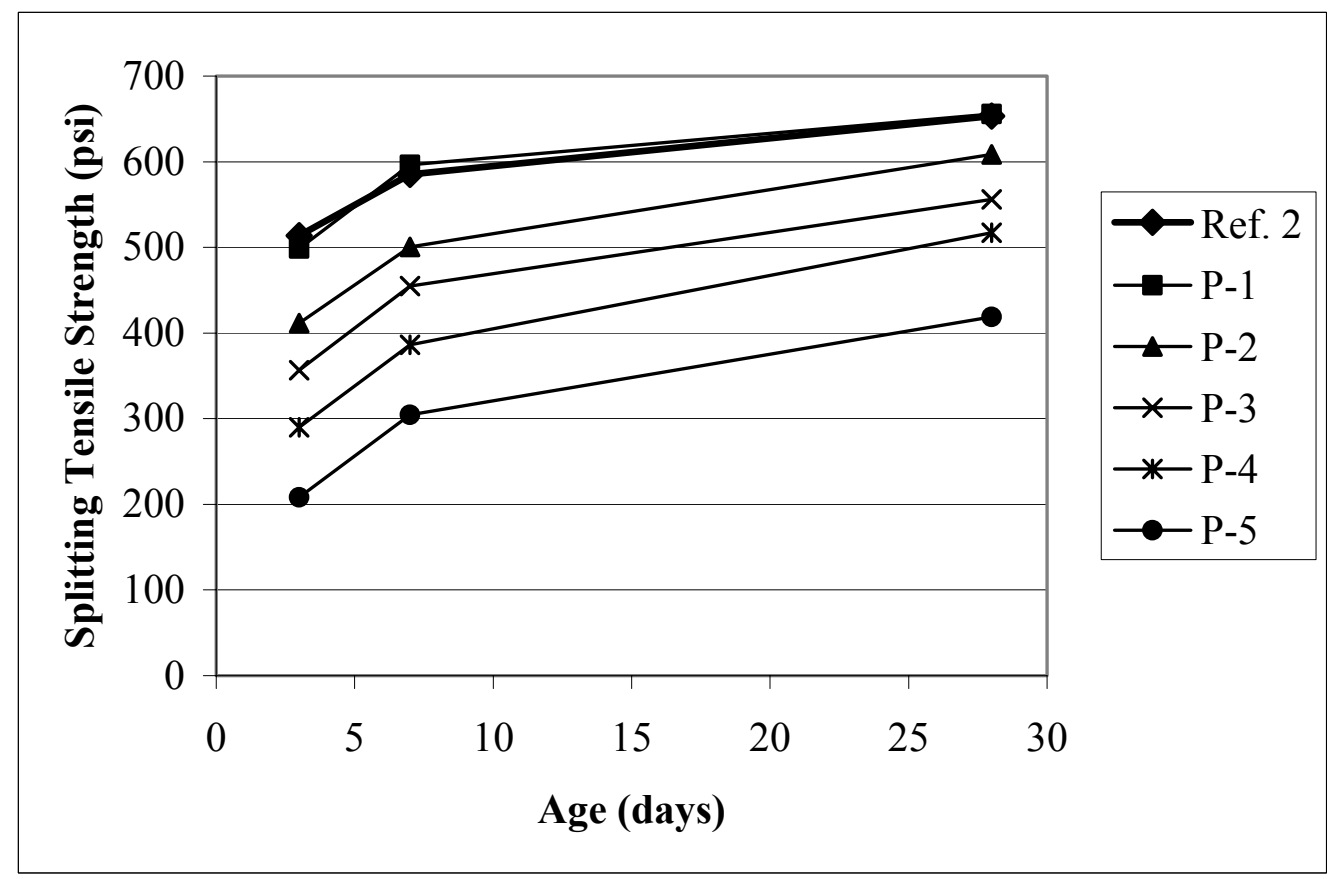

Fig. 73. Splitting tensile strength vs. age (Series 2: $\mathbf{P}$ ) 


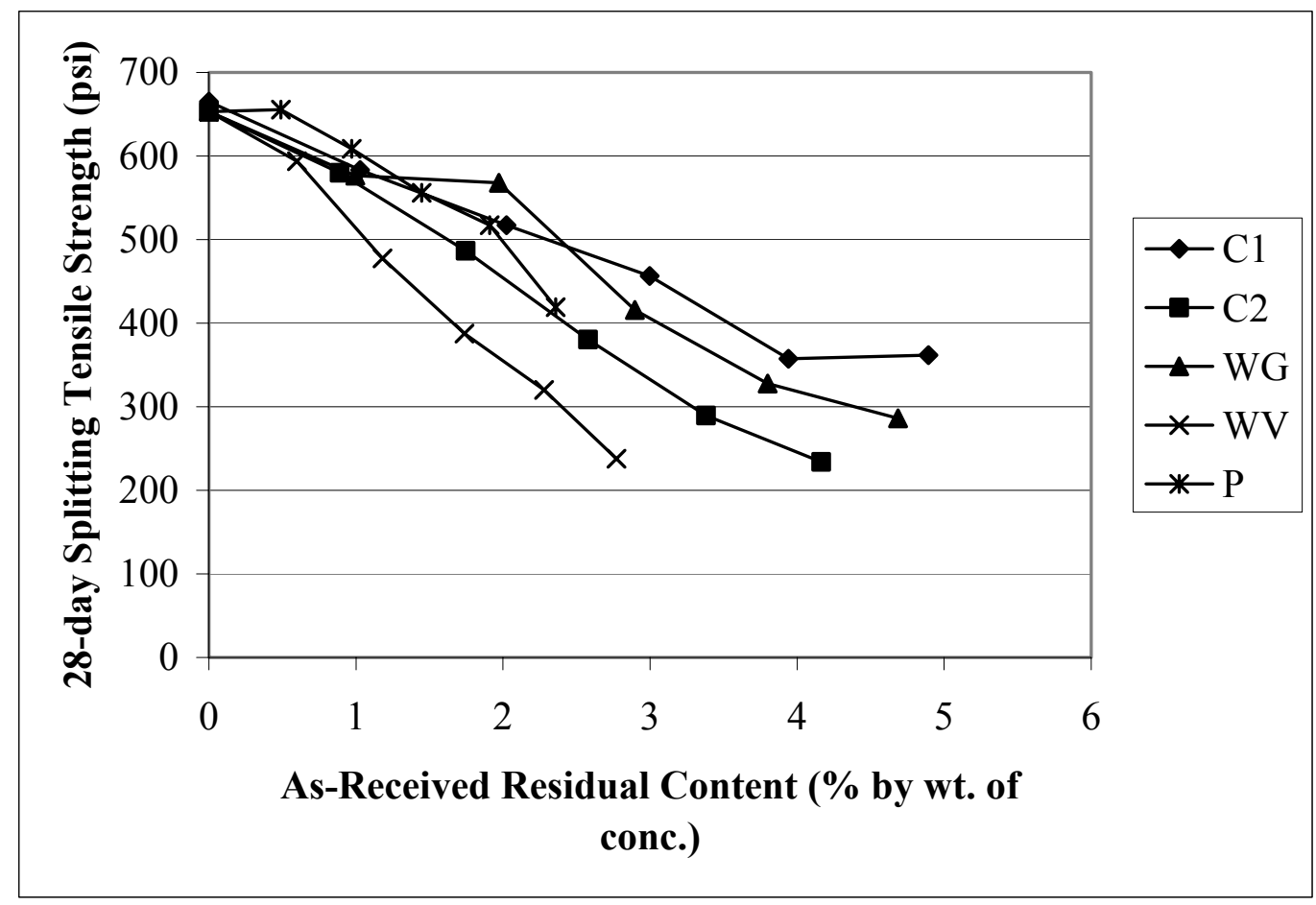

Fig. 74. 28-day splitting tensile strength vs. as-received residual content (Series 2)

Table 66. Flexural Strength of Concrete (in psi) (Series 2: C1)

\begin{tabular}{|c||c|c|c|c|c|c|}
\hline \hline Age (days) & Ref. 1 & C1-1 & C1-2 & C1-3 & C1-4 & C1-5 \\
\hline \hline 7 & 803 & 673 & 569 & 508 & 462 & 407 \\
\hline 28 & 978 & 905 & 790 & 654 & 521 & 477 \\
\hline
\end{tabular}

Table 67. Flexural Strength of Concrete (in psi) (Series 2: C2, WG)

\begin{tabular}{|c||c|c|c|c|c|c||c|c|c|c|c|}
\hline Age (days) & Ref. 2 & C2-1 & C2-2 & C2-3 & C2-4 & C2-5 & WG-1 & WG-2 & WG-3 & WG-4 & WG-5 \\
\hline \hline 7 & 795 & 642 & 550 & 428 & 369 & 308 & 644 & 568 & 486 & 387 & 286 \\
\hline 28 & 888 & 896 & 678 & 573 & 473 & 370 & 802 & 673 & 576 & 521 & 453 \\
\hline
\end{tabular}

Table 68. Flexural Strength of Concrete (in psi) (Series 2: WV, P)

\begin{tabular}{|c||c||c|c|c|c|c|c|c|c|c|c|}
\hline Age (days) & Ref. 2 & WV-1 & WV-2 & WV-3 & WV-4 & WV-5 & P-1 & P-2 & P-3 & P-4 & P-5 \\
\hline \hline 7 & 795 & 711 & 597 & 482 & 397 & 324 & 700 & 711 & 582 & 483 & 445 \\
\hline 28 & 888 & 879 & 768 & 575 & 458 & 403 & 861 & 788 & 737 & 681 & 573 \\
\hline
\end{tabular}




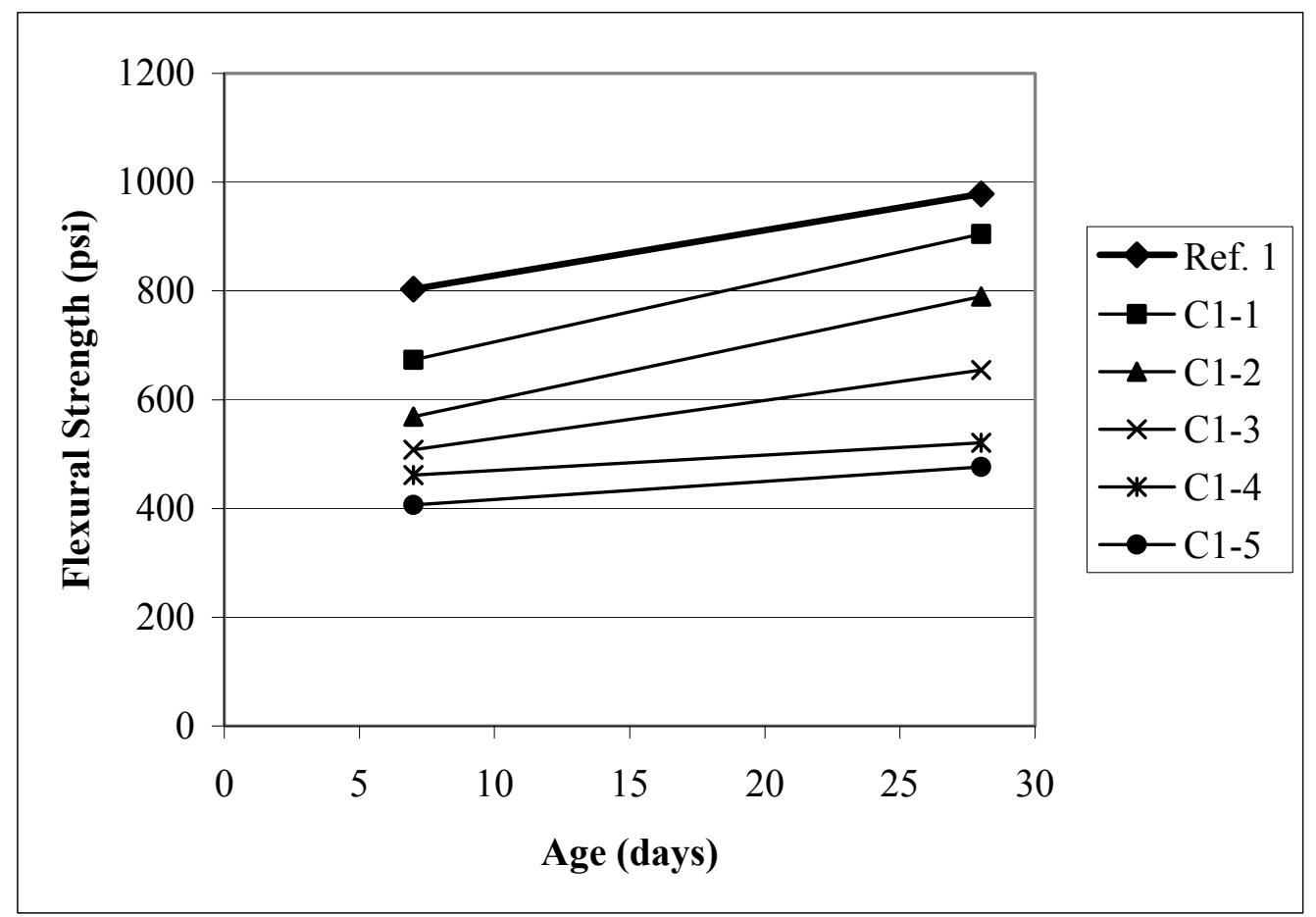

Fig. 75. Flexural strength vs. age (Series 2: C1)

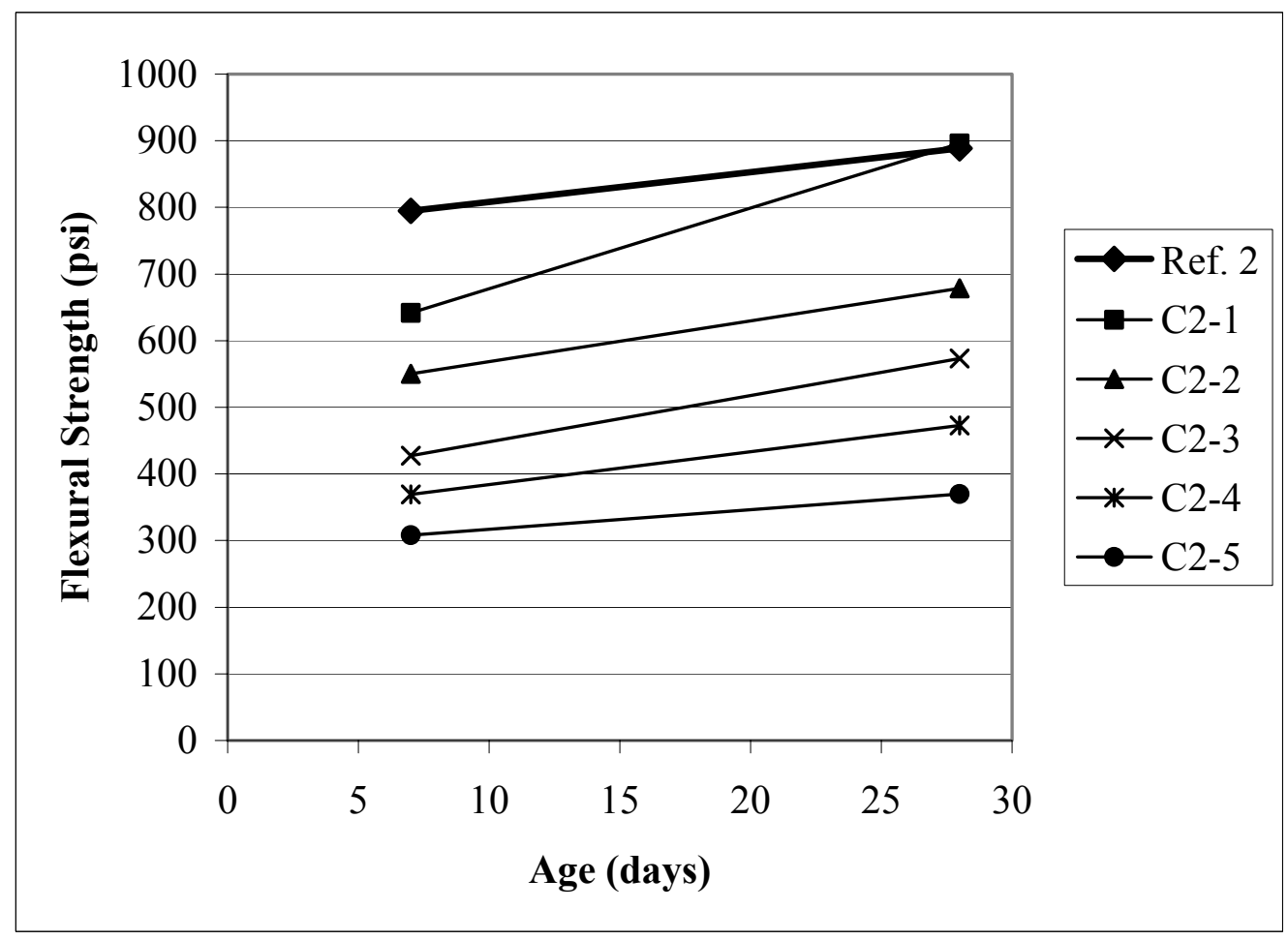

Fig. 76. Flexural strength vs. age (Series 2: C2) 


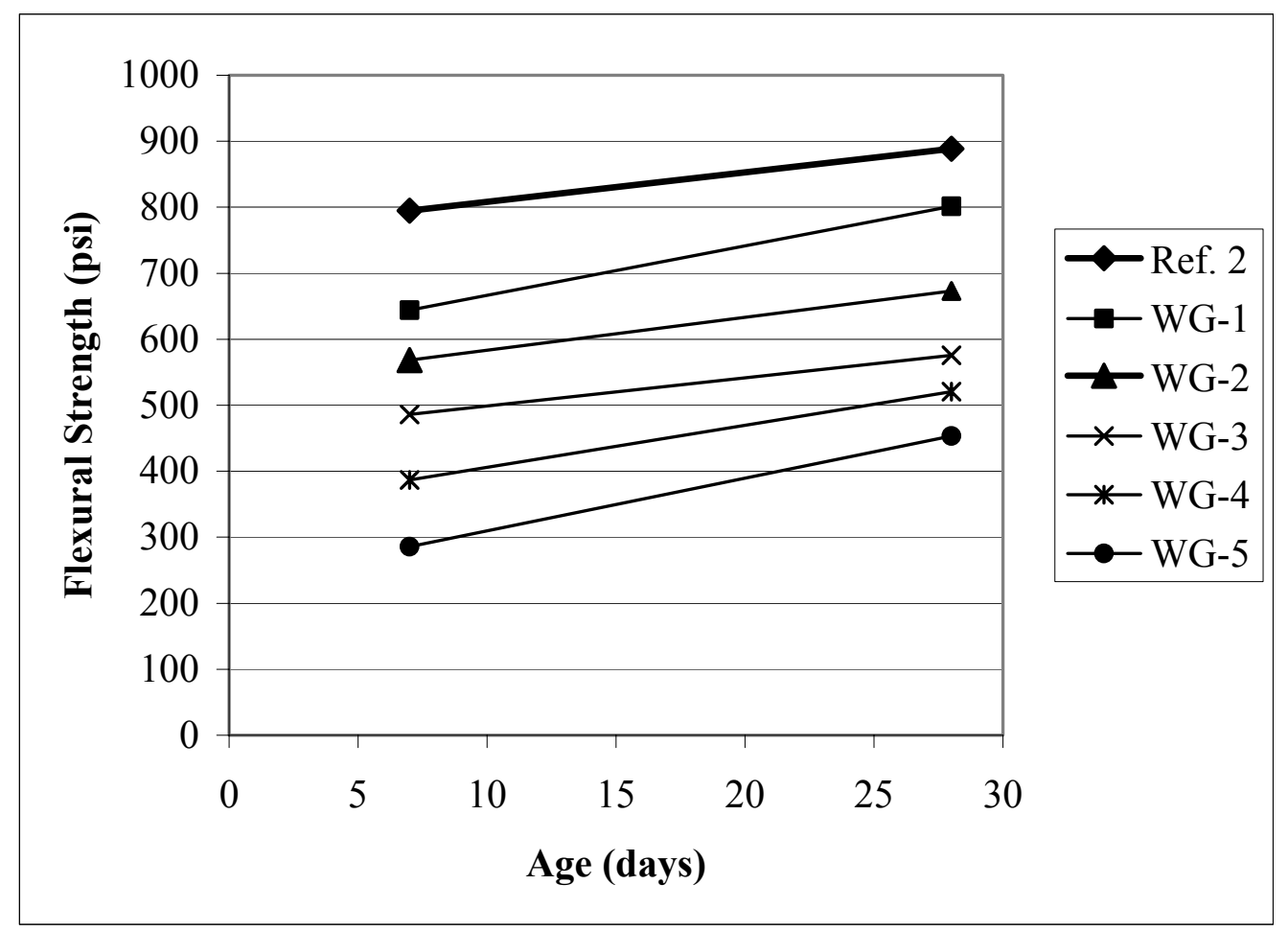

Fig. 77. Flexural strength vs. age (Series 2: WG)

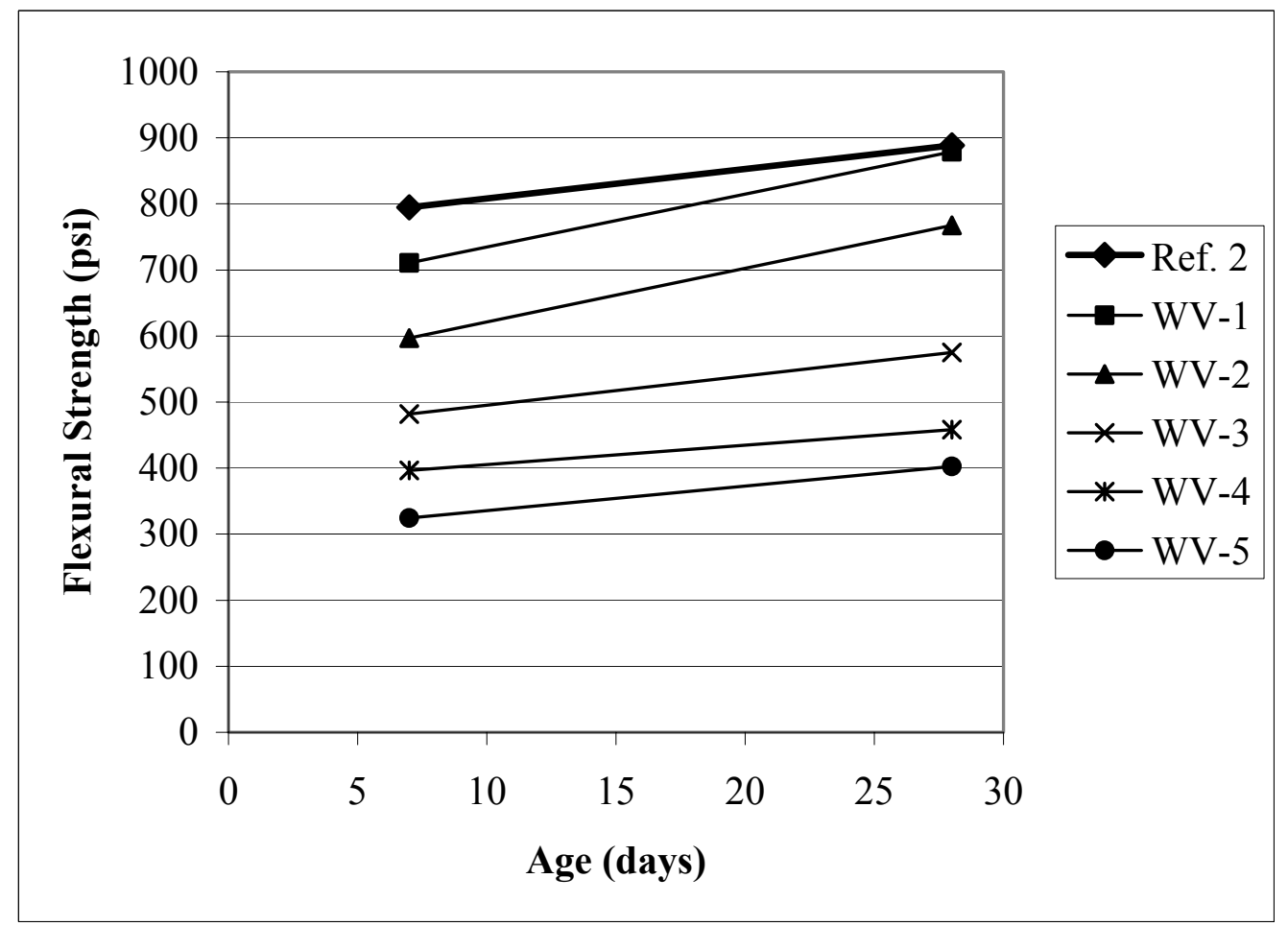

Fig. 78. Flexural strength vs. age (Series 2: WV) 


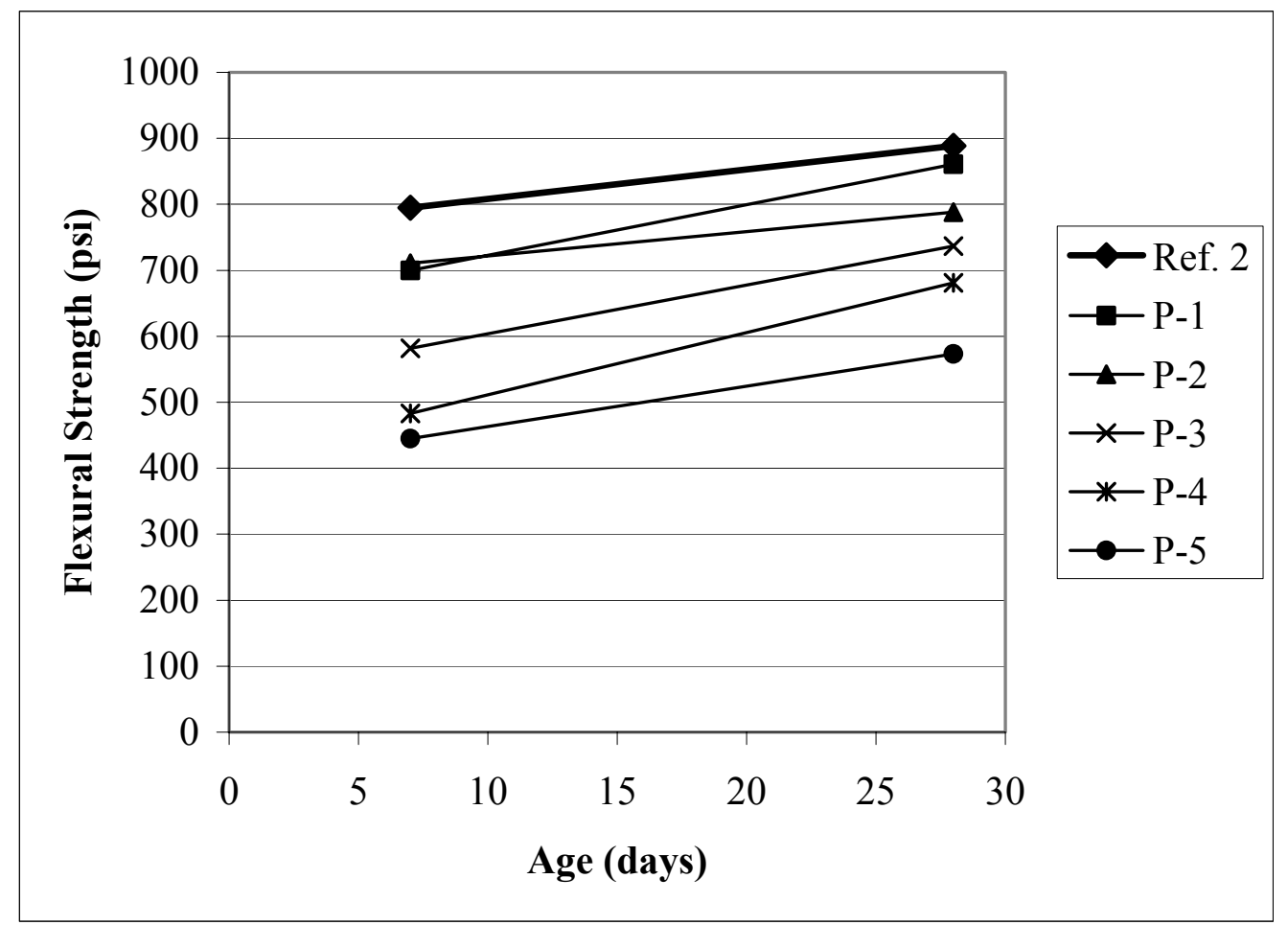

Fig. 79. Flexural strength vs. age (Series 2: P)

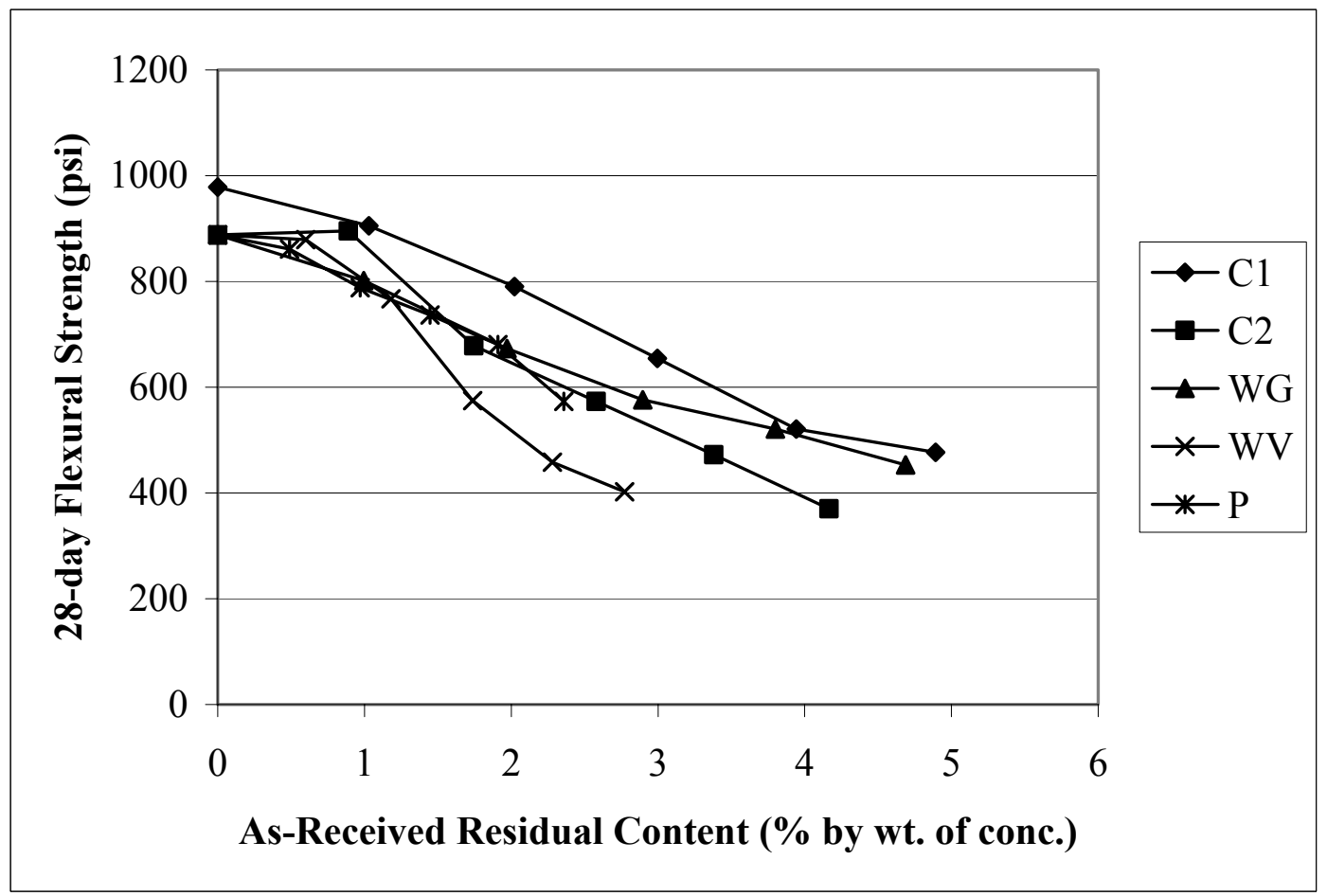

Fig. 80. 28-day flexural strength vs. as-received residual content (Series 2) 
Also, it became clear that residual solids content of $1 \%$ based on LOI at $590^{\circ} \mathrm{C}$ ( 2.4 to $4.9 \%$ based on as-received weight) would be too much for ready-mixed concrete. Initial research had shown that as-received residuals content of about $0.4 \%$ by weight of concrete could be used as an optimum amount of residuals [2].

To incorporate large amount of residuals in concrete, different types of concrete with high volume of cement paste and low volume of aggregates might be preferable.

Since compressive strength is closely related to splitting tensile and flexural strengths, only compressive strength was determined for subsequent series of preliminary mixtures (Series 3, 4, 6, 7, and 11) for an efficient progress of research.

\subsubsection{Attempt for Modeling (Series 3)}

Series 3 concrete mixtures were made in an attempt to model compressive strength of concrete as a function of residual content, HRWRA content, and $w / \mathrm{cm}$. The concept of two-level factorial design of experiment was used [53]. For background information on two-level factorial design, refer to Sect. 13.1 on p.244.

In Series 3 concrete mixtures, three variables were used: Residual WV content, HRWRA content, and $w / \mathrm{cm}$. Combinations of the variables used for the mixtures were as shown in Table 69. The combinations were in accordance with the design matrix for a $2^{3}$ factorial experiment shown in Table 127 on p. 247.

Table 69. Combinations of Variables (Series 3)

\begin{tabular}{|l|c|c|c|c|c|c|c|c|}
\hline \multirow{2}{*}{ Variables } & \multicolumn{7}{|c|}{ Mixture Name, WV- } \\
\cline { 2 - 9 } & 1 & 2 & 3 & 4 & 5 & 6 & 7 & 8 \\
\hline Residual WV (\% by wt. of concrete) & 0.15 & 0.45 & 0.15 & 0.45 & 0.15 & 0.45 & 0.15 & 0.45 \\
\hline HRWRA (fl oz/100 lb cement) & 3.2 & 3.2 & 9.5 & 9.5 & 3.2 & 3.2 & 9.5 & 9.5 \\
\hline w/cm & 0.50 & 0.50 & 0.50 & 0.50 & 0.54 & 0.54 & 0.54 & 0.54 \\
\hline
\end{tabular}


Mixture proportions and fresh properties of concrete are shown in Table 70. In two mixtures (WV-3 and 6), actual values of water-cementitious materials ratios $(w / \mathrm{cm})$ varied a little from the designed values. Depending on the combination of the variables, slump varied between 2 and 8 inches.

Table 70. Mixture Proportions and Fresh Properties of Concrete (Series 3)

\begin{tabular}{|c|c|c|c|c|c|c|c|c|}
\hline Mixture Name & WV-1 & WV-2 & WV-3 & WV-4 & WV-5 & WV-6 & WV-7 & $\mathrm{WV}-8$ \\
\hline $\begin{array}{l}\text { Residuals, as-recd (\% of } \\
\text { concrete by wt.) }\end{array}$ & 0.15 & 0.45 & 0.15 & 0.45 & 0.15 & 0.45 & 0.15 & 0.45 \\
\hline Wood Fibers $\left(\mathrm{lb} / \mathrm{yd}^{3}\right) \dagger$ & 1.9 & 5.6 & 1.9 & 5.6 & 1.9 & 5.6 & 1.9 & 5.5 \\
\hline $\begin{array}{l}\text { Residuals, LOI at } 590^{\circ} \mathrm{C} \\
(\mathrm{lb} / 100 \mathrm{lb} \text { cement })\end{array}$ & 0.34 & 1.02 & 0.34 & 1.02 & 0.34 & 1.02 & 0.34 & 1.02 \\
\hline HRWRA (fl oz/100 lb cement) & 3.2 & 3.2 & 9.5 & 9.5 & 3.2 & 3.2 & 9.5 & 9.5 \\
\hline Residual WV, as-recd (lb/yd $\left.{ }^{3}\right)$ & 6.0 & 17.7 & 6.0 & 17.9 & 5.9 & 17.6 & 6.0 & 17.6 \\
\hline HRWRA (fl oz/yd ${ }^{3}$ ) & 19.1 & 18.7 & 56.8 & 56.6 & 18.7 & 18.6 & 56.6 & 55.6 \\
\hline Cement $\left(\mathrm{lb} / \mathrm{yd}^{3}\right)$ & 603 & 589 & 598 & 596 & 590 & 587 & 596 & 586 \\
\hline Sand, SSD (lb/yd $\left.{ }^{3}\right)$ & 1390 & 1360 & 1370 & 1370 & 1360 & 1350 & 1370 & 1350 \\
\hline $\begin{array}{l}\text { Coarse Aggregate, 3/4" max., } \\
\operatorname{SSD}\left(\mathrm{lb} / \mathrm{yd}^{3}\right)\end{array}$ & 1710 & 1670 & 1700 & 1690 & 1680 & 1670 & 1690 & 1660 \\
\hline Water $\left(\mathrm{lb} / \mathrm{yd}^{3}\right)$ & 302 & 295 & 303 & 300 & 317 & 314 & 322 & 314 \\
\hline$w / \mathrm{cm}$ & 0.50 & 0.50 & 0.51 & 0.50 & 0.54 & 0.53 & 0.54 & 0.54 \\
\hline Slump (in.) & 2 & 2.5 & 8 & 6 & 4.5 & 3 & 8 & 8 \\
\hline Air Content $(\%)$ & 2.6 & 3.9 & 3.2 & 2.6 & 4.2 & 4.0 & 1.9 & 3.1 \\
\hline Density $\left(\mathrm{lb} / \mathrm{ft}^{3}\right)$ & 149 & 146 & 147 & 147 & 146 & 146 & 148 & 146 \\
\hline
\end{tabular}

$\dagger$ From residuals, dry basis

For each concrete mixture, compressive strength was determined at 1, 3, and 7 days by testing one, two, and two 4" x 8" cylinders, respectively. The results are presented in Table 71 and Fig. 81.

Table 71. Compressive Strength of Concrete (in psi) (Series 3)

\begin{tabular}{|c|c|c|c|c|c|c|c|c|}
\hline Age (day) & WV-1 & WV-2 & WV-3 & WV-4 & WV-5 & WV-6 & WV-7 & WV-8 \\
\hline 1 & 1200 & 1420 & 1590 & 1210 & 1200 & 1360 & 1350 & 910 \\
\hline 3 & 3080 & 3490 & 3370 & 2600 & 2950 & 3410 & 2680 & 2250 \\
\hline 7 & 3380 & 4260 & 3830 & 3440 & 3720 & 4290 & 3460 & 2580 \\
\hline
\end{tabular}




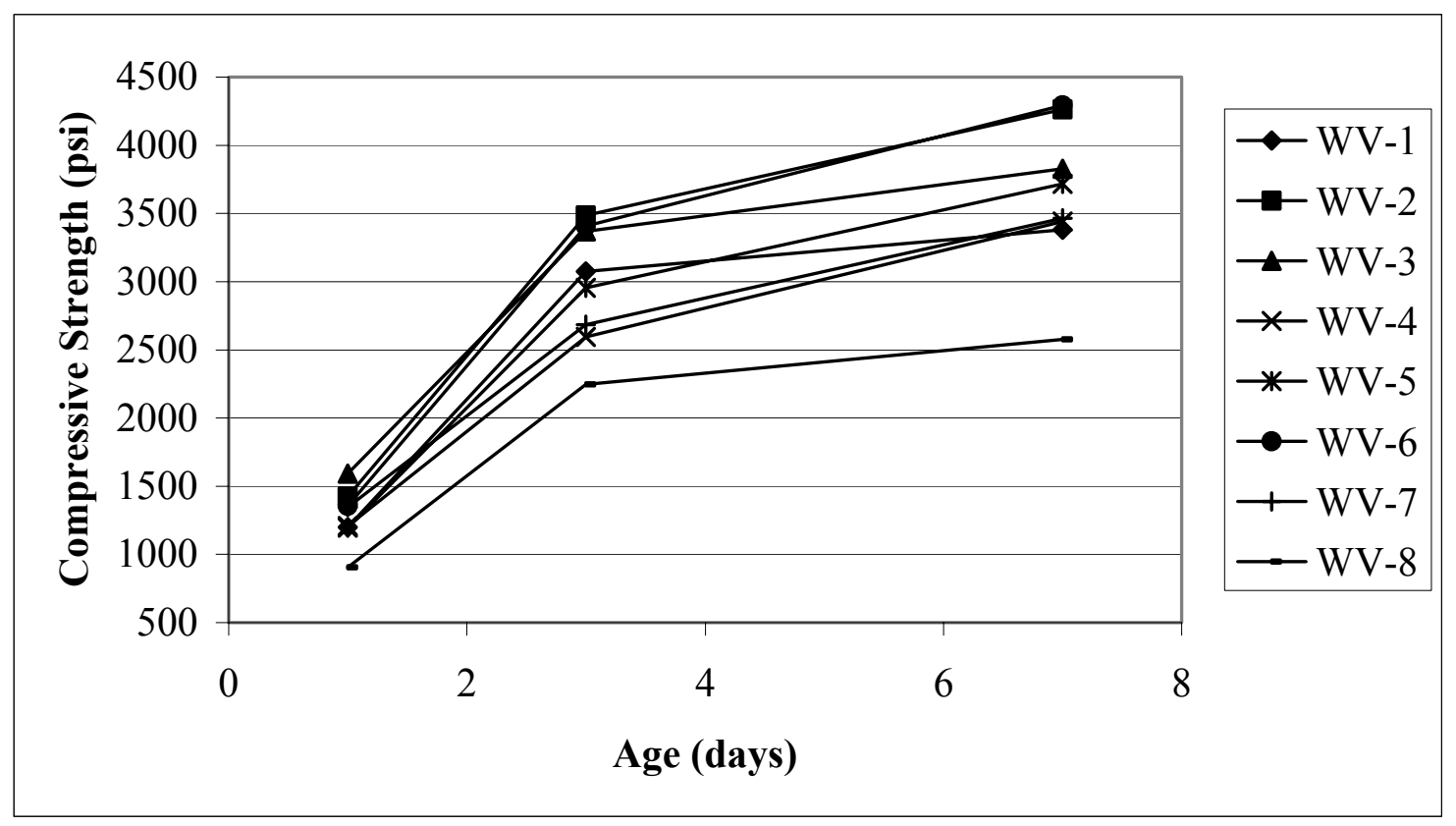

Fig. 81. Compressive strength vs. age of concrete (Series 3)

By multiplying the $1 \times 8$ matrix of the 7-day compressive strength results by the calculation matrix for a $2^{3}$ factorial design shown in Table 128 on p. 248 , a model describing the 7-day compressive strength of concrete was derived as

$$
\hat{y}(\mathrm{psi})=3620+23 x_{1}-293 x_{2}-108 x_{3}-341 x_{1} x_{2}-101 x_{1} x_{3}-199 x_{2} x_{3}-24 x_{1} x_{2} x_{3}
$$

where:

$x_{1}=$ coded value of Residual WV content of concrete

calculated as (actual value [in $\%$ by mass of concrete $]-0.30) / 0.15$,

$x_{2}=$ coded value of HRWRA content of concrete

calculated as (actual value [in $\mathrm{fl} \mathrm{oz} / 100 \mathrm{lb}$ cement] -6.35 ) / 3.15, and

$x_{3}=$ coded value of $w / \mathrm{cm}$ calculated as (actual $\left.w / \mathrm{cm}-0.52\right) / 0.02$. 
Increases of Residual WV content, HRWRA content, and $w / \mathrm{cm}$ by one level $(+0.15 \%$ by mass of concrete, $+3.15 \mathrm{fl} \mathrm{oz} / 100 \mathrm{lb}$ of cement, and +0.02 , respectively) resulted in negligible increase, a little reduction, and almost negligible reduction in compressive strength, respectively. Overall, interactions between two variables had greater effects on the strength than the main effects of individual variables. However, the magnitudes of the interactive effects were still relatively small $(<10 \%$ of the average strength). Practically no consistent or significant influence of the variables could be identified.

In this series of mixtures (Series 3), the use of HRWRA did not lead to the reduction in the amount of mixing water and $w / \mathrm{cm}$; it mainly worked only as a "superplasticizer" making the concrete more flowable and did not contribute to strength improvement. From this observation, it was decided to keep the slump of concrete within a relatively narrow range for subsequent series of concrete mixtures. Amount of mixing water required for achieving a specified slump was expected to vary with different combinations of residuals and HRWRA contents. This would affect $w / c m$, density, and compressive strength of concrete.

\subsubsection{Modeling 1 (Series 4)}

For Series 4 concrete mixtures, two-level factorial design of experiment was conducted to determine the effects of residuals and HRWRA contents on compressive strength of concrete. Test setup for the experiment is presented in Table 72. The combinations of variables were in accordance with the design matrix for a $2^{2}$ factorial experiment (Table 125 on p. 246). The test setup is presented in a Cartesian coordinate system in Table 73. 
Table 72. Test Setup for Two-Level Factorial Design (Series 4)

\begin{tabular}{|l||c|c|c|c||}
\hline Mixture Name $\left(\mathrm{X}^{*}\right)$ & 1 & 2 & 3 & 4 \\
\hline Coded Levels of Variables $\dagger$ & $(-1,-1)$ & $(+1,-1)$ & $(-1,+1)$ & $(+1,+1)$ \\
\hline Residuals Content $\left(\mathrm{lb}^{* *} / 100 \mathrm{lb}\right.$ cement) & 0.34 & 1.02 & 0.34 & 1.02 \\
\hline HRWRA Content $(\mathrm{fl} \mathrm{oz} / 100 \mathrm{lb}$ cement) & 3.1 & 3.1 & 9.2 & 9.2 \\
\hline
\end{tabular}

* X: Designation of residuals.

$\dagger-1=$ low level. $\quad+1=$ high level.

** Based on LOI at $590^{\circ} \mathrm{C}(\sim$ wood fiber content $)$.

Table 73. Test Setup in a Cartesian Coordinate System (Series 4)

\begin{tabular}{|c|c|c|c|c|}
\hline $9.2 \mathrm{fl} \mathrm{oz}^{\#}$ & \multirow{2}{*}{$\begin{array}{c}\text { HRWRA } \\
\text { Level }\end{array}$} & +1 & $\mathrm{X}-3(-1,+1)$ & $\begin{array}{c}\mathrm{X}-4(+1 \\
+1)\end{array}$ \\
\hline $3.1 \mathrm{fl} \mathrm{oz}^{\#}$ & & -1 & $\mathrm{X}-1(-1,-1)$ & $\mathrm{X}-2(+1,-1)$ \\
\hline & & & -1 & +1 \\
\hline & & & Residu & s Level \\
\hline & & & $0.34 \mathrm{lb}^{+\#}$ & $1.02 \mathrm{lb}^{+\#}$ \\
\hline
\end{tabular}

$\mathrm{X}$ : Designation of residuals.

${ }^{\#}$ Per $100 \mathrm{lb}$ of cement. $†$ Based on LOI at $590^{\circ} \mathrm{C}$ ( wood fiber content).

$\mathrm{C} 1, \mathrm{C} 2, \mathrm{WG}$, and WV residuals were used. Mixture proportions and fresh properties of concrete are given in Tables 74 and 75. In some concrete mixtures, actual values of residuals content (based on LOI at $590^{\circ} \mathrm{C}$ ) in $\mathrm{lb} / 100 \mathrm{lb}$ of cement varied a little from the planned values of 0.34 and 1.02. As-received residuals content by mass of concrete was approximately in the ranges of $0.27 \sim 0.80 \%$ for $\mathrm{C} 1,0.22 \sim 0.68 \%$ for $\mathrm{C} 2$, $0.25 \sim 0.75 \%$ for $\mathrm{WG}$, and $0.15 \sim 0.46 \%$ for WV concrete mixtures.

For a given combination of residuals and HRWRA contents, amount of mixing water was adjusted to achieve a target slump of $4 \pm 1 \mathrm{in}$. This variation in the amount of mixing water affected $w / \mathrm{cm}$, density, and, ultimately, compressive strength of concrete. 
Table 74. Mixture Proportions and Fresh Properties of Concrete (Series 4: C1, C2)

\begin{tabular}{|c|c|c|c|c|c|c|c|c|}
\hline Mixture Name & $\mathrm{C} 1-1$ & C1-2 & C1-3 & C1-4 & C2-1 & C2-2 & $\mathrm{C} 2-3$ & $\mathrm{C} 2-4$ \\
\hline $\begin{array}{l}\text { Residuals, as-recd (\% of } \\
\text { concrete by wt.) }\end{array}$ & 0.27 & 0.79 & 0.27 & 0.81 & 0.22 & 0.67 & 0.23 & 0.68 \\
\hline Wood Fibers $\left(\mathrm{lb} / \mathrm{yd}^{3}\right) \dagger$ & 1.6 & 4.7 & 1.7 & 5.0 & 1.8 & 5.3 & 1.9 & 5.5 \\
\hline $\begin{array}{l}\text { Residuals, LOI at } 590^{\circ} \mathrm{C} \\
(\mathrm{lb} / 100 \mathrm{lb} \text { cement })\end{array}$ & 0.34 & 1.03 & 0.34 & 1.03 & 0.34 & 1.02 & 0.34 & 1.02 \\
\hline HRWRA (fl oz/100 lb cement) & 3.1 & 3.1 & 9.2 & 9.2 & 3.1 & 3.1 & 9.2 & 9.2 \\
\hline Residuals, as-recd (lb/yd $\left.{ }^{3}\right)$ & 10.6 & 31.4 & 11.2 & 32.8 & 9.0 & 26.3 & 9.4 & 27.5 \\
\hline HRWRA (fl oz/yd ${ }^{3}$ ) & 18.5 & 18.0 & 58.2 & 56.5 & 18.4 & 18.0 & 58.0 & 56.4 \\
\hline Cement $\left(\mathrm{lb} / \mathrm{yd}^{3}\right)$ & 603 & 589 & 634 & 615 & 601 & 587 & 631 & 613 \\
\hline Sand, SSD (lb/yd $\left.{ }^{3}\right)$ & 1400 & 1370 & 1460 & 1430 & 1390 & 1360 & 1460 & 1420 \\
\hline $\begin{array}{l}\text { Coarse Aggregate, 3/4" max., } \\
\left.\text { SSD (lb/yd }{ }^{3}\right)\end{array}$ & 1720 & 1680 & 1800 & 1750 & 1710 & 1670 & 1800 & 1740 \\
\hline Water $\left(\mathrm{lb} / \mathrm{yd}^{3}\right)$ & 275 & 299 & 233 & 249 & 280 & 305 & 227 & 248 \\
\hline$w / \mathrm{cm}$ & 0.46 & 0.51 & 0.37 & 0.41 & 0.47 & 0.52 & 0.36 & 0.40 \\
\hline Slump (in.) & 3.25 & 2.75 & 6.5 & 4 & 3 & 2.25 & 6 & 3 \\
\hline Air Content (\%) & 3.8 & 3.7 & 2.1 & 2.8 & 3.7 & 3.2 & 2.3 & 2.6 \\
\hline Density $\left(\mathrm{lb} / \mathrm{ft}^{3}\right)$ & 148 & 147 & 153 & 151 & 148 & 146 & 153 & 150 \\
\hline
\end{tabular}

$\uparrow$ From residuals, dry basis

Table 75. Mixture Proportions and Fresh Properties of Concrete (Series 4: WG, WV)

\begin{tabular}{|c|c|c|c|c|c|c|c|c|}
\hline Mixture Name & WG-1 & WG-2 & WG-3 & WG-4 & WV-1 & WV-2 & WV-3 & WV-4 \\
\hline $\begin{array}{l}\text { Residuals, as-recd (\% of } \\
\text { concrete by wt.) }\end{array}$ & 0.25 & 0.74 & 0.25 & 0.76 & 0.15 & 0.45 & 0.16 & 0.46 \\
\hline Wood Fibers $\left(\mathrm{lb} / \mathrm{yd}^{3}\right) \dagger$ & 1.6 & 4.8 & 1.7 & 5.0 & 1.9 & 5.6 & 2.0 & 5.9 \\
\hline $\begin{array}{l}\text { Residuals, LOI at } 590^{\circ} \mathrm{C} \\
(1 \mathrm{~b} / 100 \mathrm{lb} \text { cement })\end{array}$ & 0.33 & 1.01 & 0.33 & 1.01 & 0.34 & 1.03 & 0.34 & 1.03 \\
\hline HRWRA (fl oz/100 lb cement) & 3.1 & 3.1 & 9.2 & 9.2 & 3.1 & 3.1 & 9.2 & 9.2 \\
\hline Residuals, as-recd (lb/yd $\left.{ }^{3}\right)$ & 10.1 & 29.4 & 10.4 & 31.0 & 6.1 & 17.8 & 6.4 & 18.6 \\
\hline HRWRA (fl oz/yd ${ }^{3}$ ) & 18.7 & 18.0 & 58.0 & 56.8 & 18.4 & 18.0 & 57.6 & 56.2 \\
\hline Cement $\left(\mathrm{lb} / \mathrm{yd}^{3}\right)$ & 609 & 587 & 631 & 618 & 600 & 587 & 627 & 611 \\
\hline Sand, SSD (lb/yd $\left.{ }^{3}\right)$ & 1410 & 1350 & 1460 & 1430 & 1390 & 1360 & 1450 & 1420 \\
\hline $\begin{array}{l}\text { Coarse Aggregate, } 3 / 4 " \text { max., } \\
\text { SSD }\left(\mathrm{lb} / \mathrm{yd}^{3}\right)\end{array}$ & 1730 & 1670 & 1800 & 1760 & 1710 & 1670 & 1780 & 1740 \\
\hline Water $\left(\mathrm{lb} / \mathrm{yd}^{3}\right)$ & 293 & 323 & 231 & 259 & 280 & 315 & 222 & 256 \\
\hline$w / \mathrm{cm}$ & 0.48 & 0.55 & 0.37 & 0.42 & 0.47 & 0.54 & 0.35 & 0.42 \\
\hline Slump (in.) & 3 & 5 & 5.5 & 4.5 & 2.75 & 2.5 & 4 & 2.75 \\
\hline Air Content (\%) & 2.6 & 3.1 & 2.2 & 1.8 & 3.7 & 3.6 & 2.5 & 3.1 \\
\hline Density $\left(\mathrm{lb} / \mathrm{ft}^{3}\right)$ & 150 & 147 & 153 & 152 & 148 & 146 & 152 & 150 \\
\hline
\end{tabular}

$\dagger$ From residuals, dry basis 
Overall, average and range of actual values of slump was 3.8 in. and 2.25 6.5 in., respectively. For most mixtures, actual slump was in the range of 2.75 to $5.5 \mathrm{in}$.

For each concrete mixture, compressive strength was determined at 3, 7, and 28 days by testing two 4" x 8" cylinders at each test age. The results are presented in Tables 76 to 77 and Fig. 82 to 85 .

Table 76. Compressive Strength of Concrete (in psi) (Series 4: C1, C2)

\begin{tabular}{|c||c|c|c|c|c|c|c|c|}
\hline Age (days) & C1-1 & C1-2 & C1-3 & C1-4 & C2-1 & C2-2 & C2-3 & C2-4 \\
\hline \hline 3 & 4190 & 3410 & 6430 & 5420 & 4460 & 3550 & 5880 & 5020 \\
\hline 7 & 5060 & 4490 & 7280 & 6450 & 5440 & 4480 & 6760 & 5870 \\
\hline 28 & 5920 & 5400 & 8560 & 7480 & 6420 & 5650 & 8100 & 7040 \\
\hline \hline
\end{tabular}

Table 77. Compressive Strength of Concrete (in psi) (Series 4: WV)

\begin{tabular}{|c||c|c|c|c||c|c|c|c||}
\hline \hline Age (days) & WG-1 & WG-2 & WG-3 & WG-4 & WV-1 & WV-2 & WV-3 & WV-4 \\
\hline \hline 3 & 4020 & 3330 & 5640 & 3980 & 4140 & 3300 & 6130 & 5180 \\
\hline 7 & 5090 & 4360 & 6100 & 4690 & 5130 & 4130 & 6960 & 5990 \\
\hline 28 & 6270 & 5570 & 7360 & 5380 & 5930 & 5130 & 7900 & 7150 \\
\hline
\end{tabular}

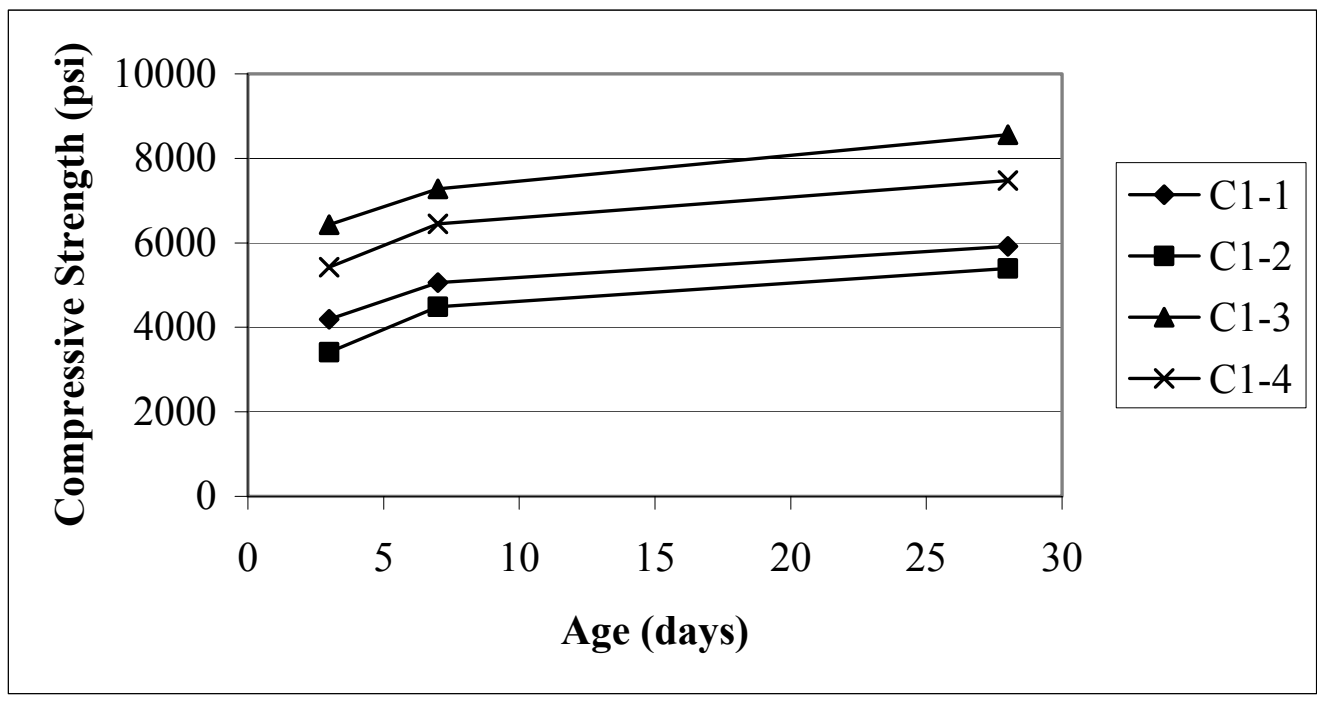

Fig. 82. Compressive strength vs. age (Series 4: C1) 


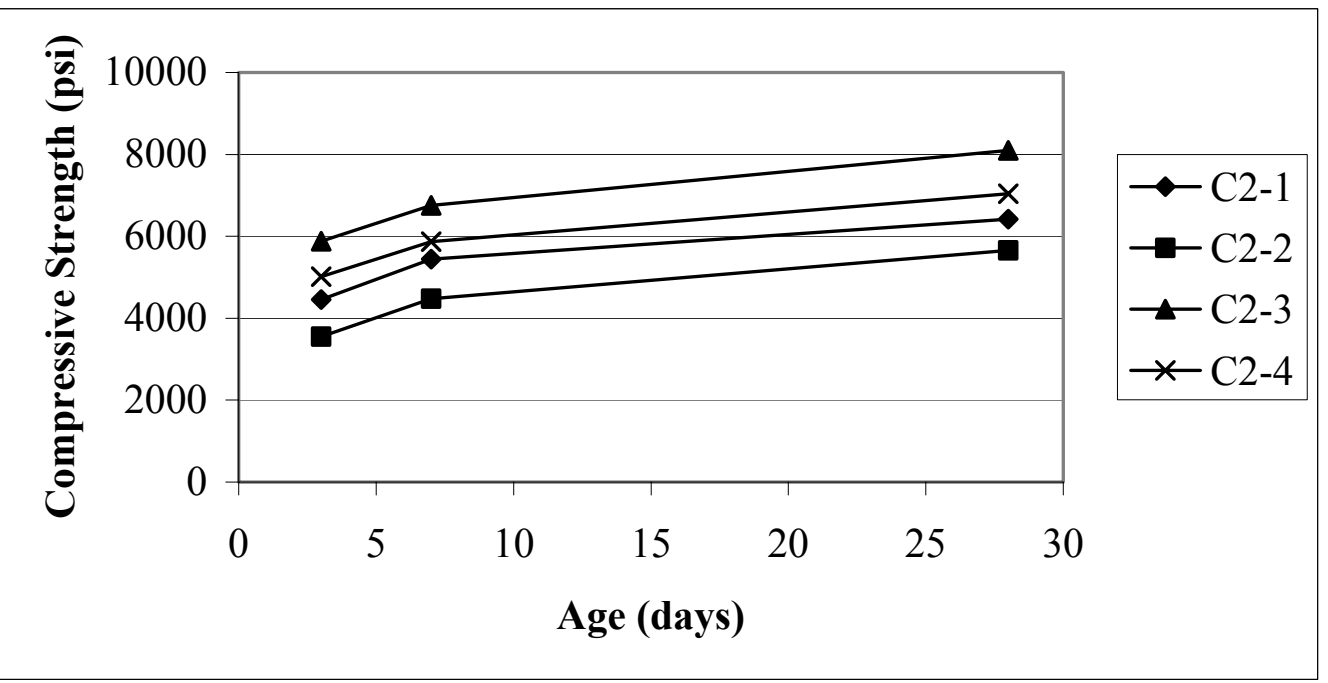

Fig. 83. Compressive strength vs. age (Series 4: C2)

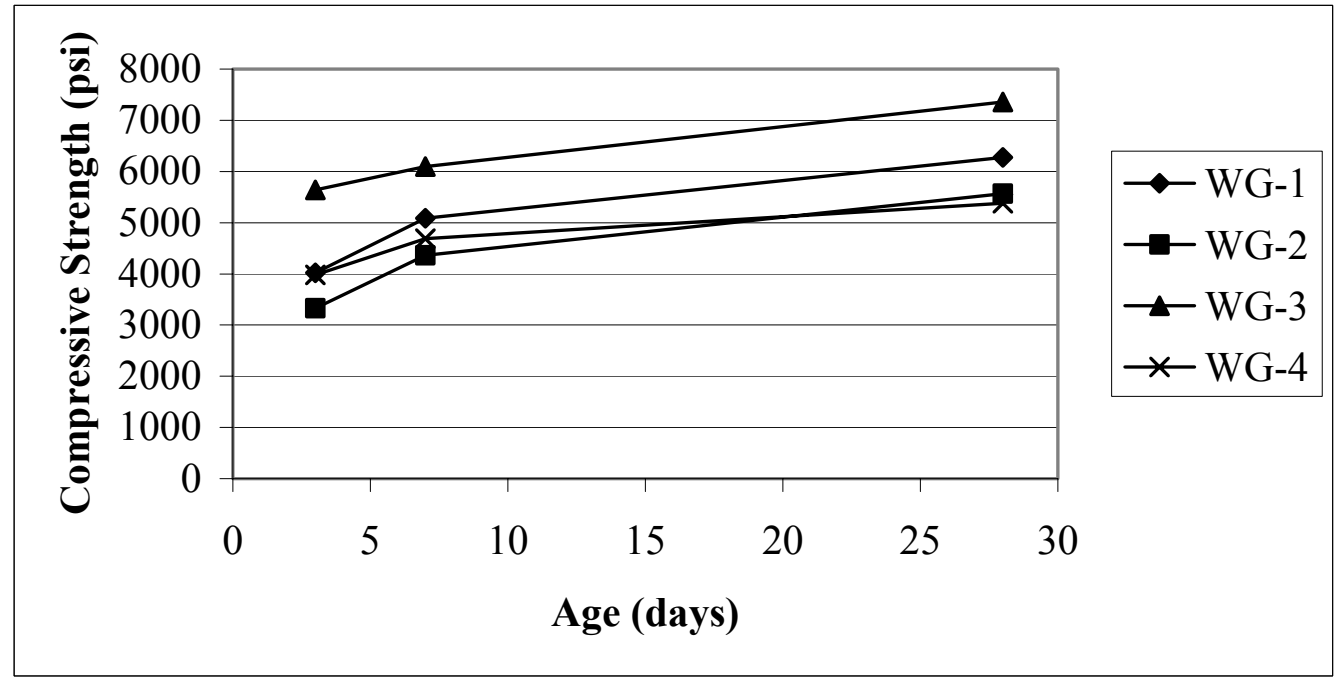

Fig. 84. Compressive strength vs. age (Series 4: WG) 


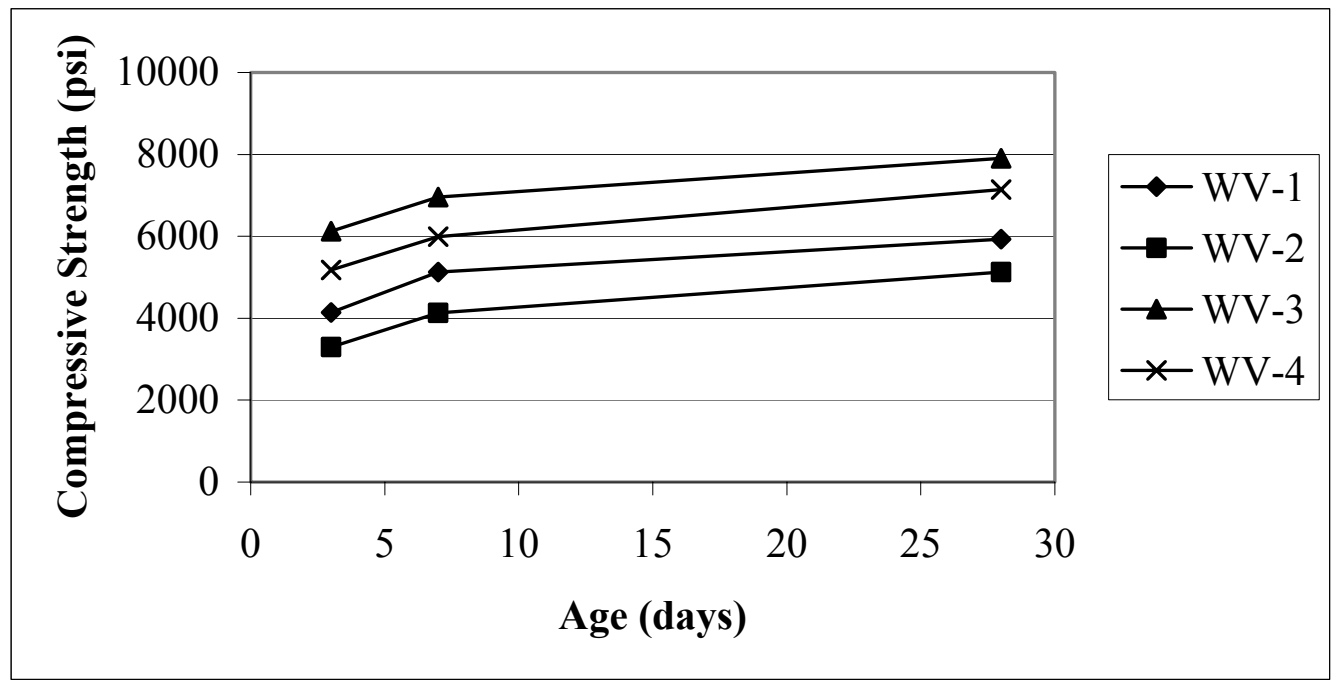

Fig. 85. Compressive strength vs. age (Series 4: WV)

All the mixtures, except for WG-4 mixture, showed similar pattern of strength development over age. WG-4 mixture showed lower level of strength and lower rate of strength gain. Although $w / \mathrm{cm}$ and density of WG-4 were lower than those of WG-1 and WG-2 (Table 75), compressive strength of WG-4 mixture was lower than WG-1 mixture from early age and lower than WG-2 mixture at 28 days (Table 77 and Fig. 84). The reason for this is not known.

28-day compressive strength of concrete is shown in perspective in Fig. 86 to 89 to present the influence of residuals and HRWRA contents on compressive strength. 


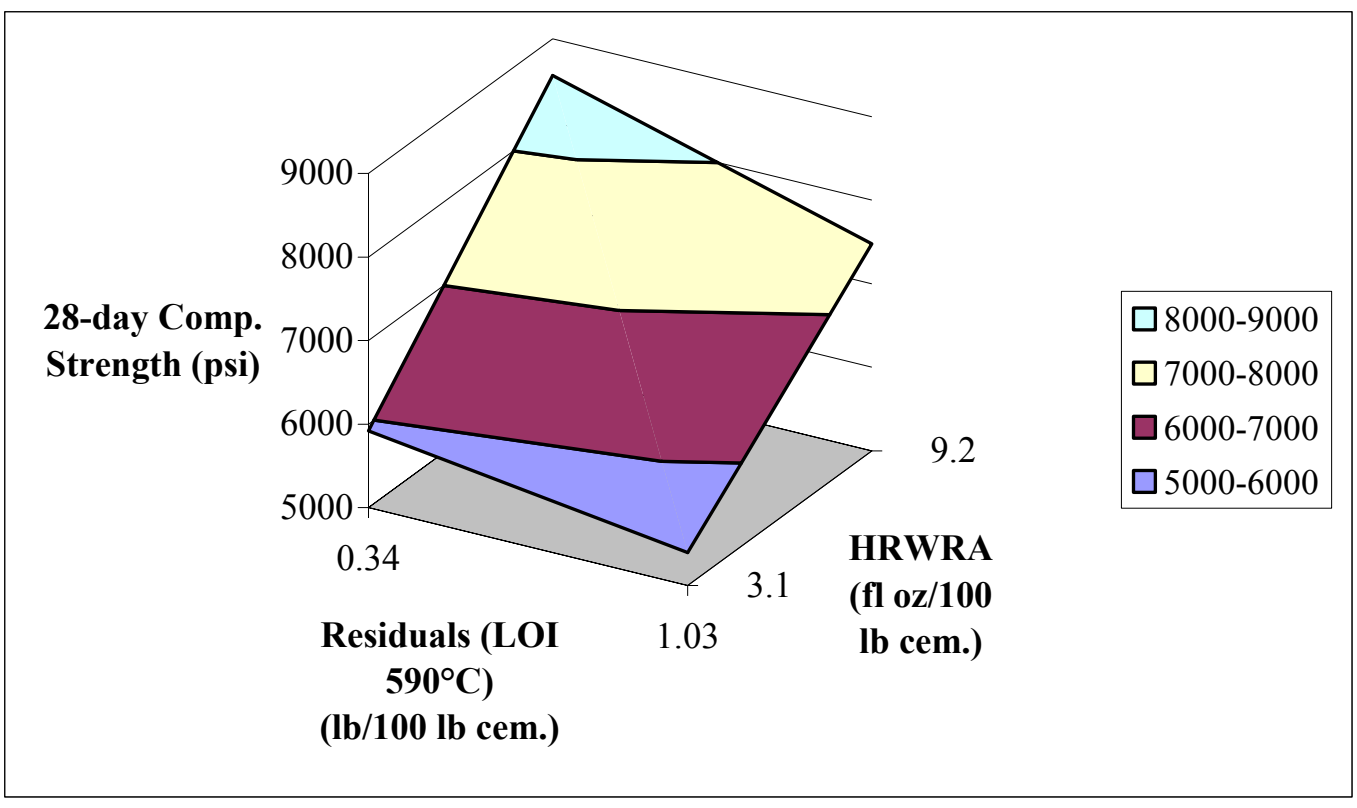

Fig. 86. 28-day compressive strength of concrete as influenced by residual and HRWRA contents (Series 4: C1)

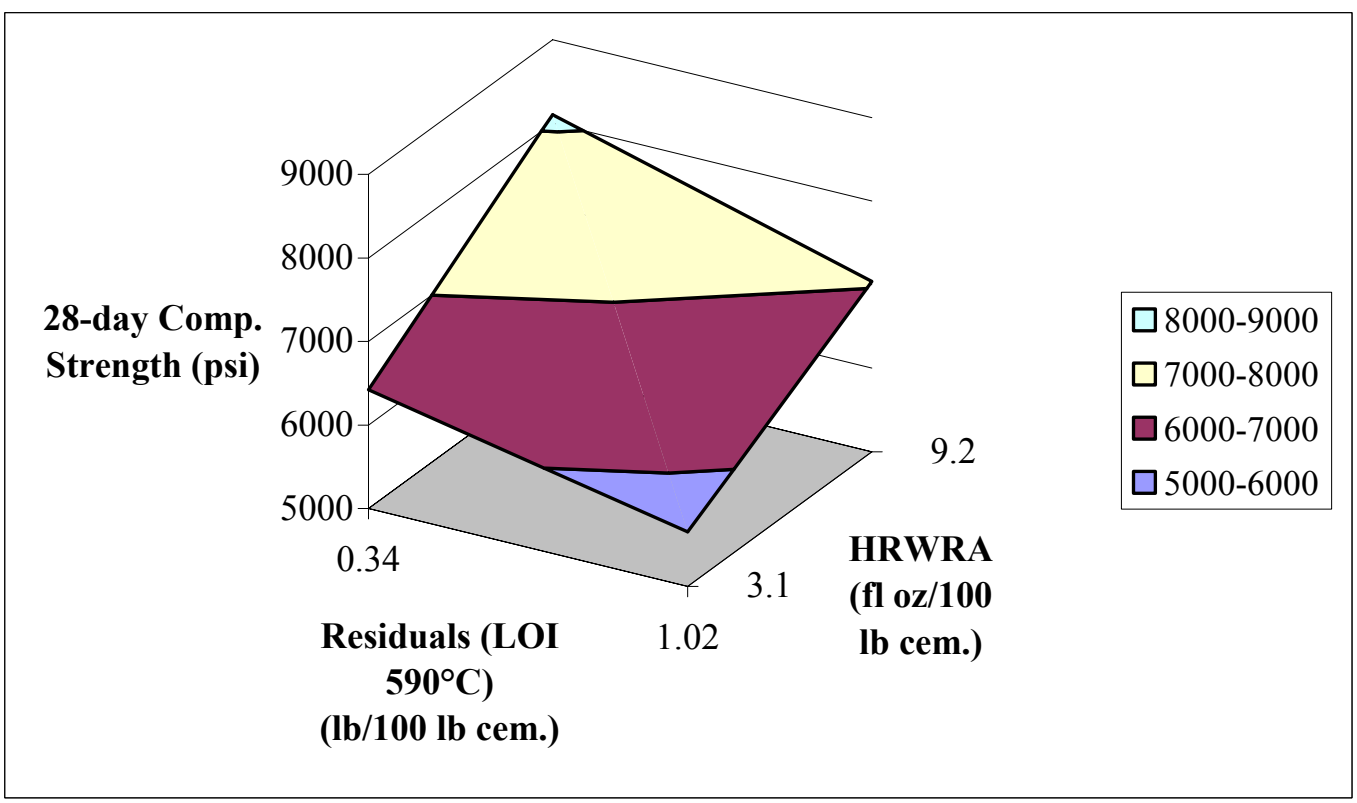

Fig. 87. 28-day compressive strength of concrete as influenced by residual and HRWRA contents (Series 4: C2) 


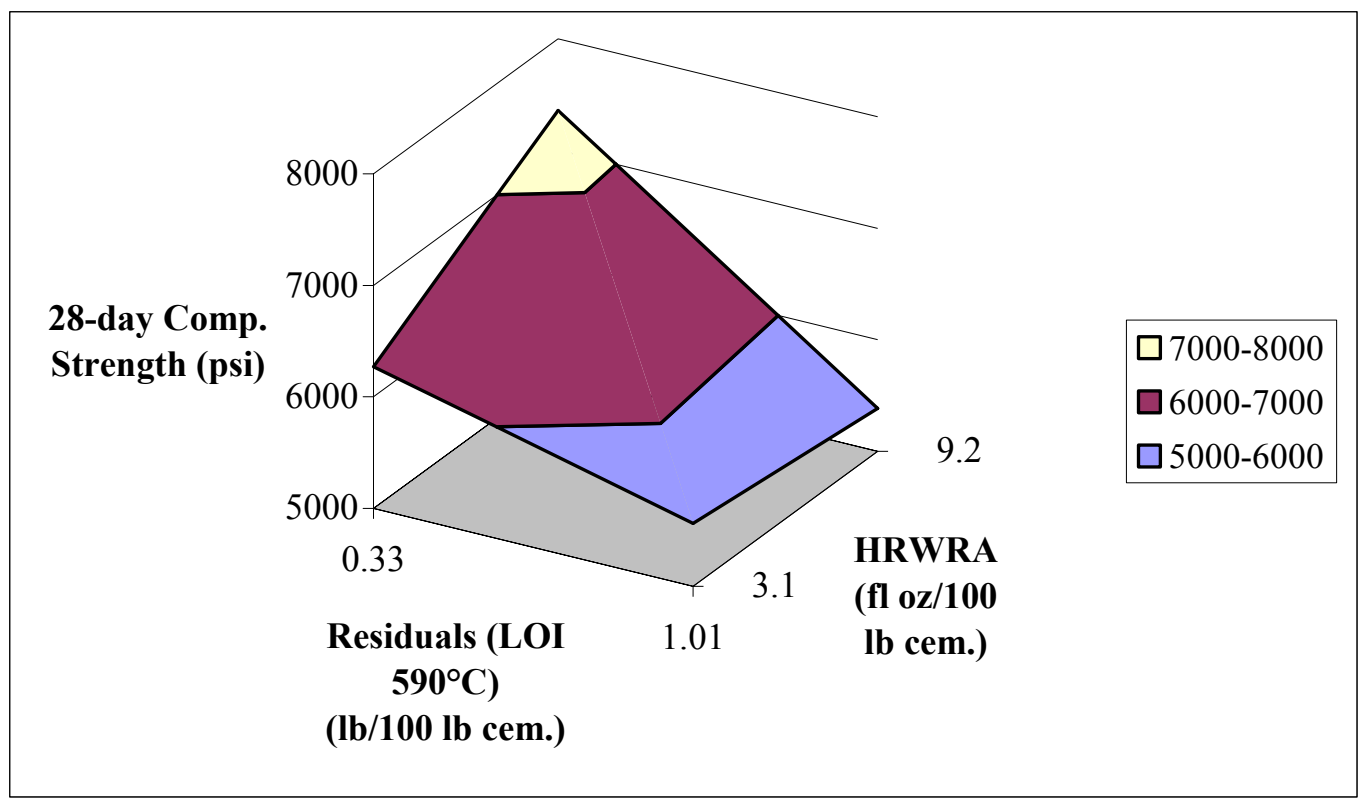

Fig. 88. 28-day compressive strength of concrete as influenced by residual and HRWRA contents (Series 4: WG)

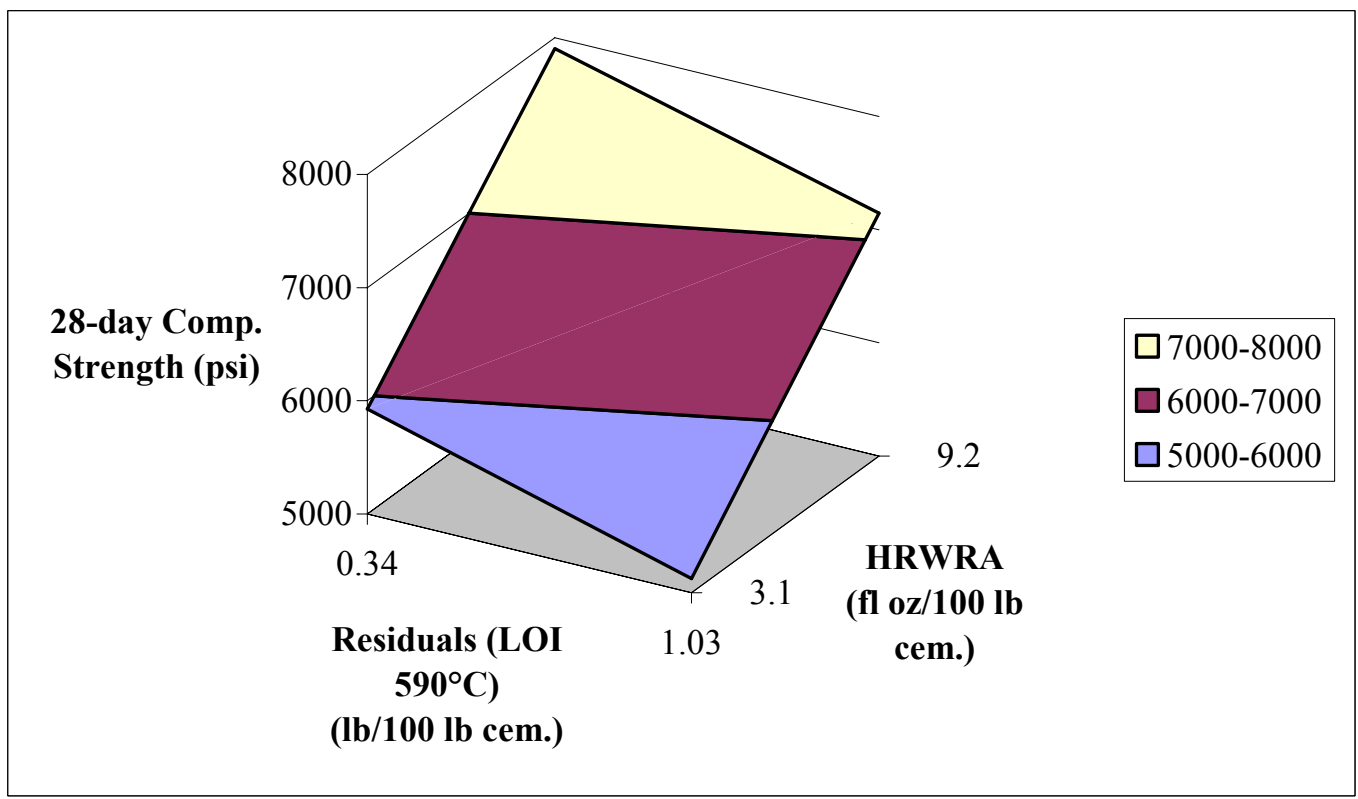

Fig. 89. 28-day compressive strength of concrete as influenced by residual and HRWRA contents (Series 4: WV) 
Overall averages of w/cm, air content, fresh concrete density, and 28-day

compressive strength of concrete are summarized in Table 78. Overall-average 28-day compressive strength is shown in perspective in Fig. 90.

Table 78. Overall Averages of $w / \mathrm{cm}$, Air Content, Fresh Concrete Density, and 28day Compressive Strength of Concrete (Series 4)

\begin{tabular}{|c|c|c|c|c|c|c|c|c|c|}
\hline & \multicolumn{2}{|c|}{$w / \mathrm{cm}$} & \multicolumn{2}{|c|}{ Air Content ( $\%)$} & \multicolumn{2}{|c|}{$\begin{array}{l}\text { Fresh Concrete } \\
\text { Density }\left(\mathrm{lb} / \mathrm{ft}^{3}\right)\end{array}$} & \multicolumn{2}{|c|}{$\begin{array}{l}\text { 28-day Comp. } \\
\text { Strength (psi) }\end{array}$} \\
\hline \multirow{2}{*}{$\begin{array}{c}\text { HRWRA } \\
(\mathrm{fl} \mathrm{oz})^{\#}\end{array}$} & 9.2 & 0.36 & 0.41 & 2.3 & 2.6 & 153 & 151 & 7980 & 6760 \\
\hline & 3.1 & 0.47 & 0.53 & 3.5 & 3.4 & 148 & 146 & 6140 & 5440 \\
\hline & & 0.34 & 1.02 & 0.34 & 1.02 & 0.34 & 1.02 & 0.34 & 1.02 \\
\hline & & \multicolumn{8}{|c|}{ Residuals (lb) $\dagger^{\#}$} \\
\hline
\end{tabular}

${ }^{\#}$ Per $100 \mathrm{lb}$ of cement. $†$ Based on LOI at $590^{\circ} \mathrm{C}(\sim$ wood fiber content $)$.

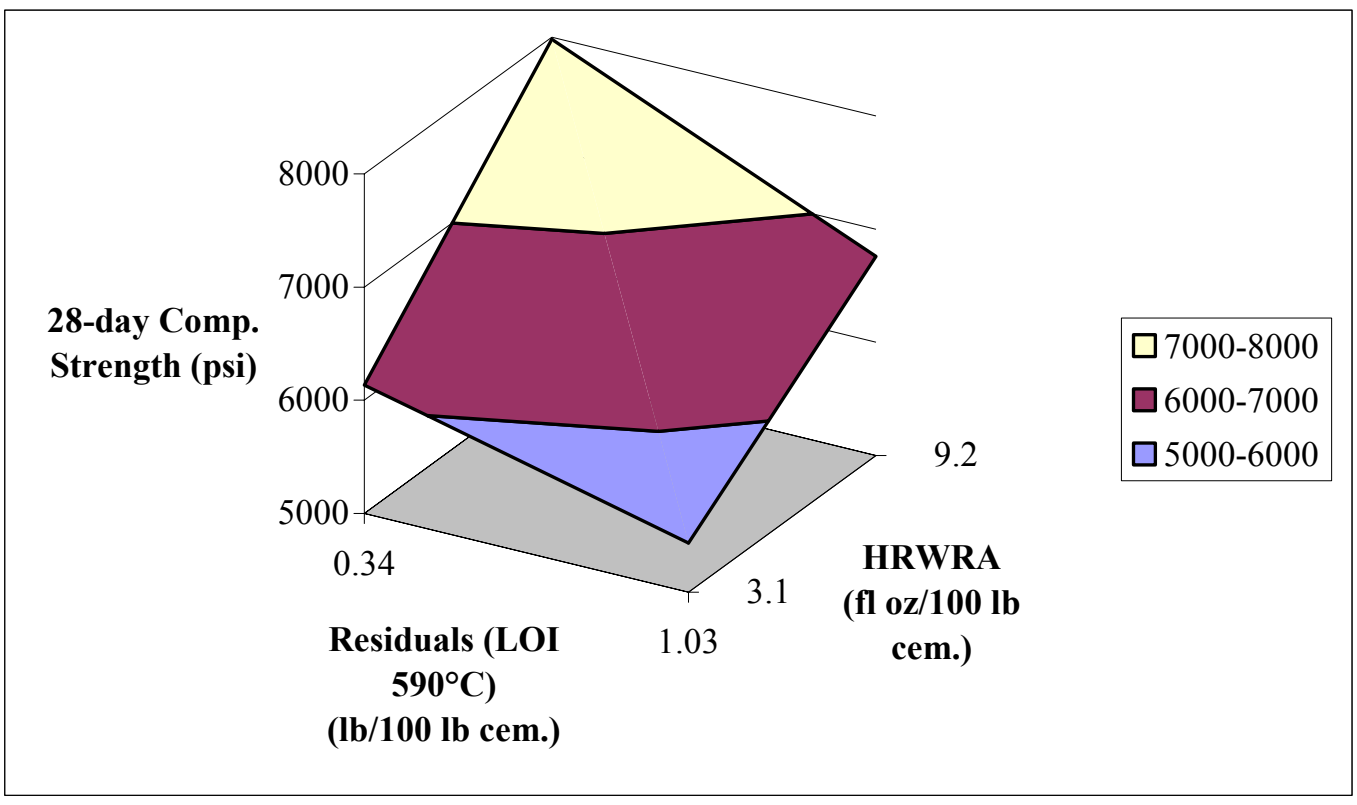

Fig. 90. Overall-average 28-day compressive strength of concrete as influenced by residual and HRWRA contents (Series 4) 
Coefficients of the prediction models of $w / \mathrm{cm}$, air content, fresh density, and 28day compressive strength of concrete were derived as shown in Table 79. The coefficients in each row were determined by multiplying a $1 \mathrm{x} 4$ matrix of response by the calculation matrix for a $2^{2}$ factorial design (Table 126 on p. 246). The models thus built were used in proportioning concrete mixtures in Series 6 and 7. The models were especially useful in predicting the amount of HRWRA to be used in a concrete mixture. Overall, due to increased water demand for maintaining a slump of about 4 in., addition of paper mill residual solids in concrete resulted in increase in $w / \mathrm{cm}$, negligible increase in air content, and decreases in fresh density and compressive strength of concrete. Addition of high-range water-reducing admixture (HRWRA) resulted in decreases in $w / \mathrm{cm}$ and air content and increases in fresh density and compressive strength. It follows then that, with proper combination of residuals and HRWRA contents, strength of residuals concrete can be made equivalent to that of reference concrete containing no residuals. 
Table 79. Coefficients for Prediction Models of Responses (Series 4)

\begin{tabular}{|c|c|c|c|c|c|}
\hline $\begin{array}{c}\text { Predicted } \\
\text { Response } \\
\qquad \hat{y}\end{array}$ & $\begin{array}{l}\text { Mixture } \\
\text { Group }\end{array}$ & $\begin{array}{c}\text { Average } \\
\hat{b}_{0} \\
\end{array}$ & \begin{tabular}{|c|} 
Coefficient of \\
Variable 1, \\
Residual \\
Content \\
$\hat{b}_{1}$ \\
\end{tabular} & $\begin{array}{c}\text { Coefficient of } \\
\text { Variable 2, } \\
\text { HRWRA } \\
\text { Content } \\
\hat{b}_{2} \\
\end{array}$ & $\begin{array}{c}\text { Coefficient of } \\
\text { Interaction of } \\
\text { Variables } 1 \\
\text { and } 2 \\
\hat{b}_{12}\end{array}$ \\
\hline \multirow[t]{5}{*}{$w / \mathrm{cm}$} & $\mathrm{C} 1$ & 0.43 & 0.02 & -0.05 & 0.00 \\
\hline & $\mathrm{C} 2$ & 0.44 & 0.02 & -0.06 & 0.00 \\
\hline & WG & 0.45 & 0.03 & -0.06 & 0.00 \\
\hline & WV & 0.44 & 0.03 & -0.06 & 0.00 \\
\hline & Overall & 0.44 & 0.03 & -0.06 & 0.00 \\
\hline \multirow{5}{*}{$\begin{array}{c}\text { Air } \\
\text { Content } \\
(\%)\end{array}$} & $\mathrm{C} 1$ & 3.1 & 0.2 & -0.7 & 0.2 \\
\hline & $\mathrm{C} 2$ & 3.0 & 0.0 & -0.5 & 0.2 \\
\hline & WG & 2.4 & 0.0 & -0.4 & -0.2 \\
\hline & WV & 3.2 & 0.1 & -0.4 & 0.2 \\
\hline & \begin{tabular}{|l|} 
Overall \\
\end{tabular} & 2.9 & 0.1 & -0.5 & 0.1 \\
\hline \multirow{5}{*}{$\begin{array}{c}\text { Density } \\
\text { of Fresh } \\
\text { Concrete } \\
\left(\mathrm{lb} / \mathrm{ft}^{3}\right)\end{array}$} & $\mathrm{C} 1$ & 150 & $\begin{array}{l}-1.0 \\
\end{array}$ & 2.3 & $\begin{array}{l}-0.2 \\
\end{array}$ \\
\hline & $\mathrm{C} 2$ & 149 & -1.1 & 2.3 & -0.2 \\
\hline & WG & 150 & -1.1 & 1.9 & 0.5 \\
\hline & WV & 149 & -0.8 & 1.9 & -0.1 \\
\hline & Overall & 150 & -1.0 & 2.1 & 0.0 \\
\hline \multirow{5}{*}{$\begin{array}{c}\text { 28-day } \\
\text { Compressive } \\
\text { Strength } \\
\text { (psi) }\end{array}$} & $\mathrm{C} 1$ & 6840 & -402 & 1180 & $\begin{array}{l}-139 \\
\end{array}$ \\
\hline & $\mathrm{C} 2$ & 6800 & -458 & 766 & -74 \\
\hline & WG & 6140 & -669 & 226 & -317 \\
\hline & WV & 6530 & -389 & 998 & 11 \\
\hline & Overall & 6580 & -479 & 792 & -130 \\
\hline
\end{tabular}

Note: The prediction model for the mean value of $y$ is represented as

$$
\hat{y}=\hat{b}_{0}+\hat{b}_{1} x_{1}+\hat{b}_{2} x_{2}+\hat{b}_{12} x_{1} x_{2}
$$

where:

$x_{1}=$ coded value of residuals content calculated as

(actual value [in $1 b^{*} / 100 \mathrm{lb}$ cement $\left.]-0.68\right) / 0.34$, and

$x_{2}=$ coded value of HRWRA content calculated as

(actual value [in fl oz/100 lb cement] - 6.15) / 3.1.

(* based on LOI at $590^{\circ} \mathrm{C}[\sim$ wood fiber content $]$ )

(The test results and discussions for Series 5 mixtures are presented starting from page 259.) 


\subsubsection{Attempt for Equivalent Strength (Series 6)}

In Series 6 investigation, concrete mixtures were produced with comparable $w / \mathrm{cm}$ in an attempt to obtain comparable strength. Target $w / \mathrm{cm}$ and slump were 0.4 and 3 in., respectively. As-received residuals contents of $0,0.35$, and $0.65 \%$ by weight of concrete were used. Amount of HRWRA required for achieving the target $w / \mathrm{cm}$ at a given residuals content was calculated using the models of $w / \mathrm{cm}$ derived in Series 4 .

Mixture proportions and fresh properties of concrete are presented in Table 80.

Water-cementitious materials ratio $(w / \mathrm{cm})$ ranged from 0.40 to 0.42 . Slump showed wide variation (1 to 8 in.). C2-65 mixture showed lower density than other mixtures.

Table 80. Mixture Proportions and Fresh Properties of Concrete (Series 6)

\begin{tabular}{|c|c|c|c|c|c|c|c|c|c|}
\hline Mixture Name & Ref. & $\mathrm{C} 1-35$ & C1-65 & C2-35 & $\mathrm{C} 2-65$ & $\begin{array}{c}\text { WG- } \\
35\end{array}$ & $\begin{array}{c}\text { WG- } \\
65\end{array}$ & $\begin{array}{c}\text { WV- } \\
35\end{array}$ & $\begin{array}{c}\text { WV- } \\
65\end{array}$ \\
\hline $\begin{array}{l}\text { Residuals, as-recd (\% of } \\
\text { concrete by wt.) }\end{array}$ & 0 & 0.35 & 0.65 & 0.35 & 0.65 & 0.35 & 0.65 & 0.35 & 0.65 \\
\hline Wood Fibers $\uparrow\left(\mathrm{lb} / \mathrm{yd}^{3}\right)$ & 0 & 2.1 & 3.9 & 2.8 & 5.0 & 2.3 & 4.3 & 4.5 & 8.2 \\
\hline $\begin{array}{l}\text { Residuals, LOI at } 590^{\circ} \mathrm{C} \\
\text { (lb/100 lb cement) }\end{array}$ & 0 & 0.45 & 0.82 & 0.53 & 0.97 & 0.47 & 0.86 & 0.78 & 1.45 \\
\hline $\begin{array}{l}\text { HRWRA (fl oz/100 lb } \\
\text { cement) }\end{array}$ & 6.0 & 9.2 & 11.1 & 9.0 & 11.7 & 9.8 & 12.0 & 10.1 & 17.3 \\
\hline Residuals, as-recd (lb/yd $\left.{ }^{3}\right)$ & 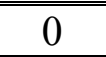 & 14.1 & 26.0 & 14.2 & 25.2 & 14.3 & 26.3 & 14.2 & 25.9 \\
\hline HRWRA (fl oz/yd ${ }^{3}$ ) & 38 & 56 & 68 & 55 & 69 & 61 & 74 & 62 & 105 \\
\hline Cement $\left(\mathrm{lb} / \mathrm{yd}^{3}\right)$ & 626 & 608 & 609 & 613 & 591 & 621 & 616 & 613 & 607 \\
\hline Sand, SSD (lb/yd $\left.{ }^{3}\right)$ & 1460 & 1410 & 1410 & 1420 & 1370 & 1440 & 1430 & 1420 & 1410 \\
\hline $\begin{array}{l}\text { Coarse Aggregate, } 3 / 4 " \\
\max ., \mathrm{SSD}\left(\mathrm{lb} / \mathrm{yd}^{3}\right)\end{array}$ & 1770 & 1720 & 1720 & 1730 & 1670 & 1750 & 1740 & 1730 & 1720 \\
\hline Water $\left(\mathrm{lb} / \mathrm{yd}^{3}\right)$ & 263 & 250 & 242 & 253 & 237 & 254 & 246 & 250 & 250 \\
\hline$w / \mathrm{cm}$ & 0.42 & 0.41 & 0.40 & 0.41 & 0.40 & 0.41 & 0.40 & 0.41 & 0.41 \\
\hline Slump (in.) & 5 & 7 & 6 & 8 & 2.25 & 7 & 2.25 & 3 & 1 \\
\hline Air Content (\%) & 2.0 & 3.7 & 3.7 & 2.8 & 3.8 & 1.7 & 2.4 & 3.2 & 2.9 \\
\hline Density $\left(\mathrm{lb} / \mathrm{ft}^{3}\right)$ & 152 & 148 & 149 & 149 & 144 & 151 & 150 & 149 & 149 \\
\hline
\end{tabular}

$\dagger$ From residuals, dry basis 
Compressive strength of concrete was determined at 3,7 , and 28 days by testing three cylinders at each test age for each mixture. The results are presented in Table 81 and Fig. 91 to 95 . Strengths of $\mathrm{C} 1$ and $\mathrm{C} 2$ mixtures were almost equivalent to that of Reference concrete. However, in spite of almost equivalent density of concrete, WG and WV mixtures showed considerable decrease in strength with the increase in residuals content. Strength of WG concrete (Fig. 95) decreased more sharply than it did in Series 2 (Fig. 96), for which no HRWRA was used. The reason for this is not known. To achieve equivalent strength of concrete containing residuals, especially $\mathrm{WG}$ and $\mathrm{WV}$, a different approach was used in Series 7.

It is noteworthy that although Series 6 concrete mixtures showed lower $w / \mathrm{cm}$ (0.41 vs. 0.49) and higher density (150 vs. $\left.148 \mathrm{lb} / \mathrm{ft}^{3}\right)$ than Series 2 mixtures (Table 80 vs. Table 57) (with residuals content $\leq 0.65 \%$ ), average 28-day compressive strengths of both Series of concrete were about the same (Fig. 95 vs. Fig. 96).

One of the improvements for Series 6 made over Series 2 was the increase of slump. For concrete with as-received residual content of about $0.65 \%$, slump increased from about 0.8 in. for Series 2 to about 3 in. for Series 6.

Table 81. Compressive Strength of Concrete (in psi) (Series 6)

\begin{tabular}{|c||c||c|c|c|c|c|c||c|c|}
\hline Age (days) & Ref. & C1-35 & C1-65 & C2-35 & C2-65 & WG-35 & WG-65 & WV-35 & WV-65 \\
\hline \hline 3 & 5520 & 5240 & 4950 & 4930 & 4690 & 4830 & 3860 & 4780 & 3590 \\
\hline 7 & 6360 & 6070 & 6000 & 5900 & 5770 & 5440 & 4390 & 5640 & 4310 \\
\hline 28 & 7470 & 7250 & 7220 & 6970 & 6770 & 6030 & 4730 & 6310 & 5340 \\
\hline
\end{tabular}




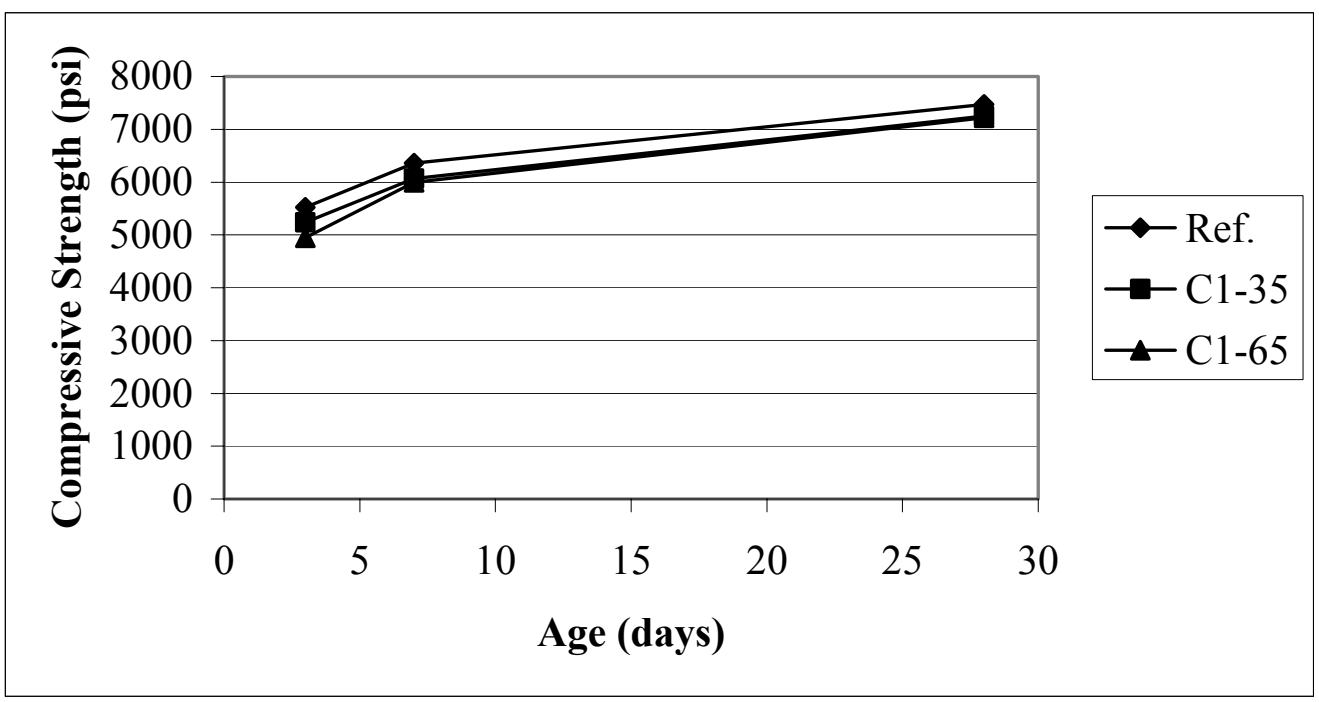

Fig. 91. Compressive strength vs. age (Series 6: C1)

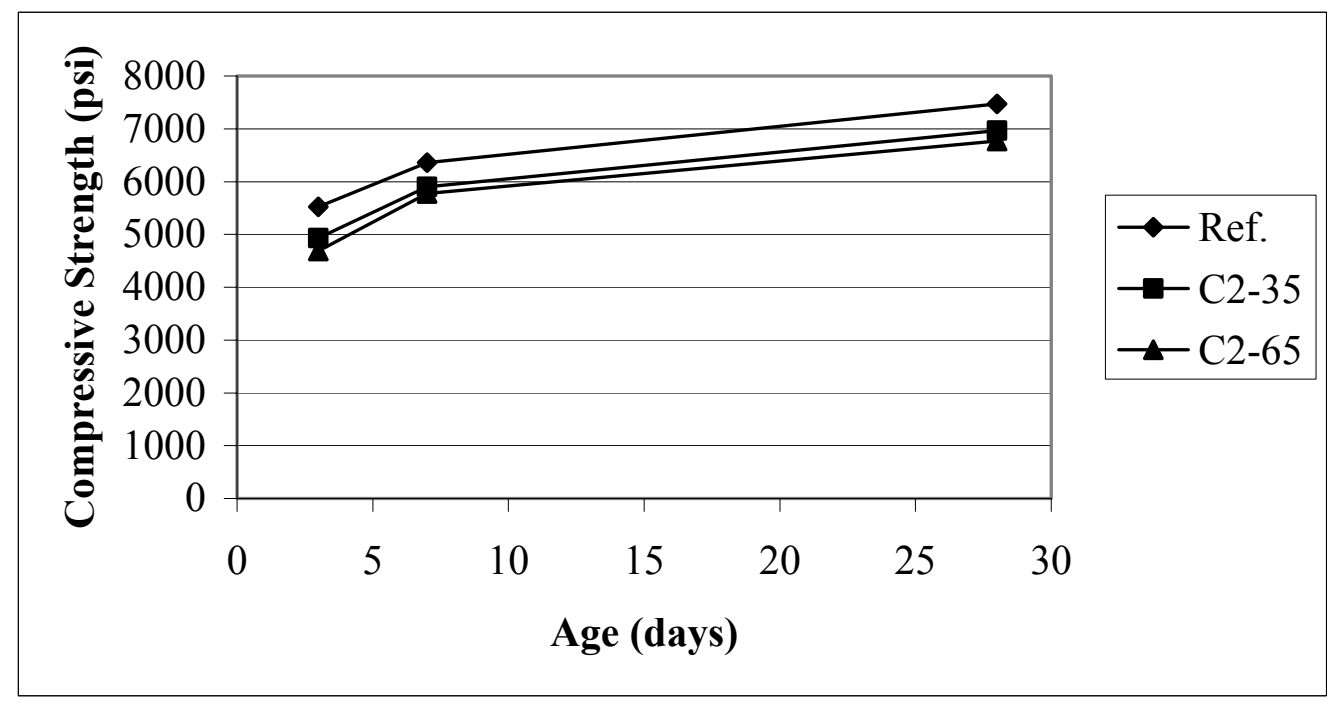

Fig. 92. Compressive strength vs. age (Series 6: C2) 


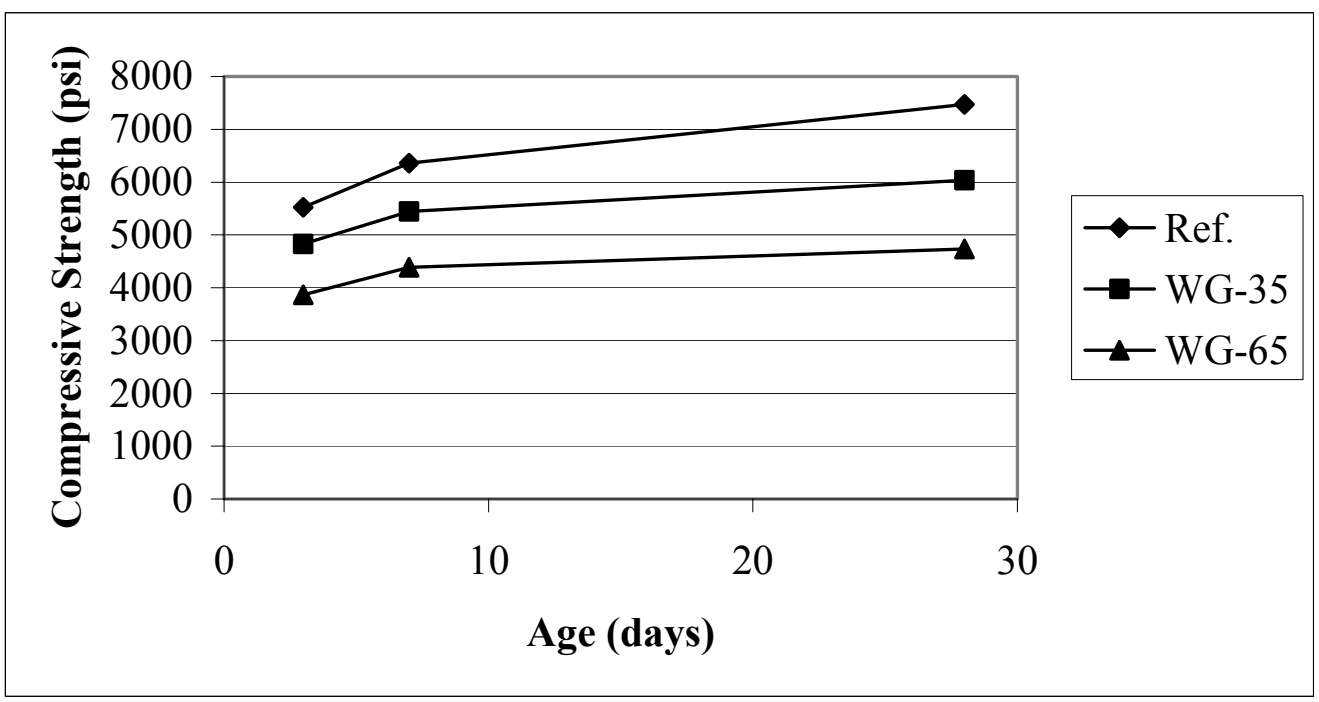

Fig. 93. Compressive strength vs. age (Series 6: WG)

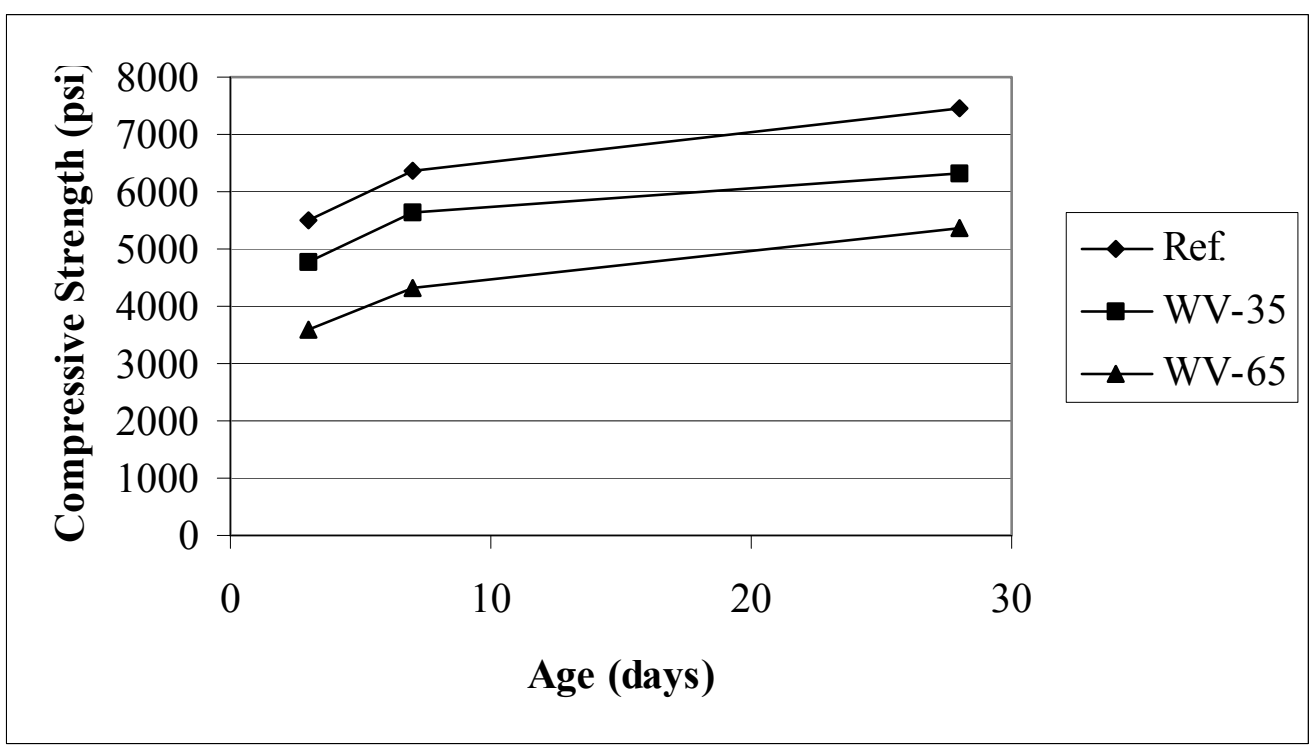

Fig. 94. Compressive strength vs. age (Series 6: WV) 


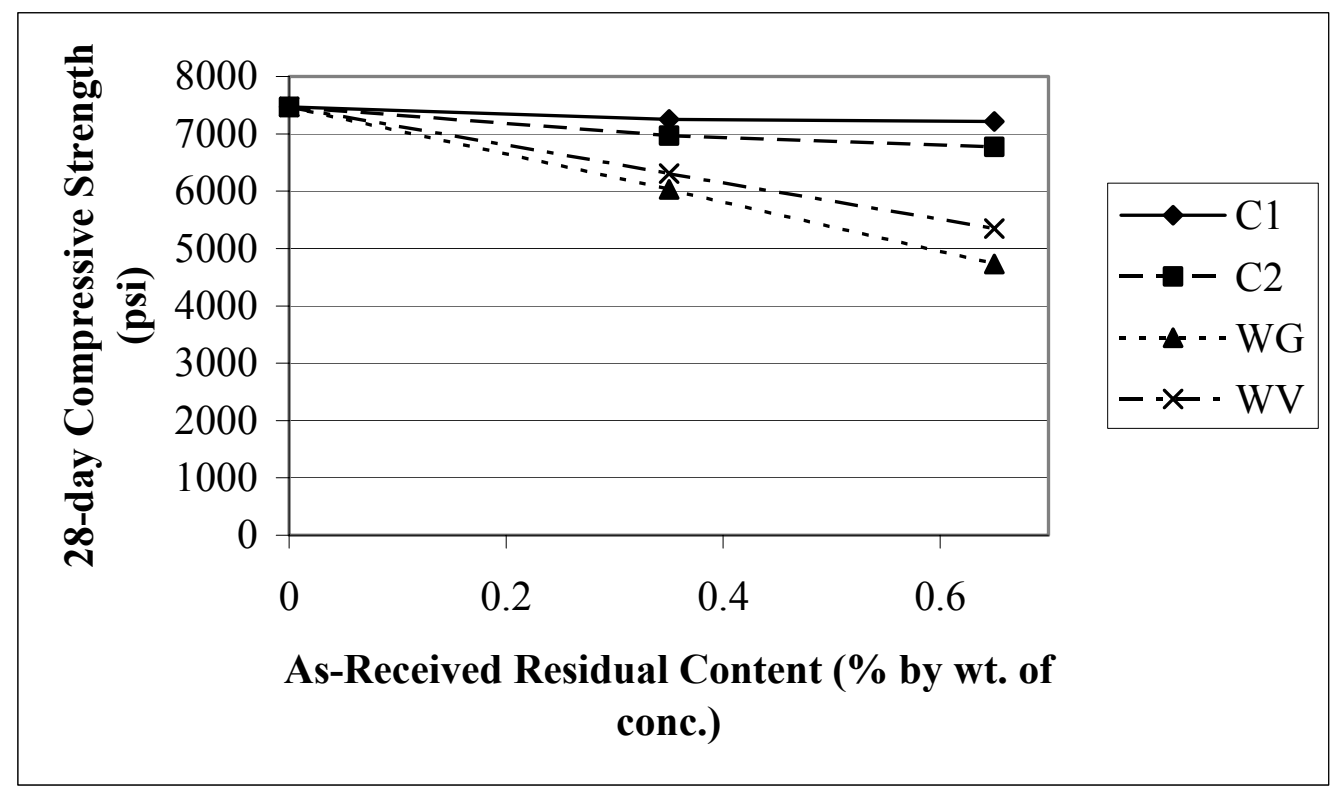

Fig. 95. 28-day compressive strength vs. as-received residual content (Series 6)

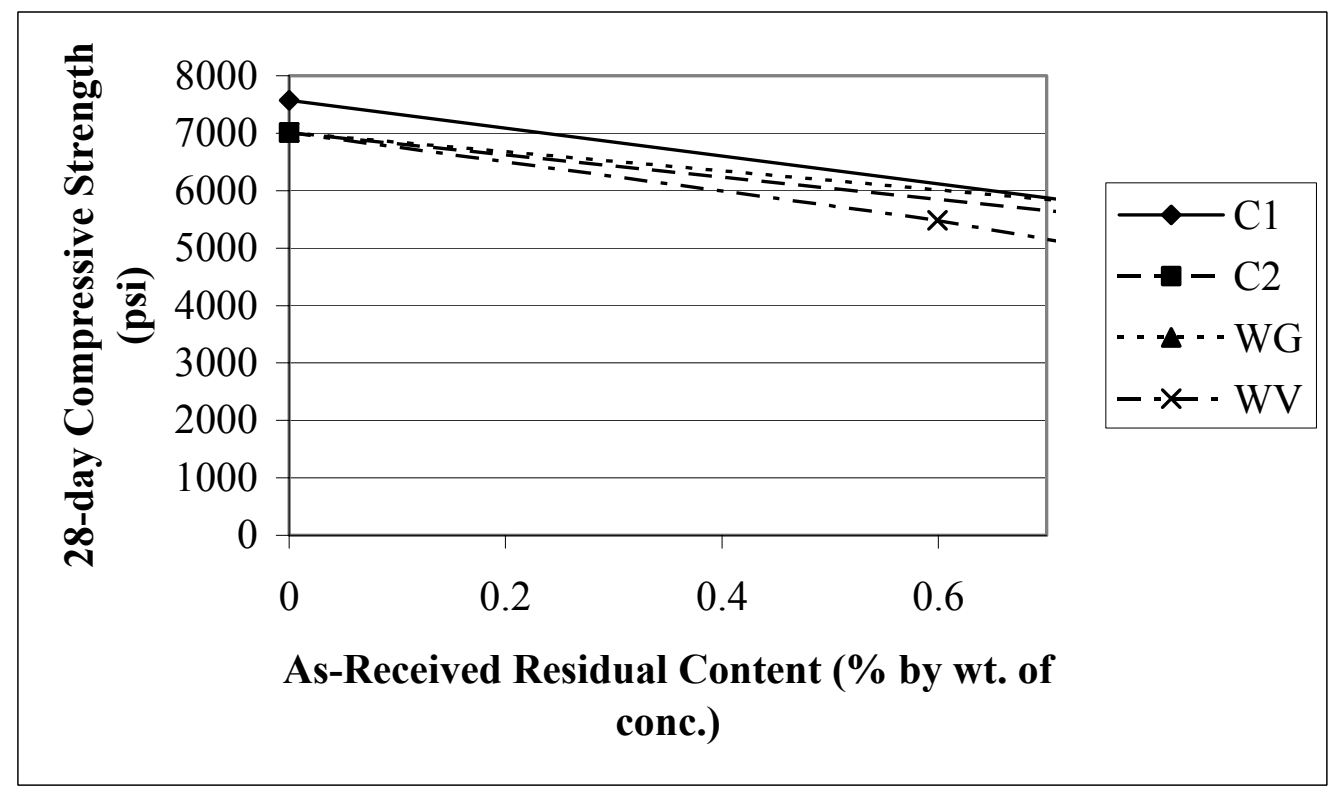

Fig. 96. 28-day compressive strength vs. as-received residual content (Series 2) (partial reproduction of Fig. 68.) 


\subsubsection{Equivalent Strength for C1, C2, WG, and WV (Series 7)}

The objective of Series 7 investigation was to produce residuals concrete equivalent to Reference Concrete in slump and compressive strength by keeping the density of concrete at a constant level. Cement, sand, and coarse aggregate are denser than residual solids, HRWRA, and water. If parts of cement, sand, and coarse aggregate in a unit volume of concrete are displaced due to the addition of residuals, it may be expected that the residuals concrete would have lower strength than Reference Concrete.

Amount of mixing water in concrete was adjusted so that one part of as-received residuals plus HRWRA introduced would replace one part of mixing water on volume basis. This would lead to: (1) constant total volume of mixing water, residual solids, and HRWRA; (2) constant total volume of cement, sand, and coarse aggregate; and (3) more uniform density of concrete.

As-received residuals consist of 100 parts of solid and $M C$ parts of water by mass. Here, $M C$ is moisture content of residuals on oven-dry basis shown without the $\%$ sign. One pound of as-received residuals contain $100 /(100+M C) \mathrm{lb}$ of solid and $M C /(100+$ $M C) \mathrm{lb}$ of water.

Since the solid portion of the residuals is $S G$ times denser than water, the solid in one pound of as-received residuals occupies same volume as 100/[(100+MC) x $S G] \mathrm{lb}$ of mixing water. Here, $S G$ is specific gravity of the residuals on oven-dry basis, or specific gravity of the solid. Of course, the water in one pound of as-received residuals occupies same volume as $M C /(100+M C) \mathrm{lb}$ of mixing water.

On the other hand, one fluid ounce ( $\mathrm{fl} \mathrm{oz}$ ) of HRWRA occupies a volume of 29.6 $\mathrm{mL}$, which corresponds to the volume occupied by $29.6 \mathrm{~g}$ or $29.6 / 454 \mathrm{lb}$ of water. 
Therefore, the amount of mixing water to be replaced with $R \mathrm{lb}$ of as-received residuals and $H$ fl. oz. of HRWRA is

$$
\left(\frac{100}{S G}+M C\right) \frac{R}{100+M C}+\frac{29.6}{454} H(\mathrm{lb})
$$

For example, for a cubic yard of concrete, the amount of mixing water that needs to be replaced with $25 \mathrm{lb}$ of as-received residual $(M C=150 \%, S G=1.80)$ and $50 \mathrm{fl} \mathrm{oz}$ of HRWRA is

$$
\begin{gathered}
\left(\frac{100}{1.80}+150\right) \frac{25}{100+150}+\frac{29.6}{454} 50 \\
=5.56+15+3.26 \\
=23.8(\mathrm{lb})
\end{gathered}
$$

So, if a control mixture without residuals or HRWRA was made with $270 \mathrm{lb}$ of mixing water per cubic yard of concrete, then the amount of mixing water to be used in the residuals concrete would have to be reduced to about $246 \mathrm{lb}$ per cubic yard (about $9 \%$ reduction) in order to keep the density of concrete at the same level.

In Series 7 investigation, as-received Residuals C1, C2, WG, and WV were used at residuals content of 0.35 and $0.65 \%$ by mass of concrete. Reference concrete without residuals was made for comparison. Overall, amount of HRWRA was reduced from that of Series 6 mixtures. Concrete mixture proportions and fresh properties of concrete are presented in Table 82 for Series 7 concrete mixtures.

Average $w / \mathrm{cm}$ was about 0.43 . Water-cementitious materials ratio $(w / \mathrm{cm})$ slightly decreased as the residual content increased. Slump was in the range of 2 to 6 in. As planned, the density of concrete was relatively uniform. 
Table 82. Mixture Proportions and Fresh Properties of Concrete (Series 7)

\begin{tabular}{|c|c|c|c|c|c|c|c|c|c|}
\hline Mixture Name & Ref. & $\mathrm{C} 1-35$ & $\mathrm{C} 1-65$ & $\mathrm{C} 2-35$ & $\mathrm{C} 2-65$ & $\begin{array}{c}\text { WG- } \\
35 \\
\end{array}$ & $\begin{array}{c}\text { WG- } \\
65 \\
\end{array}$ & $\begin{array}{c}\mathrm{WV}- \\
35 \\
\end{array}$ & $\begin{array}{c}\mathrm{WV}- \\
65 \\
\end{array}$ \\
\hline $\begin{array}{l}\text { Residuals, as-recd (\% of } \\
\text { concrete by wt.) }\end{array}$ & 0 & 0.35 & 0.65 & 0.35 & 0.65 & 0.35 & 0.65 & 0.35 & 0.64 \\
\hline Wood Fibers $\left(\mathrm{lb} / \mathrm{yd}^{3}\right) \dagger$ & 0 & 2.1 & 3.9 & 2.8 & 5.2 & 2.3 & 4.2 & 4.4 & 8.2 \\
\hline $\begin{array}{l}\text { Residuals, LOI at } 590^{\circ} \mathrm{C} \\
(\mathrm{lb} / 100 \mathrm{lb} \text { cement })\end{array}$ & 0 & 0.45 & 0.82 & 0.53 & 0.97 & 0.47 & 0.86 & 0.78 & 1.45 \\
\hline $\begin{array}{l}\text { HRWRA (fl oz/100 lb } \\
\text { cement) }\end{array}$ & 3.4 & 6.2 & 8.7 & 6.7 & 10.6 & 7.2 & 9.6 & 8.4 & 14.3 \\
\hline Residuals, as-recd (lb/yd $\left.{ }^{3}\right)$ & 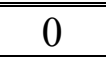 & 14.0 & 25.8 & 14.0 & 26.0 & 14.1 & 26.0 & 13.9 & 25.9 \\
\hline HRWRA (fl oz/yd H $^{3}$ & 20.7 & 37.4 & 52.7 & 40.6 & 64.5 & 43.9 & 58.5 & 50.5 & 86.6 \\
\hline Cement $\left(\mathrm{lb} / \mathrm{yd}^{3}\right)$ & 613 & 608 & 605 & 607 & 610 & 609 & 609 & 601 & 607 \\
\hline Sand, SSD (lb/yd $\left.{ }^{3}\right)$ & 1430 & 1420 & 1410 & 1420 & 1420 & 1420 & 1420 & 1400 & 1420 \\
\hline $\begin{array}{l}\text { Coarse Aggregate, } 3 / 4 " \\
\max ., \operatorname{SSD}\left(1 \mathrm{~b} / \mathrm{yd}^{3}\right)\end{array}$ & 1720 & 1710 & 1700 & 1710 & 1720 & 1710 & 1710 & 1690 & 1710 \\
\hline Water $\left(\mathrm{lb} / \mathrm{yd}^{3}\right)$ & 277 & 263 & 252 & 262 & 254 & 265 & 256 & 258 & 255 \\
\hline$w / \mathrm{cm}$ & 0.45 & 0.43 & 0.42 & 0.43 & 0.42 & 0.43 & 0.42 & 0.43 & 0.42 \\
\hline Slump (in.) & 4.5 & 3.5 & 4 & 3.5 & 4 & 6 & 5.5 & 3.5 & 2 \\
\hline Air Content (\%) & 1.8 & 2.8 & 3.2 & 2.5 & 2.3 & 2.0 & 1.9 & 3.2 & 2.8 \\
\hline Density $\left(\mathrm{lb} / \mathrm{ft}^{3}\right)$ & 150 & 149 & 148 & 149 & 149 & 149 & 149 & 147 & 149 \\
\hline
\end{tabular}

$\dagger$ From residuals, dry basis

Compressive strength of concrete was determined at 3, 7, and 28 days by testing three cylinders at each test age for each mixture. Regardless of residuals content, compressive strength of concrete was almost uniform for all the mixtures of Series 7 (Table 83 and Fig. 97 to 103). This was a breakthrough proof of the use of pulp and paper mill residual solids in concrete. Average 28-day compressive strength was about 7130 psi. Compressive strength of C-35, C-65, WG-35, and WV-35 concrete mixtures was even higher than that of Reference concrete containing no residuals.

Mixture proportions for Ref., C1-65, C2-65, WG-65, and WV-65 mixtures of Series 7 formed the basis of the mixture proportions used in Series 9 for the evaluation of 
time of setting, average-residuals strength, and durability of concrete containing Residual C1, C2, WG, or WV (p. 123).

Table 83. Compressive Strength of Concrete (in psi) (Series 7)

\begin{tabular}{|c||c||c|c||c|c||c|c||c|c||}
\hline Age (days) & Ref. & C1-35 & C1-65 & C2-35 & C2-65 & WG-35 & WG-65 & WV-35 & WV-65 \\
\hline \hline 3 & 4830 & 5090 & 4970 & 4950 & 5100 & 5250 & 4830 & 5180 & 4440 \\
\hline 7 & 5720 & 5900 & 5710 & 5750 & 5980 & 6240 & 5780 & 6310 & 5400 \\
\hline 28 & 7060 & 6970 & 6970 & 7350 & 7260 & 7450 & 6930 & 7510 & 6860 \\
\hline
\end{tabular}

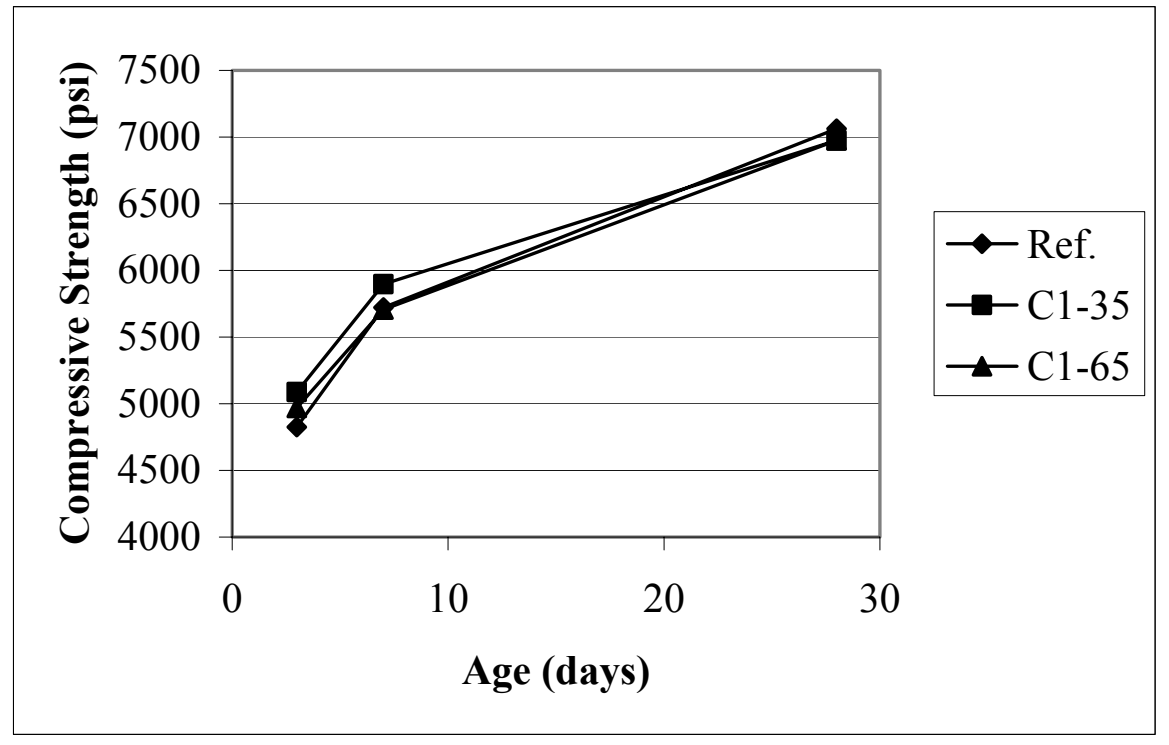

Fig. 97. Compressive strength vs. age (Series 7: C1) 


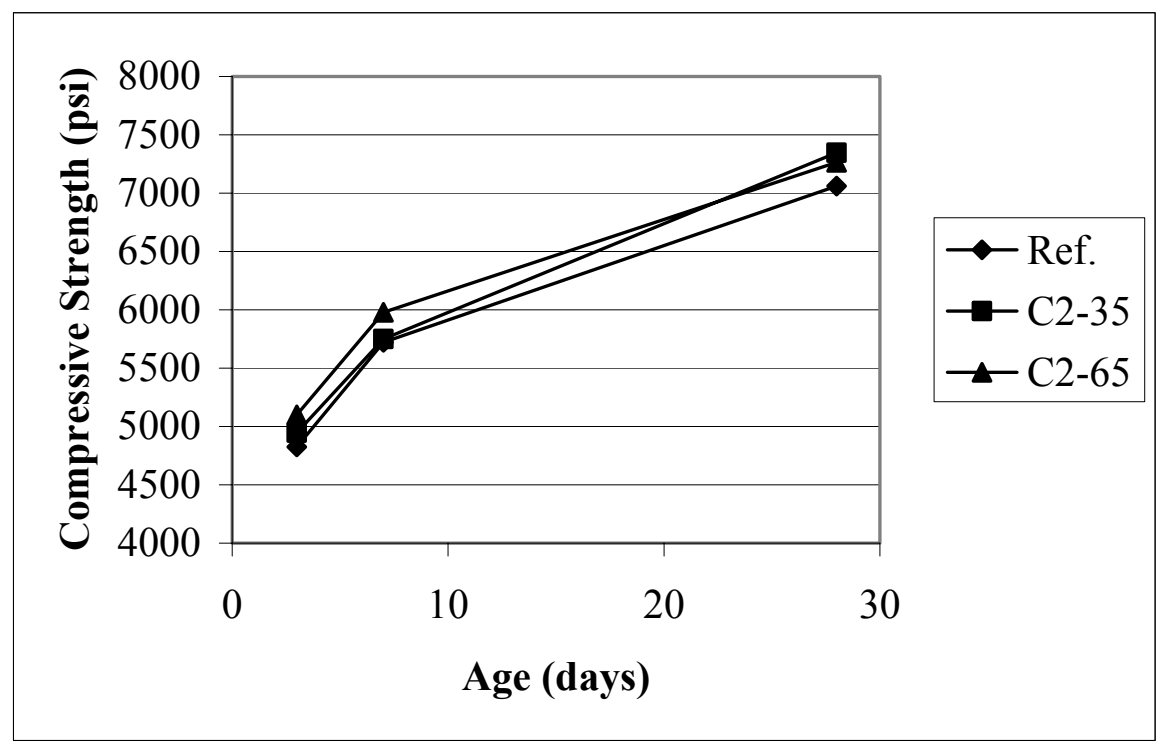

Fig. 98. Compressive strength vs. age (Series 7: C2)

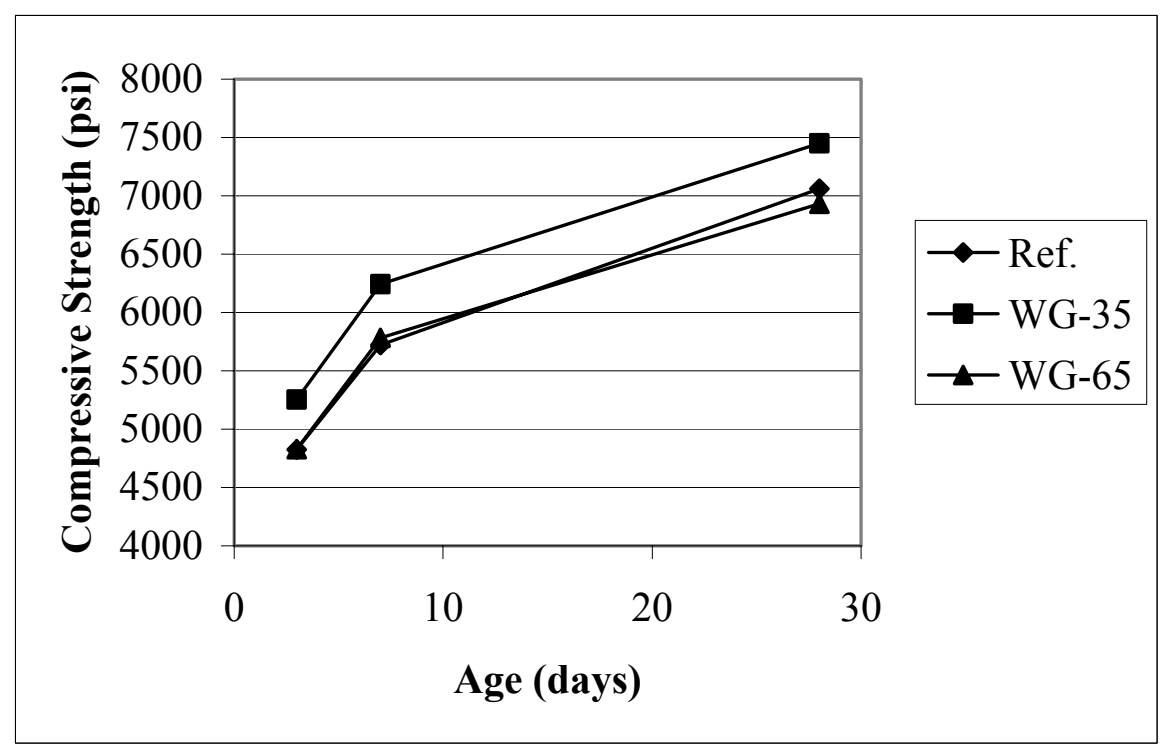

Fig. 99. Compressive strength vs. age (Series 7: WG) 


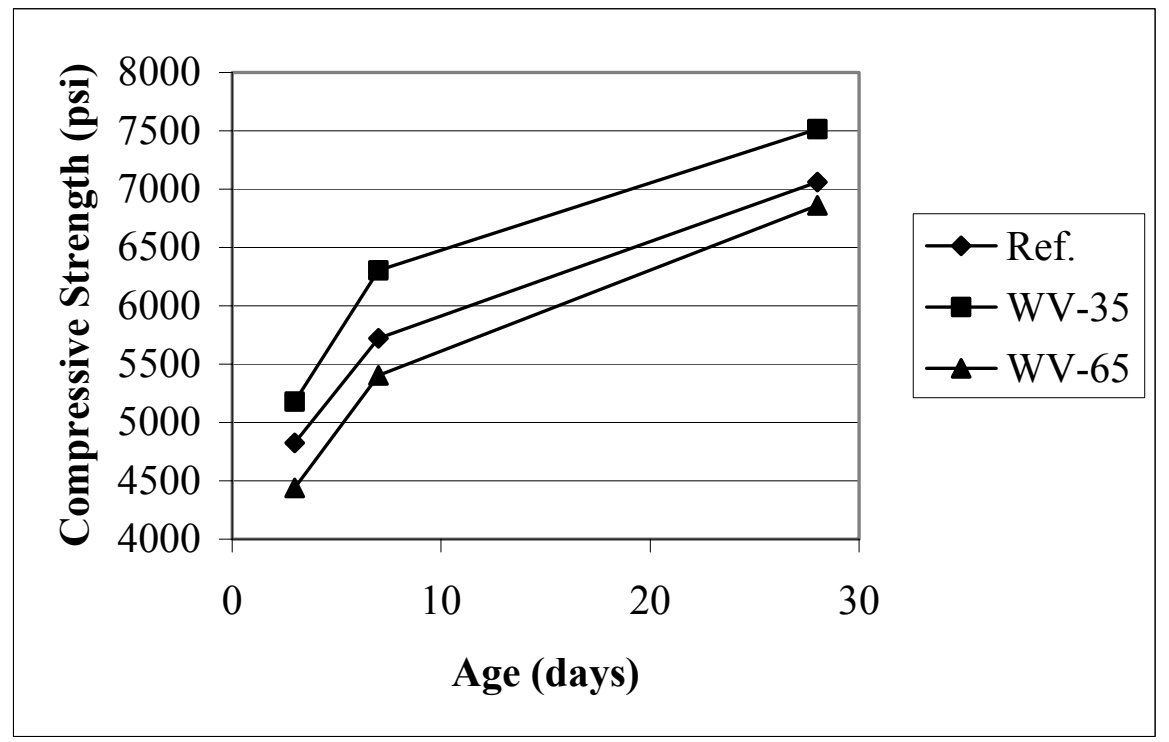

Fig. 100. Compressive strength vs. age (Series 7: WV)

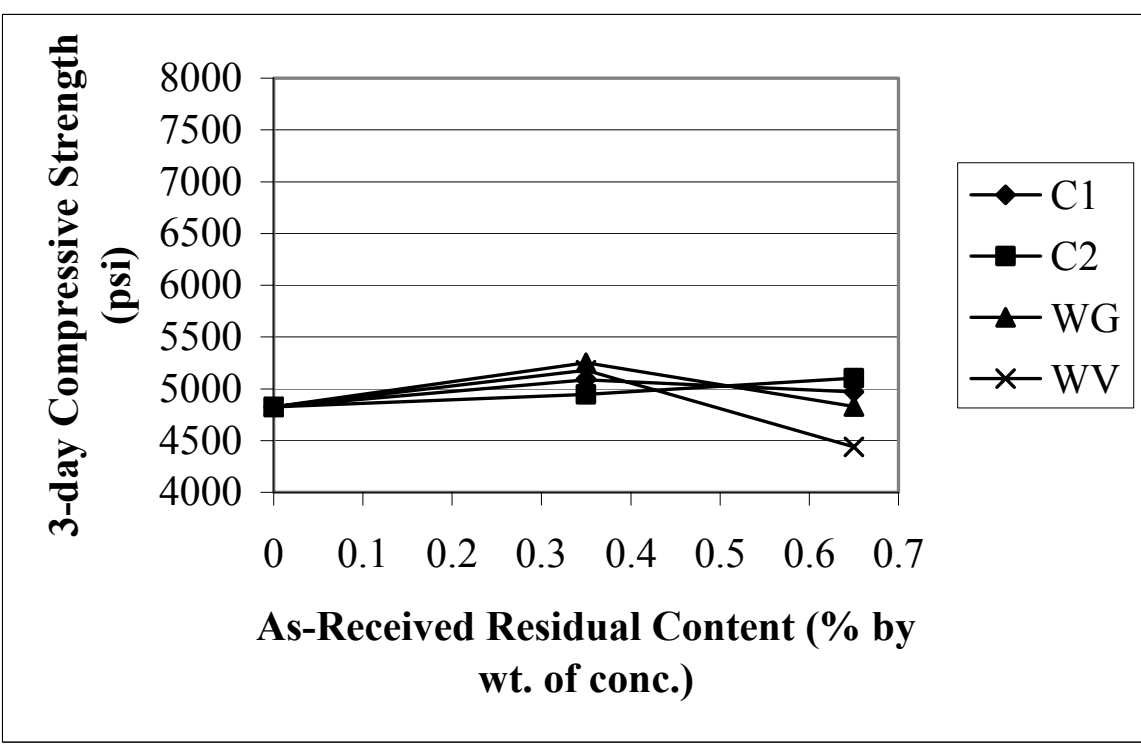

Fig. 101. 3-day compressive strength vs. as-received residuals content (Series 7) 


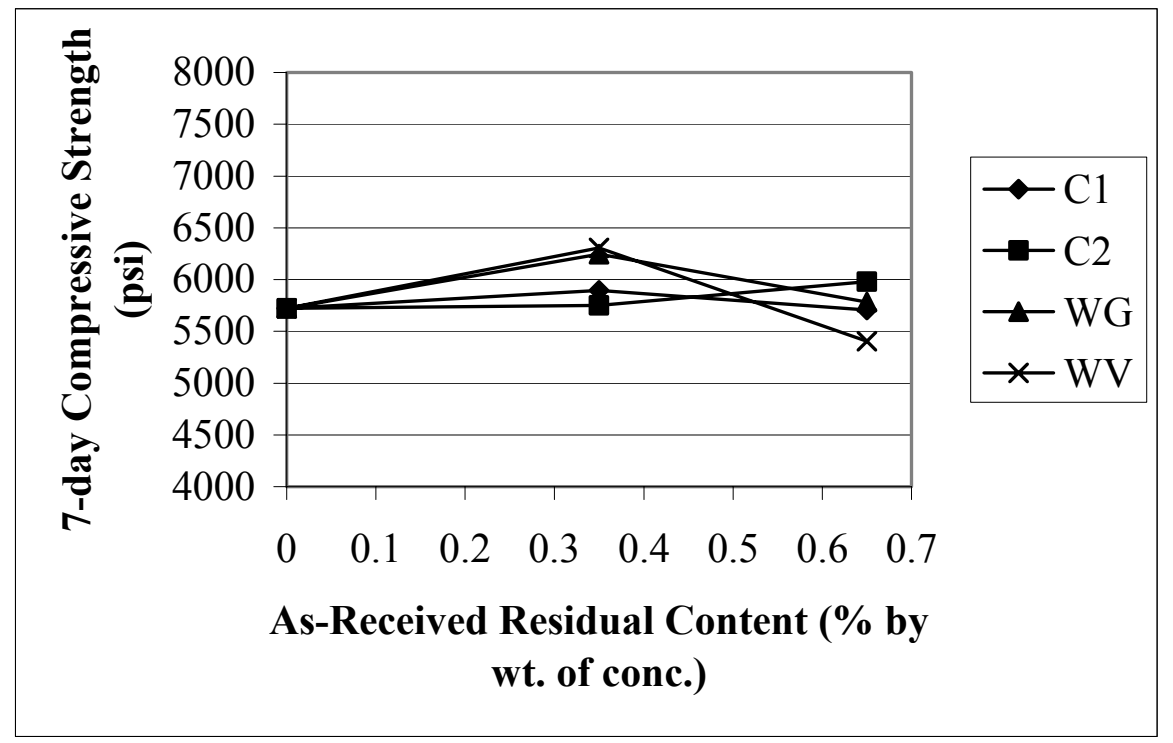

Fig. 102. 7-day compressive strength vs. as-received residuals content (Series 7)

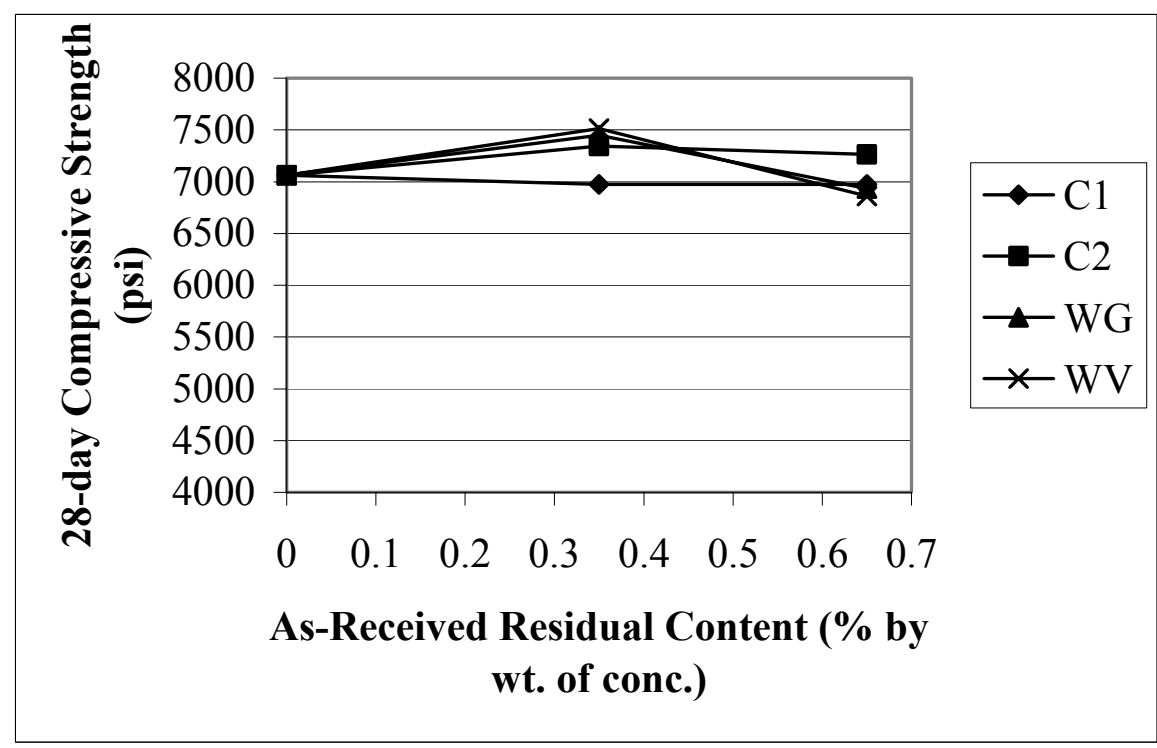

Fig. 103. 28-day compressive strength vs. as-received residuals content (Series 7)

(The test results and discussions for Series 8, 9, and 10 mixtures are presented starting from pages 261,123 , and 267 , respectively.) 


\subsubsection{Equivalent Strength for BR, I, and S (Series 11)}

A series of concrete mixtures containing I, S, and BR residuals were made at as-received residuals contents of $0,0.35$, and $0.65 \%$ by weight of concrete. The objective was to produce residual concrete comparable to Reference Concrete in slump and compressive strength. Amount of mixing water was adjusted as in Series 7 in order to keep the density of concrete constant regardless of residuals content in concrete. Mixture proportions for Reference concrete were same as those used in Series 7. Amount of HRWRA was adjusted during mixing to achieve a target slump of about $3 \pm 1$ in.

Concrete mixture proportions and fresh properties of concrete are presented in Table 84. Segregation of fresh concrete was observed for BR-65 mixtures containing 19.5 fl. oz. of HRWRA per $100 \mathrm{lb}$ of cement. Slump of concrete ranged from 2.25 to 4.5 inches. Air content ranged from 1.9 to $2.5 \%$. Almost uniform density of concrete was achieved.

For each mixture, compressive strength of concrete was determined by testing three cylinders at 28 days. The results are presented in Table 85 and Fig. 104 to 106. Equivalent compressive strength was achieved for I and $\mathrm{S}$ residuals. Reduction in strength of concrete was observed for BR content of $0.65 \%$.

Mixture proportions for Ref., BR-35, I-65, and S-65 mixtures of Series 11 were used in Series 12 for the evaluation of time of setting, average-residuals strength, and durability of concrete containing Residual BR, I, or S (p. 123). 
Table 84. Mixture Proportions and Fresh Properties of Concrete (Series 11)

\begin{tabular}{|c|c|c|c|c|c|c|c|}
\hline Mixture Name & Ref. & $\mathrm{I}-35$ & I-65 & S-35 & S-65 & BR-35 & BR-65 \\
\hline $\begin{array}{l}\text { Residuals, as-recd (\% of } \\
\text { concrete by wt.) }\end{array}$ & 0 & 0.35 & 0.64 & 0.35 & 0.64 & 0.35 & 0.64 \\
\hline Wood Fibers $\left(\mathrm{lb} / \mathrm{yd}^{3}\right) \dagger$ & 0 & 2.9 & 5.3 & 3.8 & 6.9 & 4.0 & 7.5 \\
\hline $\begin{array}{l}\text { Residuals, LOI at } 590^{\circ} \mathrm{C} \\
(1 \mathrm{~b} / 100 \mathrm{lb} \text { cement })\end{array}$ & 0 & 0.59 & 1.09 & 0.73 & 1.34 & 0.70 & 1.29 \\
\hline $\begin{array}{l}\text { HRWRA (fl oz/100 lb } \\
\text { cement) }\end{array}$ & 3.5 & 7.1 & 14.6 & 9.5 & 23.3 & 6.2 & 19.5 \\
\hline Residuals, as-recd (lb/yd $\left.{ }^{3}\right)$ & 0 & 14.3 & 26.1 & 14.2 & 26.0 & 14.0 & 26.3 \\
\hline HRWRA (fl oz/yd H $^{3}$ ) & 21.3 & 43.6 & 89.2 & 58.3 & 142.0 & 37.4 & 120.4 \\
\hline Cement $\left(\mathrm{lb} / \mathrm{yd}^{3}\right)$ & 616 & 617 & 612 & 616 & 610 & 607 & 617 \\
\hline Sand, SSD (lb/yd $\left.{ }^{3}\right)$ & 1440 & 1440 & 1430 & 1440 & 1420 & 1420 & 1440 \\
\hline $\begin{array}{l}\text { Coarse Aggregate, } 3 / 4 " \\
\max ., \mathrm{SSD}\left(\mathrm{lb} / \mathrm{yd}^{3}\right)\end{array}$ & 1740 & 1740 & 1730 & 1740 & 1720 & 1720 & 1740 \\
\hline Water $\left(\mathrm{lb} / \mathrm{yd}^{3}\right)$ & 273 & 263 & 253 & 264 & 255 & 257 & 253 \\
\hline$w / \mathrm{cm}$ & 0.44 & 0.43 & 0.41 & 0.43 & 0.42 & 0.42 & 0.41 \\
\hline Slump (in.) & 4.25 & 2.75 & 3.75 & 4.5 & 2.5 & 3.5 & 2.25 \\
\hline Air Content (\%) & 1.9 & 2.1 & 1.9 & 2.0 & 2.0 & 2.5 & 1.9 \\
\hline Density $\left(\mathrm{lb} / \mathrm{ft}^{3}\right)$ & 151 & 151 & 150 & 151 & 150 & 149 & 151 \\
\hline
\end{tabular}

$\uparrow$ From residuals, dry basis

Table 85. Compressive Strength of Concrete (in psi) (Series 11)

\begin{tabular}{|c||c||c|c||c|c||c|c||}
\hline Age (days) & Ref. & I-35 & I-65 & S-35 & S-65 & BR-35 & BR-65 \\
\hline \hline 3 & 4930 & 5750 & 5070 & 5170 & 4300 & 5770 & 3240 \\
\hline 7 & 5640 & 6490 & 6010 & 5870 & 5110 & 6490 & 4020 \\
\hline 28 & 6570 & 7710 & 7080 & 6850 & 6120 & 7440 & 4880 \\
\hline
\end{tabular}




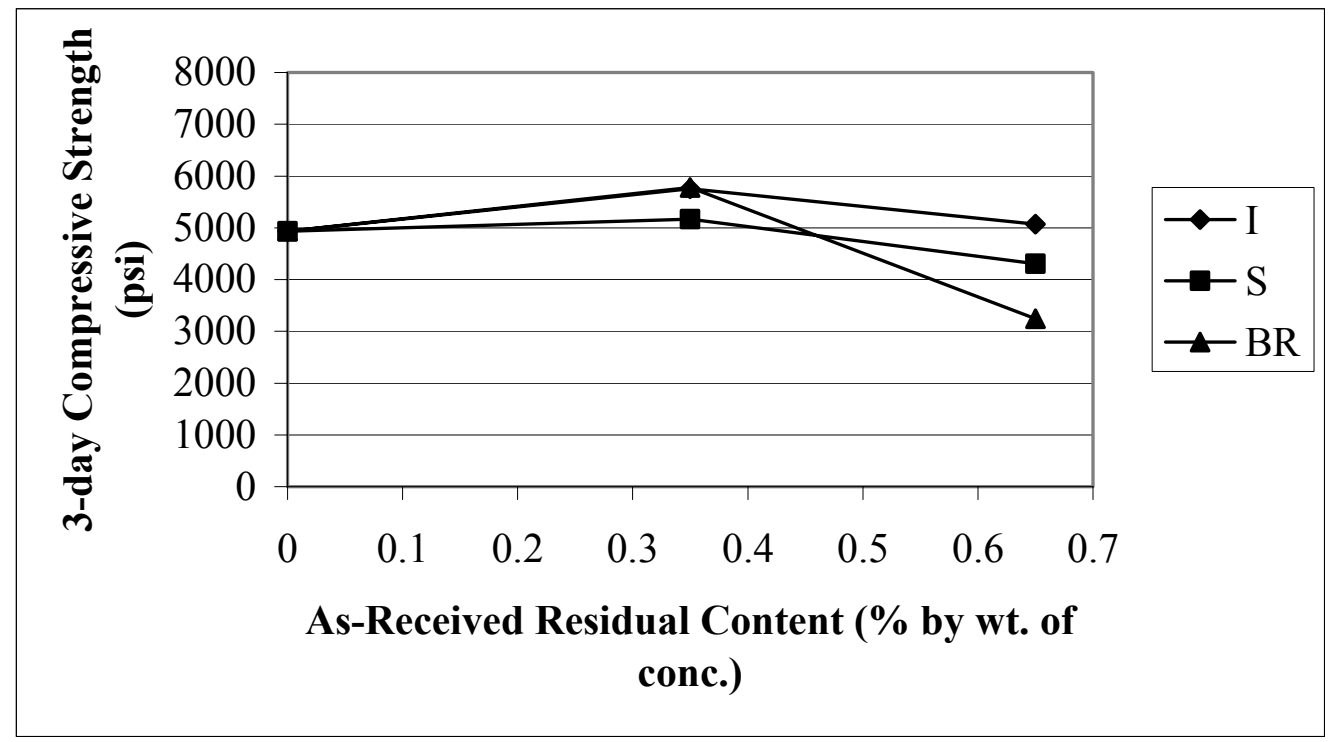

Fig. 104. Compressive strength of concrete vs. residuals content (Series 11)

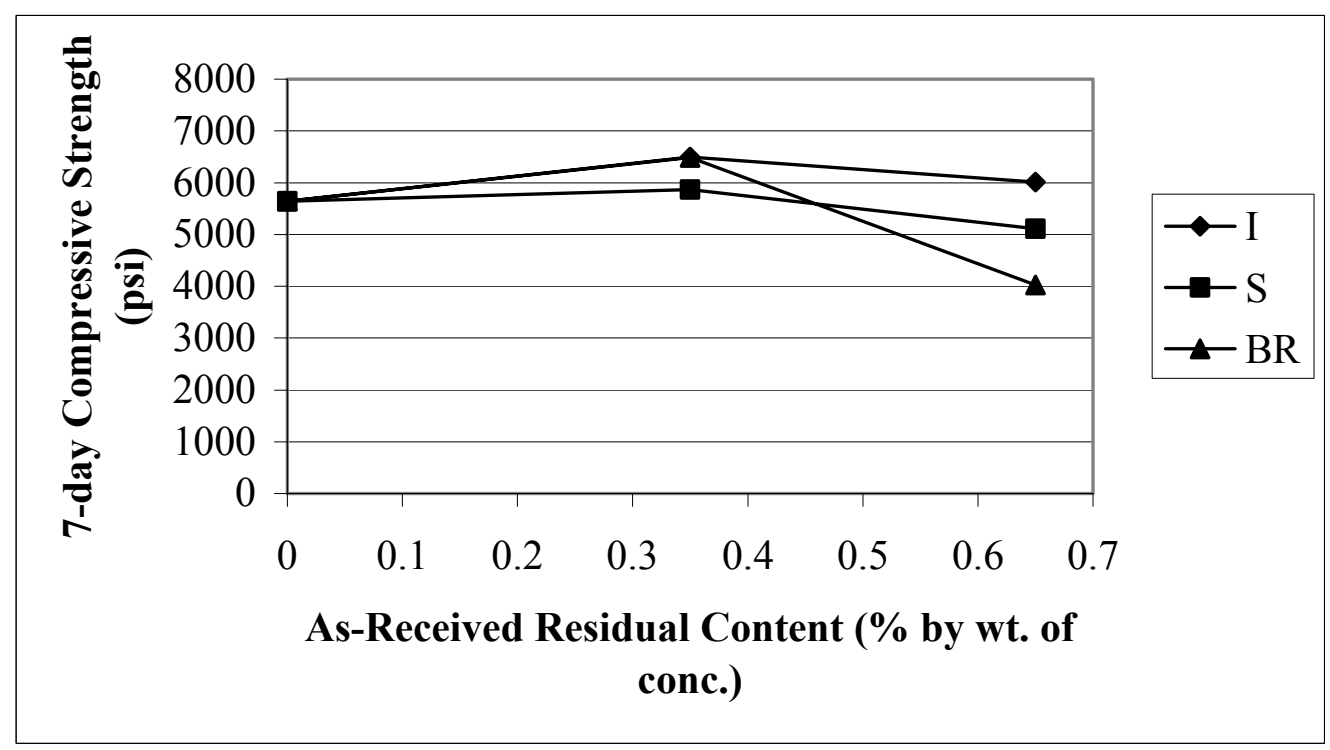

Fig. 105. Compressive strength of concrete vs. residuals content (Series 11) 


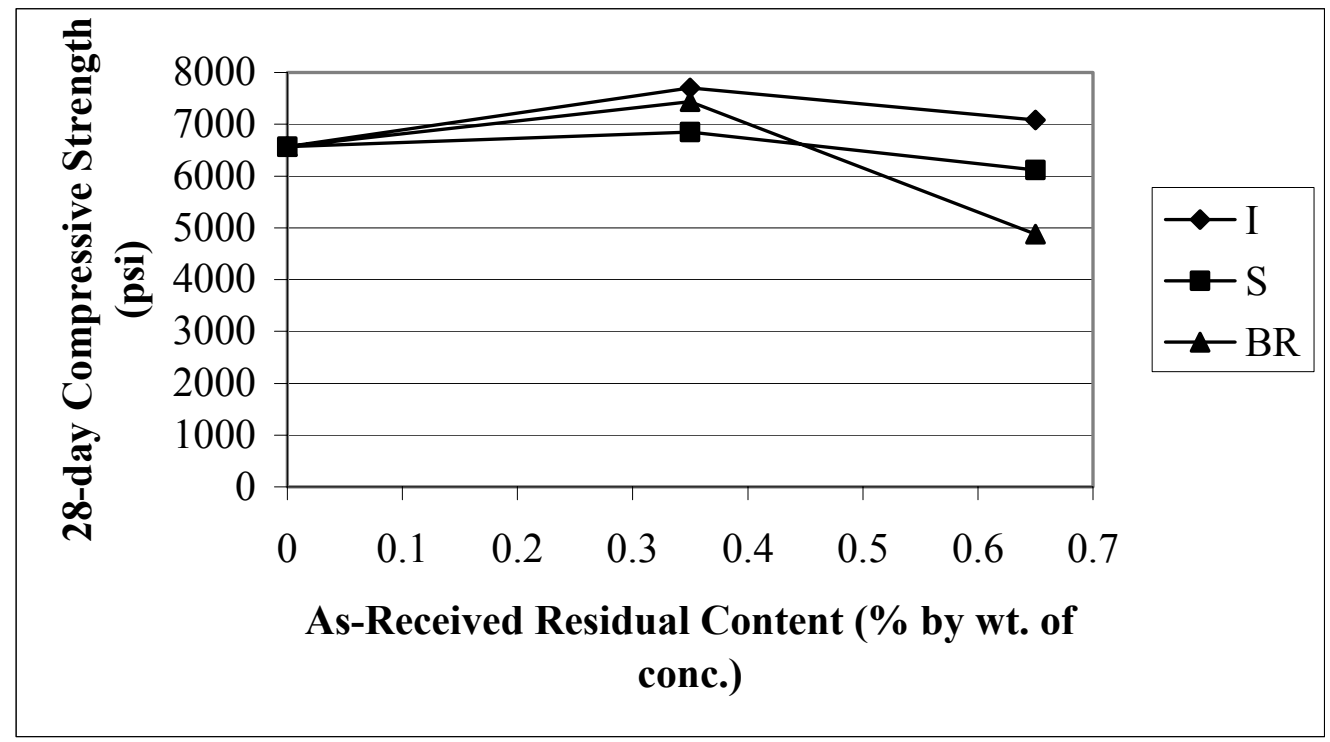

Fig. 106. Compressive strength of concrete vs. residuals content (Series 11)

\subsection{Laboratory Mixtures for Durability and Long-Term Properties}

Based on the mixture proportions that had been established in Series 7 and 11 for achieving equivalent compressive strength for reference and residuals concrete, concrete mixtures (Series 9 and 12) were produced for the evaluation of time of setting, average residual-strength, and durability of concrete. The mixtures were produced in two groups with a three-month interval between them: (1) Reference 1 (without residuals), C1, C2, WG, and WV; and (2) Reference 2 (without residuals), BR, I, and S. As-received residuals content by weight of concrete was $0.65 \%$ for $\mathrm{C} 1, \mathrm{C} 2, \mathrm{WG}, \mathrm{WV}, \mathrm{I}$, and $\mathrm{S}$ residuals, and $0.35 \%$ for BR residual. High-range water-reducing admixture (HRWRA) was used to control the amount of mixing water and slump of concrete. No air-entraining admixture (AEA) was used. Mixture proportions and fresh properties of concrete are presented in Table 86. 
Table 86. Mixture Proportions and Fresh Properties of Concrete (Series 9 and 12)

\begin{tabular}{|c|c|c|c|c|c|c|c|c|c|}
\hline Mixture Name & Ref. 1 & $\mathrm{C} 1$ & $\mathrm{C} 2$ & WG & WV & Ref. 2 & $\overline{\mathrm{BR}}$ & $\overline{\mathrm{I}}$ & $\overline{\mathrm{S}}$ \\
\hline $\begin{array}{l}\text { Residuals, as-recd (\% of } \\
\text { concrete by wt.) }\end{array}$ & 0 & 0.65 & 0.65 & 0.65 & 0.65 & 0 & 0.35 & 0.65 & 0.65 \\
\hline Wood Fibers $\left(\mathrm{lb} / \mathrm{yd}^{3}\right) \dagger$ & 0 & 4.0 & 5.3 & 4.2 & 8.3 & 0 & 4.1 & 5.5 & 7.0 \\
\hline $\begin{array}{l}\text { Residuals, LOI at } 590^{\circ} \mathrm{C} \\
(1 \mathrm{~b} / 100 \mathrm{lb} \text { cement })\end{array}$ & 0 & 0.84 & 0.99 & 0.87 & 1.47 & 0 & 0.70 & 1.11 & 1.36 \\
\hline $\begin{array}{l}\text { HRWRA (fl oz/100 lb } \\
\text { cement) }\end{array}$ & 3.4 & 7.6 & 12.6 & 9.6 & 14.3 & 3.4 & 6.2 & 14.6 & 23.3 \\
\hline Residuals, as-recd (lb/yd $\left.{ }^{3}\right)$ & 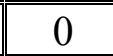 & 26.3 & 26.5 & 26.2 & 26.4 & 0 & 14.4 & 26.9 & 26.5 \\
\hline HRWRA (fl oz/yd ${ }^{3}$ ) & 20.8 & 46.1 & 76.8 & 58.1 & 86.7 & 21.3 & 37.9 & 90.4 & 142.3 \\
\hline Cement $\left(\mathrm{lb} / \mathrm{yd}^{3}\right)$ & 620 & 606 & 611 & 605 & 609 & 618 & 615 & 620 & 611 \\
\hline Sand, SSD (lb/yd $\left.{ }^{3}\right)$ & 1440 & 1410 & 1430 & 1410 & 1420 & 1430 & 1430 & 1440 & 1420 \\
\hline $\begin{array}{l}\text { Coarse Aggregate, 3/4" } \\
\text { max., SSD }\left(\mathrm{lb} / \mathrm{yd}^{3}\right)\end{array}$ & 1760 & 1730 & 1740 & 1720 & 1730 & 1760 & 1750 & 1770 & 1740 \\
\hline Water $\left(\mathrm{lb} / \mathrm{yd}^{3}\right)$ & 263 & 250 & 263 & 272 & 265 & 266 & 254 & 263 & 268 \\
\hline$w / \mathrm{cm}$ & 0.43 & 0.41 & 0.43 & 0.45 & 0.44 & 0.43 & 0.41 & 0.42 & 0.44 \\
\hline Slump (in.) & 4.5 & 3.5 & 6 & 7 & 5 & 3 & 5 & 3.5 & 3 \\
\hline Air Content (\%) & 1.6 & 2.8 & 1.6 & 1.8 & 1.7 & 1.9 & 2.3 & 1.3 & 1.8 \\
\hline Density $\left(\mathrm{lb} / \mathrm{ft}^{3}\right)$ & 151 & 149 & 151 & 150 & 150 & 151 & 150 & 152 & 151 \\
\hline
\end{tabular}

$\uparrow$ From Residuals, dry basis

Depending on the source of residuals, amount of wood fibers (on dry basis) in concrete varied between 4.0 to $8.3 \mathrm{lb} / \mathrm{yd}^{3}$. In general, higher dosage of HRWRA was required for concrete with higher wood fiber content to keep the slump within the range of 3 to 6 in. Water-cement ratios $(w / c)$ of reference and residuals concrete mixtures were similar ( 0.43 vs. 0.43 on average). Overall, air content values of reference and residuals concrete mixtures were similar (1.8 vs. $1.9 \%$ on average). Density of fresh concrete was almost uniform.

Overview of test methods for this research was presented in Tables 47 to 49 on pages 101 through 105. In view of the importance of the current series of concrete mixtures (Series 9 and 12), overview of tests methods, specimens, and test ages specific 
to the current series of mixtures is presented in Table 87 for ready reference. Additional information can be found in Tables 47 to 49 .

Table 87. Test Methods, Specimens, and Test Ages (Series 9 and 12)

\begin{tabular}{|c|c|c|c|c|}
\hline ASTM & Test & Specimens & $\begin{array}{l}\text { Test } \\
\text { Age, } \\
\text { day(s) }\end{array}$ & $\begin{array}{c}\text { Number of } \\
\text { Specimens per } \\
\text { Test Age for } \\
\text { Each Mixture }\end{array}$ \\
\hline C 403 & $\begin{array}{l}\text { Time of } \\
\text { Setting }\end{array}$ & $\begin{array}{l}\text { Mortar obtained by sieving fresh } \\
\text { concrete through a } 4.75-\mathrm{mm} \text { sieve }\end{array}$ & 0 & 2 \\
\hline C 39 & $\begin{array}{l}\text { Compressive } \\
\text { Strength }\end{array}$ & 4" x 8" cylinders & $\begin{array}{c}7,28 \\
91\end{array}$ & 3 \\
\hline C 1399 & $\begin{array}{l}\text { Avg. Residual- } \\
\text { Strength }\end{array}$ & 4" x 4" x 14" beams & 112 & $2^{\#}$ \\
\hline C 157 & Length Change & 3" x 3" x 11 1/4" beams & $1 \dagger$ & 3 \\
\hline C 944 & $\begin{array}{l}\text { Abrasion } \\
\text { Resistance* }\end{array}$ & $\begin{array}{l}\text { Top surface of } 1.75 \text {-in. thick slices } \\
\text { saw-cut from the top of } 6 " \text { x } 12 " \\
\text { cylinders }\end{array}$ & 28 & 3 \\
\hline C 1202 & $\begin{array}{l}\text { Resistance to } \\
\text { Chloride-Ion } \\
\text { Penetration }\end{array}$ & $\begin{array}{l}\text { 2-in. thick slices saw-cut from the } \\
\text { top of } 4 " \text { x } 8 \text { " cylinders }\end{array}$ & 28 & 3 \\
\hline C 666, A & \begin{tabular}{|l|} 
Resistance to \\
Rapid Freezing \\
and Thawing
\end{tabular} & 3" x 4" x 16" beams & $42 \dagger$ & 3 \\
\hline C 672 & $\begin{array}{l}\text { Salt-Scaling } \\
\text { Resistance }\end{array}$ & Top surface of 9" x 9" x 3" blocks & $28 \dagger+$ & 2 \\
\hline
\end{tabular}

\# One specimen and two specimens were used for determining flexural strength and average residual-strength, respectively.

$\dagger$ Test start age

* Double load (44 lbf) was used.

$\$$ Moist-cured until the age of 14 days, and then cured in air for 14 days at $73.5 \pm 3.5^{\circ} \mathrm{F}$ and $50 \pm 5 \%$ relative humidity.

\subsubsection{Time of Setting}

Time of setting test results are presented in Table 88 and Fig. 107. Time of setting of mortar fraction of concrete increased in proportion to HRWRA content of concrete. HRWRA was used for Reference 1 and 2 concrete as well as for residuals concrete. 
Since HRWRA was used approximately in proportion to wood fiber content, concrete containing higher amount of residuals showed longer times of setting than Reference Concrete.

Table 88. Time of Setting of Concrete (Series 9 and 12)

\begin{tabular}{|l|c|c|c|c|c||c|c|c|c|}
\hline Mixture Name & Ref. 1 & C1 & C2 & WG & WV & Ref. 2 & BR & I & S \\
\hline Initial Setting Time (hr) & 4.2 & 5.2 & 7.8 & 5.9 & 8.2 & 4.1 & 5.1 & 10.4 & 12.7 \\
\hline Final Setting Time (hr) & 5.5 & 6.8 & 9.8 & 7.7 & 10.1 & 5.3 & 7.0 & 13.5 & 15.6 \\
\hline HRWRA (fl oz/100 lb cement) & 3.4 & 7.6 & 12.6 & 9.6 & 14.3 & 3.4 & 6.2 & 14.6 & 23.3 \\
\hline
\end{tabular}

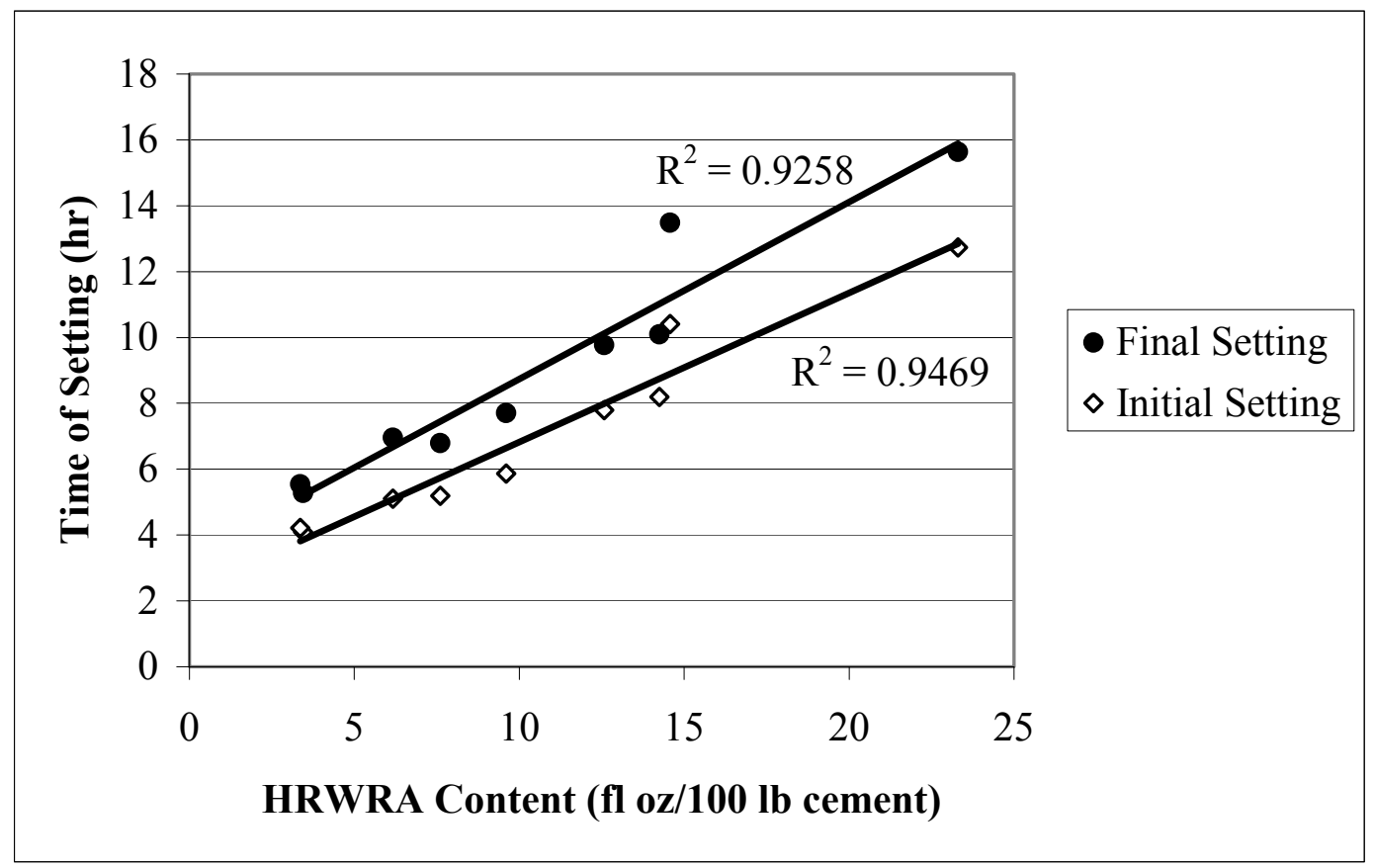

Fig. 107. Relation between time of setting and HRWRA content of concrete (Series 9 and 12)

\subsubsection{Compressive Strength}

Test results for compressive strength of concrete are presented in Table 89 and Fig. 108 and 109 . 
Table 89. Compressive Strength of Concrete (in psi) (Series 9 and 12)

\begin{tabular}{|c|c|c|c|c|c||c|c|c|c|}
\hline Age (days) & Ref. 1 & C1 & C2 & WG & WV & Ref. 2 & BR & I & S \\
\hline \hline 7 & 5700 & 4990 & 5360 & 5050 & 5130 & 6100 & 5810 & 4470 & 4620 \\
\hline 28 & 6990 & 5870 & 6190 & 5970 & 6070 & 7190 & 6970 & 5760 & 5420 \\
\hline 91 & 8200 & 6920 & 7210 & 6940 & 7010 & 7980 & 7900 & 6460 & 6260 \\
\hline
\end{tabular}

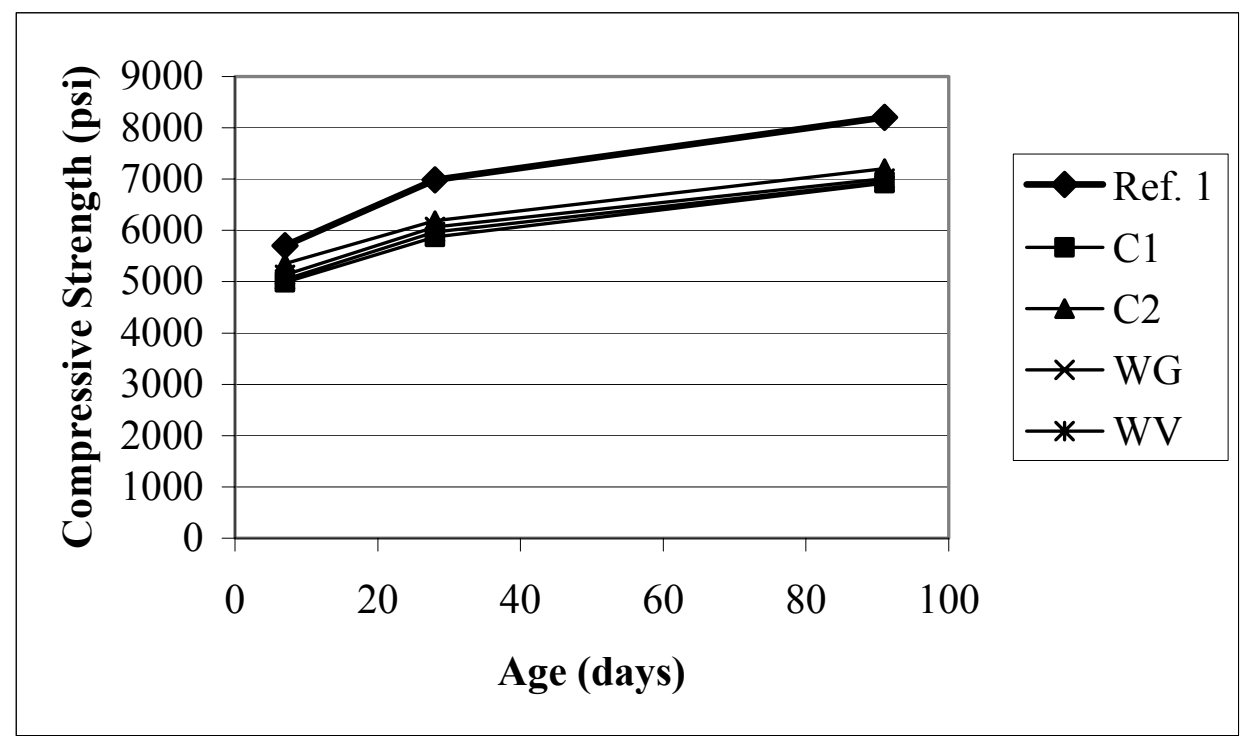

Fig. 108. Compressive strength of concrete vs. age (Series 9)

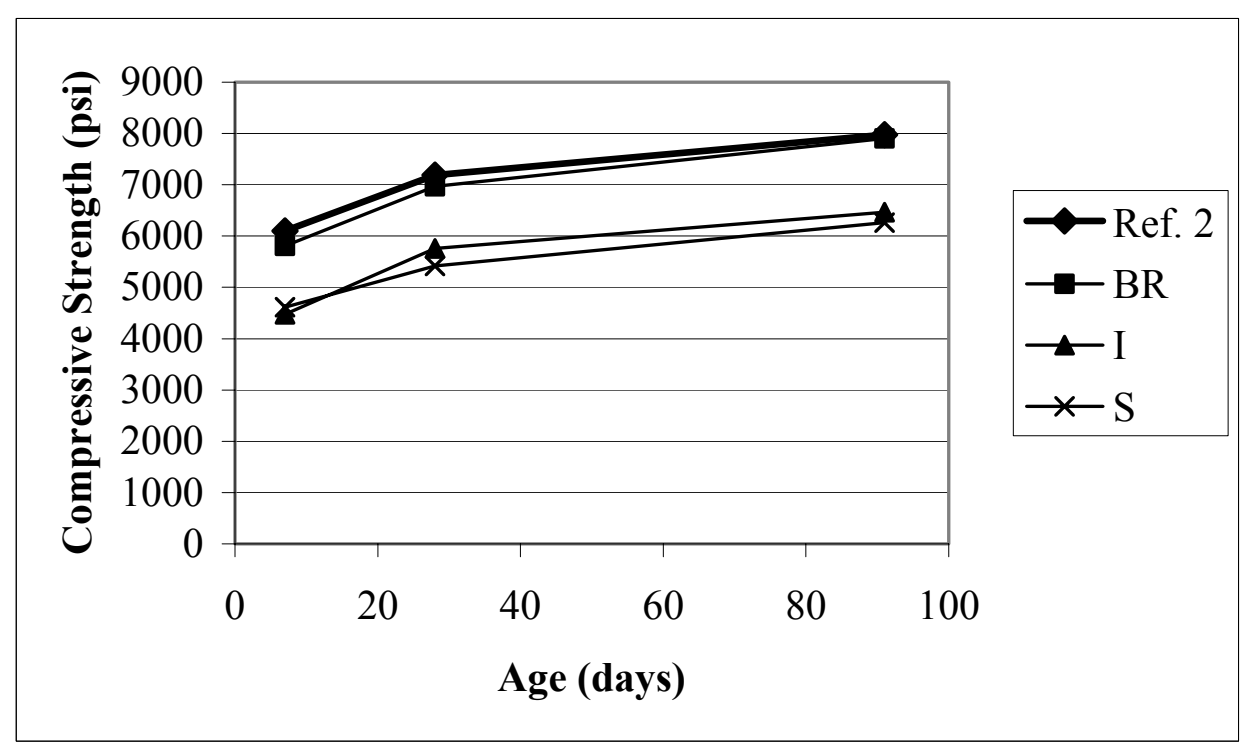

Fig. 109. Compressive strength of concrete vs. age (Series 12) 
Reference and residuals concrete mixtures showed similar patterns of strength development. Overall, average 28 -day compressive strength was about 6270 psi. All the mixtures were structural-grade concrete.

In these particular series of mixtures (Series 9 and 12), although $w / c$ and density values were equivalent to Reference Concrete, residuals concrete showed average about $15 \%$ lower 28-day compressive strength than Reference Concrete (7090 vs. 6040 psi). This might be due to the higher dosage of HRWRA in some of the concrete mixtures containing residuals. A lot of yellow bleeding water was observed on top of I and S concrete mixtures, and these mixtures showed lowest compressive strength. Relationship between 28-day compressive strength and HRWRA content of concrete produced in Series 9 and 12 is presented in Table 90 and Fig. 110.

As the HRWRA increased, 28-day compressive strength of concrete decreased (Fig. 110). Residuals concrete equivalent to reference concrete in compressive strength had been produced in Series 7 and 11 (pp. 166 and 173) by achieving equivalent density of concrete. Those mixtures were small batches ( $1 \mathrm{ft}^{3}$ each), and it took a very short time to cast all the specimens for each mixture (nine-4" x 8" cylinders). In other words, there was no delay in casting the specimens in Series 7 and 11.

Table 90. HRWRA Content and 28-day Compressive Strength of Concrete (Series 9 and 12)

\begin{tabular}{|l|c|c|c|c|c|c|c|c|c|}
\hline Mixture Name & Ref. 1 & C1 & C2 & WG & WV & Ref. 2 & BR & I & S \\
\hline HRWRA (fl oz/100 lb cement) & 3.4 & 7.6 & 12.6 & 9.6 & 14.3 & 3.4 & 6.2 & 14.6 & 23.3 \\
\hline 28-day Comp. Strength (psi) & 6990 & 5870 & 6190 & 5970 & 6070 & 7190 & 6970 & 5760 & 5420 \\
\hline
\end{tabular}




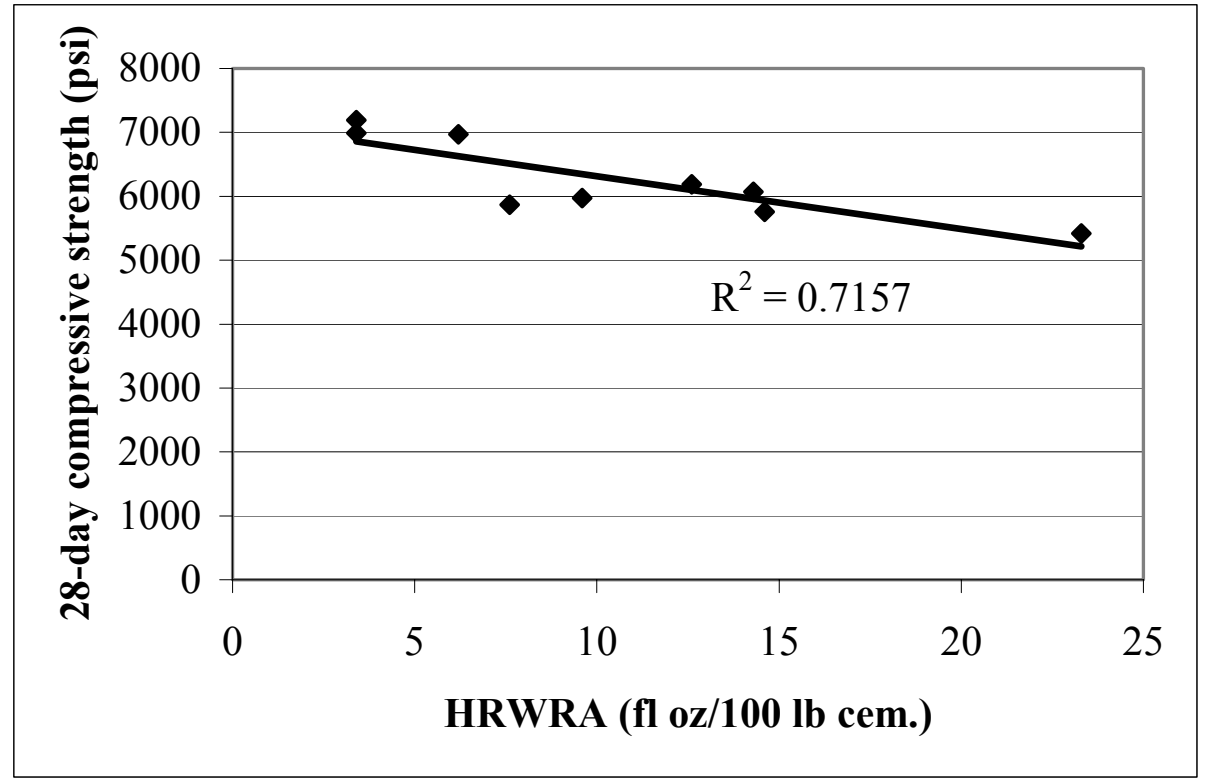

Fig. 110. Relation between 28-day compressive strength and HRWRA content of concrete (Series 9 and 12)

However, the current mixtures (Series 9 and 12) made for detailed evaluation of properties of concrete were large batches $\left(3.7 \mathrm{ft}^{3}\right.$ each), and there were a lot of specimens to be cast. So, it took longer to cast all the specimens planned for each batch. This delay in casting specimens, combined with adverse effect of excessive dosage of HRWRA (segregation and delay in setting and hardening), seems to have adversely affected compressive strength of concrete. Rather rapid loss of slump and segregation of concrete mixtures were observed when high dosage of HRWRA was used. The results suggest that the amount of HRWRA in concrete should be restricted.

\subsubsection{Average Residual-Strength}

\section{Background}

Test method for flexural toughness of concrete is covered in ASTM Standard Test Method for Flexural Toughness and First-Crack Strength of Fiber-Reinforced Concrete 
(Using Beam with Third-Point Loading) (C 1018) [47]. This test method evaluates the flexural toughness of concrete in terms of areas under the flexural load and mid-span deflection curve. Flexural toughness index of concrete is calculated as: (the area up to the specified mid-span deflection [passing peak load]) / (the area up to the first-crack mid-span deflection). For cement-based composites containing small amount of fibers, however, the postpeak load response obtained from open-loop testing machines tends to be very unreliable because of the sudden release of energy in these machine at the occurrence of the peak load. In such cases, use of a closed-loop, displacement-controlled testing machine is required to obtain the true postpeak response [54].

The residual strength test method covered in ASTM Test Method for Obtaining Average Residual-Strength of Fiber-Reinforced Concrete (C 1399) [47] is a recently developed method of measuring the flexural toughness of concrete in terms of its postpeak residual flexural strength $[54,55]$. Here, the word "residual" should be distinguished from pulp and paper mill wastewater treatment residual. This test method was developed primarily for use with an open-loop testing machine. Closed-loop feedback controlled deflection apparatus is not required for this test.

In residual strength test method, an initial flexural load is applied to the beam specimen supported by a $1 / 2$ "-thick stainless steel plate to create a stable narrow crack in the specimen. Then the steel plate is removed, and the specimen is reloaded in flexure to obtain the postcrack load-displacement curve. The reloading curves of concrete beams containing various volume fractions of fibers showed a very good agreement with the load-displacement curves obtained by testing identical beams in a closed-loop machine $[54,55]$. 
Average residual-strength is the average flexural stress-carrying ability of the cracked beam and is calculated as average of flexural strengths at four specified deflections $(0.02,0.03,0.04$, and 0.05 in.) on the reloading curve. The average residualstrength can be compared with flexural strength of concrete beams (not supported by the steel plate) determined according to ASTM Standard Test Method for Flexural Strength of Concrete (Using Simple Beam with Third-Point Loading) (C 78) [47]. Residual strength index (\%) is calculated as: average residual-strength / flexural strength $\mathrm{x} 100$ $[54,55]$. Residual strength indices of 0.8 to $91.0 \%$ have been reported for concrete mixtures containing 0.2 to $3.0 \%$ of polypropylene, nylon, and/or steel fibers by volume [55]. Flexural strength of the concrete was in the range of 730 to 1000 psi.

In the current research, the residual strength test method (ASTM C 1399) was adopted to determine residual strength of concrete using an open-loop testing machine.

\section{Test Results and Discussions}

Overall, mean value of average residual-strength of concrete after cracking in flexure was about $1 \%$ of flexural strength (Table 91 and Fig. 111). In general, concrete containing residual solids showed about 50\% higher average residual-strength than Reference Concrete (1.1 vs. $0.7 \%$ ). However, in view of the small magnitude of average residualstrength compared to flexural strength, the current results suggest that there is no significant influence of the use of paper mill residuals on average residual-strength of concrete. 
Table 91. Average Residual-Strength of Concrete (Series 9 and 12)

\begin{tabular}{|l|c|c|c|c|c|c|c|c|c|}
\hline Mixture Name & Ref. 1 & C1 & C2 & WG & WV & Ref. 2 & BR & I & S \\
\hline Flexural Strength (psi) & 887 & 943 & 962 & 868 & 876 & 947 & 887 & 964 & 953 \\
\hline Average Residual-Strength (psi) & 3.2 & 6.6 & 11.6 & 4.9 & 11.4 & 9.6 & 8.0 & 14.4 & 14.3 \\
\hline Residual Strength Index* (\%) & 0.4 & 0.7 & 1.2 & 0.6 & 1.3 & 1.0 & 0.9 & 1.5 & 1.5 \\
\hline
\end{tabular}

Note: Properties of Ref. 1, C1, C2, WG, and WV reported in this table were determined by testing recast beams and may not correlated with other properties such as compressive strength.

* Residual Strength Index (\%) = Average Residual-Strength / Flexural Strength x 100

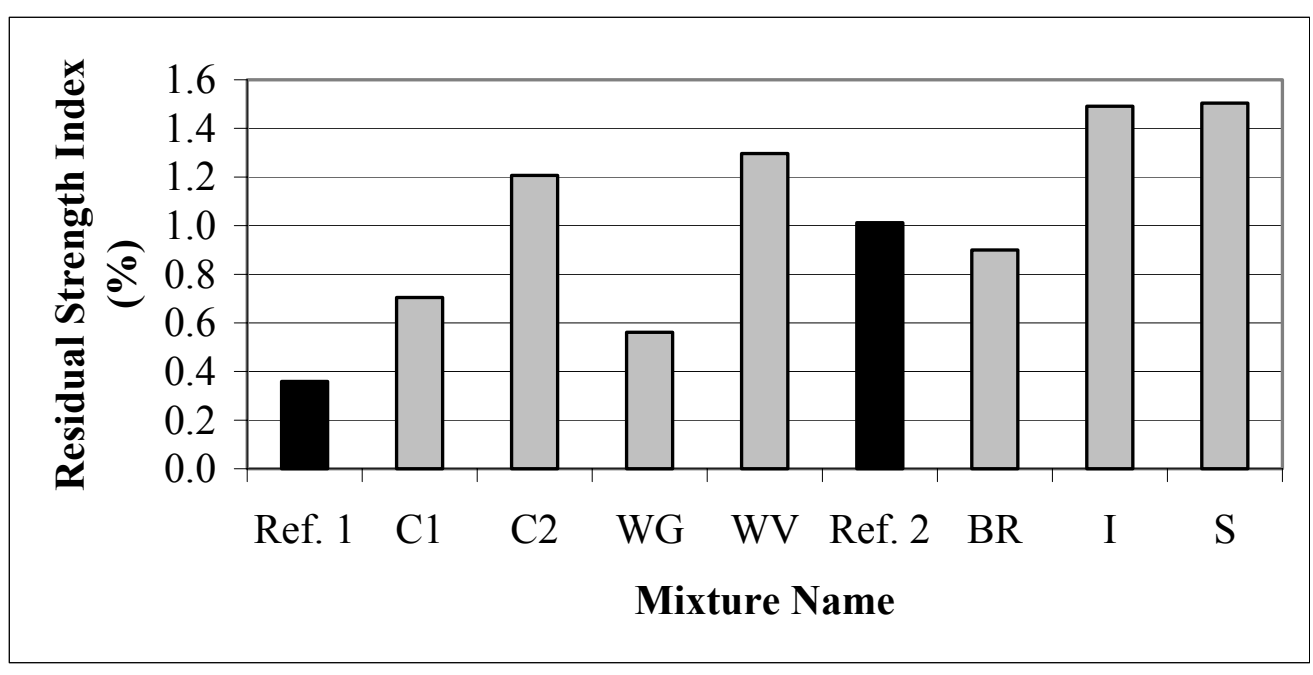

Fig. 111. Residual strength index of concrete (Series 9 and 12)

\subsubsection{Length Change}

Test results for length change (lengthening in water and drying shrinkage in air) of concrete are shown in Table 92 and Fig. 112 and 113. C1, C2, WG, and WV mixtures showed somewhat higher drying shrinkage than their reference mixture (Ref. 1). BR, I, and S mixtures showed a little lower drying shrinkage than their reference mixture (Ref. 2). Overall, length change of residuals concrete was similar to that of the Reference Concrete. 
Table 92. Length Change of Concrete Due to Curing in Water Until the Age of 28 Days and Subsequent Drying in Air (in \%) (Series 9 and 12)

\begin{tabular}{|c|c|c|c|c|c|c|c|c|c|c|c|}
\hline \multirow{2}{*}{$\begin{array}{l}\text { Mixture } \\
\text { Name }\end{array}$} & \multicolumn{11}{|c|}{ Age (days) } \\
\hline & 1 & 3 & 7 & 28 & 32 & 35 & 42 & 56 & 84 & 140 & 252 \\
\hline Ref. 1 & 0.000 & $\ldots$ & $\ldots$ & 0.015 & 0.000 & -0.005 & -0.016 & -0.017 & -0.026 & -0.031 & -0.035 \\
\hline $\mathrm{C} 1$ & 0.000 & $\ldots$ & $\ldots$ & 0.013 & -0.002 & -0.008 & -0.014 & -0.021 & -0.031 & -0.035 & -0.039 \\
\hline $\mathrm{C} 2$ & 0.000 & 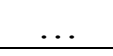 & $\theta$ & 0.015 & -0.004 & -0.011 & -0.017 & -0.023 & -0.032 & -0.036 & -0.039 \\
\hline WG & 0.000 & $\ldots$ & $\ldots$ & 0.012 & -0.010 & -0.016 & -0.027 & -0.026 & -0.036 & -0.039 & -0.046 \\
\hline WV & 0.000 & $\ldots$ & $\ldots$ & 0.014 & -0.006 & -0.013 & -0.025 & -0.026 & -0.038 & -0.043 & -0.047 \\
\hline Ref. 2 & 0.000 & 0.006 & 0.006 & 0.007 & -0.010 & -0.013 & -0.024 & -0.032 & -0.040 & -0.045 & -0.050 \\
\hline $\mathrm{BR}$ & 0.000 & 0.005 & 0.007 & 0.007 & -0.007 & -0.012 & -0.020 & -0.029 & -0.036 & -0.041 & -0.047 \\
\hline $\mathrm{I}$ & 0.000 & 0.002 & 0.004 & 0.007 & -0.006 & -0.009 & -0.018 & -0.027 & -0.034 & -0.040 & -0.047 \\
\hline $\mathrm{S}$ & 0.000 & 0.004 & 0.007 & 0.009 & -0.006 & -0.007 & -0.019 & -0.028 & -0.034 & -0.042 & -0.048 \\
\hline
\end{tabular}

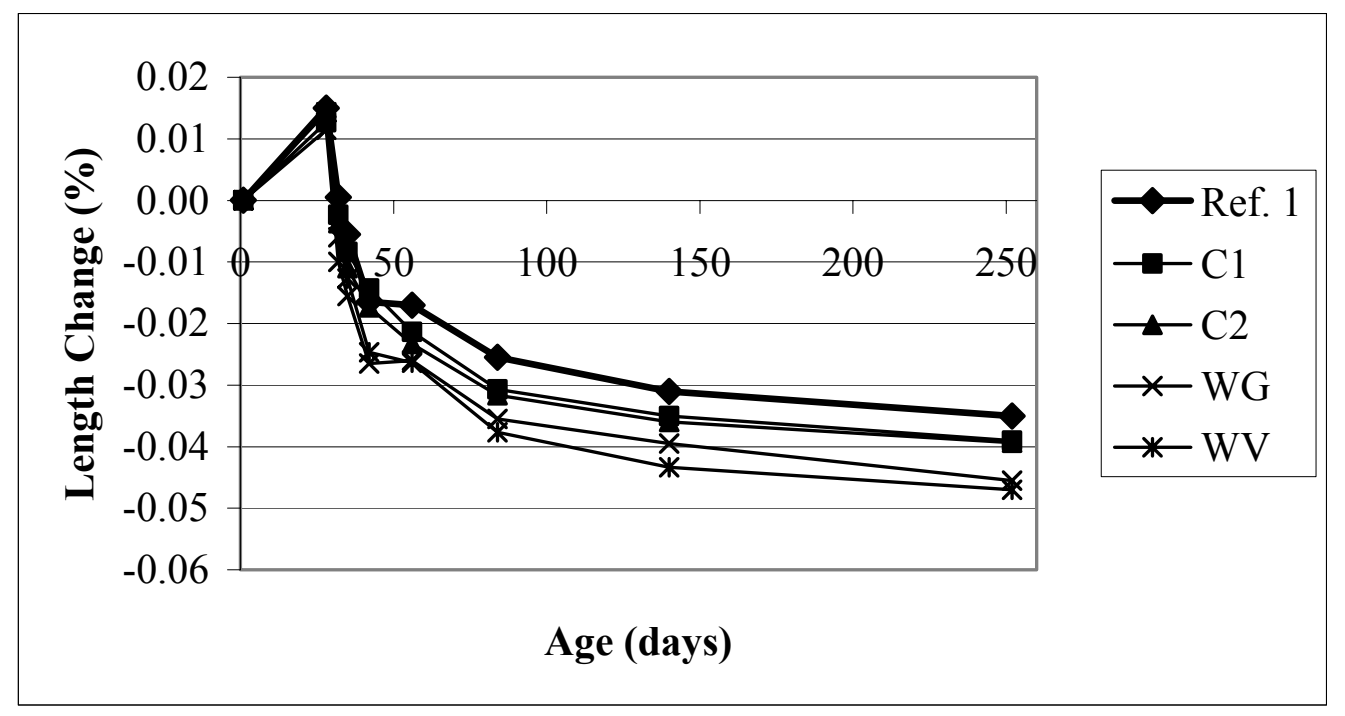

Fig. 112. Length change of concrete due to curing in water until the age of 28 days and subsequent drying in air (Series 9) 


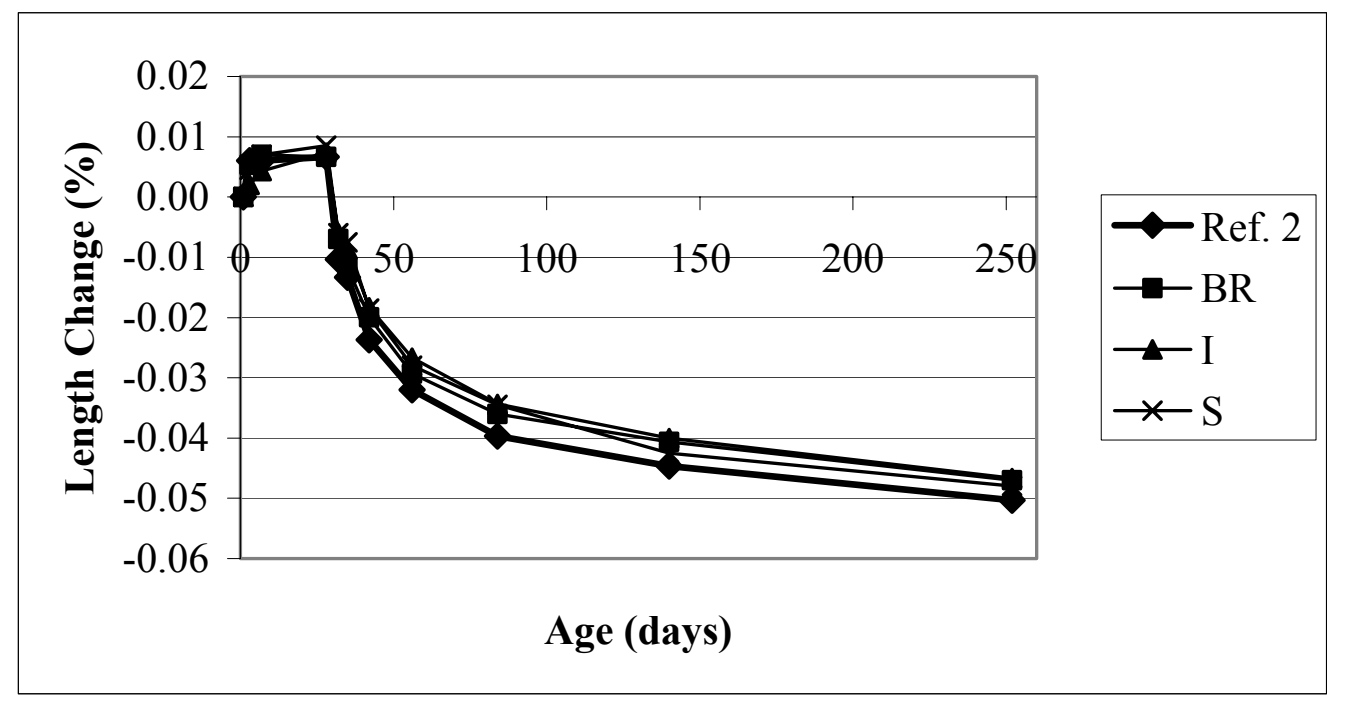

Fig. 113. Length change of concrete due to curing in water until the age of 28 days and subsequent drying in air (Series 12)

\subsubsection{Resistance to Chloride-Ion Penetration}

Lower charge passed implies higher resistance of concrete to chloride ion penetration. In spite of generally lower compressive strength than Reference concrete, C1, BR, I, and S mixtures showed chloride-ion penetration resistance that is equivalent to that of Reference Concrete. C2, WG, and WV mixtures showed lower chloride-ion penetration resistance $(18,30$, and $37 \%$, respectively, higher charge passed) than Reference Concrete. Overall, with average 15\% lower 28-day compressive strength than Reference concrete, concrete containing residuals showed either equivalent or somewhat lower chloride-ion penetration resistance when compared with Reference concrete.

\subsubsection{Abrasion Resistance}

Test results for mass loss of concrete due to abrasion are presented in Table 93 and Fig. 114 to 116 . Lower mass loss implies higher abrasion resistance of concrete. Abrasion resistance of $\mathrm{C} 1$ concrete was equivalent to that of Reference concrete. WG concrete 
showed somewhat higher abrasion resistance than Reference concrete. C2, BR, I, and S concrete showed lower abrasion resistance than Reference concrete. Overall, due in part to lower compressive strength than Reference concrete, concrete containing residuals showed either equivalent or lower abrasion resistance when compared with Reference concrete.

WV concrete showed about three times as much abrasion mass loss as Reference concrete (Ref. 1). Clumps of WV residuals that had not been deflocculated might have adversely affected the abrasion resistance of concrete containing WV residuals. The clumps embedded in the surface layer of concrete might be considered as tiny potholes.

The area on top of a specimen subjected to abrasion by rotating cutters was about $6000 \mathrm{~mm}^{2}$. For density of hardened, air-dried concrete of $140 \mathrm{lb} / \mathrm{ft}^{3}\left(2245 \mathrm{~kg} / \mathrm{m}^{3}\right)$, mass loss of one gram corresponds to volume loss of about $450 \mathrm{~mm}^{3}$ and thickness loss of about $0.075 \mathrm{~mm}(0.003 \mathrm{in}$.$) .$

Table 93. Mass Loss of Concrete Due to Abrasion (in grams) (Series 9 and 12)

\begin{tabular}{|c||c|c|c|c|c||c|c|c|c|}
\hline $\begin{array}{c}\text { Abrasion } \\
\text { Time (min.) }\end{array}$ & Ref. 1 & C1 & C2 & WG & WV & Ref. 2 & BR & I & S \\
\hline 2 & 0.26 & 0.23 & 0.40 & 0.24 & 1.44 & 0.39 & 0.57 & 0.78 & 0.53 \\
\hline 4 & 0.53 & 0.50 & 0.71 & 0.43 & 2.07 & 0.72 & 1.04 & 1.14 & 0.89 \\
\hline 6 & 0.78 & 0.78 & 1.02 & 0.66 & 2.61 & 1.06 & 1.48 & 1.42 & 1.21 \\
\hline 12 & $\ldots$ & $\ldots$ & $\ldots$ & $\ldots$ & $\ldots$ & 1.83 & 2.36 & 2.01 & 1.93 \\
\hline
\end{tabular}

Note: Mass loss of 1 gram $=$ Thickness loss of about $0.075 \mathrm{~mm}$. 


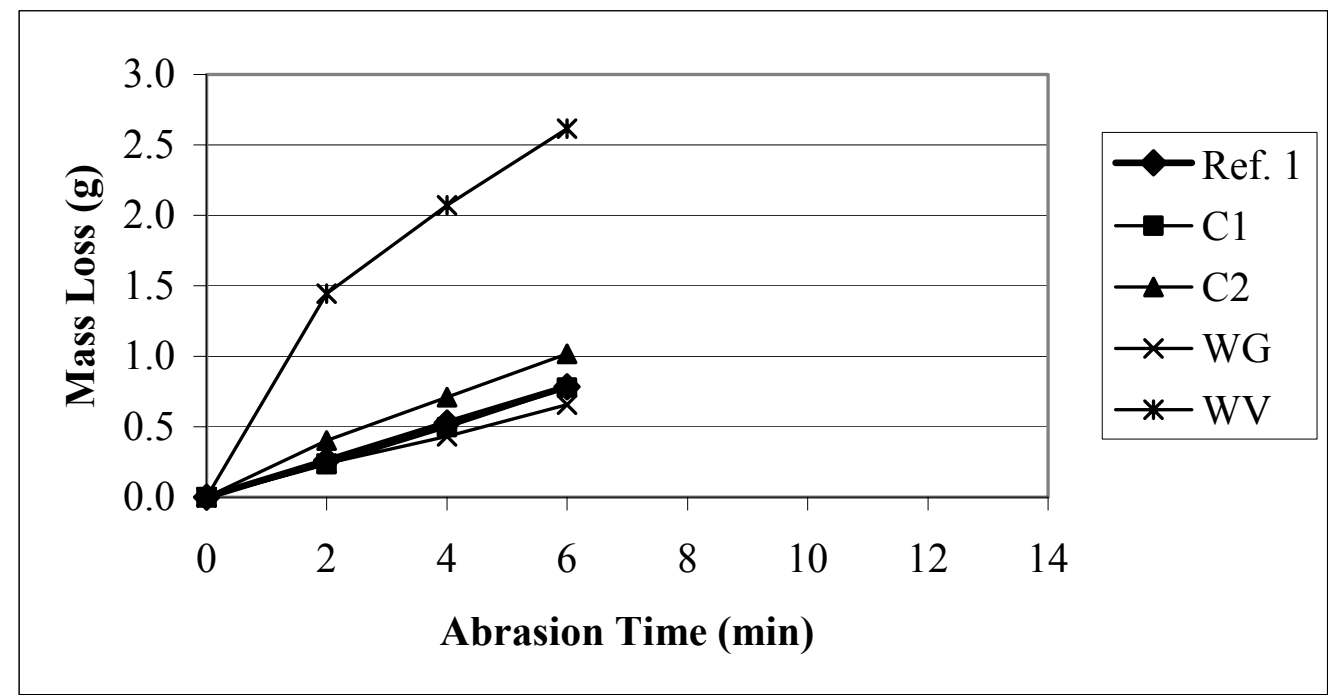

Fig. 114. Mass loss of concrete specimens due to abrasion (Series 9)

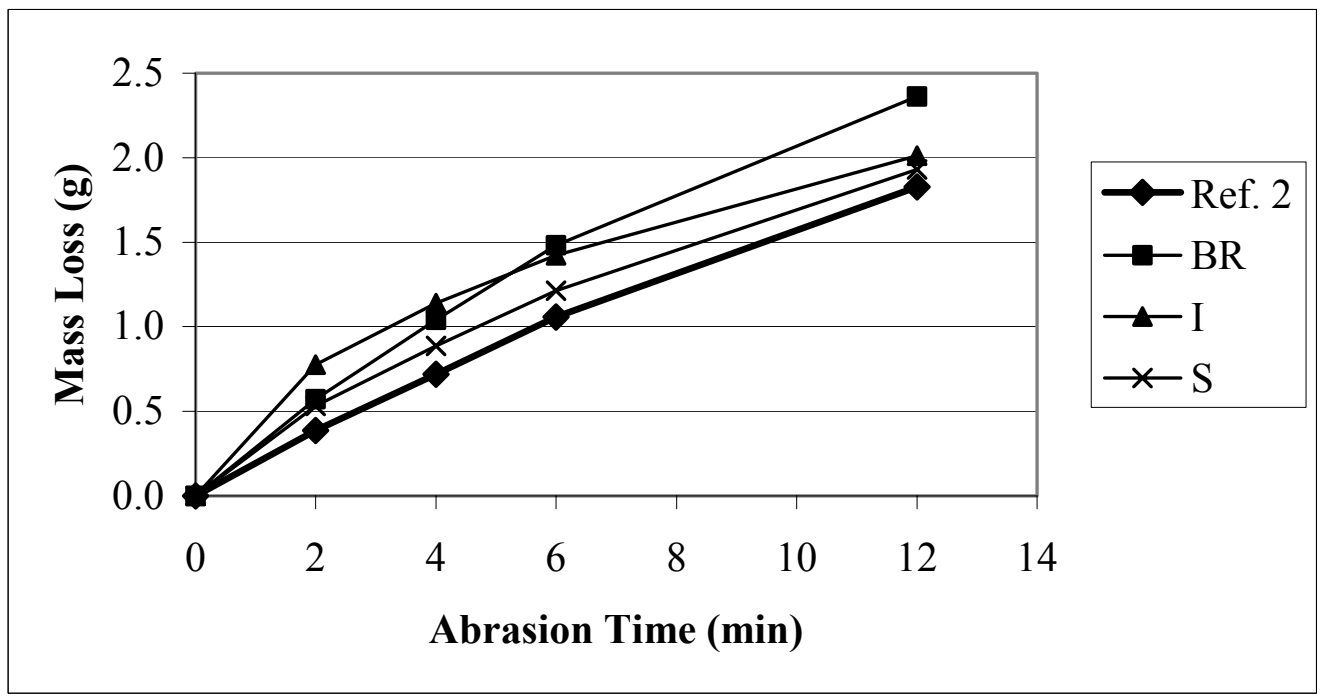

Fig. 115. Mass loss of concrete specimens due to abrasion (Series 12) 


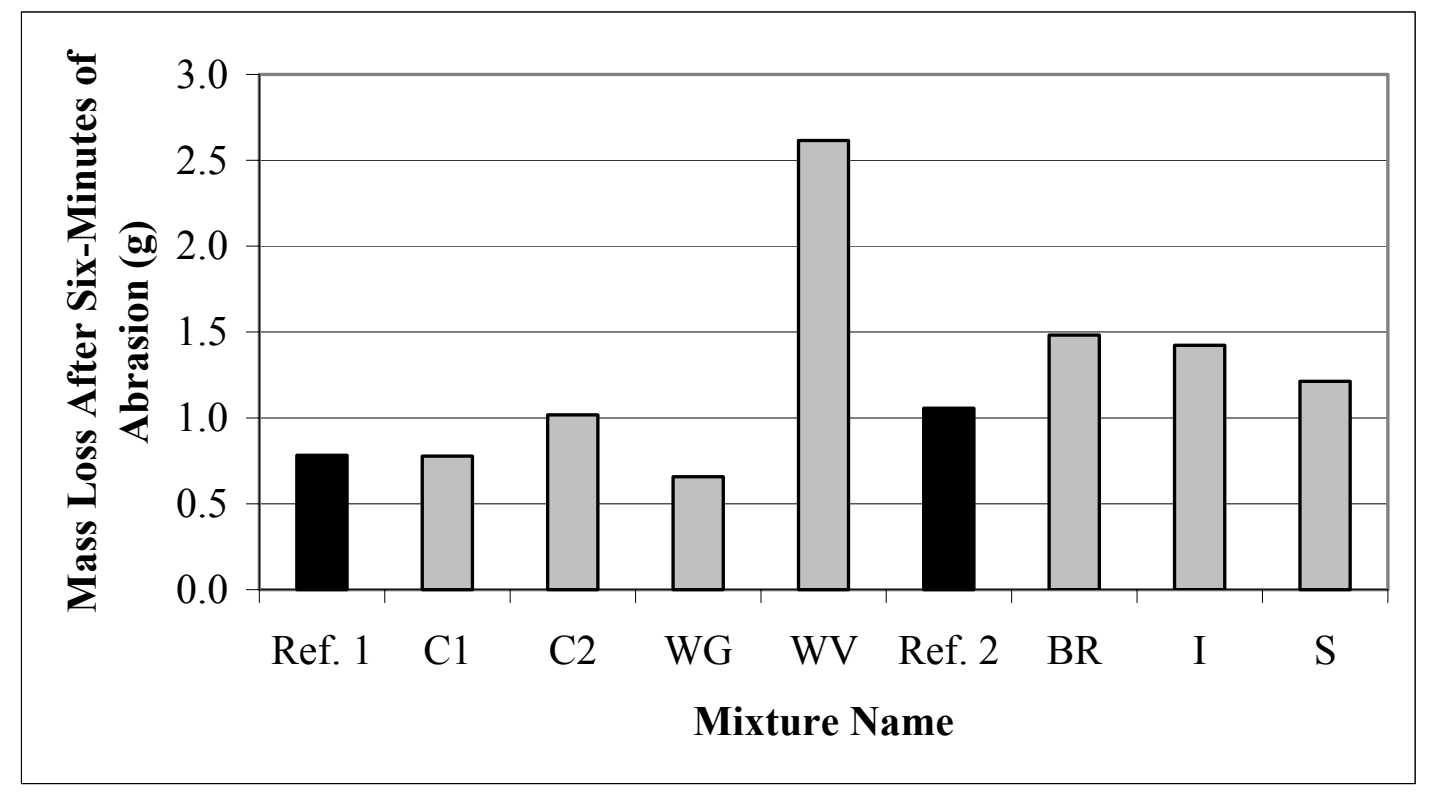

Fig. 116. Mass loss of concrete specimens due to abrasion for six minutes (Series 9 and 12)

\subsubsection{Resistance to Rapid Freezing and Thawing}

Pictures of specimens after 300 cycles of freezing and thawing are shown in Fig. 117 and 118.

Highest possible durability factor is 100 , which means that dynamic modulus of elasticity of concrete did not decrease (no deterioration) after 300 cycles of freezing and thawing. A concrete beam is considered to have failed when its relative dynamic modulus of elasticity (RDMOE) reaches $60 \%$ of the initial modulus. If RDMOE is higher than $60 \%$ at 300 cycles, durability factor is same as the RDMOE at 300 cycles. If a beam fails (RDMOE reaches $60 \%$ ) at $N$ cycles of freezing and thawing before completing 300 cycles, its durability factor is calculated as $60 \times \mathrm{N} / 300$. 


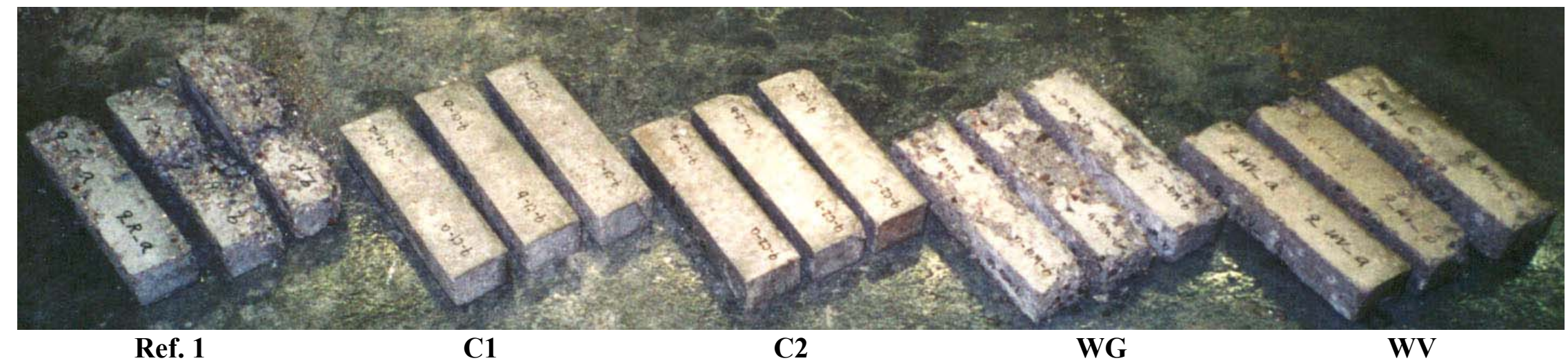

Fig. 117. Specimens after 300 cycles of freezing and thawing (Series 9)

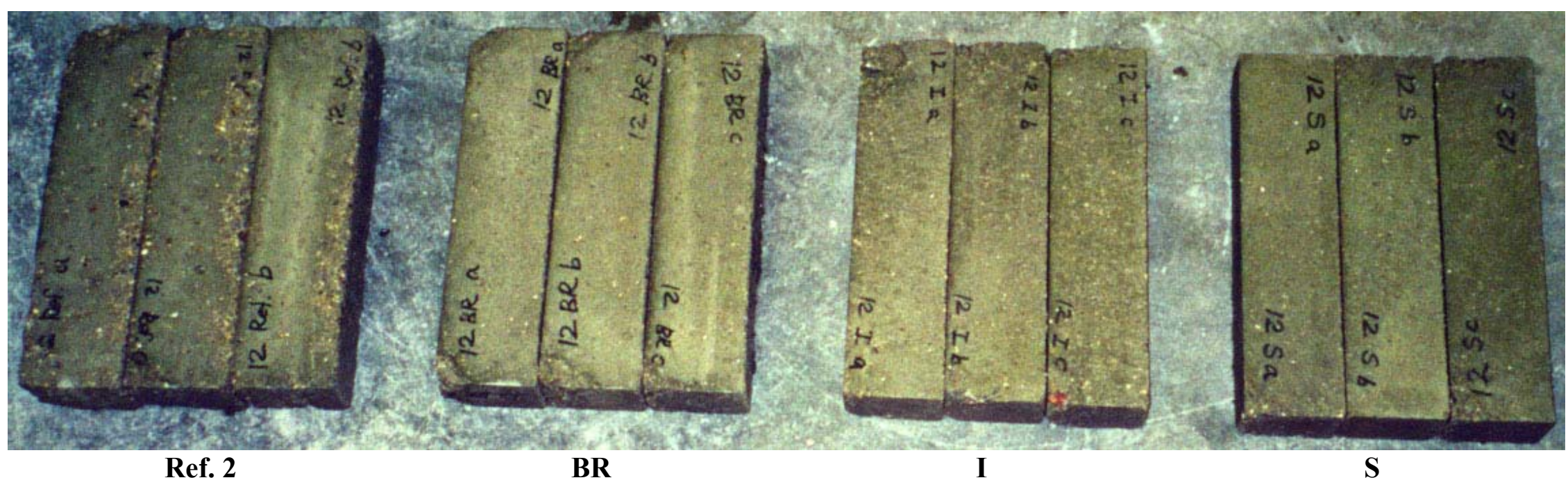

Fig. 118. Specimens after 300 cycles of freezing and thawing (Series 12) 
Concrete mixtures $\mathrm{C} 1$ and $\mathrm{BR}$ showed highest durability factors, and it is noteworthy that, within the group of residuals used in each series of mixtures, Residuals C1 (in Series 9) and BR (in Series 12) were the best sources of residuals as far as the ease of "repulping" was concerned (p. 94). As shown in Table 94, within each group of concrete mixtures, durability factors of residuals concrete were generally in agreement with the ease of repulping the residuals. In general, concrete containing easier-to-repulp residuals showed higher resistance to freezing and thawing.

Table 94. Relation between Ease of Repulping of Residuals and Freezing-andThawing Durability Factor of Concrete

\begin{tabular}{|l||c|c|c|c|c|c|c|}
\hline Mixture Series & \multicolumn{4}{|c||}{ Series 9 } & \multicolumn{3}{|c|}{ Series 12 } \\
\hline Order & 1 & 2 & 3 & 4 & 1 & 2 & 3 \\
\hline $\begin{array}{l}\text { Ease of } \\
\text { Repulping* }\end{array}$ & C1 & C2 & WG & WV & BR & S & I \\
\hline Durability Factor' & C1 & C2 & WV & WG & BR & S & I \\
\hline
\end{tabular}

* Residuals listed in descending order of ease of repulping (easy $\rightarrow$ difficult to repulp) within each series. Refer to Table 44 on p. 94.

$\dagger$ Concrete mixtures listed in descending order of durability factor (higher $\rightarrow$ lower resistance to freezing and thawing) within each series.

This means that lower degree of dewatering at the paper mill wastewater treatment plant and resulting better repulping of residuals would lead to improved freezing-and-thawing resistance of residuals concrete. As-received Residual WV of the second delivery, which had not been dewatered, was in a well-deflocculated condition ( $\mathrm{p}$. 66). Concrete containing well-dispersed WV is expected to possess much higher freezing-and-thawing resistance than the WV concrete produced in this research containing highly-dewatered, hard-to-deflocculate WV of the first delivery. Among the 
residuals of the first deliver, Residual WV was one of the hardest sources of residuals to repulp (p. 94) along with Residual I.

Four-fold improvement in compressive strength of composite of portland cement and residual from a wastepaper recycling plant was reported with the use of wet residual that had been collected before thickening and dewatering when compared with the use of dewatered residual (p. 49) [17]. This was attributed to improved fiber dispersion with the use of non-dewatered residual.

\subsubsection{Salt-Scaling Resistance}

Pictures of specimens of Ref. 2, BR, I, and S mixtures after 15 cycles of freezing and thawing while covered with deicing salt solution are presented in Fig. 119. Pictures of Ref. 1, C1, C2, WG, and WV specimens after salt-scaling are not available.

As shown in Table 95, within each series of concrete mixtures (Series 9 and 12), salt-scaling resistance of residuals concrete was in agreement with the ease of repulping the residuals. Concrete containing easier-to-repulp residuals showed higher resistance to salt scaling.

This means that lower degree of dewatering at the pulp and paper mill wastewater treatment plant and resulting better repulping of residuals would lead to improved saltscaling resistance of residuals concrete. Concrete containing well-dispersed WV is expected to possess much higher salt-scaling resistance than the WV concrete produced in this research containing highly-dewatered, hard-to-deflocculate WV of the first delivery. 


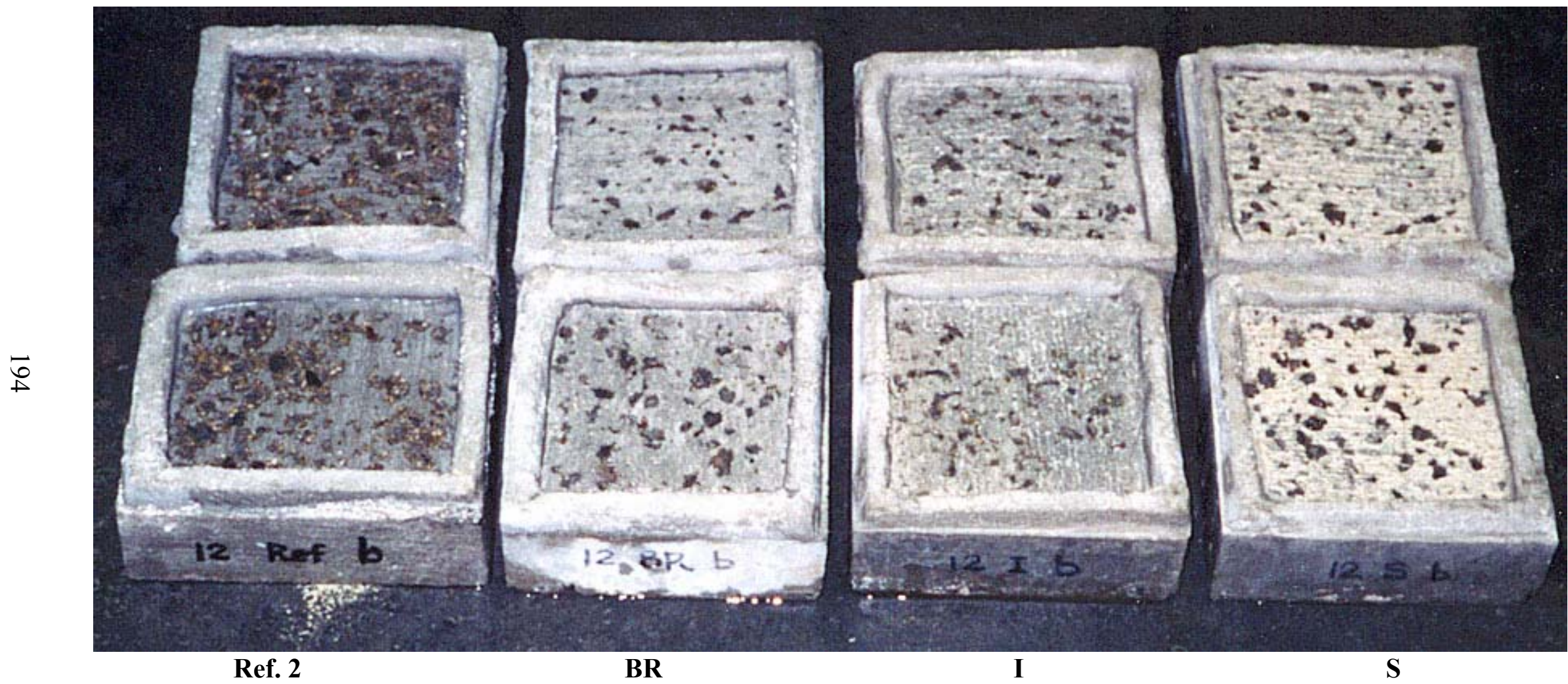

Fig. 119. Salt scaling of concrete after 15 cycles of freezing and thawing while covered with deicing salt solution (Series 12) 
Table 95. Ease of Repulping Residuals and Salt-Scaling Resistance of Concrete

\begin{tabular}{|l||c|c|c|c||c|c|c||}
\hline \multicolumn{1}{|l||}{ Mixture Series } & \multicolumn{4}{|c||}{ Series 9 } & \multicolumn{3}{c|}{ Series 12 } \\
\hline Order & 1 & 2 & 3 & 4 & 1 & 2 & 3 \\
\hline Ease of Repulping* & $\mathrm{C} 1$ & $\mathrm{C} 2$ & WG & WV & BR & S & I \\
\hline Salt-scaling Resistance $\dagger$ & C1 & $\begin{array}{c}\text { C2, } \\
\text { WG }\end{array}$ & -- & WV & BR & S & I \\
\hline \hline
\end{tabular}

* Residuals listed in descending order of ease of repulping (easy $\rightarrow$ difficult to repulp) within each series. Refer to Table 44 on p. 94.

$\dagger$ Concrete mixtures listed in descending order of salt-scaling resistance in terms of cycles to reach severe scaling (higher $\rightarrow$ lower resistance) within each series.

\subsection{Field Mixtures}

\subsubsection{Field Prototype Concrete Mixtures Manufactured at a Commercial Plant}

A ready-mixed concrete producer was selected to be near the sources of residuals that were selected. A total of five concrete mixtures were manufactured at the facilities of the ready-mixed concrete producer. Mixtures consisted of one reference mixture and four additional mixtures of concrete with residual solids. Details of the mixtures are shown in Table 96. Fresh concrete testing was performed for each mixture, including initial and final time of setting, and test specimens were cast for compressive strength, flexural strength, abrasion resistance, resistance to salt-scaling, and resistance to freezing and thawing. A portion of a concrete slab was also cast from each mixture to evaluate its long-term field performance.

Prototype field mixtures were evaluated for time of setting (Table 97, Fig. 120) and for compressive strength (Table 98, Fig. 121), flexural strength (Table 99, Fig. 122), and abrasion resistance (Table 100, Fig. 123). 
Table 96. Mixture Proportions and Fresh Properties for Prototype Field Mixtures

\begin{tabular}{|c|c|c|c|c|c|}
\hline Mixture Name & Ref. & C1-L1 & C1-L2 & BR-L & BR-H \\
\hline Residuals, as-recd (\% by wt. of concrete) & 0 & 0.25 & 0.25 & 0.24 & 0.48 \\
\hline Wood Fibers $\left(\mathrm{lb} / \mathrm{yd}^{3}\right)^{*}$ & 0 & 1.5 & 1.5 & 2.8 & 5.2 \\
\hline $\begin{array}{l}\text { Residuals, LOI at } 590^{\circ} \mathrm{C}(\mathrm{lb} / 100 \mathrm{lb} \\
\text { cement })\end{array}$ & 0 & 0.38 & 0.38 & 0.53 & 1.02 \\
\hline HRWRA (fl oz/100 lb of cement) & 7.0 & 10.8 & 8.0 & 8.0 & 9.8 \\
\hline Residuals, as-recd (lb/yd $\left.{ }^{3}\right)$ & 0 & 9.3 & 9.0 & 9.8 & 18.2 \\
\hline HRWRA (fl oz/yd ${ }^{3}$ ) & 39.9 & 55.8 & 40.4 & 44.8 & 52.8 \\
\hline Cement (lb/yd $\left.{ }^{3}\right)$ & 566 & 516 & 505 & 558 & 540 \\
\hline Water $\left(\mathrm{lb} / \mathrm{yd}^{3}\right)$ & 233 & 191 & 213 & 226 & 195 \\
\hline Sand, SSD (lb/yd $\left.{ }^{3}\right)$ & 1450 & 1320 & 1280 & 1450 & 1360 \\
\hline Gravel, 3/4" max., SSD (lb/yd $\left.{ }^{3}\right)$ & 1850 & 1660 & 1610 & 1780 & 1680 \\
\hline$w / \mathrm{cm}$ & 0.41 & 0.37 & 0.42 & 0.40 & 0.36 \\
\hline Slump (in.) & 3 & 9.75 & 5.5 & 3 & 7.25 \\
\hline Air Content (\%) & 2.8 & 10 & 15 & 5.3 & 9.7 \\
\hline Density $\left(\mathrm{lb} / \mathrm{ft}^{3}\right)$ & 152 & 137 & 134 & 149 & 140 \\
\hline Yield $\left(\mathrm{yd}^{3}\right)$ & 3.00 & 3.30 & 3.39 & 3.05 & 3.24 \\
\hline
\end{tabular}

* From Residuals. On dry basis.

Table 97. Time of Setting (Prototype Field Mixtures)

\begin{tabular}{|l|c|c|c|c|c|}
\hline Mixture Name & Ref. & C1-L1 & C1-L2 & BR-L & BR-H \\
\hline \hline Initial Setting Time (hr) & 2.8 & 6.5 & 4.4 & 3.8 & 5.5 \\
\hline Final Setting Time (hr) & 3.8 & 8.0 & 5.7 & 5.1 & 6.9 \\
\hline \hline HRWRA (fl oz/100 lb cement) & 7.0 & 10.75 & 8.0 & 8.0 & 10.0 \\
\hline
\end{tabular}




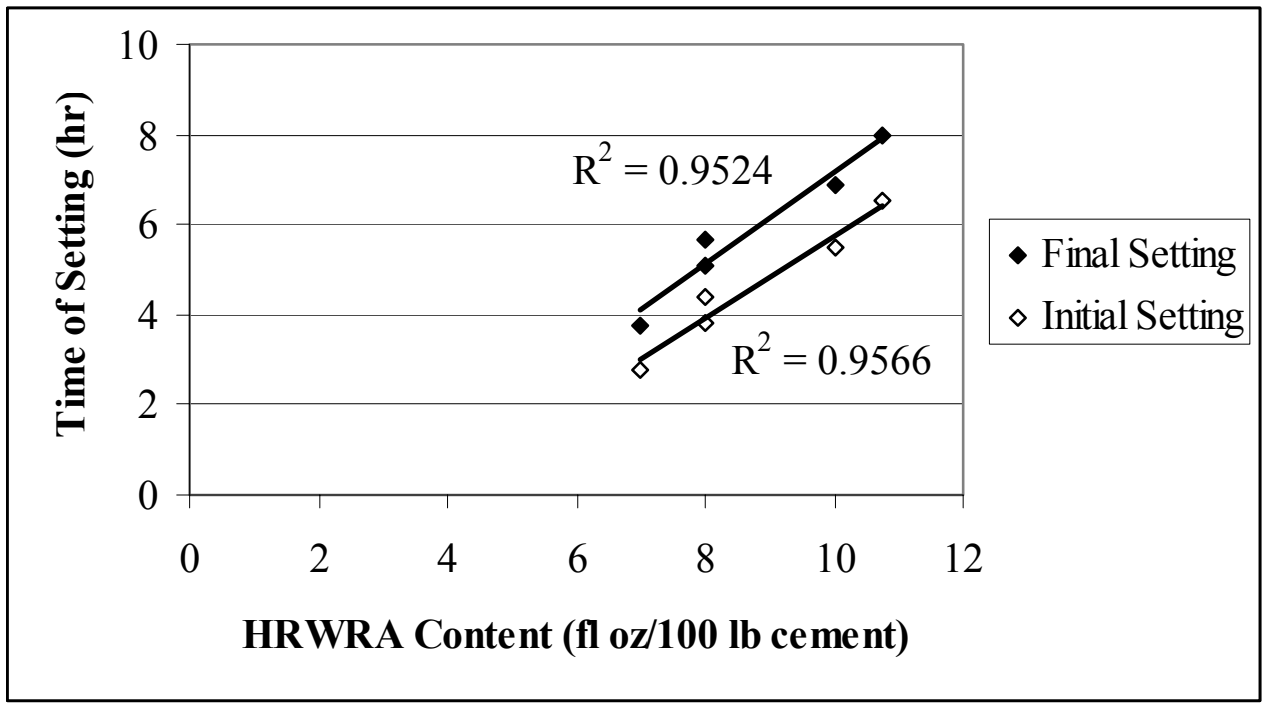

Fig. 120. Relation between time of setting and HRWRA content of concrete (Prototype Field Mixtures)

Table 98. Compressive Strength of Concrete (Prototype Field Mixtures)

\begin{tabular}{|c|c|c|c|c|c||}
\hline $\begin{array}{c}\text { Age } \\
\text { days })\end{array}$ & Ref. & C1-L1 & C1-L2 & BR-L & BR-H \\
\hline 3 & 7770 & 3060 & 3140 & 6070 & 4070 \\
\hline 7 & 7640 & 3320 & 3270 & 6110 & 4310 \\
\hline 28 & 9530 & 4360 & 4070 & 7540 & 5330 \\
\hline 91 & 10240 & 4670 & 4490 & 8640 & 5790 \\
\hline
\end{tabular}

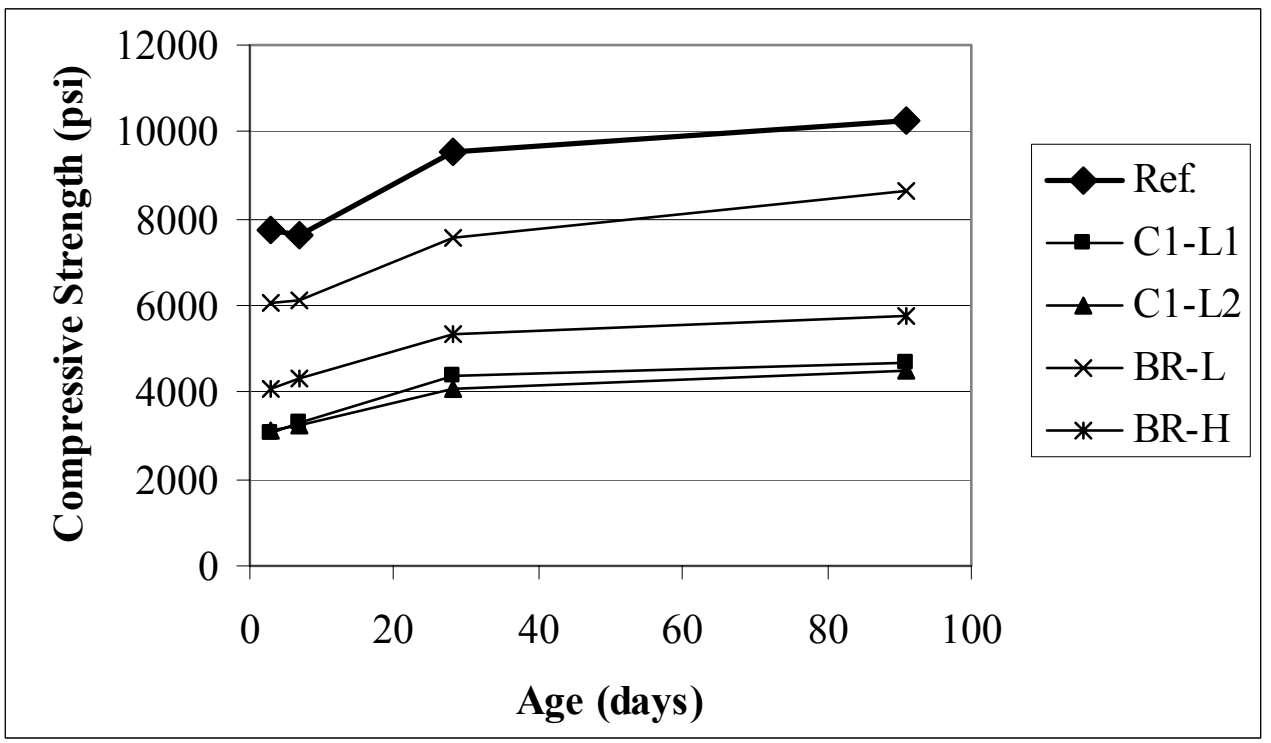

Fig. 121. Compressive strength of concrete vs. age (Prototype Field Mixtures) 
Table 99. Flexural Strength of Concrete (Prototype Field Mixtures)

\begin{tabular}{|c||c|c|c|c||}
\hline $\begin{array}{c}\text { Age } \\
\text { (days) }\end{array}$ & Ref. & C1-L2 & BR-L & BR-H \\
\hline 3 & 950 & 665 & 820 & 710 \\
\hline 7 & 930 & 680 & 910 & 760 \\
\hline 28 & 1035 & 735 & 975 & 790 \\
\hline 91 & 1030 & 765 & 975 & 835 \\
\hline
\end{tabular}

Note: Specimens for flexural strength of C1-L1 were not cast.

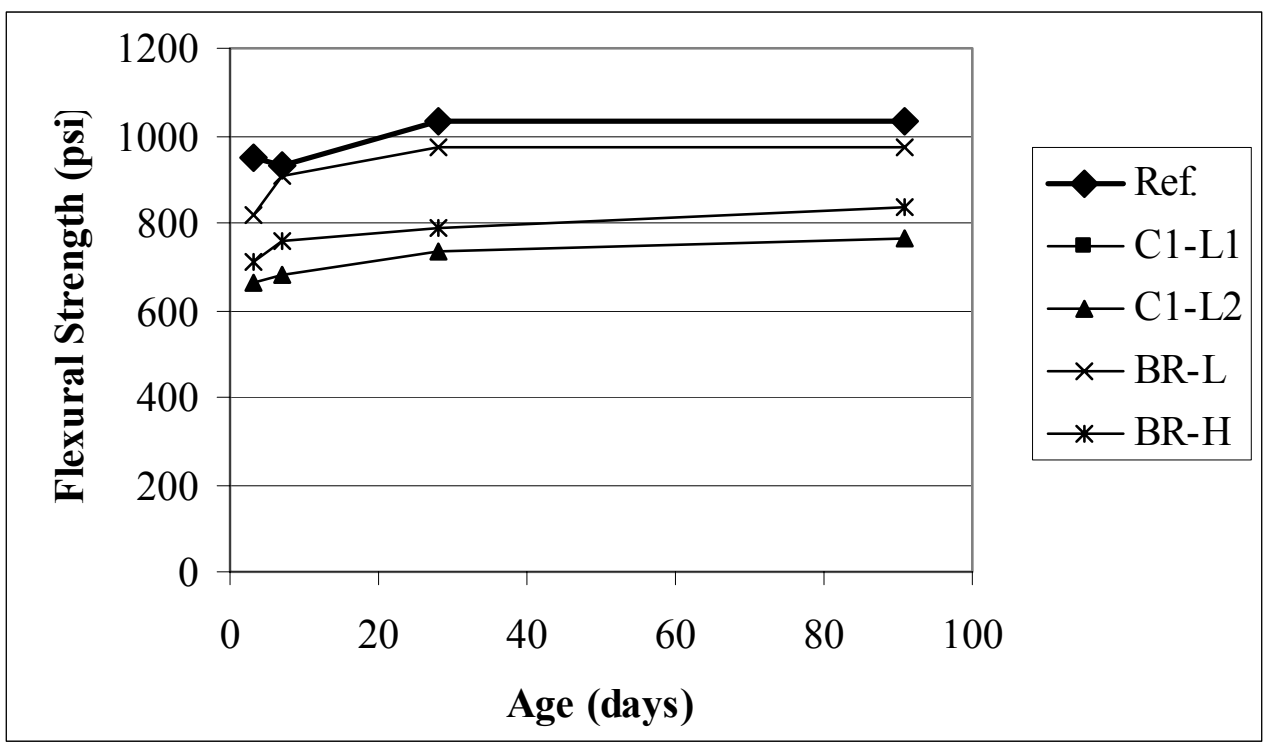

Fig. 122. Flexural strength of concrete vs. age (Prototype Field Mixtures)

Table 100. Mass Loss of Concrete Due to Abrasion (in grams) (Prototype Field Mixtures)

\begin{tabular}{||c||c|c|c|c|c||}
\hline $\begin{array}{c}\text { Abrasion } \\
\text { Time (min.) }\end{array}$ & Ref. & C1-L1 & C1-L2 & BR-L & BR-H \\
\hline 0 & 0 & 0 & 0 & 0 & 0 \\
\hline 2 & 0.24 & 1.86 & 0.83 & 0.49 & 0.41 \\
\hline 4 & 0.43 & 3.36 & 1.55 & 0.80 & 0.98 \\
\hline 6 & 0.64 & 5.13 & 2.43 & 1.13 & 1.58 \\
\hline 8 & 0.90 & 6.85 & 3.58 & 1.49 & 2.32 \\
\hline 10 & 1.22 & 8.12 & 4.39 & 1.85 & 3.03 \\
\hline 12 & 1.41 & 9.59 & 5.44 & 2.13 & 3.95 \\
\hline
\end{tabular}




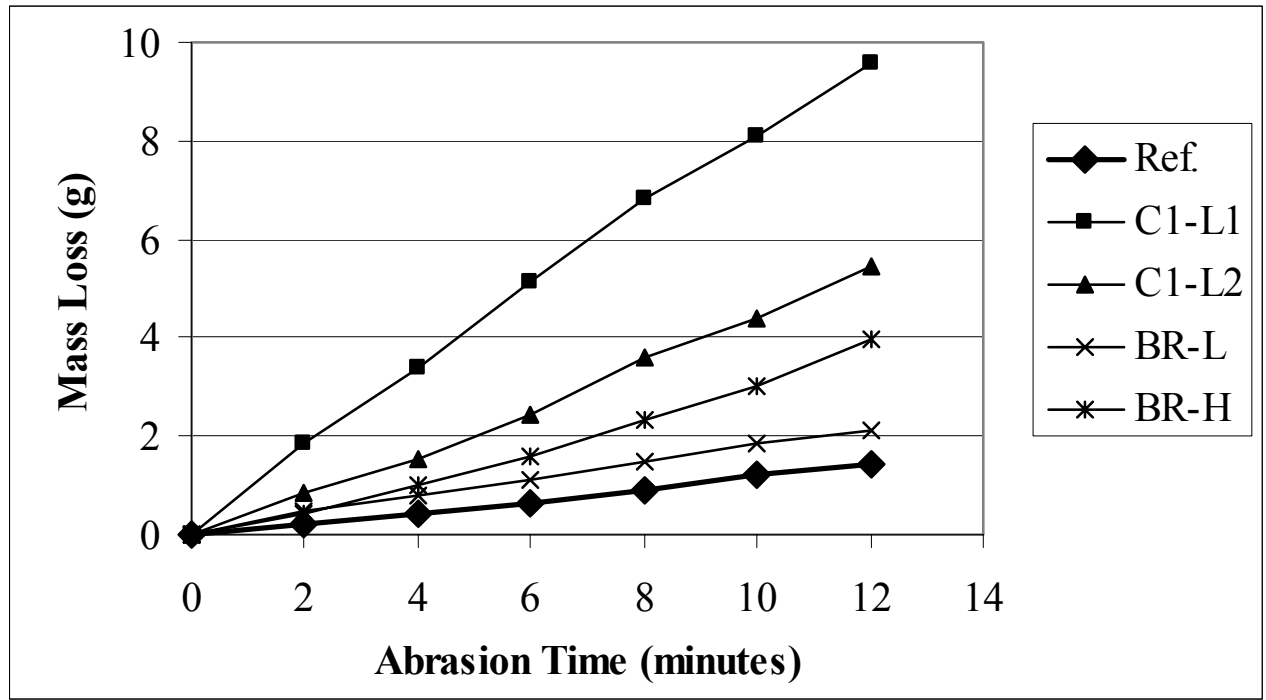

Fig. 123. Mass loss of concrete specimens due to abrasion (Prototype Field Mixtures)

Long-term tests were conducted in order to evaluate the length change (drying shrinkage), freezing-and-thawing resistance, and salt-scaling resistance of the prototype field concrete mixtures.

Concrete incorporating approximately $0.24 \%$ to $0.48 \%$ (by mass of concrete) pulp and paper mill fibrous residuals showed equivalent length change (drying shrinkage) when compared with Reference Concrete made without fibrous residuals (Fig. 124). These results are in agreement with the results observed for concrete mixtures made in the laboratory (Sect. 7.3, p. 176). 


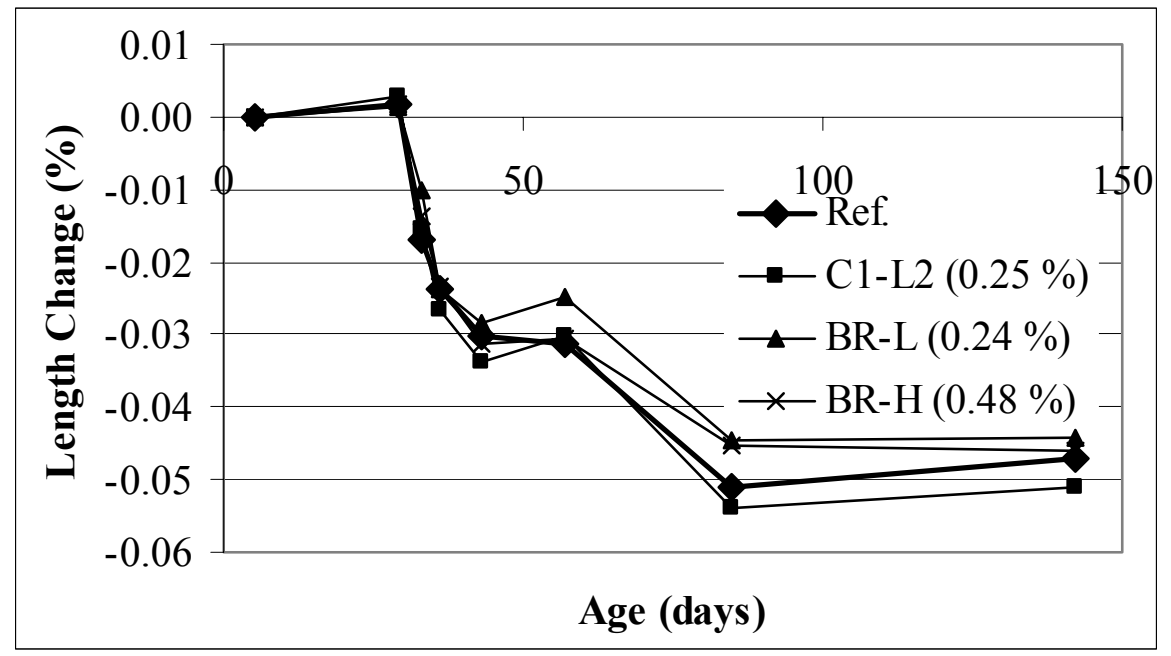

Fig. 124. Length change of concrete (Prototype Field Mixtures)

\subsubsection{Technology Transfer Workshop and Field Concrete Mixture for Construction Demonstration}

A technology transfer workshop was held in Wisconsin Rapids, WI, on November 1, 2002 in conjunction with the construction demonstration. A lecture was given by a guest speaker on the management of paper industry residuals. Also, a presentation was given by the principal investigator (T. R. Naik) of the project on characteristics of residual solids, mixture-proportioning techniques, and strength and durability test results for concrete containing residual solids. After the lecture and presentation, construction demonstration was conducted in the afternoon.

The site for the construction demonstration was near the source of Residual C1. The site is outdoors and exposed to severe cold weather in winter. Six cubic yards of concrete incorporating Residual C1 was manufactured at the ready-mixed concrete plant, and test specimens were cast and a concrete slab was constructed. Mixture proportions and fresh properties of the concrete mixture are presented in Table 101. 
Table 101. Mixture Proportions and Fresh Properties of Concrete (Construction Demonstration)

\begin{tabular}{|c|c|}
\hline Mixture Name & $\overline{\mathrm{C} 1}$ \\
\hline Residual C1, as-recd (\% of concrete by wt.) & 0.49 \\
\hline Wood Fibers $\left(\mathrm{lb} / \mathrm{yd}^{3}\right)^{*}$ & 3.2 \\
\hline Residual C1, LOI at $590^{\circ} \mathrm{C}(\mathrm{lb} / 100 \mathrm{lb}$ cement $)$ & 0.75 \\
\hline HRWRA (fl oz/100 lb cement) & 8.3 \\
\hline Residual C1, as-recd (lb/yd $\left.{ }^{3}\right)$ & 19.5 \\
\hline HRWRA (fl oz/yd $\left.{ }^{3}\right)$ & 45.8 \\
\hline Cement $\left(\mathrm{lb} / \mathrm{yd}^{3}\right)$ & 554 \\
\hline Sand, SSD (lb/yd $\left.{ }^{3}\right)$ & 1450 \\
\hline Gravel, 3/4" max., SSD (lb/yd $\left.{ }^{3}\right)$ & 1770 \\
\hline Water $\left(\mathrm{lb} / \mathrm{yd}^{3}\right)$ & 201 \\
\hline$w / \mathrm{cm}$ & 0.36 \\
\hline Slump (in.) & 8.25 \\
\hline Air Content $(\%)$ & 3 \\
\hline Density $\left(\mathrm{lb} / \mathrm{ft}^{3}\right)$ & 148 \\
\hline Yield $\left(\mathrm{yd}^{3}\right)$ & 6.15 \\
\hline
\end{tabular}

* From Residual C1. On dry basis

Compressive and flexural strengths of the construction-demonstration concrete mixture are presented in Table 102 and Fig. 125 and 126.

Test results for abrasion resistance of the construction-demonstration concrete mixture are presented in Table 103 and Fig. 127.

Table 102. Compressive and Flexural Strengths of Concrete (Construction Demonstration)

\begin{tabular}{|c||c|c|}
\hline Age (days) & $\begin{array}{c}\text { Compressive } \\
\text { Strength (psi) }\end{array}$ & $\begin{array}{c}\text { Flexural } \\
\text { Strength (psi) }\end{array}$ \\
\hline 3 & 4705 & 640 \\
\hline 7 & 5995 & 705 \\
\hline 28 & 7510 & 895 \\
\hline
\end{tabular}




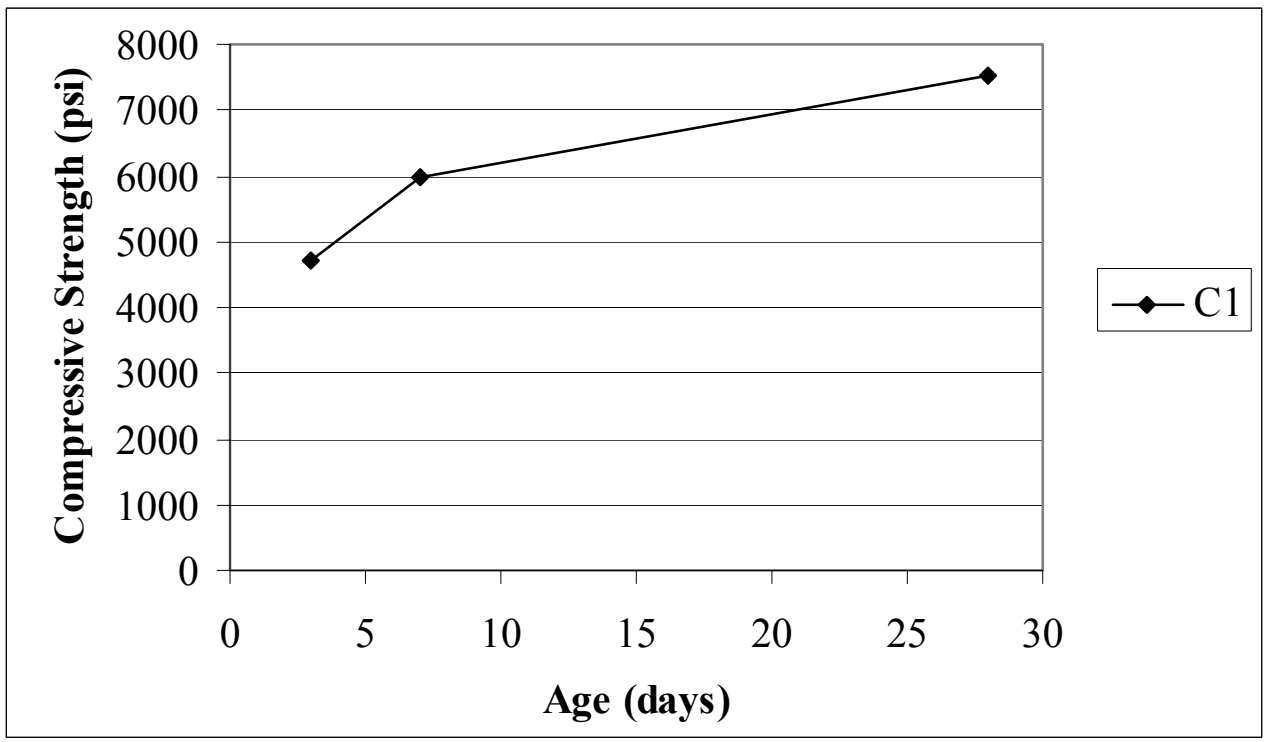

Fig. 125. Compressive strength of concrete vs. age (Construction Demonstration)

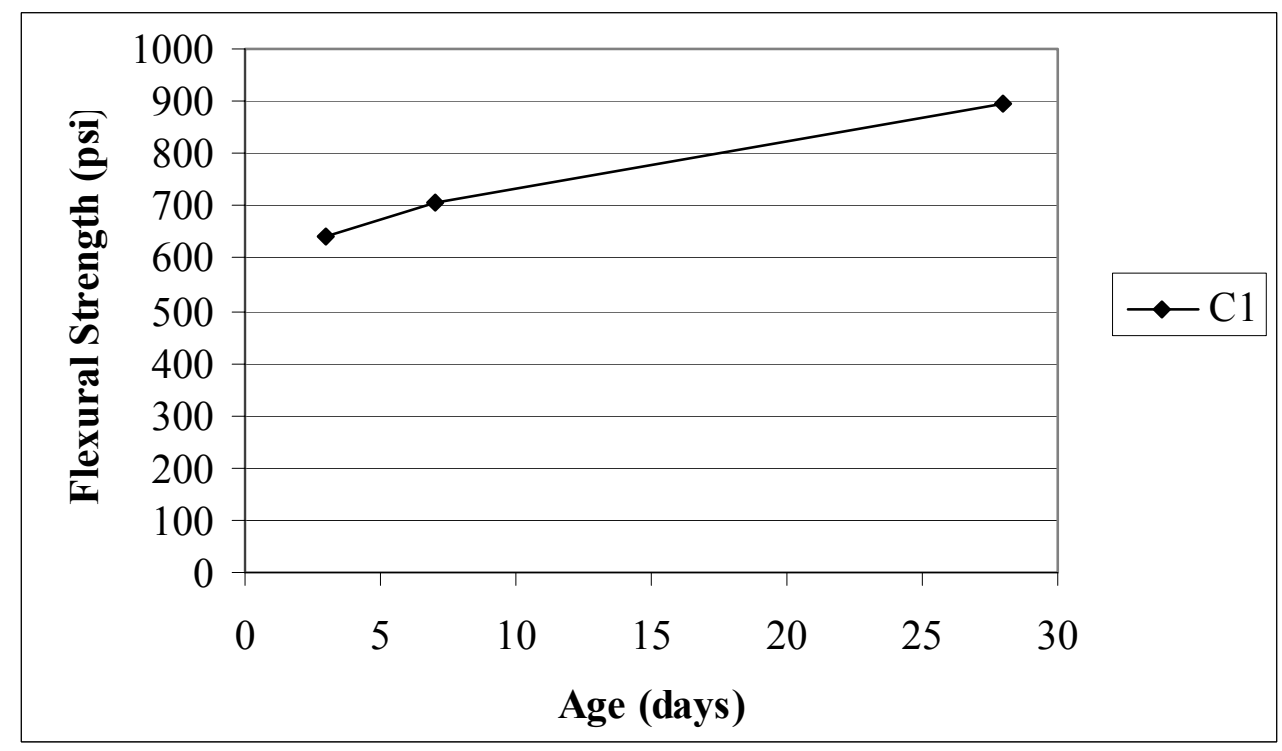

Fig. 126. Flexural strength of concrete vs. age (Construction Demonstration)

Table 103. Mass Loss of Concrete Due to Abrasion (Construction Demonstration)

\begin{tabular}{|l|c|c|c|c|c|c|c|}
\hline Abrasion Time (min.) & 0 & 2 & 4 & 6 & 8 & 10 & 12 \\
\hline Mass Loss (g)* & 0 & 0.37 & 0.64 & 0.95 & 1.29 & 1.75 & 2.35 \\
\hline
\end{tabular}

* Bottom surfaces of cylinders were tested. 


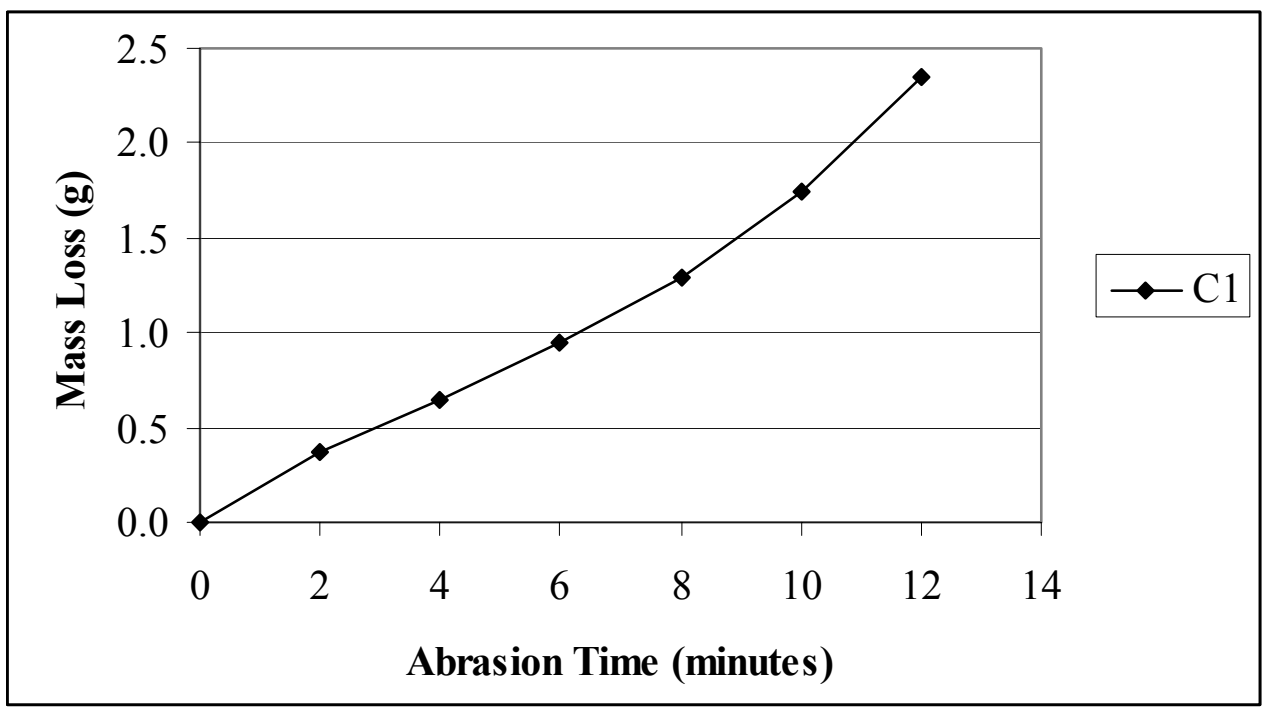

Fig. 127. Mass loss of concrete specimens due to abrasion (Construction Demonstration)

Long-term tests were conducted in order to evaluate the freezing-and-thawing resistance and salt-scaling resistance of the concrete mixture for the field construction demonstration.

\subsection{Additional Laboratory Mixtures}

\subsubsection{Modeling 2 (Series 14)}

Modeling of compressive strength of concrete was conducted a second time to obtain summary information, again using two-level factorial design of experiment. Two variables were used at two levels each: (1) residuals content (based on LOI at $590^{\circ} \mathrm{C}[\sim$ wood fiber content]) of 0 and $1 \mathrm{lb} / 100 \mathrm{lb}$ of cement; and (2) HRWRA content of 0 and $7.5 \mathrm{fl} \mathrm{oz} / 100 \mathrm{lb}$ of cement. Table 104 summarizes the test setup for the two-level factorial design. The setup was constructed in accordance with the design matrix for a $2^{2}$ factorial experiment (Table 125 on p. 246). 
Table 104. Test Setup for Two-Level Factorial Design (Series 14)

\begin{tabular}{|l|c|c|c|c|}
\hline Mixture Name & $\begin{array}{c}\text { Ref. } \\
(-1,-1) \dagger\end{array}$ & $\begin{array}{c}\mathrm{X}^{*} \\
(+1,-1) \dagger\end{array}$ & $\begin{array}{c}\mathrm{H} \dagger \\
(-1,+1) \dagger\end{array}$ & $\begin{array}{c}\mathrm{X} \\
(+1,+1) \dagger\end{array}$ \\
\hline Residuals Content $\left(\mathrm{lb}^{* *} / 100 \mathrm{lb}\right.$ cement) & 0 & 1 & 0 & 1 \\
\hline HRWRA Content (fl oz/100 lb cement) & 0 & 0 & 7.5 & 7.5 \\
\hline
\end{tabular}

* X: Residuals. H: HRWRA.

$\$$ Coded levels of variables: $-1=$ low level. $+1=$ high level.

** Based on LOI at $590^{\circ} \mathrm{C}(\sim$ wood fiber content $)$.

To confirm the models, concrete mixtures containing $0.5 \mathrm{lb}$ of residuals (based on LOI at $590^{\circ} \mathrm{C}[\sim$ wood fibers $\left.]\right) / 100 \mathrm{lb}$ of cement and $3.75 \mathrm{fl} \mathrm{oz}$ of HRWRA/100 lb of cement were also produced. Such mixtures were designated as $\mathrm{X}(0,0)$, where $\mathrm{X}$ is used in place of designation for residuals.

Mixture names and the levels of residuals and HRWRA used for the mixtures are presented in a Cartesian coordinate system in Table 105.

Table 105. Mixture Names and Levels of Residuals and HRWRA (Series 14)

\begin{tabular}{|c|c|c|c|c|c|}
\hline $7.50 \mathrm{fl} \mathrm{oz}^{\#}$ & \multirow{3}{*}{$\begin{array}{c}\text { HRWRA } \\
\text { Level }\end{array}$} & +1 & $\mathrm{H} \dagger(-1,+1)$ & 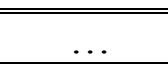 & $\mathrm{X}^{*}(+1,+1)$ \\
\hline \multirow{2}{*}{$\frac{3.75 \mathrm{fl} \mathrm{oz}^{\#}}{0.00 \mathrm{fl} \mathrm{oz}^{\#}}$} & & 0 & $\ldots$ & $X^{*}(0,0)$ & \\
\hline & & -1 & $\begin{array}{c}\text { Ref. }(-1,- \\
1)\end{array}$ & $\cdots$ & $\mathrm{X}^{*}(+1,-1)$ \\
\hline & & & -1 & 0 & +1 \\
\hline & & & & siduals Le & \\
\hline & & & $0 \mathrm{lbt}$ & $0.5 \mathrm{lbt}$ & $1 \mathrm{lbt}$ \\
\hline
\end{tabular}

* X: Residuals. $†$ H: HRWRA.

${ }^{\#}$ Per $100 \mathrm{lb}$ of cement. $\$$ Based on LOI at $590^{\circ} \mathrm{C}(\sim$ wood fiber content).

Target slump for concrete mixtures was three inches. Mixture proportions and fresh properties of concrete are presented in Tables 106 to 109. 
Table 106. Mixture Proportions and Fresh Properties (Series 14: $(-1,-1),(-1,+1))$

\begin{tabular}{|c|c|c|}
\hline Mixture Name & $\begin{array}{c}\text { Ref. } \\
(-1,-1) \\
\end{array}$ & $\begin{array}{c}\mathrm{H} \dagger \\
(-1,1) \\
\end{array}$ \\
\hline $\begin{array}{l}\text { Residuals, as-recd (\% of } \\
\text { concrete by wt.) }\end{array}$ & 0 & 0 \\
\hline Wood Fibers $\left(\mathrm{lb} / \mathrm{yd}^{3}\right)^{*}$ & 0 & 0 \\
\hline $\begin{array}{l}\text { Residuals, LOI at } 590^{\circ} \mathrm{C} \\
(\mathrm{lb} / 100 \mathrm{lb} \text { cement })\end{array}$ & 0 & 0 \\
\hline HRWRA (fl oz/100 lb cement) & 0 & 7.5 \\
\hline Residuals, as-recd (lb/yd $\left.{ }^{3}\right)$ & 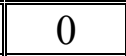 & 0 \\
\hline HRWRA (fl oz/yd ${ }^{3}$ ) & 0 & 46.6 \\
\hline Cement $\left(\mathrm{lb} / \mathrm{yd}^{3}\right)$ & 604 & 621 \\
\hline Sand, SSD $\left(1 \mathrm{lb} / \mathrm{yd}^{3}\right)$ & 1440 & 1450 \\
\hline $\begin{array}{l}\text { Coarse Aggregate, 3/4" max., } \\
\text { SSD }\left(1 \mathrm{lb} / \mathrm{yd}^{3}\right)\end{array}$ & 1710 & 1760 \\
\hline Water $\left(\mathrm{lb} / \mathrm{yd}^{3}\right)$ & 300 & 290 \\
\hline$w / \mathrm{cm}$ & 0.50 & 0.47 \\
\hline Slump (in.) & 3 & 2.5 \\
\hline Air Content (\%) & 1.6 & 2.0 \\
\hline Density $\left(\mathrm{lb} / \mathrm{ft}^{3}\right)$ & 150 & 153 \\
\hline
\end{tabular}

$\dagger$ H: HRWRA. * From residuals, dry basis.

Table 107. Mixture Proportions and Fresh Properties (Series 14: $(+1,+1)$ )

\begin{tabular}{|c|c|c|c|c|c|c|c|c|}
\hline Mixture Name & \begin{tabular}{|c|}
$\mathrm{WG}$ \\
$(1,1)$ \\
\end{tabular} & $\begin{array}{c}\mathrm{I} \\
(1,1) \\
\end{array}$ & $\begin{array}{c}\text { C1 } \\
(1,1) \\
\end{array}$ & $\begin{array}{c}\mathrm{S} \\
(1,1) \\
\end{array}$ & $\begin{array}{c}\mathrm{C} 2 \\
(1,1) \\
\end{array}$ & $\begin{array}{c}\text { WV } \\
(1,1) \\
\end{array}$ & $\begin{array}{c}\text { BR } \\
(1,1) \\
\end{array}$ & $\begin{array}{l}\text { Avg. } \\
(1,1) \\
\end{array}$ \\
\hline $\begin{array}{l}\text { Residuals, as-recd (\% of } \\
\text { concrete by wt.) }\end{array}$ & 0.74 & 0.59 & 0.78 & 0.48 & 0.67 & 0.44 & 0.50 & 0.60 \\
\hline Wood Fibers $\left(\mathrm{lb} / \mathrm{yd}^{3}\right)^{*}$ & .8 & 4.8 & 4.7 & 5.1 & 5.4 & 5.6 & 5.7 & 5.2 \\
\hline $590^{\circ} \mathrm{C}$ & 1.00 & 1.00 & 1.00 & 1.00 & 1.00 & 1.00 & 1.01 & 1.00 \\
\hline HRWRA (fl oz/100 lb cement) & 7.5 & 7.5 & 7.5 & 7.5 & 7.5 & 7.5 & 7.5 & 7.5 \\
\hline Residuals, as-recd (lb/yd $\left.{ }^{3}\right)$ & 29.9 & 23.7 & 31.4 & 19.1 & 27.1 & 17.7 & 20.1 & 24.2 \\
\hline HRWRA (fl oz/yd ${ }^{3}$ ) & 45.3 & 45.4 & 45.5 & 45.2 & 46.3 & 45.2 & 45.3 & 45.5 \\
\hline Cement $\left(\mathrm{lb} / \mathrm{yd}^{3}\right)$ & 603 & 605 & 606 & 603 & 617 & 602 & 604 & 606 \\
\hline Sand, SSD (lb/yd $\left.{ }^{3}\right)$ & 1410 & 1410 & 1410 & 1410 & 1370 & 1410 & 1410 & 1400 \\
\hline $\begin{array}{l}\text { Coarse Aggregate, } 3 / 4 " \text { max., } \\
\operatorname{SSD}\left(\mathrm{lb} / \mathrm{yd}^{3}\right)\end{array}$ & 1710 & 1710 & 1720 & 1710 & 1740 & 1710 & 1710 & 1720 \\
\hline Water $\left(\mathrm{lb} / \mathrm{yd}^{3}\right)$ & 274 & 274 & 273 & 285 & 267 & 267 & 260 & 271 \\
\hline$w / \mathrm{cm}$ & 0.45 & 0.45 & 0.45 & 0.47 & 0.43 & 0.44 & 0.43 & 0.45 \\
\hline Slump & 2.5 & 2.75 & 3.5 & 2.75 & 4 & 3 & 3.25 & 3.1 \\
\hline Air Content & 2.0 & 2.0 & 1.8 & 2.3 & 2.2 & 2.5 & 2.0 & 2.1 \\
\hline Density $\left(\mathrm{lb} / \mathrm{ft}^{3}\right)$ & 149 & 149 & 150 & 149 & 149 & 148 & 148 & 149 \\
\hline
\end{tabular}

* From residuals, dry basis. 
Table 108. Mixture Proportions and Fresh Properties (Series 14: $(+1,-1)$ )

\begin{tabular}{|c|c|c|c|c|c|c|c|c|}
\hline Mixture Name & $\begin{array}{c}\text { WG } \\
(1,-1) \\
\end{array}$ & $\begin{array}{c}\mathrm{I} \\
(1,-1) \\
\end{array}$ & $\begin{array}{c}\mathrm{C} 1 \\
(1,-1) \\
\end{array}$ & $\begin{array}{c}\mathrm{S} \\
(1,-1)\end{array}$ & $\begin{array}{c}\mathrm{C} 2 \\
(1,-1) \\
\end{array}$ & $\begin{array}{c}\text { WV } \\
(1,-1)\end{array}$ & $\begin{array}{c}\text { BR } \\
(1,-1) \\
\end{array}$ & $\begin{array}{l}\text { Avg. } \\
(1,-1)\end{array}$ \\
\hline $\begin{array}{l}\text { Residuals, as-recd (\% of } \\
\text { concrete by wt.) }\end{array}$ & 0.74 & 0.58 & 0.77 & 0.47 & 0.66 & 0.44 & 0.50 & 0.59 \\
\hline Wood Fibers $\left(\mathrm{lb} / \mathrm{yd}^{3}\right)^{*}$ & 4.7 & 4.7 & 4.5 & 4.9 & 5.2 & 5.4 & 5.5 & 5.0 \\
\hline $\begin{array}{l}\text { Residuals, LOI at } 590^{\circ} \mathrm{C} \\
\text { (lb/100 lb cement) }\end{array}$ & 1.00 & 1.00 & 1.00 & 1.00 & 1.00 & 1.00 & 1.01 & 1.00 \\
\hline HRWRA (fl oz/100 lb cement) & 0 & 0 & 0 & 0 & 0 & 0 & 0 & 0 \\
\hline Residuals, as-recd (lb/yd $\left.{ }^{3}\right)$ & 29.3 & 23.1 & 29.9 & 18.6 & 25.9 & 17.1 & 19.3 & 23.3 \\
\hline HRWRA (fl oz/yd ${ }^{3}$ ) & 0 & 0 & 0 & 0 & 0 & 0 & 0 & 0 \\
\hline Cement $\left(1 \mathrm{lb} / \mathrm{yd}^{3}\right)^{-}$ & 590 & 589 & 577 & 585 & 591 & 581 & 580 & 585 \\
\hline Sand, SSD $\left(1 \mathrm{lb} / \mathrm{yd}^{3}\right)$ & 1370 & 1360 & 1330 & 1350 & 1360 & 1340 & 1340 & 1350 \\
\hline $\begin{array}{l}\text { Coarse Aggregate, } 3 / 4 " \text { max., } \\
\text { SSD }\left(1 \mathrm{~b} / \mathrm{yd}^{3}\right)\end{array}$ & 1670 & 1670 & 1640 & 1660 & 1670 & 1650 & 1640 & 1660 \\
\hline Water $\left(\mathrm{lb} / \mathrm{yd}^{3}\right)$ & 301 & 318 & 298 & 325 & 288 & 305 & 296 & 304 \\
\hline$w / \mathrm{cm}$ & 0.51 & 0.54 & 0.52 & 0.56 & 0.49 & 0.52 & 0.51 & 0.52 \\
\hline Slump & 3 & 2.5 & 4.25 & 2.5 & 2.75 & 2.25 & 3.5 & 3.0 \\
\hline Air Ce & 1.9 & 2.3 & 3.9 & 2.4 & 2.6 & 3.7 & 3.8 & 2.9 \\
\hline Density $\left(\mathrm{lb} / \mathrm{ft}^{3}\right)$ & 147 & 146 & 143 & 146 & 146 & 144 & 144 & 145 \\
\hline
\end{tabular}

* From residuals, dry basis.

Table 109. Mixture Proportions and Fresh Properties (Series 14: $(0,0)$ )

\begin{tabular}{|c|c|c|c|c|c|c|c|c|}
\hline Mixture Name & $\begin{array}{c}\text { WG } \\
(0,0)\end{array}$ & $\begin{array}{c}\mathrm{I} \\
(0,0)\end{array}$ & $\begin{array}{c}\mathrm{C} 1 \\
(0,0) \\
\end{array}$ & $\begin{array}{c}\mathrm{S} \\
(0,0)\end{array}$ & $\begin{array}{c}\mathrm{C} 2 \\
(0,0)\end{array}$ & $\begin{array}{c}\text { WV } \\
(0,0)\end{array}$ & $\begin{array}{c}\text { BR } \\
(0,0)\end{array}$ & $\begin{array}{l}\text { Avg. } \\
(0,0)\end{array}$ \\
\hline $\begin{array}{l}\text { Residuals, as-recd (\% of } \\
\text { concrete by wt.) }\end{array}$ & 0.37 & 0.29 & 0.39 & 0.24 & 0.33 & 0.22 & 0.25 & 0.30 \\
\hline Wood Fibers $\left(\mathrm{lb} / \mathrm{yd}^{3}\right)^{*}$ & 2.4 & 2.4 & 2.4 & 2.6 & 2.7 & 2.8 & 2.9 & 2.6 \\
\hline $\begin{array}{l}\text { Residuals, LOI at } 590^{\circ} \mathrm{C} \\
(\mathrm{lb} / 100 \mathrm{lb} \text { cement })\end{array}$ & 0.5 & 0.50 & 0.50 & 0.50 & 0.50 & 0.50 & 0.50 & 0.50 \\
\hline HRWRA (fl oz/100 lb cement) & 3.75 & 3.75 & 3.75 & 3.75 & 3.75 & 3.75 & 3.75 & 3.75 \\
\hline Residuals, as-recd (lb/yd $\left.{ }^{3}\right)$ & 15.1 & 11.9 & 15.9 & 9.7 & 13.3 & 8.9 & 10.1 & 12.1 \\
\hline HRWRA & 22.9 & 22.8 & 23.0 & 22.9 & 22.8 & 22.7 & 22.8 & 22.8 \\
\hline Cement $\left(\mathrm{lb} / \mathrm{yd}^{3}\right)$ & 609 & 607 & 614 & 609 & 607 & 606 & 608 & 608 \\
\hline Sand, SSD $\left(1 \mathrm{lb} / \mathrm{yd}^{3}\right)$ & 1430 & 1430 & 1450 & 1440 & 1430 & 1430 & 1440 & 1440 \\
\hline $\begin{array}{l}\text { Coarse Aggregate, } 3 / 4 " \text { max., } \\
\text { SSD }\left(1 b / y^{3}\right)\end{array}$ & 1730 & 1720 & 1740 & 1730 & 1720 & 1720 & 1720 & 1720 \\
\hline Water $\left(\mathrm{lb} / \mathrm{yd}^{3}\right)$ & 261 & 273 & 261 & 276 & 266 & 279 & 264 & 269 \\
\hline$w / \mathrm{cm}$ & 0.43 & 0.45 & 0.42 & 0.45 & 0.44 & 0.46 & 0.43 & 0.44 \\
\hline Slump (in.) & 1.75 & 1.75 & 2 & 2 & 2 & 2.25 & 2.75 & 2.1 \\
\hline Air Content ( & 2.2 & 2.6 & 2.5 & 2.3 & 2.1 & 2.5 & 2.0 & 2.3 \\
\hline Density $\left(\mathrm{lb} / \mathrm{ft}^{3}\right)$ & 150 & 150 & 151 & 150 & 150 & 150 & 150 & 150 \\
\hline
\end{tabular}

* From residuals, dry basis. 
Test results for air content of concrete are summarized in Table 110. Results of density of fresh concrete are summarized in Table 111. Addition of paper mill residual solids in concrete resulted, on average, in some increase in air content and reduction in fresh density of concrete due to the use of more mixing water for maintaining a slump of about 3 in. Addition of high-range water-reducing admixture (HRWRA) resulted in negligible change in air content and increase in density.

Table 110. Summary of Air Content of Concrete (in \%) (Series 14)

\begin{tabular}{|c|l||c|c|c|}
\hline \multirow{2}{*}{$\begin{array}{c}\text { HRWRA } \\
\text { (fl oz/100 }\end{array}$} & 7.5 & 2.0 & $\ldots$ & $2.1^{*}$ \\
\cline { 2 - 5 } lb cement) & 3.75 & $\ldots$ & $2.3^{*}$ & $\ldots$ \\
\cline { 2 - 5 } & 0 & 1.6 & $\ldots$ & $2.9^{*}$ \\
\hline \multirow{2}{*}{} & \multicolumn{2}{|c|}{ Residuals (lb/100 lb of cement) $\dagger$} \\
\cline { 2 - 5 }
\end{tabular}

* Averages. $\dagger$ Based on LOI at $590^{\circ} \mathrm{C}(\sim$ wood fiber content $)$.

Table 111. Summary of Density of Fresh Concrete (in $\mathrm{Ib} / \mathrm{ft}^{3}$ ) (Series 14)

\begin{tabular}{|c|l|c|c|c|}
\hline \multirow{2}{*}{$\begin{array}{c}\text { HRWRA } \\
\text { (fl oz/100 }\end{array}$} & 7.5 & 153 & $\ldots$ & $149^{*}$ \\
\cline { 2 - 5 } lb cement) & 3.75 & $\ldots$ & $150^{*}$ & $\ldots$ \\
\cline { 2 - 5 } & 0 & 150 & $\ldots$ & $145^{*}$ \\
\cline { 2 - 5 } & & 0 & 0.5 & 1 \\
\cline { 2 - 5 } & \multicolumn{2}{|c|}{ Residuals (lb/100 lb of cement) $\dagger$} \\
\hline
\end{tabular}

* Averages. $\dagger$ Based on LOI at $590^{\circ} \mathrm{C}(\sim$ wood fiber content $)$.

Compressive strength of concrete was determined at 3,7 , and 28 days by testing three cylinders at each test age for each mixture. The results are presented in Tables 112 to 115 . 
Table 112. Compressive Strength of Reference and H Concrete Mixtures (in psi) (Series 14: Ref. \& H)

\begin{tabular}{|c|c|c|}
\hline $\begin{array}{c}\text { Age } \\
(\text { days })\end{array}$ & $\begin{array}{c}\text { Ref. } \\
(-1,-1)\end{array}$ & $\begin{array}{c}\mathrm{H} \dagger \\
(-1,+1)\end{array}$ \\
\hline 3 days & 4200 & 6720 \\
\hline 7 days & 5080 & 7530 \\
\hline 28 days & 6750 & 9250 \\
\hline
\end{tabular}

Table 113. Compressive Strength of Concrete with High Levels of Residuals and HRWRA (in psi) (Series 14: $(+1,+1)$ )

\begin{tabular}{|c|c|c|c|c|c|c|c|c|c|}
\hline Age & $\begin{array}{c}\text { WG } \\
(+1,+1)\end{array}$ & $\begin{array}{c}\text { I } \\
(+1,+1)\end{array}$ & $\begin{array}{c}\text { C1 } \\
(+1,+1)\end{array}$ & $\begin{array}{c}\text { S } \\
(+1)+1)\end{array}$ & $\begin{array}{c}\text { C2 } \\
(+1,+1)\end{array}$ & $\begin{array}{c}\text { WV } \\
(+1,+1)\end{array}$ & $\begin{array}{c}\text { BR } \\
(+1,+1)\end{array}$ & $\begin{array}{c}\text { Avg. } \\
(+1,+1)\end{array}$ & $\begin{array}{c}\text { Std. Dev. } \\
(+1,+1)\end{array}$ \\
\hline 3 days & 5290 & 4730 & 4110 & 4500 & 4370 & 4710 & 3750 & 4490 & 470 \\
\hline 7 days & 6190 & 5510 & 4830 & 5490 & 5400 & 5620 & 4510 & 5370 & 530 \\
\hline 28 days & 7450 & 7170 & 6380 & 7150 & 7140 & 7280 & 5770 & 6910 & 620 \\
\hline
\end{tabular}

Table 114. Compressive Strength of Concrete with High Level of Residuals and Low Level of HRWRA (in psi) (Series 14: $(+1,-1)$ )

\begin{tabular}{|c|c|c|c|c|c|c|c||c|c|}
\hline Age & $\begin{array}{c}\text { WG } \\
(+1,-1)\end{array}$ & $\begin{array}{c}\text { I } \\
(+1,-1)\end{array}$ & $\begin{array}{c}\text { C1 } \\
(+1,-1)\end{array}$ & $\begin{array}{c}\text { S } \\
(+1,-1)\end{array}$ & $\begin{array}{c}\text { C2 } \\
(+1,-1)\end{array}$ & $\begin{array}{c}\text { WV } \\
(+1,-1)\end{array}$ & $\begin{array}{c}\text { BR } \\
(+1,-1)\end{array}$ & $\begin{array}{c}\text { Avg. } \\
(+1,-1)\end{array}$ & $\begin{array}{c}\text { Std. Dev. } \\
(+1,-1)\end{array}$ \\
\hline \hline 3 days & 3200 & 2750 & 2690 & 2760 & 3140 & 2780 & 2860 & 2880 & 200 \\
\hline 7 days & 4090 & 3950 & 3770 & 3750 & 4490 & 3860 & 3990 & 3980 & 250 \\
\hline 28 days & 5260 & 5280 & 5080 & 4940 & 5900 & 5100 & 5280 & 5260 & 340 \\
\hline
\end{tabular}

Table 115. Compressive Strength of Concrete with Medium Levels of Residuals and HRWRA (in psi) (Series 14: $(0,0)$ )

\begin{tabular}{|c|c|c|c|c|c|c|c|c|c|}
\hline Age & $\begin{array}{c}\text { WG } \\
(0,0)\end{array}$ & $\begin{array}{c}\text { I } \\
(0,0)\end{array}$ & $\begin{array}{c}\mathrm{C} 1 \\
(0,0)\end{array}$ & $\begin{array}{c}\mathrm{S} \\
(0,0)\end{array}$ & $\begin{array}{c}\mathrm{C} 2 \\
(0,0)\end{array}$ & $\begin{array}{c}\text { WV } \\
(0,0)\end{array}$ & $\begin{array}{c}\text { BR } \\
(0,0)\end{array}$ & $\begin{array}{c}\text { Avg. } \\
(0,0)\end{array}$ & $\begin{array}{c}\text { Std. Dev. } \\
(0,0)\end{array}$ \\
\hline \hline 3 days & 4420 & 4250 & 4490 & 4280 & 4220 & 4010 & 4160 & 4260 & 170 \\
\hline 7 days & 5640 & 5270 & 5540 & 5330 & 5500 & 5380 & 5550 & 5460 & 150 \\
\hline 28 days & 6450 & 6220 & 6560 & 6270 & 6560 & 6510 & 6570 & 6450 & 170 \\
\hline
\end{tabular}


Compressive strength results are summarized in Tables 116 to 118 and Fig. 128 to 130.

Table 116. Summary of 3-day Compressive Strength of Concrete (in psi) (Series 14)

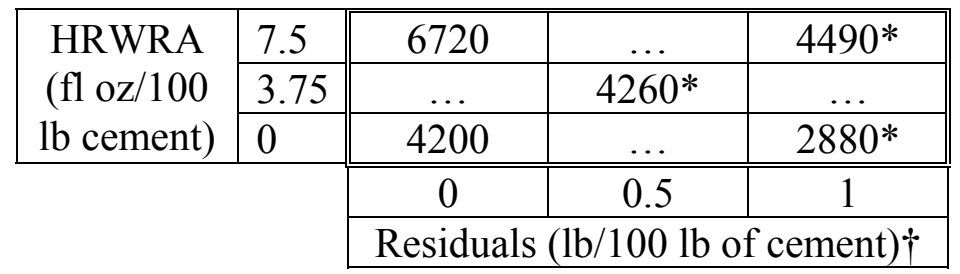

* Averages. $†$ Based on LOI at $590^{\circ} \mathrm{C}(\sim$ wood fiber content $)$.

Table 117. Summary of 7-day Compressive Strength of Concrete (in psi) (Series 14)

\begin{tabular}{|c|c|c|c|c|}
\hline \multirow{3}{*}{$\begin{array}{c}\text { HRWRA } \\
\text { (fl oz/100 } \\
\text { lb cement) }\end{array}$} & \multirow{2}{*}{$\begin{array}{l}7.5 \\
3.75 \\
\end{array}$} & 7530 & \multirow{2}{*}{$\frac{\ldots}{5460 *}$} & $5370^{*}$ \\
\hline & & .. & & 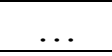 \\
\hline & 0 & 5080 & $\ldots$ & $3980 *$ \\
\hline & & 0 & 0.5 & 1 \\
\hline
\end{tabular}

* Averages. $†$ Based on LOI at $590^{\circ} \mathrm{C}(\sim$ wood fiber content $)$.

Table 118. Summary of 28-day Compressive Strength of Concrete (in psi) (Series 14)

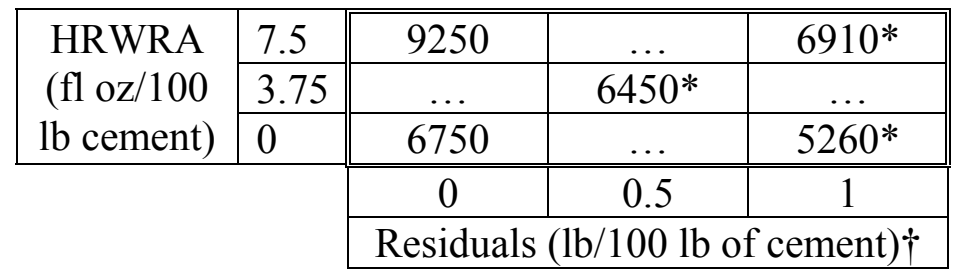

* Averages. $\uparrow$ Based on LOI at $590^{\circ} \mathrm{C}(\sim$ wood fiber content $)$. 


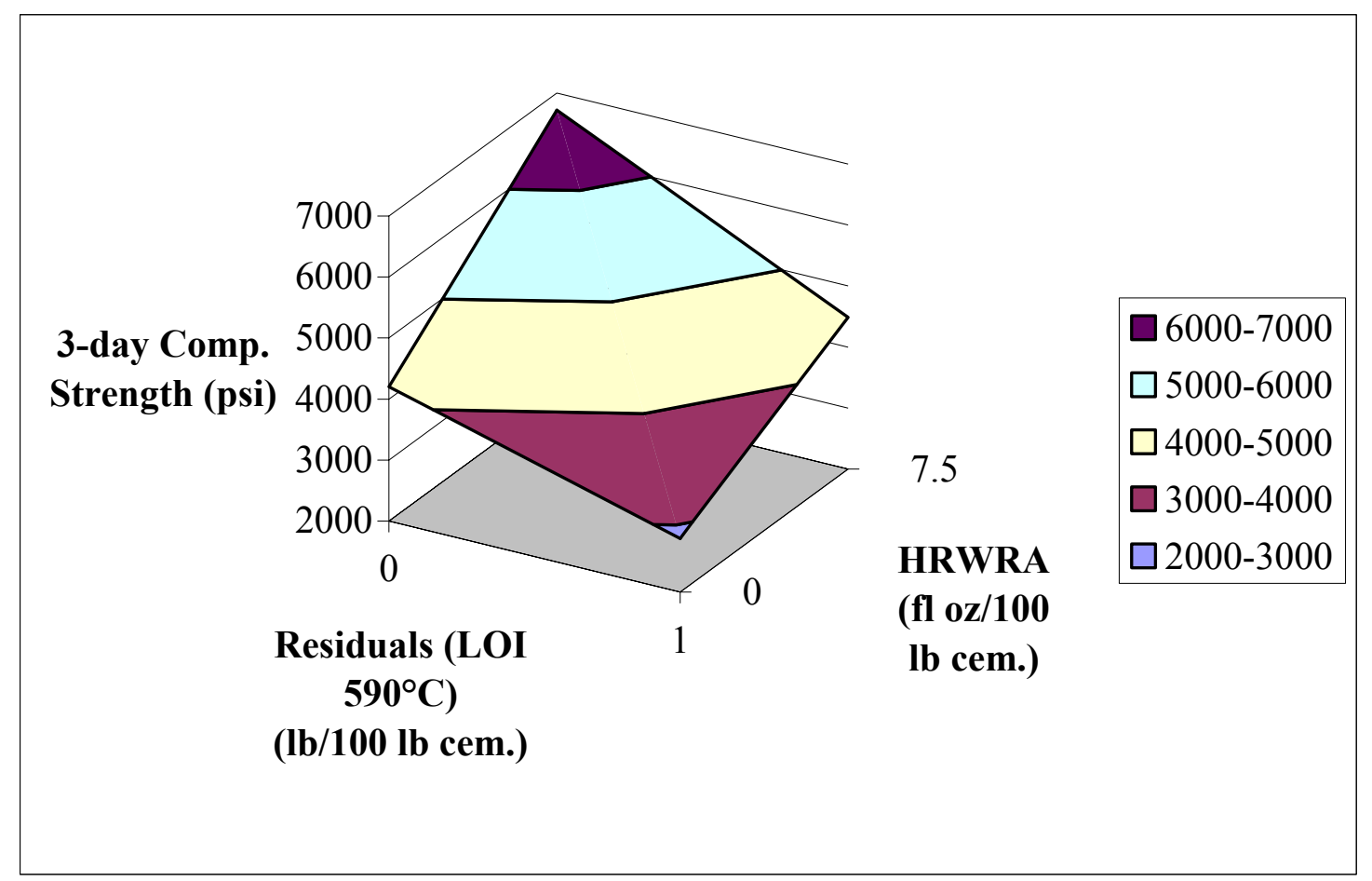

Fig. 128. Overall-average 3-day compressive strength of concrete as influenced by residual and HRWRA contents (Series 14)

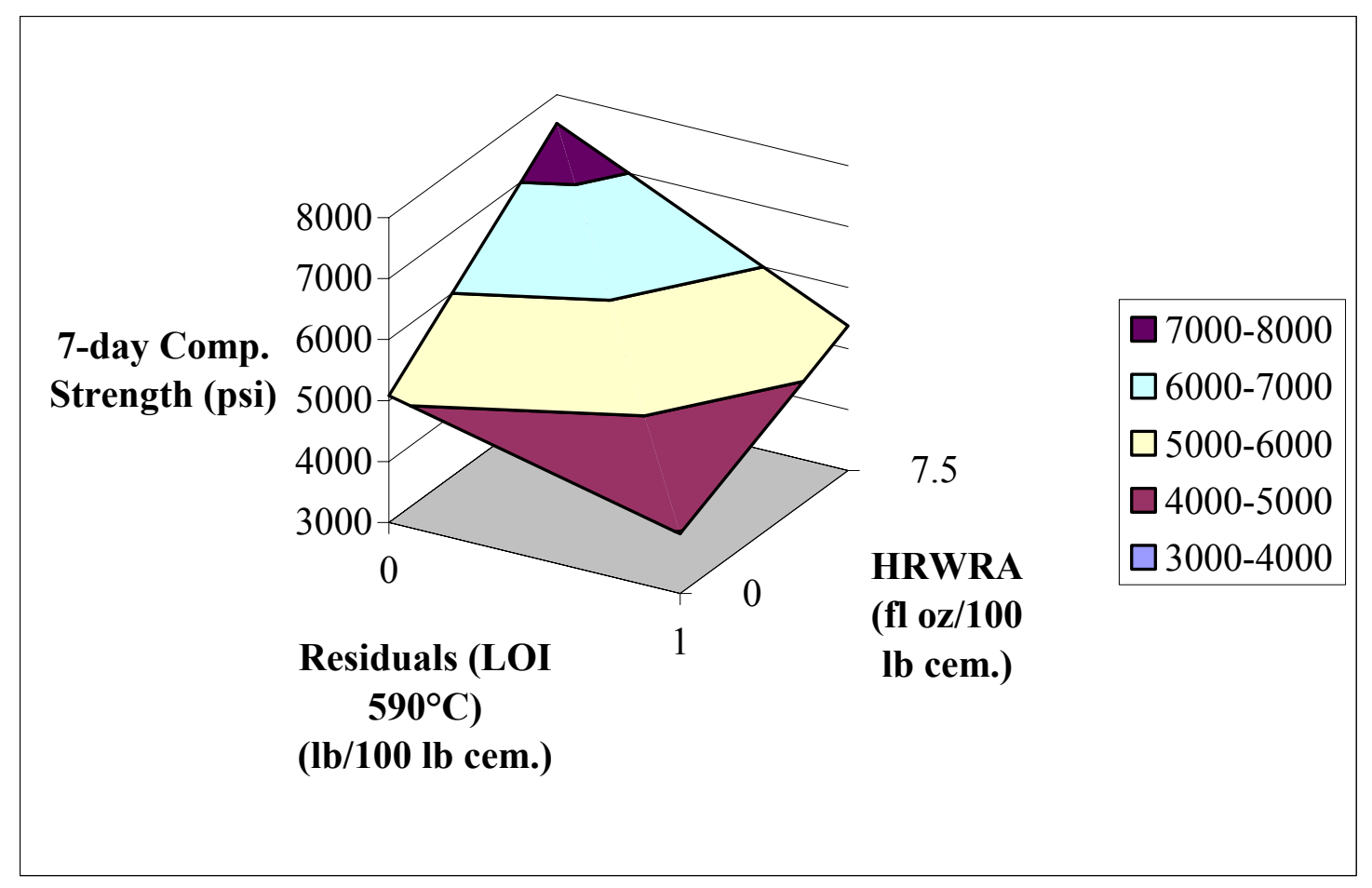

Fig. 129. Overall-average 7-day compressive strength of concrete as influenced by residual and HRWRA contents (Series 14) 


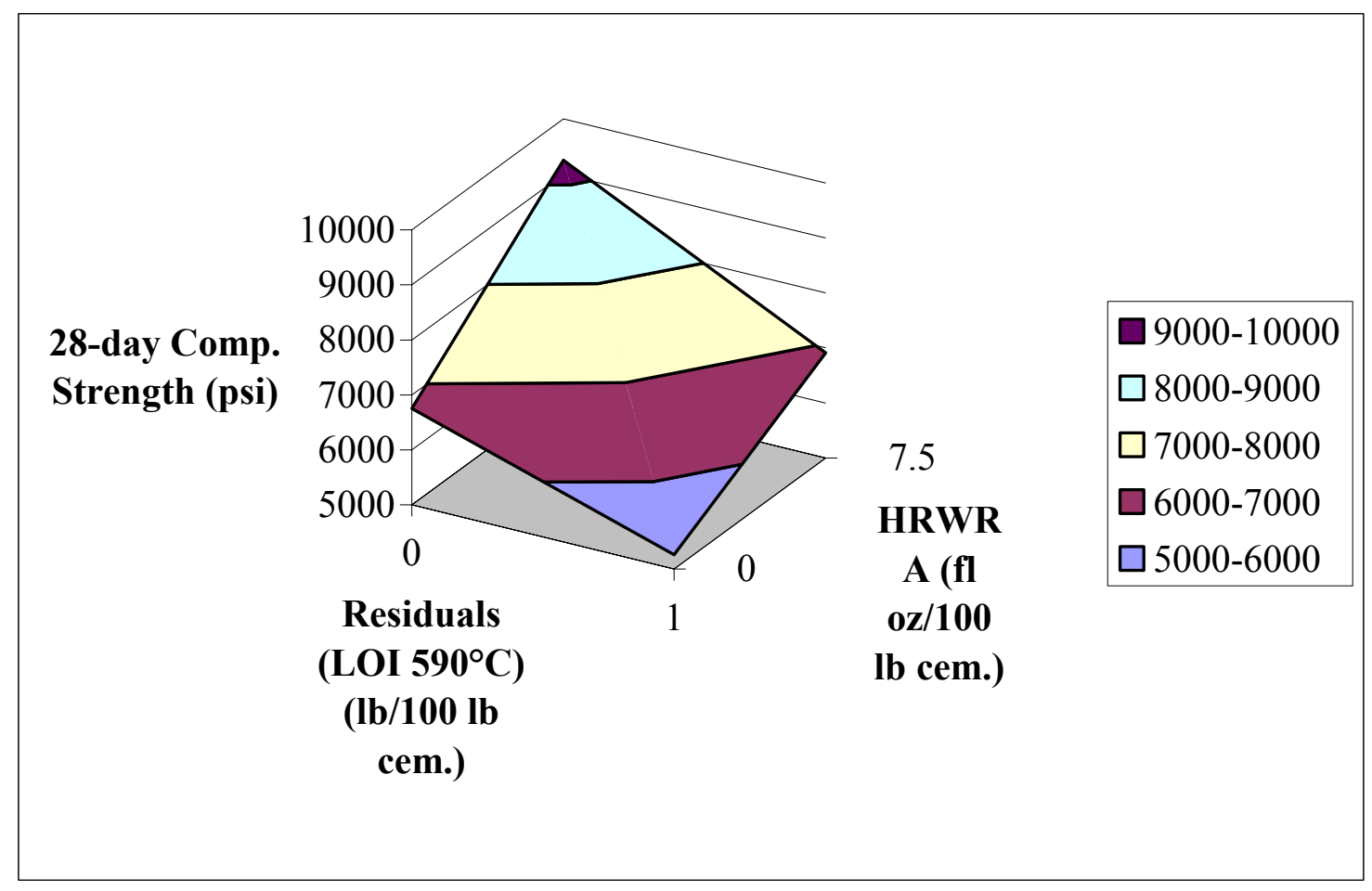

Fig. 130. Overall-average 28-day compressive strength of concrete as influenced by residual and HRWRA contents (Series 14)

By multiplying a 1 x 4 matrix of the average 28-day compressive strength, [6750 526092506910 ], by the $4 \times 4$ square matrix in Table 126 on p. 246 , the following model for the average 28-day compressive strength of concrete was determined:

$$
y(\mathrm{psi})=7043-958 x_{1}+1038 x_{2}-213 x_{1} x_{2}
$$

where:

$x_{1}=$ residuals level calculated as (actual $[$ in $l b * / 100 \mathrm{lb}$ cement $\left.]-0.5\right) / 0.5$, and $x_{2}=$ HRWRA level calculated as (actual [in fl oz/100 lb cement $\left.]-3.75\right) / 3.75$

(* based on LOI at $590^{\circ} \mathrm{C}$ ).

Overall, as the residuals content $\left(x_{1}\right)$ increased, compressive strength of concrete decreased because of the use of more mixing water required for keeping the slump 
around the target slump ( 3 in.). However, the residuals concrete mixtures made without HRWRA still showed average compressive strength of 5260 psi at 28 day (Table 118).

As the HRWRA content $\left(x_{2}\right)$ increased, compressive strength increased because of reduction of mixing water. Concrete made without residuals but with HRWRA reached compressive strength of $9250 \mathrm{psi}$ at 28 days.

When residuals and HRWRA were used in proper proportions-in this case, $1 \mathrm{lb}$ of residuals (based on LOI at $590^{\circ} \mathrm{C}$ ) for $7.5 \mathrm{fl} \mathrm{oz} \mathrm{of} \mathrm{HRWRA} \mathrm{(each} \mathrm{variable} \mathrm{per} 100 \mathrm{lb}$ of cement) — density and 28-day compressive strength of residuals concrete were equivalent to those of Reference concrete, which did not contain residuals or HRWRA (149 vs. $150 \mathrm{lb} / \mathrm{ft}^{3}$ in Table 111 on p. 207 and 6910 vs. 6750 psi in Table 118 on p. 209).

\subsubsection{Splitting Tensile and Flexural Strengths (Series 15)}

Splitting tensile and flexural strengths of plain concrete and residuals concrete were compared. Having confirmed the mixture proportions for achieving equivalent slump and compressive strength in Series 14, the mixture proportions identical to those of Reference and X $(+1,+1)[X$ : Residuals] mixtures of Series 14 were used in Series 15 in order to produce equivalent compressive strength for plain and residuals concrete mixtures.

Air-entraining admixture (AEA) was not used. Reference (plain) concrete did not contain high-range water-reducing admixture (HRWRA), whereas residuals concrete contained $7.5 \mathrm{fl} \mathrm{oz}$ of HRWRA/100 lb of cement. Average wood fiber content in residuals concrete was about $5.2 \mathrm{lb} / \mathrm{yd}^{3}$ of concrete $(0.85 \mathrm{lb} / 100 \mathrm{lb}$ of cement). Asreceived residuals content ranged from 0.44 to $0.78 \%$ by weight of concrete. 
Mixture proportions and fresh properties of concrete are presented in Table 119.

Density of fresh concrete was nearly uniform. Air content values of the Reference

Concrete and residuals concrete were similar (1.6 vs. $2.1 \%$ on average).

Table 119. Mixture Proportions and Fresh Properties of Concrete (Series 15)

\begin{tabular}{|c|c|c|c|c|c|c|c|c|c|}
\hline Mixture Name & Ref. & WG & I & $\mathrm{C} 1$ & $\mathrm{~S}$ & $\mathrm{C} 2$ & WV & $\mathrm{BR}$ & Avg.* \\
\hline $\begin{array}{l}\text { Residuals, as-recd (\% of } \\
\text { concrete by wt.) }\end{array}$ & 0 & 0.75 & 0.59 & 0.78 & 0.48 & 0.66 & 0.44 & 0.50 & 0.60 \\
\hline Wood Fibers $\left(\mathrm{lb} / \mathrm{yd}^{3}\right) \dagger$ & 0 & 4.9 & 4.9 & 4.8 & 5.1 & 5.3 & 5.6 & 5.8 & 5.2 \\
\hline $\begin{array}{l}\text { Residuals, LOI at } 590^{\circ} \mathrm{C} \\
(1 \mathrm{~b} / 100 \mathrm{lb} \text { cement })\end{array}$ & 0 & 1.00 & 1.00 & 1.00 & 1.00 & 1.00 & 1.00 & 1.01 & 1.00 \\
\hline $\begin{array}{l}\text { HRWRA (fl oz/100 lb } \\
\text { cement) }\end{array}$ & 0 & 7.5 & 7.5 & 7.5 & 7.5 & 7.5 & 7.5 & 7.5 & 7.5 \\
\hline Residuals, as-recd (lb/yd $\left.{ }^{3}\right)$ & 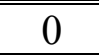 & 30.0 & 23.8 & 31.8 & 19.3 & 26.7 & 17.9 & 20.5 & 24.3 \\
\hline HRWRA (fl oz/yd ${ }^{3}$ ) & 0 & 45.3 & 45.5 & 45.9 & 45.7 & 45.7 & 45.5 & 46.1 & 45.7 \\
\hline Cement $\left(\mathrm{lb} / \mathrm{yd}^{3}\right)$ & 615 & 605 & 608 & 613 & 610 & 610 & 607 & 615 & 610 \\
\hline Sand, SSD $\left(1 \mathrm{~b} / \mathrm{yd}^{3}\right)$ & 1430 & 1410 & 1420 & 1430 & 1420 & 1420 & 1420 & 1440 & 1420 \\
\hline $\begin{array}{l}\text { Coarse Aggregate, } 3 / 4 " \\
\max ., \mathrm{SSD}\left(\mathrm{lb} / \mathrm{yd}^{3}\right)\end{array}$ & 1740 & 1710 & 1720 & 1740 & 1730 & 1730 & 1720 & 1740 & $\mid$\begin{tabular}{||l}
$\mid 1730$ \\
\end{tabular} \\
\hline Water $\left(\mathrm{lb} / \mathrm{yd}^{3}\right)$ & 277 & 258 & 264 & 258 & 267 & 252 & 255 & 248 & 257 \\
\hline$w / \mathrm{cm}$ & 0.45 & 0.43 & 0.43 & 0.42 & 0.44 & 0.41 & 0.42 & 0.40 & 0.42 \\
\hline Slump (in.) & 2.75 & 5 & 2.5 & 6.5 & 3 & 4.25 & 2.25 & 3.5 & 3.9 \\
\hline Air Content (\%) & 1.6 & 2.1 & 2.0 & 2.2 & 2.0 & 2.0 & 2.6 & 1.9 & 2.1 \\
\hline Density $\left(\mathrm{lb} / \mathrm{ft}^{3}\right)$ & 151 & 149 & 150 & 151 & 150 & 150 & 149 & 151 & 150 \\
\hline
\end{tabular}

* For residuals concrete. † From residuals, dry basis.

For each mixture, compressive, splitting tensile, and flexural strengths of concrete were determined at 28 days by testing three cylinders, three cylinders, and three 4 " x 4 " x 14" beams, respectively. The results are presented in Table 120 and Fig. 131. Based on the equations shown in Fig. 131, it can be shown that splitting tensile and flexural strengths of residuals concrete having same compressive strength as the Reference Concrete would be about 696 and 834 psi, respectively. These expected strengths of residuals concrete are about 4 and 17\% higher than the actual strengths (670 and 711 psi) 
of the Reference (plain) concrete. Conversely, at the same level of splitting tensile or flexural strength, residuals concrete showed lower compressive strength than the Reference Concrete (Table 120).

Table 120. Compressive, Splitting Tensile, and Flexural Strength of Concrete at 28days (in psi)

\begin{tabular}{|l|c|c|c|c|c|c|c|c|c|}
\hline \multicolumn{1}{|c|}{ Strength } & Ref. & WG & I & C1 & S & C2 & WV & BR & Avg.* \\
\hline Compressive & 7050 & 6290 & 6680 & 6300 & 6840 & 6720 & 7460 & 7350 & 6810 \\
\hline Splitting Tensile & 670 & 653 & 678 & 656 & 682 & 683 & 712 & 716 & 683 \\
\hline Flexural & 711 & 766 & 801 & 732 & 758 & 776 & 854 & 935 & 803 \\
\hline
\end{tabular}

* For residuals concrete

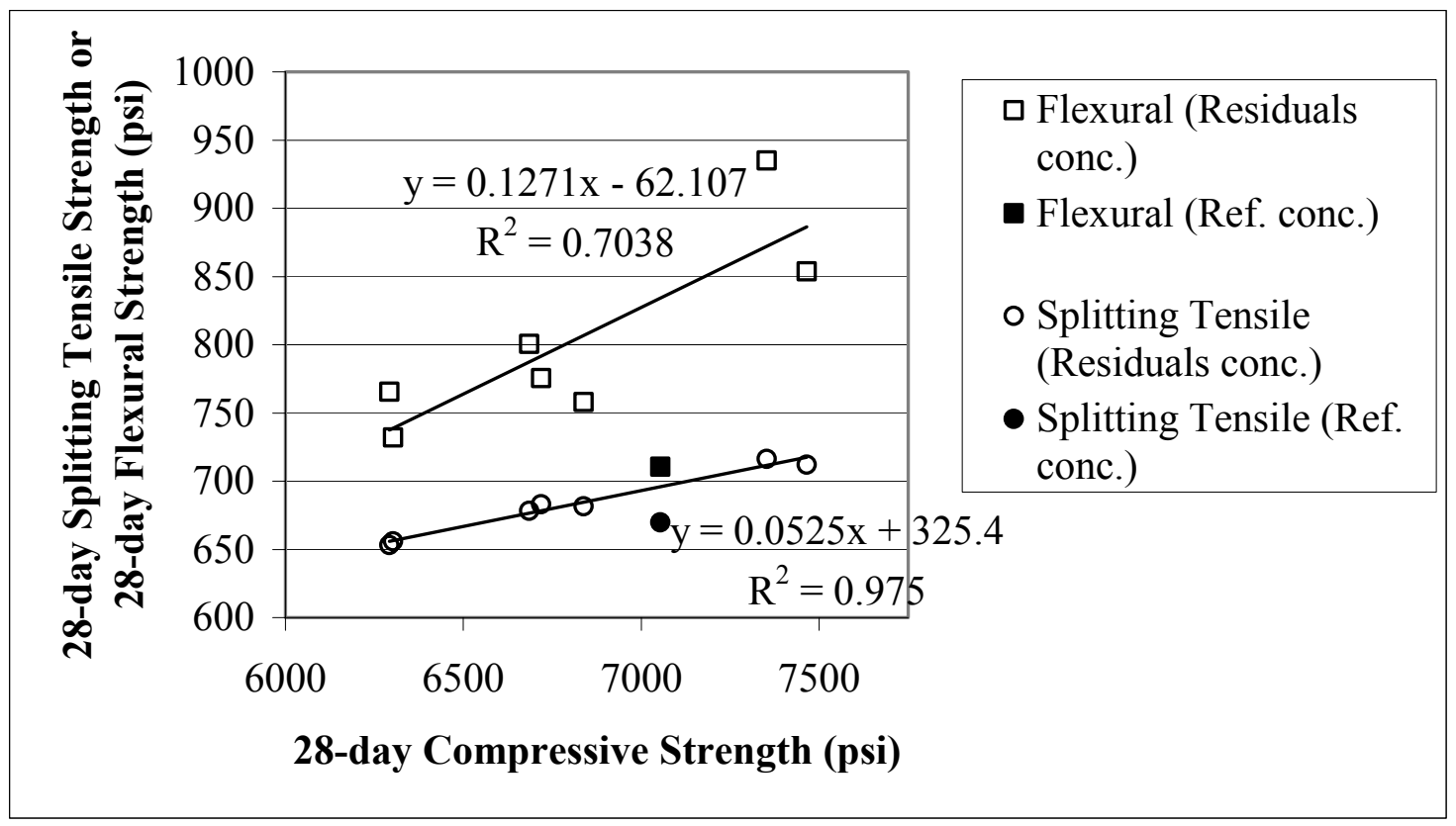

Fig. 131. Flexural and splitting tensile strengths of concrete in relation to compressive strength (Series 15)

\subsubsection{Response to AEA (Series 16)}

Responses of no-residuals concrete and residuals concrete to air-entraining admixture (AEA) were compared. Mixture proportions were identical to those of Reference and X 
$(+1,+1)$ [X: Residuals] mixtures of Series 14, except that AEA was used for both Reference and residuals concrete mixtures. For both the Reference and the residuals concrete mixtures, $2.7 \mathrm{fl}$ oz of AEA was used per $100 \mathrm{lb}$ of cement. Reference concrete did not contain high-range water-reducing admixture (HRWRA), whereas residuals concrete contained $7.5 \mathrm{fl} \mathrm{oz} \mathrm{of} \mathrm{HRWRA/100} \mathrm{lb} \mathrm{of} \mathrm{cement.} \mathrm{Average} \mathrm{wood} \mathrm{fiber} \mathrm{content}$ in residuals concrete was about $5.1 \mathrm{lb}$ per cubic yard of concrete $(0.85 \mathrm{lb} / 100 \mathrm{lb}$ of cement). As-received residuals content ranged from 0.44 to $0.78 \%$ by mass of concrete. Mixture proportions and fresh properties of concrete are presented in Table 121. Compressive strength of concrete was determined at 3,7 , and 28 days by testing three cylinders at each test age for each mixture. The results are presented in Table 122 and Fig. 132.

Air content, density, and 28-day compressive strength of the air-entrained Reference concrete were $6.6 \%, 143 \mathrm{lb} / \mathrm{ft}^{3}$, and $5150 \mathrm{psi}$, respectively. Corresponding average values for residuals concrete were $4.2 \%, 147 \mathrm{lb} / \mathrm{ft}^{3}$, and $5840 \mathrm{psi}$. Residuals concrete mixtures showed nearly uniform air content (ranging from 3.8 to $4.8 \%$ ).

The results suggest that concrete containing residuals may require higher dosage of AEA compared with Reference concrete without residuals. The reason for this is not known. 
Table 121. Mixture Proportions and Fresh Properties of Concrete (Series 16)

\begin{tabular}{|c|c|c|c|c|c|c|c|c|c|}
\hline Mixture Name & Ref. & WG & $\overline{\mathrm{I}}$ & C1 & $\overline{\mathrm{S}}$ & C2 & WV & BR & Avg.* \\
\hline $\begin{array}{l}\text { Residuals, as-recd (\% of } \\
\text { concrete by wt.) }\end{array}$ & 0 & 0.75 & 0.59 & 0.78 & 0.48 & 0.66 & 0.44 & 0.50 & 0.60 \\
\hline Wood Fibers $\left(\mathrm{lb} / \mathrm{yd}^{3}\right) \dagger$ & 0 & 4.8 & 4.8 & 4.7 & 5.0 & 5.3 & 5.5 & 5.7 & 5.1 \\
\hline $\begin{array}{l}\text { Residuals, LOI at } 590^{\circ} \mathrm{C} \\
(1 \mathrm{~b} / 100 \mathrm{lb} \text { cement })\end{array}$ & 0 & 1.00 & 1.00 & 1.00 & 1.00 & 1.00 & 1.00 & 1.01 & 1.00 \\
\hline $\begin{array}{l}\text { HRWRA (fl oz/100 lb } \\
\text { cement) }\end{array}$ & 0 & 7.5 & 7.5 & 7.5 & 7.5 & 7.5 & 7.5 & 7.5 & 7.5 \\
\hline AEA (fl oz/100 lb cement) & 2.7 & 2.7 & 2.7 & 2.7 & 2.7 & 2.7 & 2.7 & 2.7 & 2.7 \\
\hline Residuals, as-recd (lb/yd $\left.{ }^{3}\right)$ & 0 & 29.6 & 23.4 & 31.3 & 19.0 & 26.4 & 17.5 & 20.0 & 23.9 \\
\hline HRWRA (fl oz/yd $\left.{ }^{3}\right)$ & 0 & 44.8 & 44.9 & 45.2 & 45.0 & 45.2 & 44.6 & 45.1 & 45.0 \\
\hline AEA (fl oz/yd $\left.{ }^{3}\right)$ & 15.7 & 16.1 & 16.2 & 16.3 & 16.2 & 16.3 & 16.1 & 16.2 & 16.2 \\
\hline Cement $\left(\mathrm{lb} / \mathrm{yd}^{3}\right)$ & 582 & 597 & 598 & 602 & 600 & 602 & 595 & 601 & 599 \\
\hline Sand, SSD (lb/yd $\left.{ }^{3}\right)$ & 1370 & 1390 & 1390 & 1410 & 1400 & 1410 & 1390 & 1410 & 1400 \\
\hline $\begin{array}{l}\text { Coarse Aggregate, } 3 / 4 " \text { max., } \\
\text { SSD }\left(\mathrm{lb} / \mathrm{yd}^{3}\right)\end{array}$ & 1650 & 1690 & 1690 & 1710 & 1700 & 1710 & 1690 & 1700 & 1700 \\
\hline Water $\left(\mathrm{lb} / \mathrm{yd}^{3}\right)$ & 266 & 253 & 268 & 253 & 269 & 253 & 261 & 242 & 257 \\
\hline$w / \mathrm{cm}$ & 0.46 & 0.42 & 0.45 & 0.42 & 0.45 & 0.42 & 0.44 & 0.40 & 0.43 \\
\hline Slump (in.) & 2.75 & 4.75 & 2.5 & 6.5 & 3 & 4 & 3.5 & 3 & 3.9 \\
\hline Air Content (\%) & 6.6 & 4.8 & 3.8 & 4.2 & 4.2 & 4.0 & 4.1 & 4.0 & 4.2 \\
\hline Density $\left(\mathrm{lb} / \mathrm{ft}^{3}\right)$ & 143 & 147 & 147 & 148 & 148 & 148 & 146 & 147 & 147 \\
\hline
\end{tabular}

* For residuals concrete. † From residuals, dry basis. 
Table 122. Compressive Strength of Concrete (Series 16) (in psi)

\begin{tabular}{|c||c||c|c|c|c|c|c|c|c|}
\hline Age (days) & Ref. & WG & I & C1 & S & C2 & WV & BR & Avg.* \\
\hline \hline 3 & 2930 & 3550 & 3720 & 3860 & 4020 & 3820 & 3900 & 4230 & 3750 \\
\hline 7 & 3880 & 4580 & 5010 & 5210 & 5090 & 5070 & 5080 & 5300 & 4900 \\
\hline 28 & 5150 & 5290 & 5640 & 6010 & 6020 & 6370 & 6270 & 5980 & 5840 \\
\hline
\end{tabular}

* For residuals concrete

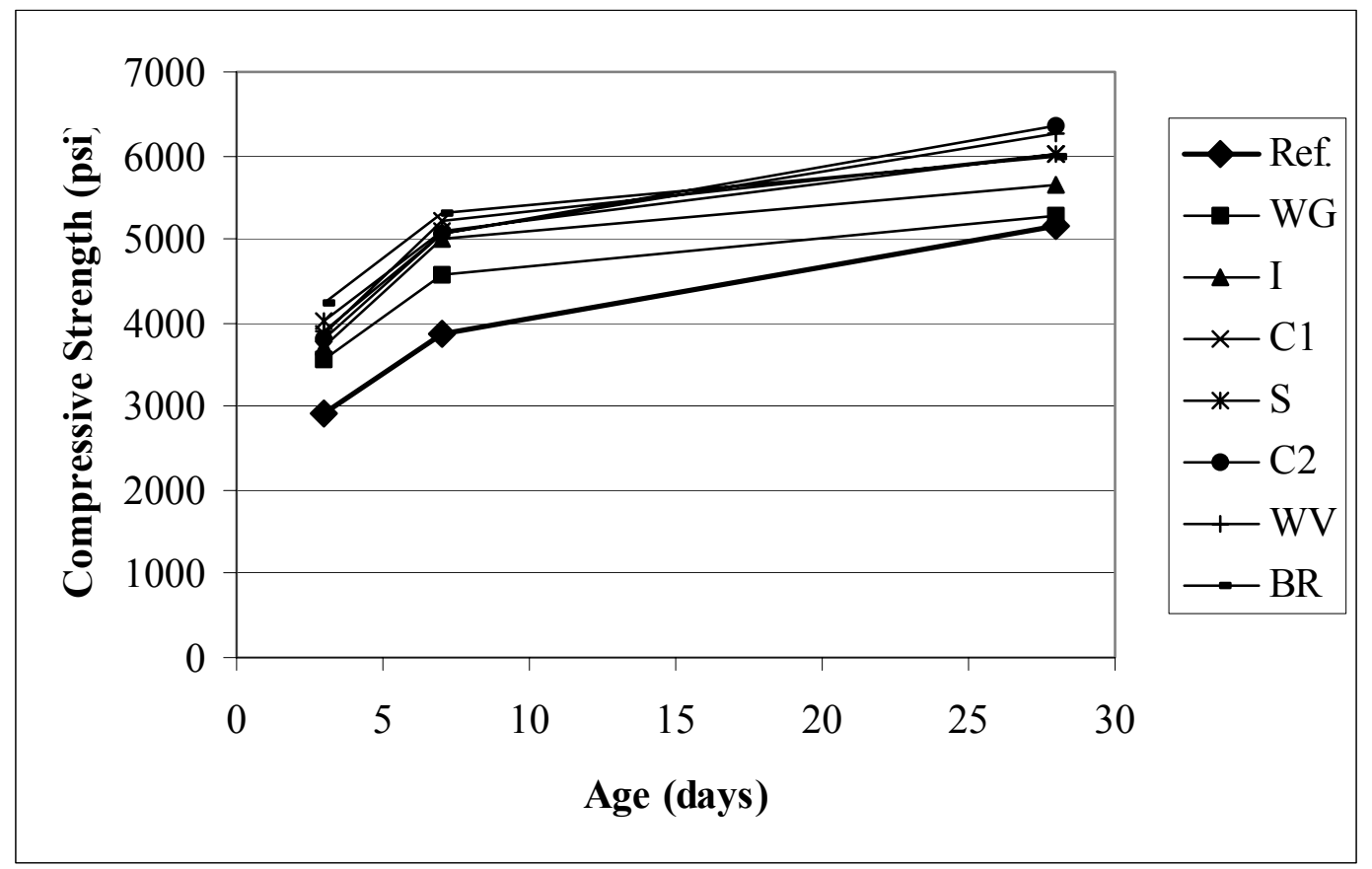

Fig. 132. Compressive strength of concrete (Series 16) 


\section{CHAPTER 8 MARKET STUDY}

\subsection{Overview}

A market survey was distributed to 360 ready-mixed concrete producers and affiliated members of the national and state ready-mixed concrete associations. The survey assessed the potential market for pulp and paper mill wastewater treatment residual fibers in concrete as well as established preliminary pricing information needed to conduct the economic impact of using these sources of fibers. The survey described potential performance characteristics of concrete containing residual fibers and requested the concrete manufacturer to provide comparative estimated market and pricing for such fibers. Results of the responses were compiled and the data analyzed. Based upon the results of the survey, economic impact information was compiled for each state having a significant pulp and paper industry.

\subsection{Market Survey}

A market survey is considered to be one of the most powerful tools in marketing. The purpose of a market survey is to measure the existing and/or potential market for a new product. In order to determine the potential market of residual fibers in concrete, a market survey was prepared as a first step in the marketing process. For this project, the market survey was developed as a questionnaire. Several steps were taken to establish and carefully conduct this survey. 


\section{- Objective of the questionnaire}

The objective statement established for the questionnaire included a brief summary of the project describing the project and the expected benefits of using recycled wood fibers in concrete. The overall objective of the questionnaire was to establish the potential market of recycled wood fibers as well as to determine preliminary pricing data to be used in an economic impact study. Also, technical and environmental issues were to be identified as part of this questionnaire.

\section{- Determination of the population to be studied}

The targeted population of the survey was chosen to be ready-mixed concrete producers. If used in the marketplace, the concrete producers will be the group that purchases the fibers for use in ready-mixed concrete. A representative sample of members of state and national ready-mixed concrete associations and affiliated members were selected.

\section{- Pre-Study}

A pre-study was conducted to obtain preliminary responses to the questionnaire as well as comments on the questions, format, etc. A total of six people were selected as a part of this pre-study. Based upon their responses, questions were modified for the final version that was distributed.

\section{- Development of questions}

A sample questionnaire is presented in Fig. 133. The final selections of questions included a question to determine if the end users would be willing to pay for the recycled wood fibers at its introduction. Other information to be gathered included an estimate of the percentage of customers that would benefit from the enhanced concrete properties 
offered by the product. Finally, the survey asked for any technical or environmental hurdles that could be identified at this time to establish the marketability of the product. This information was collected to enhance the marketability of the product and determine if any other testing information should be added to the existing plan to overcome any perceived obstacles. Secondary information gathered as a part of the survey included the amount of concrete produced annually, as well as the added value expressed in dollars per cubic yard that a ready-mixed concrete could be sold that included the recycled wood fibers. This information was necessary for determining the economic impact of the use of residual wood fibers in concrete.

\section{- Contact Method}

The contact method chosen for this survey was by mail. This method was selected to allow the customers flexibility in completing the questionnaire according to their schedule. Many times, a phone survey has been found to intrude on customers' schedules. A list of 360 potential contact people was prepared based upon the potential users selected from the ready-mixed concrete producers and affiliate members of state and national ready-mixed concrete associations. 
Date

Address

Subject: Recycled Natural Fibers for Concrete

Gentlemen/Madam:

Currently, we are in the final stages of developing a new type of ready-mixed concrete using recycled fibers from pulp and paper mills (wood fibers). Earlier work by the UWM Center for By-Products Utilization in the states of Wisconsin and Washington has shown that judicious use of the fibers leads to:

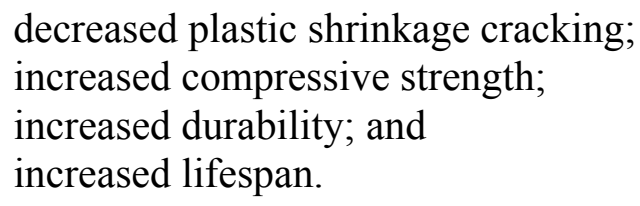

This new type of ready-mixed concrete with wood fibers is expected to double the durability of regular concrete.

Before we finish the final testing stage, we would like to get your opinion on this product. This will help us in the final stages of this new concrete development in terms of cost and technology. Enclosed is a brief questionnaire. We would very much appreciate it if you would take a few minutes and fill out the form and mail or fax it back to us (at 414-229-6958).

Thank you very much for your help. If you have any questions or comments, please feel free to call us at (414) 229-6696 or (414) 229-4105.

Sincerely,

Tarun R. Naik

Enclosure

Fig. 133. Sample of market survey - letter of transmittal and questionnaire 


\section{Use of Recycled Natural Fibers in Concrete \\ Request for Input From the Concrete Industry}

Company Name:

Contact Person:

Phone Number e-mail Address

Amount of Concrete Produced Annually $\left(\mathbf{y d}^{3}\right)$

Currently we are in the final stages of developing a new type of ready-mix concrete using recycled fibers from pulp and paper mils (wood fibers). Varying lengths of such fibers will help reduce the plastic and drying shrinkage cracks in the concrete. Earlier work by the UWM Center for By-Product Utilization has shown that judicious use of fibers leads to decreased cracking in concrete, which leads to increase in strength and durability of the concrete. This new type of ready-mix concrete is expected to double the durability of regular concrete.

If the results of our trials are successful, how likely are you to pay for a product that has these extra benefits? (circle one) $\begin{array}{ccccc}1 & 2 & 3 & 4 & 5 \\ \text { not likely } & & & & \text { very likely }\end{array}$

Estimate the percentage of your customers that would benefit from a product that has these extra benefits. (circle one) $\quad 25 \% \quad 50 \% \quad 75 \% \quad 100 \%$ Other (specify)

What added value in dollars per cubic yard would you estimate a product with these benefits would bring? $\$$ per cu. yd.

What technical or environmental hurdles would you see in incorporating this product into your concrete?

THANK YOU VERY MUCH FOR YOUR HELP

Please FAX or mail your input to:

Tarun R. Naik, Ph.D., P.E.

FAX: (414) 229-6958

UWM Center for By-Products Utilization

University of Wisconsin - Milwaukee

P.O. Box 784

Milwaukee, WI 53211

Fig. 133. Sample of market survey - letter of transmittal and questionnaire (cont'd) 


\subsection{Survey Results}

The results of the survey were then collected and analyzed. The results of the survey are given below.

- Total Number of Surveys Distributed: 360

- Total Number of Responses: 36 (of which 21 were ready-mixed concrete companies)

- Response Rate: $10 \%$

- Total amount of concrete produced by ready-mixed producers responding: 4.32 million cubic yards per year.

- Likelihood that the concrete producer will pay for recycled wood fibers

$\begin{array}{lcc}\text { CATEGORY } & \text { \# RESPONDING } & \text { PERCENTAGE } \\ 1 \text { (not likely) } & 2 & 6 \% \\ 2 & 1 & 3 \% \\ 3 & 10 & 32 \% \\ 4 & 12 & 39 \% \\ 5 \text { (very likely) } & 6 & 19 \%\end{array}$


- Estimation of the percentage of concrete buyers (customers of concrete producers) benefiting from the use of recycled wood fibers in concrete.

$\begin{array}{ccc}\text { \% BENEFITTING } & \text { \# RESPONDING } & \text { PERCENTAGE } \\ 1 & 1 & 3 \% \\ 10 & 1 & 3 \% \\ 25 & 10 & 33 \% \\ 50 & 9 & 30 \% \\ 75 & 4 & 13 \% \\ 100 & 5 & 17 \%\end{array}$

- Estimated value added to concrete produced by using recycled wood fibers

$\begin{array}{llc}\text { \$CUBIC YARD } & \text { \# RESPONDING } & \text { PERCENTAGE } \\ \$ 2.00 & 8 & 35 \% \\ \$ 3.00 & 2 & 9 \% \\ \$ 4.00 & 4 & 17 \% \\ \$ 5.00 & 1 & 4 \% \\ \$ 6.00 & 2 & 9 \% \\ \$ 7.00 & 2 & 9 \% \\ \$ 10.00 & 3 & 13 \% \\ \$ 30.00 & 1 & 4 \%\end{array}$


- Technical and environmental hurdles identified.

Establish a process to introduce these fibers into the concrete

Floatation of the fibers within the mixture

Fiber decay

Effective sales and marketing of the fibers

Assure even distribution of fibers within the concrete mixture

Storage of fibers

Durability in moist conditions

Providing a product that meets performance criteria

Acceptance by engineers and architects

\subsection{Market Share}

Based upon the results of the survey, the following general conclusions may be drawn.

Estimated potential market for the residual solids in concrete is approximately $25 \%$ of the total ready mixed concrete produced. The potential that the ready-mixed concrete producer would pay for the fibers was rated as an average of 3.6, which was between neutral and likely. This would indicate that initial pricing of the fibers should be in-line with other fiber types (such as steel, plastic, or nylon) and may require aggressive pricing to introduce the fibers effectively. For certain brands of steel, polypropylene, and nylon fibers, unit prices of $0.50,5.00$, and $3.00(\$ / 1 b)$ were reported. At fiber addition rates of about 50,1.5, and $1 \mathrm{lb}$ per cubic yard of concrete, unit prices of these fibers were about 25,8 , and 3 dollars, respectively, per cubic yard of concrete. 


\subsection{Technical Issues Identified by the Market Survey}

Technical issues identified through the responses to the market survey included concerns regarding the methodology to incorporate fibers into concrete at a production facility, fiber storage, and adequate mixing to assure even distribution of the fibers within the concrete. Other issues deal with long-term durability of the fibers in concrete. It is not expected that the performance of the concrete containing the paper mill residuals will degrade over time (p. 43). 


\section{CHAPTER 9 ECONOMIC IMPACT}

The National Ready-Mixed Concrete Association has estimated that a total of approximately 400 million cubic yards of concrete was produced in the U.S. in 2000 . From the total production, the total concrete produced in individual states was estimated based upon population of the state versus total U.S. population. Production of concrete was estimated only for states where significant amount of paper mill residuals were generated. The estimated amount of concrete production that would use residuals was taken as $25 \%$ of the total estimated concrete produced for each state, which was the value determined from the market survey.

Based upon the research conducted to date for this project, the amount of residuals that could be effectively used in concrete was estimated to be 10 pounds $(0.005$ ton) per cubic yard of concrete, on dry basis. The quantity of residuals potentially to be used in concrete was determined by multiplying this addition rate by the quantity of concrete assumed to be produced with residuals.

No cost has been designated for transportation of the fibers to the concrete readymixed plant. It was assumed that initially the transportation costs would be equivalent to revenues generated from sales of the residuals. The revenue obtained by the concrete industry was estimated to be $\$ 4.50$ per cubic yard of concrete, based upon the results of the market survey. The avoided disposal cost was assumed to be $\$ 30$ per ton of asproduced dewatered residuals. This converts to $\$ 72$ per dry ton with average moisture content of as-produced residuals assumed to be $150 \%$ of oven-dry mass. Cost of HRWRA was not taken into account. 
With the above assumptions, saving on disposal cost of residuals can also be expressed as $\$ 0.375 /$ cubic yard of concrete.

Table 123 shows the economic impact of using the residual solids in concrete on U.S. state economies. The use of residuals in concrete in the U.S. could have an impact of about $\$ 390$ million for the concrete industry and about $\$ 30$ million in avoided disposal cost for pulp and paper mills per year.

Potential economic impact on U.S. national economy of the use of pulp and paper mill residual solids in concrete is presented in Table 124. If residuals were used for microfiber reinforcement of $20 \%$ of concrete produced in the U.S., there could be economic benefits of $\$ 360$ million for the concrete industry and $\$ 30$ million for the paper industry per year.

Finally, the cost of using virgin pulp as a source of cellulose fibers is discussed for comparison. Average price of U.S. market pulp for the period of 1991 to 1997 was about $\$ 640$ per ton as delivered [56]. With an average fiber content of paper mill residuals assumed to be about $60 \%$ on dry basis (p. 78), 1 ton of dry residuals would contain approximately same amount of cellulose fibers as 0.6 ton of market pulp.

Referring to Table 124, in order to reinforce $20 \%$ of concrete produced in the U.S. with cellulose fibers supplied as virgin pulp, $0.24(=0.6 \times 0.4)$ million tons market pulp would be required at the cost of $154(=640 \times 0.24)$ million dollars. 
Table 123. Potential Annual Impact of the Use of Residuals in Concrete on U.S. State Economies

\begin{tabular}{|c|c|c|c|c|c|c|}
\hline State & $\begin{array}{c}\text { Popu- } \\
\text { lation as } \\
\text { of } 2000 \\
\text { (million) }\end{array}$ & $\begin{array}{c}\text { Estimated } \\
\text { Concrete } \\
\text { Production } \\
(\text { million } \\
\left.\mathrm{yd}^{3}\right)\end{array}$ & \begin{tabular}{|c|} 
Potential \\
Concrete \\
Production \\
with \\
Residuals \\
$\left(\right.$ million yd $\left.^{3}\right)$ \\
\end{tabular} & $\begin{array}{l}\text { Potential } \\
\text { Residuals } \\
\text { Use in } \\
\text { Concrete } \\
\text { (million } \\
\text { dry tons) } \\
\end{array}$ & $\begin{array}{l}\text { Value } \\
\text { Added to } \\
\text { Concrete } \\
\text { (million \$) }\end{array}$ & \begin{tabular}{|c|} 
Saving \\
from \\
Avoided \\
Disposal of \\
Residuals \\
(million \$) \\
\end{tabular} \\
\hline Alabama & 4.4 & 6.2 & 1.6 & 0.008 & 7.0 & 0.6 \\
\hline Arizona & 5.1 & 7.2 & 1.8 & 0.009 & 8.1 & 0.7 \\
\hline Arkansas & 2.7 & 3.7 & 0.9 & 0.005 & 4.2 & 0.4 \\
\hline California & 33.9 & 47.5 & 11.9 & 0.059 & 53.4 & 4.5 \\
\hline Florida & 16.0 & 22.4 & 5.6 & 0.028 & 25.2 & 2.1 \\
\hline Georgia & 8.2 & 11.5 & 2.9 & 0.014 & 12.9 & 1.1 \\
\hline Idaho & 1.3 & 1.8 & 0.5 & 0.002 & 2.0 & 0.2 \\
\hline Illinois & 12.4 & 17.4 & 4.4 & 0.022 & 19.6 & 1.6 \\
\hline Indiana & 6.1 & 8.5 & 2.1 & 0.011 & 9.6 & 0.8 \\
\hline Kentucky & 4.0 & 5.7 & 1.4 & 0.007 & 6.4 & 0.5 \\
\hline Louisiana & 4.5 & 6.3 & 1.6 & 0.008 & 7.1 & 0.6 \\
\hline Maine & 1.3 & 1.8 & 0.4 & 0.002 & 2.0 & 0.2 \\
\hline Maryland & 5.3 & 7.4 & 1.9 & 0.009 & 8.4 & 0.7 \\
\hline Massachusetts & 6.3 & 8.9 & 2.2 & 0.011 & 10.0 & 0.8 \\
\hline Michigan & 9.9 & 13.9 & 3.5 & 0.017 & 15.7 & 1.3 \\
\hline Minnesota & 4.9 & 6.9 & 1.7 & 0.009 & 7.8 & 0.6 \\
\hline Mississippi & 2.8 & 4.0 & 1.0 & 0.005 & 4.5 & 0.4 \\
\hline New Hampshire & 1.2 & 1.7 & 0.4 & 0.002 & 1.9 & 0.2 \\
\hline New Jersey & 8.4 & 11.8 & 3.0 & 0.015 & 13.3 & 1.1 \\
\hline New York & 19.0 & 26.6 & 6.7 & 0.033 & 29.9 & 2.5 \\
\hline North Carolina & 8.0 & 11.3 & 2.8 & 0.014 & 12.7 & 1.1 \\
\hline Ohio & 11.4 & 15.9 & 4.0 & 0.020 & 17.9 & 1.5 \\
\hline Oklahoma & 3.5 & 4.8 & 1.2 & 0.006 & 5.4 & 0.5 \\
\hline Oregon & 3.4 & 4.8 & 1.2 & 0.006 & 5.4 & 0.4 \\
\hline Pennsylvania & 12.3 & 17.2 & 4.3 & 0.022 & 19.4 & 1.6 \\
\hline South Carolina & 4.0 & 5.6 & 1.4 & 0.007 & 6.3 & 0.5 \\
\hline Tennessee & 5.7 & 8.0 & 2.0 & 0.010 & 9.0 & 0.7 \\
\hline Texas & 20.9 & 29.2 & 7.3 & 0.037 & 32.9 & 2.7 \\
\hline Virginia & 7.1 & 9.9 & 2.5 & 0.012 & 11.2 & 0.9 \\
\hline Washington & 5.9 & 8.3 & 2.1 & 0.010 & 9.3 & 0.8 \\
\hline Wisconsin & 5.4 & 7.5 & 1.9 & 0.009 & 8.5 & 0.7 \\
\hline SUM & 245 & 344 & 86 & 0.430 & 387 & 32 \\
\hline
\end{tabular}

US population: 285 million. Residuals Concrete/Total Concrete Production: 0.25. Other assumptions used were same as those used in Table 124. 
Table 124. Potential Annual Impact of the Use of Residuals in Concrete on U.S. National Economy

\begin{tabular}{|c|c|c|c|c|c|}
\hline $\begin{array}{c}\text { Concrete } \\
\text { Production } \\
\text { with } \\
\begin{array}{c}\text { Residuals } \\
\text { (\% of total } \\
\text { concrete } \\
\text { production) }\end{array}\end{array}$ & $\begin{array}{c}\text { Concrete } \\
\text { Production } \\
\text { with } \\
\text { Residuals } \\
\text { (million } \\
\text { cubic yards) }\end{array}$ & $\begin{array}{c}\text { Use of } \\
\text { Residuals in } \\
\text { Concrete } \\
\text { (million dry } \\
\text { short tons) }\end{array}$ & $\begin{array}{c}\text { Value } \\
\text { Added to } \\
\text { Concrete } \\
\text { (million \$) }\end{array}$ & $\begin{array}{c}\text { Saving on } \\
\text { Disposal } \\
\text { Cost of } \\
\text { Residuals } \\
\text { (million \$) }\end{array}$ & $\begin{array}{c}\text { Total } \\
\text { Economic } \\
\text { Benefit } \\
\text { (million \$) }\end{array}$ \\
\hline 0 & 0 & 0.0 & 0 & 0 & 0 \\
\hline 10 & 40 & 0.2 & 180 & 15 & 195 \\
\hline 20 & 80 & 0.4 & 360 & 30 & 390 \\
\hline 30 & 120 & 0.6 & 540 & 45 & 585 \\
\hline 40 & 160 & 0.8 & 720 & 60 & 780 \\
\hline 50 & 200 & 1.0 & 900 & 75 & 975 \\
\hline
\end{tabular}

Assumptions:

Total production of ready-mixed concrete: 400 million cubic yards/year.

Residuals content in concrete: $10 \mathrm{lb}$ (or 0.005 ton)/cubic yard, on dry basis.

Total pulp and paper mill residuals generation: 5.83 million dry tons/year.

Revenue obtained by the concrete industry: $\$ 4.50 /$ cubic yard of concrete.

Moisture content of as-produced residuals: $150 \%$ of oven-dry mass.

Disposal cost of residuals: $\$ 30 /$ wet ton, or $\$ 75 /$ dry ton.

Saving on disposal cost of residuals: $\$ 0.375$ (=75 x 0.005)/cubic yard of concrete. 


\section{CHAPTER 10 GUIDELINES FOR PRODUCING CONCRETE CONTAINING RESIDUAL SOLIDS}

Based on test results collected, a preliminary specification was developed for use of residual solids in concrete. This was based on test results on concrete containing about $600 \mathrm{lb}$ of cement, $1400 \mathrm{lb}$ of sand, and $1700 \mathrm{lb}$ of angular coarse aggregate per cubic yard, with about four-inch slump and 7000 psi expected 28-day compressive strength. High-range water-reducing admixture (HRWRA) was used in concrete. A total of seven sources of pulp and paper mill primary residual solids were included in concrete. Average moisture content and wood fiber content of residual solids used in the research were about $150 \%$ (range: 84 to $230 \%$ ) and $60 \%$ (range: 35 to $94 \%$ ), respectively, expressed as percentages of oven-dry mass.

1. Residual solids

For achieving improved resistance of concrete to freezing-and-thawing and saltscaling, residual solids with higher wood fiber content are desirable.

For easier and uniform distribution of cellulose fibers and particulates (if any) of residual solids in concrete, excessive dewatering of residual solids at a pulp and paper mill wastewater treatment plant needs to be avoided.

If residual solids need to be stored for an extended period of time, they should be stored in a refrigerated room to prevent potential bio-degradation of cellulose fibers. 


\section{Characterization of Residual Solids}

For checking uniformity of residual solids delivered at different times, moisture content and wood fiber content of residual solids should be determined. Moisture content can be determined by drying as-received residual solids at $105^{\circ} \mathrm{C}$. Wood fiber content may be assumed to be same as loss on ignition (LOI) of residual solids at $590^{\circ} \mathrm{C}$.

\section{Mixture Proportioning}

For improved resistance of concrete to freezing-and-thawing and salt-scaling, use about five pounds of wood fibers (on dry basis) per cubic yard of concrete. This corresponds to 20 to 40 pounds of as-received residual solids per cubic yard of concrete ( 0.5 to $1.0 \%$ of concrete by mass), depending on moisture content and wood fiber content of residual solids.

Existing mixture proportions for ordinary ready-mixed concrete mixtures can be used.

Equivalent strength of concrete containing residual solids can be obtained by reducing the amount of mixing water by the weight of as-received residual solids added to concrete. In this case, if desired, equivalent slump can be obtained by adding adequate amount of HRWRA. Fifty to $100 \%$ of the maximum dosage rate recommended by the HRWRA manufacturer may be used.

If the amount of mixing water is not adjusted, about 10 to $20 \%$ reduction in 28 day compressive strength of concrete containing residual solids may be expected when compared with reference concrete. Currently, durability data for such a case are not available. 


\section{Mixing}

a. Deflocculation of residual solids in water

For effective use of cellulose fibers, residual solids needs to be dispersed

uniformly in water before its introduction into the concrete batch. This can be done by mechanically stirring residual solid in water using, for example, a high-shear mixer.

b. Batching sequence

Follow generally established batching sequence used for ordinary ready-mixed concrete.

\section{Placing}

Conventional method of placing works satisfactorily with concrete containing residual solids. 


\section{CHAPTER 11 SUMMARY, CONCLUSIONS, AND RECOMMENDATIONS}

\subsection{Summary}

In this research, an investigation was conducted to study benefits of using pulp and paper mill residual solids in concrete. A total of eight sources of residuals were studied and evaluated. Main components of the residuals were virgin and/or recycled cellulose fibers, moisture, kaolinitic clay (if any), and calcite (if any).

For each source of residuals (except for one source), concrete mixture proportions were developed for producing residuals concrete that was equivalent to reference (noresiduals) concrete in workability and compressive strength. Based on these mixture proportions, additional mixtures were produced for evaluation of durability of concrete.

Market study and economic impact analysis were also conducted.

Based on the mixture proportions developed in the laboratory, construction demonstration with concrete containing one source of the residuals was conducted at a commercial ready-mixed concrete plant. The concrete showed good workability and strength.

\subsection{Conclusions}

Based on the results of this research, the following broad conclusions may be drawn:

1. Without the use of high-range water-reducing admixture (HRWRA), pulp and paper mill residuals increase water demand of concrete for a given slump. 
2. With proper dosage of HRWRA, slump and compressive strength of concrete containing the residuals can be managed as desired.

3. Concrete containing residuals was equivalent to reference (no-residuals) concrete in average residual-strength and length change (drying shrinkage).

4. For most sources of residuals, chloride-ion penetration resistance of concrete containing the residuals was equivalent to that of concrete without residuals. Concrete containing some sources of residuals showed lower resistance to chlorideion penetration (up to $37 \%$ higher charge passed) than concrete without residuals.

5. Abrasion resistance of concrete with residuals was generally equivalent to that of concrete without residuals. For some sources of residuals, abrasion resistance of concrete with the residuals was lower than that of concrete without residuals.

6. If the residuals were used as a source of cellulose fibers for micro-fiber reinforcement of $20 \%$ of ready-mixed concrete produced in the USA, its annual economic impact would be about $\$ 360$ million for the concrete construction industry due to improved properties of concrete and about $\$ 30$ million for the paper industry in avoided disposal cost of the residuals.

\subsection{Recommendations for Further Study}

For continuing research investigations in the use of residual solids, the following points may be considered: 
1. To utilize the cellulose fibers contained in residuals fully and achieve best performance of concrete, use non-dewatered residuals, which can be deflocculated with little effort (p. 66). If this is not possible, deflocculate or "repulp" dewatered residuals at a highest possible mixing speed in a covered container (to minimize the loss of residuals due to splashing). Use hot water (at about $120^{\circ} \mathrm{F}$ ) for repulping.

2. A test method is needed to assess the degree of fiber dispersion in "repulped" residuals. Uniformity of fiber distribution in hardened concrete should also be examined; however, test methods for such measurements are non-existent, currently.

3. Maximum amount of residuals in concrete may be increased to improve the durability of concrete further and to utilize more residuals. Concrete containing a large amount of cellulose fibers $\left(>7 \mathrm{lb} / \mathrm{yd}^{3}\right.$ of concrete $[>\sim 0.8 \%$ residuals by mass of concrete $\left.]\right)$ may show a low slump $(<1$ in.) even at a high water-cementitious materials ratio $(w / \mathrm{cm})$; however, the concrete may still exhibit good workability (p. 135). Instead of using a mid-range slump (for example, 3 to 6 in.), a lower slump (for example, 1 in.) may be used (with or without HRWRA) for concrete containing large quantities of residuals, thereby reducing $w / \mathrm{cm}$ and improving strength and durability of such concrete. Such concrete could be readily used for pavements, precast concrete, and dry-cast concrete products (for example, bricks and blocks).

4. Strength, durability, and economic impact may be compared between non-airentrained concrete with residuals and air-entrained concrete without residuals. Properties of air-entrained concrete with residuals may also be compared. Use of HRWRA may not be necessary for the comparison. 
5. Compatibility of residuals and various brands of HRWRA (if used) may need to be examined. High air content of concrete was noted for a pilot-scale concrete produced at a ready-mixed concrete plant due to incompatibility of the residuals and a particular brand of HRWRA (p. 128).

6. Long-term durability of cellulose fibers in concrete needs to be examined. Long-term retention of improved durability of concrete containing residuals needs to be evaluated.

7. Practical means of transporting, storing, and dispensing residuals need to be further developed for acceptance and use of the residuals at majority of ready-mixed concrete plants. 


\section{CHAPTER 12 REFERENCES}

1. NCASI, "Solid Waste Management Practices in the U.S. Paper Industry - 1995," Technical Bulletin No. 793, National Council of the Paper Industry for Air and Stream Improvement, Inc. (NCASI), Research Triangle Park, NC, 1999.

2. Naik, T. R., "Use of Pulp and Paper Mill Residual Solids in Production of Cellucrete," A report prepared for the Weyerhaeuser Company, Tacoma, WA, October 1998.

3. Naik, T. R. and Kraus, R. N., "Development of Concrete Utilizing Paper Mill Residual Solids," Report No. CBU-1998-13, UWM Center for By-Products Utilization, Department of Civil Engineering and Mechanics, The University of Wisconsin-Milwaukee, November 1998.

4. Unwin, J., "Why Bury It When You Can Use It?: NCASI's Support of the Industry's Efforts To Find Beneficial Uses For Solid Wastes," Proceedings of the 2000 NCASI National Meeting, Denver, CO, May 8-9, 2000, NCASI, Research Triangle Park, NC, 2000, pp. 57-74.

5. NCASI, "Solid Waste Management and Disposal Practices in the U.S. Paper Industry," Technical Bulletin No. 641, NCASI, New York, NY, 1992.

6. Scott, G. and Smith, A., "Sludge Characteristics and Disposal Alternatives for Recycled Fiber Plants," 1995 Recycling Symposium, Technical Association of the Pulp and Paper Industry (TAPPI), Atlanta, GA, 1995, pp. 239-249.

7. NCASI, "Alternative Management of Pulp and Paper Industry Solid Wastes," Technical Bulletin No. 655, NCASI, New York, NY, 1993.

8. Glenn, J., "Paper Mill Sludge: Feedstock for Tomorrow," Progress in Paper Recycling, Appleton, WI, May 1998, pp. 54-59.

9. Wiegand, P. and Unwin, J., "Alternative Management of Pulp and Paper Industry Solid Wastes,” TAPPI Journal, Vol. 77, No. 4, TAPPI, Atlanta, GA, 1994, pp. 91-97.

10. NYSERDA, "Beneficial Uses of Paper Mill Residuals for New York State's Recycled-Paper Mills," Report 95-15, The New York State Energy Research and Development Authority (NYSERDA), Albany, NY, September 1995.

11. Soroushian, P., "Secondary Reinforcement_-Adding Cellulose Fibers," Concrete International: Design \& Construction, Vol. 19, No. 6, American Concrete Institute (ACI), Farmington Hills, MI, June 1997, pp. 28-34.

12. PCA, "Fiber Reinforced Concrete," Portland Cement Association (PCA), Skokie, IL, 1991. 
13. Fordos, Z., "Natural or Modified Cellulose Fibres as Reinforcement in Cement Composites: Chapter 5," Natural Fibre Reinforced Cement and Concrete, R. N. Swamy, ed., Blackie and Son Publishers, London, England, UK, 1988, pp. 173-207.

14. Soroushian, P. and Marikunte, S., "Reinforcement of Cement-Based Materials with Cellulose Fibers," Thin-Section Fiber Reinforced Concrete and Ferrocement, ACI Special Publication SP-124, ACI, Detroit, MI, 1990, pp. 99-123.

15. Soroushian, P. and Marikunte, S., "Durability Characteristics of Cellulose Fiber Reinforced Cement Composites," Fiber Reinforced Concrete: development and innovations, ACI Special Publication SP-142, ACI, Detroit, MI, 1994, pp. 73-89.

16. Marikunte, S. and Soroushian, P., "Statistical Evaluation of Long-Term Durability Characteristics of Cellulose Fiber Reinforced Cement Composites," ACI Materials Journal, Vol. 91, No. 6, ACI, Detroit, MI, November-December 1994, pp. 607-616.

17. Thomas, C. O.; Thomas, R. C.; and Hover, K. C., "Wastepaper Fibers in Cementitious Composites," Journal of Environmental Engineering, ASCE, Vol. 113, No. 1, New York, NY, February, 1987, pp. 16-31.

18. Pigeon, M.; Pleau, R.; Azzabi, M.; and Banthia, N., "Durability of MicrofiberReinforced Mortars," Cement and Concrete Research, Vol. 26, No. 4, Pergamon Press, Tarrytown, NY, Apr. 1996, pp. 601-609.

19. Pigeon, M.; Azzabi, M.; and Pleau, R., "Can Microfibers Prevent Frost Damage?" Cement and Concrete Research, Vol. 26, No. 8, Pergamon Press, Tarrytown, NY, Aug. 1996, pp. 1163-1170.

20. Pierre, P.; Pleau, R.; and Pigeon, M., "Mechanical Properties of Steel Microfiber Reinforced Cement Pastes and Mortars," Journal of Materials in Civil Engineering, Vol. 11, No. 4, American Society of Civil Engineers (ASCE), Reston, VA, Nov. 1999, pp. 317-324.

21. Smook, G. A., "Handbook for Pulp and Paper Technologists," 2nd Ed., Angus Wilde Publications, Bellingham, WA, June 1992, 419 pp.

22. Heinricks, H., "Manufacture of Non-asbestos Cement Fiberboards," InorganicBonded Wood and Fiber Composite Materials, Vol. 2, Forest Products Society, Madison, WI, 1991, pp. 120-124.

23. Soroushian, P.; Won, J.; Ravanbakhsh, S.; Hsu, J.; and Ostowari, K., "Enhanced Processing of Cellulose Fiber-Reinforced Cement Composites," Inorganic-Bonded Wood and Fiber Composite Materials, Vol. 5, Forest Products Society, Madison, WI, 1997, pp. 3-7. 
24. Vinson, K. D. and Daniel, J. I., "Specialty Cellulose Fibers for Cement Reinforcement," Thin Section Fiber Reinforced Concrete and Ferrocement, ACI Special Publication SP-124, ACI, Detroit, MI, 1990, pp. 1-18.

25. Soroushian, P. and Marikunte, S., "Moisture Sensitivity of Cellulose Fiber Reinforced Cement," Durability of Concrete, ACI Special Publication SP-126, Vol. 2 , ACI, Detroit, MI, 1991, pp. 821-835.

26. Soroushian, P.; Marikunte, S.; and Won, J., "Statistical Evaluation of Mechanical and Physical Properties of Cellulose Fiber Reinforced Cement Composites," ACI Materials Journal, Vol. 92, No. 2, ACI, Detroit, MI, March-April 1995, pp. 172-180.

27. Soroushian, P.; Shah, Z.; and Won, J., "Optimization of Wastepaper Fiber-Cement Composites," ACI Materials Journal, Vol. 92, No. 1, ACI, Detroit, MI, JanuaryFebruary 1995, pp. 82-92.

28. Soroushian, P. and Marikunte, S., "Moisture Effects on Flexural Performance of Wood Fiber-Cement Composites," Journal of Materials in Civil Engineering, Vol. 4, No. 3, ASCE, New York, NY, August 1992, pp. 275-291.

29. Akers, S. A. S.; Crawford, D.; Schultes, K.; and Gerneka, D. A., "Micromechanical Studies of Fresh and Weathered Fiber Cement Composites. Part 1: Dry Testing," The International Journal of Cement Composites and Lightweight Concrete, Vol. 11, No. 2, Construction Press, Harlow, England, UK, May 1989, pp. 117-124.

30. Tait, R. B. and Akers, S. A. S., "Micromechanical Studies of Fresh and Weathered Fiber Cement Composites. Part 2: Wet Testing," The International Journal of Cement Composites and Lightweight Concrete, Vol. 11, No. 2, Construction Press, Harlow, England, UK, May 1989, pp. 125-132.

31. Coutts, R. S. P. and Campbell, M. D., "Coupling Agents in Wood Fibre-Reinforced Cement Composites," Composites, IPC Business Press Ltd., London, England, UK, October 1979, pp. 228-232.

32. Soroushian, P.; Marikunte, S.; and Won, J., "Wood Fiber Reinforced Cement Composites under Wetting-Drying and Freezing-Thawing Cycles," Journal of Materials in Civil Engineering, Vol. 6, No. 4, ASCE, New York, NY, November 1994, pp. 595-611.

33. Sarigaphuti, M.; Shah, S. P.; and Vinson, K. D., "Shrinkage Cracking and Durability Characteristics of Cellulose Fiber Reinforced Concrete," ACI Materials Journal, Vol. 90, No. 4, ACI, Detroit, MI, July-August 1993, pp. 309-318.

34. Sharman, W. R. and Vautier, B. P., "Accelerated Durability Testing of Autoclaved Wood-Fiber-Reinforced Cement-Sheet Composites," Durability of Building Materials, Vol. 3, Elsevier, Amsterdam, The Netherlands, 1986, pp. 255-275. 
35. Akers, S. A. S. and Studinka, J. B., "Ageing Behavior of Cellulose Fibre Cement Composites in Natural Weathering and Accelerated Tests," The International Journal of Cement Composites and Lightweight Concrete, Vol. 11, No. 2, Construction Press, Harlow, England, UK, May 1989, pp. 93-97.

36. Sharman, W. R. and Vautier, B. P., "Durability Studies on Wood Fibre Reinforced Cement Sheet," in Developments in Fibre Reinforced Cement and Concrete, Proceedings of the RILEM Symposium, Sheffield, England, UK, 1986, Paper 7.2.

37. Gumpertz, W. H. and Condren, S. J., "The Deteriorating Artificial Slate," Roofing Research and Standards Development, 4th Volume, ASTM STP 1349, American Society for Testing and Materials (ASTM), West Conshohocken, PA, 1999.

38. Bentur, A. and Akers, S. A. S., "The Microstructure and Ageing of Cellulose Fiber Reinforced Cement Autoclaved Composites," The International Journal of Cement Composites and Lightweight Concrete, Vol. 11, No. 2, Construction Press, Harlow, England, UK, May 1989, pp. 111-115.

39. Soroushian, P.; Shah, Z.; Won, J.; and Hsu, J., "Durability and Moisture Sensitivity of Recycled Wastepaper-Fiber-Cement Composites," Cement \& Concrete Composites, Vol. 16, No. 2, Elsevier Science Publishers, Barking, Essex, England, UK, 1994, pp. 115-128.

40. Berkenkamp, R., "Wood Fiber-Cement Product, Process, and Properties," InorganicBonded Wood and Fiber Composite Materials, Vol. 5, Forest Products Society, Madison, WI, 1997, pp. 8-13.

41. Soroushian, P. and Ravanbakhsh, S., "High-Early-Strength Concrete: Mixture Proportioning with Processed Cellulose Fibers for Durability," ACI Materials Journal, Vol. 96, No. 5, ACI, Farmington Hills, MI, September-October 1999, pp. 593-599.

42. Soroushian, P. and Ravanbakhsh, S., "Control of Plastic Shrinkage Cracking with Specialty Cellulose Fibers," ACI Materials Journal, Vol. 94, No. 4, ACI, Farmington Hills, MI, July-August 1998, pp. 429-435.

43. Alkire, B. D. and Newton, S. M., "Using Paper Mill Sludge as Concrete Admixture," Technical Note, Journal of the Environmental Engineering Division, Proceedings of the American Society of Civil Engineers, Vol. 101. No. EE3, June 1975, pp. 469-473.

44. Soh, Y. S., Soh, S. Y., and Lee, D. S., "Use of Paper Sludge Ash in Concrete Products," Proceedings of the International RILEM Workshop on Disposal and Recycling of Organic and Polymeric Construction Materials, Edited by Ohama, Y., March 26-28, 1995, Tokyo, Japan, Published by E \& FN Spon, London, UK, 1995, pp. 271-278. 
45. Ishimoto, H. and Yasuda, M., "Technology for Converting Papermaking Sludge into Micro-porous Crystal Materials," NTT Review, Vol. 9, No. 4, Nippon Telegraph and Telephone Corp., Tokyo, Japan, July 1997, pp. 51-56.

46. Pera, J. and Amrouz, A., "Development of Highly Reactive Metakaolin from Paper Sludge," Advanced Cement Based Materials, Vol. 7, No. 2, March 1998, pp. 49-56.

47. ASTM, "Annual Book of ASTM Standards, Vol. 04.02: Concrete and Aggregates," American Society for Testing and Materials, Philadelphia, PA, 1999.

48. ASTM, "Annual Book of ASTM Standards, Vol. 04.01: Cement; Lime; Gypsum," American Society for Testing and Materials, Philadelphia, PA, 1999.

49. Encyclopædia Britannica, Encyclopædia Britannica 2000 DVD, "History," from "Natural Fibre", Encyclopædia Britannica, Inc., Chicago, IL.

50. ASTM, "Annual Book of ASTM Standards, Vol. 04.10: Wood," American Society for Testing and Materials, Philadelphia, PA, 1999.

51. ASTM, “Annual Book of ASTM Standards, Vol. 15.09: Paper; Packaging; Flexible Barrier Materials; Business Imaging Products," American Society for Testing and Materials, Philadelphia, PA, 1999.

52. NCASI, "A Summary of Available Data on the Chemical Composition of Forest Products Industry Solid Wastes," Special Report No. 99-04, NCASI, Research Triangle Park, NC, October 1999.

53. DeVor, R. E.; Chang, T.; and Sutherland, J. W., "Statistical Quality Design and Control," Prentice Hall, Upper Saddle River, NJ, 1992, Chapters 15-18.

54. Banthia, N. and Dubey, A., "Measurement of Flexural Toughness of FiberReinforced Concrete Using a Novel Technique-Part 1: Assessment and Calibration,” ACI Materials Journal, Vol. 96, No. 6, ACI, Farmington Hills, MI, November-December 1999, pp. 651-656.

55. Banthia, N. and Dubey, A., "Measurement of Flexural Toughness of FiberReinforced Concrete Using a Novel Technique-Part 2: Performance of Various Composites," ACI Materials Journal, Vol. 97, No. 1, ACI, Farmington Hills, MI, January-February 2000, pp. 3-11.

56. Miller Freeman, Inc., "Pulp \& Paper 1997 North American Factbook," Miller Freeman, Inc., San Francisco, CA, 1996.

57. Delagrave, A.; Marchand, J.; Pigeon, M.; and Boisvert, J., "Deicer Salt Scaling Resistance of Roller-Compacted Concrete Pavements," ACI Materials Journal, Vol. 94, No. 2, ACI, Farmington Hills, MI, March-April, 1997, pp. 164-169. 
58. Bilodeau, A.; Sivasundaram, V.; Painter, K. E.; Malhotra, V. M., "Durability of Concrete Incorporating High Volumes of Fly Ash from Sources in the U.S.," ACI Materials Journal, Vol. 91, No. 1, ACI, Detroit, MI, January-February, 1994, pp. 312.

59. Neville, A., "Properties of Concrete," Forth Edition, Longman Group Ltd., Harlow, Essex, England, UK, 1995, p. 661.

60. Mendenhall, W. and Sincich, T., "Statistics for Engineering and the Sciences," Fourth Edition, Prentice Hall, Upper Saddle River, NJ, 1994, Chapters 11-14.

61. Neville, A., "Properties of Concrete," Forth Edition, Longman Group Ltd., Harlow, Essex, England, UK, 1995, p. 189. 


\section{CHAPTER 13 APPENDIXES}

\subsection{Appendix A. Model Building Using Two-Level Factorial Designs}

\subsubsection{Introduction}

Empirical models of a response can be effectively built through the use of two-level factorial designs [53]. A two-level factorial design with $k$ variables consists of $2^{k}$ combinations of levels of variables. For example, if the number of variables $(k)$ is three, eight $\left(=2^{3}\right)$ different tests (each with unique combination of levels of the three variables) are required for building the model.

For the purpose of building a model, actual values of two levels of each variable are converted to coded values of -1 (low level) and +1 (high level). For example, if wood fiber content of 0 and $1 \mathrm{lb}$ and HRWRA content of 0 and $7.5 \mathrm{fl}$. oz. (each variable per $100 \mathrm{lb}$ of cement) are planned for building a model describing compressive strength of concrete using a $2^{2}$ factorial design, tests with the following four combinations of variables need to be conducted: ( $0 \mathrm{lb}, 0 \mathrm{oz}),(1 \mathrm{lb}, 0 \mathrm{oz}),(0 \mathrm{lb}, 7.5 \mathrm{oz})$, and $(1 \mathrm{lb}, 7.5 \mathrm{oz})$. However, for the purpose of building the model, the combinations are expressed in coded values as $(-1,-1),(+1,-1),(-1,+1)$, and $(+1,+1)$, respectively.

To use a model that is already built, actual value of each variable needs to be converted into a coded value valid for use in the model. Suppose a model was built using the combinations of variables described in the preceding paragraph. To predict the compressive strength of concrete containing $0.8 \mathrm{lb}$ of wood fibers and $3 \mathrm{fl}$. oz. of HRWRA (each per $100 \mathrm{lb}$ of cement) using the model, the actual values of wood fiber 
and HRWRA contents need to be converted to coded values of $0.6(=[0.8-(1+0) / 2] /$ $[(1-0) / 2])$ and $-0.2(=[3-(7.5+0) / 2] /[(7.5-0) / 2])$, respectively. The predicted compressive strength of concrete will be obtained by inputting these coded values into the model. A coded value of a variable outside the range of -1 and +1 needs to be used with caution because the variable lies outside the domain of the model.

\subsubsection{Model Building}

For a $2^{2}$ factorial design, the response is assumed to be described by a model of the following form $[53,60]$ :

where:

$$
y=b_{0}+b_{1} x_{1}+b_{2} x_{2}+b_{12} x_{1} x_{2}+\varepsilon
$$

$y=$ response (compressive strength, density, etc.),

$b_{0}=y$-intercept; the value of $E(y)$ when $x_{1}=x_{2}=0$,

$b_{1}=$ coefficient of variable 1 ,

$x_{1}=$ variable 1 (for example, residual content),

$b_{2}=$ coefficient of variable 2 ,

$x_{2}=$ variable 2 (for example, HRWRA content),

$b_{12}=$ coefficient of interaction of variables 1 and 2 , and

$\varepsilon=$ random error.

The mean value of $y$ is the deterministic component of the model and is represented as

$$
E(y)=b_{0}+b_{1} x_{1}+b_{2} x_{2}+b_{12} x_{1} x_{2}
$$


The prediction model for the mean value of $y$ is represented as

$$
\hat{y}=\hat{b}_{0}+\hat{b}_{1} x_{1}+\hat{b}_{2} x_{2}+\hat{b}_{12} x_{1} x_{2}
$$

where:

$\hat{y}=$ an estimator of the mean value of $y$ and a predictor of some future values of $y$, and

$\hat{b}_{0}, \hat{b}_{1}, \hat{b}_{2}$, and $\hat{b}_{12}=$ estimators of $b_{0}, b_{1}, b_{2}$, and $b_{12}$, respectively.

In a $2^{2}$ factorial design, four tests are conducted with combinations of variables shown in Table 125. The response to the tests is determined and arranged in order in a 1 x 4 matrix.

Table 125. Design Matrix for a $2^{2}$ Factorial Experiment

\begin{tabular}{|c|c|c|c|c|}
\hline $\begin{array}{c}\text { Variable } \\
s\end{array}$ & \multicolumn{4}{|c|}{ Test } \\
\cline { 2 - 5 } & 1 & 2 & 3 & 4 \\
\hline$x_{1}$ & -1 & +1 & -1 & +1 \\
\hline$x_{2}$ & -1 & -1 & +1 & +1 \\
\hline
\end{tabular}

-1 : low level. +1: high level

Then, coefficients of the $2^{2}$ prediction model of the response (Eq. 2) can be determined by multiplying the $1 \times 4$ matrix of the response by the $4 \times 4$ matrix shown in Table 126 [53]. The entries in the fourth column of the $4 \times 4$ matrix are given by multiplying the corresponding entries in columns 2 and 3.

Table 126. Calculation Matrix for $2^{2}$ Factorial Design

$$
\frac{1}{4} \begin{array}{cccc}
\hat{b}_{0} & \hat{b}_{1} & \hat{b}_{2} & \hat{b}_{12} \\
\cline { 5 - 6 }+1 & -1 & -1 & +1 \\
+1 & +1 & -1 & -1 \\
+1 & -1 & +1 & -1 \\
+1 & +1 & +1 & +1 \\
\hline
\end{array}
$$


For a $2^{3}$ factorial design, the prediction model for the mean value of $y$ is represented as

$$
\hat{y}=\hat{b}_{0}+\hat{b}_{1} x_{1}+\hat{b}_{2} x_{2}+\hat{b}_{3} x_{3}+\hat{b}_{12} x_{1} x_{2}+\hat{b}_{13} x_{1} x_{3}+\hat{b}_{23} x_{2} x_{3}+\hat{b}_{123} x_{1} x_{2} x_{3}
$$

In a $2^{3}$ factorial design, eight tests are conducted with combinations of variables shown in Table 127. The response to the tests is determined and arranged in order in a 1 x 8 matrix.

Table 127. Design Matrix for a $2^{3}$ Factorial Experiment

\begin{tabular}{|c|c|c|c|c|c|c|c|c|}
\hline $\begin{array}{c}\text { Variable } \\
\mathrm{s}\end{array}$ & \multicolumn{10}{|c|}{ Test } \\
\cline { 2 - 9 } & 1 & 2 & 3 & 4 & 5 & 6 & 7 & 8 \\
\hline$x_{1}$ & -1 & +1 & -1 & +1 & -1 & +1 & -1 & +1 \\
\hline$x_{2}$ & -1 & -1 & +1 & +1 & -1 & -1 & +1 & +1 \\
\hline$x_{3}$ & -1 & -1 & -1 & -1 & +1 & +1 & +1 & +1 \\
\hline
\end{tabular}

-1 : low level. +1 : high level.

Then, coefficients of the $2^{3}$ prediction model of the response (Eq. 3) can be determined by multiplying the $1 \times 8$ matrix of the response by the $8 \times 8$ matrix shown in Table 128 [53]. The entries in the columns 5,6 and 7 of the $8 \times 8$ matrix are given by multiplying the corresponding entries in columns 2 and 3,2 and 4, and 3 and 4, respectively. The entries in the column 8 are given by multiplying the corresponding entries in columns 2,3 , and 4 . 


\section{Table 128. Calculation Matrix for $2^{3}$ Factorial Design}

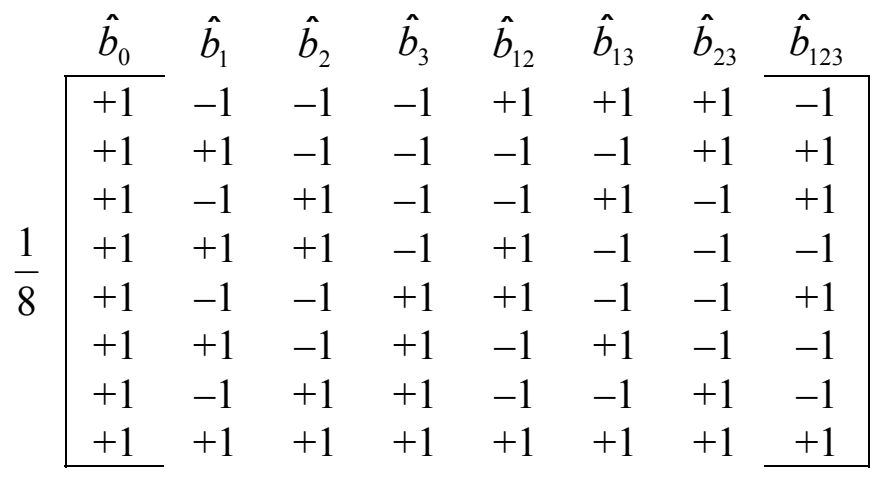

At least one additional test is usually required to confirm the model. Use of combinations of coded values of variables $(0,0)$ and $(0,0,0)$ may be useful in confirming a $2^{2}$ model and a $2^{3}$ model, respectively.

\subsubsection{Example}

28-day compressive strength values and corresponding combinations of HRWRA and wood fiber contents (per $100 \mathrm{lb}$ of cement) of four concrete mixtures were 7000, 5500, 9500, and 7500 psi for (0 lb, $0 \mathrm{oz}),(1 \mathrm{lb}, 0 \mathrm{oz}),(0 \mathrm{lb}, 7.5 \mathrm{oz})$, and (1 lb, $7.5 \mathrm{oz})$, respectively. Determine the empirical model of the compressive strength. (Assume that the model is confirmed by conducting an additional test.) Also, using the model, predict the 28-day compressive strength of a concrete mixture containing $0.8 \mathrm{lb}$ of wood fibers and 3 fl. oz. of HRWRA (each per $100 \mathrm{lb}$ of cement).

First, coefficients of the model (Eq. 2) are determined by multiplying the $1 \mathrm{x} 4$ matrix of the 28-day compressive strength, [7000 550095007500 ], by the 4 x 4 matrix shown in Table 126. The coefficients are $7375,-875,1125,-125$, respectively. Thus the prediction model of 28-day compressive strength is 


$$
\hat{y}(\mathrm{psi})=7375-875 x_{1}+1125 x_{2}-125 x_{1} x_{2}
$$

where:

$x_{1}=$ coded value of wood fiber content calculated as (actual value $[$ in $\mathrm{lb} / 100 \mathrm{lb}$ cement $]-0.5) / 0.5$, and $x_{2}=$ coded value of HRWRA content calculated as (actual value [in fl oz/100 lb cement] - 3.75)/3.75.

Wood fiber and HRWRA contents of $0.8 \mathrm{lb}$ and $3 \mathrm{fl}$. oz. (each per $100 \mathrm{lb}$ of cement) correspond to $x_{1}$ and $x_{2}$ values of 0.6 and -0.2 , respectively (as shown earlier in the introduction of this appendix). Substituting these values for $x_{1}$ and $x_{2}$, respectively, in the model gives a predicted 28-day compressive strength of $6640 \mathrm{psi}$. 


\subsection{Appendix B. Setup for Average Residual-Strength Test (ASTM C 1399)}

\subsubsection{Introduction}

In this section, a brief description of apparatus and test setup used in this research for determining average residual-strength of concrete (ASTM C 1399) is provided. For more information on the background of using this test method, see p. 182. Brief description of test procedures is also presented there.

Toughness is an indication of the energy absorption capability of concrete. There are two test methods covered by ASTM for determining flexural toughness of fiberreinforced concrete. They are (1) ASTM Standard Test Method for Flexural Toughness and First-Crack Strength of Fiber-Reinforced Concrete (Using Beam with Third-Point Loading) (C 1018) [47] and (2) ASTM Test Method for Obtaining Average ResidualStrength of Fiber-Reinforced Concrete (C 1399) [47].

In ASTM C 1018, toughness of concrete is determined in terms of areas under the flexural load-deflection curve of concrete beams. The test method requires the use of the testing machine "capable of operating in a manner which produces a controlled and constant increase of deflection of the specimen." To establish the post-crack portion of the load-deflection curve, use of a closed-loop, servo-controlled testing system is specified.

However, many laboratories are equipped with open-loop test machines only.

ASTM C 1399 is a recently developed test method of measuring the flexural toughness of 
concrete in terms of its postpeak residual flexural strength using an open-loop test machine [55].

In this research, ASTM C 1399 was used to measure average residual-strength of concrete using an open-loop test machine. Pictures of test setup and testing were presented in Fig. 42 to 45 on pages 113 to 115.

\subsubsection{Apparatus and Test Setup for ASTM C 1399}

Information on the apparatus used in this research for average residual-strength test is presented in Table 129. Schematic of the test setup is presented in Fig. 134.

In Fig. 134, the excitation voltages for the LVDTs and the wiring of the output leads of the LVDTs were configured so that the net movement of the pen of the X-Y recorder in $\mathrm{X}$ direction would correlate to the mid-span net deflection of the beam. The mid-span net deflection is given as:

$$
d_{\text {mid, net }}=d_{2}-\frac{1}{2}\left(d_{1}+d_{3}\right)
$$

where:

$d_{2}=$ deflection at mid-span measured by LVDT 2 , and

$d_{1}, d_{3}=$ deflections at supports measured by LVDTs 1 and 3 , respectively.

Pictures of the apparatus for average residual-strength test of concrete are presented in Fig. 135 through 143. For pictures of actual testing and setup, refer to Fig. 42 to 45 on pages 113 to 115 . 
Table 129. Apparatus for Average Residual-Strength Test (ASTM C 1399)

\begin{tabular}{|c|c|c|c|c|c|}
\hline Apparatus & Plotter* & $\mathrm{LVDT}^{\#}$ & Load Cell† & Amplifier & $\begin{array}{l}\text { Power } \\
\text { Supply }\end{array}$ \\
\hline Purpose & $\begin{array}{l}\text { To plot } \\
\text { load- } \\
\text { deflection } \\
\text { curve. }\end{array}$ & $\begin{array}{l}\text { To send to } \\
\text { the plotter } \\
\text { DC voltage } \\
\text { proportional } \\
\text { to the mid- } \\
\text { span net } \\
\text { deflection of } \\
\text { the beam. }\end{array}$ & $\begin{array}{l}\text { To send to the } \\
\text { amplifier DC } \\
\text { voltage } \\
\text { proportional } \\
\text { to the flexural } \\
\text { load applied } \\
\text { to the beam. }\end{array}$ & $\begin{array}{l}\text { - To excite the load } \\
\text { cell with regulated } 10 \\
\text { V DC. } \\
\text { - To amplify the } \\
\text { output voltage from } \\
\text { the load cell and send } \\
\text { it to the plotter. }\end{array}$ & $\begin{array}{l}\text { To provide } \\
\text { regulated } \\
\text { DC } \\
\text { excitation } \\
\text { voltages to } \\
\text { the plotter, } \\
\text { LVDTs, and } \\
\text { amplifier. }\end{array}$ \\
\hline $\begin{array}{l}\text { Manu- } \\
\text { facturer }\end{array}$ & - & - & - & - & - \\
\hline Type & $\begin{array}{c}\mathrm{X}-\mathrm{Y} \\
\text { recorder }\end{array}$ & $\begin{array}{l}\text { Gaging } \\
\text { transducer }\end{array}$ & Compression & In-line & $\mathrm{DC}$ \\
\hline Model No. & - & - & - & - & - \\
\hline Quantity & 1 & 3 & 1 & 1 & 1 \\
\hline $\begin{array}{l}\text { Working } \\
\text { Range }\end{array}$ & $\begin{array}{c}370 \times 280 \\
\mathrm{~mm}\end{array}$ & $\pm 0.1^{\prime \prime}$ & $0 \sim 10,000 \mathrm{lbs}$ & (See below) & (See below) \\
\hline $\begin{array}{l}\text { Input } \\
\text { Voltage }\end{array}$ & $110 \mathrm{~V} \mathrm{AC}$ & $6-28 \mathrm{~V} \mathrm{DC}$ & $10.0 \mathrm{~V} \mathrm{DC}$ & $18-32 \mathrm{~V} \mathrm{DC}$ & $110 \mathrm{~V} \mathrm{AC}$ \\
\hline $\begin{array}{l}\text { Output } \\
\text { Voltage }\end{array}$ & $\ldots$ & $\begin{array}{c} \pm 10.4 \mathrm{~V} \mathrm{DC} \\
@ 28 \mathrm{~V} \mathrm{DC} \\
\text { input }\end{array}$ & $2.1 \mathrm{mV} / \mathrm{V}$ & $0-10$ V DC & $0-18 \mathrm{~V} \mathrm{DC}$ \\
\hline $\begin{array}{l}\text { Acces- } \\
\text { sories }\end{array}$ & \begin{tabular}{|c|}
$\mathrm{LO} / 45$ \\
metric pad \\
(papers)
\end{tabular} & $\begin{array}{c}\text { C000-0026 } \\
\text { cable } \\
\text { assembly }\end{array}$ & $\begin{array}{c}\text { In-line } \\
\text { amplifier }\end{array}$ & $\ldots$ & $\ldots$ \\
\hline
\end{tabular}

* Features built-in noise rejection modules in most cases.

Unlike a (PC-based) digital data log system, real-time data logging may not be possible using a plotter. Load-deflection curve drawn by a plotter would most likely be distorted whenever the magnitude of load or deflection input signal suddenly changes.

* Linear Variable Differential Transformer (or Transducer)

$\dagger$ Certain test machines are equipped to provide output voltage signal of load. However, unlike the real-time load signal generated by a load cell, the load signal provided by a test machine tend to lag behind the deflection signal provided by LVDTs. This lag will cause varying extent of distortion of load-deflection curve when the beam suddenly cracks.

+ Excitation voltage. 


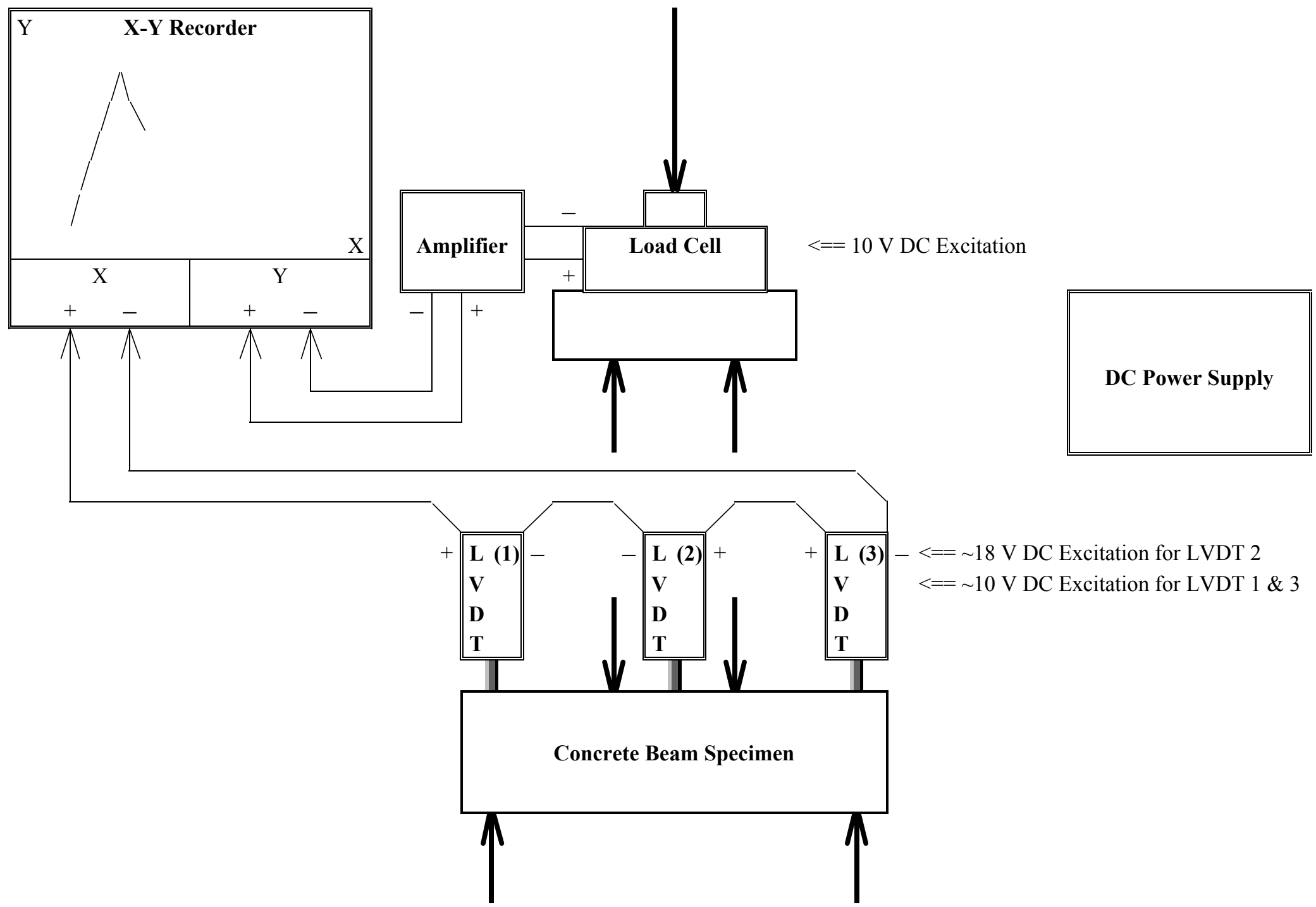

Fig. 134. Schematic of test setup for average residual-strength (ASTM C 1399) 


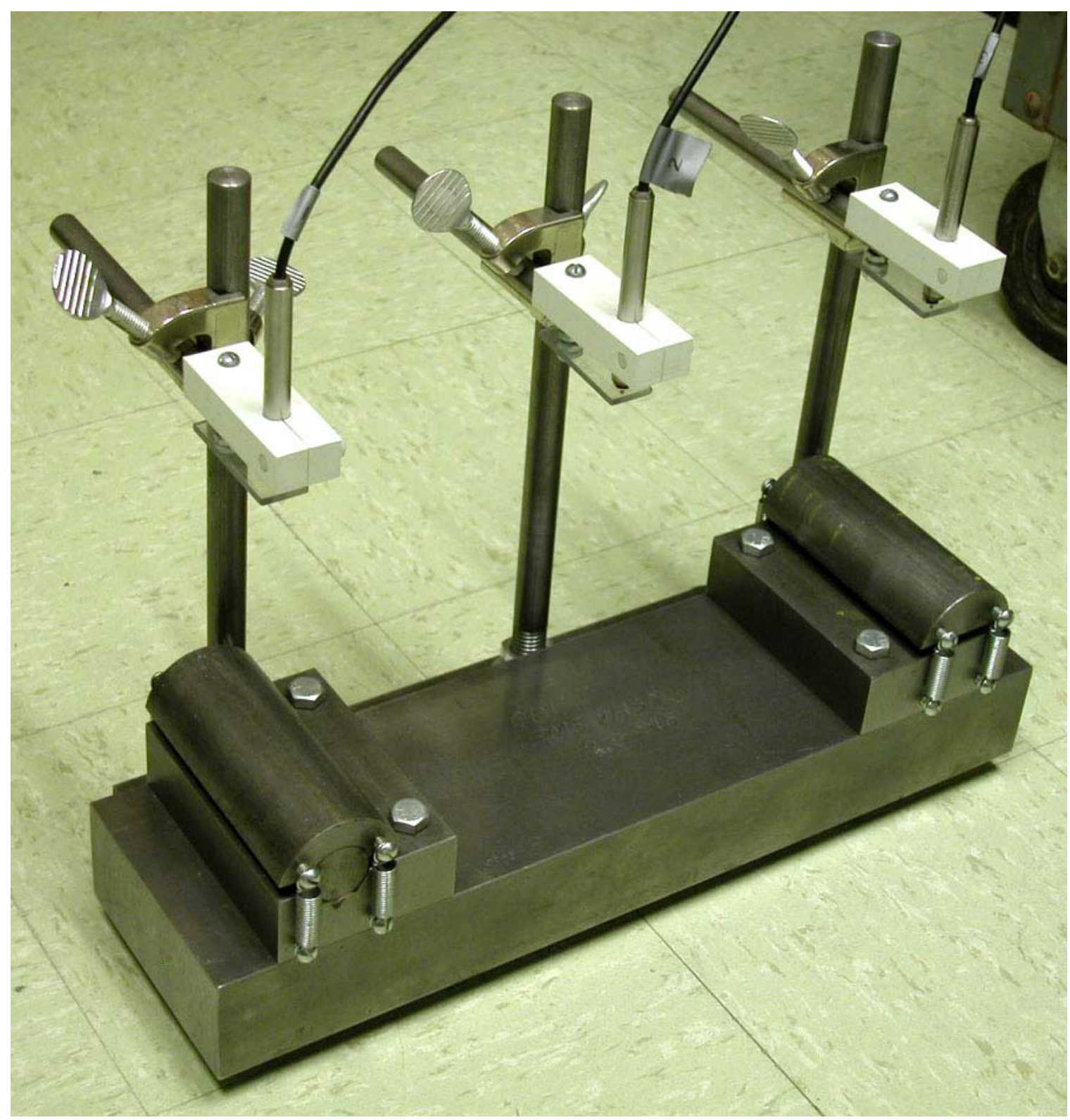

Fig. 135. LVDTs and supports for average residual-strength test 


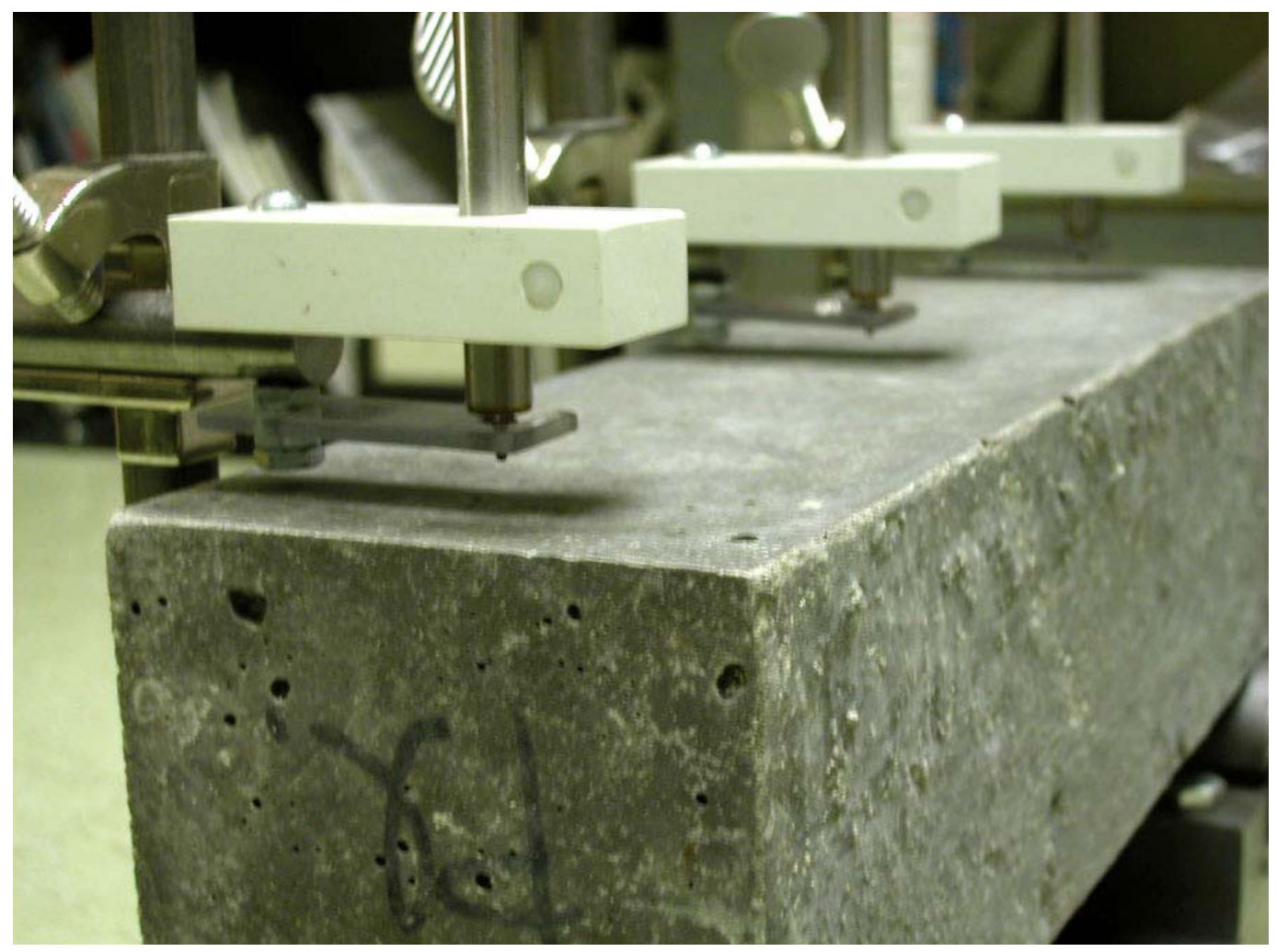

Fig. 136. LVDTs with their tips held back for setting the beam on supports

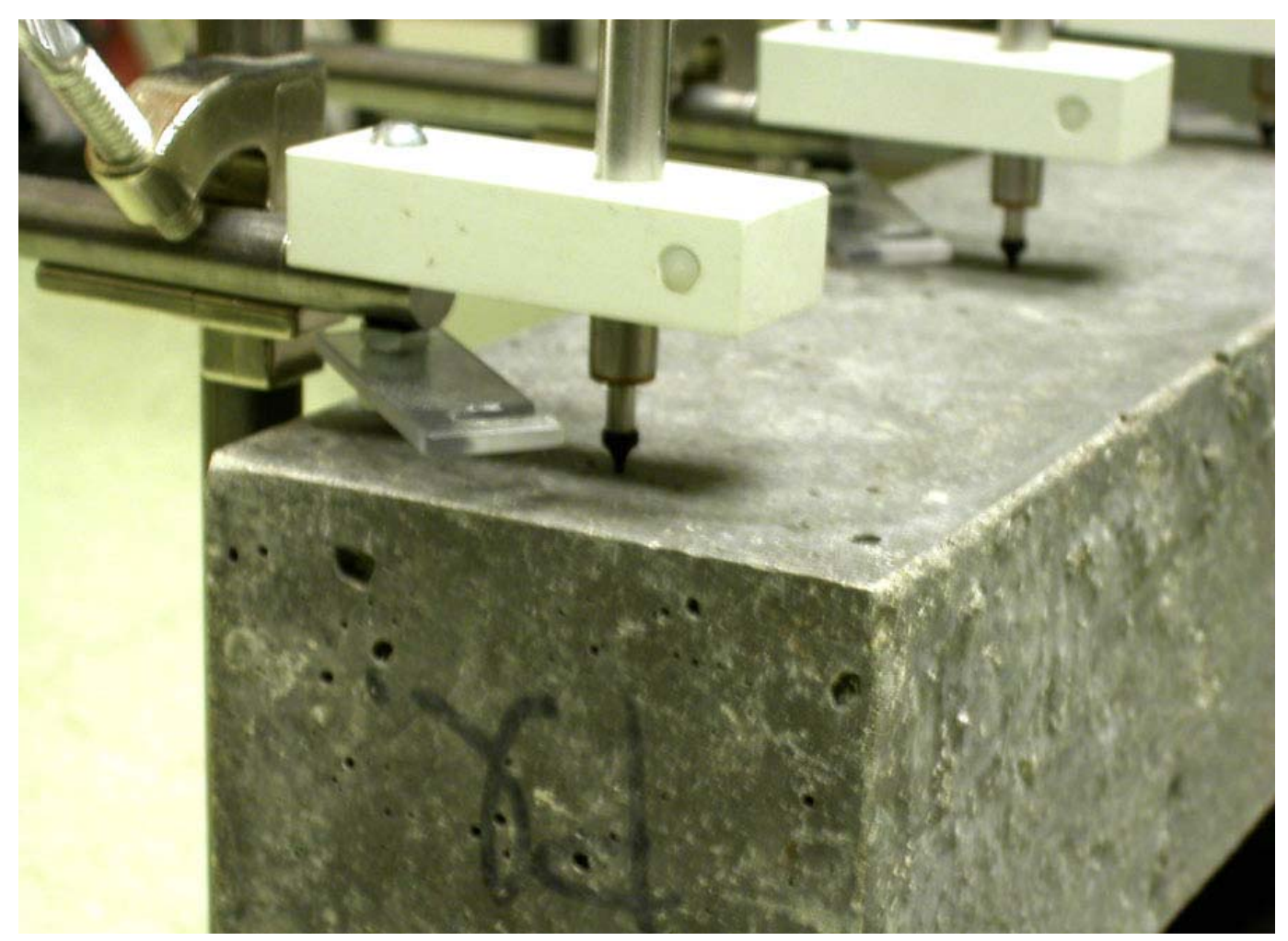

Fig. 137. LVDTs with their tips in contact with the beam 


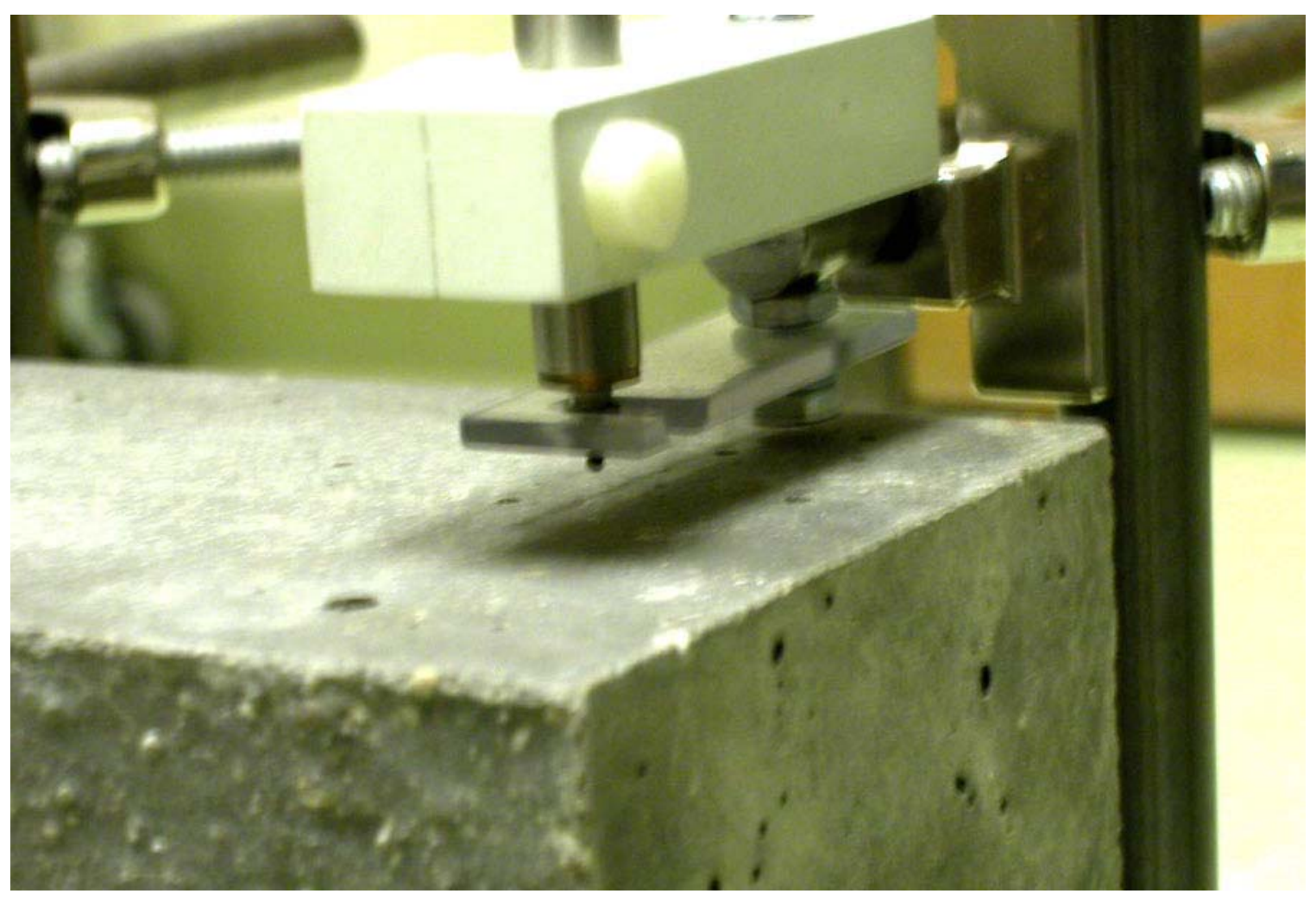

Fig. 138. Stopper holding back the tip of LVDT

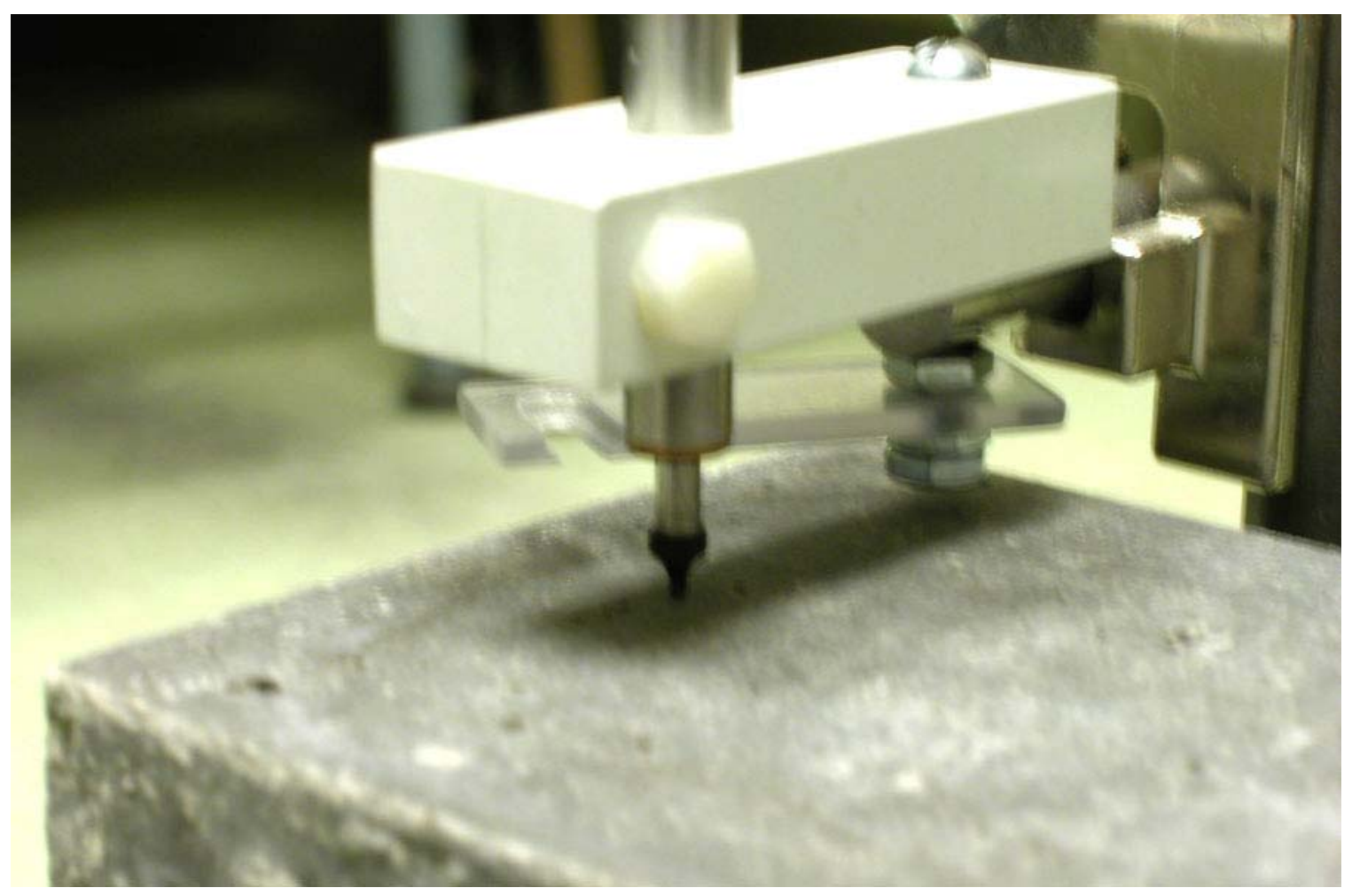

Fig. 139. Tip of LVDT released from the stopper 


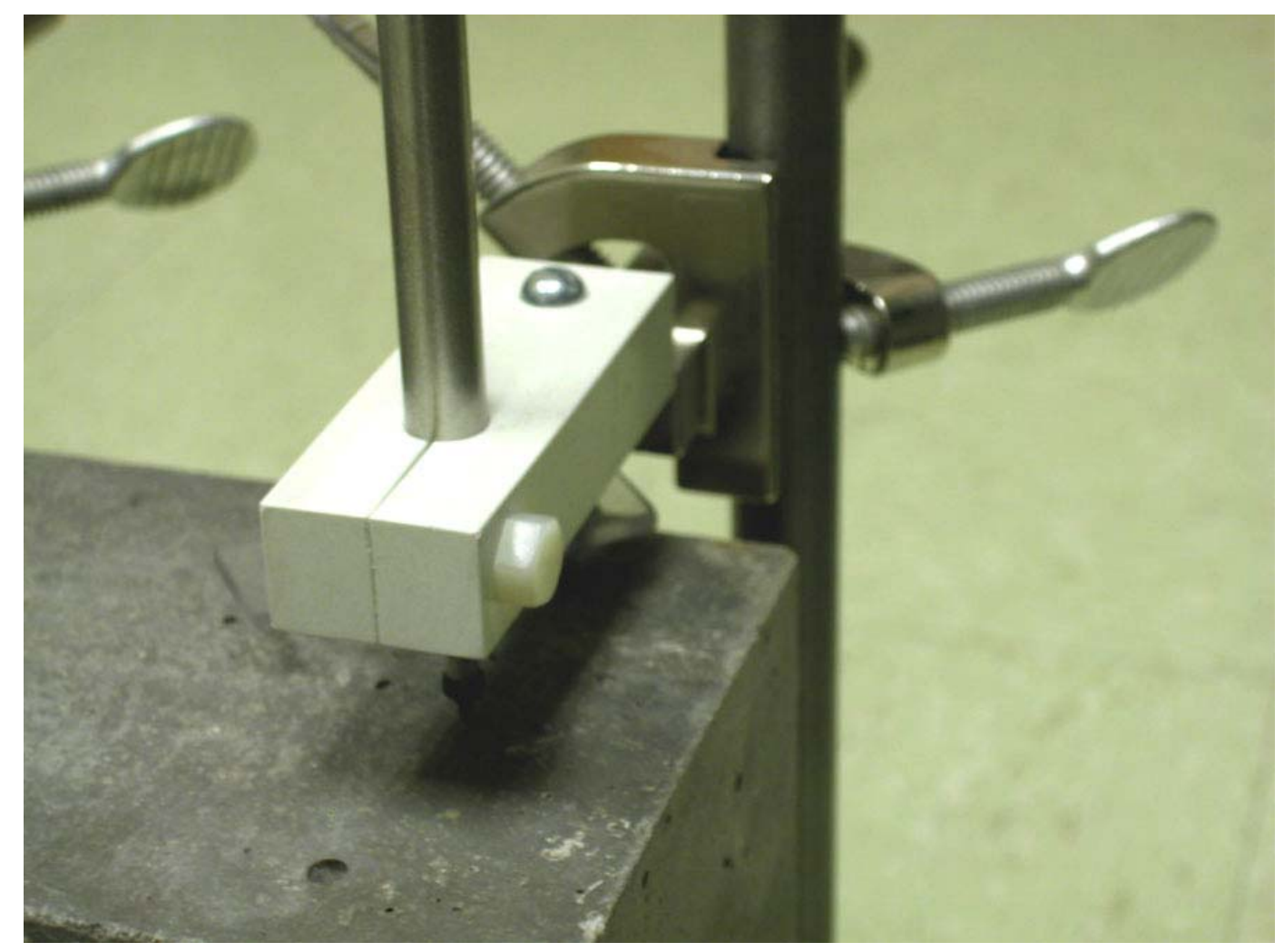

Fig. 140. Clamping device for securing the LVDT in place

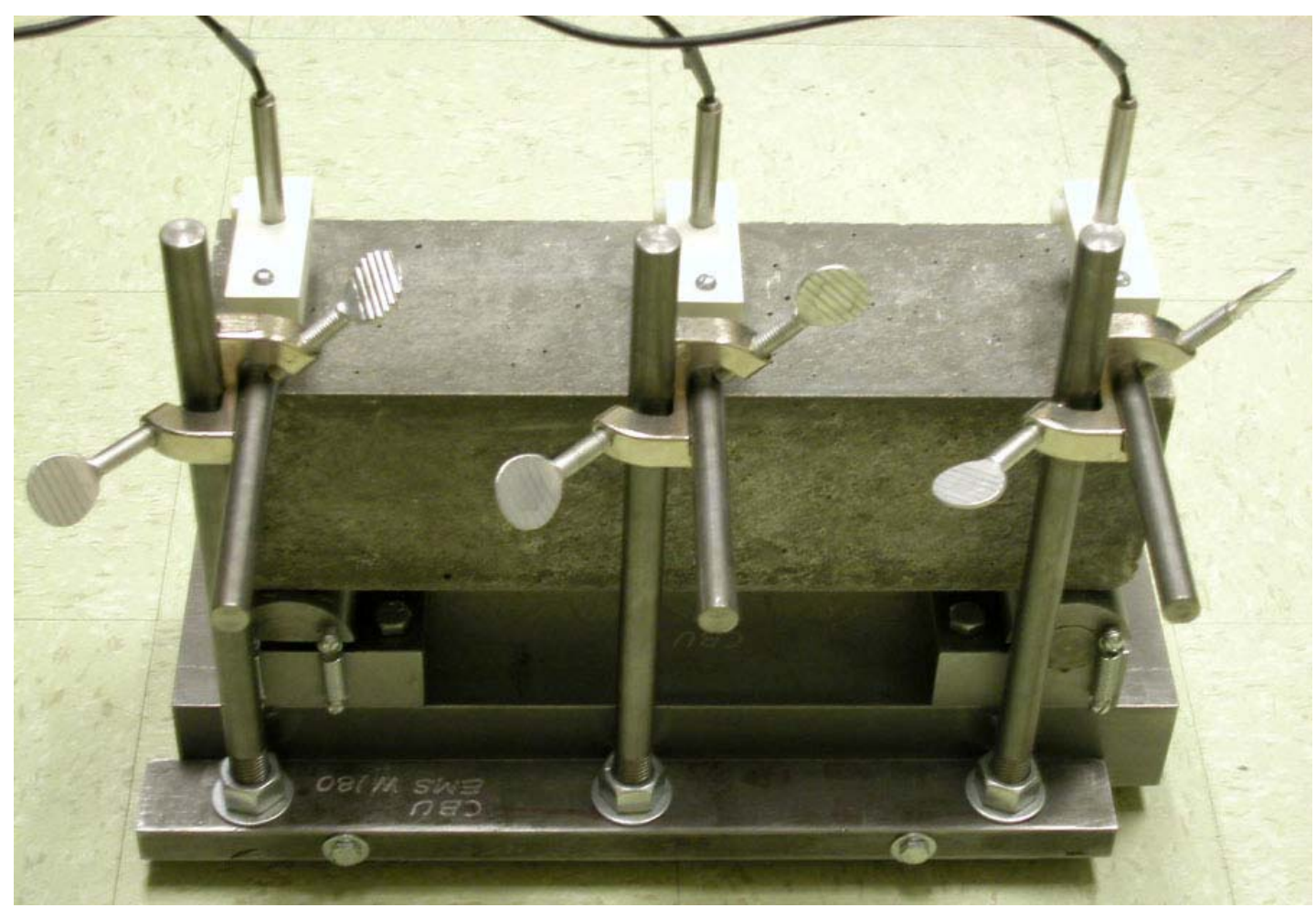

Fig. 141. LVDTs, beam, and supports viewed from the back 


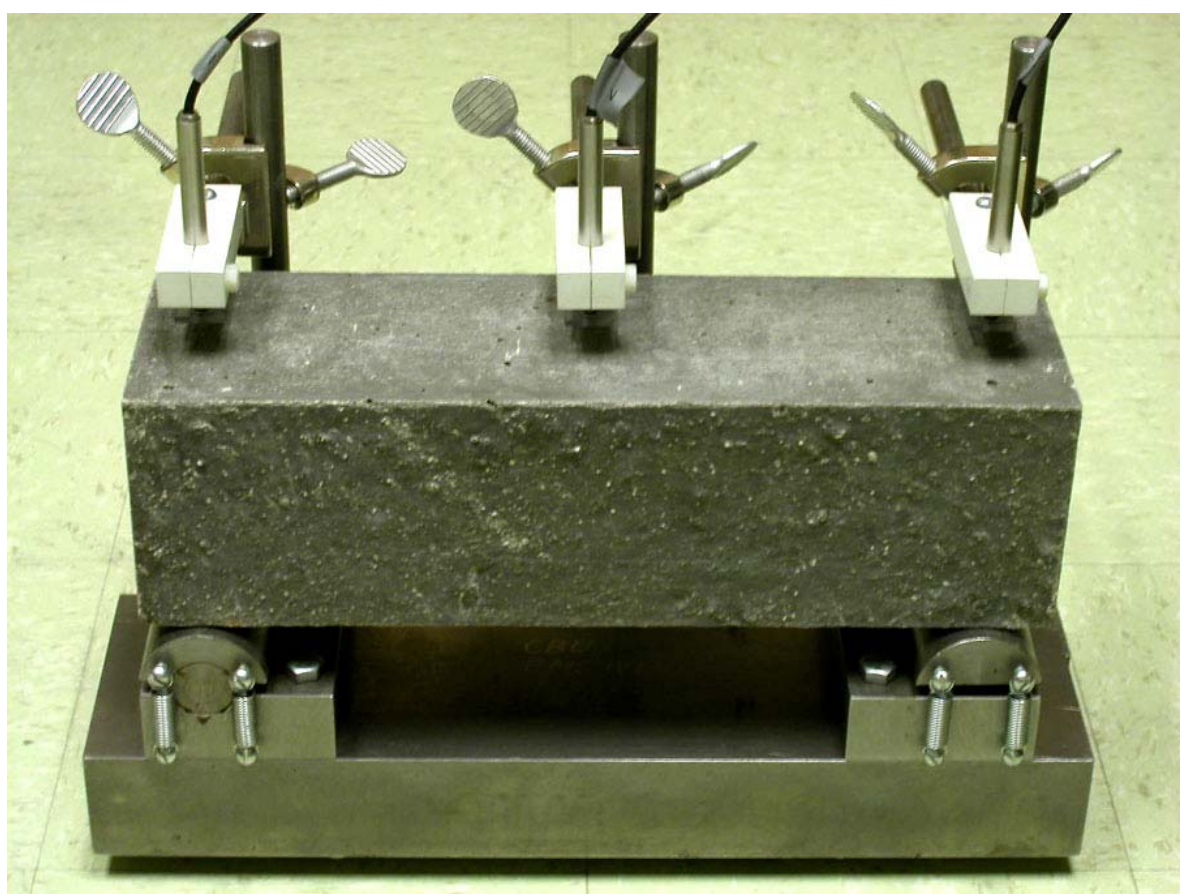

Fig. 142. LVDTs, beam, and supports viewed from the front

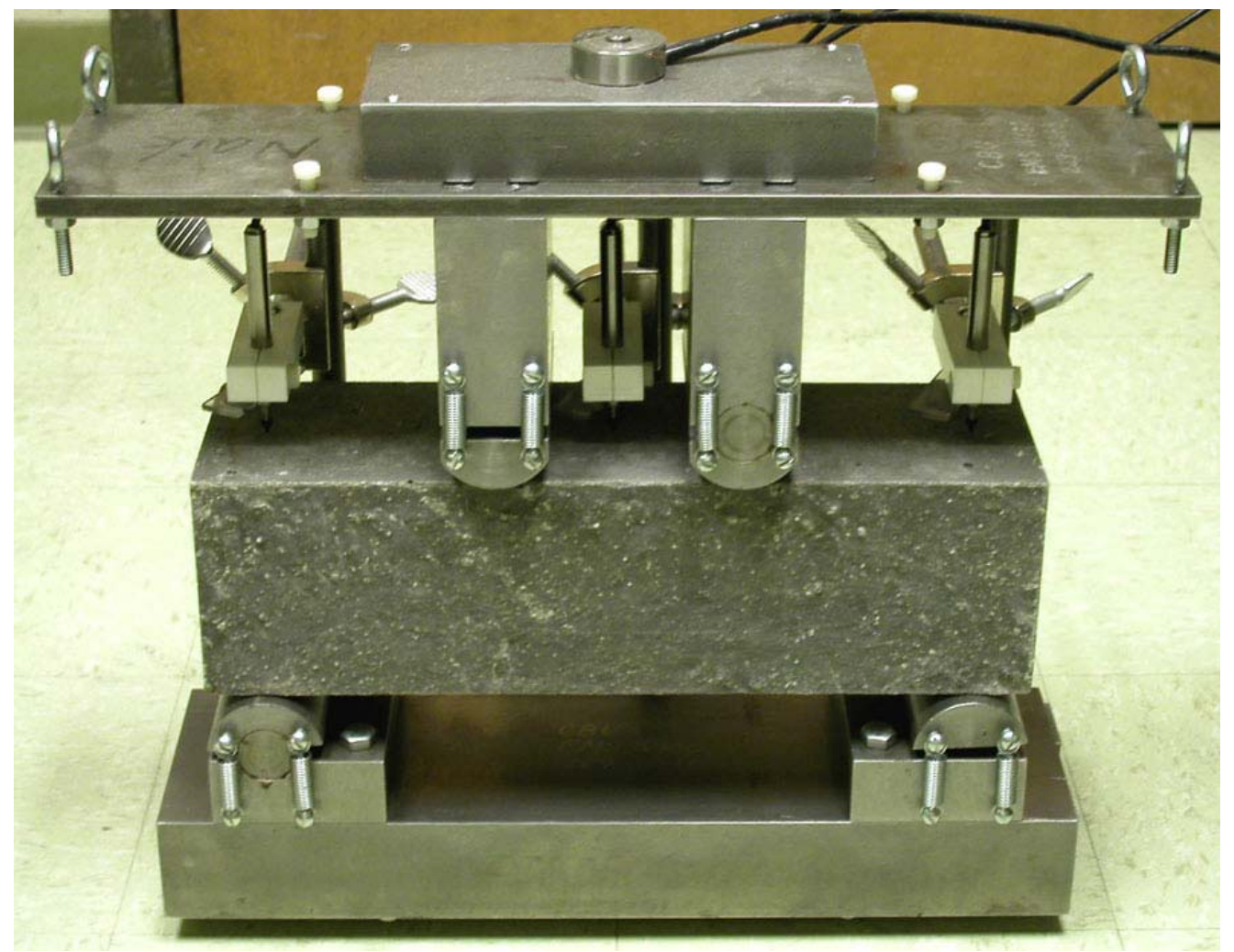

Fig. 143. Load cell, top loading apparatus, LVDTs, beam, and supports (To prevent damage to the tips of the LVDTs located at ends of the beam when the beam ruptures, a block needs to be placed under the beam. Refer to Fig. 45 on p.115.) 


\subsection{Appendix C. Miscellaneous Laboratory Mixtures}

\subsubsection{Paste, Mortar, and Concrete (Series 5)}

In Series 5 investigation, cement paste, mortar, concrete with 3/8 " maximum size aggregates, and concrete with $3 / 4 "$ maximum size aggregates were produced in order to gain experience with the use of residual solids in various cement-based products.

Residual P was used.

Mixture proportions and fresh properties of concrete are presented in Table 130. Reference products did not contain HRWRA, whereas residuals products contained 5.4 to 6.1 fl. oz. of HRWRA per $100 \mathrm{lb}$ of cement. During mixing operations, it was observed that, as the volume of cement paste in cement-based product increased $(860 \rightarrow 1150 \rightarrow$ $1190 \rightarrow 3010 \mathrm{lb} / \mathrm{yd}^{3}$ in concrete-3/4 ", concrete-3/8 ", mortar, and paste, respectively), more residual solids could be incorporated $(0.50 \rightarrow 0.68 \rightarrow 0.70 \rightarrow 7.11 \%$ by weight of the products). Also, it was observed that, for paste and mortar mixing, most of the mixing water should be added to the concrete mixer before any other materials in order to minimize balling of cement. 
Table 130. Proportions and Fresh Properties of Cement-Based Mixtures (Series 5)

\begin{tabular}{|c|c|c|c|c|c|c|c|c|}
\hline Mixture Name & $\begin{array}{l}\text { Ref. } \\
\text { Paste }\end{array}$ & $\begin{array}{c}\mathrm{P} \\
\text { Paste }\end{array}$ & $\begin{array}{c}\text { Ref. } \\
\text { Mortar }\end{array}$ & P & $\begin{array}{c}\text { Ref. } \\
\text { Conc.- } \\
3 / 8 \text { " }\end{array}$ & $\begin{array}{c}\mathrm{P} \\
\text { Conc.- } \\
3 / 8 \text { " }\end{array}$ & \begin{tabular}{|c} 
Ref. \\
Conc.- \\
$3 / 4 "$
\end{tabular} & $\begin{array}{c}\mathrm{P} \\
\text { Conc.- } \\
3 / 4 "\end{array}$ \\
\hline $\begin{array}{l}\text { Residuals, as-recd (\% of } \\
\text { concrete by wt.) }\end{array}$ & 0 & 7.11 & 0 & 0.70 & 0 & 0.68 & 0 & 0.50 \\
\hline Wood Fibers $\left(\mathrm{lb} / \mathrm{yd}^{3}\right) \dagger$ & 0 & 90.2 & 0 & 10.3 & 0 & 10.5 & 0 & 7.8 \\
\hline $\begin{array}{l}\text { Residuals, LOI at } 590^{\circ} \mathrm{C} \\
(1 \mathrm{~b} / 100 \mathrm{lb} \text { cement })\end{array}$ & 0 & 4.23 & 0 & 1.29 & 0 & 1.37 & 0 & 1.37 \\
\hline $\begin{array}{l}\text { HRWRA (fl oz/100 lb } \\
\text { cement) }\end{array}$ & 0 & 5.4 & 0 & 5.7 & 0 & 6.0 & 0 & 6.1 \\
\hline Paste, $c m+w\left(\mathrm{lb} / \mathrm{yd}^{3}\right)$ & 3330 & 3010 & 1290 & 1190 & 1180 & 1150 & 880 & 860 \\
\hline Residual $\mathrm{P}$, as-recd (lb/yd $\left.{ }^{3}\right)$ & 0 & 231 & 0 & 26 & 0 & 27 & 0 & 20 \\
\hline HRWRA (fl oz/yd $\left.{ }^{3}\right)$ & 0 & 123 & 0 & 49 & 0 & 50 & 0 & 37 \\
\hline Cement (lb/yd $\left.{ }^{3}\right)$ & 2450 & 2280 & 845 & 850 & 834 & 819 & 607 & 608 \\
\hline Sand, SSD (lb/yd $\left.{ }^{3}\right)$ & 0 & 0 & 2540 & 2550 & 1460 & 1440 & 1420 & 1420 \\
\hline $\begin{array}{l}\text { Pea Gravel, 3/8 " max., } \\
\text { SSD }\left(1 \mathrm{lb} / \mathrm{yd}^{3}\right)\end{array}$ & 0 & 0 & 0 & 0 & 1360 & 1340 & 0 & 0 \\
\hline $\begin{array}{l}\text { Coarse Aggregate, } 3 / 4 " \\
\max ., \operatorname{SSD}\left(\mathrm{lb} / \mathrm{yd}^{3}\right)\end{array}$ & 0 & 0 & 0 & 0 & 0 & 0 & 1730 & 1730 \\
\hline Water $\left(\mathrm{lb} / \mathrm{yd}^{3}\right)$ & 881 & 736 & 442 & 338 & 346 & 328 & 273 & 254 \\
\hline$w / \mathrm{cm}$ & 0.36 & 0.32 & 0.52 & 0.40 & 0.42 & 0.40 & 0.45 & 0.42 \\
\hline Slump (in.) & 9 & 10 & 10 & 4 & 6 & 10 & 3 & 2.5 \\
\hline Air Content (\%) & 1.3 & $\ldots$ & 2.6 & 6.4 & 2.8 & 4.1 & 1.9 & 2.3 \\
\hline Density $\left(\mathrm{lb} / \mathrm{ft}^{3}\right)$ & 123 & 120 & 142 & 140 & 148 & 146 & 149 & 150 \\
\hline
\end{tabular}

$\dagger$ From residuals, dry basis

Compressive and flexural strengths of the cement-based products were

determined at three days by testing two 4" x 8" cylinders and one 3" x 4" x 12" beam, respectively, for each mixture. The results are presented in Table 131. In these particular mixtures, residuals paste, mortar, concrete- $3 / 8$ ", and concrete-3/4" showed much lower, much higher, a little higher, and somewhat higher compressive strength than Reference counterparts. In spite of much lower compressive strength, residuals paste showed higher flexural strength than Reference paste. 
Table 131. Compressive and Flexural Strengths of Cement-Based Mixtures at 3 days (Series 5)

\begin{tabular}{|l|c|c||c|c||c|c||c|c||}
\hline Mixture Name & $\begin{array}{c}\text { Ref. } \\
\text { Paste }\end{array}$ & $\begin{array}{c}\text { P } \\
\text { Paste }\end{array}$ & $\begin{array}{c}\text { Ref. } \\
\text { Mortar }\end{array}$ & $\begin{array}{c}\text { P } \\
\text { Mortar }\end{array}$ & $\begin{array}{c}\text { Ref. } \\
\text { Conc.- } \\
3 / 8 ~ "\end{array}$ & $\begin{array}{c}\text { P } \\
\text { Conc.- } \\
3 / 8 \text { " }\end{array}$ & $\begin{array}{c}\text { Ref. } \\
\text { Conc.- } \\
\text { 3/4" }\end{array}$ & $\begin{array}{c}\text { P } \\
\text { Conc.- } \\
\text { 3/4" }\end{array}$ \\
\hline Comp. Strength (psi) & 6470 & 3770 & 2990 & 4700 & 5200 & 5280 & 4580 & 4890 \\
\hline $\begin{array}{l}\text { Flexural Strength } \\
\text { (psi) }\end{array}$ & 545 & 655 & 733 & 890 & 798 & 910 & 865 & 775 \\
\hline
\end{tabular}

\subsubsection{Attempt for Maximum Residuals Content (Series 8)}

The objective of Series 8 investigation was to explore for higher residuals content that will still allow residuals concrete to be equivalent to non-residuals concrete in slump and compressive strength. Residuals $\mathrm{C} 2, \mathrm{WV}, \mathrm{S}$, and $\mathrm{BR}$ were included in concrete at asreceived residuals contents of $0,0.5,1.0$, and $1.5 \%$ by weight of concrete. HRWRA contents were $0,5,10$, and $15 \mathrm{fl}$. oz. / $100 \mathrm{lb}$ of cement. Amount of mixing water was adjusted to obtain a target slump of about 3 inches.

Concrete mixture proportions and fresh properties of concrete are presented in Tables 132 to 135 . Segregation of fresh concrete was observed for BR-5, 6, 7, and 8 mixtures containing 10.2 or $15.2 \mathrm{fl}$. oz. of HRWRA / $100 \mathrm{lb}$ of cement. For most mixtures, actual slump was in the range of 3 to 4.5 inches. Depending on the combination of residuals and HRWRA contents, density of fresh concrete varied considerably. 
Table 132. Mixture Proportions and Fresh Properties of Concrete (Series 8: C2)

\begin{tabular}{|c|c|c|c|c|c|c|c|c|}
\hline Mixture Name & $\mathrm{C} 2-1$ & $\mathrm{C} 2-2$ & $\mathrm{C} 2-3$ & $\mathrm{C} 2-4$ & $\mathrm{C} 2-5$ & $\mathrm{C} 2-6$ & $\mathrm{C} 2-7$ & $\mathrm{C} 2-8$ \\
\hline $\begin{array}{l}\text { Residuals, as-recd (\% of } \\
\text { concrete by wt.) }\end{array}$ & 0 & 0.49 & 0 & 0.49 & 0.99 & 1.46 & 0.99 & 1.47 \\
\hline Wood Fibers $\left(1 \mathrm{l} / \mathrm{yd}^{3}\right) \dagger$ & 0 & 3.9 & 0 & 4.0 & 7.8 & 11.3 & 8.0 & 11.6 \\
\hline $\begin{array}{l}\text { Residuals, LOI at } 590^{\circ} \mathrm{C} \\
\text { (lb/100 lb cement) }\end{array}$ & 0 & 0.76 & 0 & 0.76 & 1.52 & 2.28 & 1.52 & 2.28 \\
\hline $\begin{array}{l}\text { HRWRA (fl oz/100 lb } \\
\text { cement) }\end{array}$ & 0 & 0.0 & 5.1 & 5.1 & 10.2 & 10.2 & 15.2 & 15.2 \\
\hline Residuals, as-recd ( $\left.\mathrm{lb} / \mathrm{yd}^{3}\right)$ & 0 & 19.3 & 0 & 19.9 & 39.2 & 56.8 & 40.1 & 58.2 \\
\hline HRWRA (fl oz/yd ${ }^{3}$ ) & 0 & 0 & 31.4 & 30.4 & 60.0 & 58.0 & 91.1 & 88.3 \\
\hline Cement $\left(\mathrm{lb} / \mathrm{yd}^{3}\right)$ & 606 & 580 & 615 & 596 & 588 & 568 & 601 & 582 \\
\hline Sand, SSD $\left(1 b / y^{3}\right)$ & 1420 & 1360 & 1440 & 1400 & 1380 & 1330 & 1410 & 1370 \\
\hline $\begin{array}{l}\text { Coarse Aggregate, 3/4" max., } \\
\operatorname{SSD}\left(\mathrm{lb} / \mathrm{yd}^{3}\right)\end{array}$ & 1720 & 1650 & 1750 & 1690 & 1670 & 1620 & 1710 & 1660 \\
\hline Water $\left(\mathrm{lb} / \mathrm{yd}^{3}\right)$ & 309 & 324 & 269 & 305 & 289 & 323 & 269 & 300 \\
\hline$w / \mathrm{cm}$ & 0.51 & 0.56 & 0.44 & 0.51 & 0.49 & 0.57 & 0.45 & 0.52 \\
\hline Slump (in.) & 4 & 3.5 & 3 & 3.5 & 4.25 & 3.75 & 6 & 4.5 \\
\hline Air Content (\%) & 1.1 & 3.4 & 1.9 & 2.4 & 2.9 & 2.8 & 1.7 & 2 \\
\hline Density $\left(\mathrm{lb} / \mathrm{ft}^{3}\right)$ & 150 & 146 & 151 & 149 & 147 & 144 & 149 & 147 \\
\hline
\end{tabular}

$\dagger$ From residuals, dry basis

Table 133. Mixture Proportions and Fresh Properties of Concrete (Series 8: WV)

\begin{tabular}{|c|c|c|c|c|c|c|c|c|}
\hline Mixture Name & WV-1 & WV-2 & WV-3 & WV-4 & WV-5 & WV-6 & WV-7 & WV-8 \\
\hline $\begin{array}{l}\text { Residuals, as-recd (\% of } \\
\text { concrete by wt.) }\end{array}$ & 0 & 0.49 & 0 & 0.49 & 0.97 & 1.42 & 0.97 & 1.42 \\
\hline Wood Fibers $\left(\mathrm{lb} / \mathrm{yd}^{3}\right) \dagger$ & 0 & 6.0 & 0 & 5.8 & 11.9 & 17.0 & 12.1 & 17.3 \\
\hline $\begin{array}{l}\text { Residuals, LOI at } 590^{\circ} \mathrm{C} \\
\text { (lb/100 lb cement) }\end{array}$ & 0 & 1.13 & 0 & 1.13 & 2.26 & 3.40 & 2.26 & 3.40 \\
\hline $\begin{array}{l}\text { HRWRA (fl oz/100 lb } \\
\text { cement) }\end{array}$ & 0 & 0.0 & 5.1 & 5.1 & 10.2 & 10.2 & 15.2 & 15.2 \\
\hline Residuals, as-recd $\left(\mathrm{lb} / \mathrm{yd}^{3}\right)$ & 0 & 18.9 & 0 & 18.3 & 37.8 & 53.8 & 38.2 & 54.7 \\
\hline HRWRA ( & 0 & 0.0 & 31.4 & 28.0 & 58.0 & 54.9 & 86.9 & 82.9 \\
\hline Cement $\left(\mathrm{lb} / \mathrm{yd}^{3}\right)$ & 606 & 567 & 615 & 549 & 568 & 538 & 573 & 547 \\
\hline Sand, SSD $\left(\mathrm{lb} / \mathrm{yd}^{3}\right)$ & 1420 & 1330 & 1440 & 1290 & 1330 & 1260 & 1350 & 1280 \\
\hline $\begin{array}{l}\text { Coarse Aggregate, } 3 / 4 " \text { max., } \\
\operatorname{SSD}\left(\mathrm{lb} / \mathrm{yd}^{3}\right)\end{array}$ & 1720 & 1610 & 1750 & 1560 & 1610 & 1530 & 1630 & 1550 \\
\hline Water $\left(\mathrm{lb} / \mathrm{yd}^{3}\right)$ & 309 & 326 & 269 & 293 & 338 & 402 & 334 & 397 \\
\hline$w / \mathrm{cm}$ & 0.51 & 0.58 & 0.44 & 0.53 & 0.59 & 0.75 & 0.58 & 0.73 \\
\hline Slump (in.) & 4 & 4.5 & 3 & 3.5 & 3.5 & 3 & 3.5 & 3 \\
\hline Air Content (\%) & 1.1 & 4.4 & 1.9 & 8.25 & 2.6 & 2.3 & 1.9 & 1.5 \\
\hline Density $\left(\mathrm{lb} / \mathrm{ft}^{3}\right)$ & 150 & 143 & 151 & 137 & 144 & 140 & 145 & 142 \\
\hline
\end{tabular}

$\dagger$ From residuals, dry basis 
Table 134. Mixture Proportions and Fresh Properties of Concrete (Series 8: S)

\begin{tabular}{|c|c|c|c|c|c|c|c|c|}
\hline Mixture Name & S-1 & $\mathrm{S}-2$ & S-3 & S-4 & S-5 & S-6 & S-7 & S-8 \\
\hline $\begin{array}{l}\text { Residuals, as-recd (\% of } \\
\text { concrete by wt.) }\end{array}$ & 0 & 0.49 & 0 & 0.50 & 0.98 & 1.43 & 0.98 & 1.44 \\
\hline Wood Fibers $\left(1 \mathrm{l} / \mathrm{yd}^{3}\right) \dagger$ & 0 & 5.0 & 0 & 5.2 & 10.3 & 14.6 & 10.3 & 14.8 \\
\hline $\begin{array}{l}\text { Residuals, LOI at } 590^{\circ} \mathrm{C} \\
\text { (lb/100 lb cement) }\end{array}$ & 0 & 1.05 & 0 & 1.05 & 2.10 & 3.15 & 2.10 & 3.15 \\
\hline $\begin{array}{l}\text { HRWRA (fl oz/100 lb } \\
\text { cement) }\end{array}$ & 0 & 0.0 & 5.1 & 5.1 & 10.2 & 10.2 & 15.2 & 15.2 \\
\hline Residuals, as-recd $\left(\mathrm{lb} / \mathrm{yd}^{3}\right)$ & 0 & 18.9 & 0 & 19.8 & 38.8 & 55.0 & 38.8 & 55.8 \\
\hline HRWRA (fl oz/yd ${ }^{3}$ ) & 0 & 0.0 & 31.4 & 30.3 & 59.5 & 56.2 & 88.3 & 84.7 \\
\hline Cement $\left(\mathrm{lb} / \mathrm{yd}^{3}\right)$ & 606 & 567 & 615 & 593 & 582 & 550 & 582 & 558 \\
\hline Sand, SSD $\left(1 \mathrm{lb} / \mathrm{yd}^{3}\right)$ & 1420 & 1330 & 1440 & 1390 & 1370 & 1290 & 1370 & 1310 \\
\hline $\begin{array}{l}\text { Coarse Aggregate, } 3 / 4 " \text { max., } \\
\operatorname{SSD}\left(\mathrm{lb} / \mathrm{yd}^{3}\right)\end{array}$ & 1720 & 1610 & 1750 & 1690 & 1660 & 1570 & 1660 & 1590 \\
\hline Water $\left(\mathrm{lb} / \mathrm{yd}^{3}\right)$ & 309 & 345 & 269 & 297 & 318 & 378 & 323 & 350 \\
\hline$w / \mathrm{cm}$ & 0.51 & 0.61 & 0.44 & 0.50 & 0.55 & 0.69 & 0.55 & 0.63 \\
\hline Slump (in.) & 4 & 3 & 3 & 3.5 & 3 & 3 & 3 & 3 \\
\hline Air Content (\%) & 1.1 & 3.5 & 1.9 & 3 & 2.2 & 2.2 & 2 & 2.1 \\
\hline Density $\left(\mathrm{lb} / \mathrm{ft}^{3}\right)$ & 150 & 143 & 151 & 148 & 147 & 142 & 147 & 143 \\
\hline
\end{tabular}

$\dagger$ From residuals, dry basis

Table 135. Mixture Proportions and Fresh Properties of Concrete (Series 8: BR)

\begin{tabular}{|c|c|c|c|c|c|c|c|c|}
\hline Mixture Name & BR-1 & BR-2 & BR-3 & BR-4 & BR-5 & BR-6 & BR-7 & BR-8 \\
\hline $\begin{array}{l}\text { Residuals, as-recd (\% of } \\
\text { concrete by wt.) }\end{array}$ & 0 & 0.49 & 0 & 0.50 & 0.98 & 1.44 & 0.99 & 1.45 \\
\hline Wood Fibers $\left(\mathrm{lb} / \mathrm{yd}^{3}\right) \dagger$ & 0 & 5.5 & 0 & 5.7 & 11.1 & 15.6 & 11.2 & 16.2 \\
\hline $\begin{array}{l}\text { Residuals, LOI at } 590^{\circ} \mathrm{C} \\
\text { (lb/100 lb cement) }\end{array}$ & 0 & 1.01 & 0 & 1.01 & 2.01 & 3.02 & 2.01 & 3.02 \\
\hline $\begin{array}{l}\text { HRWRA (fl oz/100 lb } \\
\text { cement) }\end{array}$ & 0 & 0.0 & 5.1 & 5.1 & 10.2 & 10.2 & 15.2 & 15.2 \\
\hline Residuals, as-recd (lb/yd $\left.{ }^{3}\right)$ & 0 & 19.3 & 0 & 20.0 & 39.2 & 54.8 & 39.5 & 56.9 \\
\hline HRWRA (fl oz/yd ${ }^{3}$ ) & 0 & 0.0 & 31.4 & 30.7 & 60.0 & 56.0 & 89.9 & 86.4 \\
\hline Cement $\left(\mathrm{lb} / \mathrm{yd}^{3}\right)^{-}$ & 606 & 579 & 615 & 601 & 588 & 548 & 593 & 569 \\
\hline Sand, SSD $\left(1 \mathrm{lb} / \mathrm{yd}^{3}\right)$ & 1420 & 1360 & 1440 & 1410 & 1380 & 1290 & 1390 & 1340 \\
\hline $\begin{array}{l}\text { Coarse Aggregate, 3/4" max., } \\
\text { SSD }\left(1 \mathrm{lb} / \mathrm{yd}^{3}\right)\end{array}$ & 1720 & 1650 & 1750 & 1710 & 1670 & 1560 & 1680 & 1620 \\
\hline Water $\left(\mathrm{lb} / \mathrm{yd}^{3}\right)$ & 309 & 314 & 269 & 274 & 309 & 355 & 289 & 332 \\
\hline$w / \mathrm{cm}$ & 0.51 & 0.54 & 0.44 & 0.46 & 0.52 & 0.65 & 0.49 & 0.58 \\
\hline Slump (in.) & 4 & 3.25 & 3 & 3 & 3 & 5.5 & 2.5 & 2.5 \\
\hline Air Content $(\%)$ & 1.1 & 3.8 & 1.9 & 2.7 & 2 & 2.6 & 1.7 & 2 \\
\hline Density $\left(\mathrm{lb} / \mathrm{ft}^{3}\right)$ & 150 & 145 & 151 & 149 & 148 & 141 & 148 & 145 \\
\hline
\end{tabular}

$\dagger$ From residuals, dry basis 
Compressive strength of concrete was determined at 7, 28, and 56 days by testing three 4" x 8" cylinders for each test age for each mixture. The results are presented in Tables 136 to 139 .

The results for $\mathrm{C} 2$ mixtures suggest that maximum as-received residual content for $\mathrm{C} 2$ might be between 1 to $1.5 \%$. As for $\mathrm{WV}, \mathrm{S}$, and BR concrete mixtures, 28-day strength decreased as residuals content increased. This is probably due to the use of higher amount of residuals compared with the amount of HRWRA used in these mixtures. As Residual BR content increased, compressive strength of concrete dropped sharply. 
Table 136. Compressive Strength of C2 Concrete (in psi) (Series 8)

\begin{tabular}{|c|c|c|c|c|c||}
\hline \multirow{2}{*}{$\begin{array}{c}\text { Age } \\
\text { (days) }\end{array}$} & \multirow{2}{*}{$\begin{array}{c}\text { HRWRA } \\
\text { (fl oz/ } \\
100 \text { lb cement) }\end{array}$} & \multicolumn{4}{|c|}{ As-received Residual C2 (\% by wt. of concrete) } \\
\cline { 3 - 6 } & 0 & 5050 & 3880 & $\ldots .5$ & 1.5 \\
\hline 7 & 5 & 5860 & 5030 & $\ldots$ & $\ldots$ \\
\hline & 10 & $\ldots$ & $\ldots$ & 4750 & 3600 \\
\hline & 15 & $\ldots$ & $\ldots$ & 5450 & 4370 \\
\hline \hline 28 & 0 & 6590 & 4820 & $\ldots$ & $\ldots$ \\
\hline & 5 & 6980 & 6140 & $\ldots$ & $\ldots$ \\
\hline & 10 & $\ldots$ & $\ldots$ & 5830 & 4380 \\
\hline & 15 & $\ldots$ & $\ldots$ & 6490 & 5380 \\
\hline 56 & 0 & 7330 & 5350 & $\ldots$ & $\ldots$ \\
\hline & 5 & 7510 & 6560 & $\ldots$ & $\ldots$ \\
\hline & 10 & $\ldots$ & $\ldots$ & 6180 & 4700 \\
\hline & 15 & $\ldots$ & $\ldots$ & 6980 & 5780 \\
\hline
\end{tabular}

Table 137. Compressive Strength of WV Concrete (in psi) (Series 8)

\begin{tabular}{|c|c||c|c|c|c||}
\hline \multirow{2}{*}{$\begin{array}{c}\text { Age } \\
(\text { days })\end{array}$} & $\begin{array}{c}\text { HRWRA } \\
(\mathrm{fl} \text { oz/ } \\
100 \mathrm{lb} \text { cement }\end{array}$ & 0 & \multicolumn{5}{|c|}{ As-received Residual WV (\% by wt. of concrete) } \\
\cline { 3 - 6 } & 0 & 5050 & 3440 & $\ldots$ & 1.5 \\
\hline \hline 7 & 5 & 5860 & 2940 & $\ldots$ & $\ldots$ \\
\hline & 10 & $\ldots$ & $\ldots$ & 3520 & 2150 \\
\hline & 15 & $\ldots$ & $\ldots$ & 3410 & 2340 \\
\hline \hline 28 & 0 & 6590 & 4540 & $\ldots$ & $\ldots$ \\
\hline & 5 & 6980 & 3560 & $\ldots$ & $\ldots$ \\
\hline & 10 & $\ldots$ & $\ldots$ & 4270 & 2750 \\
\hline & 15 & $\ldots$ & $\ldots$ & 4150 & 2990 \\
\hline \hline 56 & 0 & 7330 & 4920 & $\ldots$ & $\ldots$ \\
\hline & 5 & 7510 & 3820 & $\ldots$ & $\ldots$ \\
\hline & 10 & $\ldots$ & $\ldots$ & 4480 & 2810 \\
\hline & 15 & $\ldots$ & $\ldots$ & 4310 & 3200 \\
\hline
\end{tabular}


Table 138. Compressive Strength of S Concrete (in psi) (Series 8)

\begin{tabular}{|c|c||c|c|c|c||}
\hline \multirow{2}{*}{$\begin{array}{c}\text { Age } \\
(\text { days })\end{array}$} & \multirow{2}{*}{$\begin{array}{c}\text { HRWRA } \\
\text { (fl oz/ } \\
100 \text { lb cement) }\end{array}$} & 0 & \multicolumn{4}{c|}{ As-received Residual S (\% by wt. of concrete) } \\
\cline { 3 - 6 } & 0 & 5050 & 3270 & $\ldots$ & $\ldots$ \\
\hline \hline 7 & 5 & 5860 & 4390 & $\ldots$ & $\ldots$ \\
\hline & 10 & $\ldots$ & $\ldots$ & 3760 & 2560 \\
\hline & 15 & $\ldots$ & $\ldots$ & 3500 & 2590 \\
\hline \hline 28 & 0 & 6590 & 4190 & $\ldots$ & $\ldots$ \\
\hline & 5 & 6980 & 5500 & $\ldots$ & $\ldots$ \\
\hline & 10 & $\ldots$ & $\ldots$ & 4750 & 3250 \\
\hline & 15 & $\ldots$ & $\ldots$ & 4350 & 3380 \\
\hline \hline 56 & 0 & 7330 & 4660 & $\ldots$ & $\ldots$ \\
\hline & 5 & 7510 & 5720 & $\ldots$ & $\ldots$ \\
\hline & 10 & $\ldots$ & $\ldots$ & 5060 & 3520 \\
\hline & 15 & $\ldots$ & $\ldots$ & 4760 & 3490 \\
\hline \hline
\end{tabular}

Table 139. Compressive Strength of BR Concrete (in psi) (Series 8)

\begin{tabular}{|c|c|c|c|c|c|}
\hline \multirow{2}{*}{\begin{tabular}{|l} 
Age \\
(days)
\end{tabular}} & \multirow{2}{*}{$\begin{array}{c}\text { HRWRA } \\
\text { (fl oz/ } \\
100 \text { lb cement) } \\
\end{array}$} & \multicolumn{4}{|c|}{ As-received Residual BR ( $\%$ by wt. of concrete) } \\
\hline & & 0 & 0.5 & 1 & 1.5 \\
\hline \multirow[t]{4}{*}{7} & 0 & 5050 & 3550 & $\ldots$ & $\ldots$ \\
\hline & 5 & 5860 & 5010 & ... & $\ldots$ \\
\hline & 10 & $\ldots$ & $\ldots$ & 2280 & 1300 \\
\hline & 15 & $\ldots$ & $\ldots$ & 2440 & 1620 \\
\hline \multirow[t]{4}{*}{28} & 0 & 6590 & 4640 & $\ldots$ & $\ldots$ \\
\hline & 5 & 6980 & 5970 & $\ldots$ & $\ldots$ \\
\hline & 10 & $\ldots$ & $\ldots$ & 2770 & 1670 \\
\hline & 15 & $\ldots$ & $\ldots$ & 2940 & 2050 \\
\hline \multirow[t]{4}{*}{56} & 0 & 7330 & 5060 & $\ldots$ & $\ldots$ \\
\hline & 5 & 7510 & 6570 & $\ldots$ & $\ldots$ \\
\hline & 10 & $\ldots$ & $\ldots$ & 2860 & 1870 \\
\hline & 15 & $\ldots$ & $\ldots$ & 3210 & 2290 \\
\hline
\end{tabular}




\subsubsection{Attempt for Maximum HRWRA Content (Series 10)}

\section{Background}

As presented earlier (p. 60), maximum dosage of the HRWRA recommended by its manufacturer was $10 \mathrm{fl}$. oz./100 lb of cement. However, up to $14.3 \mathrm{fl} \mathrm{oz} / 100 \mathrm{lb}$ of cement had been used in Series 9 (p. 177), and no adverse effect of it on the properties of concrete was observed. On the other hand, adverse effects of the use of higher dosage of HRWRA (10.2 to $15.2 \mathrm{fl}$. oz./100 lb of cement) on properties of BR concrete were observed in Series 8 in the form of segregation and lower compressive strength (p. 261). Therefore, it was desired to establish maximum HRWRA contents of concrete mixtures made with and without residuals.

\section{Mixture Proportions, Test Results, and Discussions}

To investigate the influence of HRWRA content on fresh properties and compressive strength of concrete, initially nine concrete mixtures were planned for three levels of two variables: (as-received residuals content of $0,0.25,0.50 \%$ by weight of concrete) x (HRWRA content of $0,9.1$, and $18.2 \mathrm{fl} \mathrm{oz} / 100 \mathrm{lb}$ of cement). It was expected that $w / \mathrm{cm}$, density, and compressive strength of concrete would vary depending on the combination of residuals and HRWRA contents.

However, due to the pressing need for the establishment of mixture proportions and evaluation of durability of concrete containing BR, I, and S residuals (Series 11 and 12), only four out of the nine planned mixtures were actually produced. Based on the test results acquired for these four mixtures, it was possible to observe: (1) the influence of residuals contents ( 0 and $0.25 \%$ ) on properties of concrete containing no HRWRA; and 
(2) the influence of HRWRA contents $(0,9.1$, and $18.2 \mathrm{fl}$. oz. $/ 100 \mathrm{lb}$ of cement) on properties of concrete containing no residuals.

Residual used in this investigation was Residual I, one of the three residuals (BR, I, and S) to be used in Series 12.

Mixture proportions and fresh properties of concrete are presented in Table 140.

Table 140. Mixture Proportions and Fresh Properties of Concrete (Series 10)

\begin{tabular}{|c|c|c|c|c|}
\hline Mixture Name & 1 & 2 & 3 & $\mathrm{I}-4$ \\
\hline Residuals, as-recd (\% of concrete by wt.) & 0 & 0 & 0 & 0.25 \\
\hline Wood Fibers $\left(\mathrm{lb} / \mathrm{yd}^{3}\right) \dagger$ & 0 & 0 & 0 & 2.1 \\
\hline Residuals, LOI at $590^{\circ} \mathrm{C}(\mathrm{lb} / 100 \mathrm{lb}$ cement $)$ & 0 & 0 & 0 & 0.43 \\
\hline HRWRA (fl oz/100 lb cement) & 0 & 9.1 & 18.2 & 0 \\
\hline Residual I, as-recd $\left(\mathrm{lb} / \mathrm{yd}^{3}\right)$ & 0 & 0 & 0 & 10.0 \\
\hline HRWRA (fl oz/yd ${ }^{3}$ ) & 0 & 60 & 119 & 0 \\
\hline Cement $\left(\mathrm{lb} / \mathrm{yd}^{3}\right)$ & 615 & 653 & 652 & 601 \\
\hline Sand, SSD $\left(\mathrm{lb} / \mathrm{yd}^{3}\right)$ & 1430 & 1520 & 1510 & 1400 \\
\hline Coarse Aggregate, $3 / 4 "$ max., SSD $\left(\mathrm{lb} / \mathrm{yd}^{3}\right)$ & 1750 & 1860 & 1850 & 1710 \\
\hline Water $\left(\mathrm{lb} / \mathrm{yd}^{3}\right)$ & 293 & 228 & 227 & 335 \\
\hline$w / \mathrm{cm}$ & 0.48 & 0.35 & 0.35 & 0.56 \\
\hline Slump (in.) & 4.25 & 6.5 & 7.5 & 2.75 \\
\hline \multicolumn{5}{|l|}{ Air Content $(\%)$} \\
\hline Density $\left(\mathrm{lb} / \mathrm{ft}^{3}\right)$ & 151 & 158 & 157 & 150 \\
\hline
\end{tabular}

$\dagger$ From residuals, dry basis

At residuals content of zero, increase of HRWRA content from 0 to $9.1 \mathrm{fl} \mathrm{oz} / 100$ $\mathrm{lb}$ of cement (Mixture $1 \rightarrow 2$ ) resulted in considerable reduction in $w / \mathrm{cm}$ (from 0.48 to 0.35 ) and considerable increase in density of concrete (from 151 to $158 \mathrm{lb} / \mathrm{ft}^{3}$ ). However, when HRWRA content increased from 9.1 to $18.2 \mathrm{fl} \mathrm{oz} / 100 \mathrm{lb}$ of cement (Mixture $2 \rightarrow$ 3), $w / c m$ remained the same (0.35) and density rather decreased a little $(158 \rightarrow 157$ $\left.\mathrm{lb} / \mathrm{ft}^{3}\right)$. Also, segregation of fresh concrete mixture was observed for Mixture 3, probably 
due to the use of excessive amount of HRWRA (18.2 $\mathrm{fl} \mathrm{oz} / 100 \mathrm{lb}$ of cement) in this nonresiduals concrete.

Segregation of fresh concrete was also noted in Series 8 (p. 261) and later in Series 11 (p. 173) for concrete containing Residual BR when relatively high dosage of HRWRA was used (10.2 to $19.5 \mathrm{fl} \mathrm{oz} / 100 \mathrm{lb}$ of cement). Also later in Series 12, a lot of yellow bleeding water was observed on top of I and S mixtures containing 14.6 and 23.3 fl oz, respectively, of HRWRA/100 lb cement (p. 181).

For each concrete mixture, compressive strength of concrete was determined at 7 day by testing one $4 " \mathrm{x} 8$ " cylinder and at 28 days by testing two 4 " x 8 " cylinders (except for Mixture 1 for which three cylinders were tested at 28 days). The results are presented in Table 141 and in Fig. 144 and 145. Concrete containing no residuals seemed to have peak strength at HRWRA content of about $9 \mathrm{fl} \mathrm{oz} / 100 \mathrm{lb}$ of cement, which is close to the maximum dosage rate of HRWRA (10 fl oz/100 lb of cement) recommended by the manufacturer. Using HRWRA beyond the recommended maximum dosage rate seemed to have adversely affected the strength of concrete containing no residuals.

Table 141. Compressive Strength of Concrete (in psi) (Series 10)

\begin{tabular}{|c|c||c|c|}
\hline \multirow{2}{*}{$\begin{array}{c}\text { Age } \\
\text { (days) }\end{array}$} & $\begin{array}{c}\text { HRWRA } \\
\text { (fl oz/100 lb } \\
\text { of cement) }\end{array}$ & \multicolumn{2}{|c|}{$\begin{array}{c}\text { As-received Residual I } \\
\text { (\% by wt. of concrete) }\end{array}$} \\
\cline { 3 - 4 } & 0 & 4400 & 0.25 \\
\hline \hline \multirow{3}{*}{7} & 9.1 & 7460 & 3800 \\
\cline { 2 - 4 } & 18.2 & 5630 & $\ldots$ \\
\hline \hline \multirow{3}{*}{28} & 0 & 5670 & 4890 \\
\cline { 2 - 4 } & 9.1 & 8260 & $\ldots$ \\
\cline { 2 - 4 } & 18.2 & 6620 & $\ldots$ \\
\hline
\end{tabular}




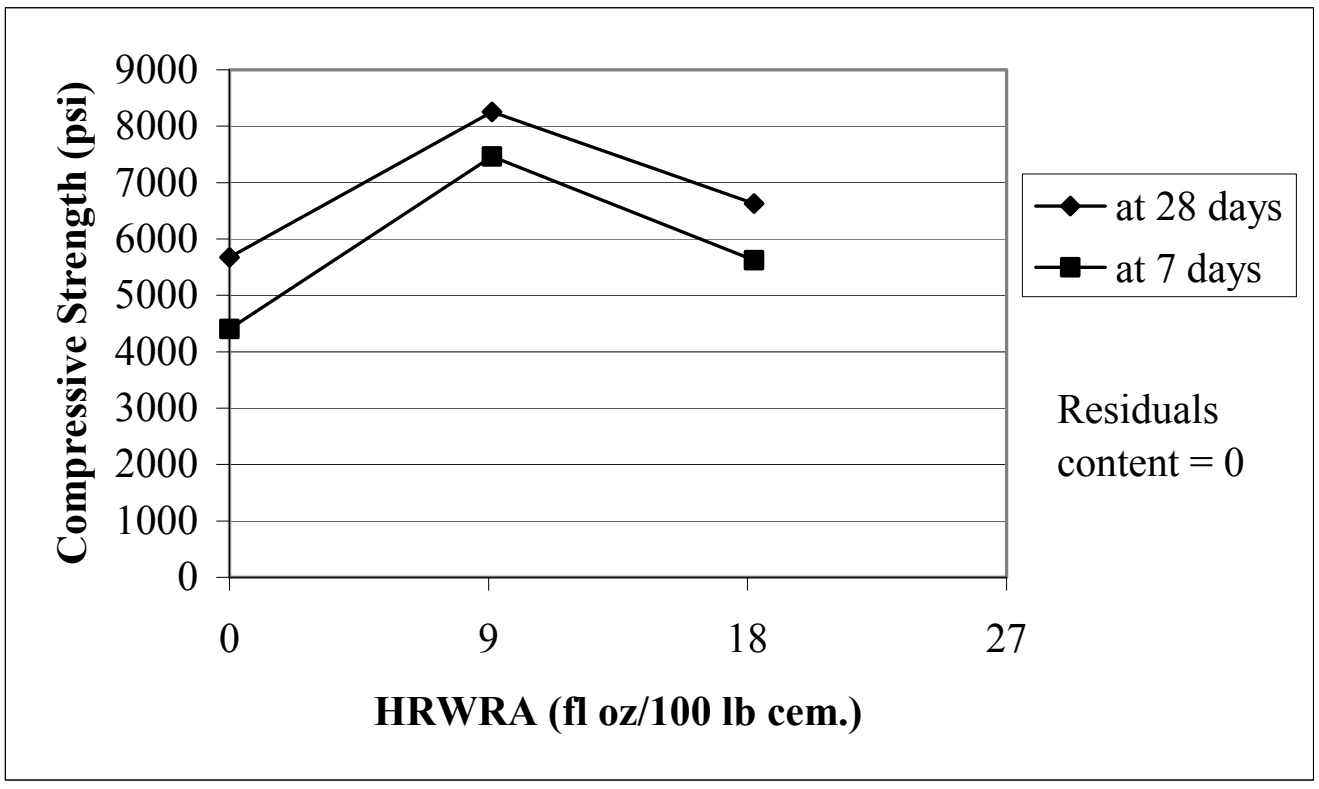

Fig. 144. Relation between HRWRA content and compressive strength of concrete containing no residuals (Series 10)

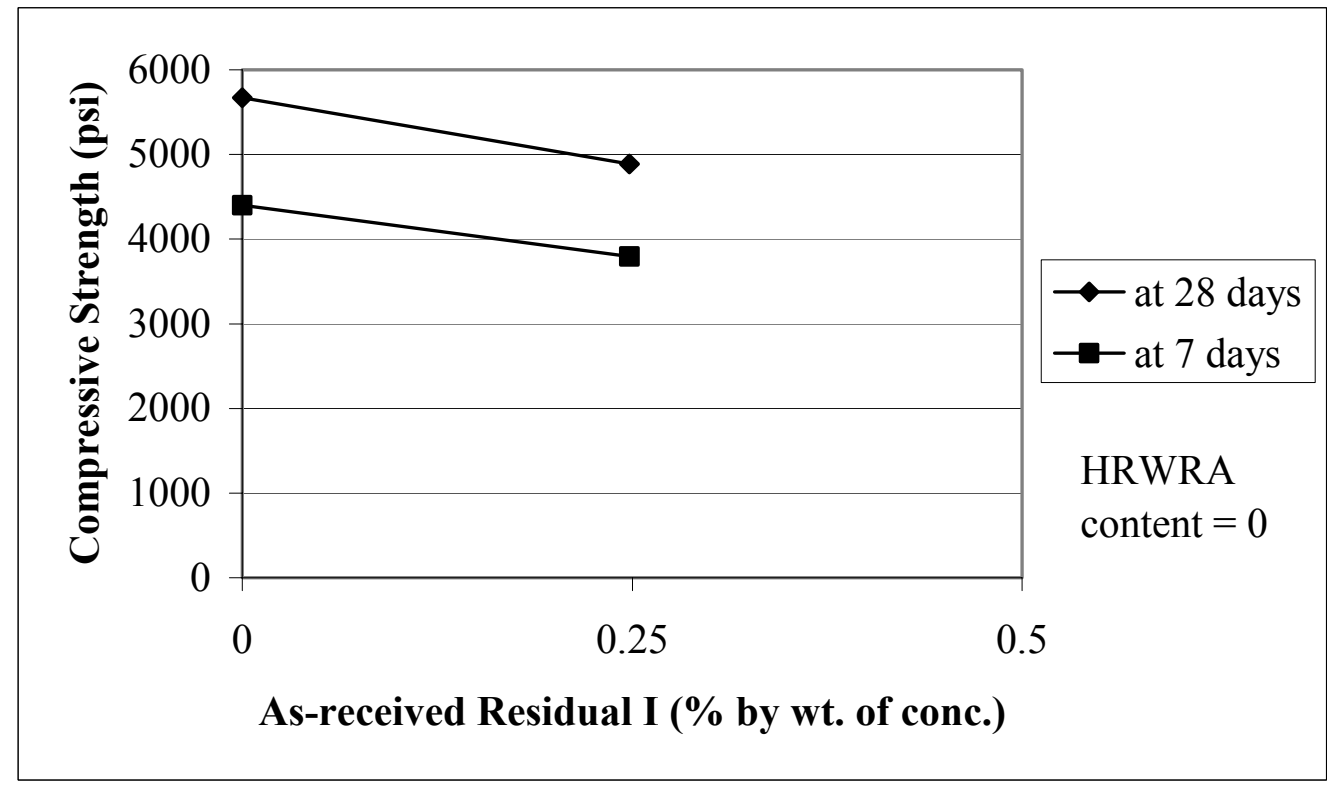

Fig. 145. Relation between residuals content and compressive strength of concrete containing no HRWRA (Series 10)

At HRWRA content of zero, compressive strength of concrete decreased as the amount of as-received Residuals I increased from zero to $0.25 \%$ by weight of concrete 
because of increase in water demand. This observation is in agreement with the observations made throughout this research (pp. 133, 150, 203).

In conclusion, based on the test results and discussions presented above, use of HRWRA beyond manufacturer's recommended maximum dosage seems to cause segregation and reduction in strength of both non-residuals and residuals concrete mixtures.

\subsubsection{Time of Flow (Series 13)}

\section{Background}

In this research, consistency of fresh concrete was quantified in terms of slump.

However, the slump test does not necessarily measure the workability of concrete [61]. With Series 2 concrete mixtures, it was noted that as residuals content increased, use of more mixing water did not always result in increase in slump. Rather, it tended to result in dilution of concrete mixtures and reduction in strength of concrete (p. 133). In Series 2 , the slump of residuals concrete was 1.25 inches or less. However, the mixtures still exhibited acceptable workability.

As discussed earlier (pp. 150, 166, 173, 123, 203), with proper combination of residuals and HRWRA contents, slump and strength of concrete can be adjusted at desirable levels.

However, there are certain problems associated with the use of HRWRA. High cost of HRWRA and rather rapid loss of slump are two of them.

The cost of the HRWRA used in this research was $\$ 15 /$ gallon, or $\$ 0.117 / f 1$ oz. This converts to about $\$ 5$ for HRWRA in a cubic yard of concrete containing about $5 \mathrm{lb}$ 
of wood fibers (on dry basis) and 45 fl. oz. of HRWRA (Series 14, p. 203). At cement cost of $\$ 70 /$ ton, or $\$ 0.035 / 1 \mathrm{~b}$, the cost of cement in a cubic yard of concrete containing $600 \mathrm{lb}$ of cement would be about $\$ 21$. Thus the cost of HRWRA in residuals concrete would be almost $25 \%$ of the cost of cement. If it can be shown that residuals concrete is workable even at low slump, amount of HRWRA in residuals concrete can be considerably reduced or brought to zero.

Also, concrete containing HRWRA can lose slump rather rapidly compared with concrete that does not contain HRWRA. In other words, although time of setting of mortar fraction of concrete may increase in proportion to the amount of HRWRA used in concrete (p. 178), the concrete itself can become stiff rather quickly making the placing and finishing of concrete difficult unless these operations are performed within a relatively short period of time (for example, 45 minutes) following the initial batching and mixing of concrete. Re-dosing HRWRA or tempering (that is, adding more mixing water) to increase the slump may adversely affect cohesiveness and strength of concrete. Use of less or no HRWRA would be beneficial for longer retention of slump and workability.

There is another aspect to be considered for the extensive use of residuals in concrete. There exists a maximum dosage rate of HRWRA, beyond which segregation and reduction in strength of concrete may result (pp. 173, 261, 267). In order to maintain the slump at a certain desirable level (for example, 3 to 6 in.), the amount of HRWRA needs to be increased in proportion to the amount of wood fibers added to concrete (Series 14, p. 203). Thus, with this approach of keeping a mid-range slump of concrete, maximum residuals content would be limited by the maximum dosage rate of HRWRA. 
Again, if it can be shown that residuals concrete is workable even at low slump, the ratio of HRWRA to wood fibers contents could be reduced considerably or even brought to zero and maximum residuals content could be increased further.

Instead of the slump test, there is an ASTM test method for use with fiberreinforced concrete. As discussed earlier (p. 55), according to ASTM C 995, "the inverted slump-cone time is a better indicator than slump of the appropriate level of workability for fiber-reinforced concrete placed by vibration because such concrete can exhibit very low slump due to the presence of the fibers and still be easily consolidated."

This series of concrete mixtures (Series 13) were produced in order to find out whether there is any difference in the relation of time of flow and slump between reference and residuals concrete mixtures. If it could be shown that residuals concrete has shorter time of flow compared with reference concrete at same level of slump, residuals concrete could be made at lower slump than reference concrete and still achieve comparable workability. This would lead to the use of less or no HRWRA and the accompanying benefits described above (that is, reduced concrete production cost, slower rate of slump loss, and higher maximum residuals content).

\section{Mixture Proportions, Test Results, and Discussions}

Concrete mixtures were made to get information on relationship between time of flow and slump of fresh concrete and to compare these relationships of reference and residuals concrete mixtures. Initially a set of mixtures was made, and time of flow of concrete was determined according to ASTM C 995. However, as described later, it was observed that the test method is not applicable to concrete with 2" or higher slump. In an attempt to resolve this problem and to establish a relationship between time of flow and 
slump (inclusive of slump higher than 2"), a modified test method for time of flow was tried using a second set of mixtures.

Residual selected for the first set of mixtures was C2, which had high wood fiber content (p. 78) and was relatively easy to de-flocculate in water (p. 94). Mixture proportions for the eight $\left(2^{3}\right)$ mixtures of the first set were based on two-level factorial design with three variables (Residuals, HRWRA, and AEA contents) to know the effect of each variable on the relation between time-of-flow and slump. However, analysis of the effects was not possible due to limited amount of data. To study the effects, half dozen sets of time-of-flow and slump data would be required for each of the eight combinations of the variables.

Residuals concrete showed slump of 0.625 to 1.5 inches, while concrete without residuals showed slump of 1.25 to 8 inches. Also, for slump higher than about 2 inches, erroneous results of time-of-flow were observed. So it was not possible to compare the relation of time of flow and slump between the two groups of concrete mixtures. Only observation of overall relationship regardless of combination of the variables was possible.

Mixture proportions and fresh properties, including time-of-flow, of concrete for the first set of mixtures are presented in Table 142.

Slump of the first set of mixtures ranged from about 0.6 to 8 inches. Time of flow of the first set of mixtures through inverted slump cone was determined according to ASTM C 995. Since there is a four-inch clearance between the small end of the cone and the bottom of the bucket (Fig. 33 on p. 108), some concrete always fell to the bottom of the bucket in the process of filling the inverted cone with concrete. As the slump 
increased, larger amount of concrete dropped through the opening of the inverted cone and fell to the bucket.

Table 142. Mixture Proportions and Fresh Properties of Concrete (Series 13: Set 1)

\begin{tabular}{|c|c|c|c|c|c|c|c|c|}
\hline Mixture Name & 1 & 2 & 3 & 4 & $\mathrm{C} 2-5$ & $\mathrm{C} 2-6$ & $\mathrm{C} 2-7$ & $\mathrm{C} 2-8$ \\
\hline $\begin{array}{l}\text { Residuals, as-recd (\% of } \\
\text { concrete by wt.) }\end{array}$ & 0 & 0 & 0 & 0 & 0.66 & 0.66 & 0.66 & 0.66 \\
\hline Wood Fibers $\left(\mathrm{lb} / \mathrm{yd}^{3}\right) \dagger$ & 0 & 0 & 0 & 0 & 5.4 & 5.4 & 5.3 & 5.2 \\
\hline $\begin{array}{l}\text { Residuals, } \\
\mathrm{lb} / 100 \mathrm{lbc}\end{array}$ & 0 & 0 & 0 & 0 & 1.0 & 1.0 & 1.0 & 1.0 \\
\hline HRWRA (f & 0 & 0 & 7.5 & 7.5 & 7.5 & 7.5 & 0 & 0 \\
\hline AEA & 0 & 1.5 & 0 & 1.8 & 0 & 1.8 & 0 & 1.5 \\
\hline Residu & 0 & 0 & 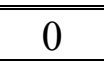 & 0 & 26.9 & 27.0 & 26.4 & 26.1 \\
\hline HRW & 0 & 0 & 48.2 & 47.8 & 46.1 & 46.2 & 0 & 0 \\
\hline Ceme & 625 & 607 & 642 & 637 & 615 & 616 & 601 & 595 \\
\hline Sand, & 1460 & 1420 & 1500 & 1490 & 1430 & 1440 & 1400 & 1390 \\
\hline $\begin{array}{l}\text { Coarse Aggregate, } 3 / 4 " \text { max., } \\
\text { SSD }\left(\mathrm{lb} / \mathrm{yd}^{3}\right)\end{array}$ & 1770 & 1720 & 1820 & 1800 & 1740 & 1740 & 1700 & 1690 \\
\hline Water $\left(\mathrm{lb} / \mathrm{yd}^{3}\right)$ & 251 & 258 & 225 & 218 & 249 & 246 & 282 & 279 \\
\hline $\mathrm{w} / \mathrm{cm}$ & 0.40 & 0.43 & 0.35 & 0.34 & 0.41 & 0.40 & 0.47 & 0.47 \\
\hline Slun & 3.25 & 1.25 & 0 & 4.75 & 1.5 & 0.875 & 0.625 & 1 \\
\hline Time & 10 & 5 & 23 & 19 & 11 & 11 & 12 & 6 \\
\hline Air Content $(9$ & 1.2 & 4.2 & 1.7 & 2.7 & 2.3 & 2.8 & 3.4 & 3.8 \\
\hline Density $\left(\mathrm{lb} / \mathrm{ft}^{3}\right)$ & 152 & 148 & 155 & 154 & 151 & 151 & 149 & 147 \\
\hline
\end{tabular}

$\dagger$ From residuals, dry basis

In case of higher-slump concrete, concrete accumulated on an area below the opening of the inverted cone and blocked the opening. Only then it was possible to fill the inverted cone with the higher-slump concrete. Once the cone was filled with concrete above a certain height, concrete in the inverted cone was stable.

Slump and time-of-flow of the first set of mixtures are also presented in Fig. 146. Comparison of time of flow and slump suggests that time of flow increased considerably as slump increases beyond about 2 inches, making the time of flow test inapplicable in this range of slump (>2 in.). This range is in agreement with the statement in ASTM C 
995 (p. 55). Also, it is written in ASTM C 995 that the test method "is not applicable to concrete that flows freely through the cone." Such concrete include concrete containing HRWRA as well as concrete with slump higher than 2 in. At the same level of slump, concrete containing HRWRA (also called "superplasticizer") is more plastic than plain concrete.

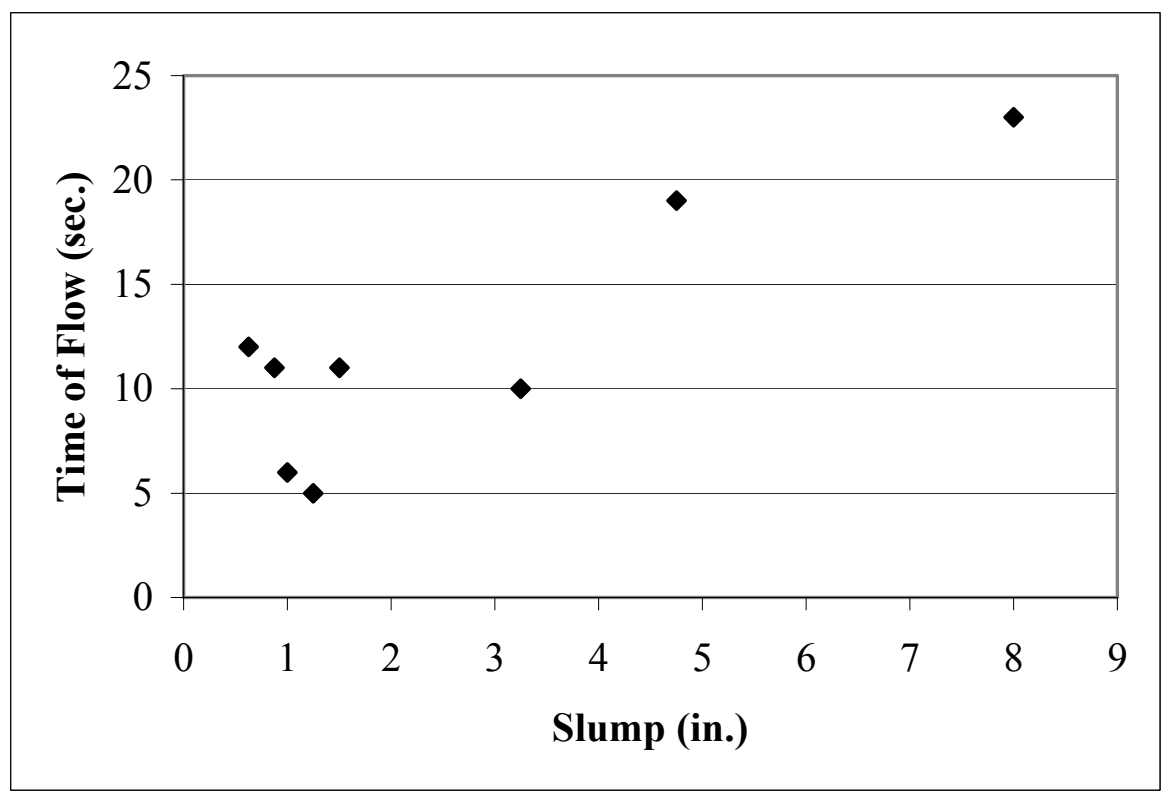

Fig. 146. Relation between time-of-flow and slump of concrete (Series 13: Set 1)

In order to overcome this problem, a modified test method for time of flow was tried on the second set of concrete mixtures. The second set of mixtures was made as trial mixtures for the sole purpose of observing the relationship between slump and modified-time-of-flow of concrete. Concrete mixing was done on a pan using a shovel because of small batch size $\left(0.25 \mathrm{ft}^{3}\right)$. Residual selected for the second set of mixtures was $\mathrm{BR}$, which is one of the easiest sources of residuals to disperse into individual fibers (p. 94). In this particular case, the residual was not deflocculated in water before its 
addition to concrete mixture, partly because of the small batch size. The residual was simply added to concrete mixture and mixed with a shovel.

In the modified test method for time of flow, the inverted slump cone was initially placed on concrete floor of the laboratory (Fig. 31 on p. 107) to prevent the drop of concrete into bucket in the process of filling the cone. After the cone was filled with fresh concrete, the inverted cone was lifted off the floor and was set on the bucket. After this, time of flow under vibration was measured as described in ASTM C 995.

Some concrete mixtures flowed freely through the inverted slump cone when the cone was lifted off the floor. In such cases, modified-time-of-flow was recorded as zero second.

Mixture proportions and fresh properties of the second set of concrete mixtures, including the modified-time-of-flow data, are presented in Table 143. Initially, a plain concrete mixture (1-a) without residuals or HRWRA was made, and slump of 2 in. and modified-time-of-flow of $3 \mathrm{sec}$. were determined. Then, some water was added to this mixture to increase the slump to $5.25 \mathrm{in}$. The diluted concrete flowed freely through the inverted cone when the cone was lifted off the floor, and modified-time-of-flow of this mixture was recorded as zero second.

Afterward $0.2 \mathrm{lb}$ of Residual BR was added to this mixture, and slump of 1.75 and modified-time-of-flow of 4 sec. were determined (Mixture 1-c). Decrease of slump from 5 to 1.75 in. was due to the addition of wood fibers. Subsequently, adding water and testing were repeated twice (Mixtures 1-d and 1-e). Mixture 1-e showed slump of 4 in. and modified-time-of-flow of zero second. 
Table 143. Mixture Proportions and Fresh Properties of Concrete (Series 13: Set 2)

\begin{tabular}{|c|c|c|c|c|c|c|c|}
\hline Mixture Name & $1-\mathrm{a}$ & $1-\mathrm{b}$ & $1-c$ & $1-\mathrm{d}$ & $1-\mathrm{e}$ & $2-\mathrm{a}$ & $2-b$ \\
\hline $\begin{array}{l}\text { Residuals, as-recd (\% of } \\
\text { concrete by wt.) }\end{array}$ & 0 & 0 & 0.5 & 0.5 & 0.5 & 0 & 0.5 \\
\hline Wood Fibers (lb)* & 0 & 0 & 0.06 & 0.06 & 0.06 & 0 & 0.06 \\
\hline $\begin{array}{l}\text { Residuals, LOI at } 590^{\circ} \mathrm{C} \\
(\mathrm{lb} / 100 \mathrm{lb} \text { cement })\end{array}$ & 0 & 0 & 1.0 & 1.0 & 1.0 & 0 & 1.0 \\
\hline HRWRA (fl oz/100 lb cement) & 0 & 0 & 0 & 0 & 0 & 7.3 & 7.3 \\
\hline Residual BR, as-recd (lb) & 0 & 0 & 0.2 & 0.2 & 0.2 & 0 & 0.2 \\
\hline HRWRA (fl oz) & 0 & 0 & 0 & 0 & 0 & 0.44 & 0.44 \\
\hline Cement (lb) & 6 & 6 & 6 & 6 & 6 & 6 & 6 \\
\hline Sand (lb) & 14 & 14 & 14 & 14 & 14 & 14 & 14 \\
\hline Coarse Aggregate, $3 / 4 "$ max. (lb) & 17 & 17 & 17 & 17 & 17 & 17 & 17 \\
\hline Water (lb) & 2.5 & $2.5+$ & $2.5+$ & $2.5++$ & $2.5+++$ & 2.25 & $2.25+$ \\
\hline Slump (in.) & 2 & 5.25 & 1.75 & 3 & 4 & 1 & 0.125 \\
\hline Modified Time of Flow (sec.) & 3 & 0 & 4 & 3 & 0 & 0 & 0 \\
\hline
\end{tabular}

* From residuals, dry basis.

+ Addition of water for increasing slump and reducing modified-time-of-flow.

Following this, a new concrete mixture (2-a) without residuals but with HRWRA was made. Its modified-time-of-flow was zero second in spite of its low slump (1 in.). This was attributed to the presence of HRWRA in the concrete. To this mixture, $0.2 \mathrm{lb}$ of Residual BR was added (Mixture 2-b). In spite of very low slump (0.125 in.), modifiedtime-of-flow was again zero second.

Slump and modified-time-of-flow results are shown also in Fig. 147. Comparison of slump and modified-time-of-flow shows that the modified-time-of-flow test is not applicable to concrete containing HRWRA. As for the concrete that does not contain HRWRA, modified-time-of-flow became zero second for slump higher than about 4 inches. Compared to the inapplicability of time of flow test (ASTM C 995) to concrete with slump higher than 2 in. (Fig. 146 on p. 276), this is an improvement. 


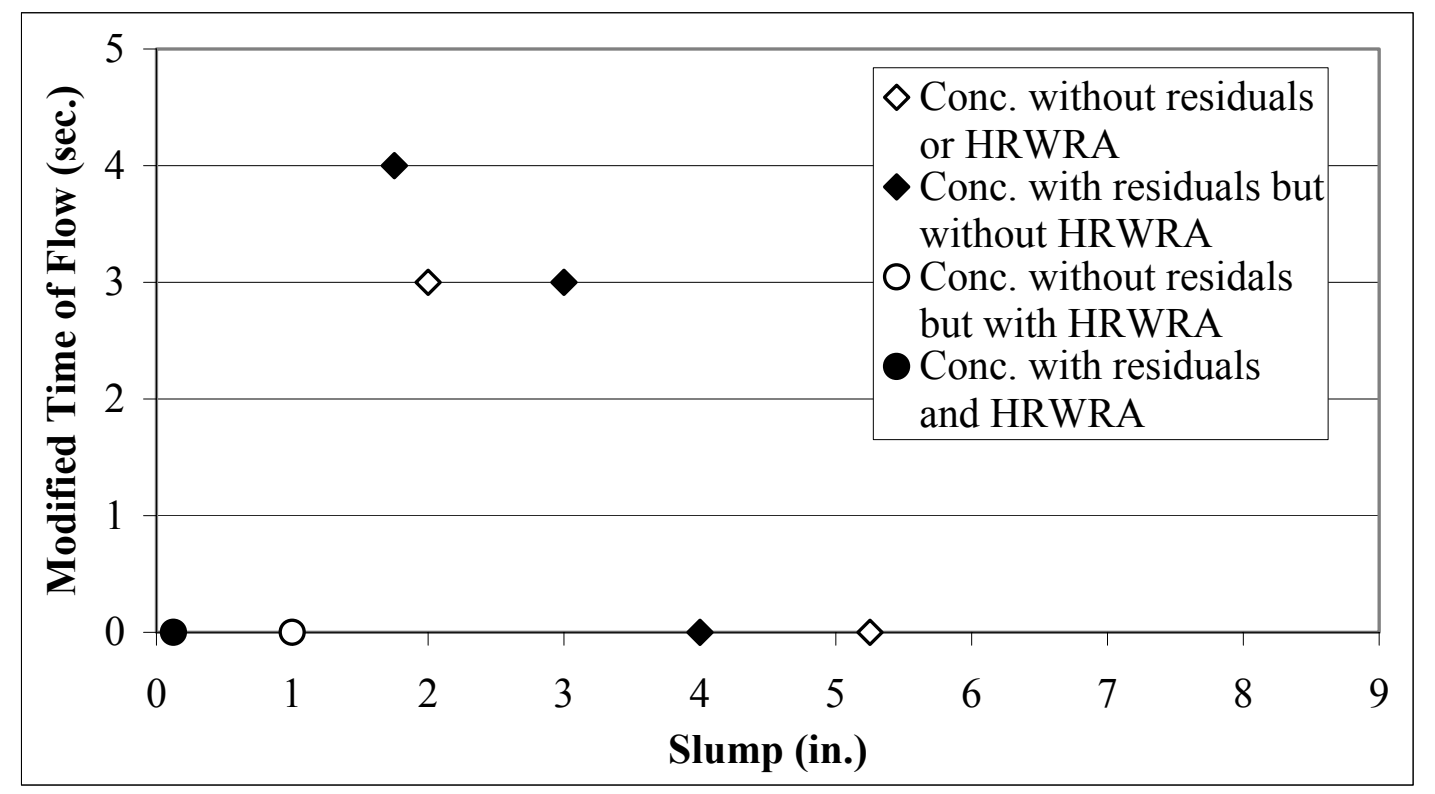

Fig. 147. Relation between modified-time-of-flow and slump of concrete (Series 13: Set 2)

As far as the relation between slump and modified-time-of-flow is concerned, the present results suggest that plain concrete and residuals concrete show similar trend. Further investigation could be conducted to find out whether modified-time-of-flow of residuals concrete is shorter than that of plain concrete at the same level of slump. The benefits of such phenomenon (if exists) were discussed earlier (p. 271).

When ASTM time of flow test results for concrete with slump of less than 2 inches and modified ASTM time of flow test results for concrete containing no HRWRA were combined (Table 144 and Fig. 148), the combined results of time of flow showed a distinct relationship with slump. As the slump increased, time of flow decreased until it became zero at a slump of about 4 inches. The results imply that this relation does not depend of mixture proportions of concrete as long as there is no HRWRA in the concrete. However, further investigation could be conducted to compare the relationships of 
ASTM time of flow (or modified ASTM time of flow) and slump of plain and residuals concrete mixtures.

Table 144. Slump and Time of Flow of Fresh Concrete (Series 13: Sets 1 \& 2)

\begin{tabular}{|l|c|c|c|c|c||c|c|c|c|c|}
\hline Mixture Name & 2 & C2-5 & C2-6 & C2-7 & C2-8 & $1-\mathrm{a}$ & $1-\mathrm{b}$ & $1-\mathrm{c}$ & $1-\mathrm{d}$ & $1-\mathrm{e}$ \\
\hline Slump (in.) & 1.25 & 1.5 & 0.875 & 0.625 & 1 & 2 & 5.25 & 1.75 & 3 & 4 \\
\hline Time of Flow (sec.) & 5 & 11 & 11 & 12 & 6 & $3^{*}$ & $0^{*}$ & $4^{*}$ & $3^{*}$ & $0^{*}$ \\
\hline
\end{tabular}

* Modified-time-of-flow of Set 2 mixtures.

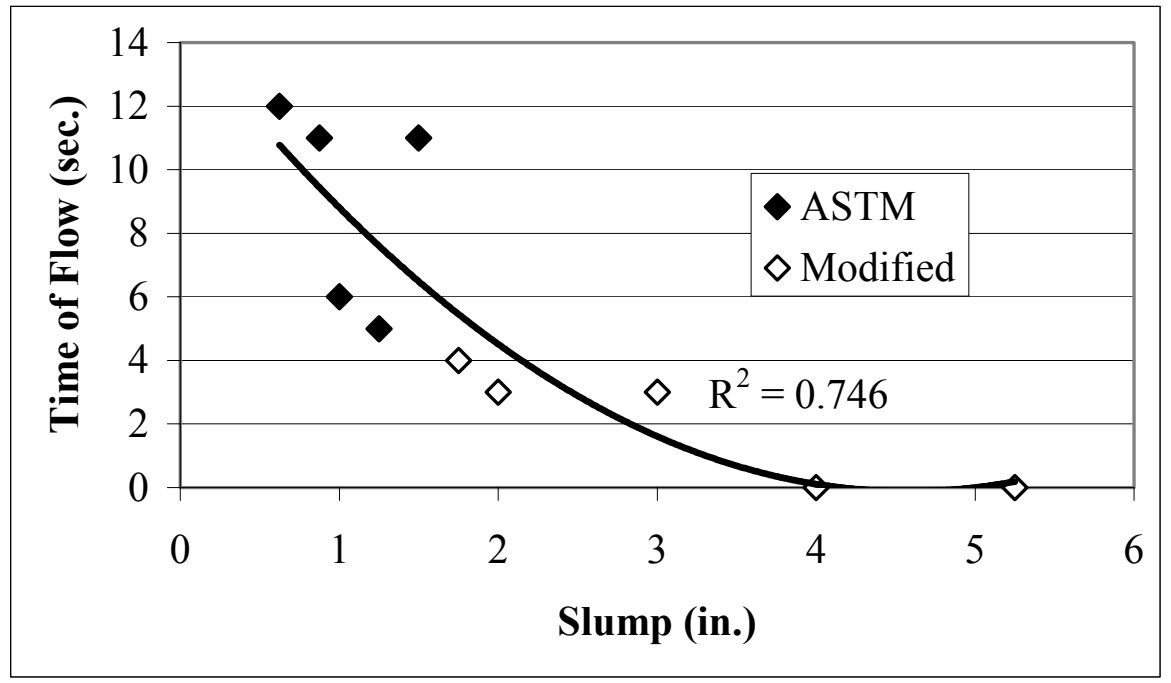

Fig. 148. Relation between time of flow and slump of concrete (Series 13: Sets 1 \& 2) 